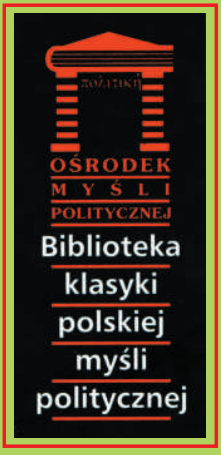

Jan Baudouin de Courtenay

MIEJCIE ODWAGE MYŚLENIA... 

Jan Baudouin de Courtenay 


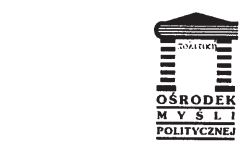

XVIII TOM W SERII

Biblioteka Klasyki

Polskiej Myśli Politycznej

KOMITET REDAKCYJNY SERII

Michał Jaskólski

\author{
Jacek Kloczkowski \\ Miłowit Kuniński \\ Ryszard Legutko \\ Jacek M. Majchrowski \\ Tomasz Merta \\ Bogdan Szlachta
}

PATRONAT NAD SERIĄ

Minister Kultury i Dziedzictwa Narodowego 


\title{
Jan Baudouin de Courtenay
}

\section{MIEJCIE ODWAGE \\ MYŚLENIA...}

\author{
WYBÓR PISM \\ PUBLICYSTYCZNYCH \\ Z LAT 1898-1927
}

Opracowat,

wstępem i przypisami opatrzył

Mirosław Skarżyński

Księgarnia Akademicka

Ośrodek Myśli Politycznej

Kraków 2007 


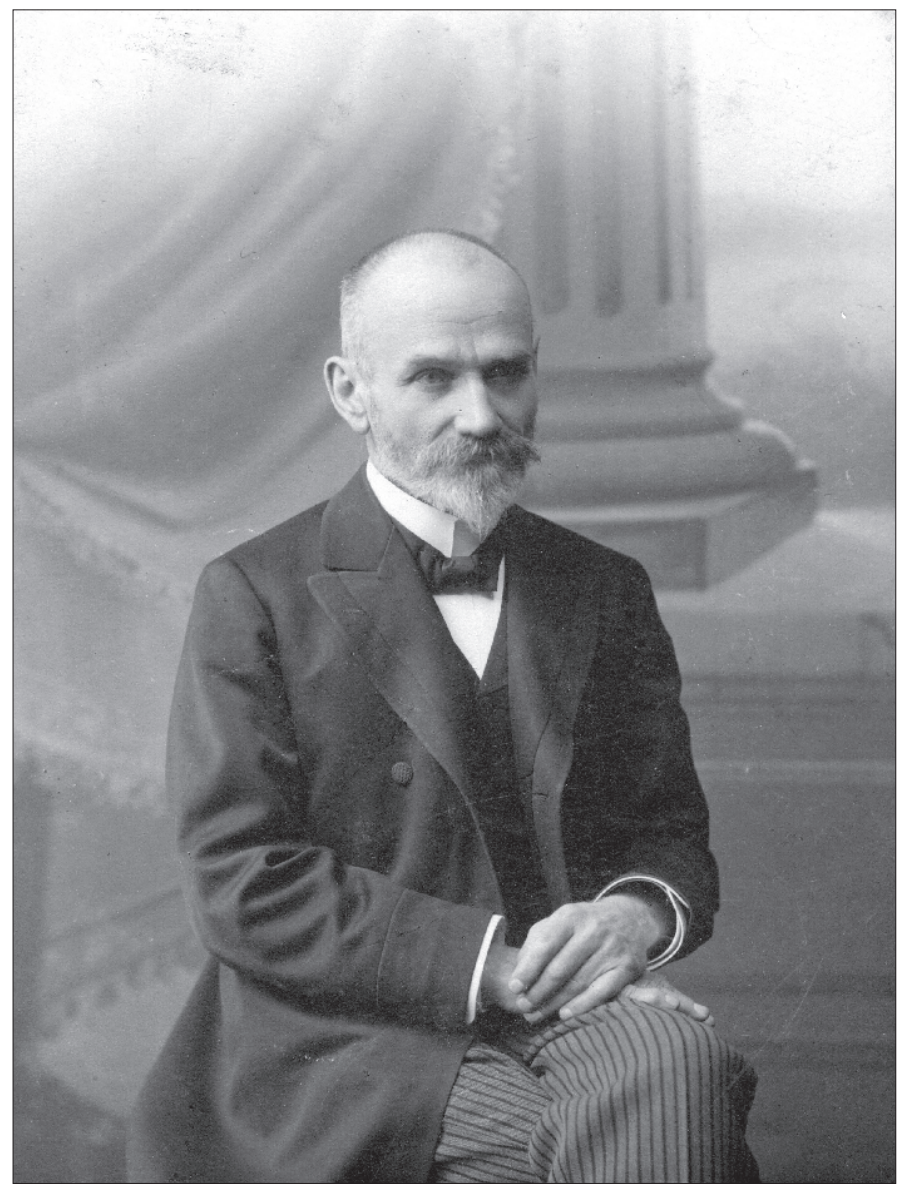

Jan Baudouin de Courtenay 
(C) Copyright by Mirosław Skarżyński

Z prac Wydziału Polonistyki Uniwersytetu Jagiellońskiego

Recenzenci

doc. dr hab. Magdalena Smoczyńska

prof. dr hab. Bogdan Szlachta

\author{
Korekta \\ Kinga Maciuszak \\ Skład i łamanie \\ Pracownia DTP „Register” \\ Okładka \\ Marek Pawłowski \\ Opracowanie komputerowe okładki \\ Paweł Sepielak
}

Fotografia Baudouina de Courtenay

ze zbiorów rodzinnych Marty Ehrenkreutz-Jasińskiej

\author{
Publikacja dotowana przez \\ Ministerstwo Nauki i Szkolnictwa Wyższego \\ oraz Wydział Polonistyki Uniwersytetu Jagiellońskiego
}

ISBN 978-83-7188-968-4

\title{
KSIEGARNIA AKADEMICKA
}

ul. św. Anny 6, 31-008 Kraków

tel./fax: 431-27-43, 422-10-33 w. 11-67

akademicka@akademicka.pl

www.akademicka.pl 


\section{SPIS TREŚCI}

Wstęp. „Savonarola racjonalizmu” .................................................................

Jeden z objawów moralności oportunistyczno-prawomyślej........................... 33

Myśli nieoportunistyczne.......................................................................... 57

Uwagi na czasie i nie na czasie.................................................................. 82

Krzewiciele zdziczenia ............................................................................ 105

Z powodu jubileuszu profesora Duchińskiego ………………………........ 140

Autonomia Polski ..................................................................................... 174

„Bracia Słowianie” ....................................................................................... 195

Narodowa i terytorialna cecha autonomii ................................................. $\quad 220$

W sprawie „antysemityzmu postępowego"...................................................... 264

Kwestia żydowska w państwie polskim.......................................................... 323

W kwestii narodowościowej ........................................................................ 357

Tolerancja, równouprawnienie, wolnomyślicielstwo, wyznanie paszportowe ……………….................................................. $\quad 390$

Wyznaniowe i pozawyznaniowe śluby i rozwody ........................................... 414

Mój stosunek do Kościoła ............................................................................. 448

Teksty drobniejsze ............................................................................... 518

Bibliografia pism publicystycznych Baudouina de Courtenay...................... 563

Indeks osobowy ...................................................................................... 585 


\section{WSTĘP}

\section{„Savonarola racjonalizmu”}

Należał do generacji nazwanej pokoleniem Szkoty Gtównej, polskiej uczelni wyższej, która przez siedem lat swego istnienia (1862-1869) miała ponad 2 tys. studentów (ukończyło ją tylko 600), a której rolę w kształtowaniu nowoczesnej inteligencji trudno przecenić. A choć sam Jan Baudouin de Courtenay niekoniecznie zupełnie identyfikował się z nią, a już na pewno nie w sensie naukowym, to trudno nie dostrzee w jego działalności społecznej rysów charakterystycznych dla innych przedstawicieli tej formacji intelektualnej. Z niej wywodzili się późniejsi uczeni, artyści, społecznicy, działacze oświatowi, tworzący nowoczesną inteligencję polską ostatnich dziesiątków lat wieku XIX i pierwszych wieku XX. Tylko dla przypomnienia powiedzmy, że studentami Szkoły Głównej Warszawskiej byli m.in. Bolesław Prus, Adolf Dygasiński, Henryk Sienkiewicz, Wiktor Gomulicki, Walery Przyborowski, Maksymilian Gierymski, Aleksander Świętochowski, historyk i krytyk literatury Piotr Chmielowski (późniejszy profesor Uniwersytetu Lwowskiego), matematyk Samuel Dickstein (potem profesor Uniwersytetu Warszawskiego i członek Akademii Umiejętności), etnograf, historyk i archeolog Zygmunt Gloger (autor m.in. Encyklopedii staropolskiej), językoznawca, nauczyciel pierwszego pokolenia polskich lingwistów, pionier dialektologii polskiej Lucjan Malinowski (profesor Uniwersytetu Jagiellońskiego, członek AU), Antoni A. Kryński (także językoznawca, profesor uniwersytetów we Lwowie i w Warszawie oraz wspótautor pierwszego w XX w. Stownika jezyka polskiego), a jest to zaledwie początek listy ważnych dla polskiej nauki i kultury postaci wywodzących się z tej uczelni.

Jan Niecisław Baudouin de Courtenay (13 III 1845 - 3 XI 1929) znany jest przede wszystkim jako uczony - językoznawca należący do nauki polskiej i rosyjskiej, ale także do światowej. W jego poglądach naukowych znajduje się wystarczająco wiele myśli i spostrzeżeń, które nie tylko były nowością w czasie, gdy Baudouin publikował swe prace, ale które weszły do podstaw dwudziestowiecznej lingwistyki, że wspomnę tu tylko rozgraniczenie statycznego i dynamicznego aspektu 
języka (to wspólnie z uczniem swoim, Mikołajem Kruszewskim), co rozwinął potem F. de Saussure, podobnie jak różnicę między językiem (abstrakcyjnym systemem) a mówieniem (indywidualnym działaniem), dalej pojęcie fonemu, teoria alternacji, zaczątki późniejszej socjolingwistyki i psycholingwistyki, rozważania nad wpływem języka na sposób postrzegania przez człowieka świata. I nie jest to bynajmniej lista pełna, ale zaledwie zarysowana, nie było bowiem takiego aspektu funkcjonowania języka, który by pozostawał poza zainteresowaniami Baudouina. Stąd też do dziś wiele jego prac jest czytanych i trudno byłoby wyobrazić sobie jakiekolwiek kompendium historii lingwistyki, w którym nie znalazłoby się miejsce, i to obszerne, dla niego. 0 tym jednak mówić tu nie będę, ponieważ interesuje nas nie Baudouin językoznawca, ale Baudouin publicysta. Więc tylko wspomnę, że gdy w roku 1979, w 50. rocznice śmierci uczonego zorganizowano na Uniwersytecie Warszawskim konferencję jemu poświęconą, wzięło w niej udział ponad 80 naukowców z Europy i Stanów Zjednoczonych. Podobna konferencja we wrześniu 2005 roku w Uniwersytecie Jagiellońskim znowu ściągnęła z różnych stron świata pokaźną liczbę referentów. To pokazuje rangę Baudouina w lingwistyce.

Jednak wypada nadmienić jeszcze o czymś; oto Baudouin był swego rodzaju uczonym „wędrownym”, z różnych zresztą przyczyn. Nie myślę tu o jego studiach, po ukończeniu Szkoły Głównej kontynuowanych w Pradze, Jenie, Lipsku - to było naturalne, językoznawstwa naukowego w Polsce wtedy nie mieliśmy, ale myślę o jego późniejszym życiu naukowym.

Był więc profesorem najpierw uniwersytetu w Kazaniu (1874-1883), potem w Dorpacie (1883-1893), w Krakowie (1894-1899), w Petersburgu (1899-1918), wreszcie w Warszawie (1918-1929) i Lublinie (KUL, 1918-1920). Zainteresowane były nim i inne uniwersytety - w Kijowie, Charkowie, Belgradzie.

Będąc Polakiem, miał zamkniętą po studiach drogę do pracy na uniwersytecie w Warszawie, ale też w Kijowie, gdzie rozważano jego kandydaturę. Marzenie o pracy na polskim uniwersytecie spełniło się dopiero w 1894 r. ${ }^{1}$, a i to na krótko, bowiem po pięciu latach nie odno-

1 Pierwszy raz propozycje pracy w Krakowie Baudouin otrzymał w 1874 r., ale ponieważ ciążył na nim obowiązek odpracowania stypendium 
wiono z nim kontraktu w Krakowie - z powodu jego poglądów, właśnie w publicystycznej broszurze ujawnionych ${ }^{1}$, ale i dlatego, że badał dialekty słowackie na terenie ówczesnych Węgier, co tamtejszemu rządowi, madziaryzującemu Słowaków, wydawało się działalnością panslawistyczną.

Ostatecznie Kraków stracił znakomitego językoznawcę, w pewnym stopniu jednak na własne życzenie, a dokładniej na życzenie środowisk konserwatywnych ${ }^{2}$, zyskał za to Uniwersytet Petersburski. Choć była to pierwsza tak dotkliwa konsekwencja zajmowania się przez Baudouina sprawami nienaukowymi, to bynajmniej nie ostatnia. W roku 1914 przyszedł proces sądowy w Petersburgu za opublikowanie broszury Nacjonalnyj i tierritorialnyj priznak $w$ awtonomii ${ }^{3}$ i wyrok dwóch lat więzienia, ostatecznie zmniejszony do trzech miesięcy, które Baudouin odsiedział od listopada 1914 r. do stycznia roku 1915. Przy tej okazji zresztą zwolniono go z Uniwersytetu Petersburskiego i dopiero: Kiedy upadt rzad carski, jednym z pierwszych kroków Uniwersytetu Petersburskiego byto przywotanie mnie na nowo do swego grona ${ }^{4}$.

naukowego w Rosji, nie mógł z niej skorzystać. Stało się to możliwe dopiero po wypracowaniu przez Baudouina tzw. małej emerytury rosyjskiej w dwadzieścia lat później.

1 Zob. Jeden z objawów moralności oportunistyczno-prawomyślnej w tym wyborze.

${ }_{2}$ W Krakowie potepiono mie wprawdzie powszechnie, ale pomimo to uniwersytet chciat mie w ten lub ów sposób zatrzymać. Z dwudziestu kilku czy teí nawet więcej niż trzydziestu catonków Wydziatu Filozoficznego, tylko ośmiu byto za bezwaglednem usunięciem mnie z uniwersytetu, resata gtosowata za mna. J. B a u d o u in de Courte n a y, Nie skandal, a po prostu objaw znamienny i pouczajacy, „Naród” 1921, nr 48.

3 Baudouina oskarżono, jak pisał w liście do W. Feldmana, 0: 1. „podburzanie do buntu $i$ do zwalenia istniejacego ustroju państwowego", 2. „Świadome fatszywe oskarżanie przedstawicieli wtadzy o różne nietadne postepki”. Zob. E. S t a c h u r s k i 2002, s. 116. W tym i następnych kilku listach (zob. s. 116-118, 120, 122-124) dalsze informacje o tej sprawie.

4 J. B a ud ou in de Courten ay, Nie skandal... 
Sprawa była skandaliczna, nawet w tamtych czasach i w tamtej atmosferze. Baudouin miał wielu obrońców - nie tylko wśród przyjaciół i zwolenników jego poglądów na reformę Rosji, ale nawet wśród politycznych przeciwników ${ }^{1}$. To poparcie okazało się ważne, bowiem sam Baudouin nie zgodził się prosić o ułaskawienie, gdyż dla niego byłoby to równoznaczne z wyrzeczeniem się własnych poglądów. Podobnie piętnaście lat wcześniej odrzucił namowy życzliwych mu członków Rady Wydziału Filozoficznego UJ i nie zgodził się na kompromis, a tym bardziej na przeproszenie dotkniętych jego broszurą galicyjskich notabli. Na tym tle już tylko wspomnieć należy o „drobnych” przykrościach, które spotykały Baudouina przez większość życia, w rodzaju konfiskat cenzuralnych w Rosji, ale i w Galicji² czy awantur wywoływanych na jego odczytach. Ale przecież już nie „drobną przykrością” była niezgoda Uniwersytetu Lwowskiego w wolnej Polsce na nadanie Baudouinowi tytułu doktora honoris causa, a także

1 Ojciec cieszyt sie wielka sympatia ludzi. Rzeczywiście oprócz tego, że byt madry, byt bardzo dobry; to sie bardzo wyraźnie zaznaczyto, kiedy byt skazany na więzienie. Jenerat Babianski pożyczyt ojcu pieniadze na kaucje, dzięki temu ojciec mógt jeszcze być $w$ domu, a nie od razu w areszcie. Ale i po tym wyroku po prostu nie zamykaty sie drzwi, zjawiaty sie delegacje, zjawiali sie prywatni ludzie z kwiatami, i Polacy, $i$ Rosjanie, i rozmaite mniejszości narodowe, itd. To wszystko byto rzeczywiście takie wzruszajace. Mam fotografie ojca, gdzie siedzi wśród kwiatów, które wtedy otrzymat. Pamiętam, jak strasznie się wtedy dziwit szwajcar w domu: „Car skazat tego cztowieka, a tu zjawiaja sie ludzie i niosa jemu kwiaty. Jak to może być?" Wtedy dopiero można byto zobaczyć, jaka sympatia cieszyt sie ojciec. Jedna z moich koleżanek wręczyta mi pieniadze: „Bo tobie będzie teraz trudno”. Wzruszajace byto to, jak odnieśli sie ludzie do tego. „Córka Baudouina de Courtenay o swoim ojcu" - Rozmowa przeprowadzona z Eweliną Małachowską-Łempicką w 1979 r. przez przedstawicieli Naukowego Koła Językoznawczego Studentów Filologii Polskiej UW, niepubl. mszps w zbiorach Biblioteki PAN w Warszawie.

2 Zob. Ze zjazdu autonomistów, czyli przedstawicieli narodowości nierosyjskich $\mathrm{w}$ tym wyborze. Warto zauważyé, że ostatnia ingerencja cenzorska miała miejsce w roku... 1984 w VI (publicystycznym) tomie Dziet wybranych B a ud ou in a de C o u rtenay-zob. przypis 1, s. 454 i 1, s. 484 do tekstu Mój stosunek do Kościota. 
nieprzyjęcie go w skład Rady Wydziału na Uniwersytecie Warszawskim, gdzie dano mu profesurę honorową, co oznaczało faktycznie pozbawienie go praw członka Rady ${ }^{1}$. Dla niektórych środowisk i ludzi, na ogół tych, którzy uważają się za mających monopol na polskość, był po prostu atym Polakiem, a nawet wrogiem Polski, który cate życie dziatat na jej szkodę2.

Gdy w wykładzie inauguracyjnym, który Baudouin wygłosił w 1918 r. na Uniwersytecie Warszawskim padty stowa: Polska odradza sie jako panstwo nie po to, by sie stać jedna z hien imperialistycznych, część audytorium zareagowała gwizdami³. Ale i dalej, przez następne lata, w swych artykułach pisał o prześladowaniu mniejszości narodowych w wolnej Polsce, tłumacząc, że naród, który doznał niewoli i prześladowań, nie powinien stosować tych samych metod, których doświadczał na sobie jeszcze nie tak dawno. Nie był Baudouin chyba dla wielu dobrym Polakiem także wtedy, kiedy ujmował się za Litwinami, Białorusinami, Ukraińcami w odradzającej się Polsce, a i wtedy, kiedy będąc przeciwnikiem koniunkturalnych zmian nazw topograficznych, protestował w $1928 \mathrm{r}$. w artykule "Wandalizm” jezzykowy przeciwko zamianie historycznej nazwy placu Saskiego na plac Piłsudskiego, co było dla niego niszezeniem składnika historii miasta ${ }^{4}$. A także wtedy (r. 1920), gdy - nie przyjąwszy propozycji objęcia katedry na Uniwersytecie Wileńskim - wyjaśniał powody swej

1 Jako profesor honorowy miał tylko prawo prowadzenia wykładów. Podobnie potraktowano w Warszawie L. Petrażyckiego (początkowo) i A. A. Kryńskiego, choć z innych powodów. Zob. w związku z tym artykuł Nie skandal, a po prostu objaw znamienny i pouczajacy w niniejszym tomie.

2 R. A. R ot h ste in 1976. Zob. też „Dobry Polak" a „wróg Polski” $\mathrm{W}$ niniejszym tomie.

3 Pisze o tym W. D o r o s z e w s k i 1972 . Z kolei w tym samym roku podczas wykładu w Teatrze Słowackiego w Krakowie, kiedy Baudouin mówił o prawie każdego do wyboru narodowości oraz do poczucia przynależności do więcej niż jednej narodowości, nacjonalistyczna młodzież zagłuszała go gwizdami, a nawet ktoś rzucił w niego zepsutym jajkiem, na szczęście nie trafiając.

$4 \quad$ „Wolnomyśliciel Polski” 1928, nr 7. 
decyzji na łamach „Tygodnia Polskiego”. Pisał wówczas o tym, że powstający uniwersytet polski może być postrzegany przez Litwinów jako instytucja polonizacyjna.

Gdy chowano Baudouina na cmentarzu ewangelickim w Warszawie $^{2}$, nad grobem padty stowa Tadeusza Kotarbińskiego: Profesor Baudouin na czarne mówit czarne, na biate mówit biate, co było zwięzłą i prawdziwą charakterystyką uczonego.

Sześédziesiąt lat uprawiania publicystyki i tyleż lat ponoszenia mniej lub bardziej dotkliwych konsekwencji głoszonych poglądów. Jednak nieustanne upominanie się Baudouina o równouprawnienie narodowości, o prawa człowieka do życia w wolności przyniosły mu piękną nagrodę - w pierwszych wyborach prezydenckich w Polsce odrodzonej zgłoszono go jako kandydata do najwyższego urzędu. Był to, realnie rzecz biorąc, gest (notabene uczyniony bez wiedzy zainteresowanego) $)^{3}$, ale gest piękny, zważywszy na środowiska, które go uczyniły. Zrobili to ci, o których prawa uczony całe życie się dopominat - przedstawiciele mniejszości narodowych.

W dorobku piśmienniczym Baudouina pozostało kilkaset prac naukowych i dobrze ponad 300 (zob. Bibliografia) tekstów publicystycznych, powstałych między rokiem 1865 a 1929, publikowanych w kilkudziesięciu gazetach i czasopismach (nie tylko polskich) lub/ i wydawanych (często nakładem samego autora) jako odrębne broszury. Tematyka ich jest szeroka, mieszczą się w niej zagadnienia polityczne, moralności społecznej, narodowościowe, nauczania i wychowania, poglądy na literaturę i jej rolę w społeczeństwie, wreszcie kwestie światopoglądowe, w tym - zawsze niezwykle ważne sprawy wolności sumienia.

Od strony formy teksty te charakteryzują się szczególnym, sugestywnym stylem, ostrością sformułowań oraz ironią, także w mówieniu o sobie samym. Bez wątpienia pojęcie dziś modnej politycznej

1 Zob. Bibliografia prac publicystycznych Baudouina de Courtenay na końcu tej książki.

2 Zob. E. Małachow ska 1976.

3 W związku z tym zob. Kandydatury demonstracyjne w niniejszym tomie. 
poprawności było czymś zupełnie obcym Baudouinowi. Wynikało to zapewne nie tylko z cech charakteru uczonego, ale też ze stałego przekonania, że należy mówić (pisać) prawdę. Tak postępował w publicystyce, tak też postąpił wtedy, gdy pisał wspomnienie o swym uczniu, Mikołaju Kruszewskim, z którym był bardzo związany, ale którego ocenę w tym wspomnieniu napisał zgodnie $\mathrm{z}$ wyznawaną zasadą „0 zmarłych albo prawda, albo nic”.

Jak zauważyła swego czasu J. Kulczycka-Saloni ${ }^{1}$, te właściwości oraz logika argumentacji czynią wrażenie, jakby ich autor nie dbał zupełnie 0 to, czy pozyska czytelnika dla swych poglądów, czy też go zniechęci lub wręcz zrani. W tym widzi ona różnicę między publicystyką Baudouina a publicystyką np. B. Prusa czy A. Świętochowskiego, dbających o kontakt z odbiorcą ich tekstów i niezrażanie go.

Jakież wobec tego były to poglądy i jakim człowiekiem był Baudouin de Courtenay? Bez pretensji do wyczerpującej odpowiedzi na to pytanie, zwrócę uwagę Czytelnika na kilka tylko rzeczy.

Dla postawy Baudouina charakterystyczne jest odrzucanie przekonań, które nie dają się udowodnić, jako sprzecznych z rozumem ludzkim, ten zaś pojmowany jest w duchu oświeceniowego racjonalizmu. W parze z tym idzie odrzucanie autorytetów jako ograniczających myślenie, odrzucanie pojęć „niejasnych”, nierozgraniczonych wyraźnie, jeśli nie dają się one objaśnić i należycie rozgraniczyć, a i pojęć motywowanych emocjonalnie, nie zaś racjonalnie, gdyż przyjęcie ich prowadzi do nierozumnych i szkodliwych zachowań tak jednostkowych, jak i zbiorowych. Obok tego znajdujemy szacunek dla faktów, które są podstawą rozważań i wnioskowania.

Zob. np. J. Ku lcz y cka-S a l o n i 1984, 1989. Pisze ona tam m.in.: Co wiecej, cechowat go pewien fanatyzm „prawdy”, prawie zupetny brak poczucia jej relatywności, zwiazania z epoka, środowiskiem, a nawet ludzkajednostka, despotyzm nieuznajacy argumentów wysuwanych przez wyznawców innych pogladów, który podsuwat mu na określenie jego rzeczywistych i przypuszczalnych oponentów zwroty i sformutowania przykre, a niekiedy wręcz obrá́liwe nie tylko dla ogótu czytelników, ale nawet dla tych, których mógtby uważać za swych zwolenników. (s. 540). Od J. Kulczyckiej-Saloni zapożyczam też określenie Baudouina użyte w tytule tego wstępu. 
Trzeba zauważyć, że owa racjonalna analiza pojęć jest konsekwencja poglądów językoznawezych Baudouina, tych mianowicie, które dotyczą związku zjawisk fizycznych z psychicznymi. W poglądach uczonego na związki języka i myślenia, świata językowego i świata fizycznego podkreśla się naturalną skłonność człowieka do animizowania pojęć odnoszących się do rzeczywistości materialnej, a następnie do przenoszenia ich na zjawiska psychiczne, co razem i ostatecznie prowadzi do tego, że

Na tym gruncie rodzą się różne słowa ś w i ę t e, n i e t y k a l n e, na tym gruncie powstają mity „0 duchu języka”, „0 duchu narodu”, „o duszy”, na tym gruncie człowiek staje się niewolnikiem wyrazów-bożyszcz'.

Niedostatek logicznego myślenia powoduje, że ludzie ulegają owej „magii słów”, biorąc rzeczywistość werbalną za realną, a stąd krok już do działań irracjonalnych jednostkowych, ale również zbiorowych. Nie jest to jedyny moment, w którym można zaobserwować ścisły związek między Baudouinem uczonym a Baudouinem myślicielem i publicystą. Nieraz w tekstach publicystycznych spotkać można rozważanie znaczenia tego czy innego wyrazu prowadzone po to, aby czytelnikowi uświadomić, iż poprzez swą niejasność (rozmyty sens), metaforyczność, ten lub ów wyraz paczy myślenie ludzi, wpływa negatywnie na ich zachowania bądź indywidualne, bądź społeczne.

Baudouin był agnostykiem. Pojęcie Boga osobowego uważał za wadliwe i nielogicznie skonstruowane, a co gorsza, motywowane ludzką megalomanią, która każe przypisywać czemuś niepoznawalnemu zwielokrotnione cechy ludzkie.

Etykę opartą na religii zastąpił etyką świecką, dla której podstawą są, posługując się sformułowaniami samego Baudouina, dwie przesłanki: logiczne myślenie i - oparte na takim myśleniu - poczucie sprawiedliwości. Pierwsze zapobiega uleganiu fałszywym pojęciom, drugie - nakazuje równe traktowanie innych ludzi i niewyrządzanie im krzywd, mówiąc najprościej.

1 J. B a udouin d e Courtenay, Charakterystyka psychologiczna jezyka polskiego, [w:] Dzieta wybrane, t. V, Warszawa 1983, s. 47. 
Zamiast wszelkich owych obłudnych „miłości bliźniego”, „braterstwa” itp. nam powinny najzupełniej wystarczać: spotęgowanie myślenia logicznego, a w zakresie etyki spotęgowanie wynikającej z myślenia logicznego idei sprawiedliwości oraz poszanowania godności ludzkiej w każdym człowieku [W sprawie porozumienia sie ludów stowiańskich, 1908].

W poglądach etycznych był Baudouin rygorystą. Wypracowane i raz przyjęte przez człowieka zasady nie moga podlegać relatywizacji; nie może być kompromisu między uznanymi normami a doraźnymi sytuacjami, w których ta czy inna z nich zostałaby „na chwile” zawieszona. I tu trzeba powiedzieć, że właśnie zarówno całożyciowa stałość podstawowych przekonań etycznych Baudouina, jak i konsekwentne ich stosowanie przysparzały mu wrogów, ale także przyciągały do niego ludzi darzących go szacunkiem, choć niekoniecznie bliskich mu światopoglądowo. I nie chodzi mi tylko 0 akcję protestów wobec skazania Badouina przez sąd w Petersburgu, w której zjednoczyli się ludzie z różnych obozów światopoglądowych i politycznych, o czym wyżej wspomniałem, ale myślę tu o szacunku i przyjaźni między nim a Marianem Zdziechowskim, a także o uznaniu, jakim darzył Baudouina Lew Tołstoj.

Dzieliły ich mocno poglądy filozoficzne, polityczne i społeczne, także cechy charakteru; łączyły wyznawane te same, choć odmiennie motywowane, zasady etyczne, wrażliwość na niesprawiedliwość, krzywdę oraz konsekwencja w wyznawaniu i stosowaniu w życiu przyjętych poglądów. Baudouin dyskutował ze Zdziechowskim, nie zgadzał się też z religijnością Tołstoja - i odwrotnie - tamci nie mogli podzielać w pełni laickich podstaw światopoglądowych Baudouina, ale te kontakty, a już na pewno szacunek, jakim się darzyli, są świetnym przykładem tego, jak można „pięknie się różnić”. Wspomnę więc tylko, kończąc ten wątek, że kiedy przygotowywano w Rosji jubileusz osiemdziesięciolecia Lwa Tołstoja, wskazał on właśnie Baudouina i Zdziechowskiego jako Polaków, których należało zaprosić do udziału w przygotowywanym almanachu ${ }^{1}$.

1 Baudouin napisał do owego almanachu artykuł pt. Lew Totstoj $i$ kara śmierci, potem wycofał go, nie chcąc by cenzura skonfiskowała cały 
Świeckośé przyjmowanych przez Badouina założeń nie wykluczała odwoływania się do tych punktów Dekalogu, które uznawał za uniwersalne (ponadreligijne), jak np. zasada „nie zabijaj”.

Przyjęcie tej normy prowadzi Baudouina do ścisłego pacyfizmu i do sprzeciwu wobec kary śmierci, bowiem nie ma, jak sądzi on, sytuacji, w której można by usprawiedliwić pozbawienie kogoś życia. Stąd każda wojna jest złem, nie tylko dlatego, że powoduje nieszczęścia różnego rodzaju i sprzyja „dziczeniu” ludzi, ale przede wszystkim dlatego, że jest naruszeniem ogólnej normy zakazującej zabijania. Tu jest powód, dla którego Baudouin był też przeciwnikiem walki zbrojnej o niepodległość, co nie świadczyło, że był „złym Polakiem”, ale że prawo moralne stawiał wyżej'. W miejsce spiskowania, aktów terrorystyeznych $^{2}$ i walki orężnej proponował działania na rzecz autonomii Królestwa. Inna sprawa, czy akurat w tym był realistą, ale trzeba pamiętać, że nadzieja, iż klęska Rosji w wojnie z Japonią, a następnie rewolucja 1905 r. wymuszą zmianę rosyjskiej polityki wewnętrznej, była udziałem sporej części świadomego społeczeństwa nie tylko rosyjskiego.

0 rygoryzmie Baudouina w kwestii wyznawanych zasad świadczy też i to, że był on jednym z sygnatariuszy prośby o ułaskawienie od kary śmierci Eligiusza Niewiadomskiego, mordercy prezydenta Narutowicza. Zbrodniczość czynu Niewiadomskiego była dla Baudouina oczywista, ale nawet wstrząs nim spowodowany nie skłonił go do złagodzenia poglądu na niedopuszczalność kary śmierci³.

Ogólnie w pozbawianiu życia widział Baudouin remanenty stanów przedcywilizacyjnych, nieusunięte w ewolucji gatunku ludzkiego (przejawy „dzikości”).

almanach. Zob. B. B i a 10 k 0 z o w i c z 2001. Przy okazji warto powiedzieć, że Baudouin pomagał Tołstojowi zdobyć książki o powstaniu listopadowym potrzebne mu w czasie pisania opowiadania $Z a$ co? (3a чmo?), był też konsultantem korekty owego opowiadania.

1 Był też Baudouin przeciwnikiem spisków, uważając, że należy działać z otwarta przytbica.

2 Chodzi przede wszystkim o okres rewolucji $1905 \mathrm{r}$.

3 Zob. w tym wyborze Nie wolno kalać ust milczeniem. 
Nie odrzucał natomiast Baudouin samego pojęcia 'walki', ale uznawał je tylko w sensie 'zmagania się' (właśnie: walki) człowieka z przyrodą dla zapewnienia rozwoju cywilizacyjnego, postępu i dobrobytu ludzkości. Natomiast o walce zbrojnej pisał następująco:

Jak tu nie pogardzać tym bydłem dwunogim, tą zgrają bezmyślną, zgrają, która zamiast wspólnie walczyé z przyrodą i w imię solidarności wszechludzkiej opanowywać i zużytkowywać ją dla wspólnych celów ogólnoludzkich, pod różnokolorowymi sztandarami, „w imię idei”, w imię bzdurnych górnolotnych haset, dla dogodzenia chciwości i próżności różnych ambitników i bandytów wszechświatowych gryzie się zaciekle między sobą, tępi się nawzajem bez litości i niszczy bezmyślnie wielowiekowe dorobki cywilizacji? [Kwestia żydowska w panstwie polskim, 1923]

Jednak jest taka sytuacja, w której Baudouin dopuszcza konieczność walki zbrojnej - to obrona przed napaścią. W artykule Obtęd komunistyczny, napisanym w czasie wojny polsko-bolszewickiej ${ }^{1}$, znajdujemy taki fragment:

Trzeba bronić siebie, trzeba bronić bliskich i dalekich.

Gdybym był młodszym, zapisałbym się do szeregów obrońców czynnych, a nie potrzebowałbym do tego pobudek patriotycznych. Wystarezyłaby mi solidarność ogólnie ludzka, wystarezyłaby potrzeba ocalenia ludzkości, potrzeba ocalenia człowieka, w lepszym znaczeniu tego wyrazu.

Jest to jedna z tych nader rzadkich w historii ludzkości chwil, kiedy „patriotyzm” brzmi unisono z uczuciami ogólnoludzkimi, kiedy sprawa „ojczyzny” staja się sprawą ludzkości. Tylko bezduszne kłody, tylko automaty nakręcone rękami „bolszewickimi”, tylko głowy obałamucone i serca zatrute jadem uczuć antyspołecznych nie są w stanie tego zrozumieć i mogąa jeszeze się wahać.

W centrum poglądów Baudouina stoi człowiek, ujmowany jako indywiduum, jako autonomiczna osoba ludzka obdarzona rozumem i wolnością myślenia i działania, dla której jedynym ograniczeniem

1 Zob. w niniejszym wyborze. 
powinno być nienaruszanie takiej samej wolności innych osobników (tu potrzebne są logiczne myślenie i poczucie sprawiedliwości). Owa autonomia człowieka, jego wolność jednostkowa i jego godność są wartościami najważniejszymi, z nich bierze się to, co nazywamy prawami człowieka. To w obronie tych praw Baudouin działał jako publicysta.

Jest w pismach Baudouina interesujące pojmowanie zbiorowości (wspólnoty narodowej, religijnej, państwa itp.), będące konsekwencją przyjęcia takiego, jak wspomniałem wcześniej, rozumienia osoby ludzkiej. Baudouin ma niezmienne przekonanie, że wszelkie formy organizacji społecznej mają rację bytu o tyle, o ile powstają w drodze suwerennych decyzji wolnych jednostek. To kształtuje poglądy uczonego na taki model społeczeństwa, w którym należenie lub nienależenie do jakiejkolwiek grupy jest konsekwencją indywidualnej decyzji człowieka, a tym samym grupy sformalizowane są tylko dobrowolnymi zrzeszeniami świadomych jednostek ludzkich, łączących się dla wspólnych działań na rzecz rozwoju cywilizacyjnego. Dalszą konsekwencją przyjęcia jako podstawy jednostki i jej praw jest powtarzane kilkakrotnie hasło o służebności urzędników (a więc aparatu państwowego) wobec obywateli (nie obywatele dla państwa, ale panstwo dla obywateli i: nie obywatele dla urzedników, ale urzednicy dla obywateli). Jeśli zebrać tego rodzaju uwagi Baudouina dotyczące organizacji społeczeństwa i jego stosunku do państwa, to składają się one na wizję tego, co potem nazwane zostanie społeczeństwem otwartym. Drogę do takiej formacji widzi Baudouin jako przechodzenie od stanu egoistyczno-stadowego do stanu indywidualno-spotecznego. Jest to więc ewolucja świadomości człowieka, dzięki której pierwotne gromady kierujących się partykularnymi interesami osobników zmieniają się w formacje złożone z wolnych i dojrzałych jednostek, które, nie tracąc swych indywidualności, z własnego wyboru łączą się i działają dla dobra wspólnego. Na tle tego poglądu istniejące realnie organizacje państwowe i wyznaniowe są owocami przymusu wywieranego na jednostki.

Poczucie przynależności narodowej, mówiąc inaczej, poczucie identyfikacji z grupą nazywaną narodem (narodowością), jest wewnętrzną sprawą człowieka, który może równie dobrze uznać swą 
przynależność do jednego narodu, do dwóch czy więcej lub czuć się niezwiązanym z żadną narodowością. Nikt natomiast nie ma prawa narzucać nikomu narodowości. Znowu, jeśli przejdziemy na współczesną terminologię, to da się to określić jako uznanie istnienia jednoi wielokulturowości i przyznanie jednostce nieskrępowanego prawa wyboru ${ }^{1}$.

Tu chyba jest miejsce, by powrócić do przytoczonego wcześniej określenia „zły Polak”. Otóż miał Baudouin ustalony pogląd na patriotyzm, a dokładniej - na patriotyzm w wydaniu polskim - histeryczny, emocjonalny, płytki i nacjonalistyczny, a nawet często szowinistyczny. W hierarchii wartości Baudouina na pierwszym miejscu stała, jak już powiedziałem, osoba ludzka. Stąd w jego tekstach poświęconych zagadnieniom narodowościowym nie ma wyróżniania jakiejkolwiek narodowości, a w każdym momencie rozważane rzeczy odnoszone są po prostu do ludzi, niezależnie od ich etnicznej przynależności. Ta bowiem jest rzeczą wtórną, umowną poniekąd ${ }^{2}$. Stąd też ustawiczne powtarzanie tezy o równouprawnieniu wszystkich narodowości, potępienie dla dyskryminacji, dla fałszywych teorii rasowych ${ }^{3}$, fałszywych ideologii „braterstwa słowiańskiego”, a także gotowość bronienia prześladowanej mniejszości.

Sam Baudouin uważał się za Polaka, czemu dawał czynnie różnorakie dowody, począwszy od egzaminowania na uniwersytecie

1 W związku z tym warto przytoczyć zacytowane przez H. D a t n e r w artykule Tożsamość inteligencji żydowskiej w XIX w. sformułowania, w jakich mówili 0 sobie niektórzy żydowscy korespondenci J. I. Kraszewskiego: Jestem Żydem-Polakiem; Polakiem należacym do innej kultury; Starozakonnym Polakiem, cztowiekiem, który umie pogodzić wymagania swej wiary z wymaganiami postepu i narodowych dą̇ności.

2 Jak pisze w biogramie Baudouina prof. Kazimierz Nitsch: Niestusznie go nieraz posadzano o dziatalność antyreligijna lub narodowa obojętność, byt tylko osobiście natura niereligijna, a narodowo niezdolna do jakiejkolwiek nieżyczliwości dla ludzi obcych jezykowo lub rasowo. (K. N it s c h 1935, s. 361).

Zob.Z powodu jubileuszu profesora Duchinskiego w tym tomie.

4 Zob. W sprawie porozumienia sie ludów stowiańskich, także „Bracia Stowianie" w niniejszym wyborze. 
w Petersburgu po polsku studentów Polaków, przez upominanie się o prześladowaną młodzież polską w Królestwie Polskim i o Polaków w zaborze pruskim, aż do wieloletniego uprawiania - jak to nazywał - „kontrabandy”, czyli faktycznie porządnie zorganizowanego i prowadzonego przemytu drukowanych w Galicji polskich wydawnictw do Rosji, gdzie zaopatrywał ok. 140 polskich odbiorców (nawet zesłańców na Syberii) w tę zakazaną literaturę. W Dorpacie Baudouin wygłaszał wykłady, z których dochód przeznaczony był na wsparcie Kasy im. Mianowskiego, a więc na pomoc dla polskich uczonych, w Petersburgu zaś dom Baudouinów stał się ośrodkiem polskiego życia intelektualnego. Przytaczam tych kilka przykładów nie po to, by bronić Baudouina przez wspomnianymi zarzutami, ale po to tylko, by dodać kilka jeszcze rysów do szkicowanego tu portretu.

Wspomniałem wyżej, że poczucie narodowości traktował Baudouin jako osobisty wybór człowieka. Podobnie rzecz ma się z wyznaniem.

Na zasadzie równouprawnienia obywatelskiego, w imię wolności osobistej i godności ludzkiej, każdemu człowiekowi powinno być wolno przyznawać się do takiej narodowości, jaką sam uznaje za własną, a nawet albo przyznawać się do dwóch i więcej narodowości jednocześnie, albo też nie przyznawać się do żadnej narodowości. Podobnie co do wyznania: człowiek ma prawo zaliczać siebie do tego lub owego wyznania według upodobania, albo też nie przystawać do żadnego wyznania i ogłosić się za bezwyznaniowca. Tylko w różnicy od narodowości subiektywnej człowiek nie może należeć jednocześnie do dwóch lub kilku wyznań albo też być jednocześnie wyznaniowcem i bezwyznaniowcem, gdyż jest to sprzecznością samą w sobie [Kwestia żydowska w państwie polskim, 1923].

Z takiego sposobu myślenia bierze się też np. postulowanie szkół w językach narodowych, nie zaś w języku uznawanym za państwowy. Stąd pochodzi stały sprzeciw wobec ograniczania praw mniejszości narodowych w Rosji, praw Ukraińców w Galicji, sprzeciw wobec nieuznawania narodowości żydowskiej w monarchii austro-węgierskiej, prześladowań Słowian we Włoszech, Polaków w państwie niemieckim, a potem, po roku 1918, sprzeciw wobec prześladowania i ogra- 
niczania praw mniejszości narodowych w wolnej już Polsce, a także protest przeciwko odziedziczonemu po Rosji carskiej obowiązkowi deklarowania wyznania w paszportach, jako procederowi nie tylko ingerującemu w najbardziej intymną sferę życia duchowego człowieka, ale też prowadzącemu do deklaratywnego traktowania religii.

Tu jest też źródło obrzydzenia wobec endeckich haseł „egoizmu narodowego", ekscesów antyżydowskich, wobec numerus clausus na niektórych uczelniach w wolnej Polsce, wobec prób ograniczania udziału Żydów w życiu społecznym Polski, wobec włoskiego faszyzmu z jednej strony, a bolszewickiej dyktatury z drugiej. Także potępienie wszelkich odmian „syjonizmu”, który to termin Baudouin stosował jako określenie każdej ideologii państwa etnicznie jednolitego, manifestującej się w hasłach w rodzaju Rosja dla Rosjan, Polska dla Polaków... Wreszcie niezgoda na klerykalizacje życia w wolnej Polsce, ale także protest przeciw przymusowej ateizacji społeczeństwa w Rosji bolszewickiej.

W poszanowaniu człowieka i jego praw przyrodzonych jest też źródło poglądów Baudouina na wolność wyznania, niezgoda na brak wolności w tej sferze i na zmuszanie ludzi do fałszywych zachowań, na deklarowanie prawdziwej lub rzekomej przynależności wyznaniowej, wymuszane przez administrację państwową, kościół lub przez środowisko. Ten wątek jest w rozmaitych pismach Baudouina niezmiernie interesujący. Otóż pozostając poza jakimkolwiek wyznaniem, Baudouin nie walczył z religią, widząc w niej środek do zaspokajania ludzkich, najbardziej intymnych potrzeb psychicznych i sposób czynienia ludzi lepszymi - rzecz jasna myślał tu o religijności autentycznej, a nie deklaratywnej.

Religię uznawał za potrzebę ludzką, a więc prawo swobodnego jej wyboru i wyznawania tej czy innej wiary trzeba szanować i trzeba go bronić, niezależnie od własnych poglądów na istnienie czy nieistnienie Boga. Nie ma tu sprzeczności miedzy bezwyznaniowością Baudouina i jego antyklerykalizmem, a angażowaniem się w obronę praw wierzących. To jest konsekwencja wyznawanej przez niego ogólnej zasady, że jeśli jakiekolwiek prawa człowieka są naruszane, należy przeciw temu protestować, w imię wolności i godności człowieka. Sam Baudouin wyraził to w taki oto sposób: 
Chociaż sam osobiście stoję poza wszelkimi wyznaniami sankcjonowanymi i legalizowanymi, to jednak, szanując godność człowieka i jego prawo być tym, czym chce, broniłem wierzących katolików przeciwko zamachom na nich ze strony prawosławnych, broniłem wierzących prawosławnych przeciwko katolikom, wierzących żydów przeciwko zamachom ze strony prawosławnych lub katolików. Każdy z tych wierzących chciał mieć swego boga wyznaniowego, nie zaś boga przemocą narzuconego [Komu i na co potrzebny jest Bóg?, „Myśl Wolna” 1925, nr 1].

Jeśli w sprawach wyznaniowych Baudouin wypowiadał się krytycznie, to dotyczyło to po pierwsze fałszywej, płytkiej religijności, motywowanej względami oportunistycznymi, po drugie samej instytucji Kościoła katolickiego (w którym widział konglomerat najgorszych cech judaizmu i cesarskiego Rzymu), instytucji tłumiącej myśl wolną oraz wymuszającej fałszywą religijność, manifestującą się czysto deklaratywnym tylko traktowaniem Dekalogu. Religia zinstytucjonalizowana, a jeszcze znajdująca oparcie we władzy państwowej, z natury rzeczy demoralizuje ludzi. Stąd postulat oddzielenia Kościołów od państwa, które powinno być pozawyznaniowe.

To jednak było powodem, dla którego w opinii środowisk klerykalnych Baudouin został uznany za wroga religii w ogóle, a polskiej wersji katolicyzmu w szczególności, a dalej polskości - stereotypowo, a przez Narodową Demokrację programowo - utożsamianej z katolicyzmem (unarodowienie wyznaniowości i uwyznaniowienie narodowości). Można tylko dodać, że podobnej kwalifikacji doczekali się w odpowiednim czasie m.in. także prof. J. S. Bystroń za Megalomanie narodowa i T. Boy-Żeleński za swoją publicystykę, a także uczeń i przyjaciel Baudouina, profesor Uniwersytetu Poznańskiego Henryk Ułaszyn.

Osobną sferą są poglądy Baudouina na literaturę i jej funkcję, które szczególnie wyraźnie przedstawił w Krzewicielach zdziczenia. I pod tym względem różnił się Baudouin od swych współczesnych, bowiem nie wyznawał kultu poezji wieszczów, a więc tej, która wychowywała pokolenia pod zaborami, wspóttworząc narodowe mity mącące umysły. Z kolei nowa literatura z jej naturalizmem, szerzyła, 
zdaniem Baudouina, zdziczenie wątkami erotycznymi i batalistycznymi lub sprzyjała pokrętnej filozofii i rozważaniu ciemnych stron ludzkiej duszy (tu wskazywał np. na H. Sienkiewicza, S. Żeromskiego, F. Dostojewskiego, L. Andrejewa, E. Zolę). Od pisarzy oczekiwał poczucia etycznej odpowiedzialności przed czytelnikiem za to, co mu proponują. W parze $\mathrm{z}$ artyzmem nie może iść zanieczyszczanie wyobraźni czytelnika, deprawowanie go. Dlatego cenił twórczość np. L. Tołstoja, I. Turgieniewa, M. Sałtykowa-Szczedrina, E. Orzeszkowej ${ }^{1}$, których dzieła, w jego ocenie, sprzyjały doskonaleniu moralnemu człowieka.

Był Baudouin indywidualistą i wolnomyślicielem konsekwentnym na tyle, że za cechę prawdziwego wolnomyślicielstwa uznawał niewiązanie się z żadnymi organizacjami, także... z organizacjami wolnomyślicieli.

Kilkakrotnie zaangażował się jednak w działalność zorganizowaną. W 1905 r. brał udział w pracach koła rodziców gimnazjum petersburskiego, do którego chodziły jego córki, na rzecz reformy szkolnej, a także należał do tych profesorów uniwersyteckich, którzy domagali się umożliwienia kobietom studiowania. W tym samym czasie związał się z liberalną partią konstytucyjnych demokratów (kadetów), był, co prawda krótko, jej członkiem i delegatem na zjazd, działał (także jako jeden z założycieli) w Związku Autonomistów-Federalistów. (Będzie potem pisał w listach o niepotrzebnie straconym czasie).

W wolnej Polsce związał się z ruchem wolnomyślicielskim. Był redaktorem (1925) „Myśli Wolnej”, póki nie doszło do konfliktu z grupą komunistów kierowaną przez Jana Hempla. Ci ostatni zwalczali Baudouina za... odgradzanie sie od mas i za odgraniczanie sie od klasy robotniczej, a w końcu doprowadzili do uchwalenia wobec

1 Na temat stosunku Baudouina do literatury zob.: J. K u l c z y c k a - S a l o n i 1978, 1984; Z. Saloni 1971; B. Białokozowicz 1980a, 1980b, 1980c, 1985, 1999, 2001, 2002, 2003. 
niego wotum nieufności, co ostatecznie spowodowało, że Baudouin wycofał się z redakcji i z ruchu' ${ }^{1}$.

W liście do adwokata lwowskiego i działacza PPS, Rafała Bubera, pisał Baudouin o tej sprawie:

Na zebraniu dorocznym Stow. Wolnom. Polskich (zjazd krajowy delegatów) dostałem od znacznej większości podwójne votum nieufności: raz wraz z całym Zarządem jako jego członek i przewodniczący, a po wtóre osobiście jako redaktor „Myśli Wolnej”. Wobec tego wypuszczam jeszcze tylko jeden numer, 4-ty, kwietniowy, a potem nie będę miał z tym pismem nic do czynienia. Przechodzi ono w ręce partyjników zwolenników „myśli karnej i zorganizowanej”, będącej antytezą „myśli wolnej”. Prócz tego występuje w ogóle z tego Stowarzyszenia, które będzie stowarzyszeniem „wolnomyślicieli” w cudzysłowie, w znaczeniu ironicznym [List z 18 IV 1925 r.]

Nie znosząc myślenia stadowego, chronił Baudouin za wszelką cenę swą indywidualność.

1 Stowarzyszenie Wolnomyślicieli Polskich, założone (czy raczej reaktywowane) w 1920 r., zostało w 1928 r. rozwiązane przez władze. W tym samym roku powstał Polski Związek Myśli Wolnej, w którego zarządzie był m.in. prof. Tadeusz Kotarbiński. Organem Związku był dwutygodnik „Wolnomyśliciel Polski”, gdzie Baudouin zamieszczał swoje artykuły w 1928 i 1929 r. Publikował także w miesięczniku naukowo-literackim „Życie Wolne”, wychodzącym od 1927 r., wokół którego skupiła się grupa zwolenników liberalnego skrzydła PZMW, nazywana „baudouinowcami”. W latach 30. zarząd PZMW powołał Towarzystwo Przyjaciół Szkoły Świeckiej im. prof. Jana Baudouina de Courtenay.

2 Dodać trzeba, że rosyjskich zwolenników owej myśli karnej $i$ zorganizowanej Baudouin miał okazję widzieć w działaniu w okresie rewolucji bolszewickiej w Piotrogrodzie. W 1921 roku Baudouin opublikował w wychodzącym w Warszawie czasopiśmie ukraińskim „Syn Ukrainy” (nr 5-6) artykuł pt. Diktatura proletariata nad naukoju, w którym postępowanie bolszewików wobec nauki i naukowców określił jako działania ...bolszewickich tyranów, despotów i katów - potworów zmieniajacych święta nauke w swoja prostytutke. (przekł. M.S., cytuję za: B. B i a ł o k o z 0 w i c z 2002, S. 101). 
Podstawy poglądów Baudouina nie zmieniały się, stanowiąc mocny fundament publicystycznej i społecznej działalności uczonego. Równie stałe były: ogromna skrupulatność w ocenianiu postępowania swojego i innych, a także nieodparty, wewnętrzny przymus głośnego mówienia tego, co uznawał za słuszne i prawdziwe, w sposób wyraźny i dosadny, bez względu na konsekwencje.

Ale w parze z tymi cechami szła jednocześnie tolerancja dla poglądów odmiennych, także dla tych, które go irytowały, a nawet widoczna chęć zrozumienia ich. Manifestowanie własnych poglądów nie oznaczało dla Baudouina próby ich narzucania komukolwiek. Nie sądzę zresztą, by wierzył w skuteczność uprawianej przez siebie „pedagogiki społecznej”. Pisał, bo uważał, że nie może milczeć. Tytuł jednego z artykułów, Nie wolno kalać ust milczeniem, jest dobrym mottem jego publicystyki, zaś wyrazy oportunizm i oportunistyczny można uznać za stojące na czele listy słów kluczy jego tekstów. Ale trzeba też zwrócić uwagę na bardzo ważną cechę postawy Baudouina polemisty, nie tylko dlatego, że wnosi ona wiele do zrozumienia samego autora, ale także dlatego, że nie jest ona, mówiąc najłagodniej, zbyt często spotykana.

OtodlaBaudouina przeciwnik jest przede ws zystki m te ż c złowieki e m, mającym takie samo prawo do wolności myśli i do wolności ich głoszenia. Stąd czytamy w jednym z tekstów: Przeciwnik ideowy niekoniecznie jest wrogiem.

Był Baudouin de Courtenay bez wątpienia publicystą ostrym, głoszącym prawdy niepopularne, co - zwłaszcza w społeczeństwie żywiącym się mitami, kompleksami i urazami - musiało przysparzać mu już nie tylko przeciwników, ale wręcz wrogów, zwłaszcza wśród posiadaczy patentów na prawdę jedyną, zawodowych obrońców wiary i polskości. Musiał drażnić ostentacyjnie podkreślany indywidualizm, niechęć do myślenia stadowego, nieidentyfikowanie się więc z popularnymi postawami, wreszcie bezlitosne demaskowanie kierujących myśleniem stereotypów, wokół których buduje się ideologie, wiodące w ostatecznym rozrachunku do wojen i rewolucji. Innych drażnił zapewne piętnowaniem oportunizmu. Stąd napaści na niego, o których wspomniałem wcześniej, ale przecież i Bolesław Prus, daleko łagodniejszy w swej publicystyce od Baudouina, nie uszedł „karzącej ręki” 
myślących „patriotycznie” przedstawicieli młodzieży, co przypłacił zdrowiem. A i historia międzywojennego dwudziestolecia dostarcza smutnych przykładów użycia argumentów siły, zamiast siły argumentów wobec ludzi piszących rzeczy niepopularne.

Można powiedzieć, że tak w życiu naukowym, jak i w życiu społecznym stosował Baudouin zasadę zawierającą się w przysiędze doktorskiej - non ad vanam gloriam, sed quo magis veritas propagetur.

W przywoływanym już biogramie Baudouina de Courtenay znajdujemy takie oto zdanie Kazimierza Nitscha:

Baudouin de Courtenay całe życie walczył o prawdę, tak w nauce jak i w życiu [...]. Wybitny intelektualista, może sobie czasem tę prawdę zbyt prosto wyobrażał, ale nigdy nie kierował się żadnym osobistym interesem, nigdy własną ambicją, zawsze gotów do uznania swej pomyłki. A że walczył w życiu gorąco, miał gorących wielbicieli, ale też w pewnych okresach i w pewnych sferach jeszcze bardziej zawziętych wrogów, niemogących się wznieść do sprawiedliwej jego oceny i wprost wyrządzających mu krzywdy. [...] Społecznie radykalny, religijnie i narodowo gorący obrońca wszelkich szczerych przekonań, namiętny wróg wszelkiego prześladowania ludzi za ich idee. [...] Epoka 63-go roku i jej odczute na własnej skórze następstwa nastawiły go bezwzględnie wrogo do wszelkich prześladowań: stał się bezkompromisowym obrońcą wszelkich nierównouprawnionych mniejszości, m.in. żydowskiej i ukraińskiej; oczywiście i polskiej, nie dopuszczając jednak odbijania swych krzywd na innych [Nitsch 1935, s. 361].

$$
* * *
$$

Niniejszy wybór tekstów publicystycznych Baudouina de Courtenay zawiera te z nich, które - jak przypuszczam - dadzą dobre wyobrażenie o jego poglądach moralnych, społecznych, politycznych. Warto chyba przypomnieć i przybliżyć jednego z najlepszych przedstawicieli generacji, która formowała postawy inteligencji polskiej następnych dziesięcioleci. A choć na skutek późniejszych „figli” historii ta war- 
stwa przestała być tym, czym była, to jednak cechy, które decydowały o byciu inteligentem, są warte przypomnienia i zachowania.

Spośród spraw wypełniających publicystykę Baudouina jedne nigdy nie znikły z polskiego życia, inne zaś gdzieś w zaciszu przeczekały zakręty dziejowe i powróciły (niekoniecznie mutatis mutandis) w naszych czasach.

Bohdan Cywiński, autor Rodowodów niepokornych, książki o postawach polskich inteligentów przełomu XIX i XX wieku, w artykule Inteligencji nekrologi przedwczesne napisał następująco:

Inteligencja istnieje przede wszystkim przez swe idee, przez wartości, które budzą jej zbiorowe uznanie i które ją niejako skupiają. Model tej społeczności rysowałbym więc poniekąd koncentrycznie, w centrum umieszczając nieco przymglony, ale co chwila inaczej przebłyskujący zbiór wartości. Wartości różnych, zaczerpniętych Z rozmaitych systemów, rzadko sformułowanych jednoznacznie i precyzyjnie, raczej już intuicyjnie odczuwanych i przywoływanych w postaci symboli. Znajdą się wśród nich treści moralności uniwersalnej, humanistycznej, wielki oświeceniowy mit wolności, przekonania odnoszące się do takiej czy innej utopii społecznej, takiej czy innej tradycji patriotycznej, terytorialnej, socjalnej czy ideowej, przejawy kultu nauki, oświaty i postępu, wzniośle abstrakcyjne zasady filozoficzne i najprostsze reguły stosunków międzyludzkich, codziennym językiem napominające, żeby nie być świnią, egoistą czy prymitywnym chamem [Cywiński 2000].

Gdzieś w tym modelu odnaleźć można także Baudouina de Courtenay.

$* * *$

Kilka z umieszczonych tu tekstów weszło już do VI tomu Dziet wybranych, wydanego w 1984 r., jednak są one tak reprezentatywne i ważne dla publicystycznego nurtu twórczości Baudouina, że siłą rzeczy muszą się znaleźć w każdym wyborze prac publicystycznych tego autora. Ponadto są w nich uwagi, które mimo czasu, jaki upłynął 
od chwili ich napisania, nie straciły aktualności, co w wielu wypadkach konstatuje się z pewnym, smutnym raczej zdziwieniem.

Całość tekstów podzielono na trzy części, kierując się pokrewieństwem tematyki: część I - zagadnienia moralności społecznej; część II - kwestie narodowościowe; część III - sprawy wyznaniowe i światopoglądowe. Dział IV - Teksty drobniejsze - zawiera kilka tekstów gazetowych z lat 20., które wybrano dla uzupełnienia sylwetki Baudouina publicysty. Nawiasem mówiąc, te drobniejsze teksty, w tym też felietony, warte są opublikowania w większym wyborze, zwłaszcza że wiele z nich ze względu na zawarte tam poglądy i oceny dopiero obecnie (po 1989 r.) mogą być powtórnie opublikowane.

W obrębie poszczególnych części teksty ułożone są w porządku chronologicznym, co pozwoli lepiej prześledzić poglądy ich autora.

Niniejsza edycja nie miała być edycją źródłową, tak więc, chcąc ułatwić współczesnemu czytelnikowi odbiór tekstów, zmodernizowano pisownię i interpunkcję (także kilkunastu zapisów rosyjskich), z wyjątkiem kilku przypadków, gdzie odbiegająca od dzisiejszej normy pisownia odbija cechy języka Baudouina.

Teksty zostały opatrzone przypisami, które mają ułatwić orientację w postaciach i faktach. Być może niektóre z nich wielu czytelnikom wydadzą się zbędne, dla innych jednak podane w nich objaśnienia mogą okazać się pomocne.

Przypisy pochodzące od autora wyboru podaje się bez oznaczenia, natomiast przypisy autorstwa samego Baudouina oznaczono: [przyp. BdeC], a przypisy redakcji „Krytyki” - [Red. „Krytyki”].

Przypisy biograficzne połączono z indeksem nazwisk. Rzecz jasna nie objaśnia się nazwisk ogólnie znanych, jak Żeromski, Zola itp.

Serdecznie dziękuję recenzentom niniejszego wyboru, Pani doc. dr hab. Magdalenie Smoczyńskiej i Panu prof. dr. hab. Bogdanowi Szlachcie za życzliwe recenzje.

Szczególną wdzięczność winien jestem Pani Docent Magdalenie Smoczyńskiej za wszystkie rady, jakich mi nie szczędziła, rozmowy o Baudouinie i za użyczenie bodunenowskich materiałów ze zbiorów własnych. 


\section{LITERATURA}

(wybór)

B e š t a T. (oprac.), 1972: Listy J. Baudouina de Courtenay do A. Černego, Wroctaw.

B i a $10 \mathrm{k}$ o z ow i c z B., 1968: Jan Baudouin de Courtenay $i$ Marian Zdziechowski, „Przegląd Humanistyczny”, nr 2.

B i a 10 k 0 z 0 w i c z B., 1980a: Jan Baudouin de Courtenay wobec literatury rosyjskiej, „Przegląd Rusycystyczny”, z. 3.

B i a 10 k o z ow i z B., 1980b: Jan Baudouin de Courtenay o Dostojewskim, „Slavia Orientalis”, $\mathrm{nr}$ 1/2.

B i a 1 o k o z 0 w i z B B., 1980c: Jan Baudouin de Courtenay o Puszkinie, ,Slavia Orientalis”, nr 3.

B i a 10 k 0 z ow i c z B., 1985: Literatury stowianskie w oczach Jana Baudouina de Courtenay, [w:] Fiodor Dostojewski. W setna rocznice śmierci, Rzeszów, s. 71-112.

B i 1 0 k o z ow i z B., 1999: Lew Totstoj w oczach Jana Baudoina de Courtenay, [w:] Oblicza wschodu w kulturze polskiej, red. G. K 0 t l a r s k i, M. F i g u r a, Poznań, s. 143-163.

B i a $10 \mathrm{k} 0 \mathrm{z} 0 \mathrm{w}$ i c z B., 2001: I. A. Boduen de Kurtene i L. Totstoj (istorija odnoj nieopublikowannoj statii), ,Lingwisticzeskij jeżegodnik Sibiri”, Wypusk 3, Krasnojarsk.

B i a $10 \mathrm{k} 0 \mathrm{z} 0 \mathrm{w}$ i c z B., 2002: Gumanisticzeskije aspiekty tworczeskogo nasledija I. A. Boduena de Kurtene. Istorija w zierkale litieratury i litieraturowiedenija. Sbornik doktadow mieżdunarodnoj naucznoj konfierencii awgust 2001 g. Gdansk, Gdańsk, s. 81-109.

B i a 10 k 0 z 0 w i c z B., 2003: Z polskiej karty Lwa Totstoja. Nowe $i$ zapomniane o Totstoju i jego percepcji w Polsce, Olsztyn. [Rozdział: Lew Totstoj w percepcji J. Baudouina de Courtenay].

Cy w i ń s k i B., 2000: Inteligencji nekrologi przedwczesne, „Rzeczpospolita" z 22 IV.

D a t n e r H., Tożsamość inteligencji żydowskiej w XIX wieku. http:// www.midrasz.pl/2002/maj/maj02_1.html

D o r o sze w sk i W., 1972: Jan Baudouin de Courtenay na tle swej epoki i jako prekursor nowych pradów w jezykoznawstwie, „Slavia Orientalis", $\mathrm{nr} 1$. 
D o r o s z e w s k i W., 1974: Jan Baudouin de Courtenay-jezykoznawca $i$ myśliciel, [w:] J. B a u dou in de Courtenay, Pisma wybrane, t. 1., Warszawa, s. 9-97.

Fa 1 k 0 w i c z S., 1991: Udziat Jana Niecistawa Baudouina de Courtenay w życiu spoteczno-politycznym Rosji na poczatku XX wieku, [w:] Dziatalność dydaktyczna i spoteczno-polityczna Jana Niecistawa Baudouina de Courtenay w Rosji, pod red. J. R ó z i e w i c z a, Wrocław, s. 139-163.

K u l c z y c k a - S a l o n i J., 1978: Jan Baudouin de Courtenay, profesor Uniwersytetu Warszawskiego, kandydat na pierwszego prezydenta Rzeczypospolitej Polskiej, „Przegląd Humanistyczny”, nr 11.

Ku l c z y c k a - S a l o n i J., 1984: Jan Baudouin de Courtenay jako publicysta, [w:] J. B a u d o u in de C o u r ten a y, Pisma wybrane, t. 6, Warszawa, s. 7-32.

K r u k o w s k a H., 1989: Postawa etyczna Jana Baudouina de Courtenay jako uczonego, [w:] Jan Niecistaw Baudouin de Courtenay a lingwistyka światowa. Materiaty z konferencji miedzynarodowej Warszawa 4-7 IX 1979, pod red. J. R i e ge r a, M. S z y mc z a k a, S. U r b a ń c z y k a, Wrocław, s. 523-528.

L e b i e d z i ń s k i W., 1978: Polska myśl laicka okresu międzywojennego, „Człowiek i Światopogląd”, nr 8/9.

M a ł a c h 0 w s k a E., 1973: Jan Baudouin de Courtenay w życiu prywatnym (wspomnienia o moim ojcu), „Przegląd Humanistyczny”, $\mathrm{nr} 3 ; \mathrm{nr} 5$.

M a 1 a ch ow s k E., 1976: Stosunek profesora do stuchaczy $w$ ich wspomnieniach, „Poradnik Językowy”, z. 1.

M u g d a n J., 1984: Jan Baudouin de Courtenay (1845-1929). Leben und Werk, München. [Rozdział Lebenslauf und Persönlichkeit].

N it s c h K., 1935: Baudouin de Courtenay Jan, [w:] Polski stownik biograficzny, t. 1, Kraków, s. 359-362.

P u l l a t R., 2004: Briefwechsel zwischen Jan Baudouin de Courtenay und Jooseppi J. Mikkola aus Jahren 1898-1926, herausgegeben von... in Zusammenarbeit mit M. S m o c z y ń s k a, Kraków, PAU, Studien und Materialen zur Geschichte der Polnischen Akademie der Wisseschaften und Künste. 
R 0 t h s t e in R. A., 1976a: Dziatalność spoteczna Jana Baudouina de Courtenay, „Poradnik Językowy”, nr 1.

R oth ste in R. A., 1976b: Poprawki $i$ dodatki do "Bibliografii prac Jana Ignacego Baudouina de Courtenay”, „Poradnik Językowy”, nr 1.

R oth ste in R. A., 1989: Jednostka ludzka jako motyw przewodni twórczości Jana Baudouina de Courtenay, [w:] Jan Niecistaw Baudouin de Courtenay a lingwistyka światowa..., s. 529-537.

R u s e k J., 1989: Krakowski okres dziatalności Jana Baudouina de Courtenay, [w:] Jan Niecistaw Baudouin de Courtenay a lingwistyka światowa..., s. 603-608.

S a 10 n i Z., 1971: Jan Baudouin de Courtenay a poetyka formalistów, „Pamiętnik Literacki”, R. 62, z. 1.

S t a c h u r sk i E., 1989: Listy Jana Baudouina de Courtenay, [w:] Jan Niecistaw Baudouin de Courtenay a lingwistyka światowa..., s. 625-646.

S t a churski E. (oprac.), 2002: J. N. B a ud ou in de Courten a y. Listy z lat 1870-1927 opracowat..., Kraków.

S t a n k i e w i c z E., 1986: Baudouin de Courtenay a podstawy wspótczesnego jezykoznawstwa, Wrocław.

S z u l k in M., 1978: Baudouin de Courtenay - uczony i wolnomyśliciel, „Człowiek i Światopogląd”, nr 12.

Uł a s zy n H., 1934: Jan Baudouin de Courtenay. Charakterystyka ogólna uczonego i cztowieka (1845-1929), Poznań.

U ł a s z y n H., 1935: W sprawie światopogladu J. Baudouin de Courtenay, „Język Polski”, 35, s. 233-235.

U r b a ń c z y k S., 1989: Życie i naukowa droga Jana N. Baudouina de Courtenay, [w:] Jan Niecistaw Baudouin de Courtenay a lingwistyka światowa... 


\section{I \\ JEDEN Z OBJAWÓW MORALNOŚCI OPORTUNISTYCZNO-PRAWOMYŚLEJ}

Wystaw sobie, czytelniku, że jako obcokrajowiec lub nawet obcopaństwowiec nieobznajomiony ze zwyczajami miejscowymi osiedlasz się w jednym z miast galicyjskich, dajmy na to we Lwowie lub w Krakowie. Najmujesz sobie tedy mieszkanie, za które, według umowy z właścicielem domu, obowiązujesz się płacié, przypuśćmy, 500 złr rocznie. Kiedy już zapłaciłeś pierwszą ratę kwartalną i oddajesz się pesymistycznemu złudzeniu, że mieszkania bądź co bądź są tu dosyé drogie, zjawia się u ciebie właściciel domu z księgą „fasji”, służącą za podstawę do „wymierzania” podatku dochodowego, i każe ci stwierdzić własnoręcznym podpisem, równoważnym przysiędze, że płacisz za mieszkanie weale nie $500 \mathrm{złr}$, ale np. 350, 300, 250 lub nawet tylko 200 złr. Jako nowicjusz do galicyjskich kłamstw procederowych nieprzywykły, a tym co najmniej dziwnym wymaganiem oszołomiony, zapytujesz, co to ma znaczyć. Gospodarz objaśnia, że tu taki zwyczaj, że wszystkie mieszkania oceniane są na piśmie daleko niżej, aniżeli rzeczywiście przynoszą dochodu. Tak poinformowany albo ustępujesz od razu, albo też odmawiasz na razie podpisu, wymagając pewnego czasu do namysłu i do dokładniejszego zorientowania się w położeniu. Na to właściciel domu oświadcza ci w sposób - stosownie do swego temperamentu - mniej lub więcej uprzejmy, że rób, jak chcesz, ale że ostatecznie będziesz musiał podpisać, bo inaczej zostaniesz wyrzucony z mieszkania; a jak się dowiedzą, za co zostałeś wyrzucony, nie znajdziesz przytułku nie tylko w całym mieście, ale nawet w całym kraju.

Udajesz się tedy do przyjaciót i znajomych i prosisz ich 0 wyjaśnienie. Przyjaciele i znajomi pouczają cię, że gospodarz twój ma zupełną słuszność, że „najporządniejsi” i „najzacniejsi” ludzie tutaj mieszkający tak z gatunku właścicieli domów, jako też z gatunku lokatorów, podają fałszywą fasję i że się tym nikt a nikt nie gorszy. Rzekomą zaś przyczyną tego sportu ma być wysoka stopa podatkowa. 
Usłyszawszy takie dictum acerbum, a nie należąc do kategorii „bohaterów”, zdecydowanych iść przebojem 0 głodzie i chłodzie, godzisz się ze swoim losem; przekonawszy się zaś, że w Galicji możesz mieszkać tylko jako kłamca i krzywoprzysiężca, już bez szemrania podpisujesz fałszywą fasję i stajesz się jeżeli nie czystej krwi, to przynajmniej czystego sumienia Galicjaninem.

Ponieważ jednak nawet moralnie zasymilowany obywatel galicyjski nie traci zdolności myślenia od czasu do czasu, więc też i w twojej głowie zjawiają się kiedy niekiedy niepokojące wątpliwości i myśli buntownicze w tym np. rodzaju:

Jeżeli przyczyną fałszywej fasji jest wysoka stopa podatkowa od dochodu z nieruchomości - a stopa ta jest istotnie potworna, bo dosiegga podobno aż $45 \%$ od dochodu brutto - to czy nie lepiej byłoby zniżyé stopę, a w zamian za to podawać prawdziwy dochód? Przecież $45 \%$ od kłamliwie podawanych 300 złr toć to zupełnie to samo, co 27\% od istotnie ściąganych $500 \mathrm{ztr}$. Istotnie to samo, ale przecież na tym to właśnie polega cały dowcip owego "prawa zwyczajowego", że daje możność uprawiania z dobrym skutkiem ulubionego sportu oszukiwania skarbu, a takiej taniej i łatwej do urzeczywistnienia przyjemności broniący „istniejącego porządku” obywatel nigdy sobie nie odmówi.

Prócz tego zwyczaj fałszywej fasji pozwala organom „wymierzającym" grać rolę miecza damoklesowego wiszącego nad głowami „kamieniczników”, którzy skutkiem tego są w stanie ciągłego podniecenia i doznają lubieżnego dreszczu ryzyka, owego dreszczu właściwego namiętnym graczom i ludziom trzymającym zawzięcie na loterii. Jeżeli kamienicznik jest jednocześnie dygnitarzem „wymierzającym” albo też jakąś inną osobą szczególnie uprzywilejowaną, to podana przez niego fasja pozostaje nietkniętą. Biada jednak kamienicznikom z gatunku zwykłych śmiertelników, a zwłaszcza kamienicznikom, z tego lub owego powodu „źle widzianym”. Z „fasjami” takich panów organa „wymierzające” obchodzą się bez ceremonii. Podane przez nich np. 250 lub 300 złr najspokojniej się przekreśla i zamienia się, np. na 400 lub 450, tak sobie od oka, według chwilowego kaprysu. Danemu kamienicznikowi przykro to bardzo, nie tyle może ze względów moralnych - chociaż okazywanie urzędowego niezaufania w ten dość oryginalny sposób powinno by boleśnie dotykać, ile raczej ze wzglę- 
dów czysto kieszeniowych. Co innego bowiem jest płacić 45\% od 250 lub 300, a co innego płacić taki sam procent od 400 lub 450. Pomimo to nikt nie protestuje, bo... do grzechu się poczuwa i wie, że gdyby zaczął się prawować, wdrożono by śledztwo i dowiedziono by mu, że oznaczona przez organa „wymierzające” stopa dochodowa jest jeszcze choć trochę niższa od dochodu rzeczywistego.

Nie da się zaprzeczyé, że i postępowanie organów „wymierzających" jest co najmniej dziwne. Przypomina ono owo swawolne przekomarzanie się z damami, które po 30 latach do tego stopnia tracą pamięć, że za nic nie mogą określić swego wieku; dlatego też do podanej przez nie same sumy dodaje się z zasady lat kilka. Taki „flirt” salonowy nie narusza niczyich interesów, oprócz chyba interesów prawdy bezwzględnej; natomiast 0 wiele mniej chwalebnym jest ów wzmiankowany dopiero co „flirt” fiskalny. Jeżeli się kogoś podejrzewa o fałszywe podanie dochodu, to należy zbadać tę sprawę i dojść do prawdy drogą obiektywną. Dowolne zaś powiększanie cyfry cudzego dochodu, powiększanie tak sobie od oka jest równoznaczne z zarzutem oszustwa. Co jednak robić, jeżeli „prawo zwyczajowe” upoważnia do uważania wszystkich obywateli galicyjskich za oszustów?

Ale czyż tylko galicyjskich? Przecież chyba to samo ma miejsce przynajmniej w całej Austrii? Otóź właśnie, że nie.

I w innych prowincjach Austrii stopa podatkowa od dochodu domowego woła 0 pomstę do nieba, i w innych prowincjach dochodzi ona do $45 \%$, a jednak fasja nie ulega tam fałszowaniu. Już w pogranicznym Śląsku - chociaż to przecież także prowincja przynajmniej w połowie polska - nie ma nic podobnego. Za to w innych prowincjach Austrii wiedzą o tym zwyczaju galicyjskim i może go nawet w cichości ducha zazdroszczą. W Wiedniu istnieje osobny termin na określenie moralności fiskalnej Galicji: tarnopoler Moral. Dlaczego jednak tarnopoler? Dlaczego np. nie lemberger, nie krakauer, dlaczego wreszcie nie po prostu galizische Moral? W każdym razie można byé z tego dumnym; przecież ex Oriente lux.

I zapewne muszą być dumni z tego nie tylko zwykli śmiertelnicy, ale także ich patentowani stróże urzędowi i „moralni”. Istnieje przecież kilka rodzajów władz obowiązanych bądź to do przeszkadzania nadużyciom i naruszaniu prawa”, bądź też do pociągania do od- 
powiedzialności „moralnej” za grzechy popełniane. Istnieją przecież władze skarbowe, istnieją władze sądowe, istnieje duchowieństwo.

Tak, rzeczywiście istnieją. Ale urzędnicy skarbowi nie mają prawa moralnego do zarządzania dochodzeń administracyjnych w sprawie „fałszywej fasji”, bo sami muszą ulegać temu prawu zwyczajowemu; bo gdyby mu nie ulegali, nie mogliby mieszkać w Galicji, z wyjątkiem chyba gmachów rządowych. Prokuratorowie i sędziowie nie mają prawa moralnego ani do wdrażania śledztwa i wytaczania podobnych spraw, ani też do sądzenia winnych „fałszywej fasji”, bo sami muszą jej ulegać, bo gdyby stawili jej czoło, nie mogliby mieszkać w Galicji, z wyjątkiem chyba gmachów rządowych. Księża nie mają prawa moralnego do potępiania tego rodzaju grzechów, bo sami muszą je ciągle popełniać; bo, gdyby ich nie popełniali, nie mogliby mieszkać w Galicji, z wyjątkiem chyba klasztorów i gmachów publicznych. Jednym słowem powinniśmy pamiętać, że tak urzędnicy skarbowi i sądowi, jako też księża muszą z małymi wyjątkami należeć albo do kategorii właścicieli domów, albo też do kategorii lokatorów; a, jak wiadomo, noblesse oblige.

Fałszywa zaś fasja - to „obowiązek społeczny” ,wolnego obywatela galicyjskiego".

Ale czyż fałszywa fasja jest naganną z ogólnie ludzkiego stanowiska, ze stanowiska tak zwanej „moralności”? Wprawdzie nie znajdujemy jej ani w dekalogu, ani w żadnym z katechizmów, ani też w innych klasyfikacjach uchybień ludzkich przeciw moralności rozwijanej na tle wyznaniowym. Nic to dziwnego, boć „fałszywa fasja" należy do najnowszych zdobyczy cywilizacyjnych, a katechizmy i inne tp. kompendia grzechoznawcze opierają się na kodyfikacjach starożytnych. Nie ma też w owych księgach mowy nawet o prostym kłamstwie i oszustwie. Za to jest tam mowa 0 „fałszywym świadectwie", blisko spokrewnionym z kłamstwem i oszustwem. Po co nam zresztą wyszukiwanie autorytetów tradycyjnych? Że fałszywa fasja jest „grzechem” i w ogóle czynem niemoralnym, 0 tym mówi każdemu człowiekowi sumienie, oczywiście o tyle, 0 ile je posiada, tj. o ile go nie zastawił lub nie stłumił. 
Nie tak to dawno, jak jeden $\mathrm{z}$ najpoważniejszych historyków polskich ${ }^{1}$ odzywał się $\mathrm{z}$ wielkim lekceważeniem 0 narodowościach niemowlecych w rodzaju Stowaków, Słowieńców, Serbów, Bułgarów, Albańczyków itd. Pod tym względem zeszedł się on z jednej strony, ze znakomitym historykiem niemieckim Teodorem Mommsenem, nawołującym swych „cywilizowanych” rodaków do kruszenia czaszek barbarzyńców słowiańskich, z drugiej zaś strony z Niemcami w parlamencie wiedeńskim, wyrażającymi pogardę dla Tschechen, Slovenen und andere minderwertige Nationalitäten ${ }^{2}$. Nawiasem mówiąc, mylą się panowie od miejscowego konserwatyzmu, twierdząc, że do tych minderwertige Nationalitäten Niemcy nie śmieliby zaliczyć także Polaków. Jeżeli bowiem tego wyraźnie nie uczynili, to tylko przez wdzięczność za gorliwe współdziałanie w zaprowadzeniu przed paru laty stanu oblężenia w Pradze ${ }^{3}$ i za inne tp. usługi. Ale niech i tak będzie, jak sądzą panowie „konserwatyści”. Istotnie Stowacy, Stowieńcy... powinni byé zaliczeni do narodowości niemowlęcych, bo nie doszli jeszcze do prawa zwyczajowego fałszywej fasji, bo na to, ażeby uprawiać na zimno ten sport fiskalny, potrzeba - nie „niemowlęctwa" moralnego - ale zupełnej zgrzybiałości moralnej i pewnej dozy cynizmu. Zresztą cynizm kieruje polityką, a panowie z Galicji są przede wszystkim politykami.

Wykarmiony moralnie na fałszywej fasji filister galicyjski podkpiwa sobie z łapownictwa urzędników rosyjskich. Zgoda; ale co lepsze, czy łapownictwo, praktykowane cichaczem i uważane za postępek mniej lub więcej hańbiący, czy też „fałszywa fasja”, podpisywana nawet przez „przodowników narodu”, podawanych na wzór cnót obywatelskich? Zresztą i co do lapownictwa mogliby wtajemniczeni powiedzieć to i owo, z tym tylko dodatkiem, że jedni mają zwyczaj,

\footnotetext{
1 Mowa 0 Józefie Szujskim.

2 Tschechen, Slovenen und andere minderwertige Nationalitäten
} (niem.) - Czechów, Słoweńców i innych mniej wartościowych narodowości.

$3 \quad$ W październiku 1868 r., po demonstracjach politycznych i starciach na ulicach Pragi, wprowadzono stan wyjątkowy. 
wziąwszy łapówkę, załatwić odnośny interes, drudzy zaś, choć każą sobie zapłacić, uważają jednak za właściwe wywieść w pole interesanta.

Praktykowanie fałszywej fasji musi rozwijać w obywatelach nie tylko najzupełniejszą apatię i obojętność na grosz publiczny, ale nawet wrogi do niego stosunek. Nigdzie może wyrażenie rosyjskie казна наш общий враг ${ }^{1}$ nie odpowiada tak dokładnie usposobieniu publiczności, jak właśnie w Galicji. Dowody tego spotykamy na każdym kroku, a najefektowniejszymi dowodami są wypadki owych „sprzeniewierzeń”, traktowanych z zimną krwią i pobłażliwie nie tylko przez zwierzchników przeniewierców, ale także przez tzw. opinię publiczną, 0 ile naturalnie dany wypadek nie nadweręża własnej kieszeni opiniującego osobnika. Ale jeżeli „skarb jest naszym wspólnym wrogiem”, a skarb jest jednym z atrybutów rządu i jedną z części składowych „istniejącego porządku”, to powinno się wyciągać dalsze konsekwencje i określać, zgodnie z wymaganiami logiki, swój stosunek do rządu i do „istniejącego porządku”.

$$
* * *
$$

Od czasu do czasu podnoszą się głosy oburzenia jednych na polecane jakoby przez drugich uprawianie tak zwanego „trójlojalizmu”, czyli „potrójnej lojalności”, tj. lojalnego stosunku do trzech „rządów zaborczych”. Otóż uspokójcie się panowie. Nie ma obawy o „trójlojalizm”, jeżeli nawet najprostszy, pojedynczy lojalizm jest rzeczą niedoścignioną. Bo jakiż to może być lojalizm, którego jednym z wyrazów jest fałszywa fasja? Lojalizm obywateli fałszujących swoje dochody i wydatki! Lojalizm urzędników zmieniających dowolnie podania obywateli!

W podobny sposób patrzyli niegdyś Węgrzy na swój stosunek do Austrii, kiedy odmawiali płacenia podatków. Ale Węgrzy nie udawali wówczas „lojalnych”; oświadczyli otwarcie: ,jesteśmy nieprzyjaciółmi państwa i dobrowolnie płacić mu nie będziemy”.

1 Skarb (fiskus) - to nasz wspólny wróg [przyp. BdeC]. 
Podobną też lojalność wobec Rosji uprawiali owi „patrioci” polscy, którzy za jeden z „uczciwych” środków walki uważali przed przeszło 30 laty podrabianie pieniędzy rosyjskich ${ }^{1}$. A jednak z ogólnego stanowiska było to uczciwsze od fałszywej fasji. Występowano otwarcie przeciwko „wrogowi”, nie łudząc go udaną „lojalnością”. Pomijam przy tym naturalnie krzywdę, jaką panowie podrabiacze pieniędzy wyrządzali Bogu ducha winnym ludziom, którym z jednej strony wsuwano podobne banknoty, a których z drugiej strony pociągano za to do odpowiedzialności.

$* * *$

Warunki, w których wychowuje się, wzrasta i żyje „wolny obywatel galicyjski”, są mniej więcej podobne do warunków życia w innych krajach, nie tylko austriackich, ale w ogóle europejskich. To samo przyuczanie od najmłodszych lat do kłamstwa i obłudy, do ukrywania się z własnym zdaniem; to samo zabijanie w zarodku wszelkiej krytyki; ta sama zależność od kaprysu wychowawców i zwierzchników; ta sama jednolita dla wszystkich tresura, pozbawiająca wszelkiej energii i osobistej inicjatywy; to samo lekceważenie w wychowaniu prywatnym i publicznym ducha praktyczności i przedsiębiorczości; to samo zagważdżanie głów bezmyślnymi bajkami; to samo marnowanie najlepszych lat na nadziewanie mózgownic skarykaturowanymi wiadomościami gramatycznymi i filologicznymi; to samo przepłukiwanie głowy pomyjami dziennikarskimi, tylko że w jeszcze podlejszym gatunku; to samo gołąbkowanie i kwilenie o „miłości bliźniego" z równoczesnym i oczywiście nierównie silniejszym wpajaniem nienawiści do innych „wyznań”, do innych narodowości, do innych „klas społecznych”; ta sama zaściankowość państwowa, narodowa, wyznaniowa i społeczna; ta sama w ogóle moralność konwencjonalna, na handlu zamiennym oparta, stadowo-egoistyczna, a nie

1 Aluzja do dekretu Rządu Narodowego z 25 VII 1863 r. z decyzją o wydrukowaniu polskich banknotów. Ostatecznie gotowych walorów nie puszczono w obieg, ale projekt ten stał się dla rosyjskiej propagandy powodem do oskarżania powstańców o fałszerstwo pieniędzy. 
indywidualnie-społeczna. Ale obok tych wszystkich „dobrodziejstw cywilizacji nowoczesnej” „wolny obywatel galicyjski” przy wstępie do życia samodzielnego spotyka uświęcony i powszechnie czczony zwyczaj fałszywej fasji. Ocknąwszy się w takiej zatrutej atmosferze moralnej, ,wolny obywatel galicyjski” zaraża się nią powoli, zaczyna ją uważać za całkiem zdrową i normalną, a wszelki przeciw niej protest za objaw naganny, za objaw karygodnego liberum veto. Podobnie w okolicach, w których wszyscy mieszkańcy mają wole pod gardłem, człowiek pozbawiony tej ozdoby musi uchodzić za kalekę.

Fałszywa fasja staje się jedną z „kategorii myślenia” „wolnego obywatela galicyjskiego", staje się jedną z teoretycznych podstaw jego „moralności społecznej”.

Na takim gruncie nierównie bujniej niż gdzie indziej wyrasta cały rój objawów, dla których wspólną nazwą kłamstwo i oszustwo. Z tak preparowaną moralnością publiczną doskonale godzi się moralnośé karciarzy, moralność pojedynkowiczów, moralność giełdziarzy, moralność fabrykantów i handlarzy świętości, moralność kuglarzy i faryzeuszów.

Na takim gruncie moralnym nierównie łatwiej niż gdzie indziej libertyni i cynicy podają się za podpory „rodziny, państwa i kościoła”, wyzyskiwacze ludu - za jego obrońców i opiekunów, robiący interesa na przedsiębiorstwach „filantropijnych” - za dobroczyńców ludzkości, uganiający się za władzą, wpływem i groszem - za bezinteresownych działaczy. Rozmaite ciemne i moralnie plugawe osobistości stają się najdokładniejszymi „wyrazicielami opinii publicznej”; plotkarstwo, spotwarzanie, denuncjacja i szantaż traktowane są jako poważna „działalność publicystyczna”, a krzykactwo, warcholstwo, okłamywanie ludku bożego, wzajemne podjudzanie i podbechtywanie dzikich i krwiożerczych instynktów tłumu uchodzą za politykę w wyższym stylu. W dzienniku pragnącym tu istnieć 0 własnych siłach, nad innymi działami, nad działem politycznym, informacyjnym, literackim itd., musi górować przede wszystkim dział skandaliczno-oszczerczy.

Z jednej strony nieustający szereg prowokujących oszczerstw i napaści osobistych, z drugiej zaś strony brutalne „wymierzanie sobie sprawiedliwości” własną ręką na policzku oszczercy rozdymają się do znaczenia walki stronnictw politycznych. 
Na takim gruncie moralnym łatwiej niż gdzie indziej wyrastają rozmaitego rodzaju Reineke Fuchsy ${ }^{1}$, mieniące się pozornie jak kameleon, a jednak wierne sobie w tym, że stale wodzą za nos ludek naiwny, a w nich zapatrzony. Na takim też gruncie łatwiej niż gdzie indziej rej wodzi i rozpiera się buńczucznie w towarzystwie ludzi, uchodzących za „przyzwoitych”, tak nazwana przez satyryka rosyjskiego „świnia tryumfująca”. Vivant, crescant, floreant! boć to przecież najdoskonalsze wcielenia „fałszywej fasji moralnej”.

Dzięki działalności istot tej kategorii dokonywają się ciekawe przesunięcia pojęć i zmiany w codziennej terminologii. Tak np. wyraz „katolik”, a nawet „chrześcijanin”, staje się synonimem człowieka podejrzanej moralności. Każdego bowiem, kto chce byé uczciwym, niezależnym, sprawiedliwym, indywidua podobne obwołują za „Żyda” lub też „żydowskiego pachołka”. Przymiotnik katolicki, chrześcijański, narodowo-chrześcijański, chrześcijansko-spoteczny lub tp., dodany do nazwy jakiegoś stowarzyszenia lub instytucji, wzbudza zaraz podejrzenie, że pod tym tytułem kryje się coś nieczystego. Wykwitem zaś tego fałszowania pojęć, wynikiem tej „fałszywej fasji moralnej” staje się wędrowny „hrabia antysemicki”, polecający wraz z innymi panami tej samej barwy rozmaite operacje finansowe „chrześcijańsko-społeczne” (w rodzaju „domu podrzutków” sub auspiciis pewnego „dyrektora”) i popierający powagą swego imienia „przemysł chrześcijański”, a w końcu zdemaskowany jako zwyczajny oszust.

Tylko w krajach fałszu i obłudy możliwym było w odezwie do składek na pomnik Pasteura wskazywanie z naciskiem na jego rzekomą wierność katolicyzmowi; a przecież odezwę tę podpisywali także przyrodnicy i lekarze.

Tylko „fałszywą fasją moralną” i beznadziejnym oportunizmem można objaśniać tę okoliczność, że w oczach dystyngowanych członków „politycznej straży pożarnej” obchodzenie pamięci Kościuszki

1 Reinecke Fuchs (pol. Lis Przechera) - bohater satyrycznego poematu J. W. Goethego (1794), lis doradca na dworze króla zwierząt, posługujący się kłamstwem i intrygami.

2 Tорэсествующаясвинья-wyrażenieM.E.Sałtykowa(N. Szczedrina) [przyp. BdeC]. 
iluminacją i innymi manifestacjami było objawem nagannym, uczczenie zaś współczesnego, a przez partię protegowanego męża stanu iluminacją i wrzaskami ulicznymi uznane zostało za wyraz „zdrowego patriotyzmu"1.

Nawet przedsiębiorstwa szlachetnie-filantropijne i oparte do pewnego stopnia na dążeniach dodatnio-moralnych wywołują, skutkiem właśnie owej „fałszywej fasji moralnej”, pewien niesmak i na wielu ludzi uświadamiających sobie wszystkie okoliczności muszą działać odstręczająco. Tak np. niezbyt dawno grono przedsiębiorców postanowiło założyé Towarzystwo Tanich Mieszkań dla Robotników Katolików. Rzecz godziwa i zasługująca na uznanie, chociaż wprowadzenie ograniczenia wyznaniowego nie jest w żadnym razie objawem ani wyrozumiałości, czyli tolerancji religijnej, ani też „miłości chrześcijańskiej”. Ale mniejsza z tym. Co jednak znaczy ów warunek, iż do towarzystwa mogą należeć tylko „katolicy”? Przecież w zastosowaniu praktycznym okazuje się, że w tym bądź co bądź zyskownym przedsiębiorstwie biorą udział nie tylko prawdziwi katolicy, ale także ludzie udający katolików. Trudno bowiem przypuszezać, żeby wszyscy członkowie Towarzystwa Tanich Mieszkań dla Robotników wierzyli w dogmat nieomylności papieskiej i w dogmat niepokalanego poczęcia Najświętszej Marii Panny; a kto w dogmaty te ślepo nie wierzy, nie może byé uważany za katolika. Wyzyskiwanie zaś nazwy „katolika” w celach geszefciarskich jest - powiedzmy to bez ogródki - rzeczą ohydną, jest... „fałszywą fasją moralną”.

Nie zapominajmy też, iż jednym z luminarzy Towarzystwa Tanich Mieszkań dla Robotników Katolików był Czesław Kieszkowski²,

1 Mowa 0 sprzeciwach konserwatystów galicyjskich wobec organizowania obchodów narodowych oraz o urządzonym przez nich w 1897 r. uroczystym powitaniu K. Badeniego po jego powrocie z Wiednia, po dymisji ze stanowiska prezesa rady ministrów monarchii austro-węgierskiej.

2 Odezwę zapraszającą do przystąpienia do tego towarzystwa, a rozsyłaną zresztą nie do samych tylko „katolików”, podpisało 25 przedstawicieli duchowieństwa, arystokracji, ,inteligencji”, świata kupieckiego i finansowego (haute finance), w tej liczbie Czesław Kieszkowski. Nie ulega wątpliwości, że znaczna większość podpisała odezwę w najlepszej wierze, kierując się szlachetnymi pobudkami, a zrobiła tylko ustępstwo co do „fałszywej fasji 
który z dogmatami jest może w porządku, ale szwankuje chyba pod względem moralności, choćby nawet osnutej tylko na tle wyznaniowym $^{1}$.

Bądźmy więc otwarci, nie obwijajmy w bawełnę. Przy zakładaniu Towarzystwa Tanich Mieszkań nie chodziło weale o katolicyzm, ale chodziło o inne sprawy. Trzymano się przy tym tego utartego prawidła życiowego, że jak tam sobie wierzysz, to zupełnie wszystko jedno, bylebyś udawał wierzącego. „Katolicyzm” zaś wypisuje się na szyldzie przez konwenans i dla tumanienia ludku bożego; boć, jak powiada Havliček:

bez Boha se sprostym lidem

neni $k$ vydrženi².

Ciekawa rzecz, czy i w „tanich mieszkaniach dla robotników” będzie także praktykowaną fałszywa fasja podatkowa i czy robotnicy „katolicy” będą éwiczeni w tym na sposób krajowy przyrządzonym „katolicyzmie”.

Na tle „fałszywej fasji moralnej” tym swobodniej mogą sobie bujać blaga i krzykactwo, towarzyszące ocenie ludzi wybitnych i wypadków krew psujących.

Wyznawca dwóch skromnych zasad, jednej kupiecko-teologicznej, do ut des, a drugiej ściśle „administracyjnej”, Polizei, Polizei

moralnej”, co do nazywania rzeczy niewłaściwym imieniem. A jeżeli tak, to każdy może się mnie słusznie zapytać: „Czegóż się więc nas czepiasz, jeżeli to samo dzieje się w całym świecie „cywilizowanym”?” Na to pytanie odpowiem również pytaniem: Czy przez to, że pewna zaraza grasuje także w innych krajach, jesteśmy już zwolnieni od zwracania na nią uwagi we własnym kraju? [przyp. BdeC].

1 C. Kieszkowski był oskarżony o defraudację pieniędzy krakowskich towarzystw asekuracyjnych.

2 bez Boha se sprostym lidem neni k vydrženi (czes.) - bez Boga z prostymi ludźmi nie da się wytrzymać. 
über alles, über alles in der Welt ${ }^{1}$, wyrasta bądź to na bohatera Stowiańszczyzny, bądź też na tyrana Austrii.

Wobec wesztej w krew i prawie że „z mlekiem matek wyssanej” zasady „fałszywej fasji moralnej” słusznie można podejrzewać szczerość i trwałość rozmaitych objawów, roztrąbywanych stugębną famą na wsze strony świata. Owe rzekome „sympatie słowiańskie” to tylko zwykła blague de la rue ${ }^{2}$, wyzyskiwana zręcznie nie tyle w celach partyjnych, ile raczej w celach osobistych - i to nawet pomimo sentymentalnych wywodów „Stowian” od stowa, ktore byto na poczatku.

Że starsze pokolenie, wykarmione i przesiąknięte fałszywą fasją, składa hołdy dobrowolne lub mimowolne falsyfikatorom i zatruwaczom tak zwanej „opinii publicznej”, to jest rzeczą całkiem zrozumiałą. Za to mniej już pocieszającym, chociaż wysoce znamiennym, jest zanik zmystu moralnego u P.T. dziarskiej $i$ sympatycznej mtodzieży, broniącej okopów... św. Anny przed urojonym niebezpieczeństwem ze strony złowrogich zastępów nowoczesnego Pankracego ${ }^{3}$. Niby urywek z Nieboskiej komedii! Tylko że andere Zeiten - andere Vögel, andere Vögel - andere Lieder ${ }^{4}$. W dzisiejszej trawestacji Nieboskiej komedii „chór lokajów” nie stoi już po stronie Pankracego i bez wątpienia bardziej się to zgadza z psychologią społeczną.

Kształćcie się, moi panowie, na przyszłych członków komitetu du salut public, wprawiajcie się do przyszłej działalności dobrowolnie inkwizytorskiej i terrorystycznej - wszystko jedno czy to w kierunku „Zachowawczym”, czy też w kierunku „przewrotowym”, czy to

$1 \quad$ Polizei, Polizei über alles, über alles in der Welt (niem.) - Policja, policja ponad wszystko, ponad wszystko w świecie.

2 Blague de la rue (fr.) - blaga uliczna [przyp. BdeC].

$3 \quad$ Mowa 0 pobiciu 29 XI 1860 r. przez uczniów gimnazjum św. Anny i studentów profesora Euzebiusza Czerkawskiego, inspektora szkolnego, fałszywie posądzonego o niechęć do wprowadzenia języka polskiego jako wykładowego w galicyjskich szkołach.

4 Andere Zeiten - andere Vögel, andere Vögel - andere Lieder (niem.) - Inne czasy - inne ptaki, inne ptaki - inne pieśni [przyp. BdeC]. 
w kierunku wyprawiania obrzydliwych burd w parlamencie, czy też w kierunku wprowadzania do niego policji - wyrzucajcie z waszych towarzystw gazety mające zdanie niezależne o bieżących sprawach politycznych, a z pewnością znajdziecie poklask i uznanie.

Niektórzy „przewodnicy młodzieży”, i to z najwybitniejszych, pieją hymny na cześć „odwagi cywilnej”, wyrzekają na jej brak w społeczeństwie polskim, a jednocześnie są tak konsekwentni i jasno myślący, że wynurzają pobożne życzenie, ażeby jeden z „nietykalnych” ośmielający się mieć własne, niezależne od „sądów” tłumowo-ulicznych i zwierzchnościowych zdanie o polityce „męża opatrznościowego" został wyprany po pysku w Tarnowie. Istotnie oryginalny sposób wyrażania hołdu odwadze cywilnej!

Ale uspokójmy się. Obawy nasze o niejasność myślenia podobnych panów są płonne. 0 zejście odwagi cywilnej na błonia galicyjskie tylko rzekomo, tylko w duchu fałszywej fasji modlą się ochlokraci i anarchiści, wytwarzający nastrój polityczny za pomocą podjudzanej przez swych kierowników i wypuszczanej na ulicę dziatwy gimnazjalnej. Przy tym nie chcą ci panowie pamiętać, że anarchia lat 18611864 i idące w ślad za nią zdziczenie „zwyciężonych” i „zwycięzców” rozpoczęły się w Warszawie między innymi od utworzenia osobnej „kurii społecznej” z tak zwanej „młodzieży” i od oddania „straży bezpieczeństwa publicznego" w ręce gimnazistów¹.

$* * *$

Proszę jednak nie myśleć, że, zacietrzewiwszy się „fałszywą fasją”, przypisuje powyżej wyliczone objawy etyki pośledniejszego gatunku wyłącznie Galicji i Galicjanom. 0! wcale nie jestem tak zaślepiony. Wiem, że prawie wszystkie te kwiatki dają się uszczknąć także w innych ogródkach; ale za to tam bywają one zwykle oceniane w sposób mniej więcej właściwy. Tylko dzięki dobroczynnemu wpływowi fałszywej fasji zwyczajowej może uchodzić za czyn nieomalże

1 Mowa 0 utworzonej w 1863 r. w Warszawie policji narodowej, której członkowie rekrutowali się w dużej części spośród warszawskiej młodzieży. 
obywatelski to, co przez normalną etykę uważane bywa za szpetne i plugawe.

Fałszywa fasja jest właśnie ową kropką nad $i$, jest owym pożądanym momentem decydującym, zamieniającym luźną grupę rozmaitych objawów fałszu i obłudy na całkiem stylowy, estetycznie skończony obraz. Z tej niezaprzeczonej stylowości prawdziwy „patriota” galicyjski może byé istotnie dumnym. Jest ona bardzo do twarzy rozestetyzowanym królewiętom i hidalgom, gwoli chwale wieków minionych zbierającym składki na rozmaite przedmioty zbytku. Mniej za to jakoś słychać o składkach na podniesienie np. zdrowotności lub moralności społeczeństwa.

Pocieszmy się jednak tym, że autorowie głośnych w ostatnich czasach „sprzeniewierzeń” należeli także do rzędu estetyków i wielbicieli sztuki.

$$
* * *
$$

Już to w Galicji nie można się uskarżać na to, że się żyje „bez dogmatu”. „Dogmatów” autonomicznych na szczéście nie brak.

Na polu gospodarstwa społecznego cieszy się w pewnych sferach wielkim uznaniem dogmat propinacji. Obok niego powszechne uznanie ma dogmat fałszywej fasji. Nareszcie gwiazdą przewodnią na polu polityki jest dogmat bezwzględnego oportunizmu, streszczający się w szczytnym aforyzmie: Die Polen sind für jede Majorität zu haben ${ }^{1}$.

Opierając się na takich podwalinach wiary społeczno-państwowej, można śmiało patrzeć w przyszłość i mężnie stawiać czoło wszelkim „przewrotowcom”.

Boć nad wszystkimi tymi dogmatami góruje dogmat „obrony istniejącego porządku”. A więc niech żyją „obrońcy istniejącego porządku”, obrońcy fałszywej fasji podatkowej, obrońcy fałszywej fasji moralnej, obrońcy prostytucji zwykłej, obrońcy prostytucji umysłowej, literackiej i innej. Tak, brońcie tego, panowie, bo to wygodnie dla was

1 Die Polen sind für jede Majorität zu haben (niem.) - Polaków można zyskać dla wszelkiej większości [przyp. BdeC]. 
samych, bo to wygodnie dla panującej klasy społecznej, dla panującego stanu, dla panującej kurii, dla płci panującej. Tak, to bardzo wygodnie, to bardzo oportunistycznie.

Tak, ale przecież panowie ci, broniąc istniejącego porządku, są także eo ipso obrońcami religii, obrońcami moralności.

Że bronią istniejącego porządku korzystnego dla ich kieszeni, dla ich podniebienia, dla ich zmysłowości..., na to zgoda bez apelacji. Czy bronią religii, niech rozstrzygają odnośni rzeczoznawcy. Żeby zaś mieli bronić moralności, przeciwko temu protestuję najuroczyściej; a sądzę, że nie tylko ja jeden, ale także wielu innych zuchwalców.

Ale przecież „moralność” i „moralność” - to są pojęcia zupełnie różne. Ci panowie bronią rzeczywiście moralności, ale moralności dziwnego autoramentu, moralności konwenansowej, moralności „prawomyślnej”, moralności sugestionowanej przez jegomościów urządzających systematyczne szczucia na całe grupy ludzi jedynie tylko za to, że są innego niż my pochodzenia. Z pojęciem zaś takiej moralności doskonale się godzi i nawet mieści się w nim wykonywanie fałszywej fasji.

A, tak to co innego; teraz już się rozumiemy.

Pomówmy więc bez obsłonek, szanowni panowie.

Wszakże oburzacie się na „złodziei”, na „oszustów”, na „krzywoprzysiężców”, wszakże karzecie ich dłuższym lub krótszym więzieniem i hańbą całego życia.

Jeżeli nędzarz ukradnie z głodu kawałek chleba - do więzienia z nim!

Baba wiejska, przekonana o to, że przyniosła na targ fałszowane masło, zostaje skazywaną w drodze administracyjnej na 14 dni aresztu i 100 złr grzywny; a przecież popełniła tylko „fałszywą fasje”, wprawdzie „maślną”, nie podatkową, ale zawsze tylko „fałszywą fasję".

Kucharka liczy sobie „koszykowe” - złodziejka! Chłop wypasa cudze pastwisko - złodziej! Chłopka zbiera grzyby i jagody w lasach „obszarnika” - złodziejka! A co takiego „fałszywa fasja”, panowie kucharek i panowie obszarnicy?

Wobec takiego chronicznego złodziejstwa bledną i maleją wszelkie „sprzeniewierzenia” w magistratach, towarzystwach ubezpieczeń 
i innych tp. instytucjach. Są to tylko paroksyzmy ostre, oczyszczające cokolwiek powietrze; a jak wiadomo, choroba ostra daje się uleczyć nierównie łatwiej aniżeli chroniczna.

Sędziowie przysięgli podpisujący stale fałszywą fasję nie mają prawa do wydawania wyroku potępiającego na żadnego złodzieja, na żadnego oszusta, na żadnego krzywoprzysiężcę. Powiedziano jest: kto $\mathrm{z}$ was bez grzechu, niech na nią kamieniem rzuci. A fałszywa fasja to grzech chroniczny, to już nie grzech, ale zatwardziałość w grzechu, w grzechu złodziejstwa, oszustwa i krzywoprzysięstwa.

Ale wróćmy do głównego przedmiotu, tj. do „obrony istniejącego porządku”.

Powiadacie panowie, że bronicie „istniejącego porządku”, a zgodzicie się zapewne ze mną, że do składu pojęcia „istniejącego porządku” wchodzi przede wszystkim pojęcie rządu. A czy rząd ma prawo do pobierania podatku uchwalonego, jeżeli nie przez was samych, to przynajmniej przez waszych przedstawicieli? Czy podatek ten jest własnością rządu? Cóż więc robią wszyscy owi „zacni” i „uczciwi” ludzie podpisujący fałszywą fasję? Przecież chyba okradają skarb i rząd i to okradają z przymieszką oszustwa i krzywoprzysięstwa.

Zestawmy więc jeszcze raz owo indywidualne, sporadyczne złodziejstwo, karane sądownie i piętnowane moralnie, z fałszywą fasją, jako powszechną, endemiczną kradzieżą, jako powszechnym, endemicznym oszustwem i krzywoprzysięstwem i pomyślmy sobie:

Albo podstawy prawa własności nie istnieją, a w takim razie ani ten, co kradnie wprost, ani też ten, co kradnie w sposób wyrafinowany, nie są złodziejami; albo też prawa własności istnieją, a w takim razie tak jedni, jak drudzy są złodziejami. Aut... aut, tertium non datur ${ }^{1}$, łaskawi panowie! Ale idźmy dalej.

Jeżeli dzisiejsze prawa własności nie mają racji bytu, a rząd niesprawiedliwie rości sobie pretensje do podatku, to uroszczenia te, wraz z całym istniejącym porządkiem, pozbawione są podstawy moralnej, a wy, szanowni panowie, uprawiając fałszywą fasję, postępu-

1 Aut... aut, tertium non datur (łac.) - Albo... albo, trzeciego wyjścia nie ma [przyp. BdeC]. 
jecie jeżeli nie prawnie, to przynajmniej sprawiedliwie, bo sprawiedliwie „Zwalczacie istniejący porządek”.

Jeżeli zaś uznajecie istniejący porządek, łącznie z wymaganiami podatkowymi, za sprawiedliwy, w takim razie musicie się ze mną zgodzić, że jesteście albo najzwyklejszymi, mizernymi oszustami, albo też ukrytymi „przewrotowcami” protestującymi w ten sam zupełnie sposób przeciwko „obecnemu ustrojowi społecznemu”, co „ideowi” fałszerze monet i papierów wartościowych, co „ideowi” włamywacze kas, rozbijacze banków itp.

Ale w takim razie pytam: co lepiej, co uczciwiej - czy otwarcie występować do walki z istniejącym porządkiem i dążyé do jego przetworzenia w sposób legalny, konstytucyjnie dozwolony, czy też podkopywać go w sposób kreci, graniczący z anarchią?

Tak moi panowie, jesteście anarchistami i to anarchistami najgorszego gatunku, bo toczącymi wyobrażenia moralne, do których wprowadzacie nierząd, nieład i chaos. Jesteście szkodliwsi dla popieranego przez was samych „istniejącego porządku” od potępionych przez was „przewrotowców”, bo utożsamiacie ten „istniejący porządek" z zanieczyszczaniem sumień, z kłamstwem i obłudą.

Dotychczas występowałem w roli prokuratora. Nie domagałem się wprawdzie „ukarania przestępców”, choćby dla tego, że w całej Galicji nie znalazłbym sędziów uprawnionych moralnie do wydawania podobnych wyroków; ale wywody moje były tego rodzaju, że jeżeli obywatel galicyjski zgodzi się z niemi i przyzna mi choć częściową słuszność, nie może powziąć zbyt wielkiego szacunku dla samego siebie. Spróbujmy teraz stanąć na stanowisku obrońcy.

Tout comprendre c'est tout pardonner ${ }^{1}$, a więc i my postarajmy się zrozumieć przyczynę powstania zwyczaju fałszywej fasji.

$\mathrm{Na}$ fałszywą fasję można napadać tylko ze stanowiska moralnego. Wiadomo zaś powszechnie, że „politycy” i dyplomaci nie potrze-

1 Tout comprendre c'est tout pardonner (fr.) - Wszystk0 zrozumieć - to wszystko przebaczyé [przyp. BdeC]. 
bują się wcale oglądać na jakiś tam dekalog i na jakieś tam przepisy moralności; a przecież Galicja słusznie się chlubi, że jest klasyczną krainą polityków i „mężów stanu”.

„Nadludziom” wolno zabijać, kraść, oszukiwać itp. Do kategorii zaś „nadludzi”, którzy pod względem moralności stoją na stanowisku „przedludzi”, na stanowisku „antropoidów”, należą także rozpolitykowani wyznawcy fałszywej fasji, którzy, zapatrując się na „wielkich” świata tego, czują się w duszy zupełnie usprawiedliwionymi.

Stąd to nawet „honorowi” pojedynkowicze podpisują pod słowem „honoru” fałszywą fasję i mogą nie widzieć w tym najmniejszej sprzeczności. Oczywiście rząd jest dla nich satisfactionsunfähig ${ }^{1}$, podobnie jak goj dla Żyda-chasyda, a Żyd dla antysemity.

Tak więc zwykła „filisterska” moralność nie obowiązuje panów polityków, dyplomatów, wojowników, ludzi „honoru”, pojedynkowiczów, gazeciarzy; nie obowiązuje też ani właścicieli domów, ani lokatorów. Kogóż więc u licha obowiązuje? Czyżby tylko bezdomnych „proletariuszów” i niewolników obecnego ustroju ekonomicznego? A teraz spójrzmy na tę sprawę jeszcze z innej strony.

Czy w czasie wojny obywatel, na którego najezdca [sic! M.S.] nakłada kontrybucję wojenną, nie ma prawa ukrywać przed wrogiem swojego majątku? Czy w razie napadu złodziei i rabusiów jesteśmy moralnie obowiązani do rozkładania przed nimi wszystkich naszych bogactw i zasobów? Czy między obdzieranym a obdzierającym, czy między świadomie wyzyskiwanym a świadomie wyzyskującym może była mowa 0 stosunkach „lojalnych”? Tu chyba hört die Gemütlichkeit auf ${ }^{2}$. Można się wprawdzie przyzwyczaić do obdzierania i wyzyskiwania, podobnie jak węgorze przyzwyczajają się do odarcia, a raki

1 Satisfactionsunfähig (niem.) - tu: niegodny satysfakcji. Nawiązanie do określenia z kodeksu honorowyego, odnoszącego się do kogoś, kto jest uznany za „niehonorowego”, nie może więc ani czuć się obrażony, ani samemu obrazić, a dalej - nie może być wyzwany na pojedynek, ani nie przyjmuje się jego wyzwania.

2 Hört die Gemütlichkeit auf (niem.) - Kończy się dobroduszność [przyp. BdeC]. 
do gotowania ich żywcem, ale do tego dochodzi się stopniowo, powoli. Zbyt szybko zarządzony rabunek nawet w najdobroduszniejszym człowieku wywołuje chęć odwetu.

A czy pewne systemy podatkowe nie sprawiają wrażenia systemów rabunkowych i drapieżnych? Czy fiskus nie musi robić wrażenia natrętnego wroga, ciągle zaglądającego człowiekowi do gardła, jeżeli każdy kąsek, co się do ust kładzie, obłożony jest podatkiem, jeżeli podatki opłaca się nie od dochodów, ale od wydatków i od najpierwszych potrzeb życia? Brakuje tylko tego, ażeby kazano płacić podatek od powietrza, którym oddycha „wolny obywatel”, ażeby temu obywatelowi zawiązano na szyi krawat, ściągany i zamykany na klucz przez urzędników skarbowych, krawat, tamujący oddychanie obywateli, zalegających z podatkiem, a rozluźniany dopiero po opłaceniu podatku.

Takie urządzenia podatkowe muszą rozwijać w duszach obywateli uczucia wrogie dla fiskusu. Przy tym „wolny obywatel” nie zdaje sobie sprawy ze źródła podobnych podatków; zapomina, że przecież podatki owe nakładają i uchwalają jego właśni przedstawiciele, jego posłowie, jego radni magistraccy; on widzi tylko wykonawców, widzi urzędników, widzi egzekucję. Na nich też przenosi swoją nienawiśé i ich stara się oszukiwać wszelkimi sposobami. Mało go zaś to obchodzi, że za fiskusem stoi rząd uwielbiany oraz broniony „istniejący porządek społeczny”.

Taką jest psychologia oszustw podatkowych, taką jest psychologia fałszywej fasji.

Dlaczego jednak takie same warunki psychiczne stworzyły prawo zwyczajowe fałszywej fasji w samej tylko Galicji, gdy tymczasem innym krajom austriackim to prawo zwyczajowe jest, jak twierdzą, całkiem obce?

Pytanie to pozostawmy bez odpowiedzi.

$* * *$

Oczywiście „wolny obywatel galicyjski” zrósł się z tym prawem zwyczajowym, czuje się w nim jak w swoim żywiole i pragnie je zachować jak najdłużej. Gdyby było inaczej, to przecież słyszelibyśmy 
o głośnych protestach i 0 usiłowaniach dążących do usunięcia fałszywej fasji.

Nie mając tedy nadziei, żeby ktokolwiek inny zwrócił uwagę na ten chwalebny zwyczaj galicyjski, zdecydowałem się sam wystąpić; zdecydowałem się zaś głównie dla tego..., że mi żal.

Żal mi wszelkiego rodzaju niewolników i nieszczęsnych ofiar vis maioris ${ }^{1}$.

Żal mi osób stojących na czele większych grup społecznych, które to osoby, pragnąc zachowywać dziesięcioro przykazań, muszą jednak pędzić całe stada ludzi na rzeź, muszą kazać zabijać i w obłudny sposób usprawiedliwiać to swoje niemoralne postępowanie jakimiś wyższymi względami.

Żal mi nauczycieli, którzy, będąc przekonani o całej bezcelowości i jałowości przyjętego systemu wychowania, muszą jednak naginać karku i chodzić bez szemrania w tym jarzmie.

Żal mi sędziów, działaczy politycznych i żołnierzy, którzy muszą być zabójcami wbrew sumieniu, wbrew instynktom, wbrew uczuciu.

Żal mi pojedynkowiczów, którzy, uznając w głębi duszy całą ohydę, bezeceństwo i idiotyzm tej instytucji „honorowej” (sit venia ver$b o^{2}$ ), pod naciskiem jednak głupich przesądów i tak zwanej „opinii publicznej” (tj. wrzasków hałastry, żądnej skandalu), wyzywają na pojedynek lub też, wyzwani, stają do niego.

Żal mi prostytutek, które, mając instynkta co najwyżej monogamiczne, zmuszone są jednak pod naciskiem warunków ekonomicznych uprawiać ze wstrętem zawodową poliandrię.

Żal mi indywiduów zmieniających wyznanie za pieniądze lub dla stanowiska, a czujących w głębi duszy, że dopuszczają się podłości.

Żal mi publicystów i „uczonych” handlujących swoimi „przekonaniami”, ale jeszcze niezupełnie pozbawionych sumienia.

Żal mi nareszcie niedostatecznie zasymilowanego obywatela galicyjskiego, który się kurczy i wije w szponach etyki autonomicznej i pragnąłby się z nich wyrwać.

1 Vis maioris (łac.) - siły wyższej, siły żywiołowej [przyp. BdeC].

2 Sit venia verbo (łac.) - z przeproszeniem [przyp. BdeC]. 
Co innego jeżeli kto wszystkie te kunszta i procedery uprawia con amore ${ }^{1}$. Tyran i okrutnik z urodzenia, stawiający otwarcie, z całym cynizmem skończonego bandyty „siłę przed prawem”, złodziej i rozbójnik zawodowy, Messalina z instynktów i popędów, pojedynkowicz oddany temu sportowi z zamiłowania, jegomość uważający handel sumieniem i rzekomą zmianę religii za takie samo źródło dochodu, jak wszelkie inne przedsiębiorstwo, figura porca ${ }^{2}$ wynajmująca się z lekkim sercem redaktorom najsprzeczniejszych kierunków, obywatel galicyjski uważający fałszywą fasję za dogmat święty i nietykalny - wszystkie takie indywidua ani współczucia naszego, ani żalu wcale nie potrzebują.

0 takich też i mnie weale nie chodzi. Chodzi mi tylko o takich, co, czując całą ohydę pewnego czynu, popełniają go jednak z musu; a mniemam, że takich jest nierównie więcej, aniżeli byśmy przypuszczali, sądząc jedynie z pozorów. Przykro mi też jest myśleć, że tym ludziom, z natury dobrym i szlachetnym, mogę sprawić ból swoim wystąpieniem. Ale co robić, jeżeli bolesna operacja niezbędną jest do wyleczenia chorego? A choroba w danym razie jest bardzo poważna.

Proszę też nie sądzić, jakoby mi przy tym chodziło głównie o szkodę, jaką skutkiem fałszywej fasji ponosi państwo; nierównie bowiem większą szkodę ponosi dane społeczeństwo. Tak zwane „państwo" ma samo dosyć środków do bronienia swoich interesów; ma na swoje rozkazy setki tysięcy bagnetów, ma przymus w formach najrozmaitszych.

Jestem więc przeciwnikiem fałszywej fasji nie ze względów abstrakcyjnych, nie dlatego, że jest ona wysoce niesprawiedliwą wobec opiekuńczego rządu, ale musze ją potępić dlatego, że demoralizuje społeczeństwo do szpiku kości, że jest nigdy niewysychającym źródłem gangreny moralnej, źródłem zgnilizny i korupcji powszechnej. Przyjąwszy fałszywą fasję za jedną z podstaw działania, mamy prawo, za przykładem jednego z „bohaterów” komedii Dobrzańskiego Ztoty cielec, powtarzać sobie bez ogródki: Pan jesteś ztodziej, ja jestem

1 Con amore (wł.) - z zamiłowaniem [przyp. BdeC].

${ }_{2}$ Figura porca - wyrażenie włoskie, dosłownie: figura świnska, tj. szuja, szubrawiec [przyp. BdeC]. 
ztodziej, wszyscy jesteśmy ztodzieje i możemy sobie tego nawzajem powinszować Jest to największa „nędza galicyjska”, bo nędza moralna, nędza wytwarzająca nie nędzarzy, ale nędzników. Co są wobec niej owe marne i wstrętne walki tak zwanych „stronnictw”, owe wymyślania sobie, owe zohydzania się wzajemne!?

W kraju trędowatych trąd jest normalnym stanem wszystkich mieszkańców; nietrędowaty musi być uważany za fizycznie upośledzonego. Gdzie wszyscy ulegają trądowi moralnemu, wytwarza się atmosfera moralna, w której nie wolno być uczciwym pod groźbą proskrypcji. Gdzie wszyscy muszą być złodziejami i oszustami, tam złodziejstwo i oszustwo przestają być zboczeniem moralnym, przestaja być grzechem, a stają się normą postępowania.

Jaki by to był gwałt, gdyby pojawiła się jakaś choroba epidemiczna, np. cholera, tyfus, dżuma! Tu zaś mamy do czynienia z tak straszną zarazą, jak korupcja ogólna, z zarazą niepozwalającą byé zdrowym moralnie żadnemu indywiduum mieszkającemu w danych granicach politycznych - a jednak zamiast krzyczeć wniebogłosy ratunku! ratunku! przechodzimy sobie nad całą tą sprawą do porządku dziennego. A dlaczego? Dlatego, że gnijemy i zżyliśmy się ze zgnilizną; dlatego że żyjemy w błocie, dlatego, że oddychamy zatrutem powietrzem i straciliśmy zdolność odczuwania niebezpieczeństwa.

$$
* * *
$$

Panowie od wielkiej polityki, matadory „stronnictw poważnych” z uporem sroki lub papugi powtarzający wiecznie tę samą piosnkę o niezdrowych pradach, o przewrotowcach, o bluźnierczych ksiazkach $i$ czasopismach, panowie pragnący klin klinem wybijać, a na „bakcylusa socjalizmu” doradzający „antydot antysemityzmu”, godzą

1 Nie mogę się powstrzymać, ażeby dla tych panów „Zachowawców”, walczących pod sztandarem „prawdziwego katolicyzmu” i nawet „prawdziwego chrześcijaństwa” w towarzystwie „miłości bliźniego”, nie dać próbki zalecanego przez nich lekarstwa. Oto co między innymi pisze jeden z fabrykantów owego upragnionego przez „Zachowawców” „antydotu”, owego „antysemityzmu”, będącego codzienną strawą umysłową znacznego zastępu „inteligencji” galicyjskiej: Gdyby Dreyfusa jako szpiega powieszono, nie bytoby dziś 
się najzupełniej z tym stanem rzeczy i nie zwracają uwagi na takie drobnostki. Oczywiście oszustwo endemiczne, przybierające formę fałszywej fasji, nie narusza równowagi społecznej, nie jest „objawem zgnilizny moralnej”, nie grozi „istniejącemu porządkowi”, bo jest przecież jego naturalnym wypływem, jego prawowitym dzieckiem.

Z tej więc strony nie ma co oczekiwać protestu przeciw fałszywej fasji. A nawet słyszę już głosy oburzenia:

My stoim na straży pamiatek narodowego kościota, a tu oto jakiś „obcopaństwowiec”, „przez nikogo do tego nieupoważniony”, ośmiela się bluźnić przeciwko zwyczajom, uświęconym wieloletnią tradycją".

Pojmuję najzupełniej wasze głębokie oburzenie, łaskawi panowie, i mocno się wstydzę, żem je wywołał swoją gadaniną; raczcie jednak uwzględnić pewne okoliczności łagodzące i pozwólcie mi się usprawiedliwić.

Jeden z profesorów Uniwersytetu Warszawskiego, dziś już nieżyjący M. A. K., chlubił się absolutnym brakiem powonienia i zapewniał swoich znajomych: знаете, для меня совершенно все равно сидеть или в нужннике, или в цветнике 1 . Szczęśliwy! Nie mniej szczęśliwi są ludzie, którym albo od urodzenia brak powonienia moralnego, albo u których powonienie to uległo stępieniu i zanikowi, albo też - i to już najwyższy błogostan tej kategorii - którzy, będąc obdarzeni instynktami przewrotnymi, na wzór niektórych dekadentów dzisiejszych lubują się w smrodzie. Ja niestety nie mam szczęścia należeć do rzędu tych wybrańców, a, mieszkając w okolicy zarażonej i zanieczyszczonej, pragnę przede wszystkim usunąc źródło zarazy.

Nie jestem też, na swoje nieszczęście, pozbawiony pewnej wrażliwości społecznej, która nie pozwala mi zachowywać się obojętnie wobec krzyczących niesprawiedliwości i pcha mię do walki, choć zwykle bezskutecznej.

tyle ktopotu, sprawa bytaby zatatwiona merytorycznie, Europa nie bytaby dreczona watpliwościami, a co najważniejsza $i$ co wcale nie jest bagatela, jednego Żyda bytoby mniej na świecie [przyp. BdeC].

Знаете, для меня совершенно все равно сидеть или в нужниике, или в цветнике (ros.) - Wiesz pan, dla mnie zupełnie wszystko jedno - siedzieć w wychodku czy też w ogródku [przyp. BdeC]. 
Tutaj może mię spotkać słuszny poniekąd zarzut, że, będąc „uczonym” obowiązanym przede wszystkim pracować naukowo, wdaję się pomimo to w takie rzeczy i tracę czas na próżno. Sam się z tym najchętniej zgadzam. Ale jeżeli tak, to, myśląc konsekwentnie, powinniśmy wymagać, ażeby uczony znosił obojętnie fałszowane jedzenie, złe powietrze itd. Traci on czas na otwieranie okien w mieszkaniu, na dezynfekcję, na stosowanie przepisów higieny. Jeżeli zaś taka strata czasu jest dozwoloną, to nie powinniśmy też mieć za złe dążenia do usunięcia cuchnącej atmosfery moralnej. A choćby nawet nie było widoków na skuteczne jej usunięcie, to wolno przynajmniej zwrócić na nią uwagę.

Nie proponuję też żadnych lekarstw na opisaną przeze mnie chorobę. Ja stawiam tylko diagnozę; terapia należy do kogo innego ${ }^{1}$.

$$
* * *
$$

Wiem, że tylko niewielu przyzna mi słuszność. Wywołam z pewnością „ogólne oburzenie” i „grozę świętą”. Oczekuję całego kubła pomyj od pewnych „organów opinii publicznej”, ale oczekiwanie to nie napełnia mię trwogą, a nawet wcale mnie nie wzrusza. Gromy ciskane przez tego rodzaju „publicystów” uważam za prawdziwy dla siebie zaszczyt. Co więcej, gdyby mię te „organa opinii publicznej” pochwaliły, przypuszczałbym, że popełniłem jakąś nikczemność.

Kończę oświadczeniem, że wystąpiłem z tą broszura po prostu dla tego, że nie mogłem nie wystąpić, dlatego, że nakazywało mi to moje sumienie. Nie łudzę się jednak nadzieją, ażeby wystąpienie moje osiągło [sic! - M.S.] jaki skutek praktyczny.

Przyznaję, że wystąpienie to jest w wysokim stopniu nieoportunistyczne; ale, gardząc z głębi duszy wszelkim oportunizmem, uważam się we własnych oczach za zupełnie usprawiedliwionego.

Kraków, w grudniu 1897 r.

[Kraków 1898. Wydane nakładem autora]

1 Podobno nowa ustawa podatkowa ma między innymi dobroczynnymi skutkami położyć także koniec prawu zwyczajowemu fałszywej fasji, a przez to wywrzeć w tej dziedzinie wpływ umoralniający. Jeżeli tak, to serdecznie się z tego cieszę i życzę powodzenia [przyp. BdeC]. 


\section{MYŚLI NIEOPORTUNISTYCZNE}

Odprto navadno uhó in okó, a usta zaprta mi nosi; če tréba, odpri pa še usta srěnó, nikjér dovolitve ne prosi.

S. Gregorčič, Samostanski vratar

1. Nic tak nic kompromituje człowieka jak szczerość.

2. Człowiek ze zdaniem niezależnym drażni tak samo szlachetne instynkta tłumów prawomyślnych, jak obcy przybysz drażni psy danej miejscowości. Jeden pies zaintonuje nagankę, a cała gromada wtóruje mu, naszczekując i napadając. Ale dość jest we właściwym czasie pokazać zęby tej hałastrze, a cofnie się z podwiniętymi ogonami. Inaczej niezawodnie rozszarpie.

3. Sztuka życia polega często na tym, ażeby się nie zdradzać z rozumem przed ludźmi.

4. Ludzie dzielą się na takich, co się do swoich błędów nigdy i przed nikim nie przyznają, na takich, co się przyznają tylko przed samymi sobą, i nareszcie na takich, co się przyznają nie tylko przed samymi sobą, ale także przed innymi. Ci ostatni najgorzej wychodzą.

5. Jedną z najczęściej spotykanych a nieuleczalnych chorób jest obłęd wielkości i nieomylności.

6. Gdyby mię zapytano, jakich ludzi jest najwięcej, odpowiedziałbym: nieomylnych. Nieomylni są ludzie partii; nieomylni są członkowie towarzystw wzajemnej adoracji; nieomylni-politycy i dyplomaci; nieomylni są znachorzy i wróżbici; nieomylni są wszyscy dogmatycy; nieomylni - augurowie i olimpijczycy; nieomylni są zwierzchnicy; nieomylni - „przodownicy narodu”; nieomylni są gazeciarze. Nareszcie wszyscy smarkacze i głupcy są nieomylni. „Nieomylników” wystarczyłoby na objęcie zwierzchnictwa w nieograniczonej ilości trzód wyznaniowych. Przyznających się do błędu z latarnią szukać należy.

7. Próbka ludzkiego obłędu wielkości (mania grandiosa): jeżeli Hund lub Wolf jest imieniem pospolitym (appellativum), to jego 
szczekanie nie może obrazić; jeżeli zaś Hund lub Wolf bierze się w znaczeniu imienia własnego (nomen proprium), to wyrządzona przezeń „obraza” może być „zmyta tylko krwią”, wszystko jedno, czy krwią jego samego czy też „obrażonego”.

8. Religia serc naiwnie wierzacych zasługuje na uznanie i szacunek choćby dlatego, że wprawia duszę do dążeń idealnych i uszlachetniających.

9. W licznych utrapieniach życia jedynymi stałymi pocieszycielkami powinny by być: religia, nauka i sztuka, każda z nich w mniejszym lub większym stopniu, stosownie do indywidualności cierpiącego. Jednakże nawet z tych pocieszycielek potrafiono zrobić narzędzia męki i katuszy.

10. Uganianie się za „estetyką” praktyczną jest jednym z najbardziej rozkładowych czynników w życiu rodzinnym i społecznym. Z zewnątrz blichtr i piękny wygląd, a pod spodem brud, nieporządek, nieład i niezaradność.

11. Są dwa egoizmy: egoizm zadowolenia z siebie i egoizm smutku. Pierwszy jest wrodzony, drugi rozwija się wskutek cierpień i nieszczęść. Pierwszy robi ludzi szczęśliwymi, drugi nieszczęśliwymi.

\section{III}

12. Znakomita większość ludzi znajduje się w stanie chronicznego przyćmienia umysłu.

13. Nie dąż do świadomości, bo zatruje ci ona życie, wykazując, że albo jesteś przestępcą, albo też dożywotnim skazańcem.

14. Najmarniejszym rodzajem „przekonań” jest bezprzekonaniowość, czyli oportunizm.

Stałym i nigdy niewysychającym źródłem demoralizacji jest oportunistyczne traktowanie dziesięciorga przykazań. 
Stałym i nigdy niewysychającym źródłem anarchii jest oportunistyezne traktowanie prawd naukowych.

\section{V}

15. „Nastrojowość” dekadentów, rozstrojowców, impresjonistów, delirantów i innych zwiastunów „nowej ery” w twórczości artystycznej jest tylko dalszym ciągiem i nową odmianą, a często tylko karykaturą mistycyzmu, wizjonerstwa i romantyzmu.

16. Apoteoza „nastrojowości” stoi na równi z oddawaniem czci pasjonatom, kapryśnikom i w ogóle ludziom nieznającym - ani dla swoich sądów, ani też dla swoich działań - innego kryterium, jak tylko popęd chwilowy i przemijające usposobienie.

17. Społeczeństwo polskie jest gruntem nadzwyczaj podatnym do rozkwitu „nastrojowości” w sztuce. Przecież żadne chyba spoteczeństwo tak łatwo się nie rozpala i nie powoduje się kaprysem i nieuzasadnionym widzimisię. Kiedy jest właściwie bardzo dobrze, kiedy są wszelkie dane do pomyślnego rozwoju życia narodowego, wrzeszczy się zajadle, że „gorzej być nie może”. Łaskawy zaś uśmiech grzecznego dygnitarza wprawia w zachwyt cielęcy i wzbudza jak najdalej sięgające nadzieje. Jak tam „nastrój” krwiożerczy i złowrogi, tak tu znowu „nastrój” dziwnie optymistyezny dadzą się objaśnić jedynie chyba tylko słabo funkcjonującym mózgiem.

18. Rozwarta przed impresjonistami politycznymi przepaść bezdenna nęci ich ku sobie z tak niepokonaną siłą i sprawia im tak potężny zawrót głowy, że, zamknąwszy oczy na wszystko, rzucają się w nią na oślep i gubią całą przyszłość narodu. Pereat mundus, fiat stultitia! $!^{1}$

19. Pewnik „filozofii polskiej”: tańczę, więc jestem.

1 Pereat mundus, fiat stultitia (łac.) - parafraza łacińskiego powiedzenia Pereat mundus fiat iustitia (Niech zginie świat, byleby się stało zadość sprawiedliwości), którą można tu rozumieć także w sensie: 'choćby świat przeminął, głupota zostanie’. 
20. Jednym z najbanalniejszych kłamstw konwencjonalnych jest mniemanie, jakoby miłość samczo-samicza miała uszlachetniać serce i podnosié ducha.

21. Lekkomyślne żenienie się „, miłością” musi być chyba „występkiem"; zamienia ono bowiem niejednokrotnie pożycie małżonków na dożywotni dom kary... bez poprawy.

22. Tak strasznie rozwielmożniona w społeczeństwach „cywilizowanych” rozpusta zmysłowa, unicestwiająca szczęście jednostek i rodzin i uniemożliwiająca w jej własnej dziedzinie prawdziwą i pełną rozkosz podnioślejszego rodzaju, jest najezęściej wynikiem autosugestii albo też sugestii ze strony otoczenia.

23. Kto choćby raz w życiu uważał siostry i córki swych „bliźnich” czy też „współobywateli” za narzędzia rozkoszy, ten nie ma prawa występować w obronie zasad czy to konserwatywnych, czy też postępowych. Obrona nietykalności rodziny nie licuje ani z wyrywaniem z tona rodzin dziewcząt i wcielaniem ich w szeregi „tolerowanych” i „kontrolowanych", w szeregi naruszających szóste przykazanie legalnie, za zgodą władz, ani też z wyrywaniem z łona rodzin synów i wcielaniem ich w szeregi legalnych przestępców przeciwko piątemu przykazaniu. Kto zaś w roli reformatora ludzkości prawi piękne słówka o równości i 0 jednakowym prawie wszystkich do życia, do pracy ete., etc., ten niech nie poniewiera jednocześnie całą połową ludzkości, ten niech nie poniewiera nieszczęśliwymi istotami, dla których los stał się niewymownie okrutnym. Miejcie odwagę myślenia, panowie! Powiedzcie: albo tak, albo owak; albo braterstwo, równość praw i sprawiedliwość, albo też wyzysk, wyuzdanie i poniewieranie jednych przez drugich. Inaczej jesteście tylko obłudnikami i faryzeuszami.

24. Dla zdobycia samiczki każdy używa takich środków, jakimi rozporządza. Stowik i tenor czarują śpiewem, elegant - pięknym krawatem i ładnie zakręconymi wąsikami, wojak - marsową postawą i urokiem munduru. Podobnie niejeden „myśliciel” i „filozof” stara się utorować sobie drogę do „serca” samiczki, „rozwijając” jej umysł przez wspólne studiowanie - stosownie do mody lub do własnej specjalności - bądź to Darwina i Haeckla, bądź też Spencera, Milla, bądź 
też Marksa i Lassalle’a, bądź też Krafft-Ebinga, bądź też Przybyszewskiego, bądź też nareszcie Platona, Tołstoja lub tp. Jeżeli przyznają się do tego otwarcie, wszystko jest w porządku. Gorzej jednak wygląda ta sprawa, jeżeli zamiast właściwego celu podstawia się obłudnie inne, a np. zawracanie głowy Platonem nazywa się uprawianiem „mitości platonicznej”. Wtedy podobni „myśliciele” i „filozofowie” stają na równi z owymi „misjonarzami” wolterowskimi, nawracającymi niewierne owieczki w sposób wcale niedwuznaczny.

25. Usprawiedliwianie wojen i zaborów jakąś „ideowością”, jakimś dążeniem do wymyślonego „dobra” itp. stoi na równi z wykrętami używanymi przez rozmaitych „nadludzi”, rozmaitych „myślicieli”, „filozofów” i „wieszezów”, którzy, dla usprawiedliwienia swych kaprysów i zachcianek, swej swawoli i swego wyuzdania zmysłowego, wprowadzają „nagą duszę” wraz z całym przyborem frazesów i pięknych słówek 0 wszechpotędze „miłości”, 0 „postępie dusz” itp. Tak jedno, jak drugie jest albo świadomym kłamstwem, albo też naiwnym łudzeniem samego siebie. Nierównie uczciwiej i naturalniej jest powiedzieć po prostu: „wojuję, bo chcę zagrabić, bo czuję w duszy krwiożerczość, bo jestem potomkiem ludożerców i rozbójników”. „Idę na wojnę, bo jestem tchórzem i boję się, bądź to zwykłej kary za dezercję; bądź też «opinii publicznej»”, „Zdradzam żonę lub „męża”, „cudzołożę”, „uwodzę”, rujnuję szczęście kobiet oraz całych rodzin, własnych i obcych - bo dogadza to mojej zmysłowości, bo czuję tego potrzebę; bo jestem zuchwałym samcem lub też rozwydrzoną samicą; bo jestem potomkiem w prostej linii poligamistów i gwałcicieli, potomkiem gorylów i dumnych rycerzy, uprawiających z dobrym skutkiem ius primae noctis.

Co tu ma do roboty „,naga dusza”, ,harmonia i postęp dusz”, „mitość platoniczna” itd., itd.?

Tak, tak, moi panowie! raubrittery ducha, „anarchiści” i „indywidualiści”, tj. Übermensche nieuznający żadnych obowiązków!

26. Dla podtrzymania autorytetu wśród tłumów niezbędne są bajki, sztuki łamane i kuglarstwa. 
21. Akcje $\mathrm{z}$ głupoty ludzkiej są najpewniejszymi. Przedsiębiorstwa i stowarzyszenia oparte na takich akcjach będą istnieć wiecznie.

28. Nieprzebrane skarby głupoty ludzkiej nadają się równie dobrze do eksploatacji jak wszelkie inne. Toteż zręczni przedsiębiorcy wyśmienicie je eksploatują i ciągną z nich niezmierne korzyści.

29. Oburzanie się znachorów i legendziarzy na myślicieli ewolucjonistycznych i to oburzanie się dochodzące nawet do podjudzania tłumów, ażeby w odpowiedni sposób rozprawiły się z zuchwalcami naruszającymi ciszę i gładką powierzchnię bagna myślowego, jest często gęsto objawem prostej zawiści nieuka ku oświeconemu. Osobnik, operujący z trudnością zaledwie czterema działaniami arytmetycznymi, spogląda z nienawiścią na tego, kto posiadł tajniki wyższej matematyki. Rachunek nieskończonościowy, pojęcie rozwojowości i determinizmu dostępne są tylko niewielu umysłom, a stąd prosty wniosek, że muszą być fałszem i zbrodnią. Tego zaś rodzaju „zdemokratyzowana” logika jest nierównie częstszą, niż się na pozór zdaje. Stanowi ona bowiem podstawę rozumowania wielu, nawet okrutnie uczonych mężów.

Pod godłem, że „lud się nigdy nie myli” abdykujemy z rozumu przed tłumem, a właściwie przed jego zręcznymi hersztami. Z tego źródła czerpie soki ożywcze uwielbienie dla dzisiejszego parlamentaryzmu i głosowania powszechnego, ściśle związane ze stanem wiedzy, w którym nie wiadomo, czy dzisiejsze 2 x $2=4$ będzie także jutro 4. Stąd chwiejność, niepewność, bezład myśli i jej najzupełniejsza anarchia. Stąd też wyprawy rozbójnicze na myśl wolną i niezależną urządzane przez motłoch kierowany widzialną lub niewidzialną ręką jawnych lub też ukrytych podżegaczy.

\section{VIII}

30. Jak nawet w matematyce potrzebne są „ilości urojone”, tak też w życiu indywidualnym i społecznym mogą oddawać wielką przysługę ilości urojone innego rodzaju.

31. Przed światłem nauki pierzchają mgliste dumania 0 nieskończonościach. 
32. Pod działaniem teologii ulatnia się religijność, pod działaniem logiki i matematyki ulatnia się teologia.

\section{IX}

33. Każdy człowiek jest żywym kwitem wydanym jego matce na przebyte przez nią cierpienia.

34. Celowość przyrody ze stanowiska komarowego: ludzie i inne zwierzęta ciepłokrwiste istnieją po to, ażeby swoją ciepłą krwią umożliwiały naszym żonom, paniom komarzycom, znoszenie jaj.

\section{X}

35. Jakżeż powolnie dokonywa się endosmoza najprostszych i najelementarniejszych zasad moralności, takich jak nie czyn drugiemu tego, co tobie niemito, nie zabijaj itd! Przecież nawet oficjalni głosiciele moralności, chociaż powtarzają bezmyślnie te zasady, to jednak w tej samej chwili gotowi są zarówno sami postępować wręcz przeciwnie, jako też zachęcać innych do czynów zadających tym zasadom kłam oczywisty. Zasady owe krążą tylko w środowisku moralnym, w którym żyją podobne indywidua, ale do ich wnętrza, z powodu ich gruboskórności moralnej, przedostać się nie mogą.

\section{XI}

36. Moralność zawodowych próżniaków, pojedynkowiczów i raubritterów godzi się doskonale z wszelką obłudą i z wszelkim oszustwem.

Pojedynkowicze i raubrittery, ludzie „honorowi”, ale bez sumienia i uczciwości, płacą skrupulatnie długi karciane, ale z najzimniejszą krwią zabijają, kradną, krzywdzą i uwodzą.

37. Wyzwać „bliźniego” na pojedynek, godzić na życie cudze i własne, a następnie, po pojedynku, dla zachowania pozorów (pour saiver les apparences) wyspowiadać się... oto próbka „moralności” dzisiejszych obrońców rodziny, kościoła i państwa, próbka „moralności” obrońców głównych podwalin istniejacego dziś porzadku spo- 
tecznego. Mimo woli przychodzą na myśl legendarni bandyci włoscy, spowiadający się po zabójstwie albo nawet i przed zabójstwem i przekonani, że wszystko jest w porządku.

Pytanie: czy panowie pojedynkowicze traktują religię i ,grzechy” własne poważnie, na serio, czy też jest to sobie tylko konwenansowy „flirt” religijny?

38. Pojedynkowicz godzący na życie „bliźniego” jest nieposzlakowany, jest „ezłowiekiem honoru”, ale kat usuwający ze świata „kwalifikowanego zbrodniarza” jest istotą pogardzaną.

Jegomość w todze i birecie podpisujący z zimną krwią wyrok śmierci nie przestaje być mężem zacnym i szanowanym; skromny zaś wykonawca najwyższej sprawiedliwości, zakładający stryczek na szyję lub oddzielający toporem głowę od kadłuba, uważany jest za wyrzutka społeczeństwa:

0 , rękę karaj, nie ślepy miecz!

39. Wytresowane przez faryzeuszów gromady dwunogich oddają nierównie większą cześć złemu aniżeli dobremu. Potęgi nadziemskie czezone są nie za swoją wmawianą w nich „dobroć”, ale za swoją grozę i okrucieństwo. Między ludźmi znowu cześć „boską” odbierają nie dobroczyńcy, ale złoczyńcy ludzkości; nie ci, co łzy koją i rany goją, ale ci, co rany zadają, co wyciskają strumienie tez i krwi; nie wielcy pedagogowie, wielcy filantropowie, ale wielcy wodzowie, wielcy rozbójnicy, wielcy inkwizytorowie.

Nie miłość rozpłomienia serca tłumów, ale nienawiść i żądza krwi.

40. Gawiedź (tj. ludzkość) najłatwiej daje się porywać i entuzjazmować genialnym egoistom, tj. indywiduom, które tylko własną korzysśc mają na widoku. To nam objaśnia powodzenie Napoleonów i innych tego rodzaju opryszków, dla których miliony ludzi poświęcały chętnie życie i wszystkie dobra swoje.

41. „Wielcy ludzie” z gatunku kanibalów są dla narodów bardzo kosztowną zabawką. Dobrobyt, rozsądek, moralność... wszystko to składa im się w ofierze.

42. Za największych ludzi w oczach tłumów uchodzą ci, co streszczają w sobie dzikość danej epoki. Napoleon I streszczał w sobie dzikość awanturniczą i dezorganizacyjną końca przeszłego i po- 
czątku bieżącego stulecia, Bismarck zaś - dzikość uorganizowaną współczesnej nam epoki ${ }^{1}$.

\section{XIII}

43. Dla większości ludzi prawa, rytuały, przepisy i ceremonie zwyczajowe są przede wszystkim dlatego tak cenne, że naruszanie ich daje sposobność do obmawiania i czernienia bliźnich.

44. Rozmaitych przykazań i przepisów moralności wyuczamy się filologicznie, tj. nie dla tego, ażeby je wypełniać, ale tylko żeby popisywać się erudycją i mydlić ludziom oczy. Stosujemy zaś te przykazania i przepisy moralności oportunistycznej, tj. geschäftsmässig².

45. Bardzo wielu ludzi utożsamia prawność z własną samowolą i kaprysem, a wszelkie odwoływanie się do prawa uważa za obrazę osobistą.

46. Poczucie sprawiedliwości oraz dążność do urzeczywistnienia ideału sprawiedliwości istnieją tylko w świecie psychicznym. Sprawiedliwości zaś obiektywnej, sprawiedliwości w życiu i w świecie w ogóle - nigdy nie było i nigdy nie będzie.

47. Poczucie sprawiedliwości może być właściwe tylko człowiekowi wolnemu od przesądów i na wskroś demokratycznie usposobionemu. „Demokratyczność” oznacza tu nie formę rządu, ale, po nowożytnemu, zasadę równości wszystkich ludzi.

48. Prawdziwe wolnomyślicielstwo, prawdziwa „demokratyczność”, prawdziwy altruizm - możliwe są tylko we wzajemnym połączeniu.

49. Jeden ze współczesnych poetów hiszpańskich ${ }^{3}$ powiedział: todos los justos por un bueno (wszystkich sprawiedliwych za jedne-

1 W Upominku, ksiażce zbiorowej na cześć Elizy Orzeszkowej (18661891), Kraków-Petersburg 1893, aforyzm ten, skutkiem niedbałej korekty, został wydrukowany w okaleczonej postaci, z opuszczeniem całego wiersza [przyp. BdC].

2 Geschäftsmässig (niem.) - dosłownie 'po kupiecku', ale też 'oficjalnie', tu: 'formalnie', 'dla interesu'.

3 Campoamor. Hiszpanom ludzie „sprawiedliwi” i czyściciele ludzkości, w rodzaju błogosławionego Tomasza de Torquemada i świętego Piotra Arbues de Epila, dali się dobrze we znaki [przyp. BdeC]. 
go dobrego). Miał on oczywiście na myśli fanatyków sprawiedliwości, a więc szaleńców, w których mniemaniu nie sprawiedliwość istnieje dla ludzi, ale ludzie dla sprawiedliwości: pereat mundus, fiat justitia. Ponieważ zaś życie samo jest wielkim okrucieństwem i wielką niesprawiedliwością tak dla „sprawiedliwego”, jak i dla jego bliźnich, i ponieważ konsekwencje „sprawiedliwości są tylko przepełnianiem miary okrucieństw, więc prawdziwie sprawiedliwym może być tylko człowiek dobry i przebaczający, przebaczający - stosownie do swego charakteru - albo nie tylko sobie, ale także innym, albo też nie tylko innym, ale także sobie.

50. Nieugiętością praw wojskowych człowiek myślący (homo sapiens) szczycié się nie powinien, podobnie jak nie ma czego zazdrościć bydlęcej prostolinijności byka. Indywiduum z myślą maszerującą na odgłos bębna lub trąbki idzie po linii prostej nie dlatego, że jest to najkrótsza odległość, ale dla tego, że zbaczać nie potrafi.

51. Die Rache ist süss ${ }^{1}-0, \mathrm{z}$ pewnością! Przecież nawet bogowie mszczą się bezgranicznie nad nędznymi robakami, skazując ich na męki wiekuiste.

XIV

52. W społeczeństwach „cywilizowanych” prawdziwa uczciwość jest zbytkiem, na który mogą sobie pozwalać bezkarnie tylko ludzie materialnie niezależni. Jako przedmiot zbytku jest ona też obłożoną dotkliwym podatkiem.

53. Bardzo wielu ludzi uchodzących za „moralnych” $i$,inteligentnych" zadawalnia się przyzwoitością i moralnością rękawiczkową, dla moralności zaś prawdziwej są oni całkiem niedostępni.

54. Kult konwenansu i „uznanych” przepisów moralności prawomyślnej jako lichy surogat moralności uniemożliwia w duszy w ten sposób spreparowanego osobnika poczucie moralności prawdziwej. Podobnie też fałszywa wiedza tamuje wiedzy prawdziwej przystęp do umysłu.

1 Die Rache ist süss (niem.) - Zemsta jest słodka. 
55. Dawnej moralności tradycyjnej grozi paraliż i marazm. Dla podtrzymania gasnących sił ucieka się ona do sztucznych środków, budząc nienawiść rasową, rozdmuchując zarzewie antysemityzmu i tłumiąc wszelkie zarodki myśli niezależnej.

56. Etyka musi byé z gruntu przerobioną i opartą na innych, nie religijno-wyznaniowych podstawach. Powinna ona byé nie narzucaną ludziom jako jeden ze środków akomodacji do otoczenia, ale wydobywaną z wewnątrz indywidualności ludzkiej, rozwijaną z zarodków, tlejących, choćby tylko w minimalnych rozmiarach, w duszy każdego człowieka niezgangrenowanego pod względem moralnym. Zwłaszcza z dziećmi dałoby się tu wiele zrobić. Jeżeli etyka nasza nie ulegnie reformie, nastąpi rozkład ostateczny społeczeństw „cywilizowanych”.

\section{$\mathrm{XV}$}

57. Im więcej przepisów i obrządków, tym mniej miejsca na cnoty indywidualne.

58. Starannie tłumimy prawdziwą oświatę oraz indywidualną, prywatną, samodzielnie w osobnikach rozwijającą się moralność. Uznajemy jedynie tylko moralność zdawkową, konwencjonalną, stadowo-egoistyczną. Brak też nam najzupełniej indywidualizmu i prawdziwego uspołecznienia. Fatalność dzisiejszego ustroju ludzkości „cywilizowanej” stanowi głównie to, że uprywatniono dobra materialne leżące poza człowiekiem, a ze skwapliwością godną lepszej sprawy upaństwowiono i uspołeczniono najindywidualniejsze i najnietykalniejsze tajniki duszy ludzkiej, poddając je bezmyślnej mustrze i tresurze.

59. Nic chyba bardziej okrutnego, jak przymusowa dziedziczność najgłębszych i najświętszych wierzeń i przekonań, Jest to tym wstrętniejsze, że owa narzucana dziedzicznośé utrzymuje się często tylko dzięki udawaniu i obłudzie.

\section{XVI}

61. Człowiek żywy, gorejący istotnie „miłością bliźniego”, nie mógłby wcale istnieć. Ogrom boleści wywołanej wspótczuciem bez- 
granicznym a beznadziejnym cierpieniom tylu milionów bliźnich zabiłby go w jednej chwili.

62. Dlaczego zwierzchnik znęca się nad podwładnym? - bo pała miłością bliźniego. Dlaczego waleczny syn Marsa strzela do tłumu, w którym mogą się znajdować jego najbliżsi bliźni? - bo pała miłością bliźniego. Dlaczego zdobywca, „bohater - bóg wojny” niszczy całe krainy ogniem i mieczem, oddając na pastwę żołdaków mienie mieszkańców i cześć ich córek? - bo pała miłością bliźniego. Dlaczego czciciel Afrodyty czyha na cześć niewieścią, niszcząc szczęście całych rodzin? - bo pała miłością bliźniego. Dlaczego „sprawiedliwy” podpisuje wyrok śmierci lub mąk dożywotnich? - bo pała miłością bliźniego. Dlaczego „rycerz pióra” rzuca potwarze i oszczerstwa? - bo pała miłością bliźniego. Dlaczego Pontifex maximus minimusque ${ }^{1}$ rzuca klątwę i pali kacerzy na stosie? - bo pała miłością bliźniego.

Na rtech misto lasky požehnani - p rok li n a $n i^{2}$.

\section{XVII}

63. Moralność teologiczna ma wiele podobieństwa zjednostronną medycyną alopatyczną: tak jedna, jak druga leczą receptami i przepisywaniem środków obcych organizmowi, bez pobudzania jego własnej samodzielności i żywotności.

64. Głosiciele panującej moralności ośmielają się krakać 0 „bankructwie nauki”. Nie, moi panowie, nauka nie bankrutuje, ale bankrutuje wasza moralność oparta wyłącznie na handlu zamiennym, na wszechludzkim obłędzie wielkości oraz na zasadzie, że „nie sam grzech jest grzechem, ale tylko zgorszenie przezeń wywołane”.

65. Moralność głosząca obłudnie miłość bliźniego, a w życiu uprawiająca szczucie i nienawiść bliską jest ostatecznego bankructwa. Jej miejsce musi zając moralność niewmawiająca w ludzi

$1 \quad$ Pontifex maximus minimusque (łac.) - kapłan najwyższy i najniższy.

2 Jan Rokyta: Auto da Fé (Světla a bludičky, V Praze 1898, str. 70 [przyp. BdC]. Przytoczony przez Baudouina cytat z wiersza Rokyty: Na rtech misto lasky požehnani - p r o $k$ l i n a n $i$ (czes.) - Na wargach zamiast btogostawieństwa mitości - przekleństwa. [uzup. M.S.] 
sprzecznej z naturą ludzką miłości „bliźniego”, ale za to oparta na rozumie oraz na pielęgnowaniu i umiejętnym rozwijaniu poczucia sprawiedliwości, wrodzonego każdemu ani nieupośledzonemu od urodzenia, ani też niespaczonemu przez wychowanie i otoczenie człowiekowi.

66. Najwyższa, najdoskonalsza moralność może się rozwinąć tylko na tle bezwyznaniowym, co zresztą nie jest jeszcze wcale równoważne $\mathrm{z}$ absolutną bezreligijnością.

\section{XVIII}

67. Nie zabijaj: ani indywiduów, ani grup; ani ludów, ani ras; ani życia, ani szczęścia; ani ciała, ani myśli; ani dobrobytu, ani ideałów. Nie zabijaj: ani nielegalnie, ani legalnie; ani „niehonorowo”, ani „honorowo"; ani skrytobójczo, ani też z całą paradą, przy odgłosie trąb i bębnów.

\section{XIX}

68. Najlepszym może być tylko rząd arystokratyczny, ale w pierwotnym, etymologicznym znaczeniu tego wyrazu - jako rząd najlepszych. Pytanie jednak: skąd brać tych najlepszych?

69. Jak dzieci poczęte w szale i pijaństwie niewielką bywają pociechą, jak genialne utwory delirantów podniecających się haszyszem lub koniakiem trącą szpitalem wariatów, tak też „reprezentacje” narodów samodzierżawnych spłodzone w chwili szału i upojenia wyborczego muszą nosić w sobie zarodki choroby nieuleczalnej.

Parlamentaryzm ochlokratyczny - to zguba społeczeństw dzisiejszych.

XX

70. Dokonywające się obecnie, a coraz szersze kręgi zakreślające upaństwowienie uczuć ludzkich ma za cel ostateczny przerobienie męskiej połowy rodu ludzkiego na maszyny bezmyślne, posiadające tylko dwa uczucia tłumowe: uczucie strachu przed batem zwierzchni- 
ka i uczucie gotowości rzucenia się na komendę na wskazanego przez zwierzchność „bliźniego” i rozszarpania go na kawałki.

Uczucia innego porządku - uczucia rodzinne, uczucia „miłości bliźniego", czyli altruistyczne, uczucia indywidualistyczne - jako nie tylko niepotrzebne, ale nawet sprzeczne z celami państwowymi, ulegają zaniedbaniu, a jako zaniedbywane coraz bardziej słabną.

Kopalnie uczuć szlachetnych leżą odłogiem, bez eksploatacji, a eksploatujemy za to gorliwie coraz bardziej rosnące zasoby uczuć antyspołecznych.

Stopniowo dojdziemy do tego, że, spotykając się na ulicy, będziemy w duchu zęby na siebie wyszczerzać i warczeć.

71. Upaństwowienie i w ogóle ugromadnienie wiary, nauki, przekonań... niszczy charaktery, niszczy oporność i samodzielność, wytwarzając bezmyślne narzędzia i zwierzęta tresowane, ale nie ludzi myślących i samodzielnie działających. Na takim gruncie wyrasta z jednej strony stadowy konserwatyzm, z drugiej zaś stadowy radykalizm - oba jednakowo niepożądane, a nawet zgubne, właśnie dla interesów gromadnych.

72. Skutkiem ustroju państwowego bywa zbyt często demoralizacja, rozprzężenie, wyniszczenie i w ogóle unieszczęśliwianie społeczeństw.

73. Jeżeli tresujecie ludzi na uorganizowanych rozbójników, nie dziwcie się, że zabijają potem na własną rękę. Jeżeli zwyczajowo uprawiacie oszustwo, nie dziwcie się wzrostowi oszustwa na własną rękę, z inicjatywy prywatnej.

74. Kto narusza prawo i dopuszcza się fałszu, jest chyba „anarchistą”, tj. „burzycielem podstaw”. A właśnie między tzw. „Zachowawcami” najwięcej jest takich mężów niekrępujących się ani prawem, ani prawdą. Doskonałym tego przykładem są procesy Dreyfusa i Zoli, rojące się od objawów deptania prawa i sprawiedliwości, od fałszerstw, od nacisku ze strony munduru itd.

75. Jeżeli chcesz zwalczyć anarchię, nie uciekaj się ani do „praw” wyjątkowych, ani też do innych środków bezprawnych i niesprawiedliwych.

Kto kuje i aprobuje prawa wyjątkowe, zwrócone przeciw narodowościom, przeciw wyznaniom, przeciw stronnictwom politycznym, 
kto już w szkole zatruwa młodociane umysły nienawiścią międzynarodową i międzywyznaniową, kto wyrywa młodzież z łona rodzin i tępi w niej uczucia ludzkie, tresując ją na organizowanych morderców, kto bezbronnych żołnierzy i urzędników oddaje na pastwę zwierzchników, a wszystkich obywateli na pastwę samowoli policyjnej, kto metodę konfiskat uważa za najdzielniejszą rękojmię wolności prasy, a wolny od przekonań oportunizm za najwyższą mądrość polityczną, kto swoim bezprawnym i niesprawiedliwym postępowaniem podkopuje wszelkie poczucie sprawiedliwości - ten, pod płaszczykiem podtrzymywania istniejącego porządku, poczyna sobie jako agent provocateur, ten pracuje, może nawet mimo wiedzy i chęci, na korzyść anarchii.

\section{XXI}

77. Polityka to smrodliwa kloaka; kto do niej wpadnie, musi się oplugawić.

Rozpolitykowanie tępi poczucie sprawiedliwości. Polityka a uczciwość wyłączają się nawzajem.

78. Jest to dowodem wielkiej naiwności domacywać się „uczciwości” w polityce i rozprawiać o uczciwych a nieuczciwych politykach. Jak wszelkie siły żywiołowe (ogien, powódź, zaraza...), jak wszelkie zawody rozbójnicze, oszukańcze i złodziejskie, chociażby nawet sankcjonowane i organizowane przez najwyższe powagi, nie mają nic wspólnego ani z uczciwością, ani z moralnością. Jak samo pojęcie moralności nie ma nic wspólnego z polityką, której ideałem jest zawsze i wszędzie władza i panowanie, a która, dążąc do tego celu, w środkach nie przebiera. Nie uczciwość lub nieuczciwość rozstrzygają 0 wartości polityki, ale tylko powodzenie lub niepowodzenie.

Gazety - to przeważnie fabryki fałszu oraz nienawiści międzynarodowej i międzystanowej. Nic dziwnego, że trucizna przesączająca się codziennie do umysłów czytelników pozbawionych zdolności krytycznej, a natomiast posiadających spory zapas egoizmu i chciwości, coraz bardziej ich roznamiętnia i robi ich gotowymi do „czynu”. 
80. Należenie do jakiegokolwiek stronnictwa czy to politycznego, czy religijnego, czy też literackiego demoralizuje człowieka. W stronnictwach bowiem panuje zwykle zasada „celów uświęcających środki” oraz zasada okłamywania niewtajemniczonych.

\section{XXII}

81. Najbezmyślniej bywają oceniane wyroby literackie: od wiersza lub od stronnicy. Perła, ziarno, kawałek złota lub kawałek kału są jednakowo opłacane, mają jednakową wartość, byle tylko posiadały te same rozmiary.

82. Czym zaściankowość w przestrzeni, tym jest tak zwana „aktualność" w czasie.

\section{XXIII}

83. Wszelkiego rodzaju liberia jest jednym z najskuteczniejszych środków podtrzymywania „istniejącego porządku”.

84. Zamiłowanie do sportu daje się spostrzegać także u zwierząt, a zwłaszcza u psów. Les beaux esprits se rencontrent ${ }^{1}$. Psie dusze spotykają się tutaj ze szlachetnymi duszami próżniaków dwunogich. Obok sportsmenów mamy także „sportsdogów”.

\section{XXIV}

85. Antysemityzm jest dzieckiem Starego Testamentu.

86. Antysemityzm daje się usprawiedliwić jedynie chyba chęcią zemsty za zanieczyszczenie naszych wyobrażeń moralnych potwornymi legendami starotestamentowymi, urągającymi wszelkiemu poczuciu prawdy i sprawiedliwości.

87. Nie zajmuję się polowaniem na ludzi, ani też w ogóle nie jestem myśliwym, a wszelkie szczucie jest mi wstrętne. Uprawiany z taką lubością sport szczucia Żydów objaśniam sobie wrodzoną większości ludzi potrzebą nienawidzenia i prześladowania. A Żydzi

1 Les beaux esprits se rencontrent (fr.) - Piękne dusze się spotykają. 
tak się doskonale do tego nadają! Przecież przez ciąg całych stuleci stanowili oni béte noire ${ }^{1}$ motłochu „chrześcijańskiego” Europy.

Jeżeli jednak ktokolwiek bądź należący do mniej uprzywilejowanych grup ludzkości, a przez to samo już za swe pochodzenie odznaczony piętnem skazańca (jak np. Litwin, Polak z Prus wypędzony, nie-Węgier w Węgrzech, nie-Rosjanin w Rosji itd., itd.), przyłącza się także do owego chóru naszczekującego na Żydów, powinien, myśląc konsekwentnie, uznać za sprawiedliwe także prześladowanie, któremu sam ulega.

Wszelkie prawa wyjątkowe, skierowane czy to przeciwko plemieniu, czy to przeciwko narodowi, czy to przeciwko wyznaniu, czy to przeciwko pewnemu stronnictwu itp., działają zawsze demoralizująco; a jednak we wszystkich epokach reakcji i upadku bywają one kute z wielkim upodobaniem, pomimo że nieśmiertelny Herod swym radykalnym wymordowaniem wszystkich niewiniątek pozostawił nam przykład aż nadto od podobnych praw wyjątkowych odstraszający. Jeżeli niektórzy Żydzi są osobiście szkodliwi, to za to powinni pokutować nie szkodliwi jako szkodliwi, ale wszyscy Żydzi jako Żydzi! ${ }^{2}$

88. Kto choćby w najniewinniejszej rozmówce towarzyskiej wyraża pobożne życzenia „wypędzenia” „wstrętnych” dla niego Żydów, kto zagadnienia ogólnospołeczne stawia na gruncie wyznaniowym, kto, pragnąc klin klinem wybić, wzdycha do „antydotu antysemityzmu”, ten tylko w zewnętrznych objawach różni się od „pijanego włóczęgi” i „niedorostka”, znęcającego się nad „wstrętnym” dla niego Żydem, i powinien z całego serca przyklasnąć wybuchłym nareszcie „rozruchom z powodu Żydów”. I klaskano by też z całą otwartością, wołano by „brawo!” na całe gardło, gdyby się nie obawiano, że od płonącego żydowskiego domostwa zajmie się także własny pałac i fabryka. Przede wszystkim „altruizm” i względy na „dobro ogólne”!

\footnotetext{
Béte noire (fr.) - tu: przedmiot antypatii, nienawiści.

2 Po raz pierwszy ogłosiłem to po niemiecku w Zur Judenfrage. Zeitgenössische Originalaussprüche. Herausgegeben von Carl Ed. Klopfer. Mit einer Vorbemerkung von Professor Dr. Ernst Hallier. München 1891 [przyp. BdeC].
} 
89. Pożar antysemicki gasimy mordem legalnym i kajdanami, ale otwarci, bezpośredni podżegacze, wlewający codziennie jad nienawiści do spragnionych podobnego pokarmu dusz „chrześcijańskich”, mogą dalej, bez żadnej przeszkody uprawiać swoje protegowane rzemiosło.

\section{XXV}

90. Czynniki psychiczne tak zwanej historii powszechnej należy studiować przede wszystkim w domach dla obłąkanych, w więzieniach kryminalnych i w menażeriach. $W$ tych to właśnie przybytkach pobudki poruszające ttumami dwunogimi i wiodące „wielkich mężów” do sławy występują daleko czyściej i wybitniej aniżeli w objawach życia codziennego.

91. Gdyby nie kanibalistyczne, czyli ludożereze, pozostałości w naszych instynktach nie byłoby z pewnością wielu czynów „bohaterskich”, nie byłoby „ruchów ludowych”, „rewolucji”, „powstań”, nie byłoby „wojen w imię świętych haseł”.

Jak „dzikiemu Azjacie” sprawia niewymowną przyjemność chrzęst noża przesuwanego po gardle znienacka napadniętej ofiary, tak samo bez wątpienia rozkosznym mrowiem przejmują „bohatera” przedśmiertne podrygi mordowanego „wroga”.

Kiedy głodny ludożerca mordował swego „bliźniego” dla zaspokojenia głodu, sprawiało mu to łatwo zrozumiałą rozkosz; dziś jego „cywilizowany” potomek rozkoszuje się śmiertelnym rzężeniem ofiary mordowanej „w imię idei”.

92. „Przykazania” moralności istnieją dla potrzeb retorycznych i dla stosowania oportunistycznego. Zresztą nikt prawie o nie się nie troszezy.

Z jednej strony głoszą ostentacyjnie, ale tak sobie, w powietrze, nie zabijaj! a jednocześnie, grożąc rozstrzelaniem lub co najmniej więzieniem, powtarzają biedakom: „zabijaj na komendę, jak gdyby nigdy nic, nawet własnych rodziców".

Z jednej strony powiada się głośno: nie kradnij, nie oszukuj, nie kłam, ale, mrugnąwszy przyjacielsko, dodaje się na ucho: „oszukuj, kłam i kradnij, jeżeli to będzie z twoją korzyścią”. 
Jeżeli skutkiem tego $\mathrm{w}$ duszy danego osobnika powstanie kolizja, to co ostatecznie zwycięży? Otóż zwykle zwycięży to, co jest lepiej dostrojone do krwiożerczej i podłej natury ludzkiej.

93. Moralność prawomyślna, moralność konwencjonalna twierdzi, że wprawdzie nie należy zabijać, ale, jeżeli każą, to zabijać trzeba. Zabijania na własną rękę wypada unikać, ale zaleca się zabijanie zbiorowe. Kto zaś ośmieliłby się twierdzić, że bezwzględnie nie należy zabijać i chciałby to w czyn wprowadzié, byłby karany i prześladowany.

94. Stosowanie dziś jeszeze „kary śmierci” tkwi bardzo głęboko w niewygasłych dotychezas instynktach krwiożerczych panów prawodawców i sędziów oraz widzów i czytelników. Powoływanie się przy tym na „sprawiedliwość” jest tylko pretekstem i mydleniem oczu.

95. Wytresowane automaty tą samą rękką żegnają się w imię „Boga mitości” i tą samą ręką wymierzają śmiertelny cios w pierś „bliźniego”, który im nic nie zawinił, ale którego kazano im zabijać.

96. Rozmaici forcénés ${ }^{1}$, rozmaici deliranci, rozmaici sataniści wielbiący „wielką rewolucję” „wielkiego narodu” uważają krwawe manifestacje i rewolucje za niezbędny warunek postępu społecznego. Do istniejących więc niesprawiedliwości szaleńcy ci chcą dodawać daleko większe: apoteozują krzywdzenie i mordowanie niewinnych, apoteozują rzeź niewiniątek, apoteozują zmuszanie broniących „istniejącego porządku" maszyn dwunogich do zabijania i niszczenia. W tym też kierunku pchają „młodzież uczącą się” rodzice i wychowawcy, grożący „ucinaniem głów przez socjalistów” i zapowiadający, że ten tylko uniknie tej smutnej ewentualności, kto sam będzie głowy ucinał. Tak spreparowany elew wyrasta na przesiąkniętego nienawiścią do ludzi „obrońcę istniejącego porządku”; a od takiego usposobienia do rzezi... tylko jeden krok.

97. Jedynie endemiczne tchórzostwo umożliwia istnienie armii i organizowanie spisków.

98. Wojska i wojny stoją tchórzostwem, biernością i głupotą ludzką. A że zawsze jest i będzie daleko więcej tchórzów, biernych

1 Forcénés (fr.) - furiaci. 
i głupich, aniżeli odważnych, samodzielnych i rozumnych, więc też istnienie ludzkości będzie równoznaczne z istnieniem wojsk i wojen.

99. Wobec fatalności wojny, wobec musu pędzącego na rzeź całe stada ludzkie szyderczo brzmi dodatek spotykany na wszystkich prawie pomnikach wznoszonych na polach bitew: polegli śmiercią bohaterską. Rozumiem bohatera bądź to ginącego na krzyżu lub na stosie za swoje przekonania, bądź też idącego śmiało na tortury i niedającego inkwizycji wydusić z siebie zeznań kompromitujących; ale bohatera z musu, bohatera oszalałego i skutkiem wrzawy wojennej pozbawionego ludzkiej świadomości, bohatera pijanego krwią, bohatera mordującego i mordowanego - takiego bohatera uznać nie mogę i nigdy nie uznam.

\section{XXVI}

100. Postęp cywilizacji polegał dotychczas na przechodzeniu od luźnego rozboju na własną rękę do zorganizowanego rozboju z musu.

101. Jeżeli istnieje rzeczywisty postęp w życiu ludzkości, to czy nie dałoby się ująć go w formule, iż jest on powolnym przejściem od stanu stadowo-egoistycznego do stanu społeczno-indywidualnego?

102. Doświadczenia wiwisekcyjne ${ }^{1}$ oraz tresowanie rekrutów są poniekąd dalszym ciągiem prześladowań inkwizycyjnych. Nic można już znęcać się nad „zbrodniarzami” i nad „heretykami”, więc się znęcamy nad zwierzętami i ubezwładnionymi żołnierzami.

103. Zaborczość państwa rzymskiego przeżyła jego istnienie, a nawet spotęgowała się po jego upadku. Używa ona innych haseł i wysyła na podbój zastępy innych wojowników, ale zastępy daleko niebezpieczniejsze niż owe dawne krwiożercze legiony.

104. Nieustająca aż do dni naszych zaborczość Rzymu starożytnego rzuca się dziś z całą bezwzględnością, zaciekłością i brutalnością już nie na ciało, ale na duszę człowieka,

1 Oczywiście wyłączam z tego wiwisekcje, będące kon i e c z n o ś c i ą metody doświadczalnej. Nie da się jednak zaprzeczyć, że w nierównie większej ilości wypadków panowie „eksperymentatorowie” męczą zwierzęta bez najmniejszej potrzeby naukowej, jedynie dla dogodzenia własnemu okrucieństwu i chęci znęcania się nad słabszym [przyp. BdeC]. 
105. Ludzi szczerze wierzących i dążących do ideału moralnego żądni wrażeń „estetycznych” cezarowie rzymscy rozszarpywali w cyrkach z pomocą dzikich zwierząt, a utworzonymi z nich „żywymi pochodniami” zdobili swoje ogrody. Takich samych ludzi spadkobiercy cezarów palili uroczyście na stosach i poddawali usystematyzowanym mękom inkwizycji świętej. Metodę cokolwiek zmieniono, ale punkt wyjścia i ostateczny rezultat pozostały nienaruszone.

100. Dopóki instytucja głosząca miłość bliźniego i obowiązek stosowania się do wymagań dziesięciorga przykazań znajdowała się W sprzeczności z instytucją opierającą się na niewoli i poniewierce oraz na obowiązku spełniania zbrodni na rozkaz zwierzchności, dopóty mogła imponować każdemu i być czystą i nieskalaną. Poniżywszy się jednak do zgody z tą drugą i stawszy się jej wspólniczką, upadła moralnie i zeszła na stopień wielkiej obłudnicy.

107. Na gruzach gniazda krwiożerczych sępów usadowił się czarny pająk; chełpi się, że sępów pokonał, a nie chce przyznać, że duch sępów w nim żyje i kieruje jeno ruchami.

\section{XXVII}

108. Ani nie strzelaj do słońca, ani też nie staraj się powstrzymywać prądu rzeki.

109. Jeżeli chcesz myśleć logicznie, nie powołuj się nigdy na „prawa historyczne”, bo, posuwając się konsekwentnie coraz dalej, staniesz w jak najjaskrawszej sprzeczności z samym sobą i będziesz musiał żądać jak najradykalniejszych przewrotów.

110. Umieć zapomnieć - to jedna z podstawnych cnót politycznych.

111. Dążność do zachowania właściwości plemiennych i wstręt do lepienia narodowości są polem, na którym mogą się zejść i podać sobie po bratersku ręce szlachetni zachowawcy (konserwatyści) ze szlachetnymi postępowcami. Jedni pragną istotnie zachowywać, konserwować, drudzy zaś szanują wolność jednostek i plemion. 


\section{XXVIII}

112. Dzisiejsi panowie świata europejsko-amerykańskiego arystokraci, bogacze i „inteligenci” „burżuazyjni” - patrzą z takim wstrętem, obrzydzeniem i oburzeniem na grube objawy „emancypacji” proletariatu, bo widzą w nich ogołocone z wszelkich obsłonek odzwierciedlenie własnych pożądań i „zasad”.

113. Na ramę rozgoryczenia społecznego przykładać jedynie plasterek z mdłych frazesów o ewangelicznym uprzywilejowaniu ubóstwa, używając przy tym samemu wszelkich wygód życia, jest to podsycać ogień naftą.

114. Do najradykalniejszych celów można dążyé środkami legalnymi, spokojnie i łagodnie; najzacieklejszy zaś „konserwatysta” może w chwilach zapomnienia uciekać się do warcholstwa i do środków eksterminacyjnych. Ale wtedy przestaje byé „Zachowawcą” i staje się reakcjonistą. Reakcja zaś i rewolucja - to dwie rodzone siostrzyce.

\section{XXIX}

115. Zanieczyszczonym kwiatkami oportunizmu pedagogicznego umysłom, prosta zdrowa logika sprawia ból nie do zniesienia.

116. Trwający do dziś dnia system wychowania zanieczyszeza głowy bajkami urągającymi logice i wynikom wiedzy przyrodniczej; usunięcie zaś wiary w te bajki połączone jest zwykle z bólem, a dla wielu jest rzeczą niedoścignioną.

117. Szkoła bywa niekiedy knajpą naukową, pracującą nad rozwinięciem we wszystkich wychowańcach jednakowego grubiaństwa i jednakowej płaskości i niskości instynktów.

118. I szkoła, i prasa, i kościót, i urząadzenia społeczno-państwowe - wszystko to wpaja nienawiść do innych ludzi, a o miłości i przebaczeniu mówi tylko dla przyzwoitości.

119. I najbliższe otoczenie, i szkoła, i kościót, i instytucje państwowe wychowują człowieka w nienawiści i pogardzie dla bliźnich. Nic więc dziwnego, że, otrząsnąwszy się z wpływu tych powag i doszedłszy do (nadzwyczaj zresztą rzadkiej) samodzielności umysło- 
wej, przenosi on owe szlachetne uczucia na swych poprzednich opiekunów.

120. Nawet dzisiejszy, najnowszy system pedagogiczny podsyca w wychowańcach nienawiść „bliźniego”, żądzę zemsty i żądzę niszczenia życia.

$\mathrm{Z}$ jednej strony zaszczepiają w młodociane umysły nienawiść i żądzę zemsty, każą lubować się opisami jatek ludzkich, gloryfikując „pomszczenie krzywd”, „zadosyćuczynienie”..., z drugiej zaś strony prawią o „miłości bliźniego”, każą „nie zabijać”, „nie pożądać”, „kochać bliźniego jak siebie samego”. Jedną ręką pokazują „kochaj bliźniego”, drugą zaś ręką „zabijaj bliźniego”. I po tym wszystkim dziwią się obłudnicy i szalbierze, że w umysłach w ten sposób zatrutych powstaje rozterka duchowa, powstaje chaos, powstają liczne sprzeczności i dążenie do usunięcia tych sprzeczności za jaką bądź cenę.

122. Jeżeli pragniesz spokojnego rozwoju ludzkości, nie zatruwaj już w szkole młodocianych umysłów nienawiścią międzynarodową i międzywyznaniową.

123. Nasza pedagogika europejska nie bardzo się posunęła poza wieki średnie. Ta sama prawie bezmyślność, ten sam brak krytycyzmu, ten sam za panią matką pacierz, to samo iurare in verba magistri ${ }^{1}$. Sposób zaś uświadamiania uczuć i wyobrażeń religijnych sięga pierwocin cywilizacji, sięga epoki najpierwszych odkryć i wynalazków w zakresie kosmogonii, higieny, medycyny, fizyki itd. Jak pojedynczemu człowiekowi usłyszane w dzieciństwie banialuki dają bardzo często obuchem w łeb i przeszkadzają dalszemu rozwojowi umysłowemu, tak samo pierwsze odkrycia i wynalazki, istotnie dla owych czasów potężne i wielkiej doniosłości, tak zaimponowały tłumom, że stały się na długie czasy doskonałym środkiem do zagważdżania głów i do oddawania ich na łaskę i niełaskę znachorów. Znachorzy ci, reprezentujący właśnie ów niższy szczebel cywilizacji, wyzyskują swój wpływ dla panowania nad światem i wiodą zaciętą walkę z przedstawicielami prawdziwej nauki, nieznającej zastoju i dążącej ciągle naprzód.

1 Iurare in verba magistri (łac.) - dosłownie: przysiegać na stowa mistrza, tzn. wierzyé ślepo w coś, opierając się na autorytecie. 
124. Nawet dzisiejsza, najnowsza pedagogika traktuje nie tylko wiedzę, ale także cnoty i „przekonania” po fabrycznemu. Po prostu tresuje w nich, narzuca je z zewnątrz, wcale się nie troszcząc o rozwinięcie cnót i przekonań drogą samodzielności indywidualnej.

125. Jednym z najbardziej upokarzających objawów dobrowolnego niewolnictwa jest tylowiekowe przeżuwanie dla celów „pedagogicznych”, pod nazwą „wykształcenia klasycznego”, rozmaitych okruchów życia umysłowego i społecznego dawnych Rzymian i Greków.

126. Karmienie młodzieży gimnazjalnej prawie wyłącznie karykaturą filologii klasycznej jest w dzisiejszych czasach wielką zbrodnią pedagogiczną i społeczną i daje się objaśnić albo własną głupotą kierowników, albo też chęcią ogłupiania społeczeństwa.

127. Zamiast żądnym wiedzy umystom otwierać księgę przyrody i życia we wszelkich jego objawach, zamiast rozwijać w tych umysłach samodzielność, krytycyzm i zdolność samokształcenia się, staramy się tłumić to wszystko przez wkuwanie pozbawionych racjonalnej podstawy prawideł gramatycznych, przez narzucanie nieprzetrawionych sądów i przez zamulanie głowy bajkami urągającymi zdrowemu rozsądkowi.

128. Niektóre rządy używają świadomie tak zwanego „wychowania klasycznego" za środek polityczny, za środek do tłumienia samodzielności i biernienia umysłów młodzieży. Trzeba przyznać, że cel zamierzony osiągają w zupełności i na razie zostają panami potożenia. Czy jednak i w dalszym ciągu takie obniżenie poziomu umysłów społeczeństwa będzie z korzyścią dla „kierowników nawy państwowej”, to już inna kwestia.

129. Usuńcie z kodeksów karnych pojęcie pracy przymusowej, a uczynicie potężny krok ku uszlachetnieniu i „uczłowieczeniu ludzkości”.

130. Zróbcie pracę obowiązkową i ćwiczenie się w rzemiosłach integralną częścią ogólnego wykształcenia, a zbliżycie się znacznie do spokojnego rozwiązania kwestii socjalnej.

131. Dotychezas jeszeze praca hańbi, a ideałem towarzyskim jest próżniak i pasożyt wstydzący się pracy. 
132. Ludzie comme il faut ${ }^{1}$ wstydzą się pracy, ale mniej już wstydzą się żebrać, a już wcale się nie wstydzą oszukiwać i krzywoprzysięgać.

133. Dewiza śmietanki inteligencji, nastrojowców-gnitoszów: „Praca upadła”.

134. Nasza obecna nerwowośé jest krokiem do zdziczenia. Rozwój umysłowości daje tylko wtedy rękojmię postępu w uspołecznieniu, kiedy mu towarzyszy uspokojenie temperamentu i wzmocnienie charakteru.

\section{XXX}

135. „Z dziesięciu ludzi, śpieszących na głos wołającego „ratunku”, dziewięciu podąża tam przez ciekawość".

[Kraków 1898. Nakładem autora]

1 Comme il faut (fr.) - jak należy. 


\section{UWAGI NA CZASIE I NIE NA CZASIE}

\section{(Z powodu ankiety „Krytyki” w sprawie konfiskat w ogóle, a konfiskaty Legend A. Niemojewskiego w szczególności)}

Fatalność dzisiejszego ustroju ludzkości „cywilizowanej” stanowi głównie to, że uprywatniono dobra materialne, leżące poza człowiekiem, a ze skwapliwością, godną lepszej sprawy, upaństwowiono i uspołeczniono najindywidualniejsze i najnietykalniejsze tajniki duszy ludzkiej, poddając je bezmyślnej mustrze i tresurze.

Nic chyba bardziej okrutnego, jak przymusowa dziedziczność najgłębszych wierzeń i przekonań. Jest to tym wstrętniejsze, że owa narzucana dziedziczność utrzymuje się często tylko dzięki udawaniu i obłudzie.

(Myśli nieoportunistyczne)

Zawierucha wywołana gorliwością denuncjatorską pewnego gatunku publicystów, powieściopisarzy i „literatów”, a rozdmuchiwana za pomocą zwykłego w takich razach ujadania masowego, zataczając coraz szersze kręgi, o mało i mnie nie porwała. Jako bowiem jeden z „piśmiennych”, otrzymałem w swoim czasie wezwanie do przyjęcia udziału w ankiecie, zarządzonej przez redakcje „Krytyki” z powodu konfiskaty Legend A. Niemojewskiego.

Przygniecenie rozmaitymi robotami z całkiem innego zakresu nie pozwoliło mi uczynić zadość temu życzeniu redaktora „Krytyki”, a że się tak stało, dobrze się stało. Bo najprzód jestem wprawdzie „piśmienny”, ale na sprawach literatury znam się bardzo mało, więc mógłbym był wystąpić z czymś arcyniekompetentnym; po wtóre zaś mogłem być posądzony o pośredni interes osobisty. Chociaż bowiem 
„płodów mojego ducha” nie konfiskowała ani policja, ani prokuratoria, to jednak ja sam uległem ongi gruntownej konfiskacie z Krakowa, dzięki zgodnemu działaniu rozmaitych rodzajów policji: tak policji zwykłej, jako też ochotniczej, tak policji urzędowej, jako też prywatnej, tak policji arystokratycznej, jako też łykowatej, tak policji świeckiej, jako też duchownej, tak policji uczonej, jako też policji nic wspólnego z nauką niemającej ${ }^{1}$.

Niedawno poznałem przypadkowo broszurę niejakiego pana Bresnitz von Sydaczoff, zatytułowaną Panslavistische Agitation in Oesterreich-Ungarn, a twierdzącą między innymi, że Kraków jest głównym siedliskiem agitacji panslawistycznej, że ta agitacja panslawistyczna grupuje się koło redakcji „Czasu”, że na czele jej stoją trzej ajenci Pobiedonoscewa: Baudouin de Courtenay, Zdziechowski i Beaupré, że głównym ajentem Pobiedonoscewa jest właśnie Baudouin de Courtenay, którego rząd austriacki za jego dziatalność panslawistyczna na Słowacczyźnie nagrodził katedra uniwersytecką w Krakowie, że Baudouin de Courtenay i Beaupré są to zwei edle Polen mit französischen Namen und jüdischer Herkunft ${ }^{2}$ (chociaż to do rzeczy nie należy, ale zdaje się, że sam pan Bresnitz von Sydaczoff jest jüdischer Herkunft) itd., itd., a nareszcie, że wszystko to jest prawdą. Broszura ta, której drugie wydanie wyszło w r. 1900, została wydaną pierwotnie w r. 1898, a dla mnie nie ulega prawie wątpliwości, że została ona zamówioną u Szmoka z Żydaczowa przez edle Polen i edle Ungarn dla skutecznego podziałania na schwachköpfige Wiener Excellenzen ${ }^{3}$ przy rozstrzyganiu sprawy mojego wyrzucenia $\mathrm{z}$ Krakowa.

1 Mowa 0 usunięciu Baudouina de Courtenay z Uniwersytetu Jagiellońskiego, m.in. z powodu broszury Jeden z objawów moralności oportunistyczno-prawomyślnej.

2 Zwei edle Polen mit französischen Namen und jüdischer Herkunft (niem.) - dwaj szlachetni Polacy o francuskich nazwiskach i żydowskim pochodzeniu.

$3 \quad$ Schwachköpfige Wiener Excellenzen (niem.) - tępe wiedeńskie ekscelencje. 
Dobrze się tedy stało, żem nie przyjmował udziału w owej ankiecie, która w ogóle wypadła zadawalniająco. Dziś, po zaznajomieniu się z oświadczeniami osób odpowiadających na pytania redaktora „Krytyki” korci mię coś, ażeby wypowiedzieć kilka uwag w tej sprawie. Niestety będą to uwagi dorywcze, bez werwy literackiej, bez połysku i świetności. Proszę mi więc wybaczyć, jeżeli przy czytaniu ich będzie się doznawało uczucia jazdy po grudzie w trzęsącym wozie bez resorów.

Przede wszystkim uważne odczytanie niektórych zwłaszcza odpowiedzi utwierdziło mię w przekonaniu, że logika ogólnie ludzka jest fikcją, że logiczność myślenia jest różnorodną, zależnie od gruntu psychicznego, przygotowanego dla niej przez wychowanie i koleje życia danego osobnika.

Czyż to bowiem nie jest godną podziwu konsekwencją logiczną, jeżeli żarliwy wyznawca i wielbiciel Tołstoja (uważającego między innymi tresurę wyznaniową za zbrodnię pedagogiczną) występuje jednocześnie jako głosiciel i wyznawca tego wszystkiego, co Tołstoj odrzuca, występuje jako żarliwy katolik, bez zastrzeżeń ubóstwiający „Kościół”? Czyż to doprawdy nie dziwne, jeżeli apostoł i wyznawca Tołstoja dopatruje się bluźnierstwa i obrzydliwości w nieuznawaniu za prawdę tego, co zostało właściwie wytworzone przez schyłkowców pewnego typu kulturalnego na tle erotyzmu uduchowionego?

Nasz zwolennik i wyznawca Tołstoja, godzący ten swój tołstoizm z bezwzględnym uwielbieniem dla „Kościoła”, powołuje się na atrofiowany przez cywilizację zmyst mistyczny i biada nad ową rzekomą atrofia tego zmystu mistycznego. Ja zaś formułuję to cokolwiek inaczej:

Istotnie ulega atrofii znachorstwo, ulega atrofii zabobon, ulega atrofii bezmyślność, a wszystko to ulega atrofii pod wpływem światła nauki i myśli krytycznej, podobnie jak ćmy i puszczyki pierzchają przed światłem słońca. Kret stracił w ciemności wzrok i nie znosi światła; dla niego światło jest objawem atrofii ciemnoty.

Usprawiedliwiając interwencję policji w sprawach sztuki i literatury, nasz wyznawca Tołstoja powołuje się także na Mickiewicza, ale chyba niesłusznie. Prawdopodobnie Mickiewicz nie nawoływałby policji i nie usprawiedliwiałby konfiskaty. 
Ten sam wyznawca Tołstoja zasłania się powaga jakiegoś człowieka wszechstronnie wyksztatconego... i bardzo prawego, który jednak wziat pewien udziat w akcji, która doprowadzita do konfiskaty ksiazki. Jeżeli to był istotnie cztowiek wszechstronnie wyksztatcony, w takim razie nie wiedział, co czyni, i sprzeniewierzył się swoim zasadom, może także wskutek „atrofii”.

Pewna pułkownikowa kozaków rosyjskich, dostawszy się w r. 1814 wraz z mężem do Paryża, dowiedziała się tam po raz pierwszy o skazaniu na śmierć i legalnym zamordowaniu Ludwika XVI. Oburzona do głębi duszy, zawołała: Króla swego zabili totry! A gdzież byta wtedy policja?

Ludzi jak ta pułkownikowa, ludzi przekonanych, że policja i cenzura robią i wstrzymują dzieje ludzkości, jeszcze dziś w społeczeństwach „cywilizowanych” jest nierównie więcej aniżeli ludzi pozwalających sobie powątpiewać o tej wszechpotędze policji i cenzury. Wiarę w opatrznościową rolę policji i cenzury zaszczepiają przede wszystkim podręczniki szkolne tak zwanej historii powszechnej. Społeczeństwo polskie roi się od osobników wzywających o pomstę do policji i cenzury i to nawet osobników ze sfer przodujących umysłowo.

Niedawno z powodu śmierci znakomitego psychiatry, doktora Balińskiego, w jednej z gazet petersburskich wydrukowano artykuł wskazujący w ironiczny sposób na polska intryge, a właściwie podnoszący wielkie zasługi psychiatrów polskich w Petersburgu. Niektórzy z tych psychiatrów, czy to skutkiem chwilowego zaćmienia umysłu niebędący w stanie zrozumieć bardzo przezroczystej myśli przewodniej owego artykułu, czy też dowiedziawszy się o jego treści z drugich rąk, udali się ze skargą na autora i redakcję do ówczesnego naczelnika zarządu prasy, księcia Szachowskiego. Książę Szachowskoj, chociaż wcale nie „wolnomyślny”, ochłodził zapały tych panów uwagą, że jako ludzie z wykształceniem uniwersyteckim powinni by zrozumieć prawdziwą intencję autora, a co do pretensji panów skarżących odesłał ich na drogę sądową, zauważywszy, że cenzura może karać organa prasy tylko albo w razie ich wystąpień przeciw rządowi, 
albo też w razie naruszenia przepisów zawartych w obowiązujących prasę okólnikach.

$$
* * *
$$

Byłoby wielką niesprawiedliwością napadać na policję, na prokuratorię i na sądy za ich postępowanie w sprawie konfiskaty Legend A. Niemojewskiego. I policja, i prokuratoria, i sądy postąpiły tak, jak powinny były postąpić zgodnie z prawem pisanym i ze szczegółowymi przepisami obowiązującymi każdą z tych instytucji. Nikt nie ma prawa posądzać urzędników państwowych o złą wolę za to tylko, że urzędnicy ci noszą niemile brzmiące nazwy, a swą działalnością dają się nam we znaki. A przy tym wszystko jedno, czy spełniają oni to z wewnętrznego przekonania i z upodobania, czy też tylko jako wykonawcy rozkazów zwierzchności kierują się wyłącznie poczuciem obowiązku urzędniczego.

Jeżeli uważamy za bohaterów żołnierzy, co z zapałem i entuzjazmem ginęli za Napoleonów i innych wodzów, to również powinniśmy uważać jeżeli już nie za bohaterów, to przynajmniej za ludzi szczerych i uczciwych wszystkich tych policjantów, prokuratorów i sędziów, którzy z przekonania bronią istniejącego porządku konfiskatami i karami, narażając się przez to jeżeli nie na utratę życia, to przynajmniej na uragowisko i oplwanie przez zainteresowanych.

Tym większym jest „heroizm” tych panów, jeżeli narażają się na te dotkliwe przykrości nie z przekonania, ale tylko przez poczucie obowiązku, jako duszą i ciałem słudzy władzy naczelnej, słudzy istniejącego porządku, słudzy stronnictwa panującego. Powiedzenia zaś Mickiewicza, że „heroizm niewoli” jest psu zastuga, cztowiekowi grzechem, nie należy znowu brać tak bardzo dosłownie.

Policja, wszelkiego rodzaju cenzura i sądownictwo są dotychczas sługami tych, co dzierżą władzę w ręku, są sługami stronnictwa panującego, stronnictwa dotychczas materialnie najpotężniejszego, a więc już przez to samo najbardziej zainteresowanego w podtrzymywaniu ,istniejącego porządku” i tłumieniu wszelkiej opozycji i krytyki. Pan każe - sługa musi. A może to być sługa nie tylko z musu, ale zarazem sługa z dobrej woli, sługa z sugestii, sługa z „przekonania”. 
Rzym panuje, a my, jego słudzy, musimy ślepo go słuchać.

Abstrakcyjnie się wyrażając: stronniczość panuje, a ludzie na niej wychowani muszą się nią kierować.

Powinniśmy tedy uznać szczerość i uczciwość policji i wszelkiego rodzaju cenzury, podobnie jak uznajemy szczerość tych, co po wszystkie wieki zbawiali ludzkość i tępili jej wrogów, bądź to rzucając ich na pożarcie lwom i tygrysom na arenach cyrków, bądź to paląc ich na stosach, bądź też oddzielając na gilotynach głowy od kadłubów.

Szczerą też i uczciwą jest czarna gwardia Rzymu zmodernizowanego, szczerymi i uczciwymi są legiony jezuitów przekonanych, legiony tych, co się zaprzedali Rzymowi z duszą i ciałem, i są nawet bardziej rzymscy aniżeli sam Rzym.

Dla zrozumienia stanowiska policji i prokuratorii nie zawadzi też przypomnieć to, co powiedział pewien cenzor warszawski, kiedy go nagabywano 0 wykreślanie wyrażeń skierowanych, zdaniem jego, przeciw domniemanym założycielom wyznań przez państwo protegowanych lub też przeciw głowom kościołów: Cóz pan chce, my dygnitarze powinnismy się wspierać wzajemnie. Dygnitarze - to cenzor, prokurator i np. - mniemany twórca religii przeważającej u ludów europejskich oraz jego rzekomi następcy, będący właściwie spadkobiercami w linii prostej cezarów rzymskich, zlanych w jedno z pontifexami maximusami.

Sędziowie zrobili swoje. We wszelkich tego rodzaju wypadkach sędziowie trzymają się kodeksów obowiązujących, a kodeksy obowiązujące układano $\mathrm{w}$ interesie pewnych stronnictw, opierając je na nietolerancji i prześladowaniu bądź to mniejszości przez większość, bądź też poddanych i niewolników przez władców i właścicieli. Stosowane w danym razie prawo jest dziełem stronnictwa, które zbrojne zachłannością tradycyjną imperium rzymskiego rości sobie pretensję do panowania już nie nad ciałem i nie nad pracą, ale nad umysłami i duszami świata całego. 
Przejawia się tu zazdrość i zawiść stronnictwa sennych widziadet, stronnictwa śpiącej i żarliwie usypianej, hipnotyzowanej, nietrzeźwej ludzkości; stronnictwa, któremu się zdaje, że wydzierżawiło na wyłączne posiadanie przywilej traktowania pewnych tematów, a traktuje te temata w sposób starczy, pikantnie ponętny, negatywnie lubieżny, doskonale harmonizujący ze sławetnym non possumus.

Naczelnicy tego stronnictwa, uważani za nieomylnych, dają się wywodzić w pole rozmaitym Leonom Taxilom, plotącym duby smalone 0 Miss Vaugan, straszą kurze umysły bajkami 0 satanizmie, 0 „mszach czarnych”, 0 wszechświatowej potędze „masonów”. Stronnictwo to, uprawiające znachorstwo i czary jak za starych dobrych czasów i kontynuujące niższy stopień rozwoju ludzkości, zagarnęło w swe ręce wychowanie młodzieży i za pomocą niekontrolowanych przez nikogo specyfików zatruwa jej serca nienawiścią, ogłupia jej umysły, przeciwdziałając w ten sposób nader skutecznie wszelkiemu krytycyzmowi i postępowi ludzkości; a sprzymierzone z innymi instytucjami, pochodzącymi z czasów barbarzyńskich, panuje prawie niepodzielnie w szkole i urzędzie publicznym.

Gdyby ludzkość rzymsko-grecka, czyli tak zwana europejskoamerykańska, nie była stale zatruwaną i hipnotyzowaną rozmaitymi legendami wszczepianymi jej gorliwie od kolebki, gdyby patrzyła trzeźwo i rozumnie, to ludzi, którzy by dziś występowali na własną rękę z podobnymi „naukami”, traktowano by jak obłąkanych.

$$
* * *
$$

Władza ogłupiaczów nad umysłami coraz bardziej słabnie, a wyzwalanie się idzie w dwóch kierunkach: albo jest to otwarte wyzwalanie się i wypowiadanie walki wrogom myśli ludzkiej, albo też jest to obłuda, to jest udane pozostawanie przy sponiewieranym sztandarze w oczywistej rozterce z własną treścią wewnętrzną.

Obłuda to kieruje owymi dygnitarzami tak galicyjskimi, jak i obcokrajowymi, którzy w przemowach swoich do nauczycieli głoszą np. następujące wielce budujące zdania: co sobie panowie myślicie, to mi wszystko jedno, byleście tylko zachowywali przepisane formalności „religijne”. 
Obłuda też skłania drukarzy książek nieprawomyślnych do uroczystego wypierania się ich w „organach prasy świątobliwej” i do oświadczania, że tylko przeoczenie i niezaznajomienie się z treścią bezbożnej książki było powodem podjęcia się jej złożenia i odbicia w prawowiernej drukarni. Nic dziwnego; przecież w tej samej drukarni wydają ojcowie świątobliwi swój szanowny organ, a stały druk takiego miesięcznika toć to wcale dobry geszeft.

Obłuda jest objawem ze stanowiska etycznego niepożądanym, ale zjawienie się obłudników w obozie wrogów myśli ludzkiej należy powitać jako prawdziwy postęp. Stronnictwo podtrzymywane przez obłudników straciło wiele ze swej dawnej mocy i przestaje być strasznym dla bojowników postępu, a to przede wszystkim dlatego, że obłudnika można kupić. Przy zmianie warunków, dygnitarz wymagający tylko spełniania „formalności religijnych” wyrzecze się otwarcie tego, co dziś obłudnie podtrzymuje. Drukarz błagający o przebaczenie za wydrukowanie książki bezbożnej z prawdziwym gustem będzie drukował całe tuziny takich książek, byle mu to zapewniło stały dochód i byle go odszkodowano za wyrzeczenie się go przez ojców świątobliwych.

Nareszcie obłuda wyjaławia duszę ludzką i wytwarza w niej pustkę nie do zniesienia. Całe życie podłym może być tylko człowiek „wyjątkowy”, a następstwo całego szeregu pokoleń obłudników jest wprost niemożliwe. Zjawia się nareszcie paląca potrzeba zapełnienia tej pustki jakąś treścią, zjawia się nieprzezwyciężony wstręt do chronicznego kłamstwa; a że powrót do dawnych wierzeń, które się obłudnie przyjmowało za dobrą monetę, jest zwykle niemożliwy, więc z konieczności następuje napełnienie duszy treścią innych wierzeń, treścią innych przekonań. A to jest stanowezo krokiem naprzód.

$$
* * *
$$

Chrystus wypędzał przekupniów z kościoła, a jego niby wyznawcy handluja „ś́więtościami”, sprzedają bilety wolnej jazdy do raju, zakładają „sklepy chrześcijańskie”, „sklepy katolickie”, wzywają do kupowania tylko u chrześcijan. 
Taki potwór psychiczny, będący utylizacją „chrześcijaństwa” do celów geszefciarskich, będący sztucznym skojarzeniem wyobrażeń wręcz sobie przeciwnych, będący wykwintem obłudy, potwór taki nie może liczyć na długowieczność i z konieczności rozpaść się musi: po jednej stronie stanie „sklep”, a po drugiej „chrześcijańskość”. Obłuda i kłamstwo i tu skazane są na stopniowe zamieranie.

$$
* * *
$$

Pewnemu młodemu uczonemu proponowano kilka lat temu miejsce wychowawcy w jednym z najpierwszych domów arystokratycznych polskich. Przedtem jednak starano się wybadać, jak się ten uczony zachowuje pod względem „religijnym”: czy chodzi na mszę, czy pości w dnie przepisane, czy się spowiada itd. Nareszcie, wypytawszy różnych znajomych tego pana, zapytano wprost jego samego. Jako człowiek niechcący udawać i występować w roli sprzecznej z jego przekonaniami odpowiedział bez ogródki: jeżeli mam prawde powiedzieć, to ja w nic nie wierze. Oczywiście o miejscu wychowawcy w domu arystokratycznym mowy być nie mogło.

Rozmaite osoby „wierzące”, rozmaite osoby „religijne” nie mogły przebaczyć naszemu uczonemu tej jego otwartości. Jak można byto dla takiego gtupstwa wyrzekać sie tak korzystnej posady? Czyż to znowu tak trudno powiedzieć, że sie jest wierzacym katolikiem? Czyż to tak trudno chodzić na msze, spowiadać sie itd.? - Zapewne, że nietrudno, ale jak dla kogo.

Zapomniały przy tym owe osoby „wierzące” i „religijne” 0 męczennikach, co za swą wiarę i przekonania ginęli w cyrkach, rozszarpywani przez lwów i tygrysów, lub później, gdy ecclesia abhorrebat sanguem, gdy Kościół krwi nie rozlewat, płonęli na stosach. Wobec takich męczeństw można chyba sobie pozwolić małego „męczeństwa” w postaci niedostania posady guwernera u księcia lub hrabiego, w postaci krzywej miny i niełaski różnych Stasiów, Leosiów, Jasiów, Michasiów i innych tp., a nawet w postaci wygryzienia z ck Uniwersytetu Jagiellońskiego. 
Metody stronnictwa panującego nie różnią się wcale od metod innych stronnictw, choćby nawet najbardziej mu wrogich. Wynika to $\mathrm{z}$ danych psychologii tłumowej.

Dlatego to walki stronnictw są tylko bardziej skomplikowanymi i „uczłowieczonymi” walkami psów szczutych przez swoich panów oraz przez całą zgraję naganiaczy. Z początku działa tu tresura i sugestia z przymieszką dziedziczności, a potem sami się już pilnujemy.

A więc czy na sztandarze wypiszemy „Rzym”, czy „Bizancjum”, czy „Mahomet”, czy nareszcie Marks, jeżeli tylko będziemy walczyé pod „sztandarem”, z konieczności zabijemy w sobie krytykę i zdolność sprawiedliwego i logicznego sądu, z konieczności będziemy siebie samych uważali za nieomylnych, z konieczności będziemy potępiali przeciwników i traktowali ich z nienawiścią i nietolerancją.

Przy tych wrzaskach potępiających i wyklinających nikt prawie nie zaznajamia się z samym corpus delicti, ale powtarza bezmyślnie na wiare tego, co zaintonował to ujadanie trzodowe.

Alboż my wiemy, co się dzieje z nami?

My tylko lecim za temi gęsiami,

które tam krzyczą na przodzie ${ }^{1}$.

Niech w pewnej miejscowości zaszczeka jeden pies, za jego przykładem pójdzie pies drugi, trzeci, czwarty..., aż nareszcie po chwili cała psiarnia zacznie zaciekle ujadać. Niech jeden pies zawyrokuje, że pewna książka jest szkodliwą, a zaraz powtórzą to za nim inne psy i, nie widząc na oczy owej książki, zażądają jej potępienia i zniszczenia.

W r. 1862 powieściopisarzowi Miniszewskiemu obcięto uszy, pastwiono się nad nim i w ohydny sposób go zamordowano za to tylko, że pisał, pisał wprawdzie drażniąco i wyzywająco, ale tylko pisał, tj. głosił za pomocą druku swoje „przekonania” i zapatrywania. Kto dzisiaj jeszcze zasztyletowanie Miniszewskiego uważa za słuszne i sprawiedliwe, ten nie ma prawa oburzać się na ck prokuratorię za dokonywane przez nią konfiskaty. W każdym razie tak sam Miniszewski, jako

\footnotetext{
$1 \quad$ Fr. Morawski, bajka Gęsi [przyp. BdeC].
} 
też jego bliscy woleliby, ażeby konfiskowano jego Komunaty, aniżeli żeby jego samego poddano skutecznym operacjom sztyletników.

Podobnie nie mają najmniejszego prawa protestować przeciwko konfiskatom dokonywanym przez ck policję i prokuratorię ani ci wszyscy, co to nie tak dawno nawoływali do bastonady 0staszewskiego-Barańskiego, ani „patrioci” płci obojej, urządzający nagankę na znienawidzonych „ugodowców” i bojkotujący nowelistów i powieściopisarzy, ogłaszających swe utwory w „Kraju” petersburskim, ani owi studenci „Polacy”, wypowiadający „głębokie oburzenie” senatowi Uniwersytetu Lwowskiego za drobne ustępstwa studentom „Rusinom”, ani też tolerancyjna „młodzież” krakowska, urządzająca nocne napaści na profesora Zdziechowskiego z kocią muzyką i wybijaniem szyb.

Wszyscy pamiętamy, jak kilka lat temu Wydział Filozoficzny Uniwersytetu Lwowskiego dopuścił jednogłośnie Iwana Frankę do prywatdocentury, ale ówczesny namiestnik Galicji, hr. K. Badeni, sprzeciwił się temu „za jego” (Franki) „przeszłość polityczną” (für sein politisches Vorleben). Rozdrażniony i oburzony tym mieszaniem się policjanta do spraw naukowych, Franko rozszerzył to swoje oburzenie zbyt daleko w przestrzeni i w czasie i między innymi spojrzał zbyt jednostronnie na Adama Mickiewicza, robiąc go par excellence „poetą zdrady”. Tak tedy za baszybuzukostwo ${ }^{1}$ hr. Badeniego oraz innych hrabiów i niehrabiów galicyjskich ucierpiał pod piórem Franki Adam Mickiewicz, ale w dalszej konsekwencji ucierpiał nierównie więcej sam Iwan Franko. Bo po jego artykułach zawrzało i zakipiało. Przedstawiciele najrozmaitszych stronnictw polskich przesadzali się w objawach bądź to szczerego, bądź też udanego oburzenia. Urządzano „zamachy” na nieszczęsnego autora nieprzyjemnych artykułów, noszono się z chęcią obicia go, wieszano jego portret czy też symbol; nawet w postępowym i wolnomyślnym „Życiu” krakowskim spotkały go obelgi słowne najniższej próby, a jakaś tajemnicza ręka wykreśliła go bezprawnie z listy członków Komisji Antropologicznej Akademii Umiejętności w Krakowie. Jakże bladymi wobec tego wszystkiego

1 Baszybuzuk (tur.) - żołnierz nieregularnych wojsk tureckich; także hultaj. 
wydają się wszelkie konfiskaty dokonywane przez ck policję i prokuratorię!

Jeżeli sprawiedliwym było zasztyletowanie Miniszewskiego za jego działalność pisarską, jeżeli sprawiedliwymi były bastonady wymierzane rozmaitym panom za ich nieprzyjemną działalność publicystyczną, jeżeli sprawiedliwym było bojkotowanie współpracowników „Kraju” petersburskiego, jeżeli sprawiedliwą była kocia muzyka i wybijanie szyb profesorowi Zdziechowskiemu, jeżeli sprawiedliwym było trzodowe ujadanie na Iwana Frankę, to o ileż sprawiedliwszymi są wszystkie konfiskaty urzędowe, a w tej liczbie także konfiskata Legend A. Niemojewskiego.

Trudno przecież wymagać od ck policji i prokuratorii, ażeby wzniosła się do takiej bezstronności, jak ongi socjaliści niemieccy, którzy w imię wolności stowarzyszeń głosowali za powrotem do Niemiec swoich największych wrogów, 00. jezuitów, albo jak Mr. Bergeret Anatola France'a, broniący nietykalności świstka antysemickiego, który usiłował zniesławić go w sposób równie głupi, jak nikczemny.

Kto denuncjuje przed „publicznością” kolegów po piórze za ich artykuły nieprzyjemne i za ich przekonania „niesympatyczne”, ten może upominać się o A. Niemojewskiego i o innych autorów, pokrzywdzonych przez ck prokuratorię nie na podstawie prawa i logiki, ale jedynie tylko na zasadzie prawa mocniejszego. To jest może grozić: „nie konfiskuj mię dzisiaj, bo jutro ja ciebie skonfiskuję. Występować przeciw konfiskatom zasadniczo, na podstawie myślenia i poczucia sprawiedliwości, może tylko człowiek bezwzględnie tolerancyjny i nienależący do żadnego stronnictwa wyznaniowego: ani religijniewyznaniowego, ani politycznie-wyznaniowego, ani estetycznie-wyznaniowego, ani w ogóle do jakiegokolwiek bądź wyznaniowego.

$$
* * *
$$

Nie możemy też mieć najmniejszej pretensji do owejforce majeure $^{1}$ obskurantyzmu, która, „karząc” Lwa Tołstoja za jego przekonania, wykreśliła go z listy członków pewnej akademii umiejętności.

1 Force majeure (fr.) - siła wyższa. 
Na szczęście samego Tołstoja ani to grzeje, ani ziębi, ale dla owej akademii despekt to niemały i można podziwiać jej członków, że znieśli ten despekt tak cierpliwie i pokornie.

Nie mniej uwielbiać należy budującą bezstronność „ministrów rodaków” i członków polskich w delegacji austriackiej przy odnawianiu trójprzymierza. Tym polskim hrabiom od wielkiej polityki moga teraz niemieccy tępiciele polskości plunąć spokojnie w twarz, a oni obliżą się i powiedzą, że to wcale dobrze smakuje.

Czołem przed mężami, celującymi bezstronnością i zaparciem się!

$$
* * *
$$

Gardłujący za konfiskatą Legend A. Niemojewskiego powoływali się przede wszystkim na to, że sieją one zgorszenie, zgorszenie mtodzieży. Przypuśćmy, że to prawda, przypuśćmy, że owe - zresztą w bardzo niewinnym tonie trzymane - Legendy są źródłem zgorszenia. Ależ w takim razie, chcąc zapobiegać zgorszeniu, należałoby skonfiskować i usunąc gruntownie: przede wszystkim matematykę, począwszy od tabliczki mnożenia, astronomię, fizykę, fizjologię, psychologię, językoznawstwo itd., jednym słowem całą naukę, ponieważ uczy ona myśleć samodzielnie i popycha do buntu przeciw wszelkim nieuzasadnionym powagom i bezmyślnym przesądom.

Następnie należałoby skonfiskować nie tylko przynajmniej 9/10 literatury, ale także wszelkie wykazy i katalogi grzechów oraz wszelkie rozpamiętywania różnych „tajemnic”, zwłaszcza z nastrojem zmysłowo-mistycznym, ponieważ wszystko to skierowuje myśl w stronę erotyzmu „idealno-realnego”, a więc wywołuje „zgorszenie”.

Trzeba skonfiskować język, przyrodę, duszę ludzką.

Trzeba skonfiskować otoczenie „młodzieży”, jej rodziców, nauczycieli, w ogóle „dorosłych”; trzeba skonfiskować zwierzęta, trzeba skonfiskować świat cały.

Trzeba skonfiskować rozmowy prowadzone przez dorosłych w obecności dzieci, trzeba skonfiskować wszelkie romanse, wszelkie poematy erotyczne, choćby o charakterze jak najpowiewniejszym, 
trzeba skonfiskować wszystkie gazety, a zwłaszcza ich „kroniki” i ich sprawozdania z procesów kryminalnych.

Trzeba skonfiskować bale z kobietami dekoltowanymi, maskarady, tingl-tangle; trzeba skonfiskować znaczną część przedstawień teatralnych; trzeba skonfiskować wystawy sztuki plastycznej.

Trzeba skonfiskować dygnitarzy i arystokratów wyprawiających orgie nie tylko w stolicach europejskich, ale nawet w Budapeszcie, we Lwowie i w innych większych miastach.

Trzeba skonfiskować powierników dusz potrącających w rozmowach najpoufniejszych o temata więcej niż drażliwe.

Nareszcie trzeba skonfiskować wszelkie objawy szczerości, bo nic chyba tak nie „gorszy”, jak szczerość.

Kiedy to wszystko skonfiskujecie, wtedy dopiero będziecie mogli przystąpić z czystym sumieniem do konfiskaty takich niewinnych baranków, jak Legendy A. Niemojewskiego i inne im podobne utwory.

$$
* * *
$$

Nie przeczę, że wiele jest tworów literackich i publicystycznych oddziaływujących nader szkodliwie na umysł i usposobienie nie tylko dzieci i „młodzieży” szkolnej, ale także wszystkich czytających, choćby nawet 0 głowach siwych i łysych. Tu należy nie tylko tak zwana „pornografia” w jakiejkolwiek bądź szacie, ale także z jednej strony opisy okrucieństw, bitew, egzekucji, gwałtów wszelakich itp., z drugiej zaś strony rozbudzanie lubieżności na tle wyznaniowym.

Nie popierając jednak epidemicznego szczucia wszystkich na wszystkich, nie widzę tymczasem żadnych skutecznych środków na to zło pochodzące z piśmiennictwa, podobnie jak nie widzę tymczasem żadnego środka na stałą chorobę naszych wieków, na rozrost olbrzymi prasy codziennej i nieustanne przemywanie głów pomyjami dziennikarskimi oraz na rozwijającą się pod wpływem dziennikarstwa płytkość i powierzchowność sądów, na histeryczną żądzę wrażeń przemijających, na hipertrofię ciekawości. Konfiskowanie wszystkich bez wyjątku gazet byłoby chyba środkiem za nadto radykalnym. 


\section{$* * *$}

Oczywiście wszelkie stronnictwa jednostronnie zacietrzewione, gdyby tylko mogły, tj. gdyby stały u steru rządu i były niczym nieskrępowane, konfiskowałyby wszystko to, co jest przeciw nim skierowane i co im niby to szkodzi.

Przede wszystkim rządy konsekwentnie klerykalne konfiskowałyby wszystkie książki i artykuły zwrócone, choćby tylko pośrednio, przeciw klasztorom, przeciw gospodarce jezuityzmu w szkołach, przeciw celibatowi księży itd., bo uważałyby to wszystko za „zgorszenie" i obraze.

Gdyby pewne nader miłe stronnictwo mogło odzyskać władze nieograniczoną, ujrzelibyśmy wskrzeszenie inkwizycji i tortur, owej najwspanialszej twórczości poetyckiej katolicyzmu średniowiecznego. Przy pewnym zaś ograniczeniu władzy tego stronnictwa czy to przez czynniki opozycyjne, czy też przez zmiany psychiczne zaszłe w samych przedstawicielach stronnictwa, mielibyśmy rozcieńczone ecclesia abhorret sanguem w formie palenia dzieł wyklętych, w formie wymazywania i wycinania całych ustępów i artykułów, w formie konfiskat, w formie cenzury prewencyjnej itd., co wszystko zreszta praktykuje się z dobrym skutkiem w niektórych państwach „europejskich”.

$$
* * *
$$

Najżarliwsi bojownicy ecclesiae militantis i dziś jeszcze z wielkim upodobaniem „unikaliby rozlewu krwi”.

Prawie trzydzieści lat temu, w epoce Barbary Ubryk, bawił w Krakowie Aleksander Świętochowski i odczytał publicznie swego Ojca Makarego. Zakotłowało się od tego w gnieździe ós, a oburzony do głębi duszy złotousty ksiądz Golian poświęcił Świętochowskiemu kilka swych tragikomicznych kazań. Jedno z tych kazań zakończył znamiennym wykrzyknikiem: Gdyby sie wrócity dawne czasy, rzucitbym na niego czarna świece! W zwykłym języku ludzkim znaczy to: „gdybyśmy znowu zapanowali bez ograniczeń nad światem, spaliłbym heretyka na stosie!”. 
Na szczęście nie dał Pan Bóg świni rogów.

A kilka miesięcy temu jeden z profesorów gimnazjalnych krakowskich „oburzony”, za pozwoleniem zwierzchności, na Legendy A. Niemojewskiego, zbierał podpisy na wezwaniu do zlinczowania, tj. do ukamienowania lub też podarcia na kawałki nie tylko autora, ale także rysownika i wydawcy. Zapały gorliwea ostudziła ck prokuratoria, skonfiskowawszy płomienną odezwę.

Jakżeż to przypomina historię Iwana Franki, tylko że tam ck prokuratoria nie wkraczała i dobrze zrobiła!

Chcę jeszcze pomówić o środkach zapobiegawczych, do których należy się uciekać w podobnych wypadkach, tj. w wypadkach „przestępstw” prasowych i stosowanych do nich konfiskat. A pomówię o tym ze stanowiska rozmaitych stronnictw.

Przede wszystkim zaś uwaga ogólna.

Nauka podająca wiedzę w formach abstrakcyjnych powinna się odznaczać bezwzględną szczerością i wyciąganiem jak najdalej idących konsekwencji. Kto to tłumi i tamuje, jest zbrodniarzem czyhającym na życie myśli. Kto nawołuje do hamowania i tłumienia, jest podszczuwaczem do zbrodni.

Podobnie ma się rzecz ze sztuką podającą także pewien zasób wiedzy za pomocą obrazów, w formach konkretnych, intuicyjnych.

Podobnie też należy traktować każdy język będący również osobnym systemem wiedzy w formie symbolów słownych. Kto nawołuje do niszczenia języka pewnego narodu lub plemienia, kto stawia tamy jego rozwojowi, stoi na równi z mężobójcą lub dzieciobójcą.

$$
* * *
$$

Wypowiadając tak te, jako też inne zdania, nie mam najmniejszego zamiaru przekonywać lub wpływać w jakikolwiek sposób na ludzi owładniętych logiką stronnictwa, na ludzi z myśleniem zanieczyszczonym sugestią stronnictwa, na obskurantów wszystkich stronnictw, chociażby nawet „najwolnomyślniejszych”. 
Dla antysemity „bluźnierstwem” jest domaganie się równouprawnienia Żydów.

Dla skazanego na pewnego rodzaju dietę duchową „bluźnierstwem" są twierdzenia, że 2 × $2=4,1$ x $1=1$ itd., że errare humanum est, że pewne zjawiska są niemożliwymi itd., itd.

Człowiek wierzący niezachwianie w wyjątkową świętość i przodownictwo narodu polskiego uważa za „bluźniercę” każdego śmiałka, pozwalającego sobie powątpiewać o prawie Polaków do panowania nad Rusinami i Litwinami.

$$
* * *
$$

Wobec grozy położenia ekonomicznego, wobec szybkich zmian dokonywanych na polu gospodarstwa społecznego, wobec konieczności skierowania wszystkich sił do ,walki” z przyrodą, ażeby ją jak najbardziej wyzyskać, nie niszcząc jej, ażeby zapewnić dobrobyt wszystkim ludziom, jakże marnie wyglądają i jakąż niepowetowaną stratę przynoszą ludziom wszelkie owe przeżytki stanu dzikości kołaczące się do dnia dzisiejszego, wszelkie owe walki ,ideowe”, walki o to, czy jajko należy rozbijać z grubszego, czy też z cieńszego końca (jak to miało miejsce u Liliputów, według świadectwa Guliwera Swifta), wszelkie owe misjonarstwa, wszelkie owe nawracania na rozmaite „wiary”, z odwracaniem oczu od ziemi, od produkcji ziemskiej!

Zamiast całą działalność państwową skoncentrować na ekonomicznej stronie życia społecznego, traci się mnóstwo sił na bezpłodne i szkodliwe „walki ideowe”, a liczna zgraja bądź to płatnych, bądź też dobrowolnych opryszków ducha zajmuje się gaszeniem światta, wiedzy i krytyki. Państwo osłabia się ekonomicznie i etycznie, tracąc sity materialne i moralne na walkę z ,wyznaniami”, na walkę z językami, na walkę $\mathrm{z}$ alfabetami!

$$
* * *
$$

W interesie każdego stronnictwa leży usuwanie tego, co szkodzi temu stronnictwu, a więc, zdawałoby się, przede wszystkim prześladowanie i tępienie wrogów. Tymczasem w pewnych warunkach właś- 
nie prześladowanie istotnych lub rzekomych nieprzyjaciół przynosi stronnictwu szkody wielce niepożądane.

Tak np. w danym wypadku p. Niemojewski, właśnie wskutek wrzasków skierowanych przeciwko niemu i przeciw jego książce oraz wskutek wywołanej tymi wrzaskami konfiskaty, wyrósł na bohatera i męczennika idei wolności, a tego chyba nie pragnęli wodzowie i pionki stronnictwa klerykalno-reakcyjnego. Dawniej zaś palenie na stosie „heretyków” i niezależnych myślicieli nie wyszło wcale na pożytek spadkobiercom inkwizytorów, budziło bowiem w ludziach, wprawdzie stopniowo i powoli, ale w coraz bardziej przyśpieszonym tempie, poczucie sprawiedliwości i ból logiczny będący jednym z najpotężniejszych czynników etycznego postępu ludzkości.

W dzisiejszych czasach cenzura i konfiskata stanowią najlepszą reklamę i najlepszy środek podnoszenia wpływu dzieł zakazywanych. To właśnie jest „sztuczną opieką” ,jadowitych kwiatów”.

Legendy Niemojewskiego rozchodziły się początkowo w bardzo skromnych rozmiarach. Dopiero kiedy się rozeszły wieści o zajadłej agitacji i przedsięwziętej przeciwko nim krucjacie mającej na celu spowodowanie konfiskaty, zaczęto je na gwałt kupować, tak że w jednej księgarni rozprzedawano po kilkadziesiąt egzemplarzy dziennie. „Jad” więc zaczął się szerzyć ze znacznie zwiększoną szybkością i to tym skuteczniej, że oczekiwane „prześladowanie” i „męczeństwo” potęgowało jego doniosłość.

Bywały wprawdzie także skutki agitacji odpowiadające zamiarom agitatorów, ale to bardzo rzadko. Podobno zaraz po wydaniu Legend pewien klasztor żeński utrzymujący szkołę dla panien zakupił 30 egzemplarzy tej książki dla rozdania jej uczennicom jako nagrodę w końcu roku szkolnego. Oczywiście po ogłoszeniu autora za bezbożnika owe egzemplarze zostały zużytkowane w inny sposób, a żaden z klasztorów nie myślał już o zaopatrywaniu się w tę zarazę; ale wstrzemięźliwość ojców, braci, matek i sióstr wielebnych została sowicie nagrodzoną przez pochopność zwykłej publiki.

W każdym razie stosowanie metody konfiskat i kar prasowych działa tylko na krótką metę, a działając jak drobne ukłucia szpilką, bez możności usunięcia źródła „złego”, wywołuje wręcz przeciwny skutek, bo uspasabia [sic! M.S.] przyjaźnie dla autora „prześlado- 
wanego”, a nieprzyjaźnie dla policji i prokuratorii „prześladującej” - a to przecież, właśnie ze stanowiska policji, ze stanowiska stronnictwa panującego, ze stanowiska kościoła wojującego, nie jest wcale pożądanym, chyba że przedstawiciele tych instytucji i stronnictw trzymają się zasady meternichowskiej: aprěs nous le déluge (po nas niech sobie nawet potop nastąpi).

Pytanie teraz, czy „przekonani katolicy” i „sodalisi Marianusi”, nawołujący do konfiskaty albo nawet tylko ją pochwalający, postąili zgodnie z wyznawaną przez nich nauką? Ja odpowiadam przecząco.

Panowie ci powinni przede wszystkim pamiętać o tej pouczającej dla nich opowieści, że kiedy Piotr św. uciął ucho Malchusowi, został zgromiony przez Mistrza uwaga: kto mieczem wojuje, od miecza zginie.

Kościół wojujący odnosi wprawdzie zwycięstwa, ale czasami zbyt wątpliwej wartości, a w końcu stosowana przezeń metoda zwraca się przeciwko niemu samemu.

Ten, w imię którego głosi się krucjatę przeciw wolnej myśli, nie uciekał się do konfiskat, nie wojował pięścią, nie wzywał policji i prokuratorów. Sam wprawdzie uległ gruntownej konfiskacie, a po nim konfiskowano tysiącami jego wyznawców. Dziś prokuratorowie w fioletach i infułach, zasłaniając się jego imieniem, nawołują do konfiskat, a gdyby mogli, nawoływaliby do tortur. Niestety ta ich gorliwość niekiedy ich tylko kompromituje i ośmiesza.

Niektórzy „wierzący katolicy” uważają ogłaszanie takich książek, jak Legendy A. Niemojewskiego, za wkraczanie do sanktuarium.

Ależ moi panowie, czyż kościół pewnego wyznania obejmuje świat cały? Więc, według was, nigdzie nie wolno zachowywać się tak, jak człowiek uważa za właściwe, jeżeli podobne zachowywanie się byłoby nieprzyzwoitym w świątyni pewnego wyznania.

Ależ zastanówcie się, łaskawi panowie, szanowni „wierzący katolicy” i „sodalisy Marianusy”! Przecież literatura w obszernym znaczeniu tego wyrazu to nie świątynia pewnego wyznania, to nie bóżnica, gdzie należy siedzieć w czapce, to nie kościół, gdzie należy zdejmować czapkę. 
Niech sobie „wierzący” i „wyznawcy” przebywają w swoich świątyniach, a nie chcąc się gorszyć, niech z nich nie wychodzą i niech nawet nie dotykają książek dla nich nieprzyjemnych i bezbożnych. Przecież nikt ich nie zmusza do czytania takich książek, a do tego, ażeby wiedzieć, jakie książki są bezbożne, wystareza chyba najzupełniej Index librorum prohibitorum. Zresztą gdyby im z konieczności wypadło byé w bliskości tych tworów szatańskich, mogą sobie, dla ulżenia, splunąć na ich widok z obrzydzeniem i to ich powinno całkiem zadowolnić. A za grzeszników, pisujących i czytujących podobne sprośności niechaj się modlą, nie uciekając się ani do inkwizycji świętej, ani do pachołków świętej Hermandady ${ }^{1}$.

„Serca katolickie” nie mogą sobie rościć pretensji do terroryzowania „sere”, mniej pod tym względem uprzywilejowanych.

„Wierzący” nie mają prawa do gnębienia niewierzących. Pięść mają, to prawda; sitę mają, to prawda; ale wara im od prawa.

„Wierzący, wierzący, wierzący” - ,wierzący” w rodzaju owego dygnitarza, co żądał od nauczycieli tylko zachowywania przepisów „religijnych”, pozwalając im zresztą myśleć, co im się żywnie podoba.

„Wierzących”, którzy nie zadawalniają się modlitwą za grzeszników, ale nawołują „władzę świecką” jeżeli nie do wprowadzania tortur i wznoszenia stosów, to przynajmniej do używania kija, więzień i konfiskat, można upomnieć słowy niedawno zmarłego, 90-letniego starca, Józefa Morawskiego: Stój, krok dalej to nikczemność!

Istotnie dziś jest to nikczemność dla każdego oświeconego człowieka, choćby nawet „wierzącego katolika”, choćby nawet dla „sodalisa Marianusa”.

W jaki jednak sposób ludzie wolnomyślni i zwolennicy postępu mają przeciwdziałać spustoszeniu moralnemu sprawianemu przez zwolenników konfiskat i wymazywań, przez zwolenników cenzury,

1 Święta Hermandad (Santa Hermandad, Święte Bractwo) - stowarzyszenie utworzone w Kastylii, Leonie i Asturii w roku 1476 dla obrony przed złoczyńcami (powstało z połączenia istniejących od 1115 r. hermandades, obronnych związków miast). Tą nazwą Baudouin posługuje się wielokrotnie, także w odniesieniu do cenzury. 
przez zwolenników regulowania biegu piśmiennictwa przez policję i prokuratorię?

Uważam za konieczne rozróżniać wolnomyślność i postępowość stadową, trzodową, od wolnomyślności i postępowości indywidualnej. Przy stadowości sama „bezwyznaniowość” może się stać wyznaniem, a nawet przeradzać się w fanatyzm. Tylko wolnomyślność ściśle indywidualna, bez wszelkiej pretensji do nawracania innych, bez zawierania przymierzy zaczepno-odpornych jest prawdziwą, bezwzględną wolnomyślnością. Kto należy do stronnictwa, choćby nawet wolnomyślnych i bezwyznaniowych, ten przez to samo nie jest prawdziwie wolnomyślnym.

Jestem jednak na tyle optymistą, iż przypuszczam możność przemawiania do rozumu wszelkiego rodzaju wolnomyślnych, choćby nawet tworzyli oni stronnictwo.

Otóż tedy, chcąc przeciwdziałać wkraczaniu policji i prokuratorii do „świątyni sztuki i literatury”, chcąc przeciwdziałać zarówno pobożnym denuncjacjom na autorów, jako też stosowaniu prawa pięści w miejscu nieodpowiednim, powinni przede wszystkim starać się usilnie o działanie na rozum swego ludzkiego otoczenia i o rozwijanie w nim poczucia sprawiedliwości.

Powinno się stale i wytrwale, pismem, słowem i uczynkiem przekonywać o bezużyteczności i szkodliwości ekonomicznej wszelkich tego rodzaju walk partyjnych (w sferze religii, narodowości itp.).

Powinno się przekonywać, że jednym z największych nieszczęść ludzkości jest upaństwowienie myśli i przekonań religijnych, jest tresura szkolna, zabijająca indywidualność i wtłaczająca w głowy młodociane „przekonania” umundurowane, jest maszerowanie myśli ludzkich pod bęben czy to klerykalny, czy też jakikolwiek bądź inny.

Z drugiej strony powinno się przekonywać, że prawdziwą fatalnością dziejową jest wyindywidualizowanie pracy ludzkiej, jest „wolność” i „indywidualizm” w sferze współzawodnictwa ekonomicznego, jest wspaniała wolność umierania z głodu i że uświadomione zwrócenie uwagi na tę fatalność dziejową, stanowiącą jedną z najpotężniejszych przeszkód do wyemancypowania myśli ludzkiej, wymaga dążenia do zmiany istniejącego porządku ekonomicznego i prowadzi z konieczności do kolektywizmu, prowadzi do „braterstwa” na polu 
pracy, na polu wyzyskiwania przyrody do celów ludzkich. Powinniśmy się też starać usuwać truciznę, przesączającą się do umysłów ludzkich dzięki dotychczasowemu wychowaniu. Podręczniki tak zwanej „historii”, a zwłaszcza historii „ojczystej”, oraz podręczniki wyznaniowe itp. wyrabiają stronniczość i podsycają nienawiść międzynarodową, międzyplemienną, międzywyznaniową, międzystanową, jednym słowem nienawiść międzytrzodową. Tak zwana „nauka religii” jest właściwie nauką nienawiści.

Oczywiście są jeszcze inne środki zaradeze na „wpuszczanie krowy do składu porcelany”, a to zależnie od warunków miejscowych.

Tak np. w Austrii, a więc też i w Galicji, istnieje podobno „konstytucja” nieprzeszkadzająca wprawdzie stróżom bezpieczeństwa publicznego urządzać obławy na ludzi i poddawać ich hańbiącym gwałtom, jedynie tylko za należenie do płci prawnie upośledzonej, ale zawsze niby to konstytucja. A konstytucja umożebnia otwarte dopominanie się o swoje prawa, umożebnia otwarte dochodzenie krzywd, umożebnia pociąganie do odpowiedzialności nie tylko niższych urzędników, ale nawet samych ministrów, umożebnia domaganie się zmiany praw, umożebnia w ogóle działanie jawne i otwarte, bez narażania się na konfiskatę osobistą. Przecież między posłami do parlamentu znajdują się ludzie wolnomyślni, którzy pełnią swoją powinność, tj. nie tylko zwracają uwagę na nadużycia i domagają się ich ukrócenia, ale także stawiają wnioski o zmianę praw przestarzałych na bardziej wymaganiom naszych czasów odpowiadające. A chociaż w danym razie wnioski te, dzięki większościom krótkowidzącym, samolubnym i reakcyjnym, mogą upadać, to jednak nie należy tracić cierpliwości, ale z żelazną wytrwałością powtarzać swe żądania. Przecież może z czasem ślepi przejrzą, samolubi zrozumieją swój własny interes, a reakcjoniści okażą się w mniejszości.

Oczywiście, że dążąc do postępu i do polepszenia warunków pracy wszelkiego rodzaju, a więc także pracy umysłowej, trudno chyba liczyć na pomoc sił nadprzyrodzonych - te nas nie zbawią. Zbawić się i oswobodzić możemy tylko my sami.

W ludziach coraz bardziej potężnieje poczucie sprawiedliwości, potężnieje logika, a to wiele znaczy. W duszach ludzkich dokonywa się stopniowo ewolucja na lepsze. 
Jak narody i klasy społeczne uciśnione nie mogą liczyć na obcą pomoc, ale tylko na samych siebie, tak samo tylko w samych sobie powinni szukać sił do walki szermierze niczym niekrępowanej wolności myśli i słowa. Jestem, więc nie zginę - oto hasło, będące dostateczną rękojmią niespożytej dążności do postępu.

Ale ci, co domagają się wolności słowa, co domagają się tolerancji, co denuncjacje literackie i konfiskaty książek uważają za rzecz szpetną i zbrodniczą, powinni zacząć od samych siebie. Niechaj nie szczują innych za wypowiadanie zdań niemile rażących, niechaj nie urządzają naganek i obław na ludzi, którzy zawinili tylko odmiennymi zapatrywaniami na pewne kwestie polityczne i religijne, jednym słowem niech pierwsi dadzą przykład bezwzględnej tolerancji, wyrozumiałości i poszanowania cudzych przekonań, a zapewnią sobie nierównie skuteczniejsze powodzenie aniżeli za pomocą hałaśliwych demonstracji, ze sztandarami, z pochodniami i z natchnionymi mowami na placach publicznych. Wtedy staną się prawdziwymi, niefałszowanymi bojownikami wolności i postępu i będą mogli zawołać:

Jeszcze ludzkość nie zginęła, póki my żyjemy!

Kraków, wrzesień 1902.

[Odbitka „Krytyki 1902, z. 11 i 12, Kraków 1903] 


\section{KRZEWICIELE ZDZICZENIA}

Artykuł ten przeznaczyłem pierwotnie do warszawskiego „Ogniwa”. Niestety, jak to mówią Niemcy, robitem rachunek bez karczmarza. Zapomniałem bowiem o zawodowych i urzędowych mordercach rytualnych wolnej myśli ludzkiej. Mnie samemu zdawało się, że w artykule nie ma nic gorszącego i obrażającego kogokolwiek bądź lub cokolwiek bądź; bystre jednak oko znawcy serc ludzkich wykryło całe ustępy niemożliwe ze stanowiska „bojaźni bożej” i nieposzlakowanej „prawomyślności”. Wskutek tego tylko początek mego artykułu mógt się ukazać w nrze 1 „Ogniwa” z r. 1904, chociaż i tu już wyrzucono dwa dość znaczne ustępy. Następnie pan cenzor usuwał nie tylko wyrazy, wyrażenia i ustępy, ale nawet całe szpalty przeszło stuwierszowe. Nie ulega wątpliwości, że dzięki tym operacjom artykuł mój nabrał cech niewinności i „przyzwoitości” obowiązującej, zdaniem cenzorów, każdego piszącego. Redakcja jednak nie mogła karmić czytelników resztkami i ochłapami, między którymi nie byłoby prawie żadnego związku, musiała więc pod naciskiem siły wyższej (vis maior) wstrzymać druk artykułu i zwrócić mi rękopis.

Nie pozostaje mi nic innego, jak z całej duszy podziękować p. cenzorowi za jego pieczołowitość i za jego usiłowania w przyuczaniu mię do szarego i bezbarwnego sposobu pisania. Ażeby zaś wiedziano i później, jacy to troskliwcy gospodarowali wszechwładnie w pewnej części Europy Środkowej na początku wieku XX, postanowitem wydrukować artykuł tam, dokąd już nie sięga ręka miłych opiekunów. Przy tym wskazuję dokładnie i szezegółowo wszystkie miejsca i ustępy, wyrzucone przez cenzora ${ }^{1}$.

1 Sygnalizowane przez autora w przypisach ingerencje cenzorskie ujmuję tu w nawiasy kwadratowe. Baudouin pisał z Peteresburga 1/14 I $1904 \mathrm{r}$. do W. Feldmana, wydawcy „Krytyki”: Oto „Ogniwo” rozpoczęto druk mego artykutu „Krzewiciele zdziczenia”. Pierwszy ciag przeszedt, choć znacznie obcięty przez cenzure; ale dalsze ciagi cenzor tak haniebnie skracat $i$ literalnie pozbawiat sensu, że niepodobna byto myśleć o traktowaniu publiczności takimi resztkami i trzeba sie byto obejść smakiem. Czy nie mógtby Pan umieścić tego artykutu w „Krytyce”? Za: J. N. B a u d o u in d e C o u rt e n a y, Listy z lat 1870-1927, oprac. E. S t a c h u r s k i, Kraków 2002, 
Pragnąłbym „unieśmiertelnić” także imię mego troskliwego opiekuna. Nie czynię tego jednak, ponieważ najprzód to zacne imię tak jakby nie doszło do mej wiadomości, a po wtóre nie chciałbym obrażać skromności tego męża, która z pewnością dorównywa jego bezinteresownej dbałości o dobro publiczne. Tyle tylko pewna, że jest to cenzor z przekonania, cenzor z „bożej łaski”.

A może dostojnik ten, jako przedstawiciel uprzywilejowanej „białej rasy”, zaliczył mię do „żółtych”, których należy dusić z taką samą bezwzględną „rycerskością”, z jaką jego współrasowcy pod względem „białości” i grubości skóry urządzają pochody przeciw innym „rasom” we Wrześni, w Poznaniu, w Błagowieszczeńsku, w Afryce, w Krożach, w Kiszyniowie, w Armenii, w Finlandii, w Priwislinii, w Chinach, na Filipinach, na Sumatrze, w Petersburgu i... gdzie się zdarzy.

Wymawiając lub też tylko uświadamiając sobie wyraz zdziczenie, myślimy oczywiście, że coś niedzikiego staje się dzikim. Ja jednak biorę tu ten wyraz w nieco obszerniejszym znaczeniu, kojarząc go nie tylko z przejściem ze stanu niedzikości do stanu dzikości, ale także ze zwiększaniem i potężnieniem już istniejącej dzikości. Tak więc krzewi zdziczenie nie tylko ten, kto człowieka niedzikiego przeobraża w dzikiego, ale także ten, kto współdziała rozrastaniu się i utrwalaniu się istniejących już zarodków lub objawów dzikości.

Co to jest jednak dzikość w różnicy od niedzikości? Spróbujmy odpowiedzieć na to pytanie.

W swych Myślach nieoportunistycznych (Kraków 1898) umieściłem między innymi następujący aforyzm (nr 101):

Jeśli istnieje rzeczywisty postęp w życiu ludzkości, to czy nie dałoby się ująć go w formule, że jest on powolnym przejściem od stanu stadowo-egoistycznego do stanu spoteczno-indywidualnego?

s. 44. Zob. tamże również list Baudouina do Feldmana z 10/23 IX 1904 (s. 45$-47)$. 
W formule tej zawiera się, zdaniem moim, także częściowe określenie stopniowego zmniejszania się dzikości, jakie daje się zauważyé w dziejach doskonalącego się rodu ludzkiego. Egoizm w swych grubych, brutalnych objawach jest czynnikiem stanowezo antysocjalnym, czyli przeciwspołecznym. Życie stadowe czy to całkiem luźne, czy to nawet choćby zorganizowane, uniemożebnia, a przynajmniej nader utrudnia rozwój indywidualny jednostek. Jedynie tylko prawdziwy indywidualizm, jako coraz bardziej uświadamiający się rozwój wewnętrzny osobników, rozwój połączony z krytyczną oceną i zrozumieniem stosunku własnego ja do innych osobników, jedynie tylko prawdziwy indywidualizm daje się pogodzić z wszechstronnym życiem społecznym, niestadowym. Społeczeństwem, w tym wyższym znaczeniu tego wyrazu, możemy nazwać tylko stowarzyszenie albo dobrowolne, albo też, chociaż niezależne od woli jednostek, to jednak sprowadzające despotyzm większości w sferze wierzeń i przekonań do możliwego minimum, a natomiast znajdujące w pracy spólnej, czyli w kooperacji, prawdziwą rękojmię stworzenia maximum dobrobytu tak dla ogółu, jak i dla pojedynczych członków.

Stadowość społeczna, czyli stado zamiast społeczeństwa, oraz kierowanie się jednostek pobudkami czysto egoistycznymi na krótką metę charakteryzują stan dzikości; w miarę zaś oddalania się od tego stanu dzikości powstaje prawdziwa społeczność ludzka, czyli uświadomienie społeczne, a jednocześnie potężnieje indywidualność. W każdym razie tak się ma dzikość do niedzikości, jak się ma stado do społeczeństwa lub też jak osobnik impulsywnie egoistyczny do osobnika indywidualnie wyrobionego.

Znamy gromady ludzkie żyjące wyłącznie życiem stadowym, bez uświadomienia społecznego. Znamy również, nawet w społeczeństwach częściowo uświadomionych, osobniki bezwzględnie dzikie, tj. kierujące się tylko chwilowymi bodźcami egoistycznymi. Nie ma zaś i dotychezas nigdzie nie było gromad ludzkich żyjących jedynie uświadomionym życiem społecznym, z zupełnym usunięciem dzikości; nie ma również, nawet w społeczeństwach najbardziej „ucywilizowanych", czyli najmniej dzikich, osobników nieskazitelnie wyindywidualizowanych i etycznie uświadomionych, tj. niemogących w pewnych warunkach stać się dzikimi. 
Nawet w społeczeństwach najnowszej formacji, w społeczeństwach niby to najbardziej oddalonych od stanu dzikości istnieją stale i nieprzerwanie instytucje, korporacje i zwyczaje, ziejące dzikością i barbarzyństwem, zniżające ludzkość do stanu przedezłowieczego (jeżeli cztowieczeństwo i ludzkość weźmiemy chwilowo w szlachetnym znaczeniu tych wyrazów). W każdym zaś człowieku, choćby nawet najwyżej posuniętym pod względem umysłowym i moralnym, drzemią dzikie instynkta, które przy sprzyjających okolicznościach wybuchają z niepohamowaną siłą i sprowadzają „śmietankę” inteligencji i „pana stworzenia” do stanu wściekłej bestii dwunogiej. Do rzędu osobników bezwzględnie dzikich, tj. kierujących się jedynie przemijającymi lub też od czasu do czasu, mniej więcej periodycznie powracającymi pobudkami egoistycznymi, należą przede wszystkim „typy okrutne i krwiożercze”, których charakterystyką zajmuje się p. L. Krzywicki w kilku ostatnich numerach „Ogniwa” z r. 1903. Dalej należą tu: ludzie uznani urzędowo za obłąkanych oraz wszelkiego rodzaju zwyrodnialcy i gnitosze, chociażby nawet podniesieni do rangi „nadludzi”. Kadry tej ostatniej kategorii bywają zasilane także przez tych artystów i poetów, u których wyuzdany impresjonizm i wybuchowość stanowią główne motywy tworzenia.

Dzikość częściowa może byé właściwą nawet indywiduom stojącym bardzo wysoko pod względem umysłowym, kulturalnym i etycznym. Tak np. idzie ona w parze z niekonsekwencją, z brakiem poczucia, że się jest obowiązanym wyciągać wnioski praktyczne ze swych przekonań teoretycznych, że w tej przede wszystkim sferze noblesse oblige. Cechą niezbędną niedzikości jest tu zgodność ze sobą, jest całkowitość i jednolitość natury, jest zgodność postępowania z przekonaniami. Uczony, choćby nawet o najpotężniejszej umysłowości, jeżeli jednocześnie jest szowinistą i bierze udział w prześladowaniu i tępieniu kogokolwiek bądź, musi być uważany za dzikiego.

Dzikość społeczeństwa podtrzymują wszelkie instytucje, dążące do krwi przelewu, do rozbudzania nienawiści, instytucje oparte na obłędzie wielkości i na obłędzie prześladowczym, instytucje, które postawity sobie za zadanie tłumienie i zabijanie indywidualności, zawodowe i uroczyste wykonywanie zemsty, pozbawianie życia i wolności. 
[Jeszcze nie tak dawno my, „cywilizowani Europejczycy”, paliliśmy czarownice, torturowaliśmy legalnie, a dziś ze zdwojoną siłą prześladujemy ludzi tak za ich przekonania, jako też za ich pochodzenie, za ich przynależność do tej lub owej narodowości, do tego lub owego wyznania. Czyż to niedzikość i „dzikość” we wszelkich znaczeniach tego wyrazu? $]^{1}$.

W historii stopniowego przechodzenia gromad ludzkich od stanu dzikości do względnej niedzikości możemy rozróżnić trzy główne fazy rozwoju:

1. Dzikość bezwzględna, bez żadnej organizacji, bez żadnej tresury, a co najwyżej bandy chwilowo formowane i luźne stada bestii dwunogich.

2. Dzikość uorganizowana, gdzie jeden chwyta innych za łeb, a inni mu się poddają. Pewne masy ludzkie zastygły w tym stanie; są to thumy, dla których jedynym hamulcem jest strach i kara, czy to w obecnym, czy też w przyszłym życiu, tłumy wyobrażające ze siebie trzodę z pastuchem.

3. Na tle dzikości uorganizowanej powstają tu i ówdzie wolne i dobrowolne związki, związki oparte na spotężnieniu indywidualizmu jednostek, na ulogicznieniu myślenia idącego ręka w rękę ze wzrostem poczucia sprawiedliwości oraz na uświadomieniu rozumnego stosunku jednostki do grupy uspołecznionej.

W pierwszej dobie rozwoju, w stanie dzikości bezwzględnej, technika i przemysł mogą się rozwijać tylko zarodkowo. Natomiast w fazie dzikości uorganizowanej technika, przemyst i w ogóle wytwórczość ekonomiczna mogą dochodzić w coraz szybszym tempie do najwyższego stopnia doskonałości, a pomimo to, skierowując się w stronę gnębienia, tłumienia, tępienia, podtrzymywania niesprawiedliwości społecznej oraz nienawiści międzyplemiennej i międzywyznaniowej, godzić się wyśmienicie z dzikością myślenia i woli. [Jeżeli najnowsze środki komunikacji służą do ułatwiania „pielgrzymek” bałwochwalczych, jeżeli najnowsze metody szkolne bywają zużytkowywane do ubierania całych gromad ludzkich w jednostajny mundur

1 Ustęp ten, od Jeszcze nie tak dawno do tego wyrazu?, został wyrzucony przez cenzora [przyp. BdeC]. 
stadowych wierzeń i „przekonan”, toć jest to chyba nadużywanie techniki i wynalazków w celu podtrzymywania dzikości] ${ }^{1}$.

Nie da się zaprzeczyé, że i w tej sferze, w sferze najbardziej zaniedbanej i pozostającej gdzieś daleko w tyle poza rozwojem techniki, to jest w sferze myślenia i etyki, ludzkość postępuje, ale postęp ten odbywa się gzygzakami: zrobiwszy dwa kroki naprzód, cofamy się na jeden krok w tył².

Zupełne usunięcie dzikości myśli i woli jest rzeczą niemożliwą, choćby po prostu ze względu na nasze pochodzenie. Jesteśmy dalszym ogniwem przodków dzikich, urządzeń dzikich, wierzeń dzikich. W naszych organizmach fizjologicznych i duchowych tkwią i tkwić muszą w najdalszych pokoleniach przeżytki dzikości przodków. Przeżytki te, choćby nawet sprowadzone do stanu zaniku, do minimum, tleją w nas jak zarzewie, które, rozdmuchane w odpowiedni sposób, może stać się zarodkiem nowego płomienia.

Przodek ludojad mordował „bliźnich” dla nasycenia głodu, a sam akt zarzynania lub też duszenia sprawiał mu rozkosz realną, rozkosz człowieka dochodzącego do celu. Potomek ludojada nasyca głód w inny sposób, ale pomimo to dziedziczy on żądzę krwi i mordu, a sam akt pociągania nożem po cudzym gardle lub też dręczenia w jakikolwiek sposób, sama „sztuka dla sztuki”, „ofiara dla ofiary” może w nim wzbudzać rozkoszne dreszcze kanibala. Człowiek taki staje się albo nieuznanym przez „prawo” mordercą i dusicielem, albo też dobrowolnym katem, a choćby tylko mężem podpisującym legalnie wyroki śmierci. Kto zaś ani nie ścina, ani nie wiesza własnoręcznie, ani nie podpisuje wyroków śmierci, ten rozkoszuje się prześladowaniami, gnębieniem ludzi innego „stanu”, ludzi należących do innych narodo-

1 Ustęp ten, od: Jeżeli najnowsze środki komunikacji do podtrzymywania dzikości, cenzor wyrzucił [przyp. BdeC].

2 Tyle tylko wydrukowano w „Ogniwie” (1904, nr 1). Następnie złożono dosyć dużo, ale wykreślania cenzorskie uniemożliwiły drukowanie [przyp. BdeC]. 
wości, do innych „wyznan”, ludzi innych „przekonan”, w ogóle ludzi inaczej wyglądających, inaczej mówiących i inaczej „myślących”, co oczywiście stanowi zmodyfikowaną i złagodzoną formę dziedzictwa psychicznego po ludojadach.

Przodek mięsożerny musiał dla zaspokojenia głodu własnoręcznie zarzynać i ćwiartować pożerane zwierzę, a uczucie zaspakajania głodu łączyło się oczywiście z błogim uczuciem osiągania celu realnego, a więc z uczuciem niezmiernie przyjemnym. To uczucie przyjemności doświadczanej przez przodka podezas aktu mordowania zwierząt przeznaczonych na pożarcie może drogą dziedziczności przechodzić do najpóźniejszych potomków, którzy podbudzani przez nie stają się zawodowymi rzeźnikami, oprawcami, a w najlepszym razie dręczycielami zwierząt. Również w „szlachetnych sportach” myślistwa i rybołówstwa amatorskiego znajduje sobie ujście odziedziczona po przodkach krwiożerczość i żądza znęcania się.

Odkrycie ognia i możności wydobywania go przez tarcie 0 siebie twardych szczap drzewa było olbrzymim wypadkiem, napełniającym dusze naszych „dzikich” przodków nieopisaną rozkoszą i wdzięcznością dla „boga ognia”. Dzisiejszy piroman, czyli podpalacz z popędów wrodzonych, odziedziczył po przodkach ów rozkoszny dreszcz, choć w życiu brak dla niego podstaw realnych. Jeden z profesorów Uniwersytetu Warszawskiego, dziś już nieżyjący M. K., przyznał mi się, że gdyby nie hamulec wykształcenia i bojaźni kary, namiętnie by podpalał; widok bowiem pożaru napawał go niewysłowioną rozkoszą.

W pierwocinach uspołecznienia członkowie męscy hord uorganizowanych mogli zawładnąć kobietami przeważnie tylko za pomocą gwałtu, którego wyobrażenie kojarzyło się z wyobrażeniem pewnego rodzaju rozkoszy. Dziedziczeniem uczuć i wzruszeń w kierunku jednorodności płciowej należy objaśniać ten fakt, że nawet w sferze inteligentnej spotykamy tylu gwałcicieli i znęcających się z amatorstwa nad „płcią słabszą”.

Podobnież, przyjmując taką samą dziedziczność w kierunku jednorodności płciowej, zrozumiemy, dlaczego pewne indywidua płci żeńskiej, pomimo zasadniczego oburzenia i wstrętu do gwałcicieli, doznają jednak pewnej dzikiej przyjemności, ulegając gwałtowi i poniewierce. 
[W dzisiejszym „kleptomanie” z nieprzezwyciężonym popędem do „przywłaszczania” sobie „cudzej własności”, jako w jednym z ogniw w szeregu dziedziczonych a potęgujących się od czasu do czasu objawów psychiki człowieka „dzikiego”, powtarzają się po prostu wzruszenia i dreszcze, których doznawał jego przodek, kładący za pomocą „rabunku” i „Zaboru” pierwsze podwaliny „świętej instytucji własności”. A zresztą czyż i dziś nie ma już zgłodniałych, czyż nie ma ,wydziedziczonych”, czyż nie ma obok nas naszych własnych przodków?

Co więcej, czyż nawet my sami, wzniesieni na „wyższy szczebel" moralności i inteligencji, gdyby nas pozbawiono warunków umożliwiających „szlachetność” uczuć i „głębokość” myśli, gdyby nas zdegradowano do stanowiska pariasów społecznych, czyż w takich warunkach nie stalibyśmy się własnymi przodkami, kładącymi podwaliny własności, zawziętymi na życie i mienie „bliźnich”?

Zróbmy doświadczenie. Wybierzmy kilku wykwintnych hrabiów i królewiąt, miotających gromy na „przewrotowców” i patrzących z pogardą na motłoch „dziki”, bo zgłodniały i pozbawiony chleba powszedniego oświaty i cywilizacji, umieśćmy tych paniczów na bezludnej wyspie lub też puśćmy ich na morze, a bądźmy pewni, że wykwintnisie ci, bez innych środków żywności, zaczną pożerać się wzajemnie, tj. robić zamachy już nie na własność, ale na życie „bliźniego”. W ogóle praktykowanie „miłości bliźniego”, tj., mówiąc językiem mniej podniostym a bardziej zgodnym z rzeczywistością, dobrowolne niekrzywdzenie innych ludzi, możliwe jest tylko przy jako tako sytym żołądku i przy dachu nad głową.

$$
* * *
$$

Jedną z głównych cech dzikości w sferze intelektualnej jest mieszanie pojęcé, gdy tymczasem wyjściu ze stanu dzikości towarzyszy rozróżnianie pojęć, myślenie świadome, myślenie krytyczne, myślenie analityczne.

Otóż owi hrabiowie i królewięta, uważając siebie za wybrańców ludzkości, mieszają pojęcia; zdaje im się bowiem, iż są oni z natury,,piękni”, wytworni, szlachetni, rozumni itd., itd. Niestety, 
są oni tym wszystkim (jeżeli są w istocie i jeżeli nie łudzą się co do swej doskonałości) tylko dzięki wyjątkowemu uprzywilejowaniu. Odejmijmy im owe wyjątkowo pomyślne warunki, a staną się może jeszcze bardziej dzikimi aniżeli jednostki należące do pogardzonego przez nich „motłochu”. Co więcej, nawet obecnie, nawet w swej niby wyższości moralnej i umysłowej, popełniając dopiero co wskazane pomieszanie pojęć, panowie ci są choćby z tego stanowiska dzikimi w najprostszym znaczeniu tego wyrazu.

W związku z pomieszaniem pojęć cechującym stan dzikości pod względem umysłowym pozostaje odwracanie oczu od interesów realnych, od interesów ekonomicznych, pozostaje „walka za idee”, za „wyznania”, za narodowości, za alfabety, za lilipucie rozbijanie jajka czy to z grubszego, czy też z cieńszego końca, pozostaje barbarzyństwo i wandalizm tępiący inne alfabety, inne literatury, inne języki, inne wyznania, innych bogów miejscowych] ${ }^{1}$.

\section{III}

Chociaż postęp umysłowo-obyczajowy, czyli intelektualnie-etyczny, wygląda nader mizernie w porównaniu z postępem techniki i sztuki, to jednak przyznać musimy, że postęp ten ma miejsce. A rozróżniamy w nim dwie strony rozwijające się w ścisłej od siebie zależności:

1. stronę intelektualną, czysto umysłową;

2. stronę moralną, etyczną.

Postęp intelektualny polega przede wszystkim na stopniowym przechodzeniu od pomieszania pojęć do ich rozróżniania. Postęp zaś moralny, doskonalenie się etyki jest równoznaczne z potężnieniem altruizmu i uczuć społecznych, a to potężnienie altruizmu idzie ręka w rękę z coraz większą indywidualizacją duchową osobników.

W związku ze wzrostem zdolności myślenia logicznego, w związku ze wzrostem zdolności porównywania i wnioskowania potężnieje także poczucie sprawiedliwości i spółczucia dla sobie podobnych. Ból obcy, obce cierpienie przenosi się na swoją własną osobistość, a to

1 Te siedem ustępów, od: $W$ dzisiejszym „kleptomanie” do innych bogów miejscowych, wykreślił cenzor [przyp. BdeC]. 
przeciwdziała świadomemu sprawianiu bólu i zadawaniu cierpień. Na takim gruncie powstają i rozwijają się nowe ideały, czerpiące soki z uznania praw człowieka, z poszanowania dla godności ludzkiej.

Ale urzeczywistnianiu tych ideałów stają na przeszkodzie dzikie instynkta odziedziczone po przodkach, a podtrzymywane i rozniecane przez wpływ otoczenia i złowrogich warunków. Nawet człowiek stojący na najwyższym szczeblu w rozwoju umysłowym i moralnym może pod działaniem pewnych czynników fizjologicznych lub też pod wpływem imaginacji wpaść w pewien „nastrój” dziki i krwiożerczy, a w ten sposób stanąć w tragicznej kolizji z samym sobą. Boć przecie niezgodność popędów i dążeń mimowolnych z światopoglądem jednostki i z jej przekonaniami stwarza dla niej położenie prawdziwie tragiczne.

Kto więc pragnie zmniejszenia tego tragizmu, kto pragnie oszczędzać sobie i innym cierpień, mogących być usuniętymi, ten powinien dążyé [albo do robienia ludzi bydlętami niezdającymi sobie sprawy z tego, co czynią, albo też] ${ }^{1}$ do jak najpotężniejszego uświadomienia, do jak największego postępu świadomości, do pełnego rozkwitu myślenia logicznego i poczucia sprawiedliwości, a to w tak silnym stopniu, ażeby te wyższe czynniki psychiczne były w stanie przeciwdziałać ślepym instynktom i popędom. Jest to ideał może niedościgniony, ale dążyé do niego jest obowiązkiem każdego człowieka logieznie myślącego i sprawiedliwego.

W życiu każdego człowieka występuje w pewnych chwilach to jeden, to drugi element: to refleksja i rozum, to znowu dzikość instynktywna. Życie spokojne i bez troski, zadowolenie najpierwszych potrzeb fizjologieznych, rozmyślanie naukowe, analityezne, [wolność od prześladowań i od brania udziału w prześladowaniach]², wszystko to sprzyja przewadze po stronie rozumu i sprawiedliwości. A podobnie jak sen zwykły, podobnie jak upojenie spirytusem lub tp., tak też wszelkie przyćmienie umysłu tym lub owym afektem, trwałym lub przemijającym, albo też jego (tj. umysłu) względna słabość w sto-

1 Wyrazy ujęte w nawias cenzor wykreślił (w oryginale zaznaczone kursywą).

2 Jak wyżej. 
sunku do popędów żywiołowych usposabia do objawów dzikości zwanej fanatyzmem, szałem religijnym, patriotyzmem przeczulonym, czyli szowinizmem, erotyzmem, krwiożerczością, wojowniczością itd., itd.

A znowu podobnie jak obłąkany, który uzna, że jest obłąkanym, znajduje się na drodze ku wyzdrowieniu, tak też pierwszym krokiem do wyjścia ze stanu dzikości jest uznanie, że się w tym stanie znajdujemy. Ja też uznaję to, a prawdopodobnie znajdzie się pewna, choć nieliczna, grupa ludzi, którzy się ze mną zgodzą.

Uznawszy, iż jesteśmy jeszcze pogrążeni w dzikości, idziemy dalej i twierdzimy, że ową dzikość, owo zdziczenie krzewi każdy, kto potęguje w nas instynkta i porywy żywiołowe pozostające w kolizji z rozumem i z poczuciem sprawiedliwości i kto wydoskonala dla nich ich bezpośrednie przewodniki, tj. drogi nerwowe naszego organizmu.

A więc przy dziś panujących poglądach i ideałach krzewi dzikość przede wszystkim ten, kto podtrzymuje nędzę społeczną, kto utrwala i kodyfikuje nierówność społeczną, kto stawia przeszkody równouprawnieniu płci, „stanów”, zawodów, wyznań i narodowości ${ }^{1}$.

W sferze życia indywidualnego i rodzinnego, a przez nie także społecznego, skutecznymi czynnikami zdziczenia bywają dosyć często tak zwane „małżeństwa z miłości”, a właściwie z głupoty, tj. małżeństwa zawierane bez względu na stan zdrowia, usposobienie, charakter, położenie społeczne i wydajność ekonomiczną małżonków. Takie bezmyślnie kojarzone stadła stwarzają zwykle „dzikie” otoczenie tak dla założycieli „gniazdka rodzinnego”, jako też dla wylęgłych w nim piskląt.

Do podtrzymywania, a nawet do zwiększania dzikości moga prowadzić nawet instytucje, których sama nazwa wskazuje, iż powinny one nie krzewić, ale - przeciwnie - usuwać i tępić dzikość umysłu i uczuć.

[Będę prawdopodobnie oskarżony o herezję przez czcicieli oświaty obowiązkowej i wywołam w nich zgrozę, ale pomimo to pozwolę sobie twierdzić, że szkoła obowiązkowa i państwowa występuje jako jeden z najwierniejszych sprzymierzeńców zdziczenia, jeżeli jej konsekwencje doprowadzają do Wrześni i Gniezna.

1 Wyrazy wyznañ $i$ narodowości cenzor wykreślił [przyp. BdeC]. 
Ale nawet bez obowiązkowości, dzięki pewnym metodom wychowawczym - pedagogicznym i dydaktycznym - możemy uważać szkołę za krzewicielkę zdziczenia. Taką musi być szkoła z rózg̨ą, z biciem po twarzy, z biciem linią po rękach, z systemem straszenia, podglądania, donosicielstwa itd. Taką też musi być szkoła, która za pomocą odpowiednio spreparowanych podręczników „religii”, historii, geografii, literatury, gramatyki itd. podtrzymuje i rozwija z jednej strony pomieszanie pojęć i chaotyczność myślenia, z drugiej zaś „nastrój” krwiożerczy i żądny ofiar ludzkich, w związku z nienawiścią międzynarodową, międzyplemienną, międzywyznaniową i międzystanową.

Taką też rolę krzewicielek zdziczenia mogą odgrywać instytucje stojące na jeszcze wyższym szczeblu umysłowo-społecznym aniżeli szkoła, mianowicie z jednej strony stowarzyszenia ekonomiczne mające na celu wytwórczość i uspołecznienie pracy, jeżeli kierują się przy tym względami na przynależność wyznaniową lub narodową członków, z drugiej zaś strony najwyższe instytucje naukowe danego kraju lub państwa. Świeżo założona akademia w Poznaniu musi krzewić zdziczenie, ponieważ przede wszystkim jako instytucja antyspoteczna podżega nienawiść między mieszkańcami tej samej ziemi i ma na celu tłumienie życia umysłowego jednego z narodów miejscowych, a następnie, jako instytucja antyindywidualna zabija indywidualność tego samego narodu, podsyca „egoizm narodowy” niemiecki w ogóle, a egoizm każdego Niemca w szczególności, w związku z czym pozostaje wzmocnienie nieuspołecznienia w wyższym stylu, ale tylko prostej stadowości niemieckiej] ${ }^{1}$.

Rozprzestrzenianie „kultury” europejskiej w krajach „dzikich” równa się znęcaniu się dzikich Europejczyków nad tubylcami innych „części świata”.

Jedna z tak mocno i słusznie sławionych „zdobyczy wieku XIX”, będąca w każdym razie doniosłym objawem uspołecznienia uorganizowanych państwowo gromad ludzkich, mianowicie parlamentaryzm zachodnioeuropejski, w pewnych chwilach swego urzeczywistniania

1 Trzy powyższe ustępy, od Bede prawdopodobnie oskarżony o „herezje”" do ale tylko prostej stadowości niemieckiej, cenzor wykreślił [przyp. BdeC]. 
daje pole do popisu wybuchom rozkiełznanej namiętności i sprzyja wzrostowi zdziczenia, tj. pomieszania pojęć i zanikowi poczucia tego, co godziwe, a co niegodziwe.

Ale nawet to, co się sprzedaje i nabywa pod etykietą nauki, może ogłupiać mózgownice i spółdziałać dziczeniu natur ludzkich. Wiedza impresjonistyezna, wchłanianie w siebie wiadomości drobiazgowych oraz wszelkiego rodzaju plotek uniwersalno-historyeznych, w ogóle zaspakajanie próżnej ciekawości i zapychanie głowy bez należytego oświetlenia, bez rozbioru, bez krytyki, bez rozróżniania pojęć, nie zmniejsza wcale dzikości tradycyjnej, ale nawet czyni ludzi jeszcze bardziej pochopnymi do przejawiania tej dzikości w najrozmaitszych kierunkach. Wprost zaś do zdziczenia, tj. do zaćmienia umysłów i do spotęgowania wybuchowości żywiołowej, prowadzi znaczna część codziennej strawy umysłowej czytelników gazet i w ogóle publicystyki.

Nareszcie pewnego rodzaju literatura, poezja i sztuka działają jak opium i haszysz, upajają, wprawiają umysły w stan graniczący z szałem i snem niespokojnym, krzewiąc przez to samo dzikość, a w najlepszym razie dzikość wysubtelnioną. Zwłaszeza pewien odłam powieściopisarstwa odgrywa rolę niepośledniego czynnika w procesie podtrzymywania i utrwalania dzikości.

Kto choć trochę obserwował ludzi i zastanawiał się nad ich naturą, ten wie, że niepodobna oddzielać bez zająknienia się kozłów od baranów, przestępeów od cnotliwych, głupców od rozumnych itd. W każdym prawie człowieku drzemie głupiec, szaleniec i zbrodniarz, a do ich obudzenia się potrzebne są tylko odpowiednie warunki. Im dany osobnik jest naturą bardziej bogatą, złożoną i wielostronną, tym łatwiej mogą się w nim łączyć pierwiastki z pozoru całkiem odmienne, jak np. zbrodniczość z wysokim talentem artystycznym. 0 zgodzie tych pierwiastków trudno mówié, zwykle bowiem jeden z nich przeważa i przyćmiewa drugi. Wiadomo jednak, że tak zwani uomini deliquenti, to jest zbrodniarze z urodzenia, pisują niekiedy natchnione poezje, kreślą obrazy nacechowane płomienną fantazją i w ogóle zasługują na uwagę estetyków i historyków literatury.

Jeden z ,potworów moralnych” drugiej połowy w. XVIII, markiz Sade, ogłaszał powieści, wprawdzie jednostronnie lubieżne i okrut- 
ne, ale zawsze powieści, które czytelnik połyka z wielkim zaciekawieniem.

Nie tak dawno słynny pisarz angielski Oskar Wilde (dziś już nieżyjący) został skazany na kilka lat ciężkich robót za krzyczące „występki” przeciw [tak zwanej] ${ }^{11}$ „moralności”.

Dostojewski², jeden z najgenialniejszych powieściopisarzy-psychologów, [odznaczał się pewnymi cechami fizycznymi, przypominającemu przestępcę z urodzenia, a nawet] ${ }^{3}$, według własnego wyznania, był z natury okrutnikiem i lubieżnikiem. Nie mógł on widzieć kobiety bez pożądania jej. Kreśląc niepospolite charakterystyki swych bohaterów psychopatycznie zwyrodniałych, czuł się w swoim żywiole. Toteż jak to wykazały niektóre procesy kryminalne, jego Prestuplenije $i$ nakazanije ${ }^{4}$ stanowi ulubioną lekturę morderców inteligentnych i półinteligentnych. Powieść tę studiował ów młodzieniec na wpół wykształcony, który parę lat temu w Petersburgu zamordował w okrutny sposób kilkoletniego chłopczyka. W tę też powieść zagłębiali się zabójcy Tomaszewskiego, a w pewnych, zapewne nielicznych, kółkach młodzieży (np. w Petersburgu), zwłaszcza młodzieży rozestetyzowanej i rozdekadenconej, wentyluje się poważnie kwestia, czy nie jest obowiązkiem ludzi przyzwoitych wyprawiać na tamten świat „darmozjadów” lichwiarzy i inne „szkodliwe jednostki”.

Jak kamerton potęguje właściwy sobie ton wydany przez strunę instrumentu muzycznego, tak też dusze, odpowiednio nastrojone, brzmią unisono z Prestuplenijem i nakazanijem.

Głośny dziś Leonid Andrejew lubuje się po prostu w wytwarzaniu nastroju ponurego, lubieżnego i krwiożerczego, a że temu „nastrojowi” towarzyszy „pesymizm filozoficzny”, to już nie zmienia faktu źródła psychicznego, z którego płyną podobne utwory.

$1 \quad$ Wyrazy ujęte w nawias cenzor wykreślił.[przyp. BdeC].

20 stosunku Baudouina do tego pisarza zob.: B. B i a $\nmid 0$ k 0 z 0 w i c z $1980 \mathrm{~b}$.

3 Wyrazy ujęte w nawias cenzor wykreślił [przyp. BdeC].

4 Prestuplenije i nakazanije (ros.) - Zbrodnia i kara.

5 O morderstwie dokonanym przez gimnazjalistę na lichwiarzu dorpackim w 1887 r. wspomina E. M a ł a c ho w s k a 1973. 
Niekiedy od „literatury nadobnej” otrzymuje się wrażenie, jak gdyby dane społeczeństwo było stadem zuchwałych samców i rozwydrzonych samic. Ten odłam beletrystyki, odłam samczo-samiczy, kwitnie i bujnie się rozwija chyba u wszystkich „narodów cywilizowanych”. Polacy weale tu innym nie ustępują; przeciwnie zajmują chlubnie jedno z miejsc w pierwszym szeregu. A niesprawiedliwością byłoby tu obwiniać tak zwany „realizm” i „naturalizm” w powieści. Przed realizmem i naturalizmem od najdawniejszych czasów ciągnie się przez utwory literatury nadobnej silnie tętniący nerw wizji podniecających zmysłowość w sferze stosunków międzypłciowych. Nie omylę się chyba, twierdząc, że na niejednego z przedstawicieli starszego pokolenia w ich młodych latach działał w ten sposób niekiedy nawet niewinny Kraszewski wraz z całym gronem spótczesnych mu powieściopisarzy. Nie da się jednak zaprzeczyé, że żywioł erotyczny uległ skondensowaniu w ostatnich lat dziesiątkach.

Pod wpływem Nany Zoli i innych pokrewnych jej utworów zjawit się i w literaturze polskiej cały zastęp „nanistów” i „nanistek”, w tej liczbie także „szanownych matron” i „dziewoi uroczych”, rozkoszujących się malowaniem lub przynajmniej robieniem bardzo przezroczystych aluzji do scen drastycznych, do scen „flirtu” daleko posuniętego, do scen uwodzenia i nawet... gwałcenia. Ileż to razy przy czytaniu tych „niewieścich utworów” muskających dziedzinę pornografii brała chętka zapytać, czy szanowna autorka zna opisywane „nastroje” i działania czynne i bierne z własnego doświadczenia, czy też je tylko „odczuwa” potęgą swej wyobraźni.

A były w tym zastępie nie same tylk0 „realistki” i „naturalistki”. Jedne z pierwszych skrzypiec trzymała pewna „dziewica litewska”, bardzo idealna, bardzo pobożna i oczywiście postępująca według pożytecznej recepty: i Bogu świeczka, i diabłu ożóg.

Bądź jak bądź, mieliśmy i „klasycyzm” samczo-samiczy, i „romantyzm” samczo-samiczy, i „realizm” samezo-samiczy, i „naturalizm” samczo-samiczy, i „symbolizm” samczo-samiczy, i „modernizm” samczo-samiczy i „dekadentyzm” samezo-samiczy i... po prostu wszeteczeński.

A nawet wielki kaznodzieja przeciwko rui $i$ porubstwu, ów mistrz słowa, którego utwory rozchodzą się tysiącami na obu pót- 
kulach $^{1}$, ileż to razy skierowuje wyobraźnię czytelnika w sfery bardzo blisko graniczące, jeżeli nie identyczne, z „rują i porubstwem”, tj. z erotyzmem i z okrucieństwami bestii dwunogich! Tak to kocioł garnkowi przygania, a sam smoli.

Nasi najnowsi, między którymi są niewątpliwie pierwszorzędne talenta, idą również utartymi drogami i unoszą się na skrzydłach wyobraźni do jaskiń pozbawionych światła rozumu, pogrążonych w pomroce snu psychicznego, a za to rozbrzmiewających wyciem i jękiem gwałcicieli i gwałconych, tępicieli i tępionych² .

\section{IV}

Do napisania tego artykułu wziąłem pochop ze wspaniałej i porywającej powieści Żeromskiego, Popioty, kawałkowanej od dość dawnego czasu na szpaltach „Tygodnika Ilustrowanego”. Niektóre z ostatnich numerów „Tygodnika”, jako też niektóre dawniejsze, zawierają ze wzmiankowanej powieści jedynie tylko sceny i obrazy, przeładowane zbyt jaskrawymi wybuchami miłości „rycerskiej” i zgęszczonym urzeczywistnianiem reklamowanego przepisu: kochaj

1 Mowa 0 Henryku Sienkiewiczu. Baudouin nie cenit jego twórczości, a w związku z wyborem Sienkiewicza na członka korespondenta Petersburskiej Akademii Nauk pisał do A. Byczkowa: Mówiqc między nami, wybranie Sienkiewicza na cztonka korespodenta Oddziatu nieco mnie zdziwito. Przecież jego działalność literacka ma mato wspólnego z zadaniami Oddziatu. Wybranie go dziwi tym bardziej, że, jeśli się nie myle, cztonkami Oddziatu nie byli i nie sa pisarze rosyjscy, nieusteppujacy wszak Sienkiewiczowi w zastugach $i$ wptywie, $i$ - niech Pan wybaczy - nawet przewyższajacy go, jak choćby I. S. Turgieniew, L. N. Totstoj i in. Pod wzgledem charakteru, szczerości, czystości przekonań nie można nawet porównywać Sienkiewicza z pomienionymi tutaj dwoma pisarzami. Wybór Sienkiewicza traktuje tylko jako akt życzliwości (courtoisie) wobec inteligentnej publiczności polskiej. Cytat w przekt. własnym przytaczam za: B. B i a 10 k 0 z o w i c z 1985.

2 Tyle tylko próbowano składać dla „Ogniwa”; dalszy ciąg, wobec nieubłaganego pastwienia się cenzora, pozostał jedynie w rękopisie [przyp. BdeC].

3 Pisałem to w ostatnich tygodniach r. 1903 [przyp. BdeC]. 
bliźniego swego, jak siebie samego. Ale nie chciałbym być posądzonym 0 „zamach na wolność sztuki” i dlatego zacznę od rozpamiętywań ogólniejszego charakteru.

Różne są sposoby dochodzenia do „prawdy”, różne są sposoby poznawania tego, co się działo w świecie psychiczno-społecznym. Poznajemy „rzeczywistość historyczną”, przeżywając ją i biorąc w niej bezpośredni udział.

Poznajemy ją również z suchych kronikarskich opisów, będących bezbarwnym sprotokółowaniem tego, co się działo. Takie opisy dostarczają materiału dla dwóch innych sposobów dochodzenia do prawdy historycznej, stanowiących zadanie z jednej strony uczonegomyśliciela, z drugiej zaś artysty-poety. Artysta ujmuje prawdę historyczną w obrazach najcharakterystyczniejszych; uczony przedstawia tę samą prawdę w abstrakcjach naukowych.

Jeżeli mowa 0 Żeromskim, to rzecz prosta, iż mamy tu do czynienia z prawdą artystycznie odtwarzaną. Przed nami pierwszorzędny mistrz, który rzeczywistość zagasłą odezuwa i odgaduje, który wskrzesza „popioły”, który domacał się tętna życia epok minionych, który z nieporównaną siłą wznieca w nas uczucia miotające duszami jego bohaterów, a kilku pociągnięciami pióra unaocznia prądy społeczne nurtujące w głębiach życia pokoleń, które od dawna zstąpiły do grobu.

A kto to wszystko potrafi, musi być pierwszorzędnym artystą. Zdawałoby się zaś, że im większy artysta, tym większa jego odpowiedzialność... przed społeczeństwem. Zgadzam się też na zdanie, iż Żeromski jest może najbardziej społecznym spośród wszystkich młodszych pisarzy polskich. Pamiętajmy jednak, że artysta, właśnie jako artysta, jako porywany niepohamowanym rozpędem tworzenia - chociażby był jak najbardziej „społecznym” - zna tylko jedną jedyną odpowiedzialność, odpowiedzialność estetyczną ${ }^{1}$.

Lew Tołstoj wypowiedział zdanie, że genialni wodzowie są wielką klęską ludzkości. Porwani pędem swego geniuszu militarnego idą

1 Co do opinii Baudouina o S. Żeromskim warto zobaczyć list do Wilhelma Feldmana z 15(28) IX 1904 r. [w:] J. N. B a u d o u in de C o u r t en a y, Listy..., s. 49-50. 
wciąż naprzód, na nic się nie oglądając, druzgocąc wszystko, co spotykają, niwecząc tysiące egzystencji ludzkich, podkopując dobrobyt, powstrzymując i cofając rozwój umysłowy i moralny. Ośmielam się twierdzić, że geniusz artystyczny może również wyrządzać szkody i spustoszenia, chociaż oczywiście w nierównie mniejszym stopniu aniżeli geniusz militarny. Tlejacy $w$ piersiach artystów ogien twórczy może ich zaślepiać na wszystkie inne potrzeby, na wszystkie inne strony życia psychiczno-społecznego. Hipnotyzowanie się obrazowaniem artystycznym pociąga za sobą bezwzględną jednostronność i niepoczytalność danego osobnika pod wszelkimi innymi względami. Artyzm porywa i ubezwzględnia twórcę, ubezwładniając jednocześnie jego krytycyzm w sferze myślenia logicznego i etyki. Przy pewnej dozie zboczenia moralnego otrzymujemy wtedy „artystę” Nerona, lubującego się pięknym widokiem pożaru, otrzymujemy maniaka i szaleńca, którego coś pcha do podłożenia lontu pod skład prochu, myśli on bowiem tylko o oczekiwanym wspaniałym widowisku, nie pytając wcale 0 skutki z innej sfery wyobrażeń. Podobnie jak człowiek „dziki”, tak również i bezwzględny impresjonista artystyczny nie poczuwa się do żadnej odpowiedzialności. On tylko „tworzy” lub „odtwarza”, wzbudza tak w sobie samym, jako też w czytelniku, słuchaczu i widzu pewien „nastrój”; każe wcielać się w „bohaterów”, przeżywać sytuacje. No a że tam przy tym to odtwarzanie „nastrojów”, to wcielanie się w rozbestwionych okrutników, w roznamiętnionych gwałcicieli itp. może rozspołeczniać, rozindywidualizowywać, o to się ani wielki artysta, ani też jego bezwzględny wielbiciel troszczyć nie potrzebują.

Sposób poznawania prawdy psychicznej i historycznej za pomocą artystycznego wzbudzania nastrojów i unaoczniającego sytuacje obrazowania najwszechstronniej porywa człowieka, każąc mu przeżywać to, co się działo, każąc mu ożywiać uczucia dawnych pokoleń i rozpalać w sobie samym dawno wygasłe wulkany namiętności i porywów. Naelektryzowany dreszczem tworzenia artystycznego, nawet najbardziej społeczny poeta zabarwia swe utwory tym, w czym - może nawet całkiem bezwiednie - lubuje się jego wyobraźnia. A nie ulega chyba żadnej wątpliwości, że znakomita większość tak genialnych, utalentowanych, zdolnych, jako też niegenialnych, nieutalentowanych i niezdolnych dwunogich samców, a nawet niekiedy i sa- 
mic, czuje nieprzeparty pociąg do bujania w sferze zmysłowości oraz „krwiożerczej lubieżności” czy też „lubieżnej krwiożerczości”.

\section{V}

Podobnie jak w dziedzinie porozumiewania się i obcowania językowego, tak też w dziedzinie obcowania artystycznego widzimy przede wszystkim dwa krańce, dwa bieguny: czynnego artystę i biernego odbiorcę wrażeń artystycznych (widza, słuchacza, czytelnika). Tak na jednym, jak na drugim krańcu trudną do osiągnięcia jest pobudliwość i wrażliwość jedynie artystyczna, z zupełnym nieodzywaniem się innych wzruszeń i dreszczów wywoływanych już przez samą psychofizyczną organizację człowieka.

Sam artysta tworzący dzieło sztuki wciela się prawdopodobnie w swoich „bohaterów”, odczuwa ich nastroje, doznaje przypisywanych im wzruszeń i namiętności. Nie mogę przypuścié, ażeby - czy to w zakresie sztuk plastycznych, czy też w zakresie twórczości poetycko-powieściopisarskiej - przy malowaniu scen krwiożerczo-lubieżnych była możliwą ich czysto artystyczna kontemplacja. Przeciwnie, zdaje mi się, że nawet uprzywilejowani wybrańcy muz, artyści i wieszeze, doświadezają w chwili tworzenia dreszczy okrutniczolubieżnych, a rozkoszując się odtwarzanymi przez siebie obrazami, grzebiąc zaciekle w tym, co rozpala wyobraźnię, wzbudzają nastrój odpowiedni nie tylko w czytelniku lub widzu, ale także w samych sobie. Pomimo to możliwym jest wypadek, że prawdziwi wirtuozi, grając na nerwach konsumenta ich wytworów, sami w chwili twórczości nie doznają żadnych wzruszeń tego rodzaju. Oni na zimno rozpalają wyobraźnię, rozstrajają nerwy, osłabiają wolę i - co za tym idzie - „demoralizują” i krzewia zdziczenie.

Uwagi powyższe są czysto ogólnego charakteru i nie mierzą specjalnie w żadnego pisarza. Co zaś do Żeromskiego, to jest on naturą zanadto głęboką, subtelną i współczującą, ażeby można go było posądzać 0 kreślenie na zimno płomiennych obrazów.

Na drugim krańcu obcowania artystyeznego staje człowiek zbiorowy, stają całe zastępy rozmaitego kalibru biernych konsumentów dzieł sztuki. Są to wszystko ludzie z nerwami, z wyobraźnią i z rozma- 
icie ustopniowanymi właściwościami fizjologicznymi i psychicznymi. Przy poddawaniu się wpływowi dzieł sztuk i wywoływaniu w sobie odpowiednich nastrojów i obrazów niepodobna chyba ograniczyé się samą tylko wyobraźnią estetyczną, boć przecie - jak już zauważyłem - ta wyobraźnia estetyczna pozostaje w ścisłym i nierozerwalnym związku z całym organizmem psychiczno-fizycznym człowieka.

Nie przeczę, że w całej tej masie zwykłych konsumentów pokarmu artystycznego może się znaleźć nieliczna garstka duchów wyższych, prawdziwych wybrańców losu i kapłanów sztuki bezwzględnej. Właściwe tym arystokratom ducha napięcie estetyczne może być tak potężne, że dostatecznie opancerza ich przed wpływami prądów nieestetycznych, towarzyszących wrażeniom estetycznym. Dla tej wykwintnej dziatwy Apollina jedynym hasłem jest i pozostaje: pereat mundus, fiat ars (niech zginie świat, byle się działa sztuka); podobnie jak fanatycy sprawiedliwości kierują się hasłem pereat mundus, fiat justitia (niech zginie świat, byle się działa sprawiedliwość). Tylko że to ostatnie można, zgodnie z wymaganiami prawdziwej sprawiedliwości, przekształcić na fiat justitia, ne pereat mundus (niechaj się dzieje sprawiedliwość, ażeby świat nie zaginął), gdy tymczasem podobne przekształcenie hasła fanatyków sztuki na fiat ars, ne pereat mundus jakoś dziwnie by wyglądało.

Ale podobni esteci z bożej łaski, ubezpłciowieni poniekąd świętym ogniem sztuki, należą do rzadkich wyjątków. Bo już o spotykanych nierównie częściej rozestetyzowanych i rozhisteryzowanych smakoszach sztuki, spożywających pokarm estetyezny nadziany erotyzmem i krwiożerczością, nie da się powiedzieć, iż doświadezają przy tym wrażeń jedynie estetycznych, bez skalania wyobraźni, bez zdenerwowania i bez rozstroju władz umysłowych. Przeważną zaś liczbę czytelników stanowią zastępy zwykłych śmiertelników płci obojga a rozmaitych wieków i o rozmaitej skali wrażliwości na podniety krwiożerczo-lubieżne. Ci szeregowcy rzeczypospolitej piśmienniczo-artystycznej - 0 ile nie są albo istotami od natury intelektualnie bezpłciowymi, albo też szambelanami sułtana i tradycyjnymi śpiewakami Kapelli Sykstyńskiej - posiadają przede wszystkim zwykłą wrażliwość psychiczno-fizjologiczną i przy odtwarzaniu scen erotycznych i lubieżno-krwiożerezych, napotykanych chociażby 
nawet w pierwszorzędnych arcydziełach sztuki i literatury, doznają nie tyle rozkoszy estetycznych, ile raczej odpowiednich owym scenom wrażeń oddziaływających szkodliwie na ich zdrowie i na ich stronę etyczną.

Artystę i estetę przekupuje i ubezwładnia świetność i genialność obrazowania właściwego danemu utworowi - na wpływ zaś fizjologiczny i psychiczny rozpłomieniający wyobraźnię, denerwujący, osłabiający wolę i odporność zamyka on oczy, uszy i wszystkie inne zmysły. Entuzjazm dla wielkich artystów i poetów robi z nich dla niejednego krytyka nietykalne bożyszcze i przeszkadza widzieć w nich jakąkolwiek skazę. Wszelka próba chłodnej krytyki, wszelka próba zastanowienia się i spojrzenia na dzieło czy też arcydzieło sztuki z innego, nie wyłącznie estetycznego, stanowiska, wydaje się entuzjaście świętokradztwem.

Nie należąc do entuzjastów, a za to cierpiąc na chroniczny brak estetyzmu, pozwalam sobie profanować zuchwale dzieła sztuki przez zastosowanie do nich miary higienicznej i etycznej.

\section{VI}

Nie wdając się weale w roztrząsanie kwestii, czy możliwą jest w ogóle, nawet u wybrańców muz, czysto artystyczna kontemplacja obrazów kapiących erotyzmem i krwiożerczością, bronię przed olśniewającym blaskiem artyzmu nie owych nielicznych arystokratów ducha, ale ogromne zastępy maluczkich duchem, do których w dziedzinie artyzmu sam zawsze należałem i należę.

Na maluczkich dzieło sztuki, jako dzieło sztuki, działa słabiej, ale za to wszechstronniej, tj. wywiera ono na nich wpływ nie tylko stroną artystyczną, ale - i to może przeważnie - wszelkimi innymi stronami fizjologiczno-psychicznymi.

Jednostronny artysta podpali miasto, ażeby się lubować wspaniałym widokiem pożaru; osobnik ubogi duchem pamięta przede wszystkim o nieszczęściach i łzach ludzkich, jakie ta uczta artystyczna wyciska. Niedościgły w swym estetyzmie kapłan sztuki rozkoszuje się bombardowaniem i szturmem twierdzy, gdyż dają mu one wielkie zadowolenie estetyczne; pogardzanemu przez estetów „filistrowi” 
przychodzi przede wszystkim na myśl związana z tymi widokami nędza ludzka, a to uniemożliwia mu wszelką rozkosz estetyczną.

I otóż ten sam „filister” pozwala sobie twierdzić, że odtwarzanie w sztuce obrazów „lubieżno-krwiożerczych”, chociażby nawet najwspanialsze i najartystyczniejsze, działa na ludzi zwykłych szkodliwie, gdyż tak czy inaczej oswaja ich z ohydą moralną. A im większy artysta, tym silniejsze wrażenie, tym potężniejszy wpływ.

Tak więc dla wielu bardzo czytelników z literatury tego rodzaju mogą powstawać pod względem higienicznym i etycznym dotkliwe szkody; albo popycha ona do odpowiednich czynów, osłabiając „wolę” i samokrytykę, albo w najlepszym razie opanowuje wyobraźnię i zużywa energię myślenia, odwracając je od analizy rozumowej, a zmuszając do niemej kontemplacji wszczepionych w duszę obrazów lubieżnych i krwiożerczych.

A jeżeli przeżywanie w wyobraźni scen krwiożerczo-lubieżnych oraz wcielanie się w „nastroje” bestii potwornych jest jadem i trucizną dla nerwów, i to jadem gorszym może od opajania się za pomocą opium, haszyszu lub gorzałki, jeżeli barwne szczegóły tego rodzaju mogą rozpalać i porywać w sferę erotyzmu i krwiożerczości wyobraźnię nawet ludzi starszych - nie mówiąc już o młodzieży, o podrostkach i podlotkach - to mam chyba prawo, nie pociągając wcale wielkiego artysty do jakiejkolwiek bądź odpowiedzialności, zastanowić się przynajmniej uważnie i zanalizować wszechstronny wpływ jego utworów.

Napoleonowie i inni „twórcy dziejów powszechnych” urządzają rzezie i orgie żołdactwa w rzeczywistości, a panowie powieściopisarze w fantazji. Skutek jednakże jest ten sam: i tu, i tam - zdziczenie bądź to przemijające i chwilowe, bądź też stopniowo się utrwalające. Przecież na stronę psychiczną człowieka nawet rzeczywistość działa tylko o tyle, o ile ją sobie wyobrażamy. Czy kto sam widział, jak rozpruwają brzuchy, gniotą klatki piersiowe, odrzynają piersi kobiece, duszą, wieszają, kłują bagnetami, gwałcą itd., itd., czy też tylko czytał plastyczne opisy tych wszystkich „czynów bohaterskich”, prawie na jedno wychodzi. Człowiek wciela się chwilowo w okrutnika, we wściekłą bestię, we wszetecznika, w gwałciciela, jednym słowem w „bohatera” znęcającego się i tępiącego, odczuwa z nim razem, upla- 
stycznia sobie jego czyny i uczucia, a to z konieczności pozostawia ślad i usposabia do odtwarzania za pomocą wyobraźni tych samych wrażeń i obrazów. Powtarzanie wrażeń potęguje je, a drogi nerwowe, drogi psychofizyczne, po których przebiegają odpowiednie prądy wrażliwości dośrodkowej oraz wyładowują się w kierunku odśrodkowym chuci i namiętności, wydoskonalają się; następnie wskutek ścisłego związku wyobraźni ze stroną fizjologiczną pewnych funkcji życiowych potężnieją objawy osłabiające organizm, przeciwdziałanie tym objawom ze strony świadomości coraz bardziej słabnie, słabnie też i niedołężnieje tak zwana wola, a w ostatecznym rezultacie preparowany w ten sposób osobnik, przynajmniej w danym zakresie życia psychofizycznego, dziczeje.

Jeżeli podobnym wpływom rozkładowym ulega jednostka nieco podnioślejszego umysłu i z dążeniami wyższymi, idealnymi, pociąga to za sobą rozterkę duchową i rozdwojenie, a w razie ich poprzedniego istnienia znakomicie je wzmacnia i poteguje. Wiem, że to ohydne, niesprawiedliwe, nikczemne, potępiam to, walczę całą siłą rozumowania i poczucia sprawiedliwości, właściwego człowiekowi oświeconemu i logicznie myślącemu, a pomimo to wyobraźnia i nerwy ciągną mię w inną stronę, pchają po równi pochyłej, dopóki nie stoczę się na dno, a ocucenie się na dnie staje się powodem „wyrzutów sumienia" i zgryzot, czasami wprost nie do zniesienia. Toteż natury wyższe i szlachetniejsze, a ze słabą wolą, nie mogąc znieść podobnej rozterki wewnętrznej, kończą niekiedy samobójstwem.

Istnieją ludzie czy to do tyla naiwni, czy też tak optymistycznie usposobieni, że im się zdaje, iż artystyczne obrazy okrucieństw wojny powinny odstraszać, odstręczać i obrzydzać wojnę, a malowanie scen lubieżnych napawać wstrętem do dzikiego erotyzmu. A więc pokazywanie obrazków pornograficznych, przechowywanych w tak zwanym piekle (enfer) Biblioteki Nacjonalnej w Paryżu, powinno być najlepszym środkiem pedagogicznym do podtrzymywania skromności wychowańców i napełniania ich wstrętem do wszelkiego rodzaju wszeteczeństw. A może dla tym skuteczniejszego oddziaływania i dla 
wzbudzania tym większego wstrętu należałoby pokazywać sceny z życia rzeczywistego: „patrz kochanku, jakie to szkaradne i ohydne”. „Tak, istotnie, bardzo to może ohydne, ale ja jednak oczu od tego oderwać nie mogę, ale mię to rozpala, roznamiętnia i ciągnie ku sobie”.

A zresztą przypatrzmy się z różnych stron odnośnej psychologii.

Czyż można uważać widowisko walki byków za środek odstręczający od znęcania się nad zwierzętami? Przecież jest to jedna z najulubieńszych zabaw szlachetnego narodu hiszpańskiego, nie tylko zwykłego motłochu, ale także elity towarzyskiej, elity tak pod względem umysłowości, jako też pod względem stanowiska zajmowanego w hierarchii społecznej. Niechby tylko rząd hiszpański zabronił tego narodowego igrzyska, a z pewnością wybuchłaby ogólna rewolucja, bo te krwiożercze bestie Półwyspu Iberyjskiego muszą paść oczy widokiem koni z rozpłatanymi brzuchami i byków torturowanych z subtelnością i wyrafinowaniem.

Cyrki rzymskie, w których przelewano krew i męczono nie tylko zwierzęta, ale także ludzi, jako też torturowania heretyków przez obrońców kościoła wojującego, chyba nie rozwijały w widzach współczucia dla cierpień bliźniego i nie oddalały ich od stanu dzikości.

A jakąż jest psychologia jatek ludzkich zwanych wojną? Ten, kto sam brał udział choćby tylko w jednej bitwie, a tym bardziej w kilku bitwach, nie zraża się wcale do „rycerskiego rzemiosła”, ale przeciwnie, zaprawia się w nim, hartuje się i zżywa się z legalnym mordowaniem „bliźnich” i z innymi okrucieństwy „prawem dozwolonymi”. Tylko na wyjątkowe jednostki wojna działa odstraszająco. A z jakąż to chciwością czytamy my, „inteligenci”, opisy bitew w ogóle, a cóż dopiero opisy bitew artystyczne i wspaniałe, niedaleko szukając, opisy bitew choćby w Popiotach Żeromskiego!

A skromny wykonawca sprawiedliwości "słusznie zwany” katem, przecież jeżeli nie jest złoczyńcą z „bożej łaski”, chybać w początkach swego szlachetnego zawodu tylko z pewnym wstrętem i obrzydzeniem oddziela głowy od kadłubów, zakłada stryczek na szyję i w ogóle dokonywa różnych operacji nad ludzkimi ciałami, oddanymi na ofiare „bogu sprawiedliwości”. Nie tylko zresztą kat; nie ulega wątpliwości, że nawet rzeźnik, niebędący okrutnikiem z urodzenia, 
doświadcza z początku podobnych uczuć co i kat. Później jednak obaj zespalają się ze swym rzemiosłem i wykonywają je z zadowoleniem i „przekonaniem”. Powtarzanie wrażeń związanych ze spełnianiem „obowiązków” swego zawodu obudza i potęguje drzemiące w duszach tych funkcjonariuszów dzikie instynkta, odziedziczone po odległych przodkach.

Sędziemu podpisującemu po raz pierwszy wyrok śmierci zadrga z pewnością ręka, jeżeli oczywiście nie jest okrutnikiem i krwiożercą z natury; ale później, po pewnym czasie, idzie mu to jak z płatka. Ce n'est que le premier pas qui coute.

Podobnie oswaja się ze zbrodniami ten, kto sam ich nie wykonywa, ale tylko bierze w nich udział przez imaginację, tj. kto wciela się wyobraźnią w „bohaterów” zbrodni, uplastycznianych ręką artysty lub poety.

Oczywiście tedy malowanie artystyczne zbrodni nikogo od niej nie odstręcza, podobnie jak nie odstręcza od niej widowisko realne czynów zbrodniczych. Co więcej, dziś chyba tylko bezdenna naiwność lub też zakorzeniałe doktrynerstwo przypuszezają jeszcze, że może odstraszać od zbrodni widok lub też opis artystyezny kary, za „zbrodnię" ponoszonej.

Lat temu trzydzieści mniej więcej, podezas wielkiego jarmarku w Niżnim Nowgorodzie, grasowały tam w sposób zatrważający rzezimieszki. Ówczesny jenerat-gubernator Niżnego Nowgorodu, Baranow, chcąc wykorzenić to zło, zaprowadził stan wojenny i oddawał schwytanych na gorącym uczynku rzezimieszków pod sąd wojenny, który, „ze względu na bezpieczeństwo publiczne” i „dla przykładu”, skazywał podsądnych na śmieré. Wyrok wykonywano, nie zwlekając; rzezimieszka wieszano lub też rozstrzeliwano, a po świeżym jego grobie, tuż na miejscu kaźni wykopanym i mieszczącym zwłoki pacjenta, przechodziło wojsko z muzyką i z wesołymi pieśniami. Było to obliczone oczywiście na odstraszanie rzezimieszków. Ale jak na to odpowiadali sami rzezimieszkowie? Oto na to bezpłatne a pikantne widowisko zbierała się masa niezliczona gawiedzi wszelkich stanów i stopni rozwoju umysłowego, a zapatrzona w procedure ,,wykonywania sprawiedliwości" nie spostrzegała, jak koledzy wieszanego lub też rozstrzeliwanego opróżniali jej kieszenie. Chwila wykonywania 
kary za „Zbrodnię” dawała najlepszą sposobność do popełniania „zbrodni” w spotęgowanych rozmiarach.

Podobne widowiska czynów lubieżnych i okrutnych, a więc rozmaitych „zbrodni”, rozmaitych „aktów sprawiedliwości i zadosyćuczynienia”, rozmaitych wybuchów zemsty, nienawiści i „miłości”, roztaczają przed naszymi oczyma nasi zdolni, utalentowani, może nawet „genialni” powieściopisarze. Jakie to plastyczne! Jakim to „drga życiem i prawdą"! Istotnie, drga to życiem i prawdą, chociażby tylko prawdą artystyczną, aleć jeszcze większym życiem i prawdą drgaja czy to widoki prawdziwych okrucieństw, czy też sceny brutalnie erotyczne, pokazywane podobno za pieniądze miłośnikom „przyrody żywej” i „prawdy realnej” w umyślnie w tym celu urządzanych zakładach niektórych stolic europejskich. Na wyobraźnię obie „prawdy”, tak „prawda życiowa”, jako też „prawda artystyczna”, działają prawie jednakowo.

Doskonałą ilustrację potęgi „nastroju”, pchającego do odpowiednich czynów, podały niegdyś „Fliegende Blätter”. Nauczyciel elementarny, poważny $i$ doświadczony pedagog, oćwiczył niemiłosiernie jednego z wychowańców za jakąś drobną swawolę. Ochłonąwszy z oburzenia, poczuł zgryzoty sumienia i postanowił przeprosić publicznie, w obecności całej klasy, niesprawiedliwie „ukaranego” malca. Na drugi dzień tedy wrócił się doń z odpowiednią przemową i zaczął wykładać przebieg sprawy w porządku chronologicznym. Kiedy zaś doszedł do opisu swawoli, która go tak wczoraj oburzyła, wpadł w ten sam „nastrój” wojowniczy i przy słowach dokazywateś, swawoliteś, byteś niepostuszny schwycił powtórnie biednego delikwenta i powtórnie wymierzył mu plagi, zapomniawszy zupełnie o swym szlachetnym postanowieniu. Podobnie dzieje się nieraz z opisującymi szczegółowo swoje „grzechy” w celu pokuty i zadosyćuczynienia. „Nastrój” odpowiedni może opanować tak spowiadającego się, jak i spowiednika.

I oto we wspaniałej powieści historycznej w wyższym stylu mamy przed sobą spowiedź powszechną człowieka zbiorowego, spowiedź, która powinna by wywołać tylko żal za grzechy i szczere postanowienie więcej niegrzeszenia. Ale że spowiedzi tej towarzyszy wskrzeszanie obrazów „grzechu” w całej ich okrutnej i porywającej 
świetności, więc ta iskra genialnej twórczości dostaje się do zbiornika materiałów wybuchowych natury ludzkiej.

Jest to smutna a nieunikniona fatalność bezwzględnej twórczości artystycznej. Nieraz powtarzano zdanie, oparte na całym szeregu spostrzeżeń, że poeta i artysta w ogóle przypomina pod wielu względami człowieka „dzikiego”. Nie dziw więc, że jego twórczość może współdziałać zdziczeniu.

W porywających prawdą artystyczną utworach pierwszorzędnego pisarza mogą byé sceny i obrazy tak dzikie i wstrząsające, do tego stopnia brudzące i kalające wyobraźnię, tak wysoce denerwujące, tak potężnie oddziaływające nawet pod względem fizjologicznym, do tego stopnia z jednej strony osłabiające wolę, z drugiej zaś wydoskonalające drogi prądów lubieżno-krwiożerczych, że trzeba je uważać za wielką krzywdę wyrządzoną spokojowi i zdrowiu nie tylko psychicznemu, ale także fizycznemu, czytelników.

Dotyczy to zwłaszcza powieści drukowanych kawałkami w dziennikach i tygodnikach. Czytelnik narzuca się na urywek pomieszczony w tylko co otrzymanym numerze, czyta go z zapartym oddechem, pochłania od jednego rozmachu i doświadcza... No, to już zależy od treści świetnych obrazów, w które wypada mu się wpatrywać. Jeżeli będą to obrazy, np. ze zdobywania Saragossy, to czytelnik, a może nawet i czytelniczka, doświadczy skutków bardzo niepożądanych, oczywiście niepożądanych tylko w takim razie, jeżeli przywiązujemy jakiekolwiek znaczenie do równowagi umysłowej, do spokoju, do zdrowia, do czystości wyobraźni.

Zwracając uwagę na te poboczne skutki bezwzględnej „prawdy artystycznej” u bieguna odbiorczego 0 tańcuchu obcowania literacko-artystycznego, nie uwłaczam bynajmniej ani potędze twórczej Żeromskiego i jemu podobnych, ani też ich zasługom obywatelskim na innych polach.

\section{VIII}

Oswobodziwszy się od hipnotyzującego uroku poezji, stosując do utworu artystyeznego pedantyczne wymagania trzeźwej krytyki historycznej, mamy prawo zapytać: 
Co oprócz rozkiełznanej i rozwydrzonej wyobraźni upoważnia panów powieściopisarzy do roztaczania przed czytelnikami tych wszystkich szczegółów rzezi i pastwienia się, z dokładnym umiejscowieniem, z nazwami ulic, domów, klasztorów itd.? Czy mają na to jakie wiarogodne dane? Z jakiego źródła czerpią materiał dla swych urojeń artystycznych? Czy opisano gdziekolwiek te wszystkie poszczególne rozpruwania brzuchów, wyrzucania starszych kobiet przez okno, a poniewierania młodszych, itd. itd.? Czy którykolwiek ze zbydlęconych uczestników tych orgii i rozpasania mógł zapamiętać szczegóły dokonanych „czynów bohaterskich” ze ścisłością konieczną do tego, ażeby opierać na nich wiarogodną, chociażby nawet całkiem wymyśloną i wysoce artystyczną opowieść?

W kalejdoskopie szczegółów ohydnej rzezi Saragossy dostrzegamy jedynie prawdopodobieństwo, a prawdopodobieństwo nie daje nikomu, a więc nawet najgenialniejszemu artyście, prawa do zanieczyszczania wyobraźni czytelników. A zresztą nawet najzupełniejsza prawdziwość faktyczna tego rodzaju szczegółów upoważniałaby jedynie do ściśle opisowego ich zestawienia i do czynienia na tej podstawie wniosków naukowych: psychicznych, psychiatrycznych, socjologicznych itd. Od nadużywania zaś podobnego materiału do mimowolnego krzewienia zdziczenia wara panom powieściopisarzom, chociażby nawet najpierwszorzędniejszym.

Taki np. autor Popiotów całą potega swego niepospolitego talentu wymyśla długą litanię okropności, od których włosy na głowie powstają, gwoli estetyce gromadzi je i grupuje w odpowiedni sposób, wzbudzając przez to albo w samym sobie i w czytelniku, albo też tylko w czytelniku nastrój lubieżno-krwiożerczy o bardzo wysokim napięciu.

Inaczej traktował swe zadanie artystyczne w stosunku do okropności wojny nowelista rosyjski Garszyn. Jego twórczość w tej dziedzinie istotnie otrzeźwia ludzi marzących 0 „bohaterstwach” i 0 „umieraniu za ojczyznę”, a otrzeźwia bez wzbudzania „nastrojów” niepożądanych. Estetyzm może na tym traci, ale korzyści etyczne pozwalają z lichwą powetować tę stratę. Jest to wprawdzie pogardzane przez estetów zanieczyszczanie sztuki obcymi jej tendencjami, ale ja pomimo to pozwalam sobie przyznać się otwarcie do tej herezji. 
Autor Popiotów z właściwym sobie mistrzostwem kreśli wspaniałe obrazy „czynów bohaterskich”, dokonywanych przez hordy najezdnicze w Hiszpanii, hordy, między którymi były także zastępy „obrońców ojczyzny” i „obrońców wolności” znad Wisły, Niemna i Warty. Ci „obrońcy ojczyzny” ćwiartowali i miażdżyli Hiszpanów, również „broniących ojezyzny”. Ci „obrońcy wolności” nie tylko dusili wolność obywatelską mieszkańców Półwyspu Pirenejskiego, ale poniewierali w najbezecniejszy sposób najelementarniejszą godnośé ludzką tamtejszych mężczyzn i kobiet. Wszystko to wyziera z obrazów Żeromskiego z przerażającą jasnością. A stąd przy odrobinie logiki i dobrej woli otrzymujemy między innymi następujące wnioski:

1. że wielki wódz tych hord umundurowanych, ów opiewany przez Mickiewicza i tylu innych poetów bóg wojny, ów bohater legendarny, ów Napoleon Wielki, przemieniając tysiące ludzi w krwiożercze i wszeteczne bestie, w młoty druzgocące „bliźnich” na miazgę, był zbrodniarzem w n-tej potędze i potworem moralnym, tak samo jak i inni jemu podobni kanibale i niszczyciele;

2. że „wojsko polskie” było zdolne do takich samych „czynów bohaterskich”, jak i wszelkie inne „wojsko” pod każdym stopniem szerokości i długości geograficznej;

3. że nie należy znów tak bardzo oburzać się na rozmaite „rzezie” przysłowiowe, jeżeli właśni „rodacy” i przedstawiciele de la grrrande nation urządzali daleko okropniejszą rzeź Saragossy;

4. że mamy nierównie mniejsze prawo do potępiania Turków znęcających się nad mężczyznami, kobietami i dziećmi Macedonii, jeżeli szanowni „rodacy” w jeszeze bezecniejszy sposób postępowali z mężczyznami, kobietami i dziećmi Hiszpanii;

5. jednym słowem, że wszelka wojna eksterminacyjna, chociażby nawet prowadzona przez własne rodzone wojsko, może wzbudzać tylko grozę, wstręt i obrzydzenie.

Że jednak powstawaniu w głowie podobnych wniosków towarzyszy skalanie wyobraźni, wywoływanie dzikiego nastroju krwiożerczo-lubieżnego i w ogóle cofnięcie się człowieczeństwa do stanu przedludzkiego, więc owe wnioski otrzeźwiające zbyt drogo są opłacane. 
A zresztą sama fatalność twórczości artystycznej przeszkadza utrwalaniu się podobnych wniosków. Nie można powiedzieć, że autor nie uświadamia sobie tych konsekwencji logicznych. Być może, iż nawet zgodzitby się na nie. Ale jako powieściopisarz-poeta traktuje on swoje zadanie wyłącznie artystycznie. Pod imponującym wpływem wspaniałych i uroczych obrazów „bohaterstwa” na polu walki i odezuwania „podniosłych nastrojów” owe ujemne wnioski i refleksje etyczno-polityczne powlekają się mgłą i prawie znikają bez śladu. A choćby nawet ślad z nich pozostał, to jednak nie ośmielamy się wypowiadać je jasno i otwarcie, bo przede wszystkim stoi temu na przeszkodzie mimowiedne i mimowolne apoteozowanie wojny i jej „boga”.

\section{X}

Gdyby ktoś sprotokółował sucho i urzędowo opisywane w Popiotach „czyny bohaterskie” wojska polskiego i francuskiego, gdyby nazywał wszystko po imieniu, gdyby nawet używał brutalnych nazw dokonywanych przez zdobywców czynności fizjologicznych, to tym swoim suchym i bezbarwnym opisem wielu by odstręczyl, a mógtby działać podniecająco tylko na nieliczną garstkę $\mathrm{i}$ to zapewne w bardzo słabym stopniu. Jednakże przeciwko podobnemu traktowaniu tematu protestowalibyśmy energicznie; my bowiem pragniemy przy tym użycia wszystkich świetnych barw, jakimi rozporządza twórcza wyobraźnia artysty, i roztaczania przed czytelnikiem opisu, wspaniałego i rozpalającego... no, a że jednocześnie denerwującego i szkodliwego dla zdrowia wielu maluczkich, to już mniejsza z tym.

Nazywanie rzeczy po imieniu bywa często poczytywane za grzech i wykroczenie przeciw przyzwoitości. Przecież właściwa pewnym mężom uczonym „skromność” każe im wyrzucać wstydliwie ze słowników wszelkie „wyrazy nieprzyzwoite”. Przecież w towarzystwie osób „dobrze wychowanych” nie mówi się weale ani 0 spodniach, ani 0 świniach, ani 0 bykach i ogierach. Jeżeli jednak przychodzi pierwszorzędny powieściopisarz i z całą siłą swego talentu roztacza przed wami wspaniałe i drgające życiem obrazy, wobec których bledną nie tylko spodnie, nie tylko świnie, nie tylko byki i ogiery, ale nawet wszelkie wyrazy jak „najnieprzyzwoitsze”, to wszystko jest w porządku i niko- 
go nie razi. A przecież jest to sfera wyobrażeń, w której nawet mniej utalentowany może „porywać” i wywoływać „nastrój”, a cóż dopiero mówić o koryfeuszach literatury opowiadawczej!

\section{XI}

Zapewne nie wszystkim wiadomo, że tak zwane nieprzyzwoite objawy twórczości ludowej, tj. piosnki wszeteczne, bajki, zagadki, przysłowia itp., w których bądź to wchodzą w grę pewne ukryte części ciała, bądź też znajduje upust brutalny erotyzm bez obsłonek, bywają zapisywane i wydawane pt. Kryptadia ${ }^{1}$ w osobnych zbiorach z egzemplarzami numerowanymi dla amatorów i badaczów psychiki i twórczości ludowej. Otóż ja nie miałbym nic przeciwko temu, ażeby pewne części utworów powieściowych, w których ich autorowie z wielką siłą i mistrzostwem kreślą obrazy z dziedziny wyładowującego się erotyzmu, w związku z napiętą do ostatecznych granic krwiożerczością drukowano osobno, w egzemplarzach numerowanych, jako nadzwyczaj cenny materiał dla psychologów, dla psychiatrów, dla estetyków i historyków literatury. Oczywiście i ci badacze musieliby zżyć się do tyla z odbieranymi wrażeniami podniecającymi, ażeby być w stanie traktować je obiektywnie i analizować je z całym spokojem i rozwagą. Wprawdzie odpadłaby wtedy zwykła utylizacja ekonomiczna tego rodzaju twórczości, jak również odpadłoby parę listków z wieńca sławy oplatającego skronie powieściopisarza. W każdym jednak razie, jeżeli stosunkowo niewinne piosnki figuruja w Kryptadiach literatury ludowej, to pewne sceny i obrazy z utworów powieściopisarzy i beletrystów mogłyby być prawdziwą ozdobą Kryptadiów literatury narodowej i wszechświatowej.

Zgoda zresztą na pozostawianie ustępów wzbudzających nastrój lubieżno-krwiożerczy w wydaniach książkowych danej powieści. Przy

1 Periodyk wydawany w Paryżu, w którym publikowano teksty folklorystyczne, niekoniecznie cenzuralne. Baudouin de Courtenay zamieścił w IV tomie tego periodyku (Paris 1898) pt. Folklore slave de la vallée de Resia en Italia, province Udine, district Moggio, a la fronetire l'Autriche zbiór utworów rezjańskich, a w tomie V (Paris 1898) Folklore polonaise - 102 śpiewki i 22 zagadki ludu polskiego. 
czytaniu książki wrażenie jednostronne od podobnych ustępów zaciera się poniekąd przez wpływ tego, co je poprzedza i co po nich następuje. Ale jeżeli jeden, dwa, trzy... numera gazety lub tygodnika są zapełnione wyłącznie takimi ustępami z drukującej się powieści, jeżeli odebrane w ten sposób wrażenia dają materiał do przeżuwania myślą w ciągu całych tygodni, to to, według mego zdania, równa się zamachowi na zdrowie i spokój czytelników. A ile to w tym obłudy, jeżeli podobną metodę praktykuje czasopismo „prawowierne”, chcące uchodzić za „czytelnię domową i rodzinną”! No, ale pamiętajmy przecież, że tak tu, jak i gdzie indziej, rozstrzygają przede wszystkim względy ekonomiczne. A trudno przecież wymagać, ażeby względy egoistyczno-pieniężne ustępowały przed względami altruistyczno-społecznymi. I chociaż fanatyczni zwolennicy absolutnej wolności sztuki protestują przeciwko jej krępowaniu i zanieczyszczaniu utylitaryzmem i tendencyjnością, to jednak okazuje się, że ten właśnie najzwyklejszy utylitaryzm bywa z konieczności decydującym czynnikiem w urzeczywistnianiu twórczości literackiej i artystycznej i jej uprzystępnianiu czytelnikom przeważnej liczby wydawnictw periodycznych.

$$
* * *
$$

Wypisując te, niestety, arcynieudolne rozpamiętywania, nie powoduję się wcale pruderią (pruderia bowiem jest mi całkiem obcą), nie nawołuje do ascezy. Przeciwnie, jestem tego zdania, że asceza religijna, czyli ascetyzm pochodzi z tego samego źródła psychicznego, co erotyzm i krwiożerczość. Ja tylko konstatuję, że „literatura” czy też „sztuka” (co kto woli) może iść ręka w rękę z pewnymi instytucjami związanymi z życiem stadowym ludzi i do spółki z tymi instytucjami krzewić zdziczenie lub też tylko kontynuować pierwotną, wrodzoną dzikość ludzkości.

Wniosków praktycznych nie wyciągam żadnych i na nikogo nie chcę oddziaływać, ale tylko, stwierdzając fakt niezaprzeczony, zapytuję:

Na co się zda cała walka z onanizmem, z wyuzdaniem młodzieży i staruszków, z prostytucją, z zamachami na cześć kobiecą, jeżeli rozwielmożniona poezja i beletrystyka, wchłaniana gorączkowo a roz- 
palająca wyobraźnię i podniecająca nerwy, pcha do tego wszystkiego z całą siłą i rozpędem nieuniknionej fatalności i... krzewi zdziczenie?

Streszczam swój pogląd na wpływ literatury i sztuki lubieżnokrwiożerczej, na usposobienie i bezwiedne, mimowolne myślenie ludzi czytających i oglądających.

Przedstawianie halucynacji artystycznych z zakresu erotyki daleko posuniętej oraz z zakresu namacalnych objawów „miłości bliźniego" bądź to za pomocą środków sztuki plastycznej, bądź też przez ujmowanie ich w obrazach wzbudzanych dzięki procesowi skojarzeń, czyli asocjacji językowych, wywołuje częstokroć takie samo, a niekiedy nawet 0 wiele potężniejsze wrażenie aniżeli sam widok zdarzeń i scen rzeczywistych. Wpływ dzieła czy też arcydzieła prawdziwego artysty może być daleko skuteczniejszy aniżeli wpływ z jednej strony nagiej natury, z drugiej zaś, grubej pornografii lub też suchego opowiadania 0 czynach ludożerczych i morderczych. Gruba pornografia i suche opowiadanie mogą odpychać swą brutalnością i nagością i budzić wstręt w istotach subtelniejszych, czulszych i wrażliwszych.

Dreszcz nerwowy, upojenie i w ogóle „nastrój” wywoływany dziełami sztuki poruszającej tego rodzaju tematy bardzo jest podobny do upojenia i „nastroju” wzbudzanego za pomocą alkoholu, opium, haszyszu itd.

Czy zaś upijamy się „siwuchą” w rynsztoku lub szynku, czy też szampanem w wykwintnym otoczeniu, to zupełnie wszystko jedno. Stopień upojenia zależy od ilości pochłoniętego alkoholu. A nawet pozwalam sobie twierdzić, że na ogół szampan jest 0 wiele szkodliwszy aniżeli prosta gorzałka. Szampan ma pewien urok „poetyczny”, pociąga ku sobie nawet dusze „wyższe” i „podniosłe”. Szampanem chętnie upijają się nawet wykwintne damy, wystrojone i od zewnątrz, i od wewnątrz z nieskazitelną wytwornością, te same damy, które od szynku i rynsztoku odwrócą się ze wstrętem, obrzydzeniem i pogardą.

A to, co ma urok, co wprawia w błogostan i „nerwy”, i „dusze”, to również pociąga ku sobie z taką niepowstrzymaną siłą, że nie jest 
mu w stanie przeciwdziałać chociażby najgłębsze i najnaukowiej uzasadnione przekonanie o jego bezwzględnej szkodliwości. Wiadomo przecież, że niektórzy lekarze doskonale zaznajomieni ze zgubnym wpływem środków podbudzających, nie tylko że palą namiętnie, upijają się itd., ale także morfinizują się, przygotowując sobie przedwczesne stępienie umysłu, przedwczesną starość i przedwczesną śmierć. Wiadomo również, że wielu uczonych i ludzi „wyższych umysłowo", pomimo głębokiego przekonania 0 niesprawiedliwości społecznej i nieetyczności tak zwanej rozpusty, uprawiają jednak ten sport z wielką gorliwością, a pędzi ich ku temu pewnego rodzaju ciekawość i żądza odnawiania rozkosznych wrażeń i „nastrojów”. I w ogóle potrzeba powtarzania wrażeń lubieżno-krwiożerczych jest potężnym czynnikiem społecznym, a raczej przeciwspołecznym, czynnikiem współdziałającym bujnemu rozkwitowi i rozpanoszeniu się zdekadencenia zezgniłoszenia i zdziczenia. Stąd to między nami tylu dzikich, za nic niebędących wstanie oprzeć się choćby najlżejszemu pociągowi do odtwarzania w sobie w ten lub ów sposób wrażeń i „nastrojów” wprawdzie przyjemnych, ale zgubnych i niszczących organizm psychofizyczny człowieka.

Wydaje się z pewnością niejednemu wielkim zuchwalstwem, że ja, zwykły karzeł i pigmej, pozwalam sobie porywać się na olbrzymów literatury, poezji i sztuki, pomawiając ich o zgubny wpływ na czytelników i widzów. Istotnie zgrzeszyłem; biję się więc pokornie w piersi, powtarzam „moja wina, moja wina, moja bardzo wielka wina” i zapytuję:

Czyż wobec wspaniałości i imponującej piękności pożaru nie powinny się wydać karlimi i ze stanowiska „estetyki” wysoce nagannymi wszelkie usiłowania skierowane ku jego tłumieniu?

Czyż wobec olbrzymiego wrażenia i poetycznej soczystości powodzi należy zaniechać karlich wysiłków, dążących do stawiania jej tam, a nawet do jej absolutnego uniemożliwienia?

A nareszcie, czyż nie napełniają nas „estetyczną” zgrozą i czyż nie dają nam wielkiego zadowolenia „estetycznego” masowe rzezie 
ścierania się tłumów z tłumami, wybuch lawy nienawiści międzystadowej z „wulkanów społecznych”? I czyż zadowolenie estetyczne od podobnych zjawisk powinno nam wystarczyć, czyż powinniśmy dać sobie pokój i wyrzec się wszelkich prób oddziaływania na jednostki w celu uniemożliwienia albo przynajmniej znacznego osłabienia tych „majestatycznych objawów” gromadnie urzeczywistnianej „miłości bliźniego"?

Petersburg, grudzień 1903.

[Kraków 1905] 


\section{Z POWODU JUBILEUSZU PROFESORA DUCHIŃSKIEGO}

Uwagi moje z powodu jubileuszu prof. Duchińskiego były napisane pierwotnie na wyraźną prośbę redaktora „Kraju” ${ }^{1}$ i naturalnie przeznaczone dla tego czasopisma. Jak się później okazało, mogły one zostać tam wydrukowane, ze względów miejscowych, tylko ze znacznymi i psującymi ogólne wrażenie skróceniami i zmianami. Nie mając zwyczaju wchodzić w kompromisa podobnego rodzaju, wolałem odstąpić od pierwotnego zamiaru. Żal mi jednak było wrzucać do kosza rękopism będący owocem pewnego namysłu i wyrazem moich przekonań, które może znajdą oddźwięk w umysłach i sumieniach, podobnie jak moje uorganizowanych.

W czasach, kiedy zbrodnie osobiste i zbiorowe, przy akompaniamencie niesłychanego bezwstydu, daleko buńczuczniej niż zwykle rozpierają się na podścielisku z głupoty i nikczemności ludzkiej, nawet najcierpliwszy i najspokojniejszy człowiek, w którym tleje jeszcze choćby iskierka uczucia sprawiedliwości i moralności, czuje w sobie taki nadmiar żółci, że mimowolnie rodzi się w nim pragnienie ulania na zewnątrz tego słodkiego płynu.

Sam prof. Duchiński i jego jubileusz byli dla mnie jedynie punktem wyjścia, dając mi sposobność wypowiedzenia bez ogródki kilku zdań o niektórych małych i wielkich znikomościach świata tego.

Dorpat, (10) 22 lutego $1886 \mathrm{r}$.

Usprawiedliwienie się z wystąpienia w tej sprawie. Jubileusz familijno-przyjacielski i jubileusz społeezno-narodowy. Zasługi uezonego i polityka. Twierdzenia prof. Duchińskiego. Dowody tyeh twierdzeń. Sposób dowodzenia. Zupełny brak pewnych niezbędnych pojęé ogólnyeh. Wrodzona aryjskośé

1 „Kraj”, polski tygodnik wydawany przez Erazma Piltza i Włodzimierza Spasowicza w Petersburgu od roku 1882. Pismo co do swego profilu mieściło się między poglądami konserwatywnymi a hasłami pozytywistycznymi, z jednej strony optując za rezygnacją z myśli o wolnym państwie polskim, jednak przy hasłach rozszerzania swobód obywatelskich w zaborze rosyjskim, z drugiej głosząc poglądy o konieczności zbliżenia z liberalnymi kręgami rosyjskimi. W sprawach światopoglądowych i społecznych linia pisma była demokratyczna. 
i wrodzony turanizm. Miłość wszecharyjska. Dwie moralności. 0 ile wpływ ,teorii” p. Duchińskiego był pożytecznym lub też szkodliwym. Wpływ na umysłowość. Wpływ moralny. Wpływ na przekonania polityczne i na postępowanie pewnej ezęści narodu. Skutki porywania się z motyką na słońce. Usprawiedliwienie p. Duchińskiego. Wniosek ostateczny o znaczeniu jubileuszu.

Z wielką obawą spełniam prośbę redaktora „Kraju” o zabranie głosu w sprawie jubileuszu profesora Duchińskiego. Obawa moja jest bardzo zrozumiałą. Każdy bowiem czytelnik może zapytać, dlaczego się biorę nie do swoich rzeczy. Ani to moja specjalność, ani też nie zostałem wybrany przez nikogo do przemawiania w jego imieniu. Druga część zarzutu mogę odeprzeć uwagą, że niekoniecznie trzeba być wybranym, ażeby przemawiać w czyimś imieniu. Co się zaś mnie tyczy, to nie mam zupełnie pretensji do odzywania się czy to „w imieniu narodu”, czy też w imieniu choćby nawet najmniejszej garstki ludzi, ale tylko występuję od siebie samego, wypowiadając jedynie swoje własne osobiste przekonania. Czy kto je podziela, czy też nie, jest dla mnie najzupełniej obojętnym. Co się zaś tyczy mojej niekompetencji, to rzeczywiście tego rodzaju kwestiami etnograficznymi specjalnie się nie zajmowałem. Pomimo to, jako lingwista, miałem z nimi niejednokrotnie do czynienia i nie uważam się w ich zakresie za zupełnego profana. Że zaś nie mam weale zamiaru pisać gruntownej i wyczerpującej rozprawy o pracach naukowych p. Duchińskiego, ale tylko ograniczam się oceną ich ze stanowiska zwykłej logiki i zdrowego rozsądku, więc też odpowiedzialność moja wobec wymagań ścisłej umiejętności niepoślednio maleje. Gruntowny i wyczerpujący artykuł o p. Duchińskim jest dla mnie choćby z tego powodu niemożebny, że tu w Dorpacie nie mogę nigdzie znaleźć dzieł samego p. D., zmuszonym będąc ograniczać się po części wyciągami zawartymi w pracach innych autorów, po części zaś własnymi wspomnieniami z dawniejszego czytania rozmaitych wywodów samego p. D-go o Aryjczykach i Turańczykach, o rolnikach i nomadach itp. Zresztą „teorie” p. D. są tak popularne, że dla uprzytomnienia ich sobie nie potrzeba się zbyt głęboko wezytywać w księgi, w których je wypowiadano i uzasadniono. 
Kilka tygodni temu obchodzono jubileusz pięćdziesięcioletniej działalności literackiej prof. Duchińskiego. Otóż przede wszystkim następujące pytanie wymaga odpowiedzi: Czy był to po prostu jubileusz familijny, jubileusz prywatny, urządzony przez grono osobistych przyjaciół i czcicieli szanownego jubilata, nieprzywłaszczających sobie roli przedstawicieli narodu, czy też nadawano całej uroczystości charakter społeczny, charakter ogólnie narodowy, czcząc w ten sposób rzekome zasługi publiczne prof. Duchińskiego? W pierwszym razie nikt nie ma prawa protestować; boć chyba każdemu wolno wyrażać w ten lub inny sposób swoje własne uznanie dla czczonych przez niego osobistości. Dlaczegóż nie uczcić człowieka, który w życiu prywatnym, o ile wiemy, niczym się nie skalał, żył uczciwie, który był jakiś czas bardzo głośnym i w ten sposób przyczynił się do uświetnienia noszonego przezeń nazwiska i rodziny, której jest najwybitniejszym członkiem? Jeżeli jednak przypuścim [sic! - M.S.], że jubileusz został wyprawiony „w imieniu narodu”, w takim razie musim [sic! - M.S.] się przede wszystkim zapytać: jakie prawo może mieć p. Duchiński do wdzięczności narodowej, jakie też oddał usługi swojemu społeczeństwu?

Działalność publiczna p. Duchińskiego przedstawia dwie strony: naukowo-literacką i ściśle z nią związaną publicystyczno-polityczną. Wszystkie prace etnograficzne naszego uczonego noszą na sobie przede wszystkim charakter polityczny. Tak więc, oceniając p. Duchińskiego jako człowieka publicznego, musimy odpowiedzieć na pytania: 1) Jaki też pożytek przyniósł on swojemu narodowi jako uczony? 2) Jakie też korzyści sprowadziła na naród działalność polityczna etnografa tendencyjnego? Postaramy się naprzód odpowiedzieć na pierwsze z tych pytań.

Już sam charakter polityczny pism p. D-go robi ich ścisłą naukowość dosyć podejrzaną. Niepodobna służyć jednocześnie i z jednakową gorliwością dwóm paniom tego rodzaju, jak prawda i polityka. Albo jedna, albo druga musi być zaniedbywaną. Uczony dążyé powinien tylko do prawdy, bez względu na to, czy wyniki tego dążenia będą przyjemne, czy też nieprzyjemne. Mąż zaś publiczny, bawiący się w politykę, ma inne zupełnie cele, a chcąc przeprowadzić pomyślnie swoją sprawę przez wszystkie instancje „opinii publicznej” i sądów 
„międzynarodowych”, w środkach zwykle nie przebiera i prawdą się nie krępuje. Nasz etnograf także poświęcał tendencyjnie prawdę polityce, jak to się zaraz pokaże ze szezegółowego omówienia jego twierdzeń, jego dowodów, mających popierać owe twierdzenia, jego metody i nareszcie jego ogólnych pojęć naukowych.

Głównym twierdzeniem p. Duchińskiego, osią, około której kręciło się całe jego myślenie naukowe, była teza, że Wielkorosjanie, czyli tak zwani przezeń „Moskale”, nie mogą byé weale zaliczeni ani do Słowian, ani nawet do „Ariów” („Aryjezyków”) w ogóle, ale że należą oni do tak zwanego szczepu „turańskiego”, na równi z innymi plemionami mongolskimi, tatarskimi, fińskimi itd. „Moskwa” (według terminologii etnograficznej p. D.: cały zbiór krain, zamieszkałych w państwie rosyjskim przez Wielkorusów i ich turańskich współplemieńców) różni się od reszty Słowian i od całej Europy aryjskiej jak niebo od ziemi. Są to dwa światy zasadniczo różne, niemające z sobą nic wspólnego oprócz chyba wrodzonego i nigdy usunąć się niedającego antagonizmu. Granicami geograficznymi tych światów są to Dniepr i Dźwina, to Dniepr i „rzeczki Finlandii”. Zresztą o drobiazgi mniejsza. Bądźmy zupełnie szczerzy i powiedzmy, że granicę świata turańskiego i aryjskiego określa po prostu granica wschodnia Rzeczypospolitej Polskiej sprzed r. 1772. Należy tylko odbudować dawną Polskę, a wnet znajdzie się na karcie i na kuli ziemskiej widoczny przedział dwóch wrogich światów, a Europa Zachodnia zyska doskonałe przedmurze przed grożącą jej bezustannie hydrą turańską. Aby jednak nie krzywdzić reszty Europejczyków, którym losy kazały osiedlić się na północo-wschód od granic Polski przedrozbiorowej, i ażeby zyskać dla swej idei politycznej jak najwięcej zwolenników i sprzymierzeńców, p. D. zalicza także do Europy Zachodniej Półwysep Skandynawski, Finlandię i wszystkie prowincje nadbałtyckie. Toć w ten sposób jeszcze radykalniej odpycha się ku wschodowi Moskali-Mongołów, a odebrawszy im Morze Bałtyckie, osłabia się ich znakomicie. Rzecz bardzo prosta, że Finowie i Estończycy należą wtedy do świata aryjskiego zachodnioeuropejskiego, a nie tylko Małorusi, ale i Białorusi okazują się plemieniem zasadniczo różnym od koczowników „moskiewskich”. Naturalnie za Małorusów i Białorusów należy uważać tylko tych Rusinów, którzy zaludniają wschodnie obszary dawnej 
Rzeczypospolitej Polskiej. Co mieszka za Dnieprem, to wszystko nosi na sobie niezatarte piętno turanizmu.

P. Duchiński broni się przeciwko posądzeniu, jakoby Turańczyków uważał za barbarzyńców. Boże uchowaj! Są oni także zdolni do cywilizacji i kultury, ale do cywilizacji i kultury sui generis, niemającej nic wspólnego z sympatyczną dla prawdziwego aryjczyka kulturą i cywilizacją zachodnioeuropejską. Jednym słowem, świat aryjski i turański, Europa Zachodnia i Europa Wschodnia wraz z całą Azją, Słowianie i „Moskale” - to dwie ilości niewspółmierne, niedające się nigdy z sobą połączyć i skazane na wieczną, nigdy nieustającą walkę.

Myśl ta nie przedstawia nic nowego. Nie pierwszy prof. Duchiński ją wypowiedział, chociaż pierwszy może starał się ją sformułować naukowo i wyszukać dla niej dowodów, mogących przekonać ludzi niezbyt krytycznie myślących. Powstawała ona jednak nieraz w głowach albo odznaczających się nieznajomością rzeczy i naiwnością, albo też zatrutych nienawiścią, albo też i jedno, i drugie razem. Choćby jednak zaszczyt podobnego wynalazku trzeba było przyznać p. Duchińskiemu, to i tak nie miałby się czym chełpić. Nie jest to bowiem wcale odkrycie naukowe, nie jest to także udatny paradoks, ale tylko po prostu zdanie podyktowane przez nienawiść plemienną i zarozumiałość narodową.

Jakież dowody przytacza p. Duchiński na poparcie swojego zdania? Oto cechami, piętnującymi turanizm „moskiewski” w różnicy od szlachetnych Aryjczyków-Słowian są między innymi: osobna, wrodzona turanizmowi forma rządu, komunizm, koczowniczość, uderzająco mała liczba miast, język itd. Przypatrzmy się bliżej każdemu z tych mniemanych dowodów.

Tak tedy stałą nieuniknioną cechą „turanizmu” ma byé osobna forma rządu autokratycznego (samowładnego), zwana przez p. Dgo „caratem”. Nie wiem, czy p. D. zdolny jest przytoczyć jakiekolwiek właściwości „caratu”, które nie spotykałyby się także w państwach zachodnioeuropejskich w pewnej fazie ich rozwoju politycznego. Formy rządów w Europie Zachodniej były i są bardzo rozmaite, a do liczby ich należy także forma przypisywana przez p. D-go wyłącznie turanizmowi. Co więcej, jeżeli można wierzyć bezstronnym badaniom 
historycznym, swoją formę rządu „turanizm” wschodnioeuropejski p. Duchińskiego odziedziczył po tak arcyaryjskim państwie, jakim było cesarstwo bizantyńskie. Gdyby zresztą p. D. chciał się zastanowić nad historią Europy Zachodniej, znalazłby tam we Francji, np. Burbonów przedrewolucyjnych (Ludwik XIV itd.), w Rzymie długi szereg cezarów, zresztą prawie wszędzie przez pewien czas coś bardzo podobnego do tego, co się wydaje naszemu historiozofowi tak specyficznie turańskim. Powinien by także wiedzieć p. D., że wyraz słowiański (południowo-słowiański i ruski) car rozwinął się przez skrócenie z cesár (cesarz), które znowu nie jest niczym innym, jak późniejszą modyfikacją Cezara (Caesar), w niemieckiej przeróbce Kaisar, Kaiser. Ani chanów, ani szachów u Turańczyków Europy Wschodniej wcale nie spotykamy. Kto wie zresztą, czy nawet zwykli, czysto azjatyccy chanowie przewyższają co do despotyzmu takiego np. czystego „Aryjczyka”, jak Napoleon I, albo też bohatera, do którego modlił się ciągle p. D., Napoleona III. Z drugiej strony należałoby zwrócić uwagę na Japonię, na różnorodne formy rządów u czysto „turańskich" ludów azjatyckich itd., a z pewnością nie można by ich było pakować do jednego worka ze wschodnio-europejskim „caratem”, w przeciwstawieniu do wszystkich razem wziętych form zachodnioeuropejskich, charakteryzujących państwa „aryjskie”. Jak inne objawy życia uspołecznionego, tak i formy rządu ulegają stopniowym zmianom. Każda forma rządu możliwą jest w pewnym czasie przy pewnym stanie społeczeństwa u każdego narodu. Pewne jej odcienie zawisłe są od warunków geograficznych, ekonomicznych itp., jako też od przeszłości narodu. Pochodzenie zaś plemienne najmniejszą tu chyba odgrywa rolę. Węgrzy w Azji, a Persowie w Europie posiadaliby zapewne całkiem inną formę rządu, aniżeli ta, do której obecnie doszli. Z aryjskością i turańskością forma rządu w każdym razie nie ma nic do czynienia.

Przy tym wszystkim należy zwrócić uwagę na tę okoliczność, że gadalnie (parlamenty) nie są tak dalece wynalazkiem wyłącznie zachodnioeuropejskim lub też „aryjskim”, i że nie od nich jedynie zależy zbawienie ludzkości. Jakie imponujące znaczenie miewają czasami gadalnie aryjskie, najlepiej to widać na dzisiejszym Landtagu pruskim i na Reichstagu niemieckim. Dobroczynne zaś skutki wielce 
patriotycznej działalności sławetnych sejmów śp. Rzeczypospolitej Polskiej odczuwany chyba dostatecznie na własnej skórze.

Drugą cechą turańską, właściwą także „Moskwie” p. Duchińskiego, ma być komunizm, gdy tymczasem Aryjczyków cechuje własność osobista. Gdyby nie poważny ton dzieł p. D-go, można by tu sądzić, że uczony nasz żartuje. Czy p. D. badał rzeczywiście pod tym względem całe społeczeństwo rosyjskie we wszystkich jego warstwach? Bo zwykli śmiertelnicy, którzy przyglądali się choćby tylko powierzchownie ludowi rosyjskiemu (wielkoruskiemu), znajduja coś w rodzaju „komunizmu” jedynie tylko u ludu wiejskiego w tak zwanym wspólnym władaniu (общинное владение) ziemią. Oprócz jednak biednych chłopów żadna klasa ludności wielkoruskiej nie wykazuje najmniejszego pociągu do komunistycznego ustroju społecznego. Czy może kupcy wielkoruscy są komunistami? Czy może duchowieństwo, szlachta? Czy czasem nie pijawki, zwane „kułakami” (кулаки), albo też właściciele jawnych zakładów lichwiarskich (глассныля кассы ссуд) uprawiają ów komunizm p. Duchińskiego? Trzeba by istotnie posiadać zbyt twórczą wyobraźnię, ażeby utrzymywać coś podobnego. I czy to nie zadziwiające, że w okolicach, gdzie lud wiejski wielkoruski mieszka tuż obok z innymi „Turańczykami” w rodzaju Tatarów, Czuwaszów, Czeremisów itd., właśnie ci ostatni mają własność indywidualną, gdy tymczasem „komunizm” cechuje urządzenia agrarne „Turańczyków” mówiących po słowiańsku?. Gdyby nie zaślepienie i zaciekłość, p. D. spostrzegłby, że ów komunizm agrarny Wielkorusów jest właśnie zabytkiem czysto słowiańskim, że coś podobnego, choć w innych rozmiarach, spotykamy jeszcze u Serbów, Bułgarów itd., że nawet czysto „aryjski” lud polski uważa dotychczas las i pastwisko za własność komunistyczną itd. Takie same poglądy i takie same urządzenia właściwe były dawniej wszystkim bez wyjątku ludom. Mamy np. pewne niezbite dane o „komunizmie” w Indiach Wschodnich, u starożytnych Germanów, u plemion kaukaskich itd. Warunki życia zmieniły się; zmieniła się także forma własności i w ogóle ustroju społecznego. „Komunizm” więc ów nie jest weale cechą wyłącznie „turańską”, ale jest po prostu pewnym stopniem rozwoju społecznego, przez który każdy lud przechodzi. Szkoda także, że p. D. zapomniał przy tej sposobności o teoriach i dążnoś- 
ciach komunistycznych u czystej krwi „Aryjczyków” Europy Zachodniej. Ale może tylko ci są Aryjezykami, co broniąc własności, obracają kapitałami i eksploatują dwunożne bydło robocze; reszta zaś to pariasy chamskiego pochodzenia.

Następnie powiada p. Duchiński, że Turańczycy to nomady, koczownicy, ludy pasterskie, gdy tymezasem Aryjezycy to rolnicy, ludy osiadłe. W oczach p. D-go Wielkorosjanie, czyli „Moskale”, są także chronicznymi koczownikami, a więc Turańczykami. Łatwośé przenoszenia się Wielkorusa z miejsca na miejsce dochodzi do najwyższego stopnia.

Zastanówmy się, czy p. D. ma słuszność. Nie ulega najmniejszej wątpliwości, że „wyższe klasy” każdego narodu przenoszą się z miejsca na miejsce z nadzwyczajną łatwością, zwłaszcza teraz, po wynalezieniu kolei żelaznych. Ale tu prym trzymają chyba najczystszej krwi Aryjezycy - Anglicy, gdy tymezasem Turańczycy „Moskale” znacznie im ustępują. Jakież to zastępy z bogatszych ludzi wszelkich narodów wędrują rokrocznie choćby do jednego Paryża, dokąd i później ciągnie serce niejednego potentata. Co się zaś tyczy biednych ludzi czy to osiadłych, czy też nieosiadłych, to ci porzucają kąt rodzinny zwykle tylko z potrzeby albo nawet z nędzy. Tak np. wędrówki Indów, jeżeli istotnie były to przenosiny ludowe, bywały przedsiębrane nie dla przyjemności, ale dla wynalezienia lepszych pastwisk lub też lepszej, urodzajniejszej ziemi w ogóle. Podobnie w ostatnich czasach emigracje Niemców, włościan galicyjskich itd. do Ameryki dowodzą tylko, że biedacy nie mają w domu co jeść i że w pogoni za kawałkiem chleba nie cofają się nawet przed tak daleką podróżą w nieznane kraje. A jakim to wymownym faktem jest tegoroczny prąd włościan niektórych okolic guberni radomskiej do przesiedlenia się do Syberii, nad Amur itd., prąd, który tylko z wielką trudnością udało się zażegnać miejscowym władzom „turańskim”. Czyż na zasadzie tych nieustannych emigracji zaliczy p. D. Niemców, Galicjan i włościan radomskich do koczowniczych ludów turańskich? Chyba że nie. Ale może odpowie p. D. i jego zwolennicy, że podobne przenosiny z musu, a ciągłe koczowanie Turańczyków z przyzwyczajenia i dla przyjemności to dwie rzeczy zupełnie różne. Być bardzo może, ale w takim razie p. D. nie zna wcale ludu wielkoruskiego i nie przyj- 
rzał się warunkom jego bytu. Owa koczowniczość zwyczajowa spotyka się wprawdzie u Kirgizów, Baszkirów, Ałtajczyków i innych ludów szczepu tureckiego w Syberii. Ale już Tatarzy, Czuwasze, Czeremisi oraz inni Turcy (,Turcy” w znaczeniu ogólnym) i Finowie mieszkający w pobliżu Wołgi i Karny nie myślą wcale o koczownictwie i oddają się albo uprawie ziemi, albo też innym zajęciom charakteryzującym ludy „osiadłe”. To samo zupełnie stosuje się do Wielkorusów. 0 Wielkorusach nomadach niceśmy dotychczas nic słyszeli. Że dla zarobku opuszczają oni tłumnie domową zagrodę, oddalając się od niej nieraz o kilkaset wiorst, to nic dziwnego. Opuszczają, bo muszą; opuszczają z nędzy. To samo czynił i czyni każdy lud wszędzie i zawsze. Jednakże ryczałtowe wysiedlanie się (emigracja) Wielkorusów, np. do Ameryki, dotychczas się nie rozpoczęło, a to dla tej prostej przyczyny, że do właściwego przeludnienia w Rosji, całkowicie wziętej, dotychczas nie doszło i długo jeszcze nie dojdzie, sama zaś Rosja (europejska i azjatycka) posiada dosyć przestrzeni dla wyżywienia jeszcze daleko znaczniejszej ilości ludzi.

Dawniej, a właściwie nie tak dawno, lud wielkoruski, na równi z małoruskim i w ogóle z każdym ludem oddanym panom w niewolę, ulegał przymusowemu koczownictwu. Boć panu mającemu majątki, np. w guberni wołyńskiej i saratowskiej, mogło się podobać przesiedlać całe wsie z jednej guberni do drugiej bądź to dla zaludnienia niezbyt ludnych obszarów w jednym majątku, bądź też po prostu z kaprysu. Nikt też nie mógł przeszkodzić panu sprzedawać ryczałtowo należące do niego dusze całymi dziesiątkami lub setkami na osiedlenie ich, choćby nawet w drugim końcu państwa. Podobnymi szlachetnymi operacjami zajmowali się nie tylko panowie „Turańczycy”, ale z pewnością równie często najczystszej krwi „Aryjczycy”, nie tylko „Moskale”, ale także najzdeklarowańsi Słowianie, tak jedni jak drudzy - wyznawcy religii Chrystusowej i gorliwi jej krzewiciele. Takie to były czasy i nikt nie obwinia ani „Turańczyków”, ani też „Aryjczyków” postępujących w ten sposób ze swym dwunogim bydłem roboczym. Prócz tego podobnemu mimowolnemu koczownictwu ulegały całe wsie z innych, czasowych powodów, i to może jeszcze nie tyle wsie „turańskie”, ile wsie polskie, litewskie itp. Tak jedno, jak drugie, tak przesiedlenie z woli właściciela majątku, jako też z woli innych 
potęg, wygląda na koczownictwo, ale pomiędzy podobnym koczownictwem a koczownictwem dobrowolnym taka sama zachodzi różnica, jak pomiędzy masażem i gimnastyką bierną a gimnastyką czynną. Rezultat otrzymujemy mniej więcej ten sam, ale odpowiedzialność przed panem Duchińskim spada na kogo innego.

Czy też p. D. był kiedykolwiek obecnym przy podobnych objawach koczownictwa, mającego charakteryzować „turanizm” „moskiewski” w różnicy od „aryizmu” słowiańskiego? Chyba że nie był; i dlatego też nie może powiedzieć, czy owi jego „Turańczycy” nie przelewali przy tym gorzkich łez rozpaczy, czy nie wydawali jęków, zdolnych wstrząsnąć każde serce ludzkie, z wyjątkiem serc zatwardziałych plantatorów i okrutnych a bezmyślnych oprawców. Tak „Turańczyk”, jak „Aryjczyk” rzucony z dala od rodzinnej zagrody, tęskni za nią w ciągu całego życia. Osobniki nietęskniące wszędzie są dość rzadkie; są to albo silne umysły, żądne coraz nowych wrażen, albo też awanturnicy, pozbawieni w ogóle zdolności przywiązywania się do tego, co ich otacza. Sam widziałem Tatarów, Czuwaszów i Czeremisów wzruszonych do łez przy zbliżeniu się do miejsc, w których się wychowali.

A przecież Tatarzy, Czuwasze i Czeremisy toć to „Turańczycy” najczystszej wody.

Być bardzo może, że Wielkorusi wydają większy procent indywiduów puszczających się dobrowolnie na życie koczownicze aniżeli inne plemiona sąsiednie, zwłaszcza plemiona mieszkające ku zachodowi od Wielkorusów. Ale bo też w ogóle Wielkorusi razem wzięci żyją w innych warunkach aniżeli owe plemiona zachodnie.

Przede wszystkim u tych plemion zachodnich, u Polaków, Małorusów, Litwinów itd., spotykamy tylko czysto indywidualne władanie rolą, gdy tymczasem u większości Wielkorusów rolników ma miejsce własność wspólna, zbiorowa. Włościanie też polscy, małoruscy, litewscy itd. mają przeciętnie więcej ziemi aniżeli włościanie wielu bardzo okolic wielkoruskich, czy to posiadający już własność indywidualną, czy też dotychczas tylko zbiorową. Prócz tego ziemia na zachodzie jest daleko lepiej zagospodarowaną i przynosi nierównie więcej dochodu. Włościanin polski lub litewski stoi jako rolnik nierównie wyżej od włościanina wielkoruskiego znad Wołgi lub Donu. Jest to bardzo zrozumiała różnica w stopniu kultury i udoskonalenia specjalnego. 
Inne plemiona, ku zachodowi mieszkające, przedstawiają na tej samej przestrzeni daleko więcej ludności; a gęstsze zaludnienie, byle tylko nie przeludnienie, jest jednym z czynników przywiązujących człowieka do miejsca. Na wpół puste przestrzenie ciągnące się bez granic nie mają w sobie tyle powabu indywidualnego, co kraje, ożywione gęsto posianymi siedzibami ludzkimi.

Dużo też może do zobojętnienia Wielkorusa pod względem wyłącznego przywiązania do jakiejś miejscowości lub pewnego niewielkiego obszaru przyczyniają się szerokie przestworza z tym samym językiem. Dziś np. Wielkorus może się przenieść z okolic Petersburga w okolice Irkucka i wszędzie znajdzie po drodze znaczne grupy ludności, z którymi się może od razu porozumiewać bez żadnej trudności. Czuje się więc na tak dużych przestrzeniach daleko bardziej u siebie, aniżeli plemiona zaludniające daleko mniejszą przestrzeń, jak np. Litwini, Łotysze, Estończycy, Finowie, a nawet Małorusi lub Polacy. Chłop polski znajdzie wprawdzie Polaków poza ściśle etnograficznymi granicami swojego plemienia, ale nie będą to ludzie stojący z nim na równi; będą to albo panowie rozsiani między ludnością litewską lub ruską, albo też mieszkańcy miast. Chłop zaś rosyjski znajdzie równego sobie i mówiącego łatwo zrozumiałym językiem na całej przestrzeni od Grodna prawie do Kamczatki, od Woroneża do Archangielska. Mieszkający tuż obok Wielkorusów oczywiści „Turańczycy”, jako to Mordwini, Czuwasze, Czeremisi, Tatarzy itd. (nie mówiąc już o Estończykach i Finach, należących, zdaniem p. D-go, do Europy „aryjskiej”, okazują może nawet więcej miłości kąta rodzinnego i rolniczości aniżeli sami Wielkorusi, którzy nawet według „teorii” p. Duchińskiego nie przewyższają pod względem turanizmu owych tylko co wymienionych plemion. Zostaje to być może w związku z tym faktem historycznym, że Wielkorosjanie później przybyli do tych krajów, wyparłszy po części inne plemiona z ich pierwotnych siedzib, do których sami nie potrafili się jeszcze dostatecznie przyzwyczaić. W ogóle kolonizatorowie przenoszą się łatwiej z miejsca na miejsce aniżeli plemiona nieruchome, w mniejszym stopniu uzdolnione do kolonizacji.

Taką samą właśnie „koczowniczość”, jak u Wielkorusów, spotykamy także u Niemców porzucających całymi masami swoją pierwot- 
ną ojczyznę i zaludniających całe obszary w obcych krajach. Cala zaś prawie dzisiejsza Ameryka zaludnioną jest przez tego rodzaju „koczowników” zachodnioeuropejskich, a więc „aryjskich”, z plemienia romańskiego i germańskiego.

Mówiąc o „koczowniczości” Wielkorosjan, trzeba mieć ciągle na uwadze różnice geograficzne tego niezmiernego obszaru etnograficznego. Inny zupełnie stopień „koczowniczości” spotkamy u Wielkorusów Syberii, inny w okolicach Moskwy, Tuły, Riazania itd. Rzadko chyba kto słyszał 0 rybakach z guberni ołoneckiej chętnie porzucających swoje zagrody i osiedlających się w innych miejscowościach. A przecież to najczystszej krwi Wielkorusi, czyli „Turańczycy” p. Duchińskiego.

Być może zresztą, że Wielkorusi mają daleko więcej skłonności koczowniczych aniżeli inni Słowianie. Ażeby jednak nasz sąd w tym przedmiocie miał jaką taką wartość naukową, należałoby go oprzeć na zupełnie pewnych i ściśle oznaczonych danych statystycznych i to mianowicie w dwóch kierunkach: w kierunku geograficznym i w kierunku chronologicznym. Dane statystyczne w kierunku geograficznym odpowiedzą na pytanie, które z plemion jednocześnie żyjących daje największy procent koczowników? Z danych zaś statystycznych w kierunku chronologicznym można by wyciągać wnioski co do zwiększania się lub też zmniejszania się z biegiem czasu „koczowniczości” pojedynczych plemion. Niestety, nauka nie może się poszczycić obecnie podobnymi danymi statystycznymi. Bez takich zaś danych przypisywanie „Moskalom”-,Turańczykom” koczowniczości, a Słowianom-Aryjczykom osiadłości jest czczą, niewiele pouczającą gadaniną.

Na zakończenie tego ustępu o koczowniczości pozwolę sobie zapytać p. D-go i jego zwolenników, do jakiej kategorii zaliczają Cyganów: czy do Aryjczyków, czy też do Turańczyków? 0 ile skądinąd wiadomo, Cyganie, których mowa należy do familii indyjskiej języków arioeuropejskich (indoeuropejskich) i którzy pod względem antropologicznym należą do szczepu kaukaskiego, powinni być chyba uważani za „Aryjczyków”, a więc za plemię osiadłe. Tymczasem są to wieczni, niczym nieuleczalni koczownicy. A jaką też kategorię powinny by stanowić, według p. D-go, owe masy żydowskie, w żaden sposób 
niedające się przywiązać do ziemi, ciągle ruchome i więcej chyba „koczownicze" aniżeli osiadłe?

Wzmianka o Żydach pozwala nam przejść do następnego dowodu, mającego, zdaniem p. D-go, popierać „turańskość” Wielkorusów. Dowód to istotnie na pozór przekonywający i mogący obałamucić ludzi głębiej się niezastanawiających.

Oto w ziemiach zamieszkałych przez Wielkorusów uderzająco mała jest liczba miast i miasteczek, których takie mnóstwo spotykamy w prowincjach leżących na zachód od tego plemienia koczowniczego. Podobno nawet Instytut Narodowy Francuski (L' Institut $\mathrm{Na}$ tional de France) ogłosił niegdyśs „konkurs i nagrodę medalu złotego za odpowiedź na pytanie: dlaczego na 8484658 mieszkańców guberni zachodnich Cesarstwa Rosyjskiego jest 1056 miast i miasteczek, kiedy na 36107270 mieszkańców Wielkorosji jest tylko 356 takich miejsc centralnych handlu i cywilizacji”. Po uważniejszym przyjrzeniu się temu niby to dowodowi znika on zupełnie jak bańka mydlana. Czy to zaślepienie i nieświadomość, czy też zła wola kazały p. D-mu i jego zwolennikom podstawić nazwę zamiast rzeczy i na podstawie tego pomieszania wykrzykiwać tryumfująco o turańskości Wielkorusów.

Według terminologii administracyjnej przyjętej w Rosji wielkoruskiej, miastem (gorod) nazywa się przeważnie tylko stolica guberni lub powiatu. Miasta zaś niebędące stolicą powiatu są nader nieliczne i noszą nazwę miast pozaetatowych (zasztatnyj gorod). Tymczasem w granicach dawnej Rzeczypospolitej Polskiej jest mnóstwo miast i miasteczek, niemających żadnego znaczenia administracyjnego i różniących się od wsi tylko większą ilością Żydów i pewnymi „przywilejami” albo raczej ciężarami miejskimi. Tego rodzaju osad posiada także i Rosja Wielkoruska liczbę dosyć znaczną; nie nazywa ich jednak pompatycznie miastami, ale po prostu stobodami lub posadami².

1 Por. między innymi: „Przegląd etnograficzno-historyczny i literacki, poświęcony badaniom Polski i krajów sąsiednich”, Kraków, 1875, nr 1, 5. marca, szp. 5 i 6 [przyp. BdeC].

2 Sioło (село) znaczy: wieś kościelna (cerkiewna) bez jarmarków, słoboda (слобода) - wieś kościelna z jarmarkami, posad (посад) - siedlisko „asesora”, czyli naczelnika policji w części powiatu (становой пристав), dawniej (заседатель), gród (город) - siedlisko przynajmniej naczelnika 
Mają one zawsze cerkiew, są siedliskiem pewnych władz administracyjnych; w nich też odbywają się jarmarki, itd.; jednym słowem, nie ustępują one weale polsko-litewsko-zachodnioruskim miasteczkom. Tego ostatniego terminu, miasteczko, jako też nawet terminu miasto Wielkorosja wcale nie zna; gorod bowiem, siedlisko dawnego horodniczego, równa się mniej więcej co do pojęcia polskiemu grodowi, siedlisku starosty. Chociaż więc Rosjanie wyraz polski miasto tłumaczą przez gorod, to jednak na oznaczenie miasteczka wprowadzili do swego języka ten sam wyraz w formie miestieczko (местечко). Niejedno zaś nawet sioło (селo) wielkoruskie przedstawia się daleko pokaźniej aniżeli owe miasteczka polskie, do których p. D. tak wielkie znaczenie przywiązuje. Lat temu kilkanaście przemianowano w Królestwie Polskim wiele bardzo miasteczek na proste osady (nuсад); gdyby więc teraz Instytut Narodowy Francuski zajął się tą kwestią, to na zasadzie nowej nomenklatury miałby już daleko mniej powodów do dziwienia się.

Sądząc jedynie według nazw, należałoby np. Włochom przypisać mniej miast i miasteczek aniżeli Polsce. We Włoszech bowiem, przynajmniej we Włoszech północnych, nawet osady bardzo znaczne, liczące po kilka tysięcy mieszkańców, będące centrami administracyjnymi całych powiatów, mieszczące w sobie średnie zakłady naukowe, nie noszą weale nazwy miast (citta), ale po prostu siót lub osad (borgo). Takimi są np. Tarcento, Gemona (przeszło 8000 mieszkańców), Moggio itd. Być miastem jest to może wielki zaszczyt, ale jeszcze większy ciężar. Podobnie w Austrii południowo-zachodniej liczba „miast” jest chyba stosunkowo niewiele większa od liczby miast w Wielkorosji. Tak np. prowincja Kraina z przeszło półmilionową ludnością ma zaledwie kilka „miast”. Czyż na zasadzie tego zaliczy p. Duchiński Włochów i Słoweńców do „Turańczyków”?

policji powiatowej (ијеzdnej), czyli isprawnika (капитан-исправпик, teraz po prostu uспрапник), a dawniej prócz tego osobnego naczelnika policji miejskiej, czyli horodniczego (городничий), zależnego nie od naczelnika powiatu, ale wprost od gubernatora. Tak więc nazwy gorod i posad noszą charakter administracyjny, stoboda zaś, sieto i dieriewnia (деревня, wieś) - charakter ekonomiczno-kościelny [przyp. BdeC]. 
Zagadka owego mnóstwa „miast i miasteczek” w guberniach zachodnich Cesarstwa Rosyjskiego rozwiązuje się bardzo prosto. Miast tych i miasteczek nie zakładali wcale pierwotni ziem tych mieszkańcy, Słowianie i Litwini. Zawdzięczają one swój początek w pewnej części Niemcom, głównie zaś Żydom. Miasteczka polsko-litewsko-zachodnioruskie, niespotykane weale w innych krajach, niemających takiej znacznej liczby Żydów, są tylko dla Żydów stworzone i im też zawdzięczają możność istnienia. Usuńcie Żydów, a owe „miejsca centralne handlu i cywilizacji” zamienią się na wioszczyny najnędzniejszego gatunku.

Przeciwko tylko co wymienionemu epitetowi - miejsca centralne handlu i cywilizacji - muszę jak najuroczyściej zaprotestować. Nazywać tak te brudne, cuchnące mieściny jest to naigrawać się ze zdrowego rozsądku. Niechaj p. D. przejedzie się po tych miasteczkach, a przekona się, że chyba tylko przez ironię można nazywać „handlem” drobną szacherkę i okpiwanie miejscowych i przyjezdnych chłopów oraz sprzedaż bułek i gomółek na nędznych straganach. Siedlisk zaś cywilizacji dopatruje p. D. chyba w niezliczonej ilości szynków, których w takich miasteczkach bywa czasami więcej aniżeli miejscowych gospodarzy chrześcijan. Wódka, ruina materialna i demoralizacja ludności wiejskiej - oto wpływy cywilizacyjne owych centrów handlu $i$ cywilizacji. Niech więc p. D. i jego zwolennicy położą rękę na sercu i przyznają, że Słowianie zachodni, uznawani przez nich za Aryjczyków w potędze najwyższej, nie mają się czego chwalić swoimi „miastami i miasteczkami”.

Załatwiwszy się w sposób bardzo pobieżny z innymi „dowodami” p. D-go, dotknę jeszcze jednego, mianowicie języka. P. Duchiński twierdzi, że chociaż „Moskale-Turańczycy” mówią dziś pewną modyfikacją języków słowiańskich, to jednak nie jest to ich język żywy, samodzielnie rozwinięty, ale sztucznie nabyty. Ta dzicz turańska mówiła dawniej innym jakimś językiem. Z wprowadzeniem zaś chrześcijaństwa przyjęła także język cerkiewno-słowiański, którym mówi dotychczas, zepsuwszy go naturalnie po turańsku. Co innego języki małoruski i białoruski. To są języki z dawien dawna właściwe mówiącym nimi plemionom, języki żywe, swobodne od sztucznego przeflancowania i od obcych naleciałości. Utrzymywać coś podobnego 
może tylko p. D. lub tė̇ „uczeni” jemu podobni, których niewinne dusze nie zostały wcale skalane znajomością budowy języków słowiańskich oraz wzajemnych stosunków pokrewieństwa między tymi językami. Gdyby panowie ci znali choćby tylko początki teorii języków słowiańskich, wiedzieliby, że wszystkie gwary wielkoruskie (w tej liczbie język literacki) i białoruskie stanowią osobną grupę w różnicy od gwar małoruskich, ale że obie te grupy razem, wielkoruska i małoruska, powinny być połączone w jedną wspólną rodzinę, w przeciwstawieniu do reszty języków słowiańskich. Że Wielkorusy są Turańczykami, którzy pożyczyli sobie języka cerkiewno-słowiańskiego, może utrzymywać tylko ten, kto ma bardzo słabe i nieokreślone pojęcie tak o budowie języków słowiańskich, jako też o tym, w jaki to sposób i jakiego rodzaju języki mogą być narzucane całym ludom. Podobne cudowne przyswojenia języków mogą mieć miejsce chyba tylko w bajeczkach p. Duchińskiego, ale nigdy w rzeczywistości.

Język wielkoruski (tj. język literacki rosyjski wraz ze wszystkimi gwarami wielkoruskimi) jest językiem czysto słowiańskim co do budowy, co do strony głosowej i morfologicznej, a do tego jednym z najżywotniejszych i najsamodzielniejszych języków słowiańskich. Są w nim wprawdzie obce naleciałości, obce żywioły leksykalne, tj. obce wyrazy i kategorie wyrazów. Jest w nim np. kilka grup wyrazów zawdzięczających swój wygląd głosowy wpływowi języka ksiąg cerkiewno-słowiańskich, biorących swój początek od Słowian południowych. Są w nim także w dość znacznej ilości wyrazy obce niesłowiańskiego pochodzenia, ale stałego wpływu obcego na fonetykę żywą, czyli na wymawianie, oraz na budowę języka morfologiczną i syntaktyczną nawet najstaranniejsze badanie nie wyśledzi. Ta sama suma obcych elementów znajdzie się także w innych językach słowiańskich. Przede wszystkim język polski, który p. D. uważa za najbardziej słowiański, zdradza bardzo zasadniczy obcy wpływ w utracie pierwotnego słowiańskiego akcentu przenośnego, zachowanego np. przez całą grupę ruską języków słowiańskich (w tej liczbie przez język wielkoruski). Na tej samej zasadzie co w języku polskim można by przypuszczać obcy wpływ w językach łużyckich, w języku czeskim, słowackim itd. Czy jednak istotnie zatrata akcentu ruchomego i przykucie akcentu do pewnej zgłoski wyrazu (np. w polskim do przed- 
ostatniej, w czeskim do pierwszej od początku itp.) jest skutkiem wpływu obcego, niepodobna rozstrzygnąć, chociaż trudno nie zwrócić uwagi na tę okoliczność, że podobny akcent, stale związany z pewnymi głoskami wyrazu, charakteryzuje właśnie języki „turańskie”, fińskie i turecko-ałtajskie.

Widzimy tedy, że ze swoim językiem cerkiewno-słowiańskim, narzuconym niby to wraz z chrześcijaństwem „Turańczykom” Europy Wschodniej, p. D. wybrał się bardzo nie w porę.

Metoda wykładu p. D-go, tj. sam sposób wiązania dowodzeń z twierdzeniami, godną jest najzupełniej samych tylko co potrąconych dowodów. Sposób ten polega na bezustannym wmawianiu w czytelnika, na podobieństwo tego, jak robią pewne kumoszki, niemogące na poparcie swoich „głębokich przekonań” przytoczyć czego innego oprócz uroczystego zapewnienia, że to jest prawdą i że one w tę prawdę wierzą. P. Duchiński powtórzy jedno i to samo jakie sto razy i sądzi, że po tak uporczywym zapewnieniu o prawdzie oczywistych niemożliwości każdy czytelnik powinien uchylić głowę przed nieubłaganą logiką i przekonywającą wymową autora. Jest to więc metoda „słowa honoru” i ,jak bozię kocham”. Na dowiedzenie jednakże „turańskości” Wielkorusów „słowo honoru” dalibóg nie wystarcza, podobnie jak nie wystarcza ono do przekonania zdrowego rozsądku, że 2 razy 2 jest 5 .

Wzmiankowaliśmy już o braku danych statystycznych. Wprawdzie p. D. posługuje się niekiedy statystyką, ale... zwykle niefortunnie. Przykład takiego nieudatnego stosowania statystyki widzieliśmy na owej sprawie miast i miasteczek, miejsc centralnych handlu $i$ cywilizacji.

Ale bo też pobudki całej owej działalności naukowej, pobudki owych twierdzeń 0 „turańskości” i „aryjskości” oraz dowodów naciąganych dla poparcia twierdzeń, nie były wcale naukowe, ale tylko polityczne. Twierdzenia te dyktowała nienawiść plemienno-polityczna i chęć adwokatowania na korzyść Polski przed „Europą”, tj. przed zgrają dyplomatów podejrzanego gatunku. Stąd to owo naciąganie i przekręcanie etnografii i geografii, stąd podnoszenie Dniepru i Dźwiny oraz rzeczek Finlandii do znaczenia granic dwóch światów; 
stąd owa ryczałtowość w określeniach i zupełny brak analizy szczegółowej.

Żaden sumienny historyk lub etnograf, czy to rosyjski, czy też obcy, nie będzie zaprzeczał, że w niektórych częściach ogromnego obszaru wielkoruskiego mamy istotnie ludność mieszaną i to zmieszaną w dość niedawnym stosunkowo czasie. Okolic zaś, gdzie by ludność innoplemienna, „turańska”, porzucała swój dawniejszy język i przyjmowała język słowiański, znajdzie się chyba bardzo niewiele. Z czystej więc „turańskości” antropologicznej i etnograficznej, choćby tylko niewielkiej części Wielkorusów - w podobnym rodzaju, jak to ma miejsce z Murzynami mówiącymi w Ameryce po angielsku lub po francusku - nawet mowy być nie może. Takie zaś zachowanie czystości rasy z zamianą jedynie języka a mieszanina etnograficzna - toć to przecie dwie rzeczy najzupełniej różne. Mieszanina ta dokonywa się drogą kolonizacji, drogą małżeństw mieszanych, przy czym co do języka, bierze przewage żywioł znajdujący się pod tym lub owym względem w pomyślniejszych warunkach.

Sądząc z tego, co dziś widzimy, nie możemy i w przeszłości przypuszczać zbyt licznych wypadków tego rodzaju. Przecież dziś np. w Syberii tak zwani inorodcy z wielką trudnością wyuczają się po rosyjsku, gdy tymczasem, odwrotnie, Wielkorusi dość często władają swobodnie językiem jakuckim oraz innymi językami „turańskimi”. P0dobnie tam, gdzie wsie rosyjskie pomieszane są z tatarskimi, czuwaskimi itp., spotykamy obok pewnego języka mieszanego, pośredniego, także wyuczanie się właściwego języka drugiego plemienia i to częściej może języków obcych przez Wielkorusów aniżeli na odwrót - pomimo wszelkiej opieki okazywanej językowi panującemu. W takich razach prędzej chyba możemy mówić o „turanizacji” Słowian aniżeli odwrotnie - o słowiańszczeniu „Turańczyków”. Niemniej przeto nikt nie zaprzeczy, że niektóre plemiona „turańskie” bardzo zmalały na korzyść prących z zachodu Słowian, a niektóre nawet zupełnie znikły. Musiały to być plemiona posiadające bardzo słabą siłę odporną, a bardzo nieliczne w stosunku do zajmowanego przez nich terytorium, co umożebniało w tych ziemiach gęstą kolonizację wielkoruską. Przypuściwszy jednak nawet w niektórych okolicach mieszaninę Słowian z „Turańczykami” przy silnej przewadze zoologicznej (antropologicz- 
nej) po stronie „Turańczyków” albo, co więcej, proste zesłowiańszczenie całych gromad „turańskich”, pomimo tego wszystkiego będziemy musieli skonstatować fakt, że w wielu okolicach mamy Wielkorusów czystych Słowian bądź to osiedlonych sposobem kolonizacyjnym na dawniej pustych, przez nikogo niezajętych obszarach, bądź też siedzących w swoich siołach i miastach $\mathrm{z}$ dawien dawna, tj. ze stanowiska historii równie dawno, jak Polacy, Czesi, Serbowie, Małorusi itd. na ziemiach przez nich zajętych. Źródła historyczne nie mogą wskazać czasu przybycia tylko co wymienionych plemion w zajmowane dziś przez nich siedziby; ale to samo ma miejsce ze znaczną częścią dzisiejszych siedzib wielkoruskich.

Podobnie żadne badania czysto historyczne nie są w stanie wykryć w wielu ziemiach wielkoruskich mieszaniny etnograficznej słowiańsko-turańskiej, a tym mniej prostego zesłowiańszczenia Turańczyków. Jeżeli zaś przypuścim [sic! - M.S.] podobny „przedhistoryczny” proces u wszystkich Wielkorusów, to nikt nam także nie zabroni wystąić z podobnym przypuszczeniem co do innych Słowian, co do Małorusów, Czechów, Polaków, Serbów itd., uważać ich za plemiona mieszane i wyszukiwać różnych „dowodów” na poparcie tego przypuszczenia. Że pod względem języka absolutna czystość i nieskazitelność słowiańska, np. Polaków, Czechów itd., jest cokolwiek podejrzaną, wzmiankowaliśmy już wyżej. Nic zaś tu nie pomoże twierdzenie p. Duchińskiego, że na płaszczyznach Mazowsza trzeba szukać pierwotnej siedziby Słowian.

W każdym razie są to kwestie bardzo zawikłane i po większej części niedające się nigdy stanowczo rozwiązać. Kto chce rzucić choć cokolwiek światła w tę ciemnię naukową, powinien postępować bardzo ostrożnie, powinien wyrzec się ryczałtowych sądów o całych plemionach, powinien kwestię obszernego zakroju rozłożyć na drobne kwestie pochodzenia mieszkańców pojedynczych ziem, zadawalniając się skromnymi a mozolnymi badaniami początku i składu ludności, np. okolic Wiatki, okolic Nowogrodu, Jarosławia, Moskwy itd., itd. Z takich sumiennie przeprowadzonych monografii (których kilka posiada już literatura etnograficzna) może się z czasem złoży ogólny obraz, choćby tylko w przybliżeniu odtwarzający istotny przebieg faktów. 
Ażeby sprostać podobnemu zadaniu, potrzeba przede wszystkim posiadać głowę wolną od przesądów, a natomiast uzbrojoną pewnymi ogólnymi pojęciami naukowymi, których brak widnieje z każdego dzieła prof. Duchińskiego. Tak np. pojęcie rozwoju, pojęcie stopniowych przemian i przejść z jednego stanu społecznego do drugiego, następnie pojęcie chronologii w jej najogólniejszym, przyrodniczym znaczeniu, tj. pojęcie nawarstwień historycznych z różnych periodów, itp. - wszystko to są rzeczy najzupełniej lekceważone przez naszego etnografa. W związku z tym nie uwzględnia on weale wpływu warunków i okoliczności na takie lub inne ukształtowanie życia pewnego plemienia.

P. Duchiński nie jest w stanie pojąć, że ludy stojące dziś na stopniu życia koczowniczego i pasterskiego mogą przy zmianie radykalnej warunków bytu stać się osiadłymi i rolnikami. Co jest właściwie tylko różnicą stopnia rozwoju, różnicą chronologiczną oraz różnicą warunków bytu, to występuje u p. D-go jako różnica zasadnicza, jako nieprzebyta granica, dzieląca ludzkość na dwa światy, nic wspólnego między sobą niemające.

I gdybyż to przynajmniej owo rozróżnianie dwóch światów było oparte na czymś więcej, jak na prostej igraszce słów, jak na ciągłym zestawianiu i przeciwstawianiu wyrazów „aryjskośé” - „turańskośé”, „Aryjezycy” - „Turańczycy”, „słowiańskość” - „moskiewskość”, „Słowianie” - „Moskale” itd.! Wygląda to jak gdyby wariacje na temat legendy o Semie, Chamie i Jafecie, gdzie oczywiście Jafetem zostaje „aryjczyk”, a Chamem „turańczyk” - nomenklatura etnograficzna nie 0 wiele szezęśliwsza od nazwania szlachcica Jafetem, a chłopa Chamem.

Ze wszystkich podań starotestamentowych p. Duchiński umiłował szczegół najwstrętniejszy, szczegót, na który wzdryga się czyste nieskalane uczucie sprawiedliwości, a mianowicie umitował on sobie podanie 0 grzechu pierworodnym i o przekleństwie ciążącym za grzechy ojców na całym ich potomstwie aż do ostatniego pokolenia. Turańczycy, dlatego tylko że Turańczycy, skazani są na wieczne koczownictwo i pasterskość. Dobrze przynajmniej, że fakta zadają oczywisty kłam twierdzeniom p. D-go. Boć przecie Chińczycy, owi „Turańczycy” par excellence, siedzą daleko uporczywiej na ojczystej ziemi i są dale- 
ko pracowitszymi rolnikami aniżeli nadwiślańscy „Aryjezycy” (Ariowie) p. Duchińskiego.

Nasz etnograf głosi ewanielię [sic! - M.S.] miłości wszecharyjskiej i co najmniej obojętności, jeżeli nie nienawiści, Ariów do świata turańskiego. Ponieważ jednak do świata aryjskiego zostają zaliczone wszystkie narody europejskie na zachód od Dniepru i rzeczek Finlandii, więc - mówiąc bez ogródki - chodzi tu po prostu o skonfederowanie całej „Europy” wraz z aryjską Polską celem odepchnięcia na wschód „Moskwy” turańskiej.

Nie mówiąc już o tym, że podobna moralność bardzo przypomina moralność żydowską, dzielącą świat na bliźnich - Żydów i goimów nie-Żydów, albo też moralność Koranu, ściśle rozróżniającą wiernych i giaurów, musimy nadto zauważyé, iż fakta historyczne i spostrzeżenia życiowe nie uprawniają w żaden sposób podobnego jednoczenia wszystkich Ariów w jedną miłującą się nawzajem owczarnię.

Niechaj no p. Duchiński i jego wyznawcy raczą sobie przypomnieć, kto był zawsze największym wrogiem Stowian zachodnich w ogóle, a Polski w szczególności. Zdaje się, że przede wszystkim arcyaryjski i arcychrześcijański zakon krzyżowy i jego germańscy wspótplemieńcy. Kto pierwszy jeszcze w r. 1392 podał projekt rozbioru „aryjskiej” Polski? „Aryjscy” Krzyżacy. Kto zawsze tępił bez litości Polaków, Litwinów i wszystko nieniemieckie, chociaż zresztą nieposzlakowanie „aryjskie”? Królowie, książęta, landraci, żandarmi pruscy - czyści „Ariowie”. Któż to dziś wypędza Polaków - „Ariów” całymi tłumami? „Aryjezyk” Bismarck i jego pachołki germańsko„aryjskie”. A co też to robil ów przyjaciel serdeczny Polaków, „aryjczyk” Napoleon I? Dusił ich żółtą febrą i pomiatał nimi jak zaślepionymi niewolnikami.

Dalej chyba ani p. Duchiński, ani żaden z jego (na szczęście, bardzo nielicznych) wyznawców nie zaprzeczy, że tak Polacy jako też inni „Ariowie” w ogóle, a Słowianie w szczególności, często gęsto wiązali się z Turkami i innymi „Turańczykami”, ażeby tym skuteczniej zgnębić innych braci „Aryjezyków”.

Podobnie wewnątrz samej Rzeczypospolitej „aryjsko”-słowiańsko-polskiej, błogosławionej pamięci Targowica i rozmaitego kalibru jurgieltnicy-„,Ariowie” wstępowali w otwarte związki z wrogami oj- 
czyzny „aryjskiej”, pamiętając jedynie 0 sobie i nie wchodząc w to wcale, czy podający im rękę potentat zagraniczny był „aryjczykiem”, czy też „turańczykiem”. „Aryjsko-słowiańskie” zaś sejmy zrywali chyba zawsze czyści „Ariowie”.

Przesuńmy teraz przed oczyma p. Duchińskiego i jego wyznawców inny kalejdoskopik. Oto od niepamiętnych czasów tępią się Słowianie północno-zachodni, łącząc się przeciwko własnym „braciom” z największymi wrogami - Niemcami. Rozrywka ta trwała dopóty, dopóki prawie wszystkie mniejsze a geograficznie skrajne plemiona nie zostały wytępione albo też zgermanizowane, a to, co pozostało, ulega dotychczas stopniowemu zagrabianiu ze strony Niemców. A tak jedni, jak drudzy, jak trzeci - przecież to tylko „Ariowie” bez najmniejszej domieszki turańskiej.

A może też znowu zechcemy sobie przypomnieć pieszczoty hajdamacko-karmazyńskie XVII i XVIII (po trosze nawet i XIX) wieku; wiekopomne czyny Jeremich Wiśniowieckich, Bohdanów Chmielnickich, starostów kaniowskich, Gontów, Żeleźniaków i całej owej krwi łaknącej zgrai. Zechciejmy nareszcie spojrzeć na „braci” Serbów i Bułgarów, tępiących się obecnie dla sprawienia pociesznego widowiska Europie „aryjsko-chrześcijańskiej”.

Wszystko to były różne przykłady z zakresu miłości plemiennej w łonie świata „aryjsko-słowiańskiego”. Może też inaczej, tj. istotnie miłośnie, przedstawi się owa miłość w zakresie religijnym. Niestety, choćby jedna noc św. Bartłomieja oświeca ten obraz równie krwawym światłem, jak łuny i pożogi wojen międzyplemiennych i międzynarodowych. A wielkie czyny świętej Inkwizycji choćby w jednej ultra„aryjskiej” i ultrachrześcijańskiej Hiszpanii! A wypędzanie bez litości całych sekt znienawidzonych! A choćby np. wygnanie „aryjskich” arianów z granic „aryjskiego” państwa polskiego.

Podobnie rozczulający obraz miłości wszecharyjskiej przedstawiają nam także stosunki społeczne, czyli socjalne, po wszystkie wieki. „Aryjskośc” nie broniła nigdy niewolników od znęcania się nad nimi ich panów, czy to owa niewola przedstawiała się w postaci zwykłych niewolników Grecji i Rzymu, czy też w postaci do ziemi przykutych chłopów, czy to znowu w postaci robotników zgadzających się z głodu na wszelkie warunki dyktowane im przez kapitalistów, czy też 
jeszcze w postaci całych zastępów niższej biurokracji, czy to nareszcie w postaci ofiar temperamentu spotecznego, trzymanych gwattem w domach nierządu i odprzedawanych z rąk do rąk jak za najlepszych czasów. Od podobnej niewoli nigdy nikogo nie broniło, nie broni i bronić nie będzie jak najczystszej krwi pochodzenie „aryjskie”. „Aryjczycy” panowie wieszali sobie dla rozrywki chłopów „aryjczyków”, gwałcili chłopki „aryjki”, stworzyli ius primae noctis ${ }^{1}$, prawo wspólne im i patriarchom gorylów czy też jakiejś innej odmiany naszych krewnych czwororęcznych. Bardzo zaś wymowną ilustracją owej bratniej miłości wszecharyjskiej na tle stosunków socjalnych w łonie tego samego społeczeństwa były rzezie obustronne w czasie Komuny Paryskiej z r. 1871.

Nie mówię już o zaciętych kłótniach w łonie jednej i tej samej rodziny, o rodzonych braciach procesujących się do upadłego i o innych tp. zjawiskach, przypominających widok dwóch psów gryzących się 0 kość, a jednakowo właściwych tak światu „turańskiemu”, jako też „aryjskiemu”. Wszędzie walka, wszędzie wzajemne czyhanie na własność i skórę bliźniego, czyhanie i tępienie się, które mądrość średniowieczna ujęła w wyrażeniu homo homini lupus (człowiek człowiekowi wilkiem). Zresztą w wyrażeniu tym za wiele mieści się zaszczytu dla człowieka, a wilk zostaje niepotrzebnie oszkalowany. Homo homini homo - oto zupełnie dokładne, zgodne z rzeczywistością sformułowanie owej maksymy. Zwierzę o tyle jest wyższym od człowieka, że przy zamachach na inne zwierzę chodzi mu jedynie o zaspokojenie głodu lub innych potrzeb fizycznych. Wilk zje owce, ale nie będzie jej zmuszał do zmiany przekonań, nie będzie jej narzucał swojej wiary, swojego języka, nie będzie jej zmuszał do stania się wilkiem. Jeden samiec zwierzę zdusi drugiego $\mathrm{w}$ walce 0 samicę, ale nie będzie wymagał od pokonanego rywala wyznania, że zwycięzca ma do tego jakieś wyższe prawo, że postąpił sprawiedliwie. A człowiek, czy to „Aryjczyk”, czy „Turańczyk”, tępi swego „bliźniego” dla ideału, dla mrzonek. Tylko między ludźmi spotykają się kanibale moralni i polityczni, domagający się np., ażeby w jednym państwie była tylko jedna narodowość, jedna religia, jeden język.

1 Ius primae noctis (łac.) - prawo pierwszej nocy. 
Jeżeli co odróżnia tu świat „aryjski” od świata „turańskiego”, to może większa obłuda, większa chęć usprawiedliwienia czynów kanibalskich przepisami osobliwej moralności politycznej. I właśnie wynalazek dwóch moralności - jednej prywatnej, a drugiej publicznej - stanowi zaszczytną zdobycz głównie świata „aryjskiego”. Przy ocenie życia prywatnego stosujemy wymagania moralności zwykłej, czy to „przykazania boskie”, czy też wyniki moralności naukowo-praktycznej. Zapytujemy, czy człowiek był uczciwym, czy nie krzywdził innych łudzi, czy jego egoizm nie zacierał w nim popędów altruistycznych itd. Tymczasem przy ocenie czynów mężów występujących na widownię polityczną nie zważamy wcale na podobne fraszki; rzadko też który z podobnych mężów nimi się krępuje. Nawet najzawziętsi możnowładni obrońcy wiary Chrystusowej trzymali się po wszystkie czasy nie ewanielii Chrystusa, ale ewanielii kanibalizmu, którą w naszych czasach najotwarciej głosi „największy mąż stulecia”, nieomylny i wszechmocny książę Bismarck von Schönhausen.

„Rwij, co możesz”, „depcz, co się da”, „niszcz, co ci w drogę włazi”, „siła przed prawem” - oto przykazania i zasady tej wielkich mężów jedynie obowiązującej „moralności” publicznej i międzynarodowej. Tutaj Bismarck okazuje się najdoskonalszym uczniem Kanta, chociaż z pewnością podobnego ucznia ani się spodziewał, ani też pożądał znakomity filozof królewiecki. „Postępuj tak, ażeby z twego postępowania dało się wyciągnąć ogólne prawidło" - tę receptę książę Bismarck stosuje z doskonałym skutkiem. Nigdy bowiem chyba nie było jeszcze „tylu przedsiębiorców” na wielką i małą skalę, którzy, spełniając największe gwałty i bezprawia, nie powoływaliby się otwarcie na przykład „wielkiego męża” i ewanielią kanibalizmu nie usprawiedliwialiby swoich „śmiałych” i „bohaterskich” czynów.

Z powyższego aż nadto jest widocznym, że p. Duchiński wybrał się bardzo nie w porę z kazaniami na temat miłości wszecharyjskiej w ogóle, a wszechsłowiańskiej w szczególności. Mógł on sobie oszczędzić zupełnie rozmaitych naciągań i przekręcań. Mógł nie poświęcać prawdy na ołtarzu miłości; mógł nie zaliczać do „Aryjezyków” takich „Turańczyków” oczywistych, jak Węgrzy i Finowie; mógł nie rozwodzić się nad wielkim znaczeniem Węgrów i Basków dla cywilizacji europejskiej. 
A jednakże wywody p. Duchińskiego brano na serio w świecie uczonym Europy Zachodniej. Przecież potrafit on nie tylko „przekonać”, ale nawet sfanatyzować dla swej „teorii” Henri Martina oraz innych „poważnych uczonych” francuskich, niemieckich itd. Dowodzi to tylko, w jak mizernym stanie znajduje się jeszcze metoda nauk historyeznych.

W tym, co dotychczas powiedziałem, dotknąłem z lekka i powierzchownie „teorii” p. Duchińskiego samej w sobie. Przypatrzmy się teraz jej praktyeznym rezultatom, jej wpływowi na umysły, na postępowanie i na losy rodaków jej twórcy.

Od chwili ostatecznego upadku politycznego w końcu przeszłego wieku, pozbawionym wielu innych organów samodzielnego życia publicznego Polakom pozostawała jednakże nauka jako jedna z niezaprzeczonych rękojmi i dźwigni sity narodowej. Na polu naukowym nikt nie mógł zabronić pracować, dążyć do prawdy i odkryé, bez żadnych przekręcań, naciągań i tendencji. Wielka więc odpowiedzialność ciążyła na polskich uczonych, odpowiedzialność jeszcze większa aniżeli u innych narodów, cieszących się odrębnością państwową. Z drugiej strony Polacy znajdują się o tyle w „szezęśliwszym” położeniu niż inne narody, że, byle tylko pozbyli się pretensji do niemożliwej restauracji tego, co zostało straconym, mogą być bezstronniejsi, mogą wyłącznie dążyé do prawdy.

U innych narodów politykujących stoją na czele wielcy męże uprawiający na wielką skalę kanibalizm polityczny, a zgraja psujących bibułę fagasów uczonych w rodzaju filozofa Hartmanna staje na tylnych łapkach, ogonem kręci, w oczy wielkim mężom patrzy, podsłuchuje ich, stara się zrozumieć każde ich skinienie i „ze stanowiska naukowego" usprawiedliwić wszystkie gwałty kanibalów. Bismarck powie Macht vor Recht (siła przed prawem), a z tego usłużni uczeni kują nie tylko prawo naukowe walki 0 byt, ale postulat moralności, zasadę działania.

Polacy nie mogą mieć swoich Bismarcków; nie powinni też mieć swoich Hartmannów, nie powinni mieć uczonych fagasów piejących chwatę bądź to Napoleona III, bądź też Bismarcka. Polacy nie mogą się bawić w grande nation, więc też i szowinizm polityczny powinien im być obcym. Wszędzie jest on wstrętnym, ale, opierając się na ar- 
matach i bagnetach, ma przynajmniej realną podstawę. Szowinizm, szukający podstawy jedynie w przeszłości i w chorobliwych utworach wyobraźni, jest tylko głupi i wstrętny.

Nie tylko nad rozwinięciem podobnego szowinizmu, ale także w ogóle nad zaślepieniem Polaków i przewracaniem im w głowach pracowali - prawdopodobnie nieświadomie - p. Duchiński i jego zwolennicy naukowi.

Już samo narzucenie Dnieprowi i rzeczkom Finlandii roli granic między Europą Wschodnią i Zachodnią - podział nieusprawiedliwiony ani geograficznie, ani historycznie - nie mogło się zbyt przyczynić do rozjaśnienia umysłów i oczyszczenia pojęć geograficznych. 0 ileż szkodliwiej działał na umysły ów brak wszelkiej krytyki i owa nuta zaciekłości politycznej, przenikająca wszystkie utwory p. Duchińskiego!

Pamiętam doskonale, z jakim to nabożeństwem wymawiała szkolna młodzież polska w r. 1861-1863 nazwisko Duchińskiego, a z jaką znowu nienawiścią i pogardą dla pochodzenia „turańskiego" ta sama młodzież (naturalnie nie wszyscy Polacy uczący się, ale znaczny ich procent) wyrzucała z siebie nazwy Bogu ducha winnych Czeremisów, Czuwaszów, Mordwy, Mieszczeriaków, Baszkirów itd., piętnując nimi Wielkorusów; w najwyższym zaś stopniu uniesienia patriotycznego utożsamiano Wielkorusów z Mongołami.

0 krytyce mowy tu być nie mogło. Mózgownice karmione nienawiścią brały na wiarę wszystko, co tylko podsycało tę nienawiść; a jakiż argument mógł się ostać przed autorytetem Duchińskiego w owe czasy, kiedy lada artykuł z „Daily News” lub „Journal des Débats”, odzywający się sympatycznie o Polakach, powtarzano z namaszczeniem, przepisywano, wyuczano się na pamięć - w owe czasy, kiedy lada wierszydło, obrzucające błotem prawdziwych lub mniemanych wrogów Polski, połykano z chciwością i deklamowano na prawo i na lewo, w owe czasy arlekinady, czasy „przebierania się za Polaków” i bawienia się w żołnierzy, w owe czasy, kiedy kilkunastoletnim malcom oddano rządy, a ci, co zupełnie prawnie mogli byli stać na czele, pochowali się po kątach, drżąc przed lada smykiem, śmiało im wymyślającym! 
P. Duchiński należał do tych ludzi, co w ciągu wielu lat pracowali nad ogłupianiem inteligencji polskiej, nad zawracaniem jej głowy, nad mydleniem jej oczu, nad odwracaniem uwagi od rzeczy niezbędnych i istotnych, a zwracaniem jej na mrzonki; skutkiem czego było bawienie się w halucynacje polityczne, a następnie tracenie sił na żebraninę 0 „interwencję”, na narzucanie się ze swą „aryjskością" dla sformowania krucjaty przeciwko Rosji w celu odbudowania starej Rzeczypospolitej, która dawniej, będąc obszerną i ludną, sama o własnych siłach nie potrafiła się utrzymać. Skutkiem tego wszystkiego była wreszcie sama w sobie bezcelowa awantura polityczna, mająca jedynie na celu za pomocą „męczeństw” wywołanie litości w Napoleonach i innych szarlatanach politycznych i sprowadzenie ich wskrzeszającej „interwencji”, i to wszystko kiedy? Wtedy właśnie, kiedy dane były wszelkie warunki po temu, ażeby się swobodnie, wszechstronnie po polsku rozwijać1.

Pamiętam, jak w dzieciństwie bawiłem się w przerabianie karty Europy, kierując się naturalnie sympatiami i antypatiami narodowymi. Polska, rozumie się, rozciągała się od morza do morza, ogarniając ujścia nie tylko Dniepru, ale nawet i Donu. Za to jej sąsiadom dostały się jakieś okrawki, na których zaledwie jako tako wegetować by mogli. Była to sobie niewinna zabawka dziecinna, podobnie jak zamki z kart itp. ćwiczenia. Ale dla ludzi dorosłych podobne bawienie się mrzonkami, podobne fantastyczne przerabianie rzeczywistości - to doprawdy zbyt szkodliwa zabawka. Obłąkany Don Kichot mógł brać swoje przywidzenia za rzeczywistość i, wprowadzając je w czyn, porywać się z włócznią na wiatrak albo z motyką na słońce. Ale jeżeli coś podobnego robi inteligentna warstwa narodu, to może być objaśnione tylko jej obłąkaniem. A nad rozwinięciem podtrzymaniem tego obłąkania pracował gorliwie pewien zastęp ludzi piszących, w ich liczbie p. Duchiński.

Pomijając utylitaryzm polityczny, nie można nie zwrócić uwagi na szkodliwy wpływ moralny podobnych „teorii”. Czyż może wpływać uszlachetniająco i umoralniająco chroniczne zacietrzewienie, ślepa nienawiść plemienna, zastąpienie analizy obelżywymi słowy

$1 \quad$ Mowa tu o polityce Aleksandra Wielopolskiego i uzyskiwanych przez niego od cara koncesjach dla Królestwa Polskiego. 
(carat, Moskwa, Moskale itp.)? Odbicie tego roznamiętnienia pod tym samym kątem nie długo kazało na siebie czekać. Przede wszystkim wywołało ono systematyczną krucjatę kanibalistyczną gazet rosyjskich przeciwko Polakom, a następnie różne środki praktyczne, podyktowane głównie przez nienawiść. W ten sposób zostało rozpoczęte szczucie Polaków (Polenhetze) ${ }^{1}$, równie wstrętne jak wszelkie tego rodzaju szczucia, Judenhetzen, Deutschenhetzen, Slawenhetzen, itd., ale w skutkach potężne i przynoszące gorzkie owoce dla szczutego plemienia.

Niemniej szkodliwym pod względem moralnym było owo przewracające w głowach powoływanie się na prawa „aryjskości”, na prawa pochodzenia arystokratycznego Polaków. Jest to wstrętny arystokratyzm plemienny, skazujący na barbarzyństwo jedynie za niższe, „niearyjskie”, pochodzenie całe plemiona i gromady plemion. Podobnie jak, według niektórych dawniejszych antropologów północnoamerykańskich, Murzyni jako tacy powinni byé skazani na wieczne niewolnictwo, tak samo, według p. D-go, różne pochodzenie, „aryjskie” lub „turańskie”, wznosi między Indami Europy Zachodniej i Wschodniej niczym nieprzełamaną przegrodę. Przy tej sposobności popełnia p. D. małą niekonsekwencję. Rozwodząc się bowiem nad wielkim znaczeniem Madziarów i Basków dla cywilizacji aryjsko-europejskiej, zalicza tym samym tak jednych, jak drugich do wybranego plemienia „Ariów”. Ze stanowiska p. D-go było to bardzo zrozumiałe. Jakżeż bowiem inaczej można było utrzymać nienaruszonym przysłowie Polak Wegier - dwa bratanki itd.? A prócz tego szlachta węgierska, dziś w Austrii rej wodząca, miała zawsze niepoślednie znaczenie w monarchii Habsburgów, której udział w koncercie arioeuropejskim, mającym wskrzeszać Polskę, wydawał się p. D-mu nieuniknionym. Co się zaś tyczy Basków, to przypisano im wielkie zasługi dla cywilizacji europejskiej i zaliczono ich do wielkiej rodziny aryjskiej chyba jedynie dla przyzwoitości i dla okrągłości. Tymczasem należało byé właściwie konsekwentnym i wszystkich nie-,Ariów”, a więc Węgrów, Finów, Basków, wyrzucić z Europy Zachodniej za Dniepr i rzeczki Finlandii.

1 Polenhetze (niem.) - nagonka na Polaków; dalej: nagonka na Żydów, na Niemców, na Słowian. 
Powołując się w literaturze i na dworach europejskich na swoją „aryjskość” dającą sama z siebie prawo do niezawisłości politycznej, Polacy tej kategorii robili wrażenie żebraków-panów albo też pasożytniczej młodzieży złotej, eo ipso roszczącej sobie prawo do zajmowania pierwszorzędnych stanowisk. Poza tym zapominano 0 „prawach” ludzkich, zapominano, że każdy człowiek, czy to „aryjczyk”, czy „turańczyk”, ma prawo wymagać, ażeby szanowano jego język, jego zwyczaje, jego przekonania, jego religie (w najobszerniejszym znaczeniu tego wyrazu), ażeby się nie wdzierano do jego spraw rodzinnych, żeby nie kazano mu umierać z głodu, ażeby, na odwrót, nie zakazywano mu oddychać, ruszać się swobodnie, mówić i pisać językiem ojczystym. Zapominano o najpierwszej zasadzie pedagogicznej, że każde, czy to „aryjskie”, czy „turańskie” dziecko ma prawo do tego, ażeby mu nie bałamucono głowy i ażeby je przede wszystkim uczono we własnym jego języku. Powoływano się ciągle na prawa szlacheckie do panowania w granicach 1772 r., w owych granicach, których prywata i jurgieltnictwo w swoim czasie obronić nie mogły, a lekceważono sobie prawa ludzkie, które można gwałcić bezkarnie, ale których żaden umysł niespodlony zaprzeczyć nie jest w stanie.

Szkodliwe skutki praktyezno-polityezne halucynacji politycznych trwają dotychczas i długo jeszcze trwać będą. Rozpoczęły się one od stłumienia awantury politycznej i od prześladowania plemienia polskiego jedynie tylko za jego polskość. Wtedy to inaugurowany został nowy period... mimowolnego „koczownictwa” Polaków. Część ich musiała wbrew woli przyjąć udział w zaludnianiu obszarów „turańskich”, het daleko za Dnieprem i Dźwiną. Inni schronili się na zachód pod skrzydła opiekuńczej Europy. Inni, nawet nienapiętnowani żadnym grzechem osobistym, jedynie dla swego grzechu pierworodnego muszą szukać chleba po wszystkich obcych kątach, bo go u siebie, na własnej ziemi znaleźć nie mogą. Jeszcze w roku bieżącym rozpoczęto nową serię mimowolnego „koczownictwa” Polaków, z łaski wszechmogącego Bismarcka ${ }^{1}$. Wszystkich tych koczownictw nie było-

1 Mowa o tzw. rugach pruskich, tj. o usuwaniu z terenów państwa pruskiego Polaków, którzy przybyli tam z innych zaborów, poszukując pracy, co miało miejsce w 1885 r. i objęło ok. 26 tys. osób. 
by, gdyby nie rozmaite w głowach zawracające „teorie”, wychodzące od lat kilkudziesięciu właśnie z obozu owych zachodnioeuropejskich koczowników polskich. Z dala od ziemi ojczystej, nie pojmowali jej potrzeb, bawiąc się tylko w przeprowadzanie swych mrzonek i wiele szkody wyrządzając krajowi.

Do tego obozu należał także p. Duchiński. I jego ręka pracowała nad spychaniem kraju w coraz większą przepaść. Że jednak pracowała nieświadomie i w najlepszej wierze, więc nikt też jej za to nic potępia. Zaślepienie patriotyezne oraz najezystsza bezinteresowność zupełnie wykupują, ze stanowiska odpowiedzialności moralnej, wszystkie błędy emigrantów. Ale uwolnienie od odpowiedzialności moralnej i składanie hołdów w imieniu narodu - to jeszcze dwie rzeczy zupełnie różne.

P. Duchińskiego osobiście usprawiedliwia jeszcze ta okoliczność, że „teorie” podobne do jego teorii były i są głoszone uroczyście w „Europie Wschodniej” i cieszą się tam uznaniem niektórych uczonych, profesorów itp. Są to „teorie” wynalazców szóstej części świata - Rosji, zaliczanych zwykle, choć niezbyt chyba słusznie, do tak zwanych „sławianofilów”, bo z tego, co piszą, wyglądających nieraz raczej na sławianożerców. Należy tylko przesunąć cokolwiek granice ze wschodu na zachód oraz zrobić małe odmiany w nomenklaturze etnograficzno-geograficznej, a w uczonych wywodach tej „szkoły” „panslawistycznej” łatwo będzie odkryć zmodyfikowaną „teorię” p. Duchińskiego.

Obie „szkoły”, tak Duchińszezycy, jako też owa grupa „sławianofilów”, dają nowy podział świata. Tylko duchińszczycy ograniczają się skromniejszą nomenklaturą, rozróżniając jedynie Europę Zachodnią i Wschodnią i robiąc Dniepr, Dźwinę i „rzeczki Finlandii” liniami granicznymi między tymi dwiema połowami naszej części świata. Owi zaś „sławianofile” sławianożerczy nie są weale tak skromni. Odkrywają oni bowiem całą szóstą częśc świata, a mianowicie Rosję, w przeciwstawieniu do Europy i Azji. Granicę zachodnią tej nowej części świata ma stanowić linia, poprowadzona od Gdańska do Triestu. Co leży na wschód od tej linii, a nie zostało jeszcze politycznie wcielone do Rosji, to tylko czasowo znajduje się w ręku zgniłej Euro- 
py, z czasem zaś musi, chcąc nie chcąc, należeć do owej szóstej części świata.

„Teoria” p. Duchińskiego została opartą na wspomnieniach przeszłości, na mrzonkach fantastycznych i na przeświadczeniu o wysokim posłannictwie cywilizacyjnym Polaków. Wynalazcy szóstej części świata opierają także swoją „teorię” na utworach fantazji, jak również na przeświadczeniu o wysokim posłannictwie cywilizacyjnym Słowian w ogóle, a Rosji w szczególności, oraz na bucie wielkopańskiej osobników czujących za plecami siłę państwową, armaty i bagnety; a na takim tle nawet największy nonsens daleko poważniej wygląda. Tymczasem za plecami p. Duchińskiego stała tylko garstka zapaleńców i żebraków politycznych. Toteż jego „teoria” sprawia daleko mizerniejsze wrażenie.

Na Greków, Albańczyków, Rumunów, Finów, Węgrów (Madziarów) itd. oba obozy są jednakowo łaskawe: jedni robią z nich „zachodnioeuropejczyków”, drudzy „Słowian” (przynajmniej Słowian politycznych, jeżeli nie etnograficznych). Duchińszczycy, przyjmując daleko szerszą rodzinę ludów, a mianowicie rodzinę „aryjsko-europejską", nie mają z Grekami, Albańczykami i Rumunami żadnego ambarasu; przecież te ludy i z języka należą do rodziny ario-europejskiej. Pozostaje więc tylko wtłoczyć w formy „aryjskości” Węgrów i Finów. „Słowianofile” wzmiankowanej „szkoły”, opierając się na wyłączności słowiańskiej, mają cokolwiek więcej kłopotu; starają się więc przekonać ludy niesłowiańskie mieszkające na wschód od linii Gdańsk-Triest, że być Słowianinem to bardzo wielki zaszczyt. Tylko o Niemcach tutaj osiedlonych jakoś niewiele wspominają. „Resztki” Niemców osiadłych na wschód od linii Gdańsk-Triest zostaną zapewne wysłane do Kamerunu, ażeby nie psuć ogólnej harmonii słowiańskiej.

„Sławianofile” tej kategorii, coraz to liczniejszej, uznają w szóstej części świata tylko jedną jedyną narodowość (национальность), zgadzając się wspaniałomyślnie tylko na istnienie różnych odrębności plemiennych (народностей) - i to właśnie ma stanowić osobliwość szóstej części świata. Tak to będzie kiedyś, a mianowicie, kiedy na jawie zobacza wnuki to, co sie ojcom śnito. Tymczasem należy twierdzić, że w jednym państwie jest możliwą i dopuszczalną tylko jedna 
narodowość, a więc w Austrii - narodowość austriacka, w Turcji turecka, w Belgii belgijska, w Szwajcarii szwajcarska, w Ameryce Północnej amerykańska, w Serbii serbska, w Czarnogórzu czarnogórska itd. Jest to istotnie stanowisko nieposzlakowanie prawomyślne i zgodne z istniejącymi urządzeniami. Tylko przy tej sposobności panowie ci znajdują się w maleńkiej sprzeczności z samymi sobą. Przyjmując bowiem za granicę zachodnią narodowości słowiańsko-ruskiej linię od Gdańska do Triestu, nie moga chyba z tym pogodzić nietykalności Austrii z narodowością austriacką, Turcji z narodowością turecką, Rumunii z narodowością rumuńską, Grecji z narodowością grecką, Serbii z narodowością serbską itd. Ale bo też w umysłach, zamierzających wprowadzać na obcym gruncie austriackim prawo 19 lutego (2 marca) 1864 r. (ukaz Aleksandra II o uwłaszczeniu włościan w Królestwie Polakiem) ${ }^{1}$, sprzeczności tego rodzaju muszą się godzić z wielką łatwością. P. Duchiński jest 0 tyle łaskawszy, że w swojej Europie Zachodniej uznaje różne narodowości. Tylko na wschodnim krańcu tej Europy Zachodniej ma istnieć jedna nierozdzielna narodowość polityczna, tj. narodowość polska, obejmująca w sobie Polskę, Litwę i Ruś - stosownie do dziedzicznej recepty. Różnica więc dwóch teorii polega na tym, że „słowianofile” wzmiankowanej grupy opierają się na obecnych urządzeniach polityczno-administracyjnych oraz na coraz hardziej rosnącym apetycie aneksyjnym, czyli zaborczym, p. Duchiński zaś na przeszłości fantastycznej i na przyszłości jeszcze fantastyczniejszej.

P. Duchiński stoi o tyle wyżej, że u niego ludy europejskie nie wyprawiają szprynców ${ }^{2}$ horyzontalnych i wertykalnych, gdy tymczasem podobne ćwiczenia ekwilibrystyczne miewają miejsce w dziełach wychodzących z obozu wynalazców szóstej części świata³

Zob. „Объ историческомъ изученіи греко-славянскаго міра въ Европ?. Изслђдованіе Владиміра Ламанскаго, С.-Петрбургъ 1871”, str. 41 [przyp. BdC].

2 Szprynce - podskoki

${ }^{3}$ Ażeby mnie nie posądzano 0 przesadę albo może nawet 0 fałszywe świadectwo przeciwko bliźniemu swemu, przytaczam dosłownie odnośne miejsca z jednego z obszernych dzieł wzmiankowanego wyżej obozu, a mianowicie z rozprawy doktorskiej „Объ историческомъ изученіи 
Tak jedni, jak drudzy byli szkodliwi swojemu społeczeństwu. Ale odpowiedzialność Duchińskiego i jego zwolenników - gdyby postępowali świadomie - byłaby daleko większą; szkodzili oni bowiem swojemu społeczeństwu nie tylko umysłowo i moralnie, ale także pod względem praktyczno-politycznym. „Słowianofile” zaś słowianożerczy psuli swoje społeczeństwo tylko umysłowo i moralnie, pracując

греко-славянскаго міра въ Европе. Изследованіе Владиміра Ламанскаго. С.-Петрбургъ 1871", (str. IV i 316). 0tóż na str. 9 czytamy: „Сь техь порь все вертикальныл и горизонтальныл столкновенія внутри Романо-Германскаго міра всегда бывали войнами внутренними, междоо-усобными, и, ослабляя Европу, были полезны Россіи и вообще міру Греко-Славянскому”. Na str. 15: „въ продолэкеніе всей средней и новой исторіи христіанско-Арійскаго человечества взаимныя отношенія Греко-Славянской и Романо-Германской ихъ половинъ, запечатлены гораздо более всемірноисторическимъ характеромъ, чемъ все народныл движенія и столкновенія, совершавшіяся какъ въ пределахь Романо-Германскаго, такъ и въ пределахь Греко-Славянскаго міра, и въ горизонтальномъ, и въ вертикальномъ напраленіи". Na str. 29-30: „Народныия движкенія и столкновенія въ среде РоманоГерманскаго міра, какъ въ вертикальномъ, такъ и въ горизонтальномъ направленіи, не отличаются глубиною и силою той взаимной племенной вражды, такимъ ожесточеніемъ той тыссячелетней слишкомъ борьбы, которая, по своему внутреннему историческому значенію и по своимъ результатамъ, во столько жее важнее всякой внутренней борьбы, происходившей въ границахъ Романо-Германскаго запада, во сколько современный восточный вопрось превышаеть своимъ значеніемъ все другіе, чисто-западные политическіе вопрось.”. Na str. 30: „Hе таковъ также въ идее и въ результатахъ тотъ внутренній антагонизмъ, который раскрывается въ народныхъ двиюееніяхь и столкновеніяххь, вертикальныхъ и горизонтальныхъ, происходящихь въ тоже время въ пределахь міра Греко-Славянскаго, т.е. въ борьбе и войнахь юэнныхъ Славянь съ Греками, Албанцами, Угріи съ Поляками и Русскими, Чеховъ и Поляковъ или Болгаръ и Сербовъ, Сербовъ и Хорватовъ, Угріи и Чехіи, северовосточной и югозападной Руси и Литвы, Москвы, Россіи и Польши" [przyp. BdeC]. 
nad ogłupianiem czytającego ludku i rozwijając w nim dzikie instynkta, instynkta nienawiści i kanibalizmu politycznego.

W każdym razie po porównaniu z „teorią” szóstej czesści świata blednie niepospolicie dziwactwo i szowinizm „teorii” p. Duchińskiego. Być nawet może, iż w zakresie nauk etnograficznych tylko takie „teorie” wyrabiały rozgłos w świecie swoim twórcom, a przez nich narodom, które ich wydały. Czy więc czasem p. Duchiński nie wsławił imienia polskiego między narodami? Jeżeli zaś wsławił, to należy mu się wdzięczność, a jako znak widzialny niewidzialnej wdzięczności - jubileusz. Tak, istotnie, wsławiał on jakiś czas imię polskie, ale też je zarazem ośmieszał i kompromitował - naturalnie w oczach ludzi trzeźwo i krytycznie na rzeczy patrzących.

Można by jednak zapytać, dlaczego by w czasach, w których lada zręczny skoczek albo też jaki mąż z gardłem rzemiennym, czarującym gości teatralnych, wyrasta na bohatera narodowego, dlaczego by w podobnych czasach nie wyprawić owacji publicznej mężowi, który rozsławiał imię swego narodu pracą na polu nauki? Zapewne na pozór nie ma nic przeciw temu do powiedzenia. Ale czyny tenora są nieszkodliwe dla bytu narodowego; głupieje od nich wprawdzie ludek boży, lecz na krótko, a psuje sobie co najwięcej gardła wykrzykujące „brawo”, otłuka sobie ręce klaszczące i wypróżnia kieszenie. Do awantur politycznych zapał tenorowy nie poprowadzi. Tymczasem wpływ takich „teorii”, jak „teoria” p. Duchińskiego, jest wprost i to na długo szkodliwy.

Jak już wyżej widzieliśmy, p. Duchiński użył swej wielkiej uczoności na złe, na skrzywienie prawdy i na zaślepianie umysłów swoich ziomków. Z drugiej atoli strony widzieliśmy także, że, znajdując się w stanie chronicznego afektu, opanowany przeważnie przez szowinizm narodowy i nienawiść plemienną, p. Duchiński nie dał z pewnością dowodu złej woli i nie może być za swą „teorię” potępiany.

Jubileusz narodowy p. Duchińskiego byłby po prostu jubileuszem chronicznego obłędu patriotycznego.

Dorpat, listopad $1885 \mathrm{r}$.

[Nakładem autora. Kraków 1886] 


\section{AUTONOMIA POLSKI}

\section{Odczyt wygłoszony \\ w sali Muzeum Techniczno-Przemystowego w Krakowie 9 lipca 1906 roku}

Dzięki Japończykom czasy się ogromnie zmieniły¹. Dziś mówimy śmiało o zupełnym równouprawnieniu, żądamy autonomii. A jeszcze nie tak dawno wszechwładny cenzor wykreślał starannie wszelką wzmiankę o równouprawnieniu, o jakiejś zaś autonomii nawet marzyć się nie ośmielano. Szczytem marzeń było uzyskanie pewnych drobnych ulg, w rodzaju wykładania po polsku nauki religii i języka polskiego. Dziś żądamy i domagamy się, a dawniej musieliśmy się zadawalniać żebraniną i wycieraniem kątów w przedpokojach ministrów i innych dostojników.

Ze wszech stron sypią się potępienia na byłą „ugodę” i byłych „ugodowców”. Jest to wielka niesprawiedliwość. Dziś, kiedy nawet zające buńczuczą się i pozują na bohaterów, łatwo jest traktować pogardliwie usitowania „ugodowców”. Jeżeli jednak przeniesiemy się w niezbyt odległe czasy, kiedy śmiało można było występować tylko w charakterze nielegalnego spiskowca, a wszelka jawna działalność obywatelska była niemożebną, musimy wyrazić uznanie dla tych ludzi, co narażali się na upokorzenia i poniżenie godności osobistej, byle tylko wytargować coś dla swego społeczeństwa.

Zresztą żebraninę i nadskakiwanie ministrom uprawiali nie sami tylko ,ugodowcy”. Metodę tę przejęli od nich ci, co na nich teraz może najgłośniejsze gromy rzucają.

Na początku listopada roku zeszłego, a więc wtedy, kiedy „ugodowcy" przestali już stanowczo wchodzić w jakiekolwiek układy z rządem rosyjskim, zjawił się w Petersburgu dość liczny zastęp przewódców jednej z najwpływowszych partii polskich, ażeby, opierając się na zasięgniętych informacjach, wytargować u hr. Wittego „auto-

1 Mowa o skutkach, zwłaszcza dla sytuacji wewnętrznej Rosji, przegranej przez nią wojny z Japonią. 
nomię Polski”. Niestety, panów tych zaskoczyło w Petersburgu ogłoszenie stanu wojennego w Królestwie Polskim. Pod wrażeniem tego krzyczącego bezprawia rządu rosyjskiego zdecydowano nieznaczną większością głosów zaniechać rokowań z rządem rosyjskim i wyjechano z Petersburga. Pozostał tam jednak jeden z głównych leaderów owej partii, a ten na własną rękę postanowił próbować szczęścia. Wyjednał on sobie audiencję u Wittego i po dość długim wstępie oświadczył mu, że w razie jeżeli rząd obdarzy Królestwo Polskie autonomią i nada językowi polskiemu należne mu prawa, partia wraz z innymi żywiołami konserwatywnymi obowiązuje się stłumić rewolucję w Polsce. Propozycja ta nadzwyczaj się podobała p. Wittemu. Oświadczył on, że tak rozumne traktowanie sprawy zasługuje na uznanie, że układ ten zostaje przezeń zaakceptowany, ale że to prywatne oświadczenie leadera musi być poparte przez grono ludzi z nim jednomyślnych, którzy gremialnie, w towarzystwie hr. Wittego, złożą podobne oświadczenie samemu cesarzowi. Warunek ten nawet naszemu wielkiemu politykowi wydał się za ostrym, a tak szczęśliwie rozpoczęte układy spełzły na niczym.

A propozycja ta wyszła nie od „ugodowców” i wyszła już po ogłoszeniu manifestu 17/30 października r. $1905^{1}$ i zainaugurowaniu przezeń krwawej „konstytucji” rosyjskiej.

Sądzę, że już po 9/22 stycznia r. $1905^{2}$ wszelkie konszachty z dotychczasowym rządem rosyjskim byłyby rzeczą szpetną i hańbiącą.

Dziś można się porozumiewać wyłącznie tylko z Dumą jako z parlamentem rosyjskim, jako z jedynym ciałem prawodawczym i rozstrzygającym. Ale jeżeli wszelkie umowy w „sprawie polskiej” sprowadzamy do porozumiewania się z parlamentem rosyjskim, musimy się przede wszystkim zapytać:

Kto z kim się tu umawia?

1 W manifeście tym, wydanym w sytuacji rewolucyjnych wystąpień w Rosji, Mikołaj II zapowiadał obdarzenie społeczeństwa niewzruszonymi swobodami obywatelskimi oraz zwołanie Dumy, która miałaby kompetencje ustawodaweze.

2 Mowa o petersburskiej „krwawej niedzieli”. 
Czy jakaś niby zwierzchność w osobie przedstawicieli panującego narodu rosyjskiego ze swoimi podwładnymi w osobie przedstawicieli poddanego narodu polskiego?

Weale nie. Układają się i umawiają się równi z równymi, wszyscy jednakowo zainteresowani w utrzymaniu całości państwowej i w uspokojeniu wzburzonego morza społecznego.

Autonomia Polski nie może być przez nikogo narzuconą bez zgody przedstawicieli tego kraju. Nadanie autonomii Królestwu Polskiemu nie jest wcale łaską, nie jest jakimś datkiem, ale jest wynikiem istotnej potrzeby całego państwa i wieloplemiennego społeczeństwa.

Ale przy umawianiu się i przy układaniu warunków autonomii niezbędną jest rzeczą, ażeby obie strony umawiające się przemawiały wspólnym językiem. Mam tu na myśli nie „wspólny język” w ścisłym znaczeniu tego wyrazu, ale tylko wspólny pogląd zasadniczy i jednakowy punkt wyjścia.

Dotychczas obie strony umawiające się przemawiają różnymi językami, a objaśnia się to różną genezą, różnym sposobem powstania tych stron umawiających się.

Ażeby to zrozumieć, dosyć jest sobie uprzytomnić historię wyborów z jednej strony w Rosji centralnej, z drugiej zaś strony w Królestwie Polskim. W Rosji przy wyborach otrzymała przewagę Partia Konstytucyjno-Demokratyczna, czyli Partia Wolności Ludu (KD), w Polsce zaś wyszła z urn wyborczych partia narodowo-demokratyczna (ND). Ten różny wynik objaśnia się warunkami miejscowymi.

Przede wszystkim mamy różne przesyłki (premisy) historyczne w obu tych częściach państwa. Wprawdzie w całym państwie panowały samowola, ucisk i bezprawie, ale rdzenna Rosja wolną była od ucisku narodowego. Przeciwnie, narodowość wielkoruska była szczególnie uprzywilejowaną, a przedstawicieli inteligencji rosyjskiej i w ogóle narodu rosyjskiego lub też osób podszywających się pod rosyjskość używano za narzędzia do bezwzględnej zbrodniczej rusyfikacji.

Gdzie przestępstwem było przemówienie w języku ojezystym, gdzie młodzież uwalniano ze szkó za czytywanie książek polskich albo też za korespondowanie z rodzicami we własnym języku, tam oczywiście musiało się rozwinąć przeczulenie narodowe, musiał się 
rozróść bujnie chwast szowinizmu zwracającego się nie tylko przeciw gnębicielom, ale także przeciw innym gnębionym. Co do tego ostatniego prądu, narodowi demokraci mogą się powoływać na przykład rusyfikatorów, chociaż podobny przykład nikogo nie usprawiedliwia. Żaden przestępca nie ma prawa usprawiedliwiać się zbrodnią popełnianą przez kogo innego.

Do tego dziedzictwa przeszłości należy dodać niezwykłe warunki dzisiejszego napięcia rewolucyjnego, które w Królestwie Polskim przybrało przy wyborach do Dumy charakter nierównie mniej pomyślny dla żywiołów postępowych aniżeli w innych dzielnicach państwa rosyjskiego.

W każdym razie taktyka partii, która zwyciężyła przy wyborach w Królestwie Polskim, była pod względem etycznym nierównie niższą od taktyki partii, która w samej Rosji otrzymała przewagę. Partia Konstytucyjno-Demokratyczna ani jednego razu nie splamiła się szczuciem na jakiekolwiek bądź narodowości lub wyznania, nie zhańbiła się odezwami antysemickimi.

Należy zaznaczyć fakt, że z sześciu przedstawicieli Petersburga jednym jest Polak, profesor Petrażycki, drugim zaś Polak-Żyd, adwokat Winawer. W Moskwie pomiędzy czterema jej przedstawicielami przeszedł Żyd, profesor Herzenstein. A wszyscy ci nie-Rosjanie zostali wybrani nie ze względów narodowościowych lub wyznaniowych, ale po prostu jako dzielni ludzie, jako wybitni członkowie partii. W działalności bowiem partii konstytucyjno-demokratycznej względy narodowościowe lub wyznaniowe nie grały, jako czynnik agitacyjny, żadnej roli, a przy stawianiu kandydatury tego lub owego osobnika zwracano uwage jedynie na jego zasługi obywatelskie.

Nic tedy dziwnego, że pierwszemu spotkaniu się przedstawicieli Królestwa Polskiego z przedstawicielami innych części państwa towarzyszyły pewne podejrzenia i uprzedzenia, a nawet, zwłaszcza ze strony posłów wyszłych z łona polskiej partii narodowo-demokratycznej, można było skonstatować pewną nieufność i nieszczerość, w dzisiejszych warunkach rosyjskiego życia parlamentarnego całkiem niewłaściwą.

Miejmy jednak nadzieję, że, pod wpływem ogółu Dumy, rozbierając i decydując solidarnie wspólne sprawy, przedstawiciele naro- 
dowej demokracji z Królestwa Polskiego pozbędą się całkowicie swej zaściankowości, utemperują się, dojrzeją politycznie, tj. dostroją się do ogólnego tonu chwili obecnej. W każdym zaś razie Koło Polskie w Petersburgu nie stanie się reakcyjnym i klerykalnym i nie pójdzie za przykładem kół polskich w Wiedniu i w Berlinie, idących ręka w rękę ze wstecznikami przeciw dążnościom postępowym i demokratycznym.

Wracam do poprzednio postawionego pytania: kto będzie się umawiał w Dumie Państwowej w sprawie autonomii Królestwa Polskiego?

Czy będzie to powtórzeniem ugody austriacko-węgierskiej z r. 1867, kiedy to „naród-gospodarz” Cyslejtanii ${ }^{1}$ umawiał się z „narodem-gospodarzem” Węgier? „Naród-gospodarz” - czytaj: oligarchowie i biurokraci, zaliczający siebie do tego narodu.

Otóż podobne postawienie i podobne załatwienie kwestii jest $\mathrm{w}$ danym razie całkiem niemożliwe.

Jak nie może być mowy o samowładztwie i wspaniałomyślności narodu rosyjskiego w całej Rosji, tak też nie może byé mowy o samowładztwie i wspaniałomyślności narodu polskiego w Polsce. Nie może też być mowy o dzieleniu narodów zamieszkujących państwo lub też pewną jego dzielnicę na „gospodarzy” i „gości”. Nie może być nareszcie mowy o stosowaniu hasła, powstałego skutkiem pomieszania pojęć i podstawiania wyrazu zamiast idei, a mianowicie hasła: Rosja dla Rosjan, Polska dla Polaków.

Nigdy, przenigdy! Przeciwko tego rodzaju zapatrywaniom należy wszelką mocą protestować.

W kwestii autonomii Królestwa Polskiego rozstrzygają przedstawiciele całej ludności Polski w porozumieniu z przedstawicielami

1 Cyslejtania - potoczna nazwa zachodniej części monarchii austrowęgierskiej, obejmującej wchodzące w skład monarchii autonomiczne królestwa, księstwa i hrabstwa, m.in. Czechy, Dalmację, Galicję z Lodomerią, obecną Dolną i Górną Austrię, Bukowinę, Karyntię, Krainę, Styrię, Salz-burg, Śląsk austriacki, Tyrol, Vorarlberg i in., w odróżnieniu od Translejtanii, jak nazywano kraje korony św. Stefana, a więc Węgry z Siedmiogrodem i półautonomiczne: Chorwację, Stowenię i Fiume. 
całej ludności reszty państwa rosyjskiego, bez różnicy wyznania i narodowości.

Przy zawieraniu tak pojętej umowy powoływania się na prawa historyczne, na umowy międzynarodowe nie mogą nikomu imponować.

Dlatego to taki rozdźwięk i niesmak wniosła do Dumy owa sławetna deklaracja polska, odczytana na jednym z pierwszych posiedzeń przez posła Harusiewicza. Zalatywała od niej stęchlizna zbutwiałych szpargałów. Dziś jest to już język na pół tylko zrozumiały i przebrzmiały niby jakaś średniowiecczyzna, jakaś łacina średniowieczna. Dziś brzmią inne nuty, dziś brzmią linguae vulgares, języki gminne.

Powoływaniami na Kongres Wiedeński, na „króla polskiego” można bawić się w gabinetach ministrów, w kancelariach biurokratów. Ależ i ci ministrowie i biurokraci mają gotową odpowiedź na natarczywe domagania się legitymistów polskich: „Wasi przodkowie zdetronizowali Mikołaja I, a wy dziś gwałtem wtłaczacie koronę polską na skronie Mikołaja II”.

Zresztą ogłoszone na kilka dni przed otwarciem Dumy „prawa zasadnicze”, przeciwko którym głównie zwróconą była owa deklaracja polska, nie zniosły wcale tytułu „króla polskiego”.

Dla nas, dla ludzi dzisiejszych, są to wszystko próżne gadania. Legitymizm szlachty i czynowników musi ustąpić miejsca innym zasadom, zasadom demokratycznym. Teraźniejsze ludy Rosji nic nie obchodzą owe uroczyste i wielokrotnie łamane umowy osób koronowanych i stanów uprzywilejowanych.

Węgrom-Madziarom chodziło przede wszystkim o koronę świętego Stefana. Patrioci czescy starego autoramentu noszą się jak kura z jajkiem z koroną świętego Wacława. Podobnie legitymiści polscy stawiają we środku koła odrębności narodowo-terytorialnej - koronę polską, jako ozdobę głowy cesarzów rosyjskich.

Ależ szanowni panowie, im mniej tych koron, tym lepiej, tym łatwiej dać sobie radę z ich posiadaczami.

Prawa historyczne!

Ależ powołując się na „prawa historyczne”, możemy żądać wskrzeszenia przywilejów szlacheckich, możemy żądać restytucji 
poddaństwa, możemy żądać utrzymania samodierżawia, możemy żądać wznowienia czcigodnej instytucji ludożerstwa. Prawa historyczne pachną inkwizycją, pachną stosami dla heretyków.

Prawo historyczne żebra Adamowego staje dotychczas na przeszkodzie równouprawnieniu kobiet. Prawo historyczne Kaina i Abla legalizuje wszelkie morderstwa, wszelkie gwatty i bezprawia. Prawo historyczne ukrzyżowania znajduje odgłos choćby w pogromie białostockim ${ }^{1}$.

Ale po co nam te wszystkie „prawa historyczne”? Dziś mamy takie zgęszczenie historii, że starczy nam jej na długie, długie lata, że zapełnić ona może nie tylko cały szereg przyszłych zmian Księżyca i obrotów Ziemi około Słońca, ale także odbić się potężnym refleksem na przeszłości. Zresztą tak czy owak, dla nas jako dla ludzi dzisiejszych jedyną podstawą historyczną przy rozwiązywaniu praktycznych kwestii politycznych jest obecna chwila historyczna.

A więc może oprzemy się na prawach etnograficznych i będziemy się kierować względami jednolitości etnograficznej danego obszaru, mającego otrzymać ustrój autonomiczny?

Takie stanowisko byłoby również błędne.

Dążenie do przeprowadzenia jednolitości etnograficznej czy to całego państwa czy też pewnej jego dzielnicy jest karygodną i bzdurną chimerą. Natomiast ogólna fizjonomia etnograficzna danego kraju może być wzięta za jedną z podstaw rozstrzygających o konieczności jego wyodrębnienia i nadania mu autonomii.

Na cóż więc ostatecznie możemy się powoływać, żądając autonomii dla Królestwa Polskiego?

Przede wszystkim przyjmujemy tu za podstawę dane granice administracyjne, które stanowią dla nas fakt niezaprzeczalny i polityczną siłę wyższą. Podobnie fakt niezaprzeczalny i polityczną siłę wyższą stanowi dla nas jedność państwowa całego państwa rosyjskiego.

1 Mowa o dokonanym przez wojsko rosyjskie 14 VI 1906 r. pogromie ludności żydowskiej w Białymstoku, w którym ok. 100 osób zginęło lub zostato rannych. 
Żądanie autonomii Królestwa Polskiego opieramy na następujących faktach:

1. Całe to administracyjnie wyodrębnione terytorium jednoczy dziś p. Skałon albo też jaki inny satrapa. Dla przeciwdziałania samowładztwu tego rodzaju ichmościów niezbędną jest miejscowa instytucja prawodawcza, niezbędnym jest osobny sejm Królestwa Polskiego.

2. Krajowi temu właściwe są osobne prawa cywilne, zaszczepione w nim za czasów Napoleona.

3. W związku z tym pozostaje prawem określona bezstanowość. W Polsce rosyjskiej ludność nie dzieli się na odosobnione stany z właściwymi każdemu z nich przywilejami i ograniczeniami, a tymezasem taka stanowość była aż do chwili obecnej cechą charakterystyczną ustroju społecznego prawie wszystkich dzielnic Rosji pozostałej. W Rosji tak zwany „włościanin” lub „mieszczanin” jest dotychezas communi adscriptus, jest dotychczas niewolnikiem gminy, a nawet człowiek kończący wyższy zakład naukowy, zanim otrzyma dyplom, musi otrzymać od gminy urzędowe zwolnienie z poddaństwa. Coś podobnego jest całkiem obce Królestwu Polskiemu.

4. Nareszcie cała prawie uświadomiona ludność Królestwa żąda autonomii i dopóty się nie uspokoi, dopóki w sprawie tej nie otrzyma zadośćuczynienia. Gdyby nie było trzech poprzednich punktów, to ten jeden już byłby zupełnie wystarezającym i rozstrzygającym.

Dla przekonania się o istotnych życzeniach ludności Polski można by urządzić plebiscyt, czyli tajne głosowanie powszechne, oczywiście pod warunkiem, że żandarmi, policja i administracja nie wywieraliby żadnego nacisku.

Przy terytorialnym odgraniczaniu kraju, zwanego Królestwem Polskim, a mającego otrzymać ustrój autonomiczny, napotykamy pewną trudność pochodzącą z niejednolitości etnograficznej tego kraju. Mianowicie ta okoliczność, że północna część guberni suwalskiej zamieszkałą jest przeważnie przez Litwinów, wschodnie zaś pasy guberni siedleckiej i lubelskiej - przez Rusinów, czyli Ukraińców, powoduje żądanie oddzielenia tych gmin i powiatów od Polski i przyłączenia ich do innych dzielnic autonomicznych: do Litwy i do Małorusi, czy- 
li Ukrainy. Zwłaszcza ze strony niektórych nacjonalistów litewskich żądanie to, wyrównania granic, stawiane jest bardzo natarczywie.

Niestety, sami Litwini występujący z tym żądaniem nie zawsze zdają sobie sprawę z zasad, na których powinna się oprzeć autonomia Litwy, i kierują się niekiedy rażącym pomieszaniem pojęć. Powołują się oni to na prawa historyczne, sięgając aż do tradycji jagiellońskich, to nawet na archeologię przedhistoryezną, to znowu na ciągłość etnograficzną.

Otóż w tej sprawie trzeba by przede wszystkim wyjaśnić stanowisko wspólne, a, żądając oddzielenia niepolskich okręgów od Polski, należałoby jednocześnie „wyrównywać granice” przez przyłączanie do Polski kilku prawie czysto polskich powiatów guberni grodzieńskiej.

Oczywiście tak jedno, jak drugie nie mogłoby byé załatwiane bez woli samej ludności. Sama ludność drogą plebiscytu powinna by rozstrzygać, do jakiej dzielnicy autonomicznej życzy sobie być wcieloną.

Dla ścisłego rozgraniczania pojęć, których mieszać się nie powinno, należy rozróżniać dwie kwestie polskie w państwie rosyjskim.

Autonomia Polski nie wypływa wcale z zasady uznania i zaspakajania potrzeb kulturalnych wszystkich narodów.

To ostatnie, tj. równouprawnienie wszystkich narodowości w ich dążeniach do wyodrębnienia kulturalnego, podpada pod kategorię praw człowieka i obywatela, niezależnie od podziałów terytorialnych. Tymczasem autonomia Polski, czyli Królestwa Polskiego, jest pojęciem ściśle terytorialnym i administracyjnym.

Gdyby cała Rosja była takiej wielkości, jak np. ziemia krakowska, i gdyby mieszkało w niej kilka narodowości, nie potrzebowałaby ona nadawać autonomii prawodawezej pojedynezym dzielnicom, chociaż przy zastosowaniu zasady demokratycznej w dziedzinie narodowościowej musiałaby uznać wszystkie zaludniające ją narodowości za równouprawnione.

Z drugiej strony gdyby Rosja w dzisiejszych swoich granicach, od Wisły do Kamczatki, była zaludniona przez jedno jednolite plemię, np. wielkoruskie, musiałaby pomimo to rozpaśé się na autonomiczne, a nawet na sfederalizowane ze sobą dzielnice, gdyż ustrój centrali- 
styczny i prawodawstwo centralistyczne na tak potwornie obszernym terytorium są absolutnie niemożliwe.

Otóż rozróżniając ściśle pojęcia, mamy obecnie dwie „kwestie polskie” w państwie rosyjskim. Wyraz polski ma w obu razach całkiem inne znaczenie.

Kiedy idzie o równouprawnienie i nadanie pełni praw wszystkim wyznaniom, narodowościom i innym grupom społecznym, wyraz „polski” oznacza narodowość polską, tj. zbiorowisko ludzi, uznających język polski za swój język ojczysty. Kiedy zaś mówimy 0 „kwestii polskiej” w znaczeniu terytorialno-autonomicznym, mamy na myśli ściśle odgraniczoną krainę, dziś wprawdzie zamieszkałą przeważnie przez ludność narodowości polskiej, która jednak z czasem - podobnie jak to się stało z Prusami, Kurlandią i tylu innymi prowincjami - mogłaby zmienić swój wygląd etnograficzny.

Jak już poprzednio zaznaczyłem, „kwestia polska” w pierwszym znaczeniu rozwiązuje się przez uznanie bezwzględnego równouprawnienia wszystkich narodowości.

Przynależność zaś do tego lub owego wyznania, czyli do tego lub owego kościoła, do tej lub owej narodowości itd. powinna byé sprawą czysto osobistą i zależeć całkowicie od wolnego wyboru danej jednostki. Tak na grupy wyznaniowe, jako też na grupy narodowościowe należy patrzyć jako na wolne związki osób uważających się za jednakowo unarodowione lub też jednakowo uwyznaniowione.

Rzecz oczywista, że przy takim poglądzie na te sprawy nie ma żadnego kościoła panującego, nie ma żadnej narodowości panującej, nie ma żadnego języka panującego czy to państwowego, czy też dzielnicowego. Jedynie tylko względy praktyczne, względy statystyczne, względy stosunków liczebnych pomiędzy pojedynczymi narodowościami, jako też względy stanu faktycznego chwili obecnej sprawiają, że język wielkoruski, czyli rosyjski, będzie tymczasem odgrywał w Rosji rolę języka centralnego, rolę języka władz centralnych, rolę języka parlamentu ogólnopaństwowego, rolę języka służącego w przeważnej liczbie wypadków za środek porozumiewania się między pojedynczymi dzielnicami tego obszernego i wieloplemiennego państwa. Z tych samych względów praktycznych podobna rola języka centralnego przypada w Królestwie Polskim językowi polskiemu. 
Ponieważ nie ludność istnieje dla urzędników, ale urzędnicy dla ludności, więc urzędnicy są obowiązani znać języki wszystkich narodowości zamieszkujących daną jednostkę administracyjną. W wyjątkowych wypadkach powinni być ustanawiani tłumacze dla pewnych języków.

Być może, iż ubliża to szlachetnemu narodowi polskiemu, że go się równouprawnia, że go się stawia na równi z narodem litewskim, tatarskim, kirgiskim, baszkirskim, estońskim, żydowskim, buriackim itd. Kilka dni temu słyszałem od jednego ze znanych uczonych polskich całkiem poważnie wypowiedziane zdanie, że język litewski nadaje się chyba tylko do rozmawiania z krowami. Zapomniał ten pan o napisach w rodzaju zdies' po polski goworit' wospreszczajetsia (tu po polsku mówić zakazuje się), zdobiących do niedawna, a może nawet i dziś jeszcze, lokale rządowe i publiczne w „Kraju Północno-Zachodnim”. Jak ten pan traktuje język litewski, tak samo cywilizatorowie ze wschodu traktowali jego własny język.

Tak temu „dumnemu Polakowi”, jako też innym panom pogardzającym narodowościami niższego gatunku radziłbym odwiedzić posiedzenia powstałego w roku zeszłym Związku AutonomistówFederalistów. Podobny związek powstaje po raz pierwszy w historii ludzkości. Zasiadają tam obok siebie na zasadach najzupełniejszego równouprawnienia przedstawiciele Polaków, Litwinów, Ukraińców, Żydów, Gruzinów, Ormian, Estończyków, Łotyszów, Tatarów, Kirgizów itd. Zasiadamy obok siebie, szanujemy się wzajemnie i roztrząsamy wspólne nasze sprawy.

Członkowie Związku Autonomistów-Federalistów nie mogą powtórzyć za jednym z najdumniejszych Polaków: Senatorska tli wspaniatość, lwi sie szlachty stara śmiatość $i$ niewoli wzgarda buch ${ }^{1}$.

Tak, „wzgarda niewoli”! Ale czyjej niewoli? Tylko swojej własnej, a na niewolę cudzą chętnie się dumny Polak zgadza.

Związek Autonomistów-Federalistów właśnie na cudzą niewolę się nie zgadza i dlatego też żąda zabezpieczenia praw wszelkiej mniejszości na zasadach reguły spółki.

$1 \quad$ Z. Krasiński, Przedświt [przyp. BdeC]. 
Druga „kwestia polska” jest kwestią autonomii dzielnicowej, nie zaś narodowo-terytorialnej. Przeciw terytorialności narodowej ja ze swej strony stanowczo protestuję. Pachnie mi ona zaraz wynaradawianiem i prześladowaniem innych narodowości. Zaraz przypomina się sentencja: Naród polski chce być na swojej ziemi gospodarzem.

A jeżeli tak, to ten sam naród polski nie powinien mieć pretensji ani do narodu rosyjskiego, ani do narodu litewskiego, które „chcą byé również na swojej ziemi gospodarzami”. Przy tym naród rosyjski uważa za swoją ziemię całe państwo rosyjskie, a naród litewski w osobie swych historyków i etnografów rości sobie pretensje do ziem byłego Wielkiego Księstwa Litewskiego i nawet w Grodnie uważa nieLitwinów za „gości narodu litewskiego".

Podobnie i ów mityczny „naród polski” reprezentowany przez swych nacjonalistów i szowinistów nadaje „swojej ziemi” granice niezupełnie określone i w tych nieokreślonych granicach chce byé „gospodarzem”, wprawdzie gospodarzem uprzejmym i gościnnym, ale pomimo to każącym gościowi płacić podatki i ponosić wszelkie ciężary. Ten uprzejmy gospodarz ziemi polskiej uznaje wprawdzie Żydów, ale tylko Żydów, czujacych siebie Polakami.

No, my się na takie „gospodarowanie” nie zgadzamy. My nie dzielimy mieszkańców kraju na „gospodarzy” i „gości”. Dla nas tak Żydzi, jako też wszyscy inni, obecnie zamieszkali w danej miejscowości, są tak samo gospodarzami, jak i roszczący sobie do tego wyłączną pretensję.

Precz „wszechpolskośé”, precz „wszechlitewskoścé, precz „Wszechniemieckość”, precz „wszechrosyjskość”, precz „wszechżydowskość", precz egoizm narodowy!

Również nie możemy się zgodzić na jakieś szczególne uprzywilejowanie niegdyś powaśnionych, a obecnie pogodzonych „braci Słowian". Dla nas Rosjanie i Polacy to nie jakiś osobliwy cymes ludzkości, mający ze względu na swą „słowiańskość” prawo do wyłącznego panowania na zajmowanej przez siebie ziemi i do rozporządzania losami innych ludów.

A więc precz z panslawizmem, precz z mitością wszechsłowiańską! 
Przy rozgraniczaniu kompetencji całego państwa rosyjskiego i jego polskiej dzielnicy autonomicznej wypadnie rozwiązać cały szereg kwestii konkretnych. Niektóre z tych kwestii pozwolę tu sobie poruszyć.

Oczywiście forma rządu będzie i tu, i tam jednakową; jeżeli cała Rosja będzie monarchią konstytucyjną, to Polska będzie stanowiła jej część. Przy zaprowadzeniu republikańskiej formy rządu w całej Rosji, Polska wejdzie do jej składu jako częściowa rzeczpospolita, sfederalizowana z innymi częściami wspólnego państwa.

Policja przejdzie pod zarząd władz autonomicznych.

Wojsko, to zło konieczne (malum necessarium) dzisiejszych stosunków międzypaństwowych, musi byé ogólnopaństwowe, choćby z tego względu, że przy istnieniu osobnej armii dzielnicowej może przyjść ochota do wojaczki. Ale ze względu na oszczędność i dla ułatwienia obywatelom odbywania tej ciężkiej powinności należy dać możność odsługiwania na miejscu. Mieszkańcy Królestwa Polskiego powinni odbywać wojskowość albo we własnym kraju, albo, co najwyżej, w pobliżu jego granic. Rzecz oczywista, iż zasada ta nie może się stosować do floty.

Przy demokratyeznym ustroju społecznym niemożliwe jest istnienie gwardii i kozaków. Ustrój autonomiczny wymaga osobnych zarządów (komisji, ministeriów) dla pewnych stron życia publicznego, jako to spraw wewnętrznych, sprawiedliwości, przemysłu i handlu, rolnictwa, oświaty.

W rządzie centralnym i w zarządach ogólnopaństwowych (ministeria wojny, marynarki, komunikacji, poczt i telegrafów, spraw zagranicznych) powinien być zapewniony udział przedstawicielom Królestwa Polskiego.

Pomimo istnienia sejmu krajowego, przedstawiciele Królestwa Polskiego powinni brać udział w parlamencie ogólnopaństwowym, czyli w Dumie wszechrosyjskiej, ale przy rozstrzyganiu spraw dotyczących jedynie innych części państwa, tylko z głosem doradezym, bez prawa głosowania.

Ponieważ dla ogółu ludności symbole i oznaki zewnętrzne posiadają doniosłe znaczenie, więc Królestwo Polskie powinno mieć prawo na osobny herb i na osobne sztandary urzędowe. 
Napisy urzędowe na instytucjach autonomicznych mogą byé albo tylko w języku polskim, albo też, na żądanie mniejszości językowych, także w innych językach krajowych. Na oddziałach, czyli filiach zarządów ogólnopaństwowych, obowiązkowym jest także napis w języku rosyjskim, jako też herb ogólnopaństwowy obok herbu krajowego. Oczywiście byłoby najlepiej, gdyby się można obchodzić bez herbów i sztandarów, zadawalniając się dla dogodności interesantów jedynie napisami.

Przede wszystkim zaś powinny byé wydane przez Dumę państwową wspólne prawa zabezpieczające wolność obywateli i ustanawiające istotną praworządność w całym państwie.

A ponieważ jest rzeczą nie tylko niesprawiedliwą, ale po prostu potworną stosować bezwzględnie zasadę, że nikt się nie może wymawiać nieznajomościa prawa, tj. żądać od obywateli znajomości prawa, jeżeli nie dało się im możności zaznajomienia się z prawem, więc konieczną jest rzeczą stworzenie na całym obszarze państwa instytucji juryskonsultów dla ludności. Zadaniem takich juryskonsultów powinno byé zaznajamianie mieszkańców z ich prawami i obowiązkami oraz zapobieganie katastrofom prawnym, tj. katastrofom wynikającym z nieznajomości prawa.

Bardzo ważną dziedzinę życia społecznego, prawem określonego, stanowią szkoły i wychowanie w ogóle. Otóż należy o nich pomówić tak ze stanowiska równouprawnienia narodowości, ze stanowiska poszanowania praw wszelkiej mniejszości, jako też ze stanowiska autonomii terytorialnej.

Szkołom prywatnym powinna być pozostawiona jak najszersza wolność tak co do wyboru języka wykładowego, jako też co do programu, byle tylko ten program nie sprzeciwiał się wymaganiom moralności.

Szkoły rządowe i w ogóle publiczne powinny być:

1. bezwyznaniowe, tj. bez obowiązkowego wykładu jakiejkolwiek religii,

2. jednojęzykowe.

Powinny być święcie przestrzegane prawa mniejszości, a więc w obrębie obecnego Królestwa Polskiego mają prawo do swoich osobnych szkół publicznych z własnym językiem wykładowym, w miarę 
możności i w odpowiednim zakresie Żydzi, Litwini, Niemcy, Rusini, czyli Ukraińcy itd.

W każdej szkole obowiązkową jest praktyczna znajomość tylko jednego języka, języka wykładowego. Uświadamianie właściwości tego języka powinno służyć za jeden ze środków do rozwijania umysłów uczni w kierunku obserwacji wewnętrznej.

Żaden inny język nie może być obowiązkowym. Ale za to, o ile pozwolą środki i siły nauczycielskie, powinna być dana wszystkim uczniom możność uczenia się następujących kategorii języków:

1. języka rosyjskiego, jako języka centralnego całego państwa;

2. bardziej rozprzestrzenionych języków wszechświatowych: niemieckiego, francuskiego, angielskiego, esperanto...;

3. języków innoplemiennych współobywateli, a więc w szkołach polskich Królestwa Polskiego, stosownie do miejscowości: języka żydowskiego, języka litewskiego, języka małoruskiego, czyli ukraińskiego...;

4. tak zwanych języków „klasycznych”, łaciny i greckiego, które są wielu z nas potrzebne ze względu na ich rolę kulturalną w życiu społeczeństw europejskich, ale których znajomość jedynie tylko przesąd średniowieczny może uważać za niezbędną integralną część ukształcenia ogólnego;

Uniwersytet Warszawski oraz inne wyższe zakłady naukowe w Królestwie Polskim muszą być oczywiście polskie. Będą one służyły za ogniska oświaty wyższej i wyższego wykształcenia technicznego nie tylko dla mieszkańców Polski, ale także dla chcących z nich korzystać obywateli krajów ościennych, o ile będą oni woleli kształcić się w języku polskim aniżeli w jakim innym.

Ze względu na współobywateli innojęzykowych, jako też ze względu na stałe stosunki kulturalne tak w całym państwie, jako też w państwach sąsiednich, w Uniwersytecie Warszawskim powinny być założone, oprócz innych samo przez się się rozumiejących, jeszcze następujące katedry:

- filologii rosyjskiej i filologii małoruskiej, czyli ukraińskiej (język, literatura, folklor...);

- filologii litewsko-łotewskiej; 
- filologii żydowskiej (języka, folkloru, literatury, historii), nie hebrajskiej, ale nowożydowskiej. (0czywiście nie przeszkadza to studiowaniu jezzyka starohebrajskiego jako przedmiotu starożytniczego i ogólnielingwistycznego).

Wykłady w Uniwersytecie Warszawskim oraz w innych wyższych zakładach naukowych (w Warszawie, w Łodzi, w Puławach...) odbywają się oczywiście w języku polskim. Ale prywat-docentom wolno jest wykładać według uznania w jakimkolwiek bądź języku. Prócz tego wykłady języków i literatur innojęzykowych mogą się odbywać w językach obcych. Nareszcie w razach wyjątkowych, tj. w razie powołania profesora niewładającego dostatecznie językiem polskim, może być dopuszezony wykład w języku obcym także innych przedmiotów.

Kiedy mowa 0 równouprawnieniu Żydów jako osobnego narodu i języka żydowskiego, czyli tak zwanego „,̇̇argonu”, jako języka wykładowego, wywołuje to na wielu ustach uśmiech ironiczny i pogardliwy. Tę ironię i tę pogardę uważam za objaw wysoce niesprawiedliwy.

Jakiż to naród złożył tyle ofiar na ołtarzu „wolności”, na ołtarzu „odkupiania” i „zbawiania” ludzkości? Pierwszą ofiarę wyrwano z tona tego ludu przed 1873 laty, a do dziś jeszcze tysiące ofiar spomiędzy ludu żydowskiego giną w pogromach i innych jatkach urządzanych przez głosicieli „miłości bliźniego”. Taki naród zasługuje chyba na uznanie i szacunek.

A ów pogardzany „żargon”, czyli żywy język kilkomilionowego ludu żydowskiego! Przecież jest to język rodzin, język, za pomocą którego porozumiewają się dzieci z rodzicami. W tym języku umierające od ran dzieci, choćby we wsławionym ostatnimi czasy Białymstoku, przywoływały rodziców pomordowanych okrutnie przez tak zwanych „chrześcijan”. Przez cały szereg lat w tym języku rozbrzmiewały jęki boleści, uzewnętrzniały się objawy uczuć najrozmaitszych, to nikczemnych, to szlachetnych i podniostych, jako też wszelakich kombinacji myślowych. Jest to język najzupełniej równouprawniony z innymi językami.

Autonomia Polski musi być osiągniętą. 
Faktycznie Królestwo Polskie ma już zupełną autonomię; ale jest to tymczasem autonomia Skałona i jego pomocników, katów ludności bezbronnej.

Mamy dziś najwyższe naprężenie terroru rządowego i przeciwrządowego. Terror i zbrodnie bezprawia doprowadzono do absurdu. I w tym właśnie widzę rękojmię osiągnięcia prawdziwej autonomii, autonomii samorządnej, autonomii ludowładczej.

Autonomia Królestwa Polskiego wypływa z obecnego stanu rzeczy drogą konieczności dziejowej, podobnie jak nowy porządek rzeczy w całej Rosji wypływa z ogólnej sumy bezprawia w niej praktykowanego.

Inaczej czeka Rosję rozkład ostateczny, a jej kresy zabór przez państwa ościenne. Polskę dzisiejszą zabrałyby oczywiście Niemcy i Austria. Czy byłoby to nieszczęściem dla narodów, kraj ten zamieszkujących? Sądzę, że nie byłoby to znowu tak straszne, jak się z pozoru wydaje. Przypuszczam, że nawet w Niemczech musiano by się zgodzić ostatecznie na pewne równouprawnienie, bo chocia $\dot{z}$ Niemiec, gtos ludzki rozumiat.

A ze względu na bezpieczeństwo osobiste, ze względu na możność istnienia ludzkiego, lepiej jest chyba należeć choćby nawet do Prus aniżeli do Skałona i jego siepaczy.

Autonomia Polski jest wspólną sprawą całej Rosji i wszystkich jej części. Pozostaje ona w związku z autonomizacją całej Rosji. Samo tylko zautonomizowane Królestwo Polskie znajdowałoby się stale pod groźbą zgniecenia przez pozostałą Rosję scentralizowaną, a podobny wynik byłby znowu stałą groźbą dla ludności całej Rosji. Całej Rosji groziłaby wtedy zaraza gwałtu i bezprawia.

Tu nas może spotkać zarzut, że mówimy tylko o samorządzie i 0 autonomii, a nie dotykamy wcale takich kwestii, jak konstytuanta w Warszawie, jak niezależność państwowa całej Polski, jak rzeczpospolita demokratyczna.

I owszem. Bardzo to smaczny jadłospis. Ale prosze przygotować same potrawy i to przygotować je nie na wiecach i na naradach spiskowców, ale w rzeczywistości. Przygotowywać zaś należy tak, ażeby to nie pociągało potwornie wielkiej liczby ofiar i ażeby nie prowadziło kraju do ostatecznej ruiny. 
Ja takiego wyjścia nie widzę, a nawet „niezależność państwową" uważam za zbyt drobny cel, ażeby przynosić mu w ofierze istnienia ludzkie.

Może z czasem uda się załatwić tę sprawę drogą pokojową, oczywiście 0 ile obie strony uznają za właściwsze i korzystniejsze rozejść się, aniżeli pozostawać w przymusowym związku. Przecież mamy przed oczyma przykład Szwecji i Norwegii.

Rzecz prosta, iż przy nieograniczonej wolności słowa i głoszenia swych przekonań powinna byé każdemu pozostawiona wolnośé propagandy tak w kierunku oderwania Polski od Rosji, jako też w kierunku zamiany monarchii konstytucyjnej przez rzeczpospolitą. Z drugiej strony powinno być wolno nawoływać do wskrzeszenia nie tylko samodzierżawia, ale nawet rządów teokratycznych. Wątpię jednak, czy tego rodzaju propaganda będzie miała powodzenie.

A teraz pytanie:

W jakim porządku należy rozwiązywać kwestie autonomii Polski?

Według mego zdania, porządek ten powinien być następujący:

Z początku Duma państwowa ustanawia ogólne zasady wolności obywatelskich i rozgranicza zakres autonomii a ogólnopaństwowości. Następnie zaś szczegóły ustroju autonomicznego zostają opracowywane w sejmie miejscowym danej dzielnicy autonomicznej.

Do zasad ogólnych związku jednostki autonomicznej z całokształtem państwowym, które to zasady muszą byé uwzględnione przy umowie przedstawicieli dzielnicy autonomicznej z przedstawicielami pozostałych części państwa, należy przede wszystkim:

Jedność państwowa Rosji, nie gwoli samowładztwu Wielkorusów, ale jako wspólna sprawa wszystkich dzielnic i wszystkich narodowości Rosji.

Następnie Duma ogólnopaństwowa powinna wypracować prawa zasadnicze dla całego państwa.

Te prawa zasadnicze powinny mieć na celu między innymi uniemożliwienie zakusów reakcyjnych w sejmach dzielnicowych. Żaden sejm dzielnicowy, czyli krajowy, nie powinien mieć prawa: karać ludzi za pochodzenie, czyli ograniczać ich w ich prawach obywatelskich, 
nadawać przywileje stanowe, ustanawiać kościół uprzywilejowany, wprowadzać karę śmierci...

Chodzić nam przy tym powinno nie tylko 0 urzeczywistnienie dostatecznie już dojrzałych idei postępowych, ale także 0 usunięcie ognisk zarazy etycznej i politycznej. Przecież nie da się zaprzeczyć, że np. istnienie Rosji dotychczasowej, grającej rolę żandarma międzynarodowego i dusiciela wszelkiej wolności, odbijało się nader zgubnie na życiu politycznym państw ościennych. Nie da się również zaprzeczyć, że bezprawia i bezeceństwa praktykowane np. przez Prusy i Węgry, znajdowały chętnych naśladowców u sąsiadów. Istnienie Galicji oddanej na pastwę klerykałom i wstecznikom wpływało pod wielu względami nader niekorzystnie na stosunki społeczne i na światopogląd polityczny w Królestwie Polskim.

Ale wszystko to należy do zakresu wpływów międzypaństwowych i o usuwaniu takiej zarazy zagranicznej nie może myśleć żadne państwo na własną rękę. Zmiana postępowania rządu oraz zmiana praw i postanowień reakcyjnych i szkodliwych w innych państwach leży poza sferą kompetencji parlamentu rosyjskiego.

Natomiast całkiem od niego zależy urządzić się odpowiednio u siebie, w granicach wspólnego państwa.

I oto z tego stanowiska parlament wszechrosyjski powinien raz na zawsze położyć tamę wszelkim zachciankom rusyfikacyjnym, które jak jad i zaraza oddziaływają demoralizująco na całe wieloplemienne społeczeństwo.

Parlament wszechrosyjski musi zdusić łeb hydrze bezprawia, zwanej jenerał-gubernatorstwami i jenerał-gubernatorami, gdyż istnienie tego potwora tamuje oddech swobodny ludności i paraliżuje życie praworządne.

Parlament wszechrosyjski musi znieść wszelkie kary za pochodzenie, wszelkie owe ograniczenia w rodzaju procentów szkolnych, w rodzaju linii osiedlenia dla Żydów itd., itd., gdyż bezprawie choćby tylko w jednej dziedzinie narusza równowage etyczną we wszystkich innych.

W imię zasad demokratycznych parlament wszechrosyjski musi przeprowadzić bezwzględne równouprawnienie prawne we wszystkich kierunkach. Dopiero na tych trwałych, ogólnie obowiązujących 
podwalinach mogą się wznosić gmachy pojedynczych autonomii, w tej liczbie także autonomii Królestwa Polskiego.

\section{$* * *$}

Godzi się zapytać: jakie też mamy cele, proponując podobny sposób rozwiązania kwestii autonomii Polski, i jakie mogą być wyniki podobnego jej rozwiązania?

Otóż, ja przynajmniej, mam przy tym następujące cele:

1. uspokojenie wrzenia, wywoływanego waśnią międzywyznaniową i międzyplemienną, i umożliwienie zgodnego pożycia rozmaitych grup społecznych zamieszkujących wspólną ojczyznę;

2. sprowadzenie walki między ludźmi do właściwych granic, do walki o sprawy ogólnopolityczne i ekonomiczne;

3. obronę wszystkich narodowości przed ich własnymi dążeniami i zachciankami, nastrajającymi wrogo względem nich inne, sąsiadujące z nimi narodowości.

4. Nareszcie pewną niepoślednią rolę gra tu może także miłość własna, narodowa i państwowa. Przecież, jeżeli nam się uda urzeczywistnić nakreślony przez nas sposób rozwiązywania podobnych, na pozór zawiłych spraw, zyskamy uznanie i podziw innych i staniemy się dla nich wzorem i przykładem.

A jakież mogą być wyniki podobnego rozwiązania kwestii narodowościowych i terytorialnych?

1. Usunięcie z obiegu całego zastępu zadań wolnościowych, które okażą się absurdem lub będą posiadały negatywną wartość nawet dla samych posiadaczy pewnych praw. Ze względu na zadanie uproszczenia życia społecznego, sami obdarowani pewnymi prawami i pewnymi swobodami nie zechcą z nich korzystać. Ale niech wiedzą, że swobody te są ich własnością i że mają prawo z nich korzystać.

2. Ta bezwzględna wolnośé, to poczucie, że się jest w niczym nieskrępowanym, o ile się innych nie krępuje, rozwinie w ludziach solidarność ogólnokrajową i ogólnopaństwową, która będzie 0 wiele poważniejszym spoidłem, aniżeli dotychezasowa „miłość ojezyzny”. 
Obecnie wypowiadają się nowe hasła, tworzą się nowe zasady, nawija się kłębek zadań doniosłych i pierwszorzędnych na odległą metę. Urzeczywistnianie tych zasad, wcielanie w życie tych haseł pójdzie po linii rozwijalnej dziejów powszechnych.

Jeżeli nie doczekamy urzeczywistnienia i wcielenia w życie, nie powinniśmy się tym zniechęcać. Powinniśmy poczuwać się do solidarności ogólnoludzkiej w długim szeregu pokoleń i pocieszać się tym, że pracujemy dla przyszłości.

[Kraków 1907. Nakładem Krakowskiego Oddziału Uniwersytetu Ludowego] 


\section{„BRACIA SŁOWIANIE”}

Zapoczątkowali tę awanturę spadkobiercy Rzymian, „bracia chrześcijanie" z Półwyspu Apenińskiego. Libia i Cyrenajka, lubo formalnie podległe Turcji, były faktycznie do wzięcia; więc urządzono na nie napad i ogłoszono przyłączenie do państwa włoskieg $0^{1}$. Wezorajsi poddani sułtana okazali się dziś poddanymi Rzymu, Rzymu zarówno świeckiego, jako też duchownego. Obeszło się bez zwykłych formalności wypowiedzenia wojny, boć przecie z bisurmanami nie ma co robić sobie ceremonii. Broniących swej ziemi krajowców ogłoszono za „buntowników”, urządzano na nich wyprawy karne i tępiono ich bez litości. Z aeroplanów rzucano bomby na bezbronną ludność tubylezą.

Kiedy onego czasu armia austriacka stosowała podobne środki lecznicze do „buntowników” w swych posiadłościach włoskich, wrzeszczano na całe gardło, a liberali europejscy wtórowali wrzaskowi „patriotów” i „męczenników za wolność”. No, ale co wolno Włochowi, tego nie wolno Trypolitańczykowi.

Za przykładem Półwyspu Apenińskiego poszedł Półwysep Bałkański² . Żarłoczność jednej z głów dwugłowego orła historii europejskiej wznieciła krwiożercze apetyty w jego drugiej głowie. „Świetne powodzenia oręża włoskiego" w walce z garstką regularnego wojska tureckiego i z nieregularną „hałastrą” tuziemczą nie dawały spać spokojnie „mścicielom” krzywd doznanych przez ich przodków od dzikich hord wyznawców Mahometa.

1 Mowa 0 tzw. wojnie trypolitańskiej toczonej w latach 1911-1912, w której wyniku Turcja utraciła na rzecz Włoch Libię, Trypolitanię i Cyrenajkę.

2 Chodzi o pierwszą (X 1912 - V 1913) i drugą (VI-VII 1913) wojnę bałkańską, które wywołane zostały roszczeniami państw bałkańskich w stosunku do Turcji. Pierwsza wojna toczyła się między Turcją a związanymi sojuszem Bułgarią, Serbią, Grecją i Czarnogórą, drugą między Bułgarią a jej wcześniejszymi sojusznikami. Pierwsza z wojen pozbawiła Turcję jej posiadłości na Bałkanach, w drugiej Bułgaria utraciła zdobyte w pierwszej wojnie tereny w Tracji, Macedonii oraz południową Dobrudżę, natomiast Serbia wzmocniła swoją pozycję, co z kolei zaostrzyło konflikt między nią a AustroWęgrami. 
Skorzystano z osłabienia, z nieładu i niezaradności Turcji i zawarto we czworo umowę napastniczą ${ }^{1} \mathrm{~W}$ celu pokonania „wspólnego wroga” i wzajemnego podziału zdobytych na nim łupów. Obok tego oczywiście „bracia Słowianie” z Belgradu i z Cetynii porozumieli się osobno z „braćmi chrześcijanami” z Aten, ażeby się wspólnie zabezpieczyć przeciw oczekiwanym i koniecznym uroszczeniom „braci Słowian” ze Sofii.

Przygotowania do pochodu na Turcję robiono już od dawna. Starano się wszelkimi sposoby podtrzymywać wrzenie w Macedonii i prowokować Turków, ażeby mieć możność podnoszenia wrzasków na okrucieństwa tureckie i poruszania „opinii Europy” na korzyść prześladowanych. Profesorowie uniwersytetów w Sofii i Belgradzie i członkowie akademii nauk, bułgarskiej i serbskiej, gościli w Petersburgu i Moskwie, ażeby agitować tam na korzyść wojny z Turcją. Przypuszczam, że dziś nie wszyscy ci profesorowie i członkowie akademii są zadowoleni ze skutków swej zajadłej propagandy.

Idąc za szlachetnym przykładem Włoch, wojny formalnie nie wypowiedziano. Ponieważ po przeciwnej stronie był Turek, więc nie wzięto tego za złe „braciom Słowianom” i „braciom chrześcijanom”, chociaż Japończyków srodze gromiono za coś podobnego. Japończycy jednak, właściwie mówiąc, wypowiedzieli wojnę Rosji, gdyż zerwali z nią stosunki dyplomatyczne, a dziś po ich zwycięstwach nikt im nie robi poważnych zarzutów.

„Bracia Słowianie” zaś i „bracia chrześcijanie” Półwyspu Bałkańskiego istotnie w żadnej formie nie wypowiadali wojny swemu „odwiecznemu wrogowi”. Pierwszą napaść „bez zrywania stosunków dyplomatycznych” urządzili dzielni $i$ sympatyczni Czarnogórcy, typowi rycerze rozboju i rzezi dla rzezi. Napaść się udała. Turków rozgromiono. Zapality się tedy serca junaków w innych „państwach sprzymierzonych" i - hajże na Soplice!

Niedołęstwo i słabość Turków były niespodzianką zarówno dla nich samych, jako też dla „sprzymierzonych” i dla wszystkich innych.

Tępiono się wzajemnie bez litości. Tępiono nie tylko siebie, ale tępiono i niszczono wszystko po drodze. Nie tylko rozstrzeliwano

$1 \quad$ Tzw. sojusz bałkański - zob. przypis poprzedni. 
lub też zakłuwano bagnetami jeńców wojennych, ale także obracano w perzynę wsie i miasta, wyrzynano ich mieszkańców, gwałcono kobiety, ażeby je potem kaleczyć lub mordować, nie przebaczano żadnemu żywemu stworzeniu.

Te „czyny bohaterskie” wzbudzały zachwyt gawiedzi, z dala od tego piekła czytającej dzienniki i lubującej się jaskrawymi opisami mordów i rzezi. Walka krzyża z potksięzycem, chrześcijanstwa z islamem entuzjazmowała tłumy. Hymny narodowe i patriotyczne ludów „walczących za wolnośé” rozbrzmiewały w teatrach, ogródkach i innych miejscach publicznych. W Rosji np. niektórzy członkowie wszechświatowej ligi pokoju oświadczyli, że dla tej wojny robią wyjątek i chwilowo przestają byé pacyfistami, bo to wojna święta, wojna cywilizacji chrzescijańskiej z barbarzyństwem muzutmanskim.

Zresztą ten zapał do „czynów bohaterskich” „braci Słowian” i „braci Greków” zataczał niezbyt szerokie kręgi. Ogarniał on tylko tych, czyje serca biją przyśpieszonym tempem na myśl bądź to 0 „braciach Stowianach”, bądź też 0 „braciach chrześcijanach”. Przede wszystkim byli wolni od tego szału prawdziwi pacyfiści, konsekwentni przeciwnicy wszelkiej wojny. Następnie nie mogli się cieszyé z powodzenia oręża stowiańskiego i chrześcijańskiego wszyscy ci, co wspótczuli napadniętym i tępionym Turkom i mahometanom. Oczywiście z oburzeniem traktowali zwycięstwa słowiańskie wszyscy ci, którzy widzieli w nich wzmocnienie wstrętnego dla nich „panslawizmu”. Nareszcie wielu dyplomatów rosyjskich nie mogło przebaczyć „świniopasom” serbskim, czarnogórskim i bułgarskim, że naruszają spokojny bieg wypadków i wywołują widma nowych starć i powikłań „międzynarodowych”.

Znakomici rozbójnicy, w rodzaju Rinaldo Rinaldiniego, Stieńki Riazina, Karmeluka, Janosika itd., uwiecznili się sympatycznie w podaniach ludowych, zyskali sławę „bohaterów” i jako tacy wcielili się w pieśn ludową. Dość tu wspomnieć pieśni ludowe, opiewające zbója karpackiego, Janosika. I istotnie, ze względu na swą dzielność osobistą, na ryzyko i niebezpieczeństwa towarzyszące ich wyprawom, ci patentowani „zbóje” zasługiwali daleko bardziej na podziw i uwielbienie, aniżeli wielcy „wodzowie”, którzy, osobiście niczym prawie 
nie ryzykując, napadali na obce kraje, niszczyli je i przywłaszczali je sobie.

Jak wyprawy zbójeckie Janosika i innych tego rodzaju „bohaterów” znalazły piewców ludowych, tak samo wyprawa zbójecka Włochów do Trypolisu odbiła się echem poetycznym w entuzjastycznych hymnach i odach rozmaitych „wieszczów”, z Gabrielem D’Annunzio na czele. Nic też dziwnego, że szlachetni entuzjaści spomiędzy poetów i publicystów, ogarnięci uczuciem „miłości wszechsłowiańskiej”, tworzyli hymny uwielbienia i zachwytu na cześć „braci Słowian”, gromiących odwiecznego wroga i ciemieżyciela, walczacych pod godtem krzyża ze znienawidzonym pótksiężycem i „wyzwalających” ludność chrześcijańską spod „jarzma tureckiego”. Odgrzewano stary romantyzm błędnych rycerzy średniowiecza, marzono 0 zatknięciu zwycięskiego krzyża na katedrze św. Zofii w dawnej stolicy cesarzów bizantyjskich, jednym słowem, zamykano troskliwie oczy na szpetną, ohydną rzeczywistość i usypiano się pajęczyną sennych widziadeł. Ostatnia wojna bałkańska zgotowała tym marzycielom bolesne przebudzenie i otrzeźwienie. Dopóki trwała walka „braci Słowian” z Turkami, we wściekłym rzucaniu się „na noże” (na bagnety), we wpijaniu zębów w ciało przeciwnika, w bezwzględnym tępieniu jeńców wojennych i spokojnych mieszkańców, w paleniu miast i wsi... widziano „czyny bohaterskie”, a nie dzikość atawistyczną dwunogiej bestii ludzkiej. Dopiero kiedy tę samą metodę walki zaczęto stosować do własnych „braci Słowian”, posypały się przekleństwa na ohydna orgie bratobójcza.

Ja od samego początku patrzyłem ze zgrozą i ze wstrętem na „czyny bohaterskie” zarówno „rycerzy” islamu, jako też „rycerzy wiary Chrystusowej”. Mnie bowiem nie imponuje nadęty frazes rzymskiego poety-pieczeniarza: Dulce et decorum est pro patria mori (Słodko jest i zaszczytnie umrzeć za ojczyznę). Frazes ten dopełniam dodatkiem: sed dulcus pro patria vivere (ale słodszą jest rzeczą żyć dla ojczyzny). Co zaś do tak zwanego „bohaterstwa”, to oceniłem je już dosyć dawno w sposób następujący:

Wobec fatalności wojny, wobec musu, pędzącego na rzeź całe stada ludzkie, szyderczo brzmi dodatek, spotykany na wszystkich prawie po- 
mnikach, wznoszonych na polach bitew: „polegli śmiercią bohaterską”. Rozumiem bohatera, bądź to ginącego na krzyżu lub na stosie za swe przekonania, bądź też idącego śmiało na tortury i niedającego inkwizycji wydusić z siebie zeznań kompromitujących; ale bohatera z musu, bohatera oszalałego i skutkiem wrzawy wojennej pozbawionego ludzkiej świadomości, bohatera pijanego krwią, bohatera mordującego i mordowanego - takiego bohatera uznać nie mogę i nigdy nie uznam. (Myśli nieoportunistyczne, Kraków 1898).

Prócz tego, pomimo że nie należę wcale do „wierzących”, biorę jednak na serio przykazania „nie zabijaj”, „nie kradnij”, „nie cudzołóż" i pozwalam sobie stosować je nawet wtedy, kiedy zabijaniem, rabowaniem i gwałceniem zajmują się „bracia Słowianie” i „bracia chrześcijanie” jakiegokolwiek bądź obrządku.

Gdybym więc był poetą i wcielał w słowa własne uczucia wywołane przez wrażenia od wszystkich wojen bałkańskich, byłyby to tylko uczucia zgrozy, wstrętu i pogardy, byłyby to tylko przekleństwa i złorzeczenia, byłyby to tylko wyrazy potępienia, bez względu na to, czy opiewałbym walki „braci Słowian” i „braci chrześcijan” z „bisurmanami”, czy też wzajemne pożeranie się „braci Słowian” i „braci chrześcijan” pomiędzy sobą. Czy „krzyż” wyrusza w pole przeciw „półksiężycowi”, czy „krzyż” przeciw „krzyżowi”, czy też mamy jaką inną kombinację godeł i symbolów, dla mnie wyrusza w pole zawsze tylko jedno bydlę ludzkie przeciw drugiemu bydlęciu ludzkiemu ${ }^{1}$.

1 Zgadzamy się zupełnie z wywodami Szan. Autora, gdy chodzi o zjawisko wojny, podobnej do ostatniej bałkańskiej, która ostatecznie okazała orgię wilczych apetytów i żądzy zaborczej, bez żadnej myśli narodowej - wszak żywe narody rozszarpano - i politycznej. Inaczej - z wojną nie zaborczą, lecz obronną, jaka czeka naród polski wobec grożącej mu eksterminacji. Dopóki nie znamy innego sposobu wyzwolenia się spod ucisku nikczemnego barbarzyństwa - musimy się gotować do wojny. Obronną będzie, nie imperialistyczną, właśnie w imię kultury - nie chciwości zoologicznej, poczuciem obowiązku - nie przymusem kierowana; uczestnicy jej więc mieliby prawo do miana bohaterstwa, śmieré w niej poniesiona byłaby najwyższym czynem etycznym: poświęcenia się jednostki za duszę i przyszłość narodu [Red. „Krytyki”, także dalej tak sygnowane przypisy - M.S.] 
Jak we wszystkich innych podobnych wypadkach, tak też i obecnie mamy do czynienia ze skutkami pomieszania pojęć i wszechwładzy języka nad naszym myśleniem. Jednośé „słowiańską” oraz poczucie tej jedności stworzyła nazwa będąca jednocześnie terminem naukowym oraz używana w życiu potocznym. „Słowianie” zaś stanowią osobne zbiorowisko ludzkie, w różnicy od innych takich zbiorowisk, jedynie i wyłącznie na podstawie podobieństwa właściwych im języków, „narzeczy” i gwar. Żadnej innej obiektywnej wspólności pomiędzy Słowianami nie ma i nigdy nie było. Natomiast istnieje w wielu głowach, pod wpływem wspólnej nazwy, z jednej strony poczucie jakiegoś osobliwego „braterstwa”, każącego np. teraz wywodzić żale nad „walką bratobójczą”, z drugiej zaś strony, u innych narodów, obawa „panslawizmu” i prześladowanie wszystkich „Stowian”.

A co to takiego są np. „Serbowie” i „Bułgarzy” w wojnach ostatnich? I jednych, i drugich łączył w jedno tylko „patriotyzm” wojskowy i jedność munduru. Do tego dołączyé należy szczucie i tresowanie w nienawiści: i „Serbów”, i „Bułgarów” do „Turków” i na odwrót, „Turków” do jednych i do drugich; „Serbów” do „Bułgarów”; „Bułgarów” do „Serbów” i do „Greków”; „Greków” do „Turków”, do „Bułgarów”, a w razie potrzeby i do „Serbów”. Boć obiektywnie biorąc, ze stanowiska językowego, we wschodnich częściach królestwa serbskiego mieszka ludność bardziej zbliżona do Bułgarów aniżeli do Serbów, a w każdym razie będącą dalszym ciągiem ludności zamieszkującej północno-zachodnie części królestwa bułgarskiego, tj. terytorium dochodzące do stolicy Bułgarii, Sofii. Gdyby tę wschodnią część Serbii zabrali Bułgarzy, ludność jej stałaby się nagle „Bułgarami”, a zabrani z niej rekruci w razie wojny mordowaliby „Serbów”, podobnie jak niedawno mordowali „Bułgarów”. Żołnierze pochodzący z północno-wschodniej części Bułgarii byli oczywiście w wojsku bułgarskim i 0 mało co nie mordowali Rumunów. Dziś tę częséc Bułgarii zabrała Rumunia i ci sami żołnierze, wcieleni do wojska rumuńskiego, mogą z czasem jako „Rumunowie” mordować „Bułgarów”.

Przypatrzmy się w ogóle składowi etnograficznemu tych państw, a przekonamy się, że we wszystkich bez wyjątku jest on mieszany,

1 Obawa - polityką Rosji aż nazbyt usprawiedliwiona. Red. 
przynależność zaś państwowa została narzuconą i stała się przymusową. Przyłączeni do Serbii i Grecji Słowianie macedońscy stają się od dnia dzisiejszego „Serbami” i „Grekami”, pomimo że subiektywnie uważają się za „Bułgarów” i nienawidzą zarówno Serbów, jak i Greków, a obiektywnie mowa ich jest bez wątpienia bardziej zbliżona do bułgarskiej aniżeli do serbskiej. I w dzisiejszej Grecji, i w Serbii, i w Bułgarii istnieją tzw. Kucowłachy, tj. ludność zbliżona językowo do Rumunów. Nawet małe Czarnogórze zagrabiło część plemion albańskich i ma u siebie kwestię narodowościową, która prawdopodobnie niemało krwi będzie kosztowała. Gdyby nie interwencja Austrii i innych mocarstw, cała Albania zostałaby podzielona między Serbię i Grecję, a jej mieszkańcy staliby się państwowo i militarnie bądź to „Serbami”, bądź też „Grekami”, podobnie jak i przedtem zarówno w Serbii, jak tym bardziej w Grecji istniała ludność, którą każdy nieuprzedzony musi pod względem językowym zaliczyé do Albańczyków.

Jednym słowem, 0 ile i Albańczycy, i Kucowłachy, i Grecy, i Żydzi, i Turcy, i Tatarzy służą w wojsku bądź to bułgarskim, bądź to serbskim, bądź też nareszcie czarnogórskim, zostają zaliczani do „braci Słowian”.

„Sprzymierzone” i „zaprzyjaźnione” państwa Austrii i Włoch czekają tylko sposobności, ażeby rzucić się na siebie. Tymczasem przygotowują się cichaczem: fortyfikują góry graniczne, urządzają manewry nadgraniczne, szpiegują się nawzajem, jednym słowem wcielają w życie zasady przymierza zaczepno-odpornego. Widziałem w tym roku w graniczącej z Austrią prowincji włoskiej całe masy kawalerii i strzelców alpejskich, którzy w mundurach koloru szaro-zielonego, przypominającego żaby, a mającego robić ich niewidzialnymi, ćwiczyli się w kunszcie wojennym stosowanym z myślą o starciu się z Austrią. W tej prowincji włoskiej mieszkają także „bracia Słowianie”. W razie wojny zabrani spomiędzy nich żołnierze pójdą na „braci Słowian”, napełniających całe pułki austriackie.

Podobna „bratobójcza walka” „braci Słowian” będzie konieczną także w razie starcia się Austro-Węgier z Rosją, Prus z Rosją, AustroWęgier z Serbią i Czarnogórą.

Gdyby politycy bułgarscy lepiej się byli orientowali w położeniu i byli bardziej przewidujący, nigdy nie daliby się brać na lep wspól- 
ności plemiennej i wyznaniowej dla organizowania krucjaty przeciwka Turkom, ale, przeciwnie, staraliby się byli wejść w sojusz z Turcją i wymóc na niej autonomię Macedonii. Przy zawieraniu przymierzy należało kierować się nie retrospektywnymi wspomnieniami o okrucieństwach Turków, ale względami na dawniejszy i dzisiejszy antagonizm bułgarsko-serbski i bułgarsko-grecki. Grecy od dawien dawna byli daleko zaciętszymi i chytrzejszymi wrogami Bułgarów aniżeli Turcy. Serbskie zaś uroszczenia do Macedonii, popierane nawet wywodami lingwistycznymi i etnograficznymi, powinny były dawać wiele do myślenia.

Prawda, że Turcja okazała się państwem niedołężnym i nieumiejącym wyzyskać okoliczności sprzyjających. W początkach rewolucji tureckiej urządzonej przez młodoturków ${ }^{1}$, w całej Macedonii, między wszystkimi jej narodowościami, nawet między Grekami, panował wielki entuzjazm dla państwowej sprawy tureckiej. Niestety młodoturcy okazali się marnymi psychologami, zziębili ten zapał żywiołowy za pomocą dążenia do otomanizacji całego państwa i do denacjonalizacji innych narodowości. Wskutek zaś niemocy rządu centralnego rozpoczęły się na nowo rozprawy krwawe z ludnością innojęzykową i innowyznaniową, między innymi także w Macedonii. Temu powinna była Bułgaria przeciwdziałać wszelkimi możliwymi sposoby, ale tak, żeby nie drażnić Turcji i nie szczuć przeciwko niej.

Nawet gdyby wszelkie próby zbliżenia się z Turcją i wywarcia na nią wpływu nie udały się, należało wstrzymywać się od kroków zaczepnych, a zwłaszcza nie zawierać przymierza z innymi państwami bałkańskimi. Bo najprzód było to tylko przymierze chwilowe, które wobec niedającego się w żaden sposób zażegnać antagonizmu zarówno interesów realnych, jak też stałej tradycji historycznej, musiało z konieczności zamienić się na rozbrat i zaciętą walkę. A po wtóre trzeba było stosować prostą arytmetykę i logikę. Turcy praktykowali wprawdzie rozmaite okrucieństwa, ale jeden dzień minionych tylko co wojen bałkańskich pochłonął daleko więcej ofiar aniżeli kilkadziesiąt

1 Ruch młodoturków w imperium otomańskim na przełomie XIX i XX w. dążył do przeprowadzenia reform politycznych, które miały zmienić państwo na wzór krajów zachodnioeuropejskich. 
lat gospodarki tureckiej. To powinni byli przewidzieć i zrozumieć politycy bułgarscy, 0 ile byli rozumni i przewidujący.

Zamiast tego, zamiast pracowania nad rozwojem kulturalnym i ekonomicznym swego państwa i społeczeństwa, zaczęli oni prowokować Turków w Macedonii, zaczęli ostentacyjnie urządzać wystawy bieżenców, tj. Macedończyków uciekających jakoby przed gwałtami tureckimi, zaczęli piorunować w swych gazetach na Turków i podniecać namiętności, jednym słowem zaczęli wytwarzać bez najmniejszej potrzeby nastrój zdenerwowania, rozbestwienia i krwiożerczości, a taki nastrój bywa złym doradcą. Doradził on sojusz z Serbią i Grecją, a od takiego sojuszu należało się wstrzymać w imię własnego „egoizmu państwowego i narodowego”.

Potworne zbrojenie się nad siły i nieustająca agitacja naładowały dusze bułgarskie elektrycznością najezdniczo-militarną, a to z konieczności prowadzito do wybuchu.

Wprawdzie politycy bułgarscy, w porozumieniu z komitetami rewolucyjnymi Macedonii, spodziewali się, że, pobiwszy z lekka Turków, wymogą na nich autonomię Macedonii, która też była celem dążeń jej mieszkańców różnych narodowości. Tymczasem pogrom Turków przeszedł wszelkie oczekiwania, a to zmieniło sytuację.

W każdym razie ufanie Serbom i Grekom, pomimo przestrzegającego przysłowia Graeca fides nulla fides ${ }^{1}$, było pierwszym i zasadniczym błędem polityki bułgarskiej.

Nieoczekiwany pogrom armii tureckiej przez wszystkich „sprzymierzonych" objaśnia się tym, że Turcy nie spodziewali się takiego gwałtownego nacisku i w ogóle nazbyt ufali we własne siły, a lekceważyli siły militarne swych przeciwników, zwłaszcza po zwycięstwach odniesionych nad Grekami w r. 1897. Bułgarom zaś po szybkich a nieoczekiwanych zwycięstwach nad Turkami zawróciło się w głowach, zaczęły w nich kiełkować i rozwijać się idee wielkopaństwowe, imperialistyezne, marzenia o hegemonii na Półwyspie Bałkańskim. Carowi Ferdynandowi zdawało się, że zostanie „królem królów”, czymś w rodzaju Agamemnona. Skutkiem zawrotu głowy zapomniano cał-

1 Graeca fides nulla fides (łac.) - dosł.: wierność grecka (to) żadna wierność. Graeca fides (także: fides Punica) - synonim wiarołomstwa. 
kiem o Macedonii, a skoncentrowano wszystkie swe siły w Tracji około Adrianopola ${ }^{1}$. Nieszczęśliwi a oszołomieni wojownicy bułgarscy staczali tam mordercze boje, ginęli całymi tysiącami i dawali z siebie krwawe widowisko „bohaterów” dla „bohaterstwa”, czyli po prostu głupców, na uciechę zgrai czytelników gazet, a zwłaszcza swych szlachetnych „sprzymierzeńców”, którzy z zadowoleniem zacierali ręce na myśl, że Bułgarzy tak się osłabiają i wyczerpują. Ponosząc straszne ofiary i prąc bezmyślnie jedynie tylko w kierunku Konstantynopola, pozwolili Grekom zająć Saloniki, a zaś Serbom i Grekom całą prawie Macedonię.

To był drugi fatalny błąd polityki i wojskowości bułgarskiej, błąd nie do poprawienia.

A teraz błąd trzeci.

Zaraz po pierwszym zawieszeniu broni powinni byli Bułgarzy zawrzeć ostateczny pokój z Turkami, zostawić im Adrianopol, a z całą swoją armią wyruszyć do Macedonii. Wprawdzie różni „bracia Słowianie” w Petersburgu, w Moskwie i w innych miastach, w których rozbrzmiewała Szumi Marica okrwawena, ptacze wdowica osirotena, pragnęli gorąco wzięcia Adrianopola i przygotowywali się nawet do urządzenia uczty w razie jego zdobycia; no, ale pia desideria „braci Słowian” znad Newy nie powinny były wpływać na postanowienia trzeźwej i przewidującej polityki bułgarskiej. Ostatecznie zerwano rokowania pokojowe, rozpoczęto ze zdwojoną zaciętością nowe oblężenia i nowe szturmy Adrianopola i ostatecznie zdobyto go. Udział Serbów we wzięciu Adrianopola był bardzo zręcznym manewrem ze strony polityki i wojskowości serbskiej, w porozumieniu oczywiście z Grekami. Bułgarowie zaś po wzięciu Adrianopola szli naprzód i dokonywali bezcelowych pochodów na Czatałdże, jak gdyby mieli zamiar zdobywać Konstantynopol.

Wzięcie Adrianopola było klęską dla Bułgarii. Zdało ją bowiem na łaskę i niełaskę czcigodnych sprzymierzeńców, „braci Słowian” i „braci chrześcijan wschodniego obrządku”.

To był trzeci błąd, trzecie głupstwo nie do darowania ze strony polityki i wojskowości bułgarskiej.

1 Adrianopol - obecnie Edirne, miasto tureckie przy granicy z Grecją. 
Czwartym błędem Bułgarii było to, że nie obstawano uparcie i stanowczo przy arbitrażu cesarza rosyjskiego co do pasa spornego w Macedonii, przy arbitrażu przewidzianym w umowie serbskobułgarskiej. Gdyby istotnie całkiem szczerze i z dobrą wiarą żądano tego arbitrażu, oszczędzono by sobie prawdopodobnie starcia z Serbią i Grecją, starcia zakończonego fatalną klęską Bułgarii, a po wtóre nie obrażono by monarchy i rządu rosyjskiego. Po przyjęciu bowiem przez cesarza Wszechrosji roli arbitra i po zwróceniu się przezeń z przedstawieniami pokojowymi do obu państw spierających się odrzucenie arbitrażu było oczywiście afrontem. Wprawdzie odpowiedzialność moralna za ten afront spada niby to jednakowo na obie strony, niestety jednak faktycznie skrupia się to głównie na tej stronie, która w prowokowanej walce orężnej została pobita ${ }^{1}$.

Nareszcie piątym błędem, i wcale chyba nie najmniejszym, ze strony wojskowości bułgarskiej było lekceważenie sprawności wojskowej Serbów i Greków, a zwłaszcza Greków. Przedtem Turcy lekceważyli siły „sprzymierzonych” i, będąc wszędzie w mniejszości, zostali sromotnie pobici. Bułgarzy zaś wycieńczeni i przetrzebieni dwiema morderczymi wojnami z Turcją, rzucając się na Greków i Serbów, sprzymierzonych z Czarnogórcami, okazali wielką zarozumiałość i lekkomyślną ufność we własną gwiazdę. Tymczasem Serbowie, a tym bardziej Grecy ponieśli w walkach z Turkami daleko mniej strat i mogli śmiało stawić czoło swemu słabszemu liczebnie i wyczerpanemu przeciwnikowi, tym bardziej że pomogli im z jednej strony Rumuni, a z drugiej Turcy.

Bułgaria tedy przerachowała się i za to srodze odpokutowała. Złudne marzenia imperialistyczne 0 wielkopaństwowości musiały

1 Na ten pogląd absolutnie pisać się nie możemy. Pomijamy stosunek do osoby „cesarza Wszechrosji”; w polityce trzeba przezwyciężać różne uczucia. Ale zdanie się Bułgarii na „arbitraż” cara byłoby utwierdzeniem panowania Rosji na Bałkanie, otworzeniem jej drogi do Konstantynopola. Godności pełen ton, w którym Ferdynand bułgarski odrzucił był arbitraż Rosji, sprowadził na nieszczęśliwy jego kraj klęski, ale zostawił mu samodzielność polityczną i piekącą świadomość, co warta jest Rosja. Z tego powinna i chce skorzystać Austria, o tyle w danym wypadku wyżej stojąca niż Rosja, że tylko się broni i nie myśli o Konstantynopolu. Red. 
ustąpić rozczarowaniu i sromotnemu upokorzeniu. Dostali oni dobra nauczkę, z której trudno korzystać poniewczasie. Nieubłagany bieg wypadków pouczył ich, że lepiej było nie zaczepiać Turcji i mieć się na baczności przed „braćmi Słowianami” i „braćmi chrześcijanami”. Na domiar nieszczęść Adrianopol, który tyle ofiar pochłonął i którego zdobycie było punktem zwrotnym powodzeń bułgarskich, powrócił do Turków i chyba niepodobna go już będzie odebrać.

Gdyby nie milczące veto ze strony Europy, dokonano by bez żadnych ceremonii rozbioru Bułgarii, podobnie jak niegdyś dokonano rozbioru Polski. Podzielono by ją między Grecję, Serbię, Rumunię i Turcję, a państwo bułgarskie znikłoby z karty Europy.

Czajenie się Serbii i Grecji na Bułgarię i rozbicie jej w przymierzu z Rumunią i Turcją sprawia wprawdzie wrażenie jednego z największych łotrostw politycznych, ale, wziąwszy pod uwagę interesy państwowe i Serbii, i Grecji, musimy być dla nich wyrozumiali.

Serbia, zależna ekonomicznie od Austrii i odcięta ze wszystkich stron od morza, marzyła stale o uzyskaniu jakiegoś portu, który by jej dał możność bezpośredniego stykania się ze światem, bez uciekania się do łaski Austro-Węgier lub Bułgarii. Gdyby jej się udało uzyskać część Albanii z jednym lub dwoma portami, prawdopodobnie zrezygnowałaby z Macedonii, na którą od dawna ostrzyła zęby, popierając swe pretensje nawet za pomoca „nauki”, tj. za pomoca fałszerstw lingwistycznych i etnograficznych, co było rzeczą całkiem zbyteczną i niepotrzebną. W każdym razie walczyła ona 0 swój interes żywotny. Niestety, nie udało jej się osiągnąć tego celu pragnień i pożądań, bo od Morza Egejskiego oddziela ją Grecja, która w razie popsucia się stosunków między tymi dwoma państwami może jej bardzo dać się we znaki. No, ale za to prawie podwoiła swe terytorium i liczbę mieszkańców, a prócz tego może się pocieszać romantycznymi i schlebiającymi próżności narodowej przechwałkami, że pomściła zarówno Kosowo Pole z XV wieku ${ }^{1}$, jako też Śliwnicę z drugiej połowy wieku XIX. Co do tego ostatniego punktu nastręcza się złośliwa uwaga, że Bułgaria, zwyciężając Serbię pod Śliwnicą, miała do czynienia tylko

1 Pomyłka autora. Właśc. bitwa miała miejsce w XIV wieku (1389). 
z nią jedną, gdy tymczasem do pomszczenia Śliwnicy potrzeba było sojuszu z Czanogórcami, z Grekami, z Rumunami i z Turkami.

Że takie państwo jak Grecja, państwo przeważnie żeglarskie i kupieckie, dążyło do rozszerzenia swych wybrzeży i do zdobycia jak największej liczby portów i rynków handlowych, to jest chyba całkiem zrozumiałe i nie można mu brać tego za złe.

Tym bardziej zrozumiałe jest obecne postępowanie Turcji. Chyba każde państwo postąpiłoby tak samo. Jej największy wróg, wróg, który jej zadał najdotkliwsze ciosy, został pokonany i rozbity przez swych niedawnych sprzymierzeńców. Cóż dziwnego, że Turcja skorzystała z tego, że zajęła Adrianopol i że chce posuwać się dalej i ze swej strony upokorzyé Bułgarię. Czy ten animusz wojowniczy nie pociągnie za sobą fatalnych skutków dla państwa tureckiego, to znowu inna kwestia.

Turcja miała przed oczyma zachęcający przykład Rumunii. Niektórzy oburzają się na Rumunów, widzą w ich postępowaniu perfidię pierwszego rzędu, stosują do nich wyrażenie punica fides itd. Jeżeli stoimy na stanowisku „interesów państwowych”, to w żaden sposób nie możemy potępiać Rumunii. Przeciwnie, postąpiła ona bardzo zręcznie i rozumnie ${ }^{1}$. Bez żadnych prawie strat, z wyjątkiem niewielkich stosunkowo kosztów na mobilizację, w każdym razie bez krwi rozlewu dokonała wspaniałego rozboju na zimno, powiększyła swe terytorium ${ }^{2}$, przedłużyła swe wybrzeże i pomogła do upokorzenia Bułgarii, która jednak cheąc nie chcąc będzie musiała pogodzić się z losem i tymczasem zawrzeć przymierze z Rumunią. Prócz tego Rumunia ukróciła zbyt daleko sięgające uroszczenia Serbii i Grecji i odegrała rolę rozjemcy i pacyfikatora, co wysunęło ją na pierwszy plan i oddało w jej ręce hegemonię na Półwyspie Bałkańskim. Kto się oburza na Rumunię wcielającą część Bułgarii, niech sobie przypo-

1 Stoimy na stanowisku państwowości, ale nie imperializmu, zagarniającego pod swój bat inne narodowości wbrew ich woli. Słowa Szan. Autora rozumiemy tedy jako ironię. Red.

2 Rumunia zdobyła wówczas na Bułgarii płd. Dobrudżę. 
mni aneksję Bośni i Hercegowiny ${ }^{1}$ przez Austro-Węgry². To także był bardzo zręczny i dowcipny krok na szachownicy politycznej, szkoda tylko, że w znacznym stopniu sparaliżowany przez cały szereg błędów i głupstw dyplomacji austriacko-węgierskiej.

Pomimo wielkich „zwycięstw i tryumfów” Rumunii trochę komicznie i operetkowo wyglądają odezwy króla Karola, dziękującego armii za jej nieustraszona waleczność i powodzenie orężne. Kiedy nikt nie stawia oporu, łatwo odnosić „Zwycięstwa”. Gdyby z podobną gaskonadą wystąpił zwykły śmiertelnik, okryłby się dozgonną śmiesznością. No, ale tym panom wszystko wolno.

W ogóle można zauważyć, że zyski i zdobycze pojedynczych państw bałkańskich pozostają w stosunku odwrotnym do poniesionych przez nie strat i ofiar. Rumunia, bez żadnych prawie strat i ofiar zyskała stosunkowo najwięcej. Grecja poniosła wprawdzie znaczne straty, ale mniej niż inni „sprzymierzeńcy”, a zyskała lwią część zdobyczy terytorialnych. Serbia przelała więcej krwi i doznała większych strat materialnych aniżeli Grecja, ale za to jej zyski są co do swej wartości znacznie mniejsze aniżeli zyski Grecji. Nareszcie Bułgaria, która głównie wyciągała gorące kasztany z ognia, której krew lała się całymi strumieniami i której koszta wojenne dosięgły kolosalnych rozmiarów, została na długi czas upokorzoną, a jej zdobycze terytorialne przyniosą jej niewiele pożytku.

Czarnogórę wyłączamy za nawias. Podobno król czarnogórski grał bardzo szczęśliwie na giełdzie i skutkiem wojny znacznie powiększył swój majątek. Z powodzenia monarchy powinni się cieszyć jego wierni poddani. Zresztą rzeź i rozbój są stanem normalnym dla „bohaterów” czarnogórskich.

1 W 1878 r. kongres berliński, zwołany dla rewizji traktatu pokojowego kończącego wojnę rosyjsko-turecką, przyznał Austro-Węgrom prawo okupowania Bośni i Hercegowiny, formalnie pozostających nadal pod władzą Turcji. W 1908 r. ck monarchia anektowała te tereny, co zaowocowało protestami i zamachami na przedstawicieli władz austriackich, organizowanymi przez radykalną, terrorystyczną i zorientowaną proserbsko organizację młodzieżową Młoda Bośnia.

2 Toteż postępowi posłowie polscy Hausner i Wolski w r. 1879 temu zaborowi się sprzeciwiali. Red. 
Powinniśmy chyba raz na zawsze zrozumieć i dobrze sobie zapamiętać, że tak jak dziś rzeczy stoją, siłę wszelkich państw występujących na widowni tak zwanej historii powszechnej - wszystko jedno, czy istnieją one pod firmą „słowiańską” czy też „niesłowiańską" - stanowi dotychczas i musi stanowić organizacja zbójecka, czyli rozbójnicza. Przy dzisiejszych zaś tendencjach uciskania jednych narodowości przez drugie, narodowość służy za pretekst, a w państwowych organizacjach zbójeckich, czyli rozbójniczych, mamy jeszcze panujące narodowości zbójeckie, czyli rozbójnicze, na przykład: w Węgrzech narodowość madziarską, w Prusiech narodowość niemiecką, we Włoszech narodowość włoską, w Rosji rosyjską itd. Oczywiście, gdyby dziś istniało państwo polskie, taką samą rolę narodowości zbójeckiej, czyli rozbójniczej, odgrywałaby w nim narodowość polska ${ }^{1}$.

Wobec tego, co tylko co powiedziałem, mówienie 0 „wojnach za wolność" - czy to na Bałkanie, czy też gdziekolwiek indziej - zakrawa na żart, zakrawa na kpiny z bliźniego swego. A jeżeli nie są to kpiny, to jest to albo obłuda, albo też naiwność i łatwowierność. 0 ,wojnach za wolność" można mówić chyba tylko ironicznie, nie zaś na serio. Łatwowierni i naiwni byli wszyscy owi poeci i entuzjaści publicystyczni, którzy opiewali „czyny bohaterskie” „walczących za wolność braci Słowian" na Półwyspie Bałkańskim.

Ładnie oswabadzali ci „Stowianie” i „chrześcijanie” innych „braci Słowian” i „braci chrześcijan” spod ,jarzma tureckiego”!

Przypomnijmy sobie przede wszystkim traktowanie Albańczyków przez Serbów z Czarnogórcami i przez Greków.

A teraz jak to oswabadzano Macedonię zaludnioną przez kilka plemion czy też narodowości: przez Słowian, w znacznej swej większości bez wątpienia bardziej zbliżonych do Bułgarów aniżeli do Serbów, następnie przez Greków, przez Kucowołochów, zbliżonych do Rumunów, przez Albańczyków, przez Turków, przez Żydów hiszpańskich?

0 ile można sądzić z tego, co się słyszało i czytało, znaczna większość uświadomionych mieszkańców Macedonii marzyła o włas-

1 Usiłowania postępu powinny więc zdążać do ochrony mniejszości narodowych w każdym państwie. Red. 
nej autonomii, tj. o utworzeniu państewka na pół niezależnego i lenniczego w stosunku do Turcji, w rodzaju tego, jakim w ciągu kilku lat po wojnie rosyjsko-tureckiej r. 1877-78 była Rumelia Wschodnia ze stolicą Filipopolem. Takiej też autonomii spodziewano się w Bułgarii, oczywiście licząc na to, że jak Rumelia wschodnia połączyła się z Bułgarią, tak też z czasem połączy się z nią Macedonia.

Rzecz oczywista, że tych marzeń chowanych w głębi serc macedońskich i bułgarskich nie można było brać za podstawę przy zawieraniu przymierza z Serbami i z Grekami. Do tego kraju, do Macedonii, roszczono pretensje z trzech stron: ze strony bułgarskiej, serbskiej i greckiej. Przewidziano więc w przymierzu zwróconym przeciw Turcji zabór Macedonii i jej podział, nie określiwszy zresztą dokładnie granic między trzema państwami zdobywczymi.

Przeciwko podobnemu postawieniu kwestii protestowali z oburzeniem patrioci macedońscy. I najzupełniej słusznie. Jeżeli „uwalniano” Macedonię „spod jarzma tureckiego”, to należało przede wszystkim „uwolnić” ją, a dopiero potem zapytać jej mieszkańców, jak się chcą urządzić: czy chcą stanowić osobną całość polityczną, czy chcą rozdzielić się i zgadzają się na poćwiartowanie swego kraju, czy nareszcie jest im zupełnie obojętne, jak z nimi postąpią łaskawi zdobywcy.

Tymczasem 0 wolę i życzenia mieszkańców nikt się nie troszczył. Grecy śpieszyli gwałtownie na północ, a zająwszy Saloniki, urządzili przede wszystkim pogrom Żydów i zwrócili ostrze swego miecza przeciw Bułgarom macedońskim, jako głównym swoim wrogom i głównym przedstawicielom separatyzmu macedońskiego. Serbowie, zajmując miejscowości z ludnością, której większość uważa się za Bułgarów, rozporządzali się jak szara gęś na lodzie. Nie czekając końca wojny, nie czekając zawarcia pokoju i ostatecznego określenia granic, zajęli się w te pędy wynaradawianiem „braci Słowian”, tj. Macedończyków, uważających się za Bułgarów. Zamykali szkoły bułgarskie, wypędzali biskupów i księży bułgarskich, zmieniali nazwiska mieszkańców, nadając im wygląd serbski zamiast bułgarskiego, jednym słowem zachowywali się wcale nie lepiej, a nawet może gorzej aniżeli Madziarowie względem innych narodowości państwa 
węgierskiego lub też „bracia Słowianie Rosjanie” względem „braci Słowian Polaków".

Bułgarowie nie mieli sposobności do wynaradawiania, bo nie zajmowali miejscowości serbskich; ograniczali się tępieniem i obracaniem w perzynę miejscowości greckich i tureckich.

Trąbienie więc na wsze strony świata, że się rozpoczyna wojne za wolność ludów Półwyspu Bałkańskiego, jęczacych pod jarzmem tureckim, było objawem bezczelnej obłudy i chęci mydlenia oczu ludziom naiwnym i łatwowiernym. Była to nie „wojna wolnościowa”, ale tylko wojna rozbójnicza i zaborcza, jak zresztą wszelka wojna, a przede wszystkim wszelka wojna napastnicza.

Patrioci macedońscy, zwłaszcza spomiędzy „braci Słowian”, porównywają podział swego kraju z rozbiorem Polski i utrzymują, że pod względem wolności narodowościowej pod rządem tureckim działo się im nierównie lepiej aniżeli się dzieje i dziać się będzie pod rządem greckim i serbskim ${ }^{1}$. Dawniej organizowano „komitety rewolucyjne" i czety powstańcze przeciwko Turkom. Kto wie, czy teraz nie zaczną się „bunty” i formowanie czet przeciwko Grekom i Serbom. Tylko że Grecy i Serbowie za pomocą represji i wypraw karnych, organizowanych nierównie lepiej aniżeli to potrafili Turey, stłumią dośé prędko wszelkie próby „buntu” ze strony swych nowych „poddanych”. Może na szubienicach serbskich i greckich zawiśnie wcale przyzwoita porcja „męczenników za wolność Macedonii”.

Dziś mamy przed sobą fait accompli, który się złożył wbrew oczekiwaniom i przewidywaniom, a który zresztą jest tylko początkowym etapem przyszłej historii Półwyspu Bałkańskiego. Jeszcze całe rzeki łez i krwi tam się poleją.

1 To twierdzenie patriotów macedońskich jest zupełnie słuszne. Turcja odznaczała się niezwykłą tolerancją narodowościową, a pod wielu względami przewyższała chyba wszystkie inne państwa. Dość powiedzieć, że na wyspach Morza Egejskiego należących do Turcji istniały szkoły greckie i że szkoły te były podwładne nie ministrowi tureckiemu, ale tylko ambasadorowi greckiemu w Konstantynopolu i ministrowi oświaty w Atenach. Proszę mi pokazać coś podobnego choćby w jednym z państw europejskich. W ogóle Turcy nie uprawiali sportu wynaradawiania [przyp. BdC]. 
Tymczasem rzućmy przekleństwo tym, co świadomie spowodowali tę rzeź i ten ogrom zbrodni gromadnych i jednostkowych. Gdyby nie ta wojna, a raczej nie te wojny, gdyby nie te wybuchy wyuzdania i rozbestwienia, oszczędziłoby się setki tysięcy ludzi, oszczędziłoby się miliardy bogactw materialnych, oszczędziłoby się całe zapasy dóbr kulturalnych, a te dziś nieszczęśliwe i spustoszone kraje rozwijałyby się, ludzie szlachetnieliby, łagodnieliby, kroczyliby spokojnie ku lepszej przyszłości. A kto wie, czy pod wpływem uspokojenia i dobrego przykładu i Turcy nie poszliby tą samą drogą.

Pochody dzikich hord Hunów, Wandalów, Mongołów, Tatarów, Turków... są niczym w porównaniu z „czynami bohaterskimi” „braci Słowian” i „braci chrześcijan” Półwyspu Bałkańskiego, oczywiście przy zgodnym akompaniamencie „czynów bohaterskich” broniących się, a następnie napastujących „wyznawców Mahometa”. Z ofiar „wojny za wolność” można by usypać całe góry szkieletów i czaszek na cześć i chwałę przodujących tym czynom zbrodniczym monarchów, dyplomatów i wodzów.

Nie tylko niesprawiedliwie, ale także głupio jest oburzać się na „okrucieństwa”, na mordy, gwałty i pożogi, dokonywane przez zastępy wojowników Półwyspu Bałkańskiego. Kto aprobuje wojnę, nie ma prawa gorszyć się jej nieuniknionymi konsekwencjami. Wmyślmy się i wczujmy się w stan psychiczny rozwścieczonego i rozszalałego, a więc niepoczytalnego żołdactwa, w stan psychiczny tych „bohaterów wolności”, tego bydła prowadzonego na rzeź, tego bydła mordującego i mordowanego. Gdybyśmy się znajdowali w podobnych warunkach, gdybyśmy byli pijani krwią, gdybyśmy gorzeli żądzą zemsty i odwetu, z pewnością tak samo mordowalibyśmy, gwałcilibyśmy, palilibyśmy. Podobnych „czynów bohaterskich” dopuszczali się, choć może nie w tak jaskrawych formach, również inni „bohaterowie wolności”, dopuszczali się ich nawet sławetni garibaldczycy w „oswabadzanych” przez nich krainach. A może byśmy porozkoszowali się przy tej sposobności barwnymi obrazami „czynów bohaterskich” polskich „bojowników wolności”, roztaczanymi w Popiotach Żeromskiego ${ }^{1}$.

1 Przeciw tej ironii zastrzegamy się kategorycznie. Bohaterom wolności polskim czynią niektórzy znany zarzut, że od Kościuszki do Traugutta byli za dobrzy, za humanitarni. Red. 
Nie da się zaprzeczyé, że przed wojną z Turkami państwa bałkańskie, z wyjątkiem może Czarnogórza, rozwijały się znakomicie na polu kulturalnym. Zwłaszcza Bułgaria robiła olbrzymie postępy, korzystając z najlepszych wzorów dostarczanych jej przez rozmaite państwa europejskie, na polu gospodarstwa, przemysłu, szkolnictwa itd., itd. Dziś wszystko to poszło na marne. Trzeba będzie przynajmniej pię́cdziesięciu lat, ażeby Bułgaria przyszła do siebie i odzyskata to, co dzisiaj straciła. I to jeszcze kwestia, czy pozwoli jej na to myśl o rewanżu i żądza odwetu za klęski zadane jej przez Greków, Serbów i Rumunów. Być może, iż czeka ją też cały szereg wstrząśnień wewnętrznych, iż czeka ją rewolucja i konwulsyjne próby zmiany formy rządu. Ale choćby nawet panował tam spokój absolutny, potrzebną będzie praca kilku pokoleń na odbudowanie tego, co zostało zburzone przez dzisiejszych szkodników. Dla podtrzymania normalnego przyrostu ludności, pożądanego nie tyle ze względu na szczęście ludzi pojedynczych, ile raczej dla „potęgi państwa”, tj. dla produkowania dostatecznej ilości „mięsa armatniego”, będzie musiała Bułgaria albo zaprowadzić wielożeństwo, albo też sprowadzać mężczyzn z innych krajów.

Serbia też chyba również nieprędko przyjdzie do siebie, chociaż pewnością daleko prędzej aniżeli Bułgaria. Najpomyślniej przedstawiają się na przyszłość szanse Grecji. 0 Czarnogórcach nie ma co mówić, bo dla nich rzeź i wzajemne tępienie się stanowi stan normalny. Przemilczymy też o ciosach zadanych Turcji, bo zadawanie jej ciosów weszło już w stały zwyczaj.

Występuje przede wszystkim złowroga kwestia: co się stanie z Konstantynopolem? Bo że on na długo nie utrzyma się przy Turcji, to zdaje się nie ulegać najmniejszej wątpliwości. Gdyby Rosja prowadziła rozumniejszą politykę, a zwłaszcza gdyby potrafiła się uporać z fatalnymi dla niej sprawami wewnętrznymi, to kto wie, czy Konstantynopol w niezbyt odległej przyszłości nie stałby się jej łupem. A wtedy oczywiście zapanowałaby ona faktycznie także nad całym Półwyspem Bałkańskim. Zdaje się jednak, że polityka rosyjska nie dorosła do rozwiązania tego zadania na swoją korzyść.

Odnosi jednak Rosja z awantury bałkańskiej niewątpliwą korzyść moralną. Wobec okropności ostatnich wojen zarówno „braci 
Słowian” i „braci chrześcijan” z Turcją, jako też „braci Słowian” i „braci chrześcijan” pomiędzy sobą, bledną okropności, które się działy i dzieją w państwie samowładców Europy Wschodniej: bledną „czyny patriotyczne” Murawiewa „wieszatiela”, blednie krwawe nawracanie unitów na prawosławie, bledną wyprawy karne lat „rewolucyjnych” i „porewolucyjnych”, blednie działalność sądów polowych i sądów wojskowych w ogóle1.

Austro-Wegry odegrały w całej tej sprawie bardzo smutną rolę. Popełniły one cały szereg głupstw nie do poprawienia, ale te wszystkie bieżące głupstwa są głupstwem w porównaniu z zasadniczym, chronicznym głupstwem, polegającym na tolerowaniu polityki wynaradawiającej Węgier w stosunku do narodowości niemadziarskich, w tej liczbie w stosunku także do wielorakich „braci Słowian”. Jeżeli z całą bezwzględnością usuwa się wszelkie ślady istnienia w Węgrzech Słowaków, Rusinów, Słoweńców, Kroatów i Serbów, jeżeli Serbowi każą zastępować, np. jego Novi Sad przez Uj-Videk, jeżeli okazuje się najwyższą pogardę narodowościom słowiańskim, a najniewinniejsze żądania równouprawnienia ogłasza się za „panslawistyczną" zdradę stanu, to nic dziwnego, że nie tylko odstręcza się te narody od macoszego państwa, ale także wzbudza się w nich nienawiść i żądzę odwetu. W państwach ze znaczną przewagą jednej narodowości nad innymi, nacjonalizm, lubo wstrętny sam w sobie, nie grozi jednak niebezpieczeństwem ze stanowiska egoizmu państwowego (Red. [„Krytyki”]). W takim jednak państwie jak Austro-Węgry wywołuje on silne prądy odśrodkowe i może je przyprawić o zgubę ostateczną. Przy pewnej konstelacji politycznej możliwe są nawet próby rozbioru Austro-Węgier ze strony sąsiadów, właśnie w imię nacjonalizmu. Powołując się na nacjonalizm, mogą rościć pretensje do zagarnięcia pewnych części Austro-Węgier przede wszystkim Niemcy, następnie Serbia z Czarnogórzem, Rosja, Rumunia, Włochy - kompanijka dość liczna i dająca wiele do myślenia. Z całych Austro-Węgier może pozo-

1 Nas jednak dotknęty najbliżej i bolą najmocniej - musi się więc ich możliwość dalszą wykorzenić. Red. 
stać albo nic, albo też resztki mizerne. W każdym razie Węgry stracą swój port Fiume ${ }^{1}$ i przestaną być „państwem nadmorskim”.

A tymczasem, pozbywszy się nacjonalizmu i oparłszy się na dobrze zrozumianej solidarności ogólnopaństwowej wszystkich swych narodowości, Austro-Węgry mogłyby być, podobnie jak Szwajcaria, wzorem ustroju państwowego, opartego nie na zasadzie menażeryjnej, rasowej lub narodowościowej, ale na zasadzie spokojnego współżycia ludzi różnoimiennych co do narodowości językowej, etnograficznej i historycznej.

Słyszałem od bardzo poważnych Serbów, że gdyby w Austro-Węgrzech nie uprawiano polityki wynaradawiania i uprzywilejowania narodowości madziarskiej i niemieckiej ze szkodą innych, trzeźwi politycy serbscy nie mieliby nic przeciwko przyłączeniu się do Austro-Węgier jako równi z równymi, przez co zyskaliby ekonomicznie i oszczędziliby sobie kosztów utrzymywania osobnego dworu i osobnej reprezentacji dyplomatycznej. Dziś oczywiście po tylu dowodach krótkowidztwa austro-węgierskiego mowy o tym być nie może.

Rzecz jasna, że na rozbiorze Austrii najgorzej by wyszli niektórzy „bracia Słowianie”, a mianowicie Czesi, Polacy, Ukraińcy, Słoweńcy, mogący tylko w Austrii manifestować otwarcie swą odrębność narodową. Ale sądzę, że nawet Kroaci, lubo językowo utożsamiani z Serbami, nie zrobiliby na upadku Austrii zbyt świetnego interesu.

Wobec tego wszystkiego opamiętanie się i porzucenie polityki wynaradawiania powinno by być wspólną sprawą wszystkich narodów Austro-Węgier. Czy jednak to zaślepione i jak gdyby niepoczytalne państwo zdobędzie się na coś podobnego, jest rzeczą bardziej niż wątpliwą.

Podobno w Sparcie starożytnej upajano Helotów i doprowadzano ich do tak zwanego zbydlęcenia, ażeby tym wstrętnym widokiem odstraszać własną młodzież od pijaństwa. Rolę takich Helotów, pijanych krwią i żądzą mordu, odegrali tylko co „bracia Słowianie” Półwyspu Bałkańskiego. Dali oni Europie przykład odstraszający, który jednak prawdopodobnie nie poskutkuje i nie powstrzyma od przyszłych wojen między „wielkimi mocarstwami”.

1 Fiume - obecnie Rijeka. 
Powinno by to także byé nauczką dla tych, co lekkomyślnie pobrzękiwali szabelką i w związku z Austrią przygotowywali się do $a k$ cji orężnej, skierowanej przeciwko Rosji. Ci duchem wojowniczym ogarnięci męże i niewiasty nie zastanawiali się nad tym, ile by to taka wojna kosztowała, jaką by spowodowała ruinę i upadek kultury ${ }^{1}$.

Według ostatecznego obliczenia, Bułgaria np. straciła w samych zabitych żołnierzach 140000 ludzi. Dołączywszy do tego zarówno tych, co wskutek ciężkich ran stali się niezdolni do pracy, jako też umarłych skutkiem różnych chorób nieodłącznych od wojny, możemy śmiało ocenić stratę Bułgarii w samych młodych mężczyznach przynajmniej na 200000 ludzi, czyli na blisko 5\% całej ludności. Nie mówię już o ludności cywilnej, pomordowanej zarówno przez Turków, jako też przez „braci Słowian” i „braci chrześcijan”. Gdyby wojna Austrii z Rosją odbywała się przy tym samym napięciu energii ,wojowniczej", Austria powinna by stracić przynajmniej dwa miliony żołnierzy, a Rosja osiem milionów! Niemcy powinny by stracić około trzech milionów, Francja blisko dwa miliony itd. Ponieważ zaś pierwszymi byłyby rzucone na Rosję ze strony Austrii pułki galicyjskie, więc na Galicję, tj. na Polaków, na Ukraińców i na Żydów galicyjskich przypadłby największy procent ofiar, więcej z pewnością niż 5\% ludności.

Ile by to matek i sióstr utraciło synów i braci, ile by pozostało wdów i sierot!

Wobec tego każdy człowiek niewyzuty z sumienia zgodzić się chyba musi, że albo zbrodnią, albo też czynem szaleńca niepoczytalnego jest nawoływanie czy to do wojny Austrii z Rosją, czy też do

1 Ruinę i upadek kultury Królestwa i prowincji zabranych sprowadzi przede wszystkim panowanie Rosji. Ono sprawia, że prowincje te razem mają stosunkowo mniej szkół ludowych niż Galicja, mniej też szkół średnich, wyższych, mniej linii kolejowych, bezpieczeństwa publicznego etc. Ono rzuca na pastwę najciemniejszych popów całe szmaty ziemi (Chełmszczyzna!), a całe kraje - jeśli nie ochrany, to żandarmów i szpiegów. Ono obdarza „poddanych” nacjonalizmem puryszkiewiczowskim, ono sprawia, że robotnik nie może się rozwinąć w duchu nowoczesnym. Ono szerzy zarazę moralną i cofa kulturę tak w Polsce, jak i we Finlandii etc. Samoobrona narodowa jest tedy właśnie nakazem kultury i żadne ofiary nie byłyby za duże, gdyby tylko prowadziły do usunięcia właśnie owej hańby cywilizacji, którą są rządy moskiewskie. Red. 
jakiejkolwiek innej. Kto sam chce iść na złamanie karku, niechże sobie idzie; ale wara mu do innych ${ }^{1}$.

Słyszałem całkiem serio głoszone zdania, że wojny takie są bardzo pożądane ze względu na przeludnienie.

Zgoda, ale w takim razie idźcie na wojnę sami, prowadźcie na nią własnych braci, synów, przyjaciół, a przysłużycie się ludzkości cierpiącej na przeludnienie.

Jeżeli potrzebne jest zmniejszanie ludności dla zapobieżenia przeludnieniu, to dlaczego ma się to odbywać przy akompaniamencie tylu męczarń, znęcań się, gwałtów? Dlaczego przy tej operacji zapobiegającej przeludnieniu kobiety mają być nasamprzód gwałcone, a następnie mordowane? Dlaczego mają byé tępione doszczętnie całe wsie i miasta tylko w pewnych okolicach? Dlaczego ten obowiązek wobec ludzkości, obowiązek zapobiegania przeludnieniu, mają pełnić tylko pewne kraje, objęte w danej chwili pożogą wojenną? Dlaczego mają ginąć w charakterze wojowników przede wszystkim tylko mężczyźni, a spomiędzy mężczyzn przede wszystkim ludzie młodzi, silni i zdrowi?

Jeżeli zapobieganie przeludnieniu za pomocą mordów uważacie za pożądane, to dlaczego karzecie zabójców? Dlaczego karzecie trucicieli? Dlaczego pogardzacie katami i macie pretensje do sędziów podpisujących wyroki śmierci? Dlaczego nie pozwalacie lekarzom przyśpieszać skonania męczennikom wijącym się w boleściach? 0btudnicy!

Jeżeli wam tak chodzi o zapobieganie przeludnieniu, to powinniście uciekać się do innych środków, nie skazując milionów ludzi na nędzę i cierpienia. Powinniście przede wszystkim zakładać i popierać kluby samobójców. Powinniście nie tylko tolerować wolną propagandę samobójstwa, ale także zachęcać do niego wszelkimi sposoby. Powinniście działać na próżność ludzką, powinniście wyznaczać premię

1 Tak rozumując, nie walczyłby człowiek nigdy ze złem, a poddawałby się bezwolnie jak baran rozmaitym hordom dzikim oraz bestiom na tronie, w ogóle wszelkiej przemocy. Walka należycie przygotowana jest obowiązkiem, jest instynktem rodziców rzucających się w niebezpieczeństwo, gdy chodzi o obronę przyszłości. A odpowiedzialność pada na tych, co swymi rządami nieproszonymi walkę prowokują. Red. 
za udatną propagandę samobójstwa, a samym samobójcom wznosić wspaniałe pomniki, uwieczniając ich imiona.

Następnie, gdyby metoda samobójstw okazała się niedostateczną, powinniście zaprowadzić losowanie na bilety obowiązujące do przenoszenia się na tamten świat. Jestem przekonany, że wielu ludzi chętnie by się temu poddawało, byleby tylko zabijano ich środkami łagodnymi, bez żadnego bólu. Ja ze swej strony polecam chloroform, za pomocą którego można by usuwać już bez losowania wszystkich kaleków, ludzi nieuleczalnie chorych, społecznie bezużytecznych, starców po dojściu do pewnego określonego wieku itp.

Te metody „zapobiegania przeludnieniu” należałoby stosować w równej mierze do „braci Słowian” wraz ze „siostrami Słowiankami”, do „braci i sióstr w Chrystusie”, „w Mojżeszu”, „w Mahomecie”, „w Buddzie”, „w Konfucjuszu”..., w szatanie.

Jeżeli zaś upieracie się przy dotychczasowych sposobach „zapobiegania przeludnieniu”, tj. proponujecie urządzać szlachtuzy i jatki ludzkie, powinniście pomyśleć, że takie mnóstwo mięsa ludzkiego idzie na marne. Wobec więc perspektywy głodu następującego po wojnach, wobec tego, że wiele wdów i sierot po „bohaterach” nie ma co do ust włożyć, powinniście zakładać fabryki konserw z mięsa „bohaterskiego”, którym moglibyście karmić wdowy i sieroty po „bohaterach" pozostałe.

Pomyślcie, obłudnicy!

0 mało nie zapomniałem o najważniejszym i najniewinniejszym, najłagodniejszym, najbardziej „ludzkim” środku na przeludnienie. Oto należy wszelkimi siłami zapobiegać rodzeniu się dzieci. A więc: wyznaczać premia dla faktycznie bezżennych, dla faktycznie niezamężnych, dla bezdzietnych; propagować neomaltuzjanizm wraz z wszelkimi sposobami zapobiegania zapłodnieniu; nie tylko nie prześladować spędzania płodu, ale przeciwnie, zachęcać do niego. Projekt ten ma na celu przede wszystkim zmniejszenie ilości cierpień ludzkich, a więc jest podyktowany przez najczystszej wody altruizm. Oczywiście nie zyska on uznania tych, którym chodzi o wyproduko- 
wanie jak największej ilości chair a canone i chair a plaisir filles de joie $)^{1}$.

Pomimo okropności wojen prowadzonych przez „braci Słowian” i „braci chrześcijan” Półwyspu Bałkańskiego, nie będą one jednak przestrogą dla przyszłości. Przeciwnie, militaryzm się wzmaga i przybiera potworne rozmiary. Do środków tępienia „bliźnich” na lądzie i wodzie przyłączają się balony „diriżable” i aeroplany. Włosi rzucali z nich bomby na tuziemców Trypolitanii, a Bułgarzy na mieszkańców Adrianopola. Europę ogarnął szał niszczenia. Wszelkie wynalazki zamieniają się ostatecznie na środki unicestwiania istnień ludzkich i zdobyczy kultury. Jeżeli tak dalej pójdzie, Europa zdziczeje ostatecznie i utonie w morzu własnej krwi. Cywilizacja europejska zniknie, a pozostaną tylko jej szczątki, których badaniem zajmą się ludzie, przybyli z innych części świata, podobnie jak my dzisiaj badamy szczątki cywilizacji babilońskiej, fenickiej, egipskiej itd.

Trudno liczyć na upamiętanie się i na zastąpienie wojen z ich okropnymi skutkami przez wzajemne porozumiewanie się w celu określania granic interesów oddzielnych państw i innych ugrupowań ludzkich, przez urządzenie czegoś, co mogłoby być nazwane „Stanami Zjednoczonymi Europy”?

Bled-Veldes, sierpień 1913.

[Kraków 1913. Nadbitka: „Krytyka” 1913, IX-X]

1 Chair a canone, chair a plaisir (filles de joie) (fr.) - mięsa armatniego, ciał dla rozkoszy (wesołych panienek).

2 Diriżable ( $\mathrm{z}$ fr.) - sterowce.

3 Tym bardziej umotywowana jest dyrektywa dla narodu: bądź silny! przygotowany na wszelkie ostateczności! Red.

4 Redakcja „Krytyki” opatrzyła artykuł Baudouina de Courtenay przypisem treści następującej: „Drukujemy artykuł, nie zgadzając się na kilka jego zasadniczych twierdzeń, nie tylko z szacunku dla znakomitego autora; jako pismo bezpartyjne chętnie korzystamy ze sposobności, aby myślącemu czytelnikowi przedstawić pro i contra w najważniejszych sprawach polityki europejskiej i spraw z nią związanych”. 


\section{NARODOWA I TERYTORIALNA CECHA AUTONOMII ${ }^{1}$}

Poświęcone wszystkim „patriotom”

\section{Spis rzeczy}

Słowo wstępne

1. Określenie ogólnego punktu widzenia

2. Źródła narodowościowej i terytorialnej cechy autonomii

3. Obiektywne i subiektywne określenie i ocena przynależności człowieka do określonej grupy społecznej

4. Praktyczne rozwiązanie kwestii autonomii

5. Federalizacja państwa rosyjskiego

6. Zagwarantowanie praw mniejszości i większości

7. Szkoda i pożytek

8. Konkretne kwestie. Kwestia żydowska. Syjonizm. „Żargon”

9. Konkretne kwestie. Kwestia szkolna

10. To, co wykonalne w najbliższej przyszłości

\section{Słowo wstępne}

Artykuł ten napisałem w początkach 1907 r. na życzenie redakcji powstającego w Moskwie, ale niestety nieurzeczywistnionego „Sbornika Awtonomistow”. Pismo to podzieliło los wielu innych przedsięwzięć literackich i społecznych. Był to czas szybkiego opadania nastrojów, zbytnio ożywionych, zuchwałych i przepełnionych fantastycznymi marzeniami. Klęska za klęską, rozczarowanie za rozczarowaniem.

Obecnie temperatura nastrojów spadła nie tylko do zera, ale nawet poniżej. Rozmyślanie nie tylko 0 „autonomii”, ale nawet 0 naj-

1 Tytuł oryginału rosyjskiego: Nacional'nyj i tierritorial'nyj priznak w awtonomii, S.-Pietierburg 1913 (przekł. pol. M. Skarżyński). 
skromniejszym samorządzie wydaje się ostatnią naiwnością, jeśli nie wprost niedorzecznością. Obecni prawodawcy i władcy Rosji chcieliby unicestwić najmniejsze ślady lokalnej odrębności, oryginalności i indywidualności, a jednocześnie uniemożliwić wszelkie próby działań społecznych, wszelkie dążenia do tego, aby wyjść ze stanu bezmyślnego stada, kierującego się jedynie egoistycznymi pobudkami sobkowskiego charakteru, strachem przed pałką i knutem pastucha. Silniejsza indywidualność i świadome uspołecznienie zaliczono do kategorii surowo karanych przestępstw przeciwko państwu.

Z tego punktu widzenia patrzę na ten artykuł nie na jako coś związanego z rzeczywistością, co może wywołać skromny choćby odzew w praktycznym życiu, ale jedynie jako na smutne przypomnienie o tym, jak ciężko pobłądziłem..., z resztą - nie ja jeden.

Uważając swój artykuł za dokument dawno minionych chwil, prawie niczego $\mathrm{w}$ nim nie zmieniłem i wydaje go w jego pierwotnym kształcie.

Maj 1910

To „słowo wstępne” napisałem przed trzema laty, kiedy to zamierzałem zamieścić swój artykuł w jednym z popularnych czasopism. Redakcja zgodziła się, ale z powodu obszerności artykułu zażądała jego skrócenia. Jednak inne prace różnego rodzaju przeszkodziły mi wówczas, potem zaś prawie o swym artykule zapomniałem.

Wydaje mi się, że właśnie teraz stał się on jak gdyby aktualniejszym, oczywiście w sensie czysto teoretycznym. Przecież właśnie teraz urzeczywistniają się rozmaite dążności i hasła, o kierunku wprost przeciwnym do przedstawionych przeze mnie zasad. Przecież na naszych oczach odrywa się od Królestwa Polskiego „męczeńska Chełmszczyzna”. Przecież „polscy” „patrioci” różnych barw ogłosili wyprawy krzyżowe przeciwko „Żydom”. A wreszcie ostatnio Koło Pol-

1 Dalej w tekście także „Ruś Chełmska”. Chodzi o położoną na wschód od Lublina po linię Bugu część guberni lubelskiej i siedleckiej, którą w roku 1912 przyłączono do Rosji, co było ukoronowaniem działań rusyfikacyjnych wobec tamtejszej ludności polskiej i ukraińskiej i nawracania siłą unitów. 
skie w Dumie Państwowej otwarcie świętowało rozstanie bez żalu z nieprawomyślną opozycją i związek z tryumfującą reakcją.

Niech więc wszystkie te szlachetne porywy otrzymają należyte oświetlenie.

Czerwiec 1913

\section{Określenie ogólnego punktu widzenia}

Do zagadnienia autonomii i właściwych jej cech można podejść dwojako: albo ściśle naukowo, po akademicku, albo też w związku z zadaniami polityki praktycznej w określonym momencie historycznym.

Tak w jednym, jak i w drugim przypadku osobiście jestem tylko dyletantem. Dyscyplinom naukowym będącym moją specjalnością obce są problemy ustroju państwa i struktury społecznej; zawsze też byłem daleki od bieżącej polityki i dopiero w ostatnich czasach, kiedy to sprawa ratowania kraju wymagała jakiegoś udziału, nawet pospolitego ruszenia starszego zaciągu, również mnie ogarnęła gwałtowna fala ruchów społecznych.

W każdym jednak razie proszę patrzeć na ten mój wykład nie jak na autorytatywny sąd specjalisty uzbrojonego we wszechstronną wiedzę o literaturze przedmiotu i samodzielnie wnikającego w głąb badanych problemów, ale jak na skromny głos jednego z obywateli. Na swoje zaś usprawiedliwienie mogę przywołać poruszające wszystkich żądanie powszechnych, równych, bezpośrednich i tajnych wyborów. Niestety, ostatni warunek pozostawiam niespełniony - ja swój głos składam nie tajnie, ale jawnie.

$$
* * *
$$

Dla przyjęcia jakichkolwiek idei niezbędna jest dobra wola i odpowiednio przygotowany umyst. Kto po prostu nie chce słyszeć o nich, a priori odrzucając je z fanatyczną nietolerancją i pogardą, w czyjej głowie brak wcześniejszego przygotowania i logicznego nastawienia albo też kto broni zasadniczo odmiennego punktu widzenia, do tego nie warto się zwracać. Wszelkie próby przekonania takich ludzi pozo- 
staną głosem wołającego na puszczy. Więc i ja w tym wypadku liczę tylko na ludzi mniej lub bardziej bliskich mi umysłowo i wyznających te same zasady ogólne. Zwracam się do czytelnika nie po to, by go przekonać, nawet nie po to, by go przekonywać, ale po to tylko, aby rzecz wyjaśnić.

Piszę nie dla tych, którzy zbywają wszystko wygodnym powiedzeniem moja chata s kraju, niczego nie znaju, ale tylko dla tych, co uważaja za obywatelski obowiązek tak lub inaczej wypowiadać się w sprawach ogólnych.

Piszę nie dla tych, którzy powodują się tylko samolubnymi względami i pierwotnym egoizmem osobnika należącego do ludzkiego stada, ale tylko dla indywiduów rozwiniętych, wyznających społeczną solidarność i powodujących się racjami szczęścia kraju.

Piszę nie dla tych, którzy całkowicie ulegają międzyplemiennemu, międzynarodowemu i międzywyznaniowemu impresjonizmowi i nie moga przełamać wszczepionego im wstrętu do innych ludzi, ale dla tych tylko, u których, co być może, zachowały się jeszcze resztki niechęci i przesądów, ale którzy potrafią mimo wszystko je przezwyciężyć i którzy w realnym życiu podporządkowują się ogólnym zasadom, nie zaś ulotnym wrażeniom.

Piszę nie dla tych, którzy są przekonani o stałej wyższości danego, swojego lub obcego plemienia, swojej lub obcej klasy i o prawie do panowania nad innymi, ale dla tych, którzy, choć widzą chwilową przewagę danego plemienia lub danej klasy społecznej, nie czynią z tego punktu wyjścia do wyprowadzania wniosków o prawie do wiecznego panowania.

Piszę nie dla tych, którzy dopuszczają możliwość przywilejów i pierwszeństwa, przysługujących określonym osobom tylko z racji ich pochodzenia, ale dla tych, którzy uznają wyłącznie o s obiste zastugi i osobistą wyższość.

Piszę nie dla tych, którzy godzą się z niewolnictwem, ale dla tych tylko, którzy, stawiając najwyżej godność człowieka, odrzucają niewolnictwo w jakiejkolwiek formie.

Piszę nie dla tych, którzy uznają prawo jednych do narzucania innym narodowościowego lub wyznaniowego piętna, ale dla tych tyl- 
ko, którzy bronią bezwarunkowego samookreślenia się w tych dziedzinach.

A wreszcie piszę nie dla tych, którzy dzielą ludność kraju na gospodarzy, mających prawo rządzenia, i na gości zobowiązanych podporządkować się rządzącym, ale dla tych tylko, którzy żadnych rządów tego rodzaju nie uznają i wszystkich mieszkańców kraju traktują w takim samym stopniu i jako gospodarzy, i jako gości. Wszyscy są gospodarzami dotąd, dopóki żyją, i wszyscy zarazem są gośćmi, ponieważ ich gospodarowanie przemija i kończy się wraz ze śmiercią.

Na takich założeniach opieram swój ogólny punkt widzenia rozpatrywania danej kwestii.

Ani razu nie wspomniałem tu o miłości bliźniego albo kogokolwiek. Mało tego, wszelkie powoływania się na „miłość”, na „miłość bliźniego”, na „miłość do rodaków”, na „miłość do współplemieńców” (na „miłość” Rosjan do wszystkich Słowian), na „miłość do współwyznawców” itd. uważam po prostu za kłamstwo i obłudę.

Jak urzeczywistnia się w naszych czasach „miłość bliźniego”, można zobaczyć, między innymi z tego, co ujawnili ks. Urusow ${ }^{1}$, p. Łopuchin i żandarmski rotmistrz Pietuchow. Coś ciekawego w tej materii mógłby powiedzieć ojciec Jan Kronsztadzki i mnisi Poczajewskiej Ławry². Obecni apostołowie „miłości bliźniego” i innych tp. wzniosłych uczuć urzeczywistniają je w pogromach, w ekspedycjach karnych, w sądach polowych i wojennych i we wzajemnym wyniszczaniu się. 0 praktykowanej w naszych czasach „miłości bliźniego” dobitnie mówią bomby i szubienice.

Kłamliwą i obłudną „miłość bliźniego” zastępuję opartym na logicznym myśleniu poczuciem sprawiedliwości. To poczucie sprawiedliwości działa niekiedy całkiem nieświadomie, ale ogólnie działa 0 wiele częściej, niżbyśmy sądzili.

$1 \quad$ Mowa 0 wydanych w 1907 r. Zapiskach gubernatora.

$2 \quad$ Właśc:: Poczajowska Ławra - klasztor i zespół świątynny koło miasteczka Poczajew w obwodzie tarnopolskim na Ukrainie, założony w latach 40. XIII w., słynny między innymi z cudownego obrazu Matki Bożej. 
Jeśli ktoś nie ma poczucia sprawiedliwości, to niech w ostateczności kieruje się pojęciem utylitaryzmu w wyższym znaczeniu, tj. pojęciem korzyści wspólnej. Powinien to być oczywiście nie utylitaryzm biurokratów, bogacących się kosztem głodnych biedaków, ale utylitaryzm altruistyczny, utylitaryzm z punktu widzenia szezęścia rodzinnego kraju, rodzinnego obwodu, rodzinnej miejscowości. Dla wyjaśnienia weźmy konkretny przykład.

Przypuśćmy, że ten czy inny „patriota” nienawidzi Żydów i uważa ich za plemię zdradzieckie, przeciwne jego obyczajom. Stosownie do tego, nasz „patriota” powinien dążyé do wysiedlenia Żydów z Rosji lub usunięcia ich w ogóle, po prostu przez wytępienie. Niestety, jest to nieosiągalne, choćby dlatego że na przeszkodzie skończenia raz na zawsze z pogańskim „żydostwem” stanętyby inne państwa. Tak więc naszemu „patriocie” nie pozostaje nic innego, jak wprawiać się w urządzaniu pogromów i ciągłych „ekspedycji karnych”. Nasz „patriota" dostarczy sobie, co prawda, najwyższych rozkoszy, ale krajowi wyrządzi niewątpliwą szkodę. Po pierwsze dlatego, że kraj niszczeje i upada ekonomicznie; po drugie nikt nie udzieli mu pożyczki, po trzecie straci ostatecznie prestiż; po czwarte w końcu i własny naród zdziczeje i stanie się przeciwspołeczny.

Tak więc jeśli nasz „patriota” życzy szczęścia własnemu krajowi, powinien, z bólem serca, wyrzec się pogromowych i karnych przyjemności.

Jak się wydaje, jeszeze Hercen zauważyt, że dopóki jedna częśé ludzkości uważa się za biesiadników, a druga z potrawę, wszystko układa się pomyślnie. Ale kiedy potrawa pyta, jakim prawem ma byé potrawą, hört die Gemütlich auf, tj. przychodzi koniec dobrowolnego niewolnictwa. Wtedy można być niewolnikiem tylko ze strachu, ale nigdy dobrowolnie. Wtedy możliwe są ciągte bunty i ich tłumienie, ale to tłumienie buntu nie zawsze kończy się szczęśliwie dla tłumiącego. A więc dla uniknięcia szkodliwych i niebezpiecznych rozruchów jest konieczne zniesienie niewolnictwa.

Na tym, jedynym możliwym w naszych czasach stanowisku stoi partia wolności ludu ${ }^{1}$ i partie jej bliskie.

1 Mowa o Partii Konstytucyjnych Demokratów (tzw. kadetach). 
Niedawno jeden $\mathrm{z}$,wybitnych mężów stanu”, obecnie w stanie spoczynku, zarzucał partii k.[onstytucyjnych] d.[emokratów] „kosmopolityzm" i dawał rady Polakom, aby trzymali się możliwie jak najdalej od tej nienarodowej partii. „Kosmopolityzm” partii wolności ludu, według naszego „męża stanu”, objawia się tym, że broni ona równouprawnienia wszystkich bez wyjątku, że nie uznaje politycznej dominacji narodu wielkoruskiego. Nasz krótkowzroczny „mąż stanu" nie jest w stanie wyobrazić sobie Rosji bez linii osiedlenia, bez ograniczających procentów i w ogóle bez narodowościowych nagonek. Gdyby rzeczywiście był on mężem stanu w dobrym stylu, rozumiałby, że partia k.d. jest partią nie tylko wysoce moralną, której obca jest pogarda i niechęć wobec kogokolwiek, ale jednocześnie jest partią najbardziej patriotyczną. Przecież to ona domaga się tego, by sprawa Rosji stała się wspólną sprawą wszystkich zamieszkujących ją narodów i plemion.

I to jest właśnie to ogólne stanowisko, na którym powinni stać moi czytelnicy.

\section{2. Źródła narodowościowej i terytorialnej cechy autonomii}

Ludzie łączą się w grupy albo niezależnie od swej woli, albo też w zależności od niej.

Niezależne, ściśle obiektywne łączenie się może mieć charakter albo naturalny, biologiczny, antropologiczny, albo też społeczny, socjalny.

Antropologicznymi, naturalnymi cechami niezależnego od woli ludzkiej zrzeszania się są: płeć, rasa, cechy fizyczne, język, rodzaj i stopień (jakość i ilość) zdolności umysłowych, charakter, temperament, pokrewieństwo biologiezne (rodzice, dzieci itp.) itd.

Społeczne podstawy łączenia się niezależnego od woli ludzkiej, są w większej części zobiektywizowaną kontynuacją znanych, niekiedy urzeczywistnionych decyzji i rozstrzygnięć. Stany, klasy społeczne, różnice majątkowe (bogaci, biedni itp.), przynależność rodowa, przynależność do gminy, do obwodu, do państwa itp.

Łączenie się ludzi w zależności od woli może byé albo przymusowe, albo dobrowolne. Skutkiem przymusowego tączenia się, tj. łącze- 
nia w zależności od woli cudzej, są w dzisiejszych czasach wszelkiego rodzaju geograficzne, terytorialne rozmieszczenia ludzi, a przede wszystkim przynależność państwowa i administracyjna. Za swobodne łączenie się ludzi, łączenie zależne od własnej woli danego osobnika, należy zasadniczo uznać zrzeszanie się według rodzaju zajęcia, wyznania, narodowości itp.

Oczywiście w olbrzymiej większości przypadków jest tu tylko złudzenie własnej woli, pozorna tylko wolność, a w rzeczywistości jest tu albo sugestia ze strony innych ludzi, albo nawet wprost przymus. W ogóle nadzwyczaj trudno określić, gdzie kończy się wpływ cudzej woli, a gdzie zaczyna się wpływ woli własnej. Te dwa rodzaje łączenia się w zależności od woli ludzkiej splatają się ze sobą i przechodzą jeden w drugi.

I tak na przykład przynależność terytorialna i administracyjna jest obowiązkowa, ale mimo to, wyjąwszy niewolnictwo, każdy mieszkaniec ma prawo zmienić nie tylko miejsce zamieszkania, ale nawet przynależność państwową, tj. zamienić jedno poddaństwo lub obywatelstwo na inne. Poza tym i tu są przeżytki niewolnictwa, właśnie w odniesieniu do ludzi obowiązanych do służby wojskowej i w następstwie tego niemających prawa zrzucić przymusowego poddaństwa. Ale w każdym przypadku każdy człowiek musi mieć taką czy inną przynależność państwową i eksterytorialność nie jest dozwolona.

W zastosowaniu do naszej kwestii, tj. terytorialnej i narodowościowej cechy autonomii, należy zauważyé, że to, co narod ow ościowe i w ogóle kulturowe okazuje się zarazem czymś zmiennym, ponieważ jego nosiciele nie są związani miejscem i administracyjnym skrępowaniem, podezas gdy pod względem terytorialnym człowiek okazuje sięglebae adscriptus.

Tak jest jednak dopiero obecnie, w państwach i społeczeństwach nowszego typu. Z historycznego punktu widzenia nastąpito tu przesunięcie. Dawniej człowiek był nie glebae adscriptus, ale genti adscriptus, nationi adscriptus, familiae adscriptus. Pozostawało to w związku z mitologicznym światopoglądem, z substantywizowaniem i personifikowaniem rodu i jego opiekuna, rodowego i narodowościowego (dokładniej: plemiennego) boga. Tego boga wszyscy członkowie rodu musieli wielbić i oddawać mu cześć. 
Tego rodzaju rodzinne i rodowe przywiązanie odpowiada warunkom życia koczowniczego i pasterskiego. Terytorium nie jest wtedy ustalone, ale zmienne; dziś tu, jutro tam. Nie ma domów, ognisk domowych, są tylko przenośne szałasy i jurty. Więzi społeczne sprowadzają się do jednej tylko więzi rodowej, w węższych lub szerszych ramach; poszczególni ludzie są ruchliwymi nosicielami wyznaniowych i plemiennych, tj zalążkowonarodowościowych, ideałów.

Kiedy życie koczownicze zmieniło się w osiadłe, a pasterstwo w rolnictwo, wtedy zmienił się też stosunek między cechą plemienną lub zalążkowonarodowościową a terytorialną. Wiążąca i konieczna staje się wtedy przynależność terytorialna, natomiast przynależności rodowe, plemienne lub zalążkowonarodowościowe usuwają się na drugi plan. Jednakże mimo przewagi elementu terytorialnego nad plemiennym i narodowościowym, przeżytki gromadzenia się ludzi na podstawach plemiennych i narodowościowych zachowują się do czasów obecnych.

Jednym z takich przeżytków jest przede wszystkim organizacja wojskowa, która - choć zawdzięcza swój kształt ogólnopaństwowej, terytorialnej jedności - ze swej natury jest ruchoma, koczownicza. Tu też należą wszelkie najazdy kolonizatorskie, rozboje, grabieże i inne przedsięwzięcia, podobnie jak masowe przesiedlenia i emigracje.

Za przeżytek koczowniczego trybu życia należy uznać wędrowne grupy społeczne i klasy w rodzaju wędrownych handlarzy i im podobnych. Typowym przeżytkiem społecznego jednoczenia się na zasadach plemiennych i zalążkowonarodowościowych, poza jakąkolwiek terytorialną zależnością, są Cygani. Na tejże podstawie, na skutek szczególnie niesprzyjających warunków, wyrosła odrębność żydowska, wyrażająca się w nowych dążeniach tak zwanego „syjonizmu”, ale o tym później.

Za odzwierciedlenie dawnej plemiennej jedności i następstwem pomieszania pojęć, tj. pomieszania państwa z daną przeważającą w nim narodowością, należy uważać wszelkie wymysły wynaradawiania w rodzaju italianizacji, madziaryzacji, germanizacji, rusyfikacji, polonizacji itd.

Ogólną podstawą tak terytorialnego, jak i narodowościowego jednoczenia się ludzi jest świadome lub nieświadome dążenie do za- 
pewnienia materialnego dobrobytu, przede wszystkim przywódców i oligarchów ruchliwej, ale plemiennie zjednoczonej lub terytorialnie zwartej grupy.

Początkowo, w stanie dzikim i koczowniczym, istniały plemiona wrogie wobec innych na całej kuli ziemskiej. Istnieli wówczas plemienni, narodowościowi bogowie-opiekunowie i ich czciciele. Później pojawiła się zalążkowoterytorialna wspólnota i nieokreślone granice geograficzne, w tych zaś granicach stały grunt dla rolnictwa. Na tym gruncie rosną domy i budowle w ogóle, osady, wsie, miasta. Początkowo powstaje zalążek, a potem już prawdziwe państwo w obecnym znaczeniu tego wyrazu.

Ziemskie, realne sprawy zamykają się w granicach terytorialnych, a element narodowościowy, jeśli nie przechodzi do sfery nieziemskiej, pozagrobowej, to $\mathrm{w}$ każdym razie staje się potrzebą kulturalną i znajduje się w ścisłym związku z uznaniem godności człowieka. Dlatego określenie przynależności narodowościowej powinno pozostawić się każdemu osobnikowi z osobna.

W sferze narodowościowej podstawowym i niewzruszonym prawem powinna byé najpełniejsza s wo bod a zrzeszania się.

Należy sądzić, że z czasem także terytorialna strona zrzeszania się ludzi znajdzie się w zakresie samookreślania się, jednak nie w odniesieniu do pojedynczych osób, lecz na zasadzie większości głosów, w drodze plebiscytu, jak to z inicjatywy Napoleona III stało się na przykład w Wenecji ${ }^{1}$ po wojnie włosko-austriackiej 1866 r. Na razie jednak terytorialność pozostaje w ogólności przymusowa. Co prawda i przynależność narodowościowa czy kulturowa pozostają na razie też przymusowe, choć z dążnością do wyzwolenia się.

Sama narodowość i kultura są na ogót ruchome, wolne, ale ich przejawy zewnętrzne są jednak terytorialne i związane z ziemią. Takimi są wszystkie budowle przeznaczone na cele kulturalne tak w pozytywnym, jak ujemnym sensie. Takimi są świątynie, szkoły, kluby, fabryki, banki. Skoro dążność kulturalna ucieleśni się i uzewnętrzni, z konieczności staje się terytorialna.

1 Wenecja, pozostająca poprzednio własnością Austrii, została wówczas włączona do Królestwa Włoch. 
3. Obiektywne i subiektywne określenie i ocena przynależności człowieka do określonej grupy społecznej

Określając według obiektywnych oznak przynależność poszczególnych ludzi do tej czy innej grupy społecznej, patrzymy na nich po prostu jak na obiekty obserwacji naukowej i klasyfikacji, jak na istoty nieosobowe, jak na zwierzęta i rośliny. W subiektywnym zaś samookreśleniu się i samoocenie mamy do czynienia z indywiduami, z obywatelami.

W obiektywnym dzieleniu ludzi według poszczególnych antropologicznych i etnograficznych kategorii jedną z najważniejszych cech jest język. Jednak język nie wyczerpuje całego bogactwa cech antropologicznych i etnograficznych. Takimi cechami są m.in.:

1) antropologiczne podobieństwa i różnice, za których pomocą określa się bliższe lub dalsze pokrewieństwo rasowe;

2) język jako główna podstawa określania pokrewieństwa plemiennego;

3) mitologiczne i inne wierzenia i cały zbiorowy światopogląd;

4) literatura narodowa;

5) obrzędy i obyczaje;

6) pomniki piśmiennictwa i sztuki;

7) warunki życia gospodarczego i domowego, typ domostw i innych budowli, itd.

Pierwsze pięć kategorii to cechy zmieniające się i związane bezpośrednio z ich nosicielami. Szósta i siódma, choć oczywiście też wyrażają określoną stronę umysłowości danego plemienia, to jednak uzewnętrzniły się, a łącząc się z tym czy innym miejscem, przeszły w sferę terytorialności.

Ponadto należy zauważyć, że takie pomniki sztuki jak rzeźby, instrumenty muzyczne itp. należą do klasy ruchomości i nie mogą być liczone do cech terytorialnych. Zabytki piśmiennictwa na skałach (np. napisy klinowe), na budowlach, na kamieniach nagrobnych itp. są złączone z ziemią, natomiast papirusy, rękopisy, książki itp. są mobiliami. 
Podobnie jak to jest z florą i fauną kuli ziemskiej, przy obiektywnym określaniu, ocenie i dzieleniu rodzaju ludzkiego, otrzymujemy an tropogeografię i związaną z nią materialną archeologię.

Ale wszystko to, co przewidziała antropogeografia i archeologia, jest poniżej płaszczyzny pojęcia związanego ze słowem narodowość w nowszym jego znaczeniu. W dziedzinie narodowości, bez subiektywnego, świadomego samookreślenia się każdego osobnika odrębnie, nikt nie ma prawa zaliczać go tu czy gdzie indziej. Tu już nie można patrzeć na ludzi jak na owce czy jak na niewolników. A nawet prawdziwego niewolnika nie moglibyśmy zaliczyć na danej narodowości, jeśli by on sam siebie do niej nie zaliczył. Moglibyśmy wpisać go do inwentarza ruchomości tej czy innej osoby, ale, pytając o jego narodowość, czynimy go człowiekiem samookreślającym się i kiedy zwracamy się do niego z pytaniem tego rodzaju, on w tym momencie przestaje byé niewolnikiem i staje się wolnym człowiekiem.

Obiektywne cechy poszczególnych ludzi jako indywiduów z gatunku homo sapiens to jedno, a subiektywne skłonności i sympatie, i świadomy wybór przynależności to drugie.

Nawet mówiąc bardzo dobrze językiem danego narodu i należąc do niego z urodzenia, można jednakowoż, z tych czy innych powodów, wyjść z jego składu i - odwrotnie - zła znajomość danego języka nie przeszkadza świadomemu zaliczeniu się do narodu posługującego się tym językiem jako narzędziem narodowej zbiorowości.

Z punktu widzenia obiektywnej oceny w żaden sposób nie można rozstrzygnąć pytania, czy Żydów w Rosji lub w Polsce uważać za narodowość, czy nie. „Ludzie prawdziwie polscy”1 uznają Żydów o tyle, 0 ile ci uważają siebie za Polaków. Dokładnie tak samo czynią „ludzie prawdziwie rosyjscy", uznając Żydów i Polaków o tyle, o ile jedni i drudzy uważają siebie za Rosjan. Ale ani w nauce, ani w poważnej polityce ani prawdziwie polski, ani prawdziwie rosyjski, ani żaden

1 Ta nazwa jest parafrazą pejoratywnego określenia zaczerpniętego od M. Sałtykowa-Szczedrina - ludzie prawdziwie rosyjscy (истиннорусские люди). Baudouin, który bardzo cenił twórczość tego rosyjskiego pisarza, wziął od niego wiele określeń. Formuły ludzie prawdziwie rosyjscy (polscy) zamiast: prawdziwi Polacy, Rosjanie Baudouin używa też w innych tekstach. 
inny prawdziwie narodowy punkt widzenia nie może mieć zastosowania.

Pytanie o przynależność narodową rozstrzygane jest przez każdego świadomego Polaka, każdego świadomego Żyda i każdego świadomego człowieka indywidualnie.

Człowiek, który nie dojrzał do pojęcia narodowości i, być może, niebędący w stanie określić własnej narodowości, nie może być zaliczany do żadnej narodowości. Tylko z czysto obiektywnego punktu widzenia należy on do tego czy innego plemienia lub narodu; zaliczenie go do „narodowości” będzie kłamstwem i gwałtem.

W świadomym odnoszeniu się do kwestii narodowości i innych kulturowych związków można należeć nie tylko do jednej z takich grup, ale nawet do kilku różnych grup albo nie należeć do żadnej z nich. Innymi słowy: całkiem możliwa jest świadoma (lub półświadoma, a nawet nieświadoma, ale mogąca być uświadomioną) przynależność do dwóch i więcej narodowości albo też całkowita beznarodowość, dokładniej: pozanarod ow ość lub pozawyznaniowość.

Można być bezwyznaniowym i bezpartyjnym, ale należeć jednocześnie do dwóch lub więcej wyznań albo też do dwóch lub więcej wykluczających się wzajemnie partii nie jest możliwe. Inna sprawa z narodowościami, oczywiście z narodowościami nie napastliwymi, nie wojującymi, a wyłącznie kulturalnymi. Jak jest możliwe pomieszczenie w jednej głowie dwóch i więcej języków, dokładnie tak samo możliwe jest pomieszczenie przynależności do dwóch lub więcej narodowości.

Gdyby nie skomplikowana polityczna, wyznaniowa, stanowa i klasowa walka i wrogość, nikomu nie wydawałoby się dziwna jednoczesna przynależność, np. do narodowości polskiej i żydowskiej, do narodowości polskiej i litewskiej, ukraińskiej i żydowskiej, ukraińskiej, polskiej i żydowskiej, ukraińskiej i rosyjskiej (wielkoruskiej), gruzińskiej i rosyjskiej, itd., a nawet do narodowości polskiej i niemieckiej, polskiej i rosyjskiej itp.

Z powyższego widać, do jakiego stopnia trzeba uznać za nieprzydatne do niczego dane pospolitej statystyki ludności. Ta niefortunna statystyka miesza cechy obiektywne z subiektywnym 
samookreśleniem się, język ojezysty z narodowością, dopuszcza możliwość jednego tylko codziennego języka, narzuca człowiekowi tę czy inną narodowość, to czy inne wyznanie.

Aby statystyka ludności przyniosła rzeczywisty pożytek tak dla nauki, jak dla praktycznej polityki, powinna ściśle rozróżniać cechy obiektywne od eech subiektywnych. Ale taka statystyka jest możliwa tylko w wolnym i rzeczywiście kulturalnym kraju, a Rosja takim jeszcze długo nie będzie.

W zakresie cech obiektywnych prawdziwa statystyka powinna stawiać pytania nie 0 to, jaki język dany osobnik uważa za swój ojczysty - wielu to ukrywa albo nie umie odpowiedzieć - ale 0 to, jakimi językami mówi i w jakiej kolejności się ich nauczyt.

Za subiektywne cechy naukowe statystyka powinna uważać świadomą przynależność do tej czy innej narodowości albo przynależność do więcej niż jednej narodowości, albo też zupełną pozanarodowość; następnie przynależność do kreślonego wyznania albo bezwyznaniowość; przynależność do tej czy innej „partii” albo bezpartyjność. Wszystko to są pytania bardzo drażliwe i nie każdy zdecyduje się szczerze na nie odpowiedzieć. Jedni mogą się bać, inni chętnie będą się chwalić. Dlatego lepiej te rubryki zostawić na razie niewypełnione, czekając lepszych czasów, tj. polityeznego i obyczajowego odrodzenia Rosji.

Oczywiście wszystkie te pytania same z siebie odpadają w odniesieniu do osób w określonym wieku, podlegających spisowi. Tak np. całkiem wykluczone są niemowlęta, a starsze dzieci podlegają najrozmaitszej stopniowej ocenie.

Narodowość, okazująca się jednym z ważnych elementów składających się na kulturowe samookreślenie się, sama w sobie jest zupełnie nieprzydatna jako cecha autonomii w ścisłym znaczeniu tego wyrazu. Szczegółowsze pojęcie narodowości podlega ogólnemu pojęciu wolnego zrzeszania się osób, uważających się za jednakowo wierzące, jednakowo unarodowione, jednakowo upartyjnione. A zatem kwestia autonomii narodowej rozwiązuje się 
za pomocą prawa całkowitej wolności związków i stowarzyszeń.

Inną rzeczą jest bezwzględna autonomia terytorialna, autonomia danego obwodu. Pytanie o taką autonomię rozstrzyga się na gruncie czysto ekonomicznych i politycznych interesów. Oczywiście, co wynika samo z siebie, taka autonomia jest określona granicami geograficznymi. W tym wypadku człowiek - rzeczywiście lub pozornie - włada ziemią, ale jednocześnie jest jej niewolnikiem.

Ludzie żyją razem, w jednym mieszkaniu, w jednym domu, w jednej miejscowości, w jednym obwodzie i mają - bez względu na ich przynależność do najrozmaitszych wyznań, partii i narodowości niezmiennie wspólne interesy i oni, ci właśnie ludzie, powinni działać wspólnie, aby ułatwiać sobie życie i nie tracić czasu na spory i walkę o to, co - z praktycznego punktu widzenia - niewarte złamanego grosza. Inna rzecz - wymiana poglądów i walka ideologiczna 0 zasady polityczne.

\section{Praktyczne rozwiązanie kwestii autonomii}

Z tego, co powiedziałem, wynika, że narod ow ość jako taka nie może być podstawą rozwiązania kwestii autonomii tego czy innego obwodu. Gdzie więc szukać punktu wyjścia nie tylko dla rozwiązania, ale nawet dla postawienia danej kwestii?

Niewielkie terytorium, na przykład w rodzaju guberni petersburskiej albo moskiewskiej, gdyby nawet składało się z najbardziej różnorodnych, nie tylko etnicznych elementów, ale i jasno uświadomionych narodowości, wcale nie potrzebuje autonomizacji swoich obwodów i może zadowolić się samorządem poszczególnych rejonów, gmin, wspólnot i okręgów. Natomiast geograficzny kolos, nawet gdyby w sensie etnograficznym i narodowościowym był całkowicie jednorodny, z powodów gospodarczych i administracyjnych nie może funkcjonować dłużej bez autonomii politycznej poszczególnych obwodów i wskutek centralizacji musi ulec postępującemu paraliżowi zarówno w poszczególnych swych częściach, jak i w całości.

Takim geograficznym kolosem jest niewątpliwie Rosja. W obecnej Rosji z jednej strony istnieją jasno wyznaczone obwody, 
w których ogromna większość świadomych mieszkańcó $\mathrm{W}^{1}$ żąda autonomii, z drugiej natomiast strony pożądana jest autonomizacja całego państwa z racji jego ogromu i obiektywnie udowodnionej szkodliwości centralizacji.

Urzeczywistniając autonomię, tj. ustalając granice poszczególnych obwodów autonomicznych, trzeba koniecznie mieć na uwadze przede wszystkim dwie zasady:

Po pierwsze, ludzie nie są dla nas pogłowiem żywego inwentarza czy bydła, które można dowolnie klasyfikować według naturalnych albo sztucznie wymyślonych cech. Obywatele nie są bezwolnymi niewolnikami lub żołnierzami, których można samowolnie umieszczać w poszczególnych oddziałach czy pułkach. Skoro pojawił się odrębny gatunek dwunogiego zwierzęcia, nazywanego obywatelem, konieczne jest liczenie się z jego wolą.

Po drugie, większość nie powinna nastawać na prawa mniejszości i na jej prawo samookreślania się, i - odwrotnie - mniejszość nie powinna terroryzować większości.

Pragnienie narzucenia innym swojej narodowości i asymilowania innoplemieńców właściwe jest wszystkim stadom ludzkim. Chorobliwe natężenie tego pragnienia, zauważalne nie tylko w obecnej Rosji, ale i w innych państwach, jest zupełnie zrozumiałe w świetle dawniejszego i wciąż jeszcze trwającego prześladowania określonych narodowości i wyznań. Kiedy zakazuje się ludziom mówić w ich ojczystym języku, kiedy likwiduje się ich piśmiennictwo, a nawet ich alfabet, to jest zrozumiałe, że w ludziach tych rozwija się hiperestezja uczuć narodowych i, jak tylko uwolnią się oni od bezmyślnych ograniczeń i dostaną możliwość rozwoju narodowego, wykazują skłonności zdobywców i przekraczają granice sprawiedliwości. Dlatego dla uniknięcia możliwej niezgody i bezproduktywnych waśni międzynarodowościowych należy ogólnopaństwowym prawem zagwarantować prawa wszystkich swobodnie jednoczących się narodow ości, wyznań i innych tp. związków.

1 Niestety, takich „świadomych mieszkańców” jest na razie całkiem niewielu. Dopisek w 1910 [przyp. BdeC]. 
Pytania 0 zasady i granice autonomii terytorialnych nie można rozstrzygnąc ani we własnym gabinecie, przy biurku uczonego czy urzędnika, ani na doraźnie zwołanych mityngach. Jakiekolwiek wymyślilibyśmy podstawy dla apriorycznego ustalenia poszczególnych obwodów autonomicznych, wszędzie napotkamy kolizje lub zetknięcie się wzajemnie sprzecznych interesów stadowych.

Przyjmijmy, że kamieniem węgielnym uczynimy prawa his toryczne poszczególnych obwodów, a wówczas zobaczymy, że nie da się zbudować żadnej autonomii na owych „prawach historycznych”. Czy np., ustalając autonomię Polski, możemy kierować się istniejącymi ongiś granicami niezawisłego państwa polskiego? Przecież po pierwsze, te granice wciąż się zmieniały, a po drugie, były oparte na arystokratycznej zasadzie, uznającej za ludzi i obywateli tylko szlachtę, zaś inne stany, a przede wszystkim chłopów, zrównującej w prawach z domowymi zwierzętami. Teraz mamy inne hasło, hasło demokratyczne, dające prawo obywatelstwa i samookreślenia się wszystkim bez wyjątku świadomym politycznie mieszkańcom kraju. „Prawa historyczne” Polski zderzają się z „prawami także historycznymi” Litwy, Ukrainy itd.

Dalej - jak stosować zasade „praw historycznych” na Zakaukaziu albo w Kraju Bałtyckim? Czyż nie będą to „prawa historyczne” niemieckich baronów do swobodnego władania łotewskim i estońskim bydłem dwunogim? Prawda, że obecni potomkowie owych rycerzy urzeczywistniają swoje „prawo historyczne”, polując razem z państwową siłą zbrojną na estońską i łotewską dziczyznę, ale temu „historycznoprawnemu” sportowi będzie kiedyś położony kres.

W ogóle można powiedzieć, że tak zwane „prawa historyczne” okazują się po prostu prawami gwałtu dokonywanemu w przeszłości. „Prawami historycznymi” można usprawiedliwić wszelki rabunek, wszelkie bezprawie, wszelkie okrucieństwo i niesprawiedliwość. Ostatnie podboje dokonane przez obecną Rosję okazują się także „historycznym” faktem i „historycznym prawem”. „Prawo historyczne” obecnej samowładnej i scentralizowanej Rosji nie pogodzi się z myślą 0 autonomizacji tego państwa.

To może zamiast „praw historycznych” wysuniemy na pierwszy plan „prawo etnograficzne” i zalążkowonarodowe, tj. spróbuje- 
my utworzyć obwody autonomiczne dla poszczególnych narodowości, biorąc jako główną cechę narodowości jej język ojczysty?

Niestety, z wyjątkiem chyba niektórych czysto wielkoruskich obwodów, a i to tylko tymezasowo, taka narodowo-terytorialna autonomizacja państwa rosyjskiego $\mathrm{w}$ ścisłym znaczeniu tego wyrazu jest niemożliwa. Czyż można utworzyé czysto narodowo-terytorialny obwód z Polski, z Litwy, z Kraju Bałtyckiego albo z Łotwy i Estonii, z Białorusi, z Zakaukazia albo choćby z jego części: zachodniej (Gruzja) i wschodniej? I po co tworzyé koniecznie czysto narodowoterytorialne obwody? Czyżby ludzie różnych narodowości mogli żyé w jednym obwodzie tylko na podobieństwo psa z kotem?

Żądanie koniecznie etnograficznej i narodowej podstawy autonomii prowadzi do absurdu i przemawia przeciwko autonomii. Zatem lepiej już wyrzec się wszelkich autonomii i zostawić jedną i niepodzielną Rosję, z przewagą samowładnej wielkoruskiej narodowości i z poddanymi jej innymi narodowościami, dopóki ów państwowy potwór nie rozpadnie się pod własnym ciężarem.

Tak więc w końcu, siedząc w swoim gabinecie albo roztrząsając rzecz na mityngach, zwrócimy uwagę na fizyczne lub ekono miczne uwarunkowania poszczególnych, podlegających autonomizacji, obwodów Rosji? A wtedy miejsce „praw historycznych” i „etnograficznych" zajmą koryta rzek, grzbiety górskie, bogactwo jezior, czarnoziemy, rybołówstwo, rolnictwo, jednolitość przemysłu, górnictwo, rejony fabryczne itp.

Takie postawienie problemu autonomii całkiem wyklucza z niego narodowy element i zastępuje go całkowicie racjami terytorialnymi. I rzeczywiście jest to rozwiązanie bardzo kuszące, ale, niestety, nie może wyjść z centrum, bez pytania miejscowej ludności, choćby tylko reprezentowanej przez osoby wybrane zgodnie z prawem jako jej przedstawiciele.

Miejsce gabinetowych biurokratyeznych rozmyślań i wiecowych rezolucji powinno zając przede wszystkim uznanie określonych lu dzkich, osobistych i ogólnych, praw, a następnie rozważenie korzyści płynących z takiego albo innego rozwiązania danego problemu.

Na czele praw człowieka stawiam z jednej strony prawo do godności człowieka iprawo do swobodnego samookreśle- 
nia się indywidualnego osobnika, z drugiej zaś strony, prawo do dobrobytu ekonomicznego i do pokojowego współżycia wszystkich mieszkańców tak całego państwa, jak jego poszczególnych części.

Dalej, scholastyczne i krwiożercze „prawa historyczne” zastępuje prawami danej historycznej chwili, tj. prawami nastrojów i dążeń mieszkańców danego obwodu.

Zamiast zaś „praw etnograficznych” proponuję wziąć pod uwagę ogólny etnograficzny stan danego terytorium. Tak np. uważam za całkiem pocieszające zjawisko to, że na Białorusi, dzięki jej swoistej etnograficznej postaci i przeszłości historycznej, rozwinął się miejscowy patriotyzm, że tak powiem, wyrozumowana miłość do rodzinnego kraju, objawiająca się jednakowo u miejscowej ludności różnych narodowości: i u prawdziwych Białorusinów, i Wielkorusów, i Polaków, i Żydów. Ta białoruska decentralizacja dążeń kulturalnych ani trochę nie przeszkadza przeciwnemu prądowi, dążeniu do zjednoczenia się z ogólnorosyjskimi dążeniami kulturalnymi.

Taki ogólny, swoisty etnograficzny wygląd jest charakterystyczny także bardziej lub mniej guberniom litewskim, obwodowi ukraińskiemu (małoruskiemu), całemu Krajowi Bałtyckiemu lub jego dwóm częściom, całemu Zakaukaziu lub też jego częściom itd.

Do kategorii praw, które mogą stać się punktem wyjścia do rozważania autonomii poszczególnych obwodów, należy dodać też wspomniane przez mnie wyżej uwarunkowania fizyczne i ekonomiczne, ale podporządkowując je prawom do samookreślenia się jednostki ludzkiej.

Nadzwyczaj ważną, a niekiedy decydującą rolę w kwestii autonomii odgrywają prawa nieprzezwyciężonych sił danej chwili historycznej. Do tych sił należą przede wszystkim określone granice polityczne i administracyjne, czynne w tych granicach odrębne przepisy prawne i uwarunkowane tym wszystkim wspólne życie całej ludności danego obszaru.

Tak wyraźnie określonym obwodem i w sensie administracyjnym, i prawnym, jest w obecnej Rosji przede wszystkim Królestwo Polskie, pomijając całą jego różnorodność etnograficzną. Specjalne prawa obywatelskie i administracyjne, odrębność pod władzą osob- 
nego generała gubernatora, czynią z tego kraju gotowe ramy do autonomii rosyjskiej Polski - przy czym wyraz „Polska” bierzemy nie w sensie etnograficznym, ale polityczno-administracyjnym.

Do wchodzącej w skład Królestwa Polskiego guberni suwalskiej wysuwają roszczenia politycy litewscy, żądający autonomii Litwy na zasadach etnograficznych. Oczywiście te roszczenia powinny zostać z czasem zaspokojone, ale nie jak za dotknięciem czarodziejskiej różdżki panów biurokratów albo zawziętych polityków, lecz przez badanie samej ludności zarówno całej guberni, jak i poszczególnych powiatów i gmin. To badanie może być albo powszechne, tj. przez tzw. plebiscyt, albo też przez zapytanie swobodnie wybranych w powszechnym głosowaniu przedstawicieli samorządnych jednostek terytorialnych.

Takimże dokładnie sposobem powinna zostać rozwiązana kwestia tzw. „Rosyjskiego Zabuża” czy „Rusi Chełmskiej”. Niech sami mieszkańcy tego kraju zdecydują większością głosów, czy życzą sobie, jak wcześniej, wchodzić w skład Królestwa Polskiego, czy też wolą być oddzieleni od niego. Obecnej próby pp. biurokratów rozwiązania tej kwestii na własną rękę, bez pytania ludności, nie można uznać za słuszną.

W każdym razie kwestia terytorialnej autonomii Królestwa Polskiego stała się całkiem jasna i dojrzała do ostatecznego rozwiązania. A jak z autonomizacją innych części Rosji?

Przede wszystkim trzeba zapytać, czy Duma Państwowa zajmie się w najbliższej przyszłości podobnymi kwestiami? Jeśli nie, to nie ma co zastanawiać się nad praktycznym aspektem sprawy i przyjdzie zostawić bieg zdarzeń historycznych w Rosji własnemu losowi. Laissez faire, laissez passer.

Jeśli zaś Duma niespodziewanie zajmie się tą, według niektórych, kwestią najwyższej wagi, to przede wszystkim przyjdzie jej ustalić, jakie obwody powinny być autonomizowane. Kierując się cechami obiektywnymi, trzeba będzie najpierw wziąć pod uwagę historycznie ukształtowane granice poszczególnych generalnych gubernatorstw, czyli samowystarczalnych satrapii. Przy czym, oczywiście, konieczne będzie wydzielenie Syberii, która ze swej strony powinna podzielić się na kilka autonomicznych obwodów. Prawdopodobnie poszczegól- 
ne autonomie będą powstawać drogą subiektywnego samookreślenia się. Praktyczne rozwiązanie wyobrażam sobie następująco:

W Dumie Państwowej przedstawiciele danego obwodu złożą oświadczenie o konieczności nadania temu obwodowi autonomicznego samorządu, przy czym zostaną dokładnie określone granice owego obwodu. Wtedy, w przypadku gdyby problem był rozstrzygany przez Dumę $e^{1}$ w zasadniczo potwierdzającym sensie, jego szczegółowe opracowanie i dalsze postępowanie przekazywane są zainteresowanym. W stolicy danego obwodu zwołuje się specjalne zgromadzenie założycielskie, wybrane w swobodnych, a nie w skrępowanych złośliwymi instrukcjami wyborach powszechnych. Zadaniem tego zgromadzenia jest po pierwsze ostateczne ustalenie granic obwodu, po drugie zaś wypracowanie podstawowego prawa dla autonomii, które następnie powinno zostać zatwierdzone przez ogólnopaństwowy parlament i inne ogólnopaństwowe władze ustawodawcze.

Przeciwko nakreślonym granicom danej autonomii mogą podnieść się głosy w zgromadzeniu założycielskim. Jeśli protestujący przedstawiciele ziem pogranicznych (guberni, powiatu, okręgu itp.) utworzą większość, wtedy te peryferia wydziela się z autonomii i albo wejdą one w skład innej, albo też na razie pozostaną bez autonomii.

Tak na przykład wyobrażam sobie, że w przypadku, jeśliby przedstawiciele dążący do autonomii obwodu litewskiego włączyli w jego skład także całą gubernię wileńską i grodzieńską, przedstawiciele tych guberni (wziętych w całości albo w znacznej części) wchodzący w skład zgromadzenia założycielskiego wypowiedzą się przeciwko włączeniu ich do Litwy jako do odrębnego obwodu autonomicznego. Jeśli natomiast, odwrotnie, dążący do autonomii Litwini ograniczaliby się z początku tylko do guberni kowieńskiej, na pewno dołączą do nich dobrowolnie niektóre części guberni wileńskiej i grodzieńskiej, jak i znaczna część guberni suwalskiej.

W ten sposób należy patrzeć na proponowaną autonomizację Kraju Północno-Zachodniego, Kraju Południowo-Zachodniego, Ro-

$1 \quad$ Tj. nie tylko przez Dumę, ale i przez inne organa ustawodawcze. 0czywiście w czasach, w których obecnie żyjemy, wszystko to jest pustym gadaniem. Uwaga w 1910 r. [przyp. BdeC]. 
sji Południowej, Kraju Bałtyckiego, Kaukazu i Zakaukazia, Syberii, środkowych guberni europejskiej Rosji itd. Z tych wszystkich krajów wątpliwe, by powstały pojedyncze obwody autonomiczne i raczej trzeba przewidywać ich rozpadanie się na dwa lub nawet więcej autonomicznych obwodów.

Wszystko to jest rzeczą bardzo skomplikowaną i wymagającą usilnej pracy, a dla urzeczywistnienia, podobnie jak dla urzeczywistnienia innych ratujących Rosję zamierzeń, konieczne jest po pierwsze, aby Duma stała się istotnie ustawodawczą i aby przed jej władzą ugięły się inne czynniki rządzące krajem, po drugie zaś, aby w samej Dumie przyjęta została zasada samookreślenia się poszczególnych obwodów.

Wszelkie jednak narady w tej materii panów, nieznajdujących niczego karygodnego w traceniu diet na lokale rozrywkowe i różne przedsięwzięcia przemysłowe wątpliwego charakteru, nie mogą byé brane poważnie. Panowie ci, hołdujący jeszcze poglądom P. I. Cziczikowa, uważają ludzi za żywy inwentarz, za żywe i „martwe dusze”, $\mathrm{z}$ tą tylko różnicą, że Cziczikow przemieniał martwe dusze w żywe, a oni przemieniają żywych ludzi w nieboszezyków. Zwracanie się do podobnych panów przez przedstawicieli poszczególnych obwodów jest nie tylko niemoralne, ale w dodatku bezowocne.

\section{Federalizacja państwa rosyjskiego}

Według niektórych osób, Rosja powinna koniecznie przejść $\mathrm{z}$ czasem do ustroju federacyjneg, ${ }_{0}$, inaczej popadnie w ostateczną anarchię i zginie. Być może ci, co myślą w ten sposób, mylą się, rację natomiast mają ci, którzy bronią, jako możliwej, niepodzielności administracyjnej i politycznej tej potwornej całości. Kto ma z nich rację, pokaże bezlitosna krytyka ze strony przyszłych zdarzeń historycznych. Na razie możemy rozważać federacyjną Rosję tylko czysto teoretycznie, nie przewidując w najbliższej przyszłości praktyeznego wprowadzenia tej zasady.

„Federalizację” Rosji wyobrażamy sobie jako jej rozpad na stany lub odrębne politycznie kraje, połączone jednoczącą je umową i tworzące, razem z tak samo niepodzielnymi i samowystarczalnymi jed- 
nostkami państwowymi składnikami, ogólnopaństwową, suwerenną całość.

Idealna „federalizacja” powinna być przeprowadzona w taki sposób, by poszczególne stany były mniej więcej równe sobie co do wielkości, a dokładniej co do liczby mieszkańców.

Mając na względzie genezę historycznie powstałych federacji, dziwnie jest nieco mówić o federalizacji Rosji. Prawdziwą federację tworzą przecież, łącząc się w jedno, odrębne poprzednio kraje, żyjące rzeczywiście oddzielnym życiem politycznym. Tu natomiast widzimy powstałą drogą podbojów i pozbawiania indywidualności przyłączanych ziem, scentralizowaną całość i oczekujemy przekształcenia jej w federację obwodów.

Aby tak się stało, konieczne jest jedno z dwojga: albo Rosja dzięki ogarniającym ją siłom odśrodkowym rozpadnie się na odrębne części, które później dla wspólnej korzyści będą szukać zbliżenia ze sobą; albo też zrozumienie korzyści z ustroju federacyjnego przeniknie do umysłów świadomego społeczeństwa, które osiągnie ten ustrój środkami prawnymi. I do jednego, i do drugiego można dojść jedynie powoli, stopniowo, po długich latach usilnych prób i niepowodzeń politycznych. W pierwszym przypadku Rosję czeka przede wszystkim dalszy ciąg obecnych zamieszek i potworności; w drugim zaś przypadku można w dalszej przyszłości mieć nadzieję na pokojowe rozwiązanie i ozdrowienie.

Zresztą dla federalizacji Rosji ramy są już gotowe. Przecież jeszcze nieżyjący już dobroczyńca Rosji, W. K. Plehve, proponował wzmocnienie władzy lokalnych pompadurów ${ }^{1}$ i obdarowanie ich niezależnością od centrum państwowego. Ten pomysł „świetnego męża stanu” od pewnego czasu jest gorliwie urzeczywistniany. Rosja jest pocięta na generalne gubernatorstwa, w których samowładni satrapowie wydają „prawa” według uznania i są oczywistymi właścicielami życia i śmierci obywateli. Czy to nie federacja?

1 Eponim od nazwiska Madame de Pompadour, faworyty Ludwika XV, której lud francuski przypisywał marnowanie państwowych pieniędzy i fatalny wpływ na polityczne decyzje króla. Baudouin przejął to określenie od M. Sałtykowa-Szczedrina. 
A czy prawo wyborcze niedopuszczające wspólnych wyborów przedstawicieli ludowych z miasta, z guberni itd. i dzielące wyborców na tzw. rejony nie jest oparte na zasadzie federacyjności? Akurat i jedno, i drugie doświadezenie federalizacji Rosji, tj. i rozkawałkowanie jej na krwawe satrapie, i układanie wyborców w oddzielnych przegródkach, zrodziły u mieszkańców dążnośé do jednoczenia się we wspólnym działaniu wszystkich obywateli państwa. Dokładnie taki sam rezultat przyniesie prawdziwa federalizacja Rosji. Wówczas odrębne, ale obdarzone samodzielnością polityczną obwody, w imię jedności państwa i dla korzyści praktycznych ustąpią z jakichś suwerennych praw i przekażą je centralnym instytucjom rządzącym.

Nie należy, jak się wydaje, pomijać tego, że dążenie do ostatecznej decentralizacji przechodzącej w ustrój federacyjny powstaje w wielu wykształconych politycznie i świadomych umysłach nie tylko wśród „różnoplemieńców” i narodowościowych pasierbów Rosji, ale także u najezystszych Wielkorusów. Ta dążność wciąż się wzmacnia, wciąż się nasila, a jej potężnemu wzrostowi pomagają wydarzenia zarówno zewnętrznego, jak wewnętrznego życia politycznego.

Jak w tym przypadku, tak i w wielu innych zauważa się przeciwieństwa tego, co miało miejsce w czasie wielkiej rewolucji francuskiej.

We Francji szalał krwawy terror rewolucyjny w imię fantastycznej przyszłości. W Rosji prawicowi jakobini doprowadzają do ostatnich granic kontrrewolucyjny terror w imię niemiłej przeszłości. We Francji z szaleńczą prędkością prowadzono ostateczną nieubłaganą centralizację całego państwa, unicestwiając wszelkie ślady autonomii poszczególnych prowincji zamienianych w bezbarwne departamenty, przeznaczone do realizowania administracyjnych działań nasłanych przez władzę centralną pompadurów. W Rosji jest akurat odwrotnie, rodzi się dążność decentralizacyjna do uwolnienia guberni i utworzenia autonomicznych obwodów, tj. do przechodzenia od guberni i pompadurów do samodzielnych i samorządnych obwodów.

Jeśli kiedykolwiek ziści się federacyjny ustrój Rosji, jeśli na terytorium obecnego państwa powstaną „stany zjednoczone”, wtedy w miejsce jednej Dumy Państwowej powstaną samorzutnie lokalne 
sejmy obwodowe obok niewielkiego parlamentu centralnego i drugiej izby w rodzaju rady federacyjnej, z izbą sądową stojącą na straży przestrzegania praw federacji.

Z tego, co powiedziano wyżej, wynika, że taka federacja poszczególnych części Rosji nie będzie federacją narodowości, ale jedynie federacją odrębnych obwodów, odrębnych terytoriów.

\section{Zagwarantowanie praw mniejszości i większości}

Słyszymy wszyscy nie tylko o zagwarantowaniu praw mniejszości, ale przy okazji, w wielu wypadkach większość domaga się takich gwarancji. Do czego prowadzi brak gwarancji dla większości, widzimy choćby w Kraju Bałtyckim, gdzie niewielki procent niemieckich baronów i ritterów, razem z niemiecką inteligencją rządził samowładnie i dławił wszelkie życie polityczne faktycznych niewolników, Łotyszy i Estończyków. Także obecne „uśmierzenie” buntu w tej prowincji nabrało takiego dzikiego i odpychającego charakteru na skutek tego, że rozmaici „zacni współpracownicy” i „sumienni lekarze” nadto gorliwie gwarantują tam prawa mniejszości, z bezlitosnym deptaniem praw większości.

Dokładnie tak samo konieczne jest zagwarantowanie praw większości na Litwie, w Kraju Północno-Zachodnim w ogóle, w Kraju Południowo-Zachodnim itd., gdzie wskutek pomieszaniu stanów i narodowości dotąd gospodarzyła uprzywilejowana polska i wielkoruska szlachta, odsuwając na dalszy plan liczebnie przeważającą ludność.

Zresztą prawa większości są wystarczająco gwarantowane wprowadzeniem w życie demokratycznej zasady wszechstanowej, a dokładniej bezstanowej gminy i powszechnego, równego prawa wyborczego. Niestety, jesteśmy jeszcze bardzo dalecy od powszechnego prawa wyborczego, a obecni władcy losów Rosji, marzący o wskrzeszeniu przywilejów stanowych w ich pełnym kształcie, wszelkimi siłami starają się nie poszerzać, ale - przeciwnie - na ile się da ograniczać i obcinać obecnie istniejące kuse prawo wyborcze.

Kiedy jednak wreszcie uzyskamy powszechne prawo wyborcze, wówczas istotnie pojawi się niebezpieczeństwo dla mniejszości. 
Aby zapobiec terroryzowaniu mniejszości przez większość, nie tylko w imię ogólnoludzkiej sprawiedliwości, ale i dla wspólnej korzyści, niezbędne jest już teraz myślenie 0 zagwarantowaniu praw mniejszości. Mam tu na myśli nie tylko narodowościową (i wyznaniową) mniejszość, ale także wszystkie inne: klasowe, partyjne itd.

Gdzie jest bezwzględne panowanie większości, może powstać fałszywy i skrajnie zgubny pogląd, że tylko ludzie należący do tej większości są „gospodarzami” danego kraju czy obwodu, natomiast wszyscy inni - tylko „gośćmi”, będącymi całkowicie zależnymi od wielkodusznych albo okrutnych gospodarzy. Wobec takiego poglądu, Żydzi na przykład będą musieli wszędzie grać rolę „gości”, a od podobnego poglądu do urządzania pogromów już tylko krok.

W Polsce „gospodarzami” okażą się ludzie narodowości polskiej, łaskawie tolerujący innoplemiennych „gości”, ale mający prawo decydowania 0 ich wysiedleniu. W pozostałej części Rosji, z wyjątkiem Królestwa Polskiego, większością, choć nieznaczną, są Wielkorusini, tj., mówiąc zwyczajnie po ludzku, oprócz wszechrosyjskich biurokratów rozporządzających samowolnie losami kraju, wszyscy pozostali mieszkańcy będą zaliczeni do „gości”.

Aby zapobiec wszystkim tego rodzaju bolesnym i szkodliwym nieporozumieniom, jednym z pierwszych praw, których ustanowienie należy do obowiązku przyszłej Dumy Państwowej, powinno być następujące: Gwarantuje się prawa mniejszości i większości we wszystkich sferach życia społecznego.

Prawa większości i mniejszości rozkładają się na prawa pojedynczych osób, a prawa pojedynczych osób składają się z takich elementów:

1) samo istnienie człowieka jako konieczny warunek jego energii społecznej;

2) osobiste obowiązki i usługi świadczone na rzecz społeczeństwa (służba wojskowa, rodzenie dzieci, spożycie itp. sprzyjające wzrostowi nie tylko pośrednich, ale i bezpośrednich podatków);

3) bezpośrednie i pośrednie wkłady, pogłówne itd. na korzyśé państwa i na korzyść poszczególnych wspólnot.

Wobec takiego postawienia i oceny praw jednostki w żaden sposób nie można się zgodzić z tezą wyprowadzaną w zakończeniu mo- 
jego artykułu Znaczenije jazyka kak priedmieta izuczenija, wydrukowanego w czasopiśmie J. J. Guriewicza „Russkaja Szkoła” (1906, nr 7-8, ijun'- awgust), a dokładniej ze stwierdzeniem:

Wszelka mniejszość narodowa ma prawo do szkoły z własnym językiem wykładowym i do sum na utrzymanie tej szkoły, odpowiadających wkładom tej mniejszości do gminnej, obwodowej lub też ogólnonarodowej szkatuły.

W tym stwierdzeniu przejawia się mimo woli czysto kapitalistyczny punkt widzenia, punkt widzenia, który zobowiązuje nas żądaniem man soll die Stimmen nicht nur zählen, sondern wiegen (powinniśmy głosy nie tylko liczyć, ale i ważyć), punkt widzenia wymagający cenzusu majątkowego i większości głosów dla stanów bogatych, punkt widzenia, według którego osobowość człowieka poddana jest majątkowi i w ogóle kapitałowi.

Przy takim ujęciu praw mniejszości i większości może się zdarzyć, że 4\% bałtyckich Niemców będzie miało większe prawo do pomocy państwa i wspólnoty dla swych szkół narodowych niż ponad 90\% ludności łotewskiej i estońskiej, skoro ta biedna ludność daje skarbowi mniej bezpośrednich dochodów. A w takim razie jak gdyby zapomina się tu 0 samym istnieniu danego osobnika, zrównującym go ze wszystkimi innymi ludźmi, i o jego innych zobowiązaniach, i podatkach pośrednich, jakie wnosi do skarbu państwa.

$$
* * *
$$

Zagwarantowanie praw narodowej i wszelkiej innej mniejszości w całym państwie i w poszczególnych jego częściach uwidocznia się dwojako:

1) w realnej reprezentacji w rządzie, w organach ustawodawczych itd.

2) w oświacie.

Co się tyczy punktu pierwszego, tj. reprezentacji politycznej w ustawodawstwie i w rządzeniu krajem, powinno się przyznać i prawnie zagwarantować swobodę zrzeszania się obywateli według zasad, jakie im odpowiadają. Ludzie mają prawo łączyć się w grupy nie tylko na podstawie swego narodowego, wyznaniowego czy partyj- 
nego wyodrębnienia, ale także według swego podobieństwa fizycznego (np. garbaci, kulawi, blondyni, rudzi, grubi itp.), według rodzaju zajęcia (stolarze, szewcy, rolnicy itp.) itd. Ale jak zagwarantować takim grupom ludności uczestnictwo w narodowym przedstawicielstwie? Weźmy konkretny przykład Żydów w Królestwie Polskim.

Żydzi w Królestwie Polskim stanowią około 12\% całej ludności. Jeśliby domagali się proporcjonalnego uczestnictwa w narodowym przedstawicielstwie do Dumy Państwowej, to na 34 deputowanych z Królestwa Polskieg $0^{1}$ przypadłoby im 4 . Ale może nie wszyscy Żydzi zechcą mieć swoich odrębnych przedstawicieli, ale tylko połowa; inni natomiast będą woleli głosować razem z pozostałą ludnością. Wtedy wśród 34 przedstawicieli Królestwa Polskiego powinno być dwóch Żydów, stanowiących odrębną grupę wyborczą. Ponieważ w żadnej guberni Żydzi nie mogą mieć prawa wyboru odrębnego przedstawiciela, będą musieli albo zjednoczyé się w jeden okręg wyborczy, albo też rozdzielić się na dwa okręgi, wybierając po jednym reprezentancie $\mathrm{z}$ każdego. Ale wówczas i w jednym, i w drugim wypadku w obecnym systemie powszechnych wyborów w guberniach i wielkich miastach, pojawia się trudność z pozostałymi deputatami. Kłopot polega na tym, która gubernia lub które miasto musi odstąpić jedno miejsce dla przedstawiciela żydowskiego.

Tak więc zagwarantowanie praw mniejszości w wyborach polityeznych prowadzi nieuchronnie do likwidacji zarówno systemu rejonów i okręgów, jak i instytucji wyborey. Jest ona możliwa tylko przy zwykłym głosowaniu, i nie w guberniach i wielkich miastach, ale ostatecznie w całych obwodach jako jednostkach wyborezych.

Zamiast przedstawionego tu przeze mnie systemu wyborczego, gwarantującego prawa mniejszości, można by wykorzystać nowy fiński system, co prawda na pierwszy rzut oka dość skomplikowany, ale jednocześnie będący w danym wypadku szczytem doskonałości.

1 Według nowego prawa wyborczego (3 czerwca 1907 r.), Król. Pol. lub „Priwislinije” deleguje do Dumy tylko 12 przedstawicieli, po jednym z każdej z 10 guberni i po jednym z Warszawy i Łodzi. Oprócz tego uprzywilejowana kuria urzędników rosyjskich ma dwóch przedstawicieli: w Warszawie i w „Chełmszczyźnie”. Uwaga [z] 1913 r. [przyp. BdeC]. 
W dziedzinie oświaty zagwarantowanie praw mniejszości wyobrażam sobie następująco:

Każda grupa ludzi, a nawet pojedynczy człowiek żyjący w danym obwodzie, ma prawo zakładać szkoły wszelkiego rodzaju i stopnia kształcenia, ze swym ojczystym i w ogóle z jakimkolwiek językiem wykładowym, i jednocześnie ma prawo do materialnej pomocy ze strony państwa, na miarę swych praw osobistych, określonych przez trzy wspomniane wyżej elementy.

Załóżmy na przykład, że kilku mieszkańców lub choćby tylko jeden mieszkaniec Królestwa Polskiego życzy sobie założyć szkołę z hiszpańskim językiem wykładowym. Oczywiście znalezienie nauczycieli jest już jego troską, ale do pomocy finansowej ze strony państwa ma on niezawodnie prawo. Być może, że ta pomoc okaże się w wielkości kilku kopiejek albo nawet mniejsza niż kopiejka, ale ona tak czy inaczej powinna zostać mu udzielona. Tak więc widzimy, że przy takim postawieniu pytania 0 zapewnienie praw mniejszości pokaże się masa szczegółowych elementów, które w oczach samego obdarowanego nimi obywatela będą miały albo wątpliwą, albo żadną, albo ujemną wartość, tak że nie przyjdzie mu nawet do głowy, aby korzystać z podobnych absurdalnych i komicznych praw. Niemniej każdy obywatel powinien mieć możliwość korzystania z nich w razie potrzeby, a nawet w razie zwykłego życzenia.

Taka powinna być rola zarówno państwa jako całości, jak i jego poszczególnych części, wolnych od walk narodowościowych, wyznaniowych i partyjnych tendencji i okazujących absolutną tolerancję w stosunku do wszystkich partii, wyznań i narodowości. I państwo, i każdy z jego obwodów powinny dawać możliwość realizowania się najrozmaitszych tendencji kulturalnych.

Choć na początku tego artykułu zapowiadałem, że piszę tylko dla ludzi zasadniczo zgadzających się ze mną i życzących sobie mnie zrozumieć, to jednak nie mogę tu pominąć milczeniem sprzeciwów albo zdecydowanych przeciwników, albo tych, którzy ogólnie zgadzają się z moimi wywodami, ale w określonych punktach nie chcą ustąpić.

Nie tylko „prawdziwie rosyjscy ludzie”, nie tylko „patrioci” w cudzysłowie, ale i wielu prawdziwych, bezinteresownych i życzliwych patriotów jest przekonanych, że w Rosji powinna panować 
narodowość wielkoruska, dlatego - powiadają - że z realnego punktu widzenia - w Rosji jest więcej Wielkorusów niż innych, poza tym - z historycznego punktu widzenia - Wielkorusi utworzyli i zjednoczyli państwo rosyjskie. Na to pozwolę sobie odpowiedzieć w taki sposób:

To prawda, że Wielkorusów jest więcej niż ludzi każdej innej (niewielkoruskiej) narodowości, wziętej z osobna, ale pozostałe, niewielkoruskie narody Rosji, wzięte razem, przewyższają liczebnością naród wielkoruski. Większość to, co prawda, nieznaczna, coś około $55 \%$ wobec 45\% Wielkorusów, ale jednak większość.

Ale zostawmy tę, w danym wypadku bezpłodną i nic niemówiącą arytmetykę. Jeśli Wielkorusów jest więcej, to ich prawa większości są zapewnione w dostatecznym stopniu powszechnymi wyborami i obiektywnie urzeczywistniającym się procentowym udziałem działaczy na wszelkiej niwie działalności społecznej. Prawnych zaś uprzywilejowań, ustalanych jedynie przewagą liczebną w stadzie, według liczby głów bydła dwunogiego, ja nie uznaję. Wszyscy ludzie w swoich prawach są równi, wszystkie narodowości w swoich prawach są równe. Co zaś się tyczy wielkich zasług plemienia wielkoruskiego, jakoby polegających na utworzeniu i zjednoczeniu państwa rosyjskiego, to jest to zasługa dość wątpliwej jakości. Cóż takiego stworzyło plemię wielkoruskie, jeśli rzeczywiście ono to stworzyło? Stworzyło wielkie więzienie nie tylko dla wszystkich innych plemion i narodów, ale także dla samego narodu rosyjskiego, więzienie, które teraz musimy z takim wysiłkiem i z tyloma ofiarami burzyć i rozbijać i jeszcze pytanie, czy uda się zburzyć to więzienie tak, żeby razem z nim nie padła też cała nieszczęsna państwowość rosyjska.

Dalej, w „zbieraniu” i tworzeniu państwa rosyjskiego Wielkorusom pomagały także inne „przyłączone” i podbite narody. W jednym szeregu z niewolnikami i poddanymi pochodzenia wielkoruskiego, cheąc nie cheąc, musieli iść także niewolnicy i poddani spośród wszelkich „inorodców”. Podczas ostatniej, japońskiej wojny, wywołanej i prowadzonej także dla „zaokrąglenia granic państwa rosyjskiego" i dla „wyniesienia imienia Rosji”, i pola Mandżurii, i Morze Japońskie pokrywały się i wypełniały nie tylko rosyjskimi, ale i „innoplemiennymi” ciałami, włączając i ciała żydowskie. 
Po cóż więc skrywać i udawać! Czyżby z wywyższenia imienia Rosji i umocnienia państwowości rosyjskiej brała się jakaś korzyść dla samego narodu rosyjskiego? W miarę wzrastania poprzedniej państwowości rosyjskiej naród coraz bardziej był ujarzmiany, a korzyść z tego miała tylko niewielka gromadka ojców-przywódców i eksploatatorów.

W imię szczęścia narodu tak wielkoruskiego, jak i każdego innego, powinniśmy raz na zawsze skończyć z molochem państwowości, któremu w ofierze składa się szczęście i dobrobyt, i pojedynczych ludzi, i całych grup społecznych. I wszystko jedno, czy idea tego molocha państwowości wciela się w jakimś stopniu w realnie istniejącą pojedynczą głowę czy też w wielogłową fikcję, nazywaną w danym wypadku „narodem rosyjskim”. Odrzucamy i państwową oligarchię, i państwową ochlokrację, składamy w archiwum koszmar wyznaniowego i narodowego państwa i kierujemy się zasadą, że narody nie istnieją dla państwa, ale państwo istnieje dla narodów.

Nie przyjmujemy utożsamiania państwa z jakimkolwiek Kościołem, z jakąkolwiek narodowością i domagamy się, aby państwo, i jako całość, i we wszystkich swych częściach, było pozawyznaniowym, pozanarodowym, jednym słowem pozapartyjnym. Fundament państwowości w naszych oczach tworzą same tylko czysto realne interesy, interesy ekonomiczne i ogólnopolityczne.

I tak, kierując się tymi realnymi interesami, dajemy pierwszeństwo właśnie językowi rosyj skiemu jako językowi wzajemnego porozumiewania się między przedstawicielami wszystkich obwodów Rosji. Do takiego rozwiązania prowadzi nas nie „hołd dla geniuszu narodu rosyjskiego” jako „pierwszego między równymi”, ale prowadzą na do tego po prostu najbardziej prozaiczne i praktyczne względy korzyści ekonomicznej i względy najmniejszej straty czasu i energii umystowej.

\section{Szkoda i pożytek}

Tj. szkoda wskutek niezaspokojenia pragnienia narodowej i terytorialnej autonomii, zaś korzyść z jego zaspokojenia. 
Autonomię narodową rozumiemy jako prawo do samookreślenia się i samorządu każdej dobrowolnie powstałej społecznej, w tej liczbie przede wszystkim narodowościowej, grupy, w granicach nienaruszających praw innych takich samych samookreślających się i samorządnych grup i związków. Tery torialna au tono mia zaś to autonomia w wąskim znaczeniu tego wyrazu.

Francuskie centralistyczne nawyki, nakładanie kiedyś przez władze francuskie kary za używanie lokalnych języków, zduszenie wszelkiej inicjatywy prowincyj, sprowadzenie etnograficznej i kulturowej różnorodności do wspólnego mianownika, bezlitosna dyktatura paryskiego rządu wobec zróżnicowanej ludności kraju spowodowały potężną szkodę życiu społecznemu narodu francuskiego, paraliżowały jego samodzielność i wywołały akurat przeciwne dążenia, które osiągnęły przerażające rozmiary w czasie Komuny Paryskiej 1871 r.

We Włoszech prowadzona jest państwowa i społeczna centralizacja, z nieubłaganą konsekwencją unicestwiająca wszelkie ślady lokalnej politycznej różnorodności; prześladuje się języki lokalne, rada miejska nakłada, np. we Florencji, kary na właścicieli hoteli za używanie na wywieszkach innych języków niż włoski itd. Rezultatem tego są ciągle wzrastające dążności decentralizacyjne, których krwawym dowodem było m.in. powstanie mediolańskie w r. $1898^{1}$.

Niemieckie, a dokładniej pruskie bestialstwa i okrucieństwa w Danii, w Elzasie, w polskich częściach Poznańskiego, Śląska, Prus Zachodnich itd. wywołują straszne pytania, niepotrzebnie pochłaniające wielką państwową i społeczną energię i w żaden sposób niedające korzyści temu, co prawda cywilizowanemu, ale jednocześnie barbarzyńskiemu państwu.

Na Węgrzech deptanie praw narodowości niemadziarskich dochodzi do monstrualnych rozmiarów, a to wiedzie do zdziczenia tak prześladowców, jak prześladowanych i osłabia trwałość jedności państwowej.

W Austrii nienawiść między narodowościami przybiera obrzydliwe formy i zatruwa życie społeczne wszystkich narodowości.

1 Mowa o stłumionych przez wojsko protestach i wystąpieniach robotników mediolańskich walczących o swoje prawa. 
W Rosji obok ckliwego i obłudnego hasła „słowianofilstwa” praktykowano i praktykuje się nadal haniebne i oburzające prześladowanie wszystkich razem i każdego z osobna. W l. 70. urządzano najazdy i ekspedycje karne na unitów za ich przywiązanie do wiary przodków. Urządzano wyprawy przeciwko katolikom. Wystarczy wspomnieć orżesko-klingenbergowską krwawą łaźnię i gwałty w Krożach ${ }^{1}$. „Surowo zakazywano” mówić po polsku. Używanie alfabetu litewskiego uważano z przestępstwo przeciwko państwu. Nie dozwalano Pisma Św. po ukraińsku (małorusku) i białorusku. Unicestwiano przejawy muzułmańskiej kultury w posiadłościach w Azji Środkowej. Wszystkie narody kaukaskie skazywano na bezlitosne prześladowania i całkowitą rusyfikację. W sposób najbardziej beztroski zaprowadzono analfabetyzm w Kraju Bałtyckim, wśród Łotyszów i Estończyków. „Patrioci” pielęgnowali kulturalne pustoszenie i rujnowanie Finlandii. Żydów ostatecznie uznano za pozostających „poza prawem”, a pastwienie się nad nimi uważano i uważa się za czyny „patriotyczne”. Pogromowa martyrologia mówi sama za siebie. Niszczono bezlitośnie próby wszelkiej samodzielności terytorialnej. I jakie przyniosło to owoce?

Przede wszystkim ogólną pogardę i nienawiść do państwa dostarezającego tego rodzaju rozkoszy. Prześladowanie narodowości doprowadziło do skutków przeciwnych; nie tylko umocnito te narodowości, ale i zasiało między nimi ohydną chorobę szowinizmu i zaczepnego, zapalczywego „patriotyzmu”. Wzmocnieniu poczucia narodowej odrębności u Ukraińców (Małorusinów), a nawet u Białorusinów, sprzyjało przede wszystkim prześladowanie ich języka i literatury. Wszędzie pojawiają się dążenia separatystyczne i decentralizacyjne i wiele wody upłynie, zanim namiętności opadną i do wzburzonych mas przeniknie świadomość wspólnych interesów państwowych.

1 Kroże (lit. Kražiai) - miejscowość na półn. zach. od Kowna. W 1893 r. z nakazu gubernatora kowieńskiego M. M. Klingenberga zamknięto tam katolicki kościół, co wywołało czynny protest chłopów, którzy pobili przedstawicieli władz. Opór stłumiono, a kilkudziesięciu chłopów postawiono przed sądem pod zarzutem zbrodni stanu. Proces, który toczył się w Wilnie, stał się sensacją, m.in. wskutek udziału czołowych przedstawicieli palestry rosyjskiej. 
W Polsce, idąc w ślady „prawdziwie rosyjskich ludzi” albo też Z własnej inicjatywy, „prawdziwie polscy ludzie” chętnie by poddali ograniczeniom i prześladowaniom Żydów, Litwinów, Rosjan, Niemców itd. i tym sposobem nastawiliby przeciw Polsce jej pasierbów i wzgardzonych.

Nieskrępowane ograniczanie i prześladowanie rodzi zawsze nienawiść i inne złowrogie uczucia wobec całego ograniczającego państwa czy też obwodu. Dla uniknięcia podobnych niszezących i złowrogich uczuć proponujemy całkiem inną metodę - budowanie stosunków między narodowościami i w ogóle między grupami.

Uznajemy ogólnopaństwowe i ogólnoobwodowe zobowiązania tylko $\mathrm{w}$ dziedzinie ziemskich, realnych interesów, ale w sferze dążeń narodowych, wyznaniowych i innych kulturalnych pozostawiamy każdemu pełną swobodę wyboru. Korzyść z tego jest jasna i oczywista.

Z porządku dziennego zdejmujemy kwestie wyznaniowe i narodowościowe, oczyszczając drogę dla zadowalającego rozwiązania kwestii ogólnopolitycznych i ekonomicznych.

Prawdziwi autonomiści i federaliści chę współdziałać w oszczędzaniu państwowej i społecznej energii traconej na denacjonalizację ${ }^{1}$, na przymusową propagandę wyznaniową i inne tp. szkodliwe i haniebne przedsięwzięcia, aby w całości skierować tę energię na rozwiązanie kwestii ogólnopolitycznych i ekonomicznych.

Uczyniwszy za pomocą odpowiednich przepisów prawnych niemożliwymi wszelkie chęci gwałtownego uzyskania przewagi jakiejkolwiek narodowości nad innymi, jakiejkolwiek klasy nad innymi, jednocześnie utrwalamy pokojowe współżycie narod ow ości i innych grup kulturowych tak w całym państwie, jak i w każdej z jego samorządnych części, pokojowe współżycie, tak konieczne dla rozwoju wewnętrznego i dla autorytetu w stosunkach międzynarodowych. Bez narzucania ogólnie obowiązującego języka państwowego utrwalamy jedność ogólnopaństwową.

1 Denacjonalizacja - tu: wynaradawianie. 
Przy całkowitej wolności sumienia i przekonań, podobnie jak zrzeszania się, państwu nie grozi niebezpieczeństwo rozpadu i utraty jedności. Przeciwnie, ze względu na korzyść ogólną i ze względów ekonomicznych, wielu wyrzeknie się swych drobnych różnic i lokalnych przywilejów i da pierwszeństwo zjednoczeniu się.

Wspomniane przeze mnie drobne różnice mogą być albo jakościowe, albo ilościowe. Na przykład w dziedzinie języka jakościowość sprowadza się do różnic dialektów, ilościowość zaś do liczby nosicieli języka. Przy dużym podobieństwie dialektów białoruskich i wielkoruskich nie przyjdzie chyba Białorusinom do głowy tworzenie odrębnego białoruskiego języka dla potrzeb nauki i literatury.

Przy całkowitej pozanarodowości tak całego państwa, jak i jego autonomicznych obwodów przydałyby się właściwie, dla uniknięcia nieporozumień, nowe nazwy, wolne od narodowych woni. Ale rzecz nie w nazwach. Można posługiwać się tradycyjnymi nazwami, byle wiedzieć, że używa się ich w znaczeniu tylko terytorialnym, a nie narodowym. Zresztą zostawiając słowa „Ru ś” i „ru ski” dla oznaczenia zarówno granic etnograficznych narodu rosyjskiego, jak i rosyjskiej narodowości, moglibyśmy w znaczeniu ogólnopaństwowym i terytorialnym postugiwać się terminami „Rosja”, „rosyjski”. Co się

1 Tak np. należałoby mówić:jezzyk ruski, ruska literatura, ale państwo rosyjskie, gospodarka rosyjska, rosyjskie linie komunikacyjne, armia rosyjska, rosyjskie prawodawstwo, podatki rosyjskie itd. Podobne rozróżnienie jest nieuniknione w takich państwach, jak Austria, Szwajcaria, Belgia, USA, Brazylia itp. Byłoby śmieszne mówić o austriackim, szwajcarskim, belgijskim, pótnocno-amerykańskim, brazylijskim itd.jezyku albo o austriackiej itd. literaturze, ale wyrażenia austriacka itd. armia, austriacki itd. rzad, austriackie itd. prawodawstwo są całkowicie na miejscu i potrzebne. Nie ma szwajcarskiej, austriackiej, belgijskiej narodowości, ale za to jest szwajcarskie, austriackie, belgijskie itd. terytorium. Jeśli można mówić o rosyjskiej armii, niemieckiej armii itd. w znaczeniu narodowym, to dopuszczalne jest mówić 0 armii w sensie wyznaniowym: armia prawostawna, armia katolicka itd., w rodzaju armii muzutmańskiej, chociaż ta ostatnia nigdy nie była jednolitą. Mówić o wyrazach obcych w jezyku rosyjskim oznacza pomieszanie pojęć, pomieszanie terytorialności z narodowością. [przyp. BdeC] 
zaś tyczy „Polski” i „Polaków”, to na razie tutaj trzeba będzie się zadowolić jednym terminem, ale trzeba wówezas dokładnie odróżniać, w jakim znaczeniu używamy tych słów: w znaczeniu etnograficznym i narodowym czy też w znaczeniu wyłącznie terytorialnym.

Gdy cała Rosja i jej poszczególne autonomiczne części zagwarantują wszystkim całkowitą wolność kultury i będą stać na straży niestykania się praw narodowych i praw jednostki, to bez żadnego przymusu rozwinie się przywiązanie do takiej jedności państwowej, rozwinie się i utrwali ogólnoobwodowa i ogólnopaństwowa solid arność, a podobne uczucie jest daleko trwalsze i poważniejsze niż przeżytkowy patriotyzm lub miłość do ojezyzny w starym stylu.

Nie można pominąć jeszcze jednej korzyści z takiego rozwiązania kwestii narodowościowej. Ta korzyść przejawi się na scenie międzynarodowej, a dokładniej, na międzypaństwowej. Ludzie mówiący tym samym językiem i należący do tego samego plemienia, żyjący w różnych państwach, będą nie jabłkiem niezgody między tymi państwami, ale, odwrotnie, będą jednoczącym ogniwem między nimi. Na przykład Litwini w Rosji i w Prusach mogliby stać się rękojmią pokojowego współżycia między Rosją a Niemcami, Polacy w Rosji, w Prusach i w Austrii - rękojmią pokoju między tymi trzema państwami, Słowianie i Włosi we Włoszech i w Austrii - jednoczącym ogniwem między Włochami i Austrią, Ormianie w Rosji, w Turcji i w Persji - rękojmią pokoju między tymi trzema państwami, Żydzi rozsiani prawie po wszystkich państwach, rękojmią wszechświatowego pokoju. Nasze postawienie kwestii narodowościowej wspótdziała z pokojowymi, an tymilitarystycznymi dążeniami.

Gdyby narodom Rosji udało się rozwiązać kwestię autonomii w zadowalającym sensie, wówczas taki rezultat pochlebiałby i narodowej, i państwowej miłości własnej; można by wtedy być dumnym z przynależności do takiej całości narodowej czy państwowej. Na razie nie można być dumnym z przynależności do państwa depezącego prawa narodowości i prawa człowieka, do państwa szkolnych procentów, linii osiedlenia i obław na „bezprawnych”. 
8. Konkretne kwestie. Kwestia żydowska.

Syjonizm. „Żargon”

0 niektórych konkretnych kwestiach i zadaniach wspomniałem weześniej. Teraz natomiast zatrzymam się na dwóch tylko: na „kwestii żydowskiej” w związku z „syjonizmem” i „żargonem” i na odniesieniu zasady autonomii, jak ja ją pojmuję, do sprawy szkolnej.

Wielu stawia przed sobą scholastyczne rozważania o tym, czy uznać Żydów za określoną narodowość, czy też nie. Kto zgadza się z wyłożonymi przez mnie wyżej racjami, dla tego pytanie tego rodzaju nie istnieje. Rozważani obiektywnie, z antropologicznego, lingwistyeznego, folklorystycznego itp. punktu widzenia, Żydzi mogą być zaliczani raz do tej, raz do innej rasy lub różnorodności gatunku zwierząt, nazywanego w nauce homo sapiens (oczywiście nie należy wszystkich Żydów rzucać na jedną kupkę antropologiczną), to do tego, to do innego określonego lingwistycznie plemienia itd. Ale gdy chodzi o narodowośé, należy pozostawié każdemu Żydowi indywidualnie zdecydowanie, do jakiej narodowości sam siebie zalicza: czy do odrębnej żydowskiej, czy do jakiejś nieżydowskiej, czy też zarazem do żydowskiej i do nieżydowskiej itd.

Natomiast nie ulega wątpliwości, że Żydzi w krajach barbarzyńskich, w tej liczbie i w Rosji, podlegają ciężkim prześladowaniom, a te prześladowania łączą ich, mimo woli, w jedno odrębne stado ludzkie. Gdybyśmy nagle zaczęli prześladować wszystkich blondynów za to tylko, że są blondynami, to według wszelkiego prawdopodobieństwa blondyni zjednoczyliby się w odrębną grupę, pozostawaliby we wrogich stosunkach z otaczającym ich środowiskiem, a nawet, byé może, zażądaliby wyodrębnienia ich w osobne królestwo bez ziemi, bujające w powietrzu.

U wszystkich prześladowanych za pochodzenie rozwija się hiperestezja narodowości, wyznaniowości i w ogóle poczucia wspólnoty. U Żydów ta hiperestezja objawia się w n-tym stopniu.

Niewysychającym źródłem narodowej i wyznaniowej hiperestezji u wspótczesnych nam Żydów jest z jednej strony ich religijna i plemienna odrębność, właściwa im od najdawniejszych czasów, z drugiej strony wyrafinowane prześladowania i pastwienie się, wymyślane 
dla nich do syta przez możnych „chrześcijan” i „miłujących bliźniego". Jeszcze niedawno znakomity petersburski naczelnik miasta Gresser wynalazł dla Żydów szczególnego rodzaju prześladowania. Kazał wszystkim handlującym Żydom umieścić na szyldach nie tylko ich nazwiska, ale także pełne, en toutes lettres, ich imiona żydowskie i otczestwa . „Chrześcijańscy” kupcy byli zwolnieni od tego swoistego zaszczytu in minus, w negatywnym sensie, od tej negatywnej autonomizacji w stylu syjonistycznym, od tego swoistego priviegium odiosum. Za pomocą podobnego środka, kontynuowanego gorliwie przez spadkobierców Gressera, panów von Wahla i Kleingelsa, po pierwsze okazywano Żydom w należytym stopniu pogardę i cynicznie poniewierano, następnie dawano, w razie czego, jasną i określoną wskazówkę dla uczestników pogromów, a wreszcie stwarzano policji możliwość brana łapówek przy obchodzeniu „prawa”.

Oprócz tych chytrych wynalazków „prawdziwie rosyjskiego” naczelnika, pana Gressera, rysują się, a nawet usuwają je w cień inne sposoby pastwienia się nad Żydami: hańbiąca Rosję linia ,żydowskiego osiedlenia”, hańbiące procenty szkolne, nie tylko dla Żydów, choć przede wszystkim i najostrzejsze dla Żydów - jednym słowem, bezlitosna i nieustająca naganka ze wszystkich stron.

A potem cała seria pogromów urządzanych przez „patriotów swojej ojczyzny”, począwszy od „prawdziwie rosyjskiego” męża stanu, p. von Plehwe, kończąc na „prawdziwie rosyjskim” dowódcy p. Tichanowskim, który zrobił „prawdziwie rosyjskie” odkrycie, że „bagnet mocniejszy od szmatki”"

Doświadczając takiej „prawdziwie chrześcijańskiej” gościny, można rzeczywiście oszaleć i stać się niepoczytalnym. Teraz więc zrozumiała staje się dla nas hiperestezja żydowskiego poczucia narodowości.

Nawet najlepsze, pierwszej klasy umysły wśród Żydów cierpią na tym punkcie na pomieszanie pojęć i wiadomego rodzaju zwyrodnienie w dziedzinie rozumienia zarówno narodowości, jak i terytorialnego elementu w autonomii.

1 Podpułkownik dragonów rosyjskich, organizator pogromu Żydów w Siedlcach. Aluzja niejasna. 
Przechodząc w szeregi „syjonistów” i marząc 0 nieziszezalnym, na razie żądają dla Rosji odrębnego ogólnożydowskiego sejmu czy parlamentu z ustawodawczymi funkcjami. Sejm ten powinien mieć prawo wydawania oddzielnych przepisów, obowiązujących jednakowo wszystkich Żydów, w różnicy od pozostałych mieszkańców państwa rosyjskiego. Żydzi powinni mieć prawo utrzymywania własnej policji dla samych tylko Żydów. Powinny zostać utworzone odrębne sądy dla Żydów: sądy kryminalne dla sądzenia przestępstw dokonywanych przez Żydów, sądy cywilne dla Żydów prawujących się między sobą. Chociaż w całym państwie będzie zniesiona kara śmierci, Żydzi mogą się z tym u siebie nie liczyć i, zgodnie ze swymi żydowskimi prawami, skazywać nadal swoich na karę śmierci (może przez ukamienowanie, według starotestamentowych przekazów). Żaden Żyd, czy to według wyznania żyd, chrześcijanin czy bezwyznaniowiec (konfessionsloss) - jeśli mu udowodnią „̇̇ydowskie pochodzenie” - nie ma prawa uchylać się od uczestnictwa w tym „państwie żydowskim” i od odpowiedzialności przed żydowskim sądem.

Oto jakie są polityczne ideały zaciekłych syjonistów, marzących o żydowskiej narodowej autonomii. Cheą stworzyć państwo bez ziemi, państwo bujające w powietrzu, państwo wędrowne, koczownicze, coś w rodzaju cygańskiej „narodowej autonomii”.

Rozumie się samo przez się, że z nowoczesnego punktu widzenia taka forma autonomii w żaden sposób nie może być uznana za kulturalną. Nie możemy w naszych czasach dopuścić obowiązkowej autonomii bez określonej podstawy, bez ustalonych granic, bez terytorium. Syjonistyezne, napowietrzne, pozaterytorialne państwo jest przeżytkiem średniowiecza, podgrzewanym i rozpalanym przez okrutne prześladowania. I przymusowe odosobnienie, i obowiązek wszystkich Żydów podporządkowania się rozkazom swoich „autonomicznych" władz - wszystko to było możliwe w wiekach średnich, ale teraz w żaden sposób nie może być tolerowane.

Po wiekach średnich odziedziczyliśmy eksterytorialne autonomie rozmaitych kościołów, z odrębną organizacją polityczną, z odrębnymi prawami, z odrębnymi sądami, z odrębną policją i cenzurą. Ale wiemy, że to jest przeżytek wieków średnich, wiemy, że ten koszmar odziedziczony z barbarzyńskiej przeszłości, trzyma się jeszcze siłą 
ciążenia i niewolniczymi uczuciami podopiecznych, i dążymy do tego, aby sprowadzić organizację kościelną na właściwy poziom wolnego zrzeszenia osób uważających się za jednakowo wierzące. Takim dokładnie związkiem może być też ogólnożydowska organizacja. Od zakusów na wolność osobistą obywatela powinniśmy ją powstrzymać.

„Syjonizm” w dużym stopniu objaśnia się marzycielskością i brakiem fundamentów, właściwymi od niepamiętnych czasów licznym myślicielom żydowskim. Tu należy też żydowski mesjanizm, nastawiony na nieskończoność i przypominający hiperbolę przybliżającą się do asymptot, ale schodzącą się z nimi dopiero w nieskończoności, tj. nigdy. Syjonizm jest zrozumiały psychologicznie, ale praktycznie szkodliwy i niedopuszczalny. Jest szkodliwy właściwie dla samych Żydów. Syjoniści chcą stworzyć i dla siebie samych, i dla całego narodu żydowskiego krańcowo niebezpieczne privilegium odiosum, będące $\mathrm{z}$ jednej strony stałym zagrożeniem $\mathrm{w}$ stosunkach $\mathrm{z}$ innymi wspótobywatelami tego czy innego terytorium, z drugiej strony stałym wyzwaniem i prowokowaniem pogromszczików i różnych innych ciemnych sił z „patriotycznego” i „chrześcijańskiego” obozu.

W związku z „kwestią żydowską" i „syjonizmem” pozostaje do powiedzenia jeszcze kilka słów o żydowskim „żargonie”.

Z naukowego punktu widzenia tak zwany „żargon” niczym się nie różni od każdego innego języka. Ma on własne cechy dźwiękowe, formalne, semazjologiczne i in., jak wszystkie inne języki kuli ziemskiej. Prawo używania w literaturze, w szkole, w administracji itd. ma on takie samo, jak wszystkie inne języki. Trzeba tylko, aby znaleźli się ludzie, którzy zechcą go używać w takich celach. Tacy ludzie już są. „Żargon” okazuje się narzędziem nie tylko domowego użytku licznych rodzin, ale także swoistej literatury i prasy, teatru, szkoły, agitacyjnych polityeznych zebrań itd.

„Przeciwnicy” „żargonu” twierdzą, że jeśli tylko zabrać mu litery żydowskie, zmieni się w język niemiecki. Nie wiem. W końcu ja nie tylko rozumiem, ale i mówię, i piszę po niemiecku, a jednak nie mogę zrozumieć mówiących żydowskim „żargonem” i nie mogę zrozumieć całkowicie napisanego w nim niemieckimi (tj. łacińskimi) literami.

Nie jestem ani przeciwnikiem, ani zwolennikiem ,żargonu”, bronię tylko całkowitej narodowej wolności i samookreślenia się każde- 
go obywatela. Pozwólcie samym pojedynczym Żydom decydować, czy uznają oni tzw. „żargon” za swój narodowy język, czy nie. Jeśli znajdzie się pewna liczba ludzi, skupiających się wokół „żargonu” jako łączącego ich języka, należy temu językowi dać te wszystkie prawa, z jakich korzysta dowolny inny język. Podobne kwestie rozstrzygaja się nie nakazem rządowym lub narodowym, ale przez samookreślenie się świadomych ludzi.

\section{Konkretne kwestie. Kwestia szkolna}

Z obecnego punktu widzenia i państwo, i obwód, i gmina powinny być pozapartyjne, pozawyznaniowe, pozanarodowe. Ale mimo całej pozanarodowości warto zatrzymać się na tym lub innym języku, ponieważ bez języka nie jest możliwe wykładanie i prowadzenie szkoły w ogóle.

Język każdej szkoły powinien być ustalony zgodnie z wolą większości mieszkańców danej samorządnej jednostki, jednak przy zagwarantowaniu wszelkich praw mniejszości. Jeżeli mniejszość żąda szkoły z inny językiem wykładowym, to żądanie to powinno zostać zaspokojone, nawet z przeznaczeniem sum z kasy gminnej, obwodowej lub państwowej, w wielkości odpowiadającej prawom obywateli i wkładowi tej mniejszości (jak to wyjaśniłem wcześniej w rozdziale 6). Ze względów pedagogicznych i ogólnoobywatelskich w każdej szkole powinien być obowiązkowym, jako przedmiot nauczania, tylko jeden język, język wykładowy. Jednak konieczne jest pozostawienie wszystkim uczniom możliwości nauczenia się także innych języków, jako to: języka najbardziej rozpowszechnionego w państwie, języka najbardziej rozpowszechnionego w danej autonomicznej jednostce, języka innojęzycznych współobywateli danej jednostki samorządowej, języków rozpowszechnionych i mających światowe znaczenie (w rodzaju niemieckiego, francuskiego, angielskiego, esperanto itp.); tzw. języków „klasycznych”, łaciny i greki.

Oprócz powszechnych szkół o wyraźnie terytorialnym charakterze, bez żadnych wyznaniowych i partyjnych tendencji, pozostawia się każdemu wyznaniu, narodowościowej i wszelkiej innej grupie kul- 
turalnej prawo urządzenia na własną rękę własnego zakładu naukowego, ale bez żadnej pretensji do pomocy ze strony państwa.

Język wykładowy lub języki wykładowe uniwersytetów i innych szkół wyższych ustala się w przybliżeniu tak, jak języki wszystkich w ogóle szkół. Należy przy tym liczyé się zawsze z obecnymi siłami nauczycielskimi.

Samo przez się jest zrozumiałe, że docenci prywatni, pracujący bez wynagrodzenia, mają prawo wykładać w języku, w jakim chcą.

Jeśli np. będzie mowa 0 założeniu uniwersytetu w Wilnie, to jest pytanie, w jakim języku powinno się na nim wykładać. Wątpliwe, czy będzie można ograniczyé się do jednego języka. W każdym wypadku, praktycznie stawiając to pytanie, wedle wszelkiego prawdopodobieństwa pierwszeństwo będzie miał język rosyjski. Nie trzeba zapominać, że wileński uniwersytet jest w znacznym stopniu uniwersytetem dla Białorusinów, tj. dla ludzi bliższych literackiemu językowi, którym może być tylko język rosyjski. Potem Litwini z bliskich Wilnu terytoriów mają niezbywalne prawo żądać choćby kilku katedr z litewskim językiem wykładowym, powinni tylko zadbać 0 wyszukanie wykładowców władających tym językiem. Wreszcie nie wolno zapomnieć o kulturalnym znaczeniu w tym kraju elementu polskiego, a zatem 0 wprowadzeniu do uniwersytetu wykładów także po polsku. Weześniej, kiedy prawie jedynym kulturalnym elementem Kraju Północno-Zachodniego byli polscy ziemianie i polska inteligencja miejska, a ludność litewska i białoruska była tylko materiałem etnograficznym, mógt istnieć w Wilnie wyłącznie polski uniwersytet. Teraz podobny uniwersytet jest nie do pomyślenia, chociażby z powodu demokratyzacji społeczeństwa i zrównania w prawach potomków dawnych chłopów pańszezyźnianych z potomkami dawnych właścicieli niewolników.

Zostawiam na boku język Żydów. Czy oni zwrócą uwagę na uniwersytet w Wilnie i przedłożą mu swoje prawa narodowościowe, to odrębna kwestia i tej nie tykam. 
10. To, co wykonalne w najbliższej przyszłości

Wszystko, co powiedziano wyżej, obracało się w sferze ideałów i dotyczyło zasadniczego, teoretycznego ujęcia sprawy. Był to, że tak powiem, autonomiczno-federalistyczny program maksimum. Teraz zapytajmy: jakie punkty, jakie szczegóły tego programu mogą liczyć na zrealizowanie w najbliższej przyszłości, jeśli w ogóle w Rosji będzie się cokolwiek urzeczywistniało? Innymi słowy - jaki możemy nakreślić program minimum?

Tak więc jednym z konkretnych zadań najbliższej sesji instytucji prawodawczej powinno być poskromienie rozszalałych satrapów i zamiana ich samodzierżawia na szeroki samorząd poszczególnych okręgów i obwodów.

Obok tego powinna iść likwidacja wszelkich przywilejów i ograniczeń związanych z pochodzeniem danej osoby, ogłoszenie całkowitego równouprawnienia wszystkich bez wyjątku obywateli i obywatelek i ustanowienie zasady całkowitego samookreślenia się w dziedzinie kultury.

Potem powinno się uznać jako obowiązującą zasadę, że państwo w całości i w oddzielnych częściach powinno brać pod uwage tylko ziemskie interesy ekonomiczne i ogólnopolityczne, i że, co z tego wynika, powinno być pozwyznaniowe (pozakonfesyjne) i pozanarodowe.

Dopiero po przeprowadzeniu w Dumie Państwowej, zgodnie z porządkiem ustawodawczym, tych ogólnie obowiązujących zasad będzie można przystąpić do ustanowienia autonomii poszczególnych obwodów, przede wszystkim autonomii Królestwa Polskiego.

Jednak w żaden sposób niedopuszczalne jest rozwiązanie kwestii autonomii Królestwa Polskiego według wzorca dualizmu austro-węgierskiego. Królestwo „Polskie” oddać, jak powiadają, na pożarcie „narodowym” Polakom, a pozostałą Rosję dać na pożarcie „narodowym” Rosjanom. Na takich warunkach spotkaliby się, być może, i pogodzili „prawdziwi rosyjscy ludzie” z ,prawdziwie polskimi ludźmi”. My jednak w żaden sposób nie możemy na to pozwolić, nie tylko dlatego, że takie rozwiązanie jest nie- 
sprawiedliwe i niemoralne, ale i dlatego, że ono byłoby zgubne i dla Polski, i dla Rosji.

Z naszego punktu widzenia, rozwiązując kwestię autonomii Królestwa Polskiego, porozumiewają się nie przedstawiciele narodu polskiego z przedstawicielami narodu rosyjskiego, ale tylko przedstawiciele pozanarodowego, terytorialnego Królestwa Polskiego z przedstawicielami pozanarodowej, terytorialnej pozostałej Rosji.

Jak rozwiązywać te i tym podobne kwestie, jak rozwiązywać liczne inne fatalne dla Rosji sprawy, zasłania mrok niewiedzy. Według mnie i według moich zwolenników, Rosja powinna iść w kierunku z jednej strony pełnego zrównania w prawach nie tylko wszystkich bez wyjątku obywateli, ale też wszystkich bez wyjątku wyznań, z drugiej zaś strony w kierunku decentralizacji, autonomii terytorialnej poszczególnych obwodów, a w końcu federalizacji. Inaczej grozi jej rozkład i ostateczny upadek. Oczywiście możemy się mylić i żadnego upadku nie będzie. Tym lepiej.

Co zaś się tyczy możliwego upadku Rosji, to pozwolę sobie zauważyć jedno. Upadek państwa, w którym bezprawie i nieubłagane okrucieństwo odbywają zwycięski tryumfalny pochód przez cały kraj, państwa, w którym chronione i wchodzące w zasadę naruszania norm etycznych, a i zwykłe przestępstwa, nie tylko nie są osądzane i nie są piętnowane, ale - przeciwnie - są wysławiane jako czyny niezwykłe i szczodrze wynagradzane, upadek takiego państwa w nikim nie wywoła żalu. Jednakże jeśli staramy się ze wszystkich sił przeciwdziałać temu upadkowi, to tylko dlatego, że boimy się wielkich ofiar, które z konieczności pociągnie za sobą upadek podobnego molocha, a i oprócz tego kierujemy się czysto egoistycznymi pobudkami, gdyż sądzimy, że razem z Rosją zginą też liczni bliscy nam ludzie i wiele skarbów kultury. 


\section{W SPRAWIE „ANTYSEMITYZMU POSTĘPOWEG0”}

Żądza odwetu za legendarne męczeństwa przedwiekowe jako podkład nieświadomy myślenia i działania polityków, publicystów, uczonych, literatów i zwykłych śmiertelników

\section{Przykład 1.}

Prawdopodobnie w mniej lub więcej odległej przyszłości na kartach tak zwanej historii powszechnej można będzie czytać opowieść następującą:

Kiedy we wszystkich państwach nowoczesnego pokroju przestano już prześladować ludzi za pochodzenie, kiedy w tych państwach przynajmniej de iure wolno było wszystkim ludziom mieszkać, gdzie im się podobało, kiedy dostępu do szkół nikomu tam nie tamowano, istniało jeszcze we wschodniej Europie i w Azji Północnej państwo, w którym „prawnie”, tj. na mocy przepisów obowiązujących, pewnym kategoriom ludzi zabraniano przekraczać granice wyznaczonych dla nich klatek, w którym dozwalano uczyé się tylko nieznacznej cząstce młodzieży tych kategorii, według ściśle określanych „procentów”, w którym, jednym słowem, naigrawano się i znęcano nad ludźmi jedynie za to, że należeli urzędowo do tego lub owego wyznania, do tej lub owej narodowości. Przepisy ograniczające prawa tych ludzi, szczutych i prześladowanych, z całą masą objaśnień, dopełnień, subtelnych rozróżniań rodzajów na gatunki, kategorii na podkategorie itd., przepisy owe mogłyby zapełnić całe tomy. Interpretowanie i stosowanie tych przepisów pochłaniało mnóstwo czasu i pracy umysłowej całej falangi urzędników, a ich, owych przepisów, obchodzenie i naruszanie stanowiło nigdy niewysychające źródło łapówek, bez których nie dał się właściwie pomyśleć urzędnik tego jedynego w swoim rodzaju państwa.

Szczególniej umiłowano sobie gatunek ludzi, zwany „Żydami”. Przede wszystkim stosowano do nich pojęcie tak zwanej „linii osiedlenia” (czerta osiodtosti), której pod grozą surowych kar nie wolno było przekraczać. Oprócz linii osiedlenia ludzie, zwani „Żydami”, posia- 
dali jeszcze całą listę nie mniej przyjemnych i zaszczytnych „praw” i „przywilejów”. Odpędzano ich od szkót, nie dopuszczano od urzędów, zabraniano pracować w rozmaitych specjalnościach, nabywać ziemię na własność itd., itd.

Otóż zdarzyło się, że w tym świętym i bogobojnym państwie umarł monarcha, a na tron wstąpił jego syn. Wielki wezyr, czyli główny minister, miał obowiązek przedstawienia ogólnego rzutu oka na stan państwa w danej chwili i na jego sprawy zasadnicze. Między innymi ułożono obszerny memoriał 0 „Żydach”. W memoriale tym wyliczano najprzód zalety „Żydów”, następnie charakteryzowano ich wady i złe strony, a nareszcie, na podstawie wszelkich pro i contra, stawiano wnioski praktyczne. Młody monarcha czytał uważnie wszystko po kolei. Oczywiście nasamprzód musiał się zaznajomić z zaletami i dobrymi stronami „Żydów” jako plemienia „trzeźwego", „oszczędnego", przykładnego w życiu rodzinnym itd. Monarcha, nie skończywszy jeszcze wykazu cnót Izraela, obruszony trochę na chwalców, wypisał własnoręcznie na marginesie memoriału: Wszystko to bardzo pięknie, ale dlaczego oni Chrystusa zabili?

A więc „Żydzi”, poddani owego monarchy w Europie Wschodniej, zabili Chrystusa w Palestynie przed dziewiętnastu wiekami. Że zaś monarcha ów, jak przystało na monarchę chrześcijańskiego, kochał Chrystusa, więc nie mógł im tego przebaczyé, zapominając zresztą, że ci nienawidzeni przezeń Żydzi czasów minionych, teraźniejszych i przyszłych byli współziomkami i wspótplemieńcami umęczonego.

\section{Przykład 2.}

Pewien Anglik, nie-Żyd, czyli „chrześcijanin”, pobożny i bogobojny, żył w zażyłości a nawet w przyjáni z pewnym „Żydem”, również Anglikiem, ale pomimo to Żydem. Pewnego razu ów Anglik chrześcijanin spotyka swego przyjaciela Żyda i, zamiast przywitać się z nim według przyjętego zwyczaju, rzuca się na niego ze wściekłością i zaczyna go bić. Tamten na to:

- Czy oszalałeś? Czego chcesz ode mnie? Za co mię bijesz?

- Za to, że zabiliście Chrystusa.

- Kto zabit?

- Wy, Żydzi. 
- Ależ, mój kochany, ten smutny wypadek zdarzył się prawie przed dwoma tysiącami lat.

- Tak, tak, zapewne, ale ja się dopiero dzisiaj o tym dowiedziałem.

Ów Anglik, pobożny i bogobojny, kochał oczywiście Chrystusa, niestety jednak nie umiał ani przebaczać, ani być sprawiedliwym, ani myśleć logicznie.

\section{Przykład 3.}

Profesor Karol Appel, zdając sprawę z broszury p. W. Mutermilcha skierowanej przeciwko sztucznemu językowi „esperanto”, twierdzi, że:

dla ludzi, patrzących na rzecz trzeźw o, bez uprzedzeń, esperanto zawdzięcza swój rozgłos światowy poparciu żydowskich kapitałów pod hasłem: „Semici wszystkich narodów łączcie się..." Ale sztucznie podniecony entuzjazm dla tego iście ohydnego żargonu już ostygł... („Książka”. Miesięcznik... Warszawa, 1910, nr 10, str. 397),

oraz, że:

tylko osobnik pozbawiony mowy ojczystej i przyrodzonego p oczucia językowego, tylko o toczenie, które przywykło bezkarnie kazić obce języki i któr g go to nie razi wcale, może „bez uczucia wstydu” „przekręcać pełne słodyczy”(?), harmonijne revue mowy Francuzów na ża rgo nowe REVU0”! (tamże, str. 398).

Oczywiście za pomocą metody wywiadowczej stosowanej z takim powodzeniem przez „Myślicieli niepodległych”, p. Appel odkrył, że wynalazca esperanta jest nie tylko Żydem, ale także „żargonowcem” i że ta „żargonowość” zabarwiła sztuczny język doktora Zamenhofa, popierany następnie przez innych „żargonowców” na chwałę i pożytek „Semitów”, a na hańbę i szkodę „Aryjczyków”.

Dowiadujemy się też od p. Appela, że

można było p o dep tać wszystkie języki świata, umiłowaną mowę ojczystą tylu narodów, ale w a r a od „esperanto”, bo to język wy o d rębniającego się semityzmu (tamże).

Nic dziwnego, że tego rodzaju insynuacje, związane z przedstawianiem sprawy w świetle fałszywym, musiały wywołać protesty 
ze strony zwolenników esperanta. Protesty te, o ile wiem, trzymano w ogóle w tonie przyzwoitym ${ }^{1}$; tylko czasami były one za gorące, co zresztą nie dziwota. W każdym razie musze p. Appela wziąć w obronę przed Leo Belmontem („Wolne Słowo”, nr 110 i 111, str. 11-12). P. Appel jest nie tylko dobrym nauczycielem języka francuskiego, ale oprócz tego jest niepospolitym lingwistą, imponującym zarówno swoją wiedzą, jak i pomysłowością i zajmującym jedno z wybitnych miejsc w historii jezzykoznawstwa w Polsce.

Tym też smutniejsza, że człowiek tej miary zostaje opanowany przez nastrój katechizmowy i gorzkożalowy, że się daje porwać źle zrozumianej miłości Chrystusa i w tym stanie poniekąd niepoczytalnym rzuca szpetne oskarżenia pod adresem ludzi idei, ludzi bezinteresownych, których można obwiniać o marzycielstwo, o nieliczenie się z różnymi siłami wyższymi, ale nigdy o geszefciarstwo i o pracowanie na korzyść jednoczącego się „semityzmu”, występującego wrogo przeciwko „Aryjczykom”.

Zapomina p. Appel, że jednoczący się Semici nie potrzebują nowego języka sztucznego, gdyż wystarczyłby im ich „,̇argon”, że dziwnym byłoby jednoczenie Semitów za pomocą języka złożonego w znacznej części z pierwiastków pochodzenia romańskiego. P. Appel głuchym jest na wszelkie dowody i jeszcze w Odpowiedzi tymczasowej p. A. Grabowskiemu („Książka”, nr 12, str. 512) twierdzi, że wiekssość esperantystów werbuje sie spośród Żydów, a podobne twierdzenie jest uporczywym mijaniem się z prawdą.

Ośmielę się też zwrócić uwagę p. Appela, że słuszność idei języka sztucznego w ogóle, a esperanta w szczególności, uznają między wielu innymi tacy pierwszorzędni lingwiści, jak Schuchardt, Meillet, Jespersen..., których nie możemy zaliczać do „Semitów”, podobnie jak dalekimi od „semityzmu” są Forster, Ostwald, Couturat, Leau i wielu innych uczonych z najróżnorodniejszych specjalności. A chociaż Couturat, Leau, Ostwald, Jespersen, Beaufront itd. odstąpili od

1 P. m.in.: A. G r a b ow s k i, Wobronie jezyka esperanto. („Esperantysta Polski”, Warszawa 1910, Nov.-Dec., nr 11-12, str. 141-144; „Nowa Gazeta”, Warszawa, 1910, nr 559, 561, 540; „Książka” 1910, nr 12, str. 511-512) [przyp. BdeC]. 
esperanta pierwotnego i stworzyli nowy język sztuczny, język delegacji” czyli „ido”, to jednak oni sami uważają ten swój nowy język tylko za przeróbkę esperanta, tylko za esperanto uproszczone. Bez esperanta nie byłoby ida, a dwa te języki sztuczne różnią się między sobą mniej niż dwie pokrewne gwary w dziedzinie języków naturalnych.

Z drugiej strony zauważę, że p. Mutermilch, który zasłużył sobie na tak gorace uznanie ze strony p. Appela, nie jest chyba „Aryjczykiem”. Stąd wniosek, że dla niektórych ludzi „Żydem” jest ten, kto się z nimi nie zgadza i broni sprawy im niesympatycznej, a nie-Żydem ten, na kogo mogą się powoływać dla poparcia swych przekonań i przesądów. Natomiast dla mnie mieszanie esperanta z „żydowstwem” i „semityzmem”, a opozycji przeciw esperantu z „chrześcijaństwem” i „aryjskością” równa się strzelaniu kulą w płot.

Nareszcie zauważę, że prawdziwemu lingwiście, jako człowiekowi kierującemu się obiektywizmem naukowym, nie do twarzy jest mówić 0 ohydnym żargonie, a choćby tylko 0 żargonie. Prawdziwy lingwista powinien wiedzieć, że tak zwany żargon jest takim samym językiem, jak i wszelki inny. Prawdziwy lingwista bada żargon w jego stanie obecnym i w jego historii, a nie psuje sobie krwi na jego wspomnienie i nie rzuca na niego wyzwisk obelżywych. Niestety i p. Appel, lubo niepospolity uczony i myśliciel, uległ zarazie „antysemityzmu”, prawdopodobnie „postępowego”.

\section{Przykład 4.}

Najefektowniejszym przykładem nieprzepartego działania zarazy „antysemickiej” jest zapisanie się do cechu otwartych antysemitów „Myśliciela niepodległego”, czyli jednego z głównych „Wolnomyślicieli” polskich. Pod wpływem zadraśnień osobistych ukryte w głębi duszy wspomnienia działających w dzieciństwie „gorzkich żalów” nad Męką Pańską wychodzą na powierzchnię i stają się przyczyną groźnych wystąpień przeciwko winowajcom tej męki, „Żydom”. Okazuje się, że kiedy „wolnomyśliciel” polski przypomina sobie, że jest szlachcicem polskim, a więc sodalisem marianusem, upodabnia się tym samym do Radziwiłła Panie Kochanku, który bez żadnych skrupułów strzelał do Żydów jak do przepiórek. „Niepodlegle myślący” szlachcic polski ima się korda i woła „hajże na Żydów!”. Jest to fakt tak godny 
uwagi i widowisko tak rozczulające, że uważam za potrzebne poświęcić mu osobny rozdział.

\section{Przykład 5.}

Przykład to dla mnie niezupełnie jasny, a przynajmniej nienadający się do jasnego o nim mówienia. W artykułach wstępnych „Kuryera Porannego” uprawiano w ostatnich czasach „antysemityzm postępowy”. Artykułów pani I. Moszczeńskiej, delikatniej zredagowanych i nie tak otwarcie zaczepnych, nie tykam. Chciałbym za to zwrócić uwagę na wojowniczy ton innych artykułów, oczywiście redakcyjnych; ponieważ jednak artykułów tych nie podpisano żadnym nazwiskiem, więc nie mogę skonstatować, kto był ich autorem czy też autorami, a do stosowania metody wywiadowezej nie mam ani czasu, ani ochoty.

Wspomnę natomiast, że przed laty redaktorem krakowskiego „Głosu Narodu” był p. Kazimierz Ehrenberg, prowadzący stale pogromową krucjatę przeciwko Żydom. Kiedy dzięki Zoli i innym ludziom uczciwym i z odwagą cywilną rozpoczęto agitację w celu zmuszenia rządu francuskiego do ponownego rozpatrzenia sprawy Dreyfusa, p. Ehrenberg pisat:

Gdyby Dreyfusa jako szpiega powieszono, nie byłoby dziś tyle kłopotu, sprawa byłaby załatwiona merytorycznie, Europa nie byłaby dręczona wątpliwościami, a co najważniejsza i co wcale nie jest bagatelą, jednego Żyda byłoby mniej na świecie. („Głos Narodu” 1897, nr 289, z d. 19 grudnia. Art. Audaxa Uwagi).

Muszę pocieszyć p. Ehrenberga. Sąd wojenny rosyjski kazał powiesić Żyda Gluskera oskarżonego o zabójstwo, pomimo że świadkowie dowiedli jego alibi. Kiedy zaś znaleziono prawdziwych zabójców i ich również powieszono, i kiedy domagano się rewizji procesu, dla rehabilitacji niewinnie zamordowanego człowieka, dla zadosyćuczynienia jego rodzinie, a nareszcie dla wrócenia z katorgi również niewinnie skazanego mniemanego spólnika Gluskera, najwyższy sąd wojenny rosyjski stanął na stanowisku p. Ehrenberga: powieszono Żyda Gluskera, o jednego Żyda jest mniej na świecie, a to powinno nam najzupełniej wystarczyć. 
Ludziom wyrażającym pewne zdziwienie z powodu wielostronności niektórych publicystów przypomnę utalentowanego Szmoka z Journalisten Freitaga. Kiedy dziwiono się, że tak bez wahania przechodzi z jednych gazet do drugich o rozmaitszych kierunkach, odpowiedziat: Ich habe geschrieben rechts, ich habe geschrieben links, jetzt werde ich querüber schreiben ${ }^{1}$.

Okazuje się, że nie tylko „Żydzi” dziennikarze trzymają się podobnych „zasad”.

\section{Przykład 6, 7, 8...}

Mówiono mi, że na niektórych hotelach w New Yorku i innych miastach Ameryki Północnej widnieje napis: No Jews admitted (Żydom wstęp wzbroniony). Jest to całkiem logiczny wywód z pojęcia grzechu pierworodnego: Ponieważ Żydzi w Palestynie przed prawie 2000 lat umęczyli Chrystusa, więc ja, jako wierny wyznawca Chrystusa, nie chcę mieć nic do czynienia z ludźmi, których uważam za potomków zabójców. Że sam umęczony był etnograficznie Żydem, że jego ówcześni zwolennicy i wyznawcy byli także Żydami, to mnie to nic a nic nie obchodzi.

A może hotelarze zabraniający wstępu do swych hoteli Żydom kierują się przeczulonym powonieniem, tj. zmysłem antagonizmu czysto rasowego, tj. tym samym zmysłem, który każe przeznaczać dla Murzynów osobne wagony, oddzielone od innych wagonów. Jeżeli powonienie antysemitów jest aż tak dalece czułe, można im tego tylko powinszować.

Przypomnę jednak, że w niektórych miastach niemieckich można było, a kto wie, czy nawet i teraz nie można widzieć na mieszkaniach do najęcia napisów w rodzaju: Die Serben verbeten, Die Russen verbeten, Die Polen verbeten...2. Czy tu także działa zmysł powonienia?

$1 \quad$ Ich habe geschrieben rechts, ich habe geschrieben links, jetzt werde ich querüber schreiben (niem.) - Pisałem na prawo, pisałem na lewo, teraz będę pisał w poprzek.

2 Die Serben verbeten, Die Russen verbeten, Die Polen verbeten (niem.) - tu: nie dla Serbów, nie dla Rosjan, nie dla Polaków. 
To, co np. p. Appel pisze z powodu esperanta, daje prawo przypuszczać, że p. Appel czuje wstręt fizyczny do „Żydów”, a ten wstręt czysto fizyczny zasłania mu oczy, mąci myśl i każe wyrzucać z siebie oskarżenia, na niczym nieoparte.

Podobnie wielki patriota rosyjski, śp. A. L. Apuchtin mówił otwarcie, że czuje wstręt fizyczny do Polaków. Ciekawa rzecz, czy Apuchtin kierował się przy tym węchem, czy też jakim innym zmysłem wywiadowczym.

Ów decydujący w sprawach przeciwieństwa rasowego zmysł powonienia zawiódł biedną „donnę Klarę” Heinego. Wymyślając ciągle na ,przeklętych Żydów”, dopiero po fait accompli dowiedziała się, że jej wybraniec jest synem rabina Izraela z Saragossy.

Czy wolnomyśliciel może być antysemitą?

Niektórym osobom wyrażenie ,antysemityzm postępowy” wydaje się sprzecznością samą w sobie (contradictio in adiecto). Ja się z tym nie zgadzam. Jeżeli może być „paraliż postępowy”, dlaczego nie miałby być także „antysemityzm postępowy”? Przecież nawet reakcja postępuje.

W każdym jednak razie łudzi się p. Andrzej Niemojewski, przypuszczając, że wielkie wrażenie wywołane wystąpieniami „Myśli Niepodległej” i „Kuryera Porannego” przeciw Żydom zawdzięczają te pisma zebranemu przez nie materiałowi, dającemu możność stawiania aposterioryeznych oskarżeń przeciw Żydom. Weale nie. Wielkie wrażenie i rozgłos zawdzięczają owe pisma nie zebranemu materiałowi, którego wiarogodność może być po większej części zakwestionowana, ale tylko efektownej niespodziance, że w roli antysemitów wystąpiły pisma niby to postępowe i wolnomyślne a, jak się teraz okazało, zajmujące się pośrednio szczuciem i sekundujące poniekąd pogromoweom zawodowym.

Charakterystyka to z mojej strony ostra i bezwzględna. Jestem więc obowiązany szczegótowiej ją uzasadnić. Zajmę się też rozpatrze- 
niem, czy metody stosowane przez naszych „antysemitów postępowych” licują z „myśleniem niepodległym” i z „wolnomyślicielstwem”.

Jak ja sobie wyobrażam - oczywiście, moge sobie mylnie wyobrażać - prawdziwy wolnomyśliciel powinien być całkiem wolny od megalomanii, czyli od obłędu wielkości, nieomylności i nietykalności. A cóż widzimy w danym wypadku?

Oto za skromne i spokojne uwagi, wypowiedziane przezp. Huzarskiego w artykule Naganne metody (Wolne Słowo”, Warszawa, 1910, nr 98 i 99, str. 19-21), a skierowane po części także przeciw redaktorowi „Myśli Niepodległej”, chociaż bez wymienienia jego nazwiska, ten ostatni potraktował nie tylko p. Huzarskiego, ale także, i to w znacznie zwiększonej dawce, redaktora „Wolnego Słowa”, p. L. Belmonta (Leopolda Blumentala), w sposób lekceważący, pogardliwy i obelżywy, jak gdyby to były jakieś pachołki, którym należą się słuszne cięgi za porwanie się na olbrzyma polskiej „Wolnej myśli” czy też „Myśli wolnej” (p. „Myśl Niepodległa”, 1910, nr 147, str. 1332-1334). Jest to zwykły sposób polemiki, stosowany przez naszego „Myśliciela Niepodległego" do wszystkich tych, którzy ośmielą się zadrasnąć go osobiście.

„Wolny myśliciel”, tak jak ja go pojmuję, powinien starannie unikać wszelkich wyzwisk i wymysłów. A tymczasem od wyzwisk i wymysłów roją się artykuły polemiczne naszego „Myśliciela niepodległego”. Kto chce rozkoszować się ciętością pióra w wyrażeniach nieprzebierającego, niechaj odczyta w nr 153 „Myśli Niepodległej” artykuł naczelny Uwertura żydowska. Ciętość podobna zdobi zwykłych krzykaczy dziennikarskich, ale „wolnych myślicieli” szpeci i stawia ich „wolne myślicielstwo” pod znakiem zapytania.

Do najdelikatniejszych wyzwisk należy z lubością powtarzane lennik żydowski, stosowane do wszystkich tych, co sobie pozwalają wątpić o pożytku dla Polski „antysemityzmu postępowego”. Dla porównania przypomnę, że organy „iścierosyjskiej” prasy „patriotycznej” przezywają szabesgojami (synonim lennika żydowskiego) wszystkich tych, co nie nawołują do pogromów i do znęcania się nad Żydami.

„Wolnomyśliciel”, tak jak go pojmuję, powinien krytycznie rozpatrywać fakty i nie wypowiadać twierdzeń sprzecznych z łatwo 
dającym się sprawdzić istotnym stanem rzeczy. Tymczasem, czy to skutkiem zdenerwowania i wywołanego przez nie zaćmienia zdolności spostrzegawczej, czy też z jakichś innych powodów, nasz „Myśliciel niepodległy" wypowiada np. pod adresem Leo Belmonta insynuacje kłócące się z oczywistymi faktami („Myśl Niepodległa” nr 147, str. 1332-4). Zarzuca mu też bez zająknienia, że on, Leo Belmont, nie ośmiela się zakpić sobie z historii żydowskiej, a kpi z historii polskiej („Myśl Niepodl.” nr 148, str. 1387-8), oraz że Żydzi z p. Belmontem na czele nic nie zrobili dla wolnej myśli śród Żydów („MN” nr 147, str. 1333). Nie chcę podejrzewać p. Niemojewskiego o złą wiarę, ale w żaden sposób nie mogę sobie wytłumaczyé, dlaczego tak jaskrawo mija się on z prawdą faktyczną. Twierdzę zaś, że Leo Belmont w cytowanym przez p. N-go ustępie nie kpił sobie weale z historii polskiej, że p. N. wkłada ma w usta wyrazy i ich połączenia, których on wcale nie wypowiedział i nie wypisał, że Leo Belmont nie kpił wprawdzie z historii żydowskiej, ale za to wykazywał właściwą jej dzikość, okrucieństwo i nierozum tak nielitościwie, że ściągał na siebie gromy Żydów prawowiernych. Od samego p. Niemojewskiego słyszałem przed paru laty uznanie i pochwały dla Belmonta za to, że on jedyny spośród Żydów warszawskich wystąpił przeciwko przesądom i potwornościom związanym z żydowskością. A teraz miesza p. Niemojewski p. Belmonta z wszystkimi „Żydami” i oskarża ich w czambuł o to, że nic nie zrobili dla wolnej myśli wśród Żydów!

Dla p. Niemojewskiego „Wolne Słowo” Leo Belmonta jest wydawanym po polsku pismem żydowskim. Oczywiście tylko folblutom na -ski i -icz pozwala p. N. wydawać pisma polskie. Podobnie dla „patriotów” rosyjskich spod sztandarów doktora Dubrowina i Puryszkiewicza, nieboszczyka Kruszewana, Mienszykowa z „Nowego Wriemieni” itd. wszystkie pisma rosyjskie, nieuprawiające szczucia narodowości i wyznań, są pismami „żydowskimi”, „żydo-kadeckimi”, „szabesgojowskimi” itp.

To wietrzenie ,żydowszczyzny”, to kwalifikowanie pewnych pism postępowych jako pism żydowskich, pisanych po polsku zaślepia p. Niemojewskiego do tego stopnia, że każe mu czepiać się niektórych czysto polskich połączeń wyrazów i uważać je za płody udającej polskość żydowskości. Tak np. wydziwia p. N. nad tytułem „Nowa 
Gazeta” (zamiast „Gazeta Nowa”, zapominając o Nowym Swiecie, o Wielkiej Nocy, o Bożym Narodzeniu, o Najświętszej Pannie, o Swiętym Janie, Zielonych Swiatkach, o czarnym fraku, o biatych rękawiczkach itd. Robi też przytyki do Belmonta, że żąda on, oczywiście jako „Żyd”, by sie gramatyka polska do niego stosowata, a nie on do niej (,MN” nr 147, str. 1334).

„Wolnomyślicielowi”, tak jak ja go pojmuję, nie wypada chyba współubiegać się z brukowymi pisemkami humorystycznymi i dla ośmieszenia swych przeciwników (nawiasem mówiąc, wcale poprawnie władających językiem polskim), przedrzeźniać język polski w ustach żydowskich. A np. w nr 145 „Myśli Niepodległej” zdarzyło się to p. N-mu aż dwa razy. Wyrażenie Diamand, choć z naszych może zadowolnić tylko czytelnika z bardzo niewybrednym podniebieniem.

Stosowanej przez kierownika „Myśli Niepodległej” metody wywiadowczej mogłyby pozazdrościć najlepiej urządzone ajentury informacyjne. Dzięki tej metodzie posiada on dokładne dane osobiste 0 wszystkich swych przeciwnikach literackich i może korzystać z tych danych jako z pocisków w starciach polemicznych. Stosunki towarzyskie danego osobnika, jego koligacje, jego stan majątkowy, jego wiek, jego kwalifikacje naukowe, jego pochodzenie itd., jednym słowem cały „stan służby” jest na usługach „Myśli Niepodległej”. 0 osobnikach tak gruntownie zbadanych powiadają Włosi: conosco la vita, la morte ed $i$ miracoli (znam jego życie, śmieré i cuda). 0 ile taka metoda wywiadoweza jest do twarzy „wolnomyślicielowi”, to już inna kwestia.

„Myśliciel Niepodległy”, wojując z przeciwnikami, wytyka im ich młody wiek i stawia ich do kąta jako smarkaczów niemających prawa do zadzierania nosa i do rzucania się na starszych i zasłużonych. Zapomina on o dość znacznym zastępie ludzi, którzy w bardzo młodym wieku, bo niektórzy nie mając nawet jeszcze 20 lat, położyli niepożyte zasługi na polu nauki, sztuki, polityki, działalności społecznej itd. Zapomina też, że wszyscy byliśmy kiedyś młodzi, a jednak wielu z nas było tak nieskromnych i zuchwałych, że, nie bacząc na strofowania poważnych „myślicieli” (z wolno- i bez wolno-), pozwalali sobie zabierać głos w sprawach publicznych. Wiekiem męskim lub nawet podeszłym jako nie naszą zasługą, nie ma się co chlubić. 
Kiedy się czyta, że Huzarski jest „Żydem”, Warski jest „Żydem”, Kamieński jest „Żydem”; kiedy się dowiadujemy, że wszyscy przeciwnicy p. Niemojewskiego są to „żydki”, które się sprzysięgły na zgubę „wolnomyślicielstwa” polskiego, a wszystkie pisma polskie postępowe, niezgadzające się z naszym „Myślicielem Niepodległym” są wydawanymi po polsku pismami żydowskimi, ogarnia nas lęk przed „niebezpieczeństwem żydowskim” i zaczynamy rozumieć p. Mienszykowa z „Nowego Wremieni” oraz innych „patriotów” rosyjskich, węszących wszędzie „Żydów” i ich zgubną intrygę. Z drugiej strony, jak obrońcy czystości rosyjskiej korzystają z usług p. Gurlanda, redaktora „Rossii”, oraz innych Żydów „iście rosyjskich”, tak znowu obrońcy czystości aryjsko-polskiej powołują się w razie potrzeby na Unszlichta, Muttermilcha, Haeckera i innych.

Wprawdzie na swoje usprawiedliwienie mógłby p. Niemojewski powołać się na Burcewa, który również założył w Paryżu ajenturę wywiadowczą i tropi różnych zbrodniarzy i najmitów spisku kontrrewolucyjnego. Zachodzi tu jednak mała różnica. Burcew demaskuje prowokatorów i zbrodniarzy, którzy położyli zasługi osobiste. Burcew nie szczuje na całe gromady ludzkie, nie wytyka ludziom „żydowstwa” lub „aryjstwa” czy też „chrześcijaństwa” jako grzechu pierworodnego wołającego o pomstę w postaci czegos, co idzie i może przyjdzie wcześniej, niż się spodziewacie. Burcew nie potęguje uczuć nienawiści do ludzi i nie skierowuje ich na podstawie antagonizmów rasowych i wyznaniowych przeciw całym plemionom, gromadom i stadom ludzkim. Przeciwnie, swymi odkryciami wpływa na opamiętanie fanatyków rewolucji, pokazując im, że ich wspótpartyjnicy byli narzędziami w rękach Azefów i innych prowokatorów działających z ramienia spisku rządowego. Czasami Burcew myli się i musi odwoływać oskarżenia. Zdarzają się też wypadki nadużycia imienia i metody Burcewa przez zemstę osobistą. No, ale wszystko to jest nieuniknione przy tego rodzaju ajenturze. W każdym razie Burcew działa nie jako „,wolnomyśliciel”, ale otwarcie jako kierownik biura wywiadowczego.

W związku z „wywiadowczością” „Myśliciel Niepodległy” oburza się na używanie pseudonimów. Tonem, jakim niegdyś dziedzic przemawiał do pachciarza, łaje Leo Belmonta, oświadczając mu, że może nareszcie warto by skończyć z ta komedia pseudonimowa („MN” 
nr 147, str. 1332). Tak postawiona kwestia pseudonimowa staje się po prostu kwestią paszportową, a kwestia paszportowa może interesować policję w ogóle, a policję wywiadowczą w szczególności. Zabranianie pseudonimów jest czymś niesłychanym ze stanowiska myśli niepodległej, uznającej godność osobistą i prawo każdej jednostki do rozporządzania sobą i objawami zewnętrznymi swego uspołecznienia, 0 ile to nie narusza praw innych jednostek.

Głosząc, że można przyjać imie Stanistawa, a dusze zachować Szai („MN” nr 147, str. 1335), niech p. Niemojewski przypomni sobie gradonaczalnikow (oberpolicmajstrów) petersburskich, Gressera i von Wahla którzy zabraniali Żydom na szyldach nad sklepami nie tylko zmieniać imiona, ale nawet choćby tylko ograniczać się inicjałami imienia, gdy tymczasem do kupców „chrześcijan” zakaz ten wcale się nie stosował. Chrześcijanin mógł użyć pseudonimu, wypisać samo tylko imię lub nazwisko itp., Żyd zaś musiał umieścić na szyldzie całe swoje imię, otczestwo i nazwisko, np. Wolf Ickowicz Muttermilch, Szloma Srulewicz Berlinerblau itp. Nie tajono się z tym wcale, że ta dokładność paszportowa na szyldach miała na celu wskazywanie palcem tych sklepów, które w razie pogromu powinny ulec „operacji patriotycznej”.

Tylko pomieszaniem pojęć, od którego powinno by być chyba wolne nie tylko „wolnomyślicielstwo”, czyli „myślenie niepodległe”, ale w ogóle wszelkie myślenie trzeźwe i umiejętne, można objaśnić ryczałtowe traktowanie wszystkich „Żydów” jako czegoś jednolitego, jako czegoś mającego duszę zbiorową z jednakowymi we wszystkich głowach wierzeniami, z jednakowymi przekonaniami, pragnieniami, potrzebami itd. Na tle tego ogólnego podkładu staje się zrozumiałym dziwne żądanie p. Izy Moszczeńskiej, ażeby przy układach z „Polakami” wszyscy Żydzi, niby stado gęsi lub baranów, wypowiadali unisono jednakowe żądania. Jest to przecież przykuwanie wszystkich jednostek podejrzanych o „żydowskość” do obowiązkowego wyznania czy też choćby tylko do pochodzenia, jest to zaprzeczanie praw indywidualności. Czyżby Żyd dlatego tylko, że jest Żydem, nie miał prawa być osobnikiem ludzkim, myśleć indywidualnie i niezależnie od stada? Niechże pani Moszczeńska spróbuje otrzymać jednakowe żądania od Żyda-Polaka i od Żyda-litwaka, od pp. Dicksteina, Nusbauma, Na- 
tansona, Kraushara itd. z jednej strony, a od pp. Żabotinskiego, Jackana, itd. z drugiej strony.

P. Niemojewski zaś wywleka rzekome sprawki kryminalne pojedynczych młodzieńców, „Kradków” i innych (może nawet nie-Żydów) i kuje z tego broń przeciwko wszystkim „Żydom”.

Jeżeli p. Haecker sekunduje p. Niemojewskiemn i dostarcza mu „materiałów” bez żadnych zastrzeżeń, to chyba jedynie dlatego, że chce upiec pieczeń partyjną przy tym ogniu o podejrzanym blasku. Nie chce jak gdyby rozumieć, że swymi rewelacjami bez zastrzeżeń pomaga p. N-mu do szczucia na wszystkich Żydów. Oświadczenie Polonus sum et nihil poloni a me alienum esse puto i obietnica, że w razie walki o niepodległość Polski przypasze się karabelę, nie uwalnia jeszcze od ostrożnego i oględnego traktowania podobnych spraw, tj. od napisania p. N-mu: „Pan N.N. jest wprawdzie złodziejem, ale to nie daje panu jeszcze prawa do urządzania hecy antysemickiej”.

Zanim przejdę do ostatecznych wniosków, pozwolę sobie uszezknąc kilka wonnych kwiatków na niwie „antysemityzmu postępowego".

Żydzi mieli u postępowców doskonałą markę. Niestety, w czasie rewolucji zaczęły pod tę markę podszywać się różne jednostki, które, chyląc się w stronę demokracji postępowej, tylko cel osobisty miały na wzgle-dzie... („MN” nr 146, str. 1253, art. Demokratyzm).

Przodkowie tej damy szynkowali wódkę ludowi polskiemu. Róża Luksemburg już wódki nie szynkuje, ale to, co daje ludowi do wypicia w postaci artykutów i broszur, posiada wszystkie cechy literackiej okowity. (tamże, nr 1265, art. Zdeklasowani).

Panów Radków i Truskierów, usiłujących proceder faktorów, w którym niezaprzeczenie posiedli wyćwiczenie rasowe i historyczne, przenieść w dziedziny stosunków ideowych i szynkować na łamach swych świstków jad duchowego obłędu, jak niegdyś ojcowie ich szynkowali trucizną fizycznego upodlenia. (W. Rzymowski, Zdemaskowani, „Prawda” 1910, nr 35; „Myśl Niepodległa” nr 145, str. 1232, art. Echa w prasie). 
Nieprzeparty rozwój świadomości klasowej i narodowej wypiera nieubłaganie tę literacką Targowicę z naszych mas robotniczych, do których się chyłkiem, zdradziecko zakradła, aby dla antypolskich szwindlów drobnomieszczańskiego nacjonalizmu żydowskiego wyzyskać siłę polityczną proletariatu polskiego przez stałe podjudzanie go przeciwko własnej ojczyźnie. (Julian Unszlicht, „Myśl Niepodległa” nr 147, str. 1330).

Ów „Henryk S. Kamieński” (mylnie brany przez Pana za Polaka) jest jednym z tych podłych żydków, który dla tym skuteczniejszego zohydzenia i oplwania ideałów i dążności polskich, przywłaszcza sobie pseudonim polski. (tamże).

Insynuujemy też, że „rewolwerowcy” socjaldemokratyczni są ajentami kapitalistów, lichwiarzy i zdzierców żydowskich, a „Żydzi” tylko po to wchodzili do komitetów rozmaitych partii, ażeby popierać swych współwyznawców przeciw ich konkurentom chrześcijanom. Klasyczne są pod tym względem odkrycia zdobiące artykuł Uwertura żydowska w nr 153 „Myśli Niepodległej”, str. 1585-1600. Oto wydrukowano tam m.in., na str. 1595-6, wyjątki z listu jednego z czytelników, który się podpisał S. Frankiewicz, wyjątki, zawierające cały szereg ciężkich oskarżeń „Żydów” o gnębienie i mordowanie chrześcijan w interesie innych „Żydów”. Ów tajemniczy p. S. Frankiewicz twierdzi:

Znam fakty, kiedy Żydzi w porachunkach z chrześcijanami uciekali się do swych współplemieńców uczestniczących w „komitecie” i od nich uzyskiwali wyroki. Stwierdzam publicznie fakt, że pewien Żyd w jednym z miasteczek, mając porachunki osobiste z chrześcijaninem i czując się pokrzywdzonym o 2 ruble, uzyskał od „komitetu”, w którym działali sami Żydzi, wyrok. Ale jaki wyrok? Wyrok... śmierci! Dla wykonania tego wyroku wystani byli dwaj litwacy z brauningami... Znam fakt, że gdy chrześcijanin w pewnej okolicy zakupił las na wyrąb, Żydzi handlujący lasami uzyskali wyrok od „komitetu”, aby materialnie zrujnować „goja” i bojówka osądzonemu konfiskowała pieniądze, truła konie, podpalała las, dopóki niefortunny handlarz nie odstąpił lasu Żydom za liche pieniądze. Znam fakt znowu z innej okolicy, gdzie Żydzi, posądzając chrześcijanina- 
inteligenta 0 uświadamianie dziewczyny żydowskiej w kwestiach religijnych, uzyskali od „komitetu” wyrok na posądzonego i wyrok ten był wykonany (!)...

Ale dosyé tych „faktów”. Starczą mi one do twierdzenia, że jegomość przytaczający podobne „fakty” bez wymienienia nazwisk i miejscowości, bez przeprowadzenia starannego dochodzenia albo przynajmniej bez powołania się na wyroki sądowe (boć przecie niektóre z tych „faktów” równają się zwykłym zbrodniom, które nie mogły chyba ujść bezkarnie); otóż jegomość przytaczający gołosłownie podobne fakty jest oszczercą i szkodnikiem społecznym, podbechtującym do odwetu zbrodniczego; redaktor zaś, publikujący bez zastrzeżeń podobne listy od „czytelników”, uprawia politykę pogromową.

Również gołosłowne są twierdzenia drugiego współpracownika „Myśli Niepodległej”, oczywiście czystego „aryjczyka”, p. Juliana Unszlichta, w artykule Pogromy i pogromcy („MN” nr 150, str. 14691472). M.in.:

Twierdzę kategorycznie, iż w okresie rewolucji Żydzi organizowali pogromy Polaków w Królestwie. Na pozór słowa te wydadzą się paradoksem, są one jednak absolutnie zgodne z rzeczywistością.

Działa mianowicie w naszym kraju sławetna organizacja nacjonalistyczna żydowska, biorąca rekord na punkcie polakożerczości, którą maskuje frazesem „nieprzejednanego marksizmu”, Socjaldemokracja Królestwa Polskiego i Litwy, czyli tzw. socjal-litwactwo. Otóż ta organizacja, będąc awangardą walczącego z Polską nacjonalizmu żydowskiego, nie zadawalniała się zwyczajnym szkalowaniem sprawy polskiej, lecz wprost organizowała pogromy Polaków. Tak było 1 Maja 1905, kiedy wszystkie organizacje uchwaliły nie urządzać manifestacji z łatwo zrozumiałych względów; owa zaś umyślnie ją organizowała, z góry wiedząc, czym się to skończy. I naturalnie wzywała na nią polski lud roboczy. Tak było w krwawych dniach czerwcowych w Łodzi tegoż roku, kiedy znów ta sama żydowska organizacja pchała bezbronne masy polskie do kroków szalonych, naturalnie umywając potem ręce...

Dalej ta sama organizacja żydowska nawoływała do ciągłych strejków masy polskie, nie tylko przez to dezorganizując bezmyślnie całe 
życie ekonomiczne kraju, lecz, co gorsza, głodząc i wyczerpując lud polski...

Następnie niebezpieczeństwo pogromów Polaków przez Żydów jeszcze nie minęło.

Oto jak ostatni (VI) zjazd tej „partii”, wypowiedziawszy się między innymi przeciwko kooperatywom podkopującym byt drobnych kramarzy żydowskich, określa najbliższe owej partii zadania: Trzeba wywoływać akcję masową i wystąpienia czynne proletariatu w formie demonstracji, strejków powszechnych lub częściowych, mityngów itp. wszędzie, gdzie to będzie możliwe i celowe ze względu na chwilowe położenie...

I kogóż to będzie posyłać na rzeź ta żydowska organizacja? Naturalnie Polaków. Słowem, jest to formalna zapowiedź nowych pogromów Polaków, wypchniętych przez Żydów korzystających z chwilowego nastroju podnieconego w masach polskich.

I trzeba zaiste podziwiać czelność nacjonalistów żydowskich, wyjących „pogrom” z powodu najłagodniejszej krytyki ich postępowania, wtedy, kiedy może ta lub inna ich grupa zdradziecko gotuje pogrom ludu polskiego!

Piekielną jest doprawdy etyka Szulchan-Aruchu¹.

A jaką jest etyka p. J. Unszlichta i jego współideowca, warszawskiego „Myśliciela Niepodległego”? Dopóki panowie ci nie zbadali źródłowo całej tej sprawy, dopóki nie udowodnili w sposób nieulegający najmniejszej wątpliwości wymienionych przez nich pobudek postępowania kierowników partii SDKPiL, dopóki nie wykazali czarno na białym, że partią tą dowodzili sami Żydzi, szulchan-aruchiści i „antygoiści”, dopóki podobne ciężkie i okropne oskarżenia będą wypowiadali gołosłownie, ja ze swej strony mam prawo twierdzić, że pracują oni nad rozdmuchiwaniem zarzewia nienawiści stadowej i nad podbechtywaniem do pogromów.

Metodę prokuratorską naszych „myślicieli niepodległych” można stosować we wszystkich podobnych wypadkach. W r. 1863 „rząd narodowy” „wiedział z góry”, jak się skończy inscenizowane przezeń powstanie, a pomimo to pchał do niego naród polski i „urządzał po-

1 Szulchan Aruch - kodeks tradycyjnych praw i praktyk żydowskich, spisany w 1564 r. przez I. Karo. 
grom narodowi polskiemu”. Czyż „rząd narodowy” składał się z „Żydów” i kierował się etyką Szulchan-Aruchu? W latach „rewolucji” (1905-1906) różne matadory od „patriotyzmu” i od socjalizmu narodowego (PPS) posyłały na manifestacje krwawe (a więc na rzeź), młodzież warszawską różnoplemienną i różnowyznaniową (nie tylko „polską”, ale także „żydowską” i nawet rosyjską); czyż panów tych będziem również oskarżać 0 „urządzanie pogromów” i 0 stosowanie etyki Szulchan-Aruchu? Co więcej, w ostatnich czasach wielcy politycy polscy, siedzący sobie w bezpiecznych kryjówkach poza granicami państwa rosyjskiego, przygotowują jakoby powstanie, organizują „armię polską”, mającą wywojować niepodległość państwową Polski. Panowie ci „wiedzą chyba z góry”, jak się to skończy, a jednak... Czyż są to także „Żydzi”, urządzający z piekielnym wyrachowaniem pogrom „Polaków”? Wiem na pewno, że w liczbie tych organizatorów kampanii irredentystycznej są najczystszej krwi „aryjezycy” i że działają oni wprawdzie pod wpływem obłędu i zaślepienia, ale z dobrą wiarą ${ }^{1}$.

Pan Niemojewski głosi wytrwale krucjatę przeciw zdradzieckim żmijom „żydowskim”. Jeszcze w ostatnich czasach twierdzi bez za-

1 „Krytyka” nie jest organem partii żadnej, pole dla siebie mają tu przedstawiciele różnych odłamów lewicy polskiej. W szczególności czcigodny prof. Baudouin de Courtenay jako indywidualista nie może być podporządkowany żadnej obcej sobie ideologii i przemawia li od siebie - ze swobodą, wobec której dalecy jesteśmy od roli cenzorskiej. W danym jednak momencie musimy dać jedno zastrzeżenie. Jesteśmy jak owi politycy, o których Szan. Autor mówi z pewną ironią, przekonania, że do niepodległości Polski droga wiedzie przez walkę i że w obecnych warunkach Europy każde społeczeństwo musi i powinno mieć swoje pogotowie wojskowe. Nikt nie jest jednak dziś tak lekkomyślnym, by wywołać grożące ,jakoby” powstanie. A gdyby kiedyśs były sprzyjające temu warunki, wówezas pokaże się, czy organizatorzy będą siedzieli „w bezpiecznych kryjówkach”. Czy walka dla wąskiego interesu egoistycznego może byé zestawiona z walką o niepodległość całego narodu i czy ta ostatnia jest „obłędem” zostawiamy uznaniu czytelnika. Redakcja. [tak oraz skrótem Red. sygnowane są w pierwodruku przypisy pochodzące od redakcji „Krytyki” - M.S.]. 
jąknienia, iż robotnicy-chrześcijanie z bojówek esdeckich ${ }^{1}$ pod wodzą „litwaków” gromili monopole, aby Żydzi mogli robić lepsze interesy na handlu wódką, wysadzali w powietrze mosty po to, by Żydzi-kramikarze mogli drożej sprzedawać prowianty. Może raczy sobie przypomnieć p. N., że urządzeniem „krwawej środy” 15 sierpnia 1906 r. oraz kilkudziesięciu napadów na monopole chełpili się członkowie partii PPS jako czynem wielce rozumnym i patriotycznym² ${ }^{2}$ A więc PPS, nie zaś SDKPiL.

Czytając oburzenie patriotyczne p. N-go wylane w zdaniu Wolno żydom po pismach niemieckich przedstawiać Polske jako zgnilizne (Uwertura żydowska w „MN”, nr 153, str. 1588), przypominamy sobie żargon zwykłej w takich razach nienawiści stadowej, żargon, właściwy zdaniom: Żydzi umeczyli Chrystusa, Polacy najechali Moskwe i osadzili w niej samozwańca, chrześcijanie urzadzali pogromy itp. Prawdziwemu wolnomyślicielowi tak wyrażać się nie wolno. To jest żargon podszczuwaczów i ludzi mieszających pojęcia czy to umyślnie, czy też dla braku zmysłu krytyeznego. Prawdziwy wolnomyśliciel powinien pamiętać 0 fatalnym wpływie wyobrażeń językowych. Język fałszuje naszą myśl i stwarza nieskończoną ilość mitów wyrazowych.

Obwinianie wszystkich Żydów o urządzanie „pogromów” nie jest wcale walką z Szulchan-Aruchem i Talmudem, podobnie jak obwinianie wszystkich chrześcijan czy też wszystkich katolików o coś podobnego nie byłoby walką z katechizmem i z całą literaturą klerykalną, napawającą dusze swych wiernych jadem nienawiści międzywyznaniowej.

Ciągle powinniśmy sobie zdawać sprawę, o jakich to „Żydach” mówimy. Czy na takie ryczałtowe sądy skazujemy wszystkich „Żydów” za ich pochodzenie czy też za ich wierzenia? Czy bierzemy Żydów narodowo czy też wyznaniowo? Czy potępiamy ich za ich ubiór? A może

1 Mowa o Socjaldemokracji Królestwa Polskiego i Litwy.

2 Mowa 0 akcji zamachów na agentów policji, żandarmów i policjantów, którą Organizacja Bojowa PPS przeprowadziła w 18 miejscowościach zaboru rosyjskiego 15 VIII 1906 r. 
za wymawianie, podobnie jak to miało miejsce w zastosowaniu do Francuzów, w czasie pogromu zwanego nieszporami sycylijskimi? ${ }^{1}$

Nasz „Myśliciel Niepodległy” staje się niekiedy natchnionym prorokiem i wieszczy. W nrze 147 „Myśli Niepodległej” w artykule Do Żydów (str. 1314-1324) zwraca się on do Żydów z groźnymi przestrogami i ponurymi groźbami; kończy zaś ten swój artykuł następującą apostrofą:

Nacjonalizm żydowski, strojący się niekiedy w piórka „marksizmu”, umieszcza po jednej stronie żargon, Szulchan-Aruch, nawet specjalny sejm żydowski - a po drugiej stronie „trupa” Polski, o którego już nikt dbać nie ma...

No, obyście tylko nie przekonali się kiedy na własnej skórze, jak ten TRUP potrafi być ŻYWYM.

Nie jest nikt z nas Pawłem ani świętym, ale zyskaliśmy prawo moralne zwrócenia się do was jego słowami: „A czyńcie kroki proste nogami waszymi”, albowiem uczyniliście istotnie wiele kroków nieprostych i trwóżcie się, że co ma przyjść, przyjdzie i nie omieszka”, a to „coś” idzie już nie tylko prostymi, ale doprawdy także wielkimi krokami.

Cóż to takiego idzie, panie Niemojewski? Chyba tylko pogrom albo przynajmniej pogromik.

Styl mglisty, „apokaliptyczny”, grożący w sposób nieokreślony działa jak para rozdymająca i rozsadzająca kocioł: pozwala się domyślać wszystkiego i nawet bez zbyt bujnej fantazji przede wszystkiem pogromów.

Pod proroctwem p. Niemojewskiego mógłby się podpisać nie tylko śp. Jan Jeleński, ale także b. redaktor krakowskiego „Głosu Narodu”, p. Kazimierz Ehrenberg, oraz śp. Kruszewan, Puryszkiewicz, Markow 2-gi i wszyscy inni urządzacze pogromów.

I istotnie tym samym stylem mglistym i proroczym, zapowiadającym coś, co idzie wielkimi krokami i wyglądającym niekiedy prawie jak dosłowny przekład z „Myśli Niepodległej”, zaczęły przema-

1 Mowa o powstaniu przeciwko panowaniu francuskiemu na Sycylii, które miało miejsce w 1282 r., a zaczęło się w Palermo od rzezi Francuzów. 
wiać w ostatnich czasach „Swiet”, „Kołokoł”, „Ziemszezina” i inne pisma pogromowe rosyjskie.

Wszelki wyraz ciemny, bez jasno określonej i odgraniczonej treści, w rodzaju ateusz, arianin, socynianin, luter, goj, giaur, żyd itp., działa na tłumy bardzo silnie, podnieca wyobraźnię w sposób nieuchwytny, wywołuje nastrój krwiożerczy i... wzywa do „czynu”, który idzie wielkimi krokami.

Pamiętam z czasów mego dzieciństwa, jakie to silne wrażenie sprawiło na mnie tradycyjne opowiadanie, że „husyci” przebili strzałą twarz Matki Boskiej Częstochowskiej. Przy tym mieszano czeskich „husytów” z „chasydami”, tj. z prawowiernymi Żydami. A chociaż ja sam od najweześniejszego dzieciństwa nie miałem skłonności do nienawiści międzywyznaniowej i międzynarodowej, to jednak wobec takiego bezeceństwa oburzałem się, a to moje oburzanie się szło oczywiście na rachunek „Żydów”. Wprawdzie legendarni „husyci” to tylko część wszystkich „husytów”, czyli „,chasydów”, a „chasydzi” to tylko część Żydów; no ale w takich razach częściej niż w innych bierze się pars pro toto.

Kiedy się ciągle szczuje Żydzi!, Żydzi!, kiedy się ciągle podkreśla jaskrawe punkty przestępstw żydowskich z usunięciem na odległy plan szarej masy zwykłych, nie „zbrodniczych” Żydów, wtedy tylko wyjątkowo krytyezne umysły mogą się połapać w tym chaosie pojęć, a w zwykłych głowach działa wszechwładnie logika i psychologia Herodowa: niechaj giną całe stada ludzkie, byleby tylko zginął w ich liczbie winowajea; a jeżeli nie sam winowajea, to przynajmniej jaki jego potomek. Ta rozszerzona logika i psychologia Herodowa i starotestamentowa, karząca potomków za winy przodków, była właściwa owemu władcy wschodnioeuropejskiemu, co to na memoriale o Żydach napisał własnoręcznie: wszystko to bardzo pięknie, ale dlaczego oni Chrystusa zabili?

Ryczałtowe napaści i wzywanie do usuwania i tępienia „Żydów”, zarówno jak ryczałtowa nienawiśé do „gojów”, jest dalszym ciągiem owego ryczałtowego tępienia przez Żydów starotestamentowych innych ludów, nieobrzezanych i nieuznających Jehowy. Jest to czysta „żydowszczyzna” wypływająca z zapatrywań wyznaniowych w ogóle, a starotestamentowych w szczególności. 
Nasi „myśliciele niepodlegli” twierdzą, że Żydzi urzadzali pogromy Polaków, a twierdząc to, kłamią. Przy tym zapominają, że przecież „Żydów” także wieszano i mordowano całymi gromadami. Zapominają, że gorliwy chrześcijanin, podpułkownik dragonów Tichanowskij, urządził w Siedlcach polowanie pogromowe na Żydów, za co „antysemici postępowi” powinni mu być wdzięczni. Zapominają, że w Lublinie rozstrzelano bez sądu z rozkazu generał-gubernatora kilkudziesięciu chłopców poniżej lat 20, o ile wiem, samych prawie Żydów. Pamiętają, że prowokator Azef jest Żydem, ale zapominają po pierwsze, iż zastępy prowokatorów rekrutowały się i rekrutują, się w znacznej ilości z „chrześcijan”, po wtóre, że ten sam Azef posyłał na szubienicę nie tylko „chrześcijan”, ale także „Żydów”. Zapominają, że nie tylko „chrześcijanie”, ale także „Żydzi” dali się ogarniać szałowi „rewolucyjnemu”, rzucali bomby i szli pod kule albo na szubienicę. Dość tu wspomnieć Szulmana, co na ulicy Świętokrzyskiej w Warszawie rzucił bombę w komisarza policji Konstantinowa, a potem sam został zastrzelony przez policjantów. Pamiętają, że Żydzi zamordowali Chrystusa, ale zapominają, że sam Chrystus był w owe czasy tylko „Żydem”. Tak samo inni mogą tylko pamiętać, że „chrześcijanie” urządzają pogromy i wieszają, zapominając jednocześnie, że wieszanymi bywają także „chrześcijanie”.

Nasz „myśliciel niepodległy” odgradza się starannie od Żydów. Powiada, że polska myśl wolna stuży polskiej sprawie $i$ niczemu wiecej („MN”, nr 147, str. 1321, art. Do Żydów), że każdy powinien być krytykiem fanatyzmu tylko swego wyznania. A więc wara, Żydzie, od krytykowania katolicyzmu. Ale zarówno też wara, goju, od krytykowania żydowstwa.

Ale jakież to jest to swoje wyznanie? Przecież dopóki się ma swoje wyznanie, dopóki się jest np. „katolikiem”, jak oczywiście p. Andrzej Niemojewski, dopóty nie wolno napadać na katolicyzm. W każdym razie bardzo mi jest przyjemnie skonstatować, że p. Niemojewski jest katolikiem, uważa bowiem katolicyzm za swoje wyznanie.

Otóż w ogóle pozwolę sobie zauważyć, że dość często tak zwane „wolnomyślicielstwo”, choćby nawet krzyczące i rzucające się, bywa mocno podejrzane co do swej szczerości. Również dziwnie wygląda- 
ją „wolni myśliciele”, domagający się koniecznie pogrzebu religijnego dla siebie i dla swych bliskich, jak również „wolni myśliciele” Zydzi, dający obrzezywać swych synów i zachowujący obrzędy „swego” wyznania. Taki brak odwagi wcielania w życie swych rzekomych przekonań jest obłudą i konwenansem demoralizującym.

Według mnie, „wolnomyślicielstwo polskie”, tj. wolnomyślicielstwo ze specyficznym zapachem polskim, jest po prostu nonsensem. Można jedynie mówić 0 „wolnomyślicielstwie w Polsce”, 0 „wolnomyślicielstwie między Polakami”, tj. w otoczeniu, w którym idee wolnomyślne rozprzestrzeniają się za pomocą języka polskiego. Wolnomyślicielstwo jest $\mathrm{w}$ swej podstawie ideowej jedno i jedyne dla całego świata ludzkiego i nie różniczkuje się według narodowości.

Wolnomyślicielstwo prawdziwe jest skrępowane pewnymi wymaganiami logiki i etyki, chyba że za „wolnomyślicielstwo” będziemy uważali wolność wypisywania i wygadywania wszystkiego tego, co ślina do ust przyniesie. Ale wtedy „wolnomyślicielstwo” staje się po prostu wyuzdaniem myśli bez oglądania się na sprawiane przez to spustoszenia.

Wystąpienia „antysemitów postępowych” i „wolnomyślicieli”, „myślących niepodległe”, tj. wydających sądy ryczałtowe o Żydach i grożących im pogromami, dyskredytują postęp w oczach narodu i własnymi rękami niszczą skutki swej dotychezasowej działalności.

Zresztą różne wyrazy przybierają w różnych czasach, w różnych miejscach i w różnych głowach jak najrozmaitsze znaczenie. Dobre staje się ztym, ciemne jasnym, haniebne zaszczytnym itd. Takiemu losowi ulegają zwłaszcza hasła i terminy polityczne: postepowość, zachowawczość, demokracja, republikanizm itd. Wobec tego i p. S. Auerbach, a za nim p. Niemojewski mają prawo dać następujące określenie: być demokrata polskim znaczy być wrogiem żydowskości (konglomeratu mozaizmu i semityzmu), znaczy być antysemita („MN”, nr 150, str. 1463, art. Antysemityzm jako walka o kulture).

A ja pozwolę to sobie uzupełnić: „być demokratą polskim znaczy być demokratą narodowym".

1 A my pozwolimy sobie „uzupełnić” ten aforyzm: Być demokratą narodowym znaczy być demokrato-narodowcem, nie zaś nacjonalistą. Red. 
Wobec takiego pojmowania demokratyzmu niech nas nie dziwi mocno arystokratyczne, przypominające Rozbitków Blizińskiego wyrażenie p. N-go: nieraz np. doktor filozofii tak nisko upadt, że zacząt występować w cyrku („MN”, nr 147, str. 1334). Czysto szlachecki i katolicki pogląd na „komediantów”, „linoskoków” i „skoczków”!

To, com dotychezas zebrał i oświecił, daje mi chyba prawo do następującego wniosku:

Człowiek, który występuje publicznie tak, jak p. Andrzej Niemojewski w ostatnich czasach, może byé wszystkim, czym mu się podoba: może być zasłużonym patriotą i pogromeą wrogów ojczyzny, może być „człowiekiem prawdziwie polskim”, może być krytykiem i pogromcą zarówno katolicyzmu, jak i żydowstwa, może być autorem obszernych i cennych dzieł oraz całej masy artykułów wojowniczych - tak, istotnie, może być on tym wszystkim, ale nie jest i nie może być wolnomyślicielem.

Zdawało się dawniej, że p. Niemojewski jest zdolny do prawdziwego wolnomyślicielstwa. Może są to periodyczne przypływy i odpływy to jednej, to drugiej fali. Może objaśnia się to możliwością, dwuosobowości, którą z takim talentem przedstawit, jeśli się nie mylę, Stevenson w swej opowieści 0 dwóch Anglikach, będących właściwie tylko dwiema postaciami tego samego fizycznie człowieka.

A może ostatnie występy p. Niemojewskiego i innych ,antysemitów postępowych" są w związku z ogólną reakcją nie tyle polityczną, ile umysłową. Przecież obok przypływu i odpływu morza wolno nam przyjąc także przypływ i odpływ w różnych stadiach i stopniach natężenia myśli ludzkiej.

Wiem aż nadto dobrze, co mię czeka za porwanie się na nieomylnych „myślicieli niepodległych”. Zostanę co najmniej zaliczony do „lenników żydowskich”, podobnie jak „patrioci” rosyjscy już od dawna zaliczyli mię do „szabesgojów”.

Na szczęście jestem otrzaskany z podobnymi charakterystykami i weale mnie one nie wzruszają.

Jeszcze w młodych latach moi „przyjaciele” warszawscy opowiadali, że jeździłem do Pragi czeskiej po to, ażeby tam propagować alfabet rosyjski, za co Czesi mieli mi urządzić kocią muzykę. A było to zaraz po wydrukowaniu przeze mnie przekładu polskiego broszu- 
ry Purkyniego ${ }^{1}$, polecającej wszystkim Słowianom alfabet łaciński, za co spotkała mię nagana ze strony warszawskich rusyfikatorów $\mathrm{z}$ urzędu.

Śp. Ludwik Rzepecki w r. 1873 zachwycał się moją odwagą wystąpienia przeciw alfabetowi „wszechsłowiańskiemu” (tj. rosyjskiemu) Hilferdinga, a w r. 1886, czując do mnie urazę osobistą, głosił w wydawanej przez siebie „Warcie”, że ja propagowałem ów alfabet wszechstowianski Niemca rosyjskiego Hilferdinga?2.

Za wskazanie na szkodę moralną od kłamstwa i oszustwa zwyczajowego, zwanego „fałszywą fasją”, a uważanego w Galicji za cnotę narodową ${ }^{3}$, panowie hrabia Tarnowski, M. Bobrzyński, biskup Puzyna, Głąbiński, wraz z całą falangą „patriotów” zarówno z obozu „konserwatywnego”, jak i , ,iberalnego”, ogłosili mię za wroga narodu polskiego, za jednostkę szkodliwą i wyrzucili mię z ck Uniwersytetu Jagiellońskiego. Przy tej sposobności śp. hr. Wojciech Dzieduszycki nazwał mię w parlamencie austriackim „ptakiem, co własne gniazdo kala”.

Jednocześnie p. Kazimierz Ehrenberg głosił w „Głosie Narodu”, że jestem przysłanym do Krakowa szpiegiem rosyjskim.

Niejaki Bresnitz von Sydačoff w broszurze Die panslavistische Agitation und die südslavische Bewegung in Oesterreich-Ungarn (2 Aufl., Berlin und Leipzig 1900) robi ze mnie agitatora panslawistycznego, wyprawionego z ramienia Pobiedonoscewa do Węgier dla buntowania Słowaków przeciwko świętej Madziarii.

Śp. Budiłowicz i inni gorliwcy od „patriotyzmu” rosyjskiego posądzali mię 0 ,jezuityzm” i „szlachetczyznę” z liberum veto i innemi ozdobami.

Syjoniści z p. Żabotinskim na czele mówili o mnie z nienawiścią jako 0 wrogu "narodu żydowskiego” i wymyślali mi za to, że propo-

10 korzyściach z ogólnego rozprzestrzenienia tacinskiego sposobu pisania w dziedzinie języków stowiańskich, przeł. z czes. J. I. N i e c i s ł a w B a u d 0 u i n, Warszawa 1865.

2 Por. mój artykut: Odwaga „Warty” na polu ktamstw i przekręcan („Kraj”, Petersburg 1886, nr 50, „Przegląd Literacki”) [przyp. BdeC].

3 Por. moją broszurę: Jeden z objawów moralności oportunistycznoprawomyślnej, Kraków 1898 [przyp. BdeC]. 
nowałem utworzenie w przypuszczalnym polskim uniwersytecie warszawskim katedry tylko języka i folkloru żydowskiego, z pominięciem literatury i historii żydowskiej.

Poseł od mniejszości rosyjskiej miasta Warszawy, p. Aleksiejew, w jednej ze swych „patriotycznych” mów w Dumie rosyjskiej oskarżał mię 0 szerzenie poglądów śp. profesora Duchińskiego, tj. o odsądzanie Rosjan od „słowiańskości”, a „oberpatriota” Puryszkiewicz nazywał mię catowiekiem z rewolucyjna przesztościa.

Mógłbym przedłużyć tę litanię, ale i tego, com wyliczył, wystarczy. Jeżeli zaś pozwoliłem sobie nudzić czytelnika tym spisem, to nie tylko dla pochwalenia się tak pochlebnymi charakterystykami, mojej osoby dotyczącymi, ale także dla ostrzeżenia łatwowiernych, że na wszelkie opinie wypowiadane o przeciwnikach w zapale polemicznym, chociażby nawet na stronicach „Myśli Niepodległej” i chociażby nawet 0 „Kradku”, należy się zapatrywać krytycznie i nawet sceptycznie.

Audiatur et altera pars

Audiatur... nie w zwykłym znaczeniu. Dotychczas zaznajomiliśmy się z metodami polemicznymi „antysemitów postępowych”, przytaczając ich własne wypowiedzenia; teraz zaś posłuchamy ich przeciwników, tj. będziemy się rozkoszowali ich eleganckim stylem i objawami ich szlachetnego oburzenia.

Otóż ton polemiki obustronnej naprowadza, niestety, na smutne refleksje. Brak najmniejszego szacunku dla godności ludzkiej, brak tolerancji i wyrozumiałości, a w dodatku ulicznikowskie wyuzdanie języka pozostawiają po sobie długotrwały niesmak. Prawdopodobnie w ten sam sposób raczą się długotrwali goście szynkowni i „herbaciarni” „patriotycznych” Związku Ludu Rosyjskiego (Sojuz Russkogo Naroda). Sam wprawdzie nie odwiedzałem tych zakładów, ale pozwalam sobie tak przypuszczać na podstawie opowiadań i zestawień. Że się przy tym rzuca na wiatr najrozmaitsze oszczerstwa bez dowodów, rozumie się samo przez się. 
Spotykamy się też z objawami ignorancji czy też umyślnego przekręcania prawdy. Tak np. czytamy:

Postawienie „kwestii żydowskiej” pod „dyskusję” na pierwszym planie było prostym posunięciem ze strony kontrrewolucji na szachownicy politycznej dla zatamowania ruchu masowego („Młot”, Warszawa 1910, nr 14, str. 7).

Kwestie żydowska stawiano na pierwszy plan bardzo wiele razy, stawiano ją chronicznie. Na „zjeździe autonomistów” w Petersburgu w końcu r. 1905 kwestie żydowska, z upośledzeniem wszystkich innych kwestii narodowościowych i dotyczących równouprawnienia, wysunął na pierwszy plan p. Żabotinskij przy zgodnym akompaniamencie innych syjonistów i przez to niemało się przyczynił do nadania temu zjazdowi charakteru menażerii, mieszczącej w sobie wzajemnie się gryzące bestie. Kwestie żydowska wysuwali też na pierwszy plan np. w Petersburgu Żydzi, członkowie Związku Równouprawnienia (Sojuz Rawnoprawia Jewrejew w Rossii), żądając od partii konstytucyjno-demokratycznej obowiązkowego wsadzania przynajmniej jednego Żyda na wyborcę w każdym okręgu wyborczym. Żydzi wymagali dla siebie głosów wirylnych w zamian za obietnicę głosowania na korzyść „kadetów”. Żadna inna „narodowość” nie stawiała podobnych warunków. Oczywiście wychodziło to na niekorzyść zarówno partii, jak i samych Żydów.

Ale jest to psychologicznie całkiem zrozumiałe. Przyzwyczajeni do ciągłego wyodrębniania na ich niekorzyść, starali się „Żydzi” skorzystać z ulg chwilowych dla wyodrębnienia siebie, z uszezerbkiem wszystkich innych grup ludności w państwie rosyjskim. Dodajmy do tego straszne przeczulenie wskutek stałych praw wyjątkowych, a zwłaszcza wskutek krwawych pogromów w Kiszyniowie, w Homlu, w Odessie, w Białymstoku, w Siedlcach i w tylu innych miejscach, a będziemy się chyba nieco pobłażliwiej zapatrywać na wrzask ze strony żydowskiej, na aroganckie rozpychanie się i wyzywajace zachowanie sie.

W każdym razie stwierdzamy, że kwestie żydowska wysuwała na pierwszy plan nie tylko „kontrrewolucja”, ale także „rewolucja”; 
wysuwali ją ciągle także sami „Żydzi”, o ile występowali świadomie jako solidarni członkowie swego plemienia prześladowanego.

W ogóle zaś to żarcie się namiętne „Żydów” z „nie-Żydami”, „antysemitów” z „Semitami”, różnych narodowości pomiędzy sobą objaśnia się w znacznej części zamknięciem ich wszystkich w ciasnej klatce, gdzie nie wolno im ani się ruszać, ani oddychać do woli. Jest to walka wzajemna niewolników pod batem dozorcy („Prawda”, Warszawa 1910, nr 46, str. 2).

W polemice przeciwko p. Niemojewskiemu ze strony jego przeciwników dużo jest napaści osobistych w połączeniu z przekręcaniami faktów, wstrętnymi obelgami, niekiedy ze złą wiarą. Częścią oddawano pięknym za nadobne, częścią zaś napadano swoiście, z własnej inicjatywy. Solidarność partyjna pokrywa oczy mgłą i każe kłamać bez zająknienia. Wszystko to są rzeczy szpetne i nieprzynoszące zaszczytu ani jednej, ani drugiej stronie.

Jednakże przeciwnicy p. Niemojewskiego stoją o tyle wyżej od niego samego, że ani razu nie podszczuwali czy to bezpośrednio, czy też choćby tylko pośrednio do ryczałtowego pogromu. Nie prorokowali pogromu „katolików”, do których przecież zalicza siebie p. N. choćby przez to, że krytykę i demaskowanie katolicyzmu uważa za swój przywilej osobisty, zabraniając tego „Żydom”, którym na pastwę pozostawia Talmud i Szulchan-Aruch. Nie prorokowali pogromu „chrześcijan”, do których p. N. jako katolik należy. Nie prorokowali pogromu Polaków, do których p. N., jako „szlachcic polski”, również bez wątpienia należy.

Na zakończenie prośba o rozwiązanie zagadki. Talmud i Szulchan-Aruch, pozostawione przez p. N-go, jako przedmiot krytyki jedynie Żydom - boć przecie każdy ma prawo krytyki tylko w granicach „swego wyznania” - ulegały też krytyce ze strony p. N-go. Jeżeli tedy p. Niemojewski uważa Talmud i Szulchan-Aruch za księgi „swego wyznania”, to w takim razie robi z siebie „żyda”. Byłaby to nowa dwuosobowość p. N-go: z jednej strony mieści on w sobie „wolnomyśliciela” i „antysemitę”, z drugiej zaś strony godzą się w nim „żyd” z „katolikiem”. 
Środek radykalny na kwestię żydowską

Wyciąg z mego artykułu przeznaczonego do gazet rosyjskich, ale niewydrukowanego z powodow od redakcji niezależnych.

Zdanie Żyda o Bogu, o cesarzu i o narodzie polskim.

Jeżeli nie można żyé zgodnie we wspólnej „ojczyźnie”, jeżeli jedni przeszkadzają drugim, jeżeli „Żyd” jest nie do zniesienia dla „Polaka”, a „Polak” dla „Żyda”, to nie ma rady, trzeba się wzajemnie wytępić, albo co najmniej wypędzić.

Jak przeprowadzić ten środek radykalny, wyłożyłem w artykule, przeznaczonym dla jednej z gazet rosyjskich, która jednak bała się go wydrukować, bo mogłoby ją to za drogo kosztować. Pozwolę tu sobie przytoczyć w polskiej przeróbce niektóre urywki z tego artykułu.

Wielu patrzy na objawy prześladowania Żydów przez administrację ze strony żartobliwej, komicznej, humorystycznej. Ja zaś nie mogę jeszcze w żaden sposób przyzwyczaić się do tego i, usłyszawszy 0 nowych faktach naigrawania się, po prostu drętwieję. Mam wprawdzie nadzieję, że ja również z czasem się przyzwyczaję i będę spotykał podobne środki „patriotyezne” z uśmiechem pobłażliwości, niby niewinne żarty figlarzy; tymczasem jednak, dopóki moje uczucia etyczne nie zostały sparaliżowane, uważam wszelkie znęcania się nad godnością ludzką i wszelkie prześladowania, którym ulegają ludzie za swe pochodzenie, za rzecz bezwstydną i haniebną, a oprócz tego za środek, niszczący nie tylko uspołecznienie, ale także państwowość.

Inaczej patrzą na tę sprawę „patrioci” rządzący teraz Rosją i uważający siebie za jedynych gospodarzy. W tych, według mnie, bezwstydnych i haniebnych środkach widzą oni objaw wysokiej mądrości państwowej i najlepszy sposób wzmocnienia Rosji. Naturalnie, jeżeli w samej rzeczy myślą o Rosji, a nie 0 swych sprawkach osobistych.

Tak więc nasze stanowiska są wręcz sobie przeciwne. To, co dla mnie jest haniebne i zgubne, to „patriotom” wydaje się zaszczytnym i zbawiennym. Potępiają zaś oni wszystko to, co, według mnie, było- 
by jedynie sprawiedliwym i zbawczym dla tego nieszezęśliwego państwa.

Niemniej przeto mogę zrozumieć „patriotów” i stanąć na ich stanowisku. Propozycje i żądania Markowa 2-go, Puryszkiewicza i spótki mają daleko więcej sensu aniżeli drażniące i niczego nierozstrzygające pótśrodki, stosowane przez ludzi tchórzliwych i niezdolnych do wypowiedzenia się stanowczo i otwarcie.

Jeżeli Żydzi są szkodliwi, to nie należy ich nigdzie puszczać. Wszelkie procenty szkolne są nonsensem i ja zupełnie się zgadzam Z „patriotami”, że dla trucizny żydowskiej dopuszczalny jest tylko procent zero. Jeżeli coś uznajemy za szkodliwe, powinniśmy dążyé do jego całkowitego wytępienia i zniszczenia.

Obecne położenie Rosji wywołuje mimo woli wspomnienia historyczne o tym, co się dokonywało w państwie polskim w ostatnich latach jego istnienia. I tam miały miejsce wzmocnione prześladowania innoplemieńców (inorodcew) i innowierców, i tam wybuchał antysemityzm, i tam była wolnościowa Konstytucja 3 Maja (w Rosji 17 października), i tam przeciw tej konstytucji uzbroiło się wszystko to, co nie mogło się rozstać z poddaństwem chłopów, wszystko to, co było przedajne i nastrojone pogromowo. Oczywiście z tego jeszcze nie wynika, ażeby Rosję czekał ten sam los. Przecież warunki są całkiem inne, a jak się rozwiąże kryzys rosyjski, przewidzieć niepodobna.

Ale z tym wszystkim w ginącej Polsce wypływały różne projekty, z których mogliby teraz skorzystać „patrioci” rosyjscy. Tak na jednym z ostatnich sejmów ktoś z „ludzi iście polskich”, zdaje się WeryhoDarowski, wystąpił z projektem ostatecznego rozwiązania kwestii żydowskiej za pomocą kastrowania wszystkich Żydów.

Sądzę, że za ten projekt powinni się uchwycić rękami i nogami obecni „patrioci” rosyjscy. Ale ja idę dalej i dopełniam dowcipny projekt „patrioty” polskiego z końca wieku XVIII.

Ponieważ Żydzi, dlatego tylko że są Żydami, są absolutnie szkodliwi, to należałoby ich po prostu wytępié, urządziwszy ogólny pogrom wszechrosyjski. Gdyby zaś to okazało się z jakichkolwiek bądź powodów niewygodnym, w takim razie trzeba ich uznać za niewolników, pozbawić całego majątku i wszystkich praw obywatelskich, a następnie, skorzystawszy z genialnego pomysłu „patrioty” polskiego, wszyst- 
kich mężczyzn okastrować, wszystkie zaś młode kobiety sprzedać do domów rozpusty w Rosji i za granicą, co mogłoby znacznie poprawić finanse państwa. Stare kobiety, równie jak i okastrowani mężczyźni, mogliby [sic!] pozostawać w kondycji niewolników do końca życia. Wskutek zaś wskazanych tylko co środków zapobiegawczych plemię żydowskie przestałoby istnieć samo przez się.

Ale trzeba być konsekwentnym i prowadzić sprawę do końca. Żydzi są szkodliwi i niebezpieczni - ze stanowiska „patriotów” nie ulega to najmniejszej wątpliwości. Jednakże nie mniej, a pod pewnymi względami nawet daleko więcej szkodliwi i niebezpieczni są także pozostali inorodcy: wszyscy ci Polacy, Finowie, Gruzini, Ormianie, Litwini, Łotysze. Estończycy..., a może nawet Ukraińcy, tj. Małorusi, uważający siebie za coś odrębnego od „plemienia panującego”. Również szkodliwi są wszyscy „szabesgoje” spomiędzy Rosjan, tj. wszyscy ludzie nieuznawani przez „patriotów” i kolący im oczy. Od wszystkich tych szkodliwych i niebezpiecznych żywiołów należy uwolnić Rosję, tj. rozprawić się z nimi według udoskonalonej metody polskiego męża stanu i „patrioty” z końca wieku.

Rosja dla Rosjan, tj. nie dla Rosjan w ogóle, ale wyłącznie dla „patriotów iście rosyjskich”. Wtedy dopiero można będzie żyć sobie rozkosznie i krzewić bez przeszkody niewzruszone ostoje kultury „iście rosyjskiej”.

Wtedy wszystkie kwestie kłopotliwe rozwiążą się same przez się. Zniknie jako niepotrzebna linia osiadłości. Znikną procenty szkolne. Nie będzie dla kogo urządzać pogromów. Starcy państwowi będą zwolnieni od konieczności rozstrzygania kwestii o wysiedlaniu ze stolicy niemowląt żydowskich, ponieważ nie będzie już chyba żadnych niemowląt żydowskich. Nie wypadnie już tracić czasu na rozwiązywanie niezmiernie trudnego zadania na temat, do jakiej kategorii zakładów naukowych należy zaliczyć Wyższe Kursy Żeńskie, boć przecie te kursy nie będą splugawione obecnością w nich Żydówek. Wycieczki słuchaczów wyższych zakładów naukowych nie będą zarażone trucizną żydowską i można się będzie obejść bez uzyskiwania zgody wszystkich gubernatorów. 
Tak czy inaczej wszystko nieuznawane przez „patriotów” i wszystko podejrzewane o pochodzenie od nieuznawanego powinno być z korzeniem wyrwane i zniszczone.

Wprawdzie tworzy się jak gdyby niebezpieczny precedens dla przyszłości. Przecież możliwą jest rzeczą, że z czasem zrodzą się w Rosji inni „patrioci” i „gospodarze” i zaczną również zawzięcie tępić potomków dzisiejszych „patriotów”. Przecież działacze „wielkiej rewolucji francuskiej” tę samą zasadę tępienia żywiołów szkodliwych i niebezpiecznych stosowali do wszystkich szlachciców i do wszystkich potomków „tyranów” i „ciemiężycieli ludu”.

Jednak w danym wypadku nic podobnego nam nie grozi. Dzisiejsi „patrioci” „iście rosyjscy” i ich potomkowie nie potrzebują się obawiać odwetu ze strony wrogów, ponieważ ci wszyscy wrogowie będą gruntownie wytępieni, na chwałę i pomyślność wielkiej i niepodzielnej Rosji.

Takie to rady leczenia radykalnego dawałem „patriotom” rosyjskim. Te same rady mogę tu powtórzyć do użytku „rdzennych Polaków” w ogóle, a „antysemitów postępowych” w szczególności.

Cheąc być atoli bezstronnym, takie same rady skierowuję w stronę „Żydów” w ogóle, a „antygoistów postępowych” w szczególności. Przecież oni również mają prawo do uważania się za "gospodarzy” danego kraju i do usuwania wszystkiego tego, co włazi im w drogę.

Tak więc należy się żreć bezustannie ze względów „ideowych”. Wzajemnie się wyrżnąć i wytępić - oto cel naszych marzeń „patriotycznych”. W imię jednolitości plemiennej i czystości rasy powinniśmy przynieść w ofierze kilka lub kilkanaście milionów istnień ludzkich.

Przed laty mniej więcej dwudziestu jechałem koleją z Wiednia do Krakowa. Ze mną razem jechał historyk Tadeusz Korzon i jakiś urzędnik Polak z guberni mińskiej. Siedzieliśmy w wagonie klasy 3. W liczbie pasażerów znajdował się typowy Żyd talmudysta z jakiegoś miasteczka galicyjskiego, człowiek młody o twarzy myślącej i zagłębionej w sobie. Modlił się jakiś czas bardzo gorliwie, a nareszcie odezwał się do nas: 
- To panowie są z Rosji? A czy to prawda, że cesarz rosyjski zabrania mówić po polsku?

Urzędnik z guberni mińskiej chciał dać odpowiedź wymijającą, powoływał się na złe informowanie władzy najwyższej itd. Ja zaś, nie chcąc wprowadzać w błąd naszego sympatycznego interlokutora, powiedziałem mu wprost:

- Istotnie, w niektórych częściach Rosji nie wolno pod groźbą surowych kar używać języka polskiego. W biurach, w szkole, w miejscach publicznych wolno tam Polakowi mówić tylko po rosyjsku albo milczeć.

- No, no to ten cesarz rosyjski chce być mądrzejszy od Pana Boga. Boć przecie Pan Bóg stworzył ten naród i powiedział: „ten naród ma być”, a cesarz rosyjski powiada: ten naród nie ma byé, ten naród musi zginąć.

Takie to słowa wyszły z ust Żyda prawowiernego, Żyda talmudysty.

\section{V \\ „Gospodarze” i „goście”}

Nie byłoby ani „antysemityzmu”, ani w ogóle walk wyznaniowych i narodowych o podkładzie niby to ,ideowym”, gdyby nie było dzikiej teorii, że pewna czesść mieszkańców danego państwa lub kraju ma prawo uważać się za jego „gospodarzy”, a inna może sobie rościć pretensje, co najwyżej do roli „gości” tolerowanych. Jest to „syjonizm” sui generis. Na tym gruncie między innymi syjonizm żydowski ściera się z syjonizmem polskim. Syjoniści polscy marzą o ziemi czysto polskiej, podobnie jak syjoniści żydowscy marzą o ziemi czysto żydowskiej.

Istnieją gorliwi stronnicy frakcji bojowej partii PPS, którzy dopiero wtedy zabiorą się do uszczęśliwiania Polaków za pomocą ustroju socjalistycznego, kiedy ziemię polską oczyszczą od wszystkich obcych przybłędów, kiedy po ziemi polskiej będą się ruszać tylko Polacy. Każdemu obcemu, każdemu nie-Polakowi kulą w łeb. Zresztą wolno będzie przyjeżdżać do Polski ludziom z innych narodowości, ale jedy- 
nie w charakterze gości czasowych, gości pokornych, nieroszezących sobie pretensji do żadnego wyodrębnienia narodowego. Cała kula ziemska zostaje podzieloną na ściśle odgraniczone klatki narodowościowe z jak najczystszymi folblutami. Będą to „ojczyzny” narodowo nieskazitelne: Niemiec siedzi w swojej klatce, Francuz w swojej, Węgier w swojej, Czech w swojej, Słowak w swojej, Polak w swojej, Litwin w swojej itd. i nikomu z nich nie wolno wytknąć nosa poza granice swej czysto narodowej ojczyzny. Rzecz prosta, iż Austria i Szwajearia zostają wykreślone z liczby państw dopuszczalnych.

- A cóż pan zrobisz z Żydami, którzy cheą byé tylko Żydami i z żadną inną narodowością się nie utożsamiają? - zapytałem jednego z głównych apostołów tej czystości narodowej ojczyzny.

- Naturalnie Żydom trzeba także wyznaczyé pewien kawał ziemi i tam ich wszystkich umieścié. Żydzi mają również prawo na odrębną, ściśle odgraniczoną ojczyznę.

0czywiście mamy tu do czynienia z ostrym obłędem syjonistycznym.

Ale i poza tą sferą maniaków spotykamy się z dzieleniem stałych mieszkańców danego kraju na „gospodarzy” i „gości”. Nawet ludzie postępowi, uważający siebie za rdzennych Polaków, a więc za „gospodarzy” ziemi polskiej, przemawiają o innych mieszkańcach tej ziemi tonem obszarników, co to mają poddanych na swych gruntach, w swych dobrach.

Panowie ci zapominają, że musimy się liczyć z faktem usamowolnienia włościan. A wobec tego faktu zapytuję, czy w miejscowościach, gdzie Polak obszarnik władał bydłem dwunogim innoplemiennym (ukraińskim, białoruskim, litewskim), usamowolnieni potomkowie tego bydła dwunogiego mają się uważać za „gości” „gospodarzy” polskich? A może odwrotnie - potomkowie byłych obszarników i panów powinni się uważać za „gości” „gospodarzy” ukraińskich, białoruskich, litewskich? Oczywiście dla „patriotów” rosyjskich tak jedni, jak drudzy są tylko „gośćmi” ,gospodarzy” rosyjskich jako jedynych panów i władców państwa rosyjskiego.

Zastosujmy te same pytania do Żydów jako usamowolnionych obywateli państwa lub też jego dzielnicy. Oczywiście dla Rosji pytania te pozostają czysto „akademickimi”, w Rosji bowiem nie ma jesz- 
cze obywateli państwa w prawdziwym znaczeniu tego wyrazu, a są tylko niewolnicy, Żydzi zaś pozostają dotychczas szczutą zwierzyną. Ale zastosujmy te pytania np. do Żydów w Galicji. W stosunku do jakiej narodowości jako „gospodarującej”, Żydzi galicyjscy powinni się uważać za gości? Np. w Galicji Wschodniej - kogo uważać za „gospodarzy”? Czy Żydzi są tam „gośćmi” Polaków czy Rusinów, czy też może Niemców? A może byłoby najwłaściwiej pozwolić każdemu Żydowi jako jednostce z pełnią praw obywatelskich być tym, czym chce. Niech każdy człowiek decyduje samodzielnie o swej przynależności wyznaniowej i narodowej.

Polskie Zjednoczenie Postępowe ${ }^{1}$ w Warszawie zawyrokowało, że Polacy nie uznają praw narodowości żydowskiej, nie uznają praw obywatelskich i narodowo-kulturalnych Żydów.

A więc panowie „Polacy” jako „gospodarze” kraju kwalifikują wszystkich innych mieszkańców, nakładając na nich stemple narodowościowe, podobnie jak na baranów lub też inne bydło nakłada stemple ich właściciel.

Polskie Zjednoczenie Postępowe powinno pamiętać, że w ten sam sposób są traktowani w Rosji wszyscy inorodcy, a więc także Polacy.

Ależ na Żyda patrzy się zawsze jeszcze jako na pachciarza i faktora, jako na pariasa pozbawionego prawa wyboru i samookreślania się. Żyd, dlatego że jest Żydem, nie ma prawa do poczucia godności osobistej, nie ma prawa jednostki uobywatelnionej.

P. Roman Dmowski i inni głosiciele „egoizmu narodowego” dzielą wszystkich mieszkańców Polski na „obywateli kraju” i na „wrogów kraju”; „obywatelem” jest wyznawca polskiego „egoizmu narodowego”, „wrogiem” zaś ten, co dąży do równouprawnienia wszystkich mieszkańców bez różnicy wyznania i narodowości. Obok tego jednak możliwe jest także zdanie, że nie tylko ci są „obywatelami kraju”, co się poddają pod komendę naczelnika partii narodowo-demokratycznej i uznają go za pana wszechwładnego nie tylko ich postępków, ale także myśli i uczuć.

1 Partia, o charakterze demokratycznym i antyendeckim, powstała w 1907 r. w wyniku zjednoczenia Polskiej Partii Postępowej z lewicą Związku Postępowo-Demokratycznego. 
Przyjmując dzielenie mieszkańców kraju na „gospodarzy” i „gości”, musimy się zgodzié, że Żydzi również mają prawo uważać siebie samych za „gospodarzy”, a innych za bydło robocze i dojne krowy.

\section{VI}

Trzeba się liczyé z faktami

Powiadają nam, że trzeba sie godzić z faktami i patrzyć trzé́wo na rzeczy. Najzupełniej się z tym zgadzam.

Otóż mamy fakt istnienia pewnego obszaru ziemi zaludnionego przeważnie przez ludność mówiącą po polsku i uważającą siebie za należącą do narodowości polskiej. Ale obok tego jest faktem niezaprzeczonym, że w obrębie tych samych granic geograficznych mieści się pewien procent ludzi mówiących innymi językami i zaliczających siebie do innych narodowości albo też nawet narodowo całkiem bezwyznaniowych. Jeżeli na obszarze etnograficznym polskim, tj. na obszarze zaludnionym przeważnie przez Polaków, znajduje się choć jeden człowiek niecheący być Polakiem, ma on, ze stanowiska sprawiedliwości i poszanowania godności ludzkiej, zupełne prawo do tego, byleby tylko nie przeszkadzał innym być tym, czym chcą, tj. w danym razie Polakami.

Stosuje się to także do Żydów. Choćbyśmy jak najenergiczniej zaprzeczali istnieniu „narodowości żargonowej”, to jednak faktycznie poczucie odrębności plemienia czy też społeczeństwa żydowskiego istnieje i żadne protesty histeryków patriotyzmu polskiego nic tu nie pomogą.

Podobno w Austrii działa „prawo” nieuznające narodowości żydowskiej i zabraniające przy spisie ludności wpisywać „żargon” jako język rozmowy danego osobnika. Kto przy spisie „ludności” poda się za „żargonowca” i nie chee na wezwanie władzy zeznania swego zmienić, bywa karany. Otóż jest to prawo dzikie i nierozsądne. Zadaje ono gwałt i zmusza do fałszowania prawdy. Jest to bezwstydne zmuszanie do „fatszywej fasji”. Jest to to samo, jak gdyby przy nieuznawaniu przez państwo pewnych wyznań lub bezwyznaniowości zmu- 
szano ludzi nienależących do żadnego z wyznań zarejestrowanych do zapisywania się jedynie tylko do jednego z tych wyznań.

Ani esperanto, ani żaden inny język sztuczny nie są przewidziane przez państwo jako języki życia potocznego. Gdyby więc istniały rodziny używające w rozmowie przeważnie jednego z języków sztucznych i gdyby zgodnie z tym niezaprzeczonym faktem przy spisie ludności podawały ten język jako swój język domowy, czyżby za to ulegały karze?

Nawet w Krakowie, na Kazimierzu, istnieją, a przynajmniej przed kilku laty istnieli Żydzi mówiący jedynie tzw. „Żargonem” i nierozumiejący żadnego innego języka. W każdym razie wiele bardzo dzieci w rodzinach żydowskich rozpoczyna mówienie od tego języka, od „Żargonu”, a dopiero później zaznajamia się z innymi językami. Czyż więc takich ludzi będziemy zmuszali do podawania języka polskiego czy też niemieckiego za język ojczysty? A może są to niemowy?

Nieuznawanie wbrew oczywistości tzw. „żargonu” za język rozmowy jest objawem głupiej, bezmyślnej, strusiej metody, a pod względem etycznym stoi nierównie niżej od praktykowanego w Rosji zabraniania mówienia po polsku. Tam przynajmniej otwarcie zatykają ludziom usta, a tu pozwalają wprawdzie mówić, ale jednocześnie każą obłudnie kłamać i wyrzekać się swego języka ojczystego.

Liczmy się z faktami. A więc obliczmy ustosunkowanie procentowe „Żydów” i „chrześcijan” na „ziemiach polskich”. Obliczmy też ustosunkowanie procentowe alfabetów i analfabetów zarówno między „Żydami”, jak i między „chrześcijanami”. Jeżeli to wszystko gruntownie rozważymy, jeżeli obok tego wspomnimy o pretensjach polskich do Litwy, Rusi itd., to może z nieco zimniejszą krwią będziemy traktować pretensje żydowskie do Polski.

Liczmy się z faktami. A więc nie zapominajmy o istnieniu bogatej liczebnie prasy „żargonowej”, o rozkwicie teatru żydowskiego, dla którego podobno stawiają nowy gmach w Warszawie.

Liczmy się z faktami. A więc nie dajmy się uwodzić nazwie „żargon”. Jest to nazwa głupia, o ile fałszuje nasze myślenie i każe nam z lekceważeniem i pogardą traktować język, który jest takim samym językiem jak i wszelkie inne. 
Powiadają, że trzeba się liczyé z „psychologią narodu” jako z faktem. Jest to oczywisty nonsens, bo gdzie znaleźć tę jednolitą „psychologię narodową?? No, ale przypuśćmy. A więc liczmy się z psychologią zbiorową narodów i grup społecznych. Liczmy się z nienawiścią Żyda prawowiernego do „goja”. Nienawiść ta wygląda z oczu i objawia się w najrozmaitszy sposób. Liczmy się z nienawiścią chrześcijanina, gorejącego „miłością bliźniego”, do Żyda. Liczmy się, jako z faktem, z fanatyzmem żydowskim, z fanatyzmem katolickim. Liczmy się $\mathrm{z}$ antysemityzmem i z antygoizmem.

Liczmy się z właściwą znakomitej większości ludzi mieszaniną pojęcé. Liczmy się z faktem, że wszędzie prawie daleko jest więcej ludzi głupich, aniżeli rozumnych, daleko więcej nikczemnych aniżeli szlachetnych. Liczmy się z faktem, że w każdym prawie człowieku jest spory zasób głupoty i podłości. Liczmy się z atawizmem, liczmy się z instynktami odziedziczonymi po przodkach. Liczmy się z przesądami zaszczepionymi nam przez otoczenie, a zwłaszcza przez wychowanie wyznaniowe.

Otóż licząc się ze wzajemną nienawiścią Żydów i chrześcijan i pragnąc stworzyć znośne warunki życia, możemy próbować dwóch sposobów działania:

albo wskazanego przeze mnie powyżej środka radykalnego, mającego na celu całkowite wytępienie nienawidzonych,

albo też kierowania się rozsądkiem i obmyślenia takiego modus vivendi, ażeby można żyć obok siebie, znosząc się i tolerując.

Asymilacja

Jako jedyny środek usunięcia antagonizmów wyznaniowych i plemiennych stawiają niektórzy „asymilację”, tj. zlanie się „Żydów” z „chrześcijanami”, czyli z „Polakami”, w jedno jednolite społeczeństwo, przy czym zasymilowanymi mają zostać „Żydzi”, rola zaś asymilatorów ma przypaść „chrześcijanom”, czyli „Polakom”. 
Licząc się z faktami i z „psychologią narodów”, tj. biorąc pod uwagę wzajemną żywiołową nienawiść, musimy zaliczyć marzenia 0 asymilacji do utopii, długo, bardzo długo nieziszczalnych.

Poznaliśmy kilka, kilkanaście, kilkadziesiąt... osób wykształconych, wysoce kulturalnych, pochodzenia „żydowskiego”, które doskonale się dopasowały do podobnych osób pochodzenia „chrześcijańskiego”. Na podstawie tej niezaprzeczonej „asymilacji” łudzimy się myślą o możności wzajemnego zasymilowania ciemnych tłumów, z jednej strony wychowywanych przez prawowiernych rabinów, cadyków i różnych cudotwórców, z drugiej zaś przez wielebnych ojców Damazych Macochów i przez ojców jezuitów.

A. Świętochowski wygłosił niegdyś następujące zdanie, powtarzane gorliwie przez ideologów ,asymilacji”:

Kto mówi, że asymilacja u nas zbankrutowała, ten mówi, że kultura polska jest za słaba, ażeby strawiła żydowską, że ona nie zdoła - jak francuska lub niemiecka - wessać i przetworzyć osad semicki u nas (Por. m.i[n]. art. Postep $i \dot{Z} y d z i$ w „Prawdzie” warszawskiej, 1910, nr 41, str. 3).

Bardzo pięknie. Zapominamy jednak przy tym, że w Polsce chodzi 0 wzajemne zasymilowanie mas żydowskich ciemnych i fanatycznych z masami katolickimi nie mniej ciemnymi i fanatycznymi. Dwa różnorodne gatunki bydląt trudno sprowadzać do wspólnego mianownika.

Trzeba je przede wszystkim uczłowieczyé, tj. oświecić po ludzku, uwolniwszy od przesądów wyznaniowych i ,rasowych”. Co zaś do Francji, Niemiec, Anglii, Włoch itd., to nie należy zapominać, że tam kultura stoi istotnie nieco wyżej niż w Polsce i posiada więcej cech przyciągających. Po wtóre, ilość pacjentów mających ulegać asymilacji, tj. Żydów, była tam bez porównania mniejsza. A nawet i tam asymilowali się tylko ci, co wyszli ze stanu fanatyzmu stadowego, co się ucywilizowali. W Polsce zaś Żyda ucywilizowanego nazywa się pogardliwie „cybulizowanym”.

W manifeście Polskiego Zjednoczenia Postępowego z dnia 5 kwietnia roku 1910 wygtoszono hasło asymilacji politycznej i kulturalnej 
jako warunku faktycznego równouprawnienia Żydów w życiu prywatnym i spotecznym (por. „Prawda”, 1910, nr 41, str. 2).

Bez wątpienia brzmi to bardzo pięknie i imponująco. Ale spójrzmy prawdzie śmiało w oczy.

Rownouprawnienie w życiu prywatnym. Stróżowi, służącemu, praczce, posłańcowi, woźnemu, chłopu... ręki się nie podaje i do stołu się ich nie sadza, chociażby to byli jak najprawowierniejsi „katolicy” i „Polacy”. Podobnie nie podaje się ręki i nie sadza się do stołu Żyda chałaciarza. A „Żydowi” lekarzowi, adwokatowi, kupcowi zamożnemu, nauczycielowi itd. rękę podajemy i sadowimy się z nim do wspólnego stołu.

Przyznajcie więc, panowie, że w waszych frazesach 0 równouprawnieniu w życiu prywatnym jest sporo kłamstwa i obłudy.

Pamiętajcie też, iż waszą logiką i psychologią kierują się owi „patrioci rosyjscy”, którzy, uważając siebie za „gospodarzy” i za sfery decydujące w całym państwie rosyjskim, głoszą hasło asymilacji politycznej $i$ kulturalnej do narodu rosyjskiego jako warunku faktycznego równouprawnienia „inorodców” w życiu prywatnym i spotecznym.

Ale wróćmy do naszej „asymilacji”.

Dopóki istnieje „koszer” i „tryf”, dopóki istnieje szabas obok niedzieli, dopóki istnieją obrzędy z jednej strony przypominające Żydom, że są narodem wybranym, przeznaczonym do panowania nad innymi, z drugiej zaś strony przypominające chrześcijanom, że Żydzi są zbrodniarzami, co umęczyli zbawiciela świata, dopóty 0 ,asymilacji” mowy byé nie może.

Powołam się na analogię z innych krajów. W Rosji wschodniej, nad Wołgą, w Krymie itd. mieszkają muzułmanie - Tatarzy obok „chrześcijan” - Rosjan. Duży procent Tatarów jest np. w Kazaniu. Otóż zdarzyło się, że jeden z Tatarów przyszedł w jakimś interesie do miejscowej inteligentki, obywatelki ziemskiej, siostry znakomitego uczonego Kawelina i matki profesora uniwersytetu, pani Korsakowej. W czasie rozmowy pozwolit on sobie oprzeć się o stót kuchenny, a nawet z lekka usiąść na nim. Po jego odejściu pani Korsakowa kazała splugawiony dotknięciem niechristia stół nie tylko starannie wyszorować, ale nawet zheblować. 
Istotne czy też tylko wyobrażane brudy innego plemienia i wyznania są nieprzepartą zaporą do „asymilacji”.

Zdaje mi się, że najważniejszą stroną wszelkiej asymilacji społecznej powinna byé asymilacja przekonaniowa, tj. oczywiście nie utożsamienie przekonań, które w takim razie przestają byé przekonaniami, a stają się bezmyślnymi wierzeniami, ale wspólny podkład tolerancyjny dla jak najróżnorodniejszych przekonań. Z tego stanowiska czyż może być mowa, np. 0 asymilowaniu się wolnomyśliciela Polaka, ale oczywiście prawdziwego wolnomyśliciela, z czcicielami Damazego Macocha i wielebnych ojców jezuitów?

Zejdźmy na grunt praktyezny i zdajmy sobie sprawę z tego, jak to ma się odbywać owa „asymilacja”. Kto kogo asymiluje?

A więc „chrześcijanie”, czyli „Polacy”, tj. dzisiejsi „Polacy”, asymilują sobie „Żydów”, tj. dzisiejszych „Żydów”. Sądzę, że Żydzi bardzo by się przeciwko temu bronili, boć przecie taka „asymilacja” nie leżałaby w ich interesie. Bierzemy oczywiście nie pojedyncze wyjątki i zboczenia, ale średnią wypadkową. Zasymilowawszy się z dzisiejszymi „Polakami”, tj. zaszczepiwszy sobie ich przymioty i wady, Żydzi musieliby stracić w znacznym stopniu ducha przedsiębiorczości, musieliby do pewnego stopnia zniedołężnieć, cofnąć się do stanu względnego analfabetyzmu itd. Z czasem, kiedy poziom umysłowy i kulturalny społeczeństwa rdzennie polskiego znacznie się podniesie, asymilacja z nim nie będzie narażała na straty.

Weźmy wypadek odwrotny. „Żydzi” asymilują sobie „chrześcijan”, czyli rdzennych „Polaków”, tj. narzucają im swe właściwości. Czy na tym zyskaliby „Polacy”? Może. Ale „Żydzi” z pewnością by stracili. Zjawiłaby się bowiem ogromna masa nowych „Żydów”, którzy dawnym „Żydom” robiliby niepożądaną konkurencję. A stwarzanie sobie konkurencji nie leży w niczyim interesie. Tak jak dziś rzeczy stoją, „Żydzi” typowi, „Żydzi” masowi patrzą na „gojów” jako na bydło do wyzyskiwania i bez takiego wyzyskiwania nie mogą sobie wyobrazić własnej racji bytu.

W każdym razie 0 ,asymilacji” wszystkich „Żydów” wszystkim „Polakom”, czyli o równouprawnieniu w życiu prywatnym, tj. przy wzajemnym obcowaniu i przestawaniu ze sobą, chyba nigdy mowy być nie może. Wystarczy tymczasem, a nawet w odległej przyszłości, 
tolerowanie się nawzajem w życiu społecznym i równouprawnienie polityczne.

\section{VIII}

„Odżydzanie” - „odpolszczanie” i „odchrześcijanianie”

Wypowiedziano nowe hasło: hasło odżydzania polskiego postepu, polskiego socjalizmu, polskiej myśli niepodlegtej ${ }^{1}$.

A więc z jednej strony stawiają Żydom za warunek równouprawnienia asymilacje polityczna $i$ kulturalna, $\mathrm{z}$ drugiej zaś strony odpędzają ich od polskości. Wara Żydom od udziału w polskim życiu umysłowym i kulturalnym, a nawet Belmont ma prawo wydawać jedynie żydowskie pisemko w jezyku polskim.

„Myśl Niepodległa” dziwnego autoramentu sądzi ludzi pod kątem grzechu pierworodnego, prześladuje ich za pochodzenie, buduje klatki plemienno-wyznaniowe. „Myśl Niepodległa” głosi bojkotowanie „Żydów” w stowarzyszeniach i zrzeszeniach „polskich”, a obok tego nie uznaje „narodowości” żydowskiej. Więc czymże są Żydzi u licha? Oczywiście czymś w rodzaju krów, psów, kotów, świń, baranów itp., tj. istot pozbawionych zdolności świadomego grupowania się. Jako proste konsekwencje ze stanowiska zajętego przez „Myśl Niepodległą” i przez cały zastęp „antysemitów” czy to „postępowych”, czy też niepostępowych, w stosunku do Żydów, wynikają:

1. ustanowienie dla Żydów pewnego rodzaju czerty osiodtosti, czyli linii demarkacyjnej, odgraniczającej ich od zrzeszeń polskich, chociażby jak najpostępowszych;

2. ustanowienie procentów szkolnych, a nawet całkowite usunięcie Żydów, jako elementu szkodliwego, ze szkół polskich;

1 Prawdopodobnie mowa tu o poglądach Wacława Sieroszewskiego. W liście do W. Feldmana, z Petersburga 27 III / 9 IV 1911 r. Baudouin pisze: [...] Owym osobnikiem, o którym to mówie, jest Sieroszewski. Sam mi on wyktadat w Zakopanem te swoja teorię: „Najprzód czystośc narodowa państwa, a dopiero potem socjalizm". J. N. B a u d o u in d e C o u r t e nay, Listy..., s. 72. 
3. zaprowadzenie osobnej cenzury, która nie pozwalałaby „Żydom” pisywać w wydawnictwach „polskich”, a „Polakom” w wydawnictwach żydowskich. Co najwięcej można by pozwolić Żydom wydawać „pisemka żydowskie po polsku”, a może także „Polakom” „pisemka polskie po żydowsku”.

Przyjmując takie środki zapobiegawcze przeciw zarazie żydowskiej, nie powinniśmy mieć za złe „patriotom” rosyjskim, że, chroniąc się od szkodliwego wpływu Żydów, Polaków i innych inorodców, utrzymują czerte osiodtosti, ustanawiają procenty szkolne i zaprowadzają osobną cenzurę dla wydawnictw polskich, żydowskich i innych tym podobnych.

Dążąc do „odżydzania” polskości, powinniśmy przede wszystkim „odżydzić” historię polską, wyrzuciwszy z niej Berka Joselewicza [sic!], następnie wyrzuciwszy z niej wszystkich tych Żydów, co, uważając się za Polaków wyznania mojżeszowego, przyjmowali w różne czasy (w roku 1831, w r. 1861-1863 itd.) żywy udział w ruchach politycznych polskich, walczyli za Polskę, cierpieli za Polskę, ginęli za Polskę.

„Odżydzamy” instytucje kulturalne i oświatowe polskie, a przede wszystkim Kasę im. Mianowskieg $0^{1}$. Wyrzucamy z niej Natansonów, Kronenbergów, Kramsztyków, Dicksteinów i wielu innych.

„Odżydzamy” naukę polską, wykreślając z listy uczonych polskich Natansonów, Dicksteinów, Kramsztyków, Nusbaumów, Krausharów, Askenazych, Heryngów, Posnerów i tylu, tylu innych. Również dokonywamy starannego „odżydzania” sztuki, literatury i publicystyki polskiej.

Jednym słowem w państwie myśli i twórczości polskiej zaprowadzamy „linię osiedlenia” i nieubłagany system paszportowy. Kto

1 Kasa im. Mianowskiego została założona w 1881 r. w Warszawie m.in. przez T. Chałubińskiego, J. Natansona, H. Sienkiewicza, F. Sulimierskiego i A. Świętochowskiego (Kasa pomocy dla osób pracujących na polu naukowym im. dr med. Józefa Mianowskiego). Celem jej było gromadzenie środków finansowych dla wspierania polskiej działalności naukowej, wydawania prac naukowych. Stała się główną instytucją naukową w Królestwie, której zasługi tak przed rokiem 1918, jak i w dwudziestoleciu międzywojennym trudno przecenić. 
się nie wylegitymuje z dziada pradziada jako „lechita” i „sarmata” nieposzlakowany i nieskazitelny, temu pięścią w kark i zrzucenie ze schodów. A nie zapomnijmy także o „odżydzeniu” „socjalizmu polskiego". Nie ma w nim miejsca dla Haeckerów, Diamandów i tylu, tylu innych. Czas by także pomyśleć na serio o „odżydzeniu” chrześcijaństwa w ogóle, a katolicyzmu w szczególności. W związku z tym przypominają mi się dwie anegdoty, mocno charakterystyczne.

Anegdota pierwsza. Pewien ksiądz, mówiąc kazanie w kościótku wiejskim, wzmiankował mimochodem, że Matka Boska była Żydówką. Uraziło to pobożnych słuchaczów. Zebrali się więc pod kościołem na naradę, a kiedy ksiądz wychodzit po nabożeństwie, zaczepili go groźnie:

- A co to ta jegomość gadał, że Najświętsza Panna była Żydówką. My ta nie pozwolimy na taką poniewierkę.

- Ależ, moi kochani, ja tylko chciałem wypróbować waszą wiarę. Uspokójcie się. Najśswiętsza Panna nie była weale Żydówką, ale tylko kasztelanką łęczycką.

- A no to co innego; a myśmy myśleli, że ksiądz naprawdę robi ją Żydówką.

Anegdota druga. Jakiś Niemiec „chrześcjanin” opowiadał znajomej pani o zachłanności plemienia żydowskiego. Wszystko jest w ręku Żydów: banki, handel, przemysł, nauka, prasa...

- Jezus Maria! - zawołała przerażona dama.

- Waren auch Juden, meine Gnädige 1.

Ale sprawę tę można traktować nie tylko anegdotycznie. Jest to sprawa nadzwyczaj poważna i głęboko tragiczna. Ta wyłączność rasowa, plemienna i wyznaniowa, to tępienie bezwzględne wszelkiego obcego ciała, to staranne usuwanie wszelkiego obcego zapachu - toć to najczystsza żydowszczyzna, skrystalizowana w legendach starotestamentowych. Był to jeden z objawów starożytnej nietolerancji i żądzy tępienia innoplemieńców, charakteryzującej ludy azjatyckie. Królowie perscy chełpią się w napisach klinowych z mordowania nieubłaganego mnogich tysięcy ludu pokonanego. To samo wiemy

1 Waren auch Juden, meine Gnädige (niem.) - Też byli Żydami, moja łaskawa (Pani). 
o innych władcach azjatyckich. Rzym, pomimo całej swej zaborczości i wstrętnego obłędu wielkości, szedł inną drogą: podbijał wprawdzie obce ludy, ale ich nie tępił; wcielał je do swego państwa, a tym i owym obcoplemieńcom pozwalał stawać się cives romani. Znalazłszy u obcych ludów nowe „bogi”, umieszczał je w swym Panteonie, a zapasy własnej kultury rodzimej bogacił nowymi elementami kulturalnymi. Kiedy zaś Rzym zżydział, kiedy rzymski światopogląd uległ w walce z mglistą nauką, która przywędrowała z Palestyny, kiedy w połączeniu cezara i pontifexa maximusa z arcykapłanem żydowskim przeważył ten ostatni, wtedy rozpoczęto walkę eksterminacyjną z inaczej wierzącymi, zachowując im życie i mienie jedynie pod warunkiem schylenia karku pod jarzmo zżydzonego pontyfikatu rzymskiego. Zaczęło się długotrwałe tępienie heretyków, zapłonęły stosy i kościół krwi nie przelewat.

Hasło jedna owczarnia $i$ jeden pasterz jest właśnie objawem zżydzenia Europy w duchu starotestamentowym. Jest to to samo hasło nacjonalistyczne, tylko że tam ten nacjonalizm ogarniał tylko jeden naród wybrany, tu zaś rozszerzono go na całą ludzkość, skazaną na ujarzmienie przez Rzym zżydzony. Żydzi tępili inne narody, wcale nie starając się o ich nawracanie; ich zaś spadkobiercy rzymscy nawracali, a wszystko to, co się nie chciało nawrócić, tępili. Chodziło tu bowiem i chodzi o panowanie nad jak największą liczbą niewolników z ciała i ducha. Jest to więc zrzymszczenie nauki pochodzenia żydowskiego, połączenie zachłanności rzymskiej z eksterminacyjnością i tępicielstwem żydowskim.

Cały duch wiejący z żydowskiego Starego Testamentu, będącego przecież podstawą światopoglądu chrześcjańskiego w ogóle, a katolickiego w szczególności, jest wysoce antyetyczny. Jest to stek bezeceństw i niesprawiedliwości uznawanych za święte i nieomylne. Tej jednej księgi starczy do zatruwania światopoglądu i uczuć moralnych i do wywoływania wrogich nastrojów, zabarwionych nienawiścią do ludzi. Nie potrzeba już ani Talmudu, ani Schulchan-Aruchu.

Chodzi więc przede wszystkim o „odżydzenie” naszego światopoglądu i naszych podstaw etycznych.

Czy ze swej strony „żydowstwo” potrzebuje „odchrześcijanienia” i „odpolaczenia”, nie wiem, ale bardzo wątpię. 
W każdym zaś razie jednoczesne nawoływania do „asymilacji” i do „odżydzania” nie dają się chyba ze sobą pogodzić.

\section{IX}

\section{„Zasady” i „oportunizm”}

„Politycy praktyczni” czują wstręt do wszelkich „Zasad” ogólnych; „zasady” im śmierdzą. Tym się objaśnia nienawiść p. Dmowskiego i innych „egoistów narodowych” do rosyjskich „kadetów”, czyli do Partii Konstytucyjno-Demokratycznej (inaczej: do Partii Wolności Ludu). „Kadeci” stoją na niewzruszonych zasadach, wychodzą z zasad i np. ani „sprawy polskiej”, ani „kwestii żydowskiej” nie chcą rozpatrywać w oderwaniu, ze stanowiska przemijających interesów i kombinacji geszefciarskich, ale zawsze ze stanowiska ogólnego, w związku z innymi tego rodzaju kwestiami. To musi oburzać i doprowadzać do wściekłości panów „egoistów narodowych”, którym daleko lepiej smakują rosyjscy październikowcy, nacjonaliści, a nawet całkiem „prawi” członkowie Związku Ludu Rosyjskiego, tj. ludzie albo bez żadnych zasad, albo też z jedyną zasadą: „rób to, co w danej chwili uważasz za korzystne dla siebie i dla swojej szajki”. Dla przyzwoitości zamiast „dla swojej szajki” mówi się „dla swego narodu”. Z takimi ludźmi daleko łatwiej się zwąchać i porozumieć. Są to pokrewne dusze, tak samo szydzące $z$ wszelkich zasad. Przy takim zobopólnym nastroju można przecież oczekiwać takiej lub owakiej kombinacji dającej możność wytargowania pewnych „ustępstw” w zamian oczywiście za pewne usługi. Byle się tylko nie powoływać na jakieś tam zasady!

Istotnie, zasady krępują, zasady nie pozwalają kraść, rabować, zajmować się ekspropriacją ani w zwykłym znaczeniu tych wyrazów, ani też w zastosowaniu do praw ludzkich i narodowych.

Kieruje więc nami bezwzględny „oportunizm” jako jedyna korzystna zasada. No ale czy też istotnie korzystna? Otóż zdaje mi się, że uprawiany przez naszych „egoistów narodowych” oportunizm jest niekorzystny nawet z ich własnego stanowiska. Bywają wypadki, kiedy największym i najkorzystniejszym oportunizmem jest brak wszel- 
kiego oportunizmu, tj. właśnie stanie na niewzruszonych zasadach i powoływanie się na zasady.

Zasługuje na zaznaczenie, że i p. Niemojewski zachorował w ostatnich czasach na ostry zasadowstręt. W artykule Liberalizm rosyjski a my („MN”, nr 154) naigrawa się on z „kadetów” i innych „liberałów” rosyjskich właśnie za to, że śmią się powoływać na zasady. Że przy tym dla wywołania efektu zabarwiono przytaczane fakty w sposób odpowiedni, rozumie się samo przez się.

Ja osobiście należę do naiwnych i niepoprawnych „marzycieli”, którzy nie mogą rozpatrywać żadnej kwestii tego rodzaju bez związku z pewnymi ogólnymi zasadami logicznymi i etycznymi. Chodzi mi zaś przede wszystkim o spokojne i znośne współżycie ludzi grupujących się pod różnymi sztandarami wyznaniowymi, narodowościowymi, zawodowymi i innymi. Zasady te przeprowadzałem w całym szeregu broszur i artykułów. Na ich czele muszę postawić artykuł-broszurę Ze zjazdu autonomistów, czyli przedstawicieli narodowości nierosyjskich (Kraków 1906), która jako artykuł w „Krytyce” zasłużyła sobie na szczególne względy ck prokuratorii, a dopiero w postaci osobnej broszury, dzięki interpelacji posła Daszyńskiego i tow., została zimunizowaną.

Następnie mogę wymienić: Z powodu jubileuszu profesora Duchinskiego (Kraków 1886), Cenzurnyje „mietoczi”. I. Kniaz’ Bismark i gonienije „Stawian” (Kraków 1898) (po rosyjsku), Myśli nieoportunistyczne (Kraków 1898), 0 zjeździe slawistów i o panslawizmie "platonicznym” (Kraków 1903), Kwestia polska w Rosji $w$ zwiazku z innymi kwestiami kresowymi i "innoplemiennymi" (Kraków 1905, odbitka ze „Świata Słowiańskiego”), Projekt osnownych potożenij dla rieszenija polskogo woprosa (Petersburg 1906) (po rosyjsku), Autonomia Polski (Kraków 1907), W sprawie porozumienia sie ludów stowiańskich (Warszawa 1908).

Do tego samego celu przeprowadzenia równouprawnienia wszystkich narodowości w państwie rosyjskim i ich zgodnego pożycia bez gryzienia się w imię jakichś haseł nadziemskich dążył powstały w końcu r. 1905 Związek Autonomistów-Federalistów, jak to widać z ułożonego przy moim współudziale projektu jego ustawy. 
Dla „polityka praktycznego” wszystko to są mrzonki i sny na jawie. Sądzę jednak, że tylko wcielenie w życie takich idei może zapobiec coraz większemu napięciu wzajemnej nienawiści i ostrzenia zębów krwiożerczych bestii dwunogich, ażeby je zapuścić w ciało „bliźniego".

\section{X}

Próba postawienia kwestii i jej rozwiązania teoretycznego zgodnie z zasadami

Są dwa patriotyzmy:

1. Patriotyzm bandytów i ekspropriatorów międzynarodowych, tj. patriotyzm nacjonalistyczny, z hasłem „egoizmu narodowego”, z hasłem wzajemnego tępienia się dwunogich różniących się wyznaniem, językiem, tradycjami, przekonaniami, patriotyzm zamieniający „ojczyznę” na więzienie skazańców, na klatkę różnogatunkowych dzikich zwierząt, na piekło zaludnione przez opętańców nacjonalizmu.

2. Patriotyzm terytorialny pod hasłem równouprawnienia wszystkich obywateli wspólnej ojczyzny, wszystkich różnowierzących, różnojęzycznych, różnoprzekonaniowych, pod hasłem solidarności w imię wspólnej pracy na korzyść wspólnej ojezyzny w zakresie dóbr doczesnych i tu na ziemi osiągnąc się dających.

Przy panowaniu patriotyzmu nacjonalistycznego żyje się dobrze tylko podszczuwaczom i nawoływaczom do pogromów albo przynajmniej do prześladowań innych wyznań i narodowości. Masy zaś dwunogie gryzą się i stwarzają sobie piekło na ziemi. Doskonale da się tu zastosować powiedzenie Napoleona I, że człowiek jest to bydlę potrzebujące bata i wymagające, ażeby je od czasu do czasu prowadzić na polowanie. Ten patriotyzm nacjonalistyczny sroży się w sposób mniej lub więcej gwałtowny we Francji, we Włoszech, w Niemczech, w Madziarii, zwanej pospolicie Węgrami, w Rosji...

Solidarność państwowo-społeczna, czyli patriotyzm terytorialny, działa uspokajająco na bestię ludzką i pozwala zajmować się sprawami ziemskimi w Ameryce Północnej, w Szwajcarii. Austria zaś jest typowym przykładem brużdżenia instynktów nienawiści mię- 
dzyplemiennej w sprawie spokojnego współżycia narodowości różnojęzykowych. Możliwość znośnego współżycia zawarunkowana jest w większości prowincji Austrii jedynie przejęciem się ich mieszkańców solidarnością terytorialną, przy zachowaniu oczywiście swych właściwości plemiennych i narodowych.

Państwa polskiego nie ma obecnie. A jednak, o ile się posiada samorząd i pewne funkcje państwowe albo też o ile się marzy o własnej państwowości, przybiera ona postać państwa narodowościowego z żądzą panowania nad niewolnikami różnojęzykowymi. Ludzi uznających zasadę równouprawnienia jest nierównie mniej.

Rzecz prosta, iż patriotyzm terytorialny i równouprawnienie wszystkich obywateli różnojęzykowych na podstawie uznania ich godności osobistej i prawa do rozporządzania swym światem wewnętrznym nie zamieni padołu płaczu na raj ziemski i nie usunie walk między ludźmi. Tak, ale będą to walki, ścierania się i objawy konkurencji w imię haseł ziemskich, w sferze interesów ekonomicznych. Takie walki mają sens i rację bytu ze stanowiska teraźniejszości. Nie mają zaś najmniejszego sensu walki pod hasłem „gorzkich żalów” i rozsmakowywania czyichś męczeństw sprzed paru tysięcy lat.

Wystarczy wymagać od wszystkich obywateli pełnienia obowiązków związanych z danym terytorium, pozostawiając im zresztą zupełną swobodę przekonań i propagandy pokojowej tych przekonań. Niestety, niektóre z tych obowiązków, jak np. obowiązek należenia do potencjalnych zabójców wytresowanych i umundurowanych, kłócą się z poczuciem etycznym; no, ale na to tymczasem nie ma rady, z wyjątkiem chyba oporu biernego.

Ze stanowiska równouprawnienia i solidarności terytorialnej rozstrzyga się bardzo prosto paląca obecnie kwestia udziału Żydów w samorządzie miejskim Królestwa Polskiego. Osobna kuria żydowska, jak i wszelkie inne kurie narodowe lub wyznaniowe, przy sądzeniu o sprawach ziemskich nie da się w uczciwy sposób usprawiedliwić, a jej utworzenie objaśnia się albo złością, albo też głupotą ludzką. Takie załatwienie kwestii nie może wyjść na pożytek krajowi. 


\section{XI}

Wychowanie młodzieży zgodnie z „zasadami”

Dotychczas wychowujemy młode pokolenie pod wpływem sugestii przesądów wyznaniowych. Skutkiem tego ludzie różnowyznaniowi albo muszą się wzajemnie ignorować, albo też, w razie starcia się ich wierzeń i „przekonań” wyznaniowych, dają widowisko opisane w Disputation Heinego. Który z nich ma stuszność, trudno powiedzieć; ale że obaj smierdza, to nie ulega najmniejszej watpliwości.

„Polskość a katolicyzm - to jedno”, „polskość a częstochowska Jasna Góra - to jedno". Pierwszy z tych aforyzmów przyjmują za punkt wyjścia swych polemik nawet „myśliciele niepodlegli” i ,antysemici postępowi”.

A tymczasem jest to po prostu złudzenie optyczne czy też w ogóle myślowe, powstałe skutkiem długoletniej i wielopokoleniowej tresury i sugestii, w związku z rozpaczliwym pomieszaniem pojęć. Dzięki podobnemu pomieszaniu pojęć zrodził się także przesąd, że azbuka rosyjska i prawosławie są nieodłączne od narodowości rosyjskiej.

Pierwszym niezbędnym krokiem do złagodzenia przeciwieństw i do uobywatelnienia wszystkich mieszkańców kraju pod hasłem solidarności terytorialnej powinno byé zniesienie wszystkich szkół wyznaniowych, przy czym wyznaniowość pojmuję w jak najszerszym znaczeniu tego wyrazu. Jest to nie tylko wyznaniowośé ściśle religijna, głosząca wyższość własnego wyznania i jego prawo do panowania nad innymi, ale także wyznaniowość narodowościowa, głosząca wyższość własnej narodowości i jej prawo do panowania nad innymi. Wychowanie powinno byé nie „narodowe”, ale tylko obywatelskie.

Zastrzegam się przeciwko nieporozumieniu. Postawiona przeze mnie zasada nie wyklucza weale przywiązania do własnej narodowości i bronienia jej przed napaściami ze strony innych. Przeciwnie, dla mnie punktem wyjścia jest godność osobista, godność ludzka, a godność ta jest ściśle związana z bronieniem wszystkiego, co się uważa za swoje.

Dlatego też szkoły powinny być prowadzone w języku własnym ludności danego kraju lub też jego części. Żadne inne języki nie mają 
prawa przeszkadzać własnemu językowi. Jaki zaś język uznaje się za własny, rozstrzyga wola samych mieszkańców.

A więc znoszą się wszelkie szkoły wyznaniowe, czy to żydowskie chedery, czy też gimnazja i inne szkoły z zabarwieniem katolickim lub innym temu podobnym. Usuwa się ze szkół zwykła nauka religii jako jedynie jątrząca, rozwijająca nienawiść do innych wyznań i obłęd wielkości własnego wyznania. Zwykła nauka religii jest szkodliwa jeszcze z tego powodu, że ma pretensje do decydowania o kwestiach z zakresu wszystkich nauk, wbrew nowszym odkryciom i poglądom. Kwestie higieny, stosunków społecznych, ekonomii politycznej itd. stanowią przedmiot roztrząsań różnych ksiąg wyznaniowych, przedstawiających dla dzisiejszej nauki jedynie zabytek historyczny, a nie zbiór przepisów racjonalnych. Obok chederowego traktowania dziejów i panowania pogladów, godnych metamedów, o których wspomina p. Niemojewski („MN”, nr 146, nr 1250, art. Demokratyzm), mamy także „katolickie traktowanie dziejów i panowanie poglądów godnych jezuitów” i inne tp.

Jeżeli w szkołach może być bez szkody dla umysłowości i uczuć etycznych dopuszczony wykład religii i historii wyznań religijnych, to jedynie pod warunkiem ich krytycznego traktowania w sposób wskazany przeze mnie w broszurze Ze zjazdu autonomistów, czyli przedstawicieli narodowości nierosyjskich (Kraków 1906, str. 24$-26)$.

Oczywiście wyłączna wyznaniowość, zasklepienie się w raz utartych formułkach i dzikich przesądach oraz bezwzględne unikanie wszelkiej krytyki w daleko wyższym stopniu charakteryzuje mozaizm aniżeli chrześcijanizm w ogóle, a nawet katolicyzm i prawosławie w szczególności. Pod względem jednostronnego fanatyzmu wyznanie żydowskie jest najbardziej wyznaniowym, jest wyznaniem par excellence. Dlatego też muszę uznać słuszność wywodów p. S. Auerbacha w jego artykule Mój antysemityzm („Prawda”, Warszawa 1910, nr 42, str. 8-10). Jeżeli z „antysemityzmem” nawet inteligencja żydowska utożsamia „żydowski antyklerykalizm”, w takim razie i ja jestem antysemitą. Twierdzenie, że „żydowski antyklerykalizm to antysemityzm” jest równoznaczne z twierdzeniem, że „katolicki antyklerykalizm to antygoizm”. Antyklerykali, tj. ludzie walczący z klery- 
kalizmem jako objawem obskurantyzmu wyznaniowego, to najwięksi przyjaciele ludzi, a więc także „Żydów”, „chrześcijan” itd. A że klerykalizm i obskurantyzm wyznaniowy kwitnie nierównie bujniej u „Żydów”, aniżeli u „chrześcijan”, więc przede wszystkim Żydom należy się zniesienie ich szkół wyznaniowych.

W artykule Genialny antysemita - Weininger Leo Belmont mówi między innymi:

Kiedy czytam karty historii żydowskiej, wydaje mi się zawsze, że widzę naród, który zwariował z przestrachu u stóp ziejącej ogniem góry Synajskiej - a potem przechodził w dziejach już tylko różne stadia obłąkania („Wolne Słowo”, nr 106 i 107, str. 17).

Zgadzam się z tym, ale przypominam, że wiele „szaleństw żydowskich" to przecież świętości dla chrześcijan.

W każdym razie wszelkie stadowe tresowanie czy to żydowskie, czy to katolickie i w ogóle chrześcijańskie, uniemożliwia spokojne wspótżycie różnowyznaniowców w imię wyrozumiałości i solidarności wszechludzkiej, uniemożliwia dążenie do jasnego i trzeźwego patrzenia na rzeczy, uniemożliwia wszelką myśl wolną, a więc powinno byé uważane za sprawę prywatną każdej rodziny, a właściwie każdego osobnika usamodzielnionego, w szkołach zaś powinniśmy za przykładem Japonii domagać się zaprowadzenia etyki bezwyznaniowej, rozwijającej uczucia braterstwa obywatelskiego i solidarności zarówno terytorialnej, jak i wszechludzkiej.

Uzupełniam to jeszcze jedną uwagą.

Wychowując nowe pokolenia, powinniśmy starannie unikać bezkrytycznego ubóstwiania jakichkolwiek bądź świętości czy to wyznaniowych, czy też narodowych. Widzieliśmy w ostatnich czasach, do czego to doprowadziło ubóstwianie ojców paulinów na Jasnej Górze, dzięki głównie ich sławnemu koledze, „bohaterowi narodowemu”, Augustynowi Kordeckiemu. Można śmiało powiedzieć, że Damazy Macoch jest koniecznym następstwem Augustyna Kordeckiego.

Nie trzeba z niczego robić poświęconych prosiąt, czyli, jak się to technicznie nazywa, tabu. W każdym wyznaniu jest mnóstwo takich 
tabu odzwyczajających umysł od rozbioru i krytyki. 0 ile się zdaje, wyznanie żydowskie przoduje tu innym wyznaniom.

Proszę nie myśleć, że ja radzę przeprowadzać proponowaną przeze mnie reformę wychowania metodą Konwentu „wielkiej rewolucji francuskiej”. W obecnych warunkach byłoby to śmieszne, a we wszelkich warunkach dzikie i niemoralne, jak dzikim i niemoralnym jest wszelki gwałt. Jeżeli pewne grupy ludności życzą sobie jeszcze szkół wyznaniowych, niechaj te szkoły wyznaniowe pozostają. Powinny tylko ulegać kontroli, ażeby nie szerzyły jadu nienawiści i zbytnio nie ogłupiały swych wychowańców. Pewna reforma jest więc tu konieczną. Ale obok tych szkół wyznaniowych, utrzymywanych kosztem zainteresowanych, należy zakładać kosztem publicznym i popierać jak najwięcej szkół świeckich i bezwyznaniowych, które z pewnością będą zyskiwały coraz większy wpływ i osłabiały szkodliwość tamtych.

W dzisiejszych czasach są to, niestety, gruszki na wierzbie i senne marzenia na jawie.

\section{XII}

Walka z Żydami

Ajednak,choćbyśmynawetmogliprzeprowadzićrównouprawnienie, uobywatelnienie i sekularyzację, czyli odklerykalizowanie szkót różnowyznaniowych, nie usuniemy jeszcze przez to „kwestii żydowskiej”. Będzie ona sterczała jako groźne widmo, jako zmora, nie tylko niedająca spać przeczulonym „patriotom polskim”, ale także niepokojąca trzeźwych obywateli, dbałych o pomyślny rozwój ekonomiczny i kulturalny kraju. Obecnośé „Żydów” takich jak obecnie, w takiej ilości jak obecnie i w takich warunkach jak obecnie, jest stałym niebezpieczeństwem i narusza równowagę społeczną.

A więc nie ma rady; trzeba się postarać 0 „prawa wyjątkowe” przeciwko Żydom.

Byłoby to jak najfatalniejsze rozwiązanie kwestii, zgubne nie tyle dla „Żydów” wziętych w oderwaniu od społeczeństwa, ile dla 
społeczeństwa rozważanego jako całość osadzona na pewnym terytorium.

Przede wszystkim pamiętajmy, że nie ma ani jednej ciemnej strony życia społecznego, którą by można utożsamić z żydostwem. Różne objawy ujemne, w zacietrzewieniu przypisywane wyłącznie Żydom, spotykają się także u „chrześcijan”, czyli „Polaków”. Różnica jest tu jedynie ilościowa, statystyezna, nie zaś jakościowa, zasadnicza.

Wobec tego należy zło leczyé nie „prawami wyjątkowymi”, skierowanymi przeciwko Żydom, ale prawami ogólnymi, wymierzonymi przeciwko występkom, nadużyciom i złym stronom życia.

Tak np. nie ulega wątpliwości, że Polska cierpi bardzo od nadmiaru ludności żydowskiej, nic nieprodukującej, a żyjącej byle jak, jak to mówią, psim swędem. Ależ przeludnienie objawia się także u ludności „chrześcijańskiej”; mnóstwo ludzi nie ma żadnego zarobku, żyje w nędzy, stanowi lumpenproletariat i element pasożytniczy. Chcąc zaradzić złemu, należy z jednej strony odkrywać nowe pola pracy, nowe źródła zarobku, z drugiej zaś strony ułatwiać wychodźstwo i osiedlanie się w innych krajach.

Nadmierne skupienie Żydów na ziemiach polskich i sąsiednich jest w znacznej części skutkiem istniejącej dotychczas w Rosji „linii osiedlenia” (czerta osiodtosti) Żydów. Otóż rzeczą obywateli, dbałych nie tylko o usunięcie tej barbarzyńskiej niesprawiedliwości, ale także o dobrobyt kraju i całego państwa, jest domagać się zniesienia drogą prawodawczą tego jedynego w swoim rodzaju ghetta. Trudno na to liczyé przy obecnej reakcji i przy istnieniu w Rosji takich jak teraz izb prawodawczych; ale przecież okoliczności mogą się zmienić na lepsze, a cierpliwość i wytrwałość są cnotą zasadniczą działaczy spotecznych.

Żydzi w masie są brudni i niechlujni, zanieczyszezają domy, w których mieszkają, zanieczyszczają ulice, zanieczyszczają całe miasteczka. Brud i niechlujstwo „Żydowskie” razi niemile każdego, komu wypada jeździć w wagonach trzeciej klasy na niektórych liniach kolei żelaznej. Ależ wszelki brud nie tylko „żydowski”, budzi wstręt i obrzydzenie. Otóż z tym złem należy walczyć wytrwale i metodycznie, uchwalając jak najsurowsze przepisy przeciwko brudasom i niechlujom. Kto zanieczyszcza mieszkania, podwórza, ulice, place publiczne 
- płaci wysokie grzywny. Do wagonów kolejowych nie wpuszcza się osobników brudnych i śmierdzących; co najwyżej, można by mieć dla nich osobne wagony, jak dla bydła. Jestem przekonany, że ścisłe stosowanie takich przepisów usunie w ciągu kilku lat brud i niechlujstwo w ogóle, a żydowskie w szczególności. Tylko że w Rosji, przy właściwym jej łapownictwie i organicznym bezprawiu, o czymś podobnym nawet marzyć niepodobna.

Mnóstwo Żydów jeździ kolejami żelaznymi „na gapę, tj. opłacając tylko niewielki haracz administracji kolejowej. Ależ na gapę moga jeździć i jeżdżą także „chrześcijanie” i rdzenni Polacy, a znowu wszyscy korzystający przy tym z opłat zarówno „żydowskich”, jak i „chrześcijańskich”, wszyscy konduktorzy, nadkonduktorzy, kontrolerzy, naczelnicy stacji, żandarmi itd. są przecież „chrześcijanami”, a nawet prawie wyłącznie „aryjczykami”. Z jeżdżeniem na gapę można walczyć nie prawami wyjątkowymi przeciwko Żydom, ale tylko prawami ogólnymi przeciwko złodziejom i łapownikom. Przy endemicznym jednak łapownictwie i przy nędznym uposażeniu funkcjonariuszy kolejowych mowy o tym również być nie może.

Wielu „Żydów” zajmuje się lichwiarstwem. To prawda; ależ lichwiarstwem zajmuje się także niepoślednia ilość jak najprawowitszych „chrześcijan”. Na tę chorobę są dwa lekarstwa: 1) prześladować surowo lichwiarzy bez względu na ich pochodzenie; 2) „bojkotować” lichwiarzy, tj. nie zaciągać pożyczek lichwiarskich. Ażeby umożliwić „bojkotowanie”, potrzeba zmienić warunki materialne i skłonności wrodzone bardzo wielu obywateli i obywatelek; o tym zaś chyba mowy być nie może.

„Żydzi” utrzymują szynki i „rozpajają” lud. Ależ gdzie nie ma Żydów, szynki również istnieją i lud bywa rozpajany. Jest to więc zło niezależne od pochodzenia wyznaniowego, a walczyć z nim można także zarówno drogą prawodawczą (np. przez ograniczanie liczby szynków a nawet całkowite ich zniesienie), jako też za pomocą propagandy antyalkoholizmu. Jeżeli ludzie przestaną pić, szynki same przez się upadną, a więc znikną także „szynki żydowskie”.

„Żydzi” zajmują się rajfurstwem i handlują żywym towarem. Przepraszam, czynią to także najpobożniejsi „chrześcijanie” i rdzenni „Polacy”. Usuwać tę zbrodnię endemiczną można tylko bardzo powoli. 
Trzeba zmieniać naturę ludzką, trzeba ją uszlachetniać - a jak tu mówić 0 uszlachetnianiu wobec panującej nędzy, zdeprawowania i tylu pokus czyhających na nas na każdym kroku? Drogą prawodawczą należałoby przeprowadzić jak najsurowsze kary na handlarzy żywym towarem - przede wszystkim pozbawienie praw osobistych i majątkowych. Ale przecież w tym szlachetnym procederze mocno jest zainteresowana policja ciągnąca z niego niepoślednie zyski. Oczywiście mówię tu 0 policji nie we wszystkich krajach i nie 0 wszystkich policjantach.

W ten sposób należy walczyć ze wszystkimi zdrożnościami, w których szczególniej mają celować „Żydzi”, ale które nie są również obce najprawowitszym „chrześcijanom”.

Do tego trzeba dodać podniesienie ogólnego poziomu oświaty, umoralnienie, uszlachetnienie mas, rozwinięcie poczucia godności osobistej i zdolności władania sobą, uwolnienie od wpływu wielebnych ojców Damazych Macochów wszelkich wyznań, a na ogólnym tle zmienionych warunków życia społecznego także ostrze kwestii żydowskiej znacznie się przytępi.

Niechaj „antysemici postępowi” przyłączą się do akcji w tym kierunku, a przyniosą pożytek społeczeństwu, nie potrzebując się uciekać do szezucia i podjudzania.

\section{XIII}

\section{„Litwacy”}

Tylko „litwacy”, nie zaś „socjallitwacy”. Ta ostatnia nazwa jest wyzwiskiem nietrafnym i niesprawiedliwym.

Istotnie, Królestwo Polskie w ogóle, a Warszawa w szczególności zostały zalane w ostatnich czasach powodzią Żydów uciekających tam po części przed pogromami, po części owczym pędem z bliższych i dalszych guberni Rosji. Żydów tych przezwano „litwakami”.

Nikt chyba nie odważy się twierdzié, że wszyscy bez wyjątku „litwacy” zachowują się wrogo wobec polskości. Znaczny jednak ich procent odznacza się niezwykłą arogancją i postępowaniem wyzywającym. 
Oto np. do sklepu polskiego, może nawet utrzymywanego przez Żyda z dawna tu osiadłego, wchodzi „litwak” i przemawia po rosyjsku. Odpowiadają mu po polsku. „Litwaka” to oburza:

Czto za biezobrazje! Wied' zdies' Rossija; ja zagawariwaju po russki, a mnie otwieczajut na kakom-to czużom jazykie! (Co za bezczelność! Przecież tu Rosja; ja zaczynam mówić po rosyjsku, a mnie odpowiadają w jakimś obcym języku!).

Istotnie, można stracić zimną krew, można się oburzyć i przy braku krytycyzmu i rozwagi posunąć się w kierunku antysemityzmu. Sądzę jednak, że nie należy psuć sobie krwi, a takiemu „iście rosyjskiemu” „litwakowi” wystarczy powiedzieć:

- Szanowny jegomość, tu jeszcze nie Rosja; jeszcze wam tu pogromów nie urządzają. Wprawdzie w Siedlcach był pogrom, ale przecież urządzał go podpułkownik rdzennie rosyjski, Tichanowskij, na czele wojska rosyjskiego, nie polskiego. Wprawdzie istnieją tu dla was procenty szkolne i inne ograniczenia; ograniczenia te jednak wprowadzili nie ludzie, mówiący tak wam wstrętnym „obcym językiem”, ale ukochani przez was „prawdziwi Rosjanie”, w których imieniu występujecie i których sprawy bronicie. Kiedy zaś antysemici zarówno postępowi, jak i niepostępowi, spełnią swe obietnice i urzeczywistnią groźbę, że to, co idzie wielkimi krokami, istotnie już przyjdzie, wtedy będziecie mieli prawo wymagać, ażeby do was tu, w Polsce, przemawiano po rosyjsku.

Oburzać też może ludzi gorących i przeczulonych, że np. w Warszawie „litwacy”, kupcy i rzemieślnicy, wywieszają szyldy tylko rosyjskie albo też rosyjskie obok żydowskich, zupełnie ignorując język polski. Oczywiście wolnoć Tomku w swoim domku; wolno też „litwakowi” usuwać język polski z szyldu nad własnym sklepem lub warsztatem. Krzyczeć z tego powodu „huzia na Żyda!” stałoby na równi ze zmuszaniem przez policję do umieszczania napisów rosyjskich na szyldach w Królestwie Polskim. Jeżeli zaś kogo irytuje podobne lekceważenie polskości, niechaj ignoruje takiego pana jako kupca lub rzemieślnika. Oczywiście daje on poznać, że nie życzy sobie kundmanów ${ }^{1}$, przywiązujących wagę do języka polskiego.

1 Kundman - klient. 
Tak więc i z „litwakami” można sobie dać radę, pozostawiając tymczasem na boku zarówno „miłość bliźniego” z przyległościami, jako też „asymilację” i „odżydzanie”.

\section{XIV}

\section{Zakończenie}

Jestem ogromnie zły na siebie za stracenie tylu godzin czasu na tę kwestię, za napisanie rozwlekłego artykułu i za nudzenie czytelnika. Do tego dołącza się obawa, że mogę się wydać „politykiem praktycznym” i rwącym to, co się da urwać w danej chwili, dziecinnym albo też zdziecinniałym marzycielem roztaczającym swe wizje i mrzonki zamiast rad mogących być urzeczywistnionemi.

Otóż bronię się. Wizje wizjami, mrzonki mrzonkami, ale zasady zasadami. Sądzę, że działanie, nawet polityczne, nieoparte za zasadach i pozbawione związku z ogólnym tłem dziejowym i społecznym, nie może dać trwałych rezultatów. To, co ja tu pozwoliłem sobie wywodzić szeroko i długo, nie da się oczywiście urzeczywistnić w najbliższej przyszłości. Może być jednak postawione jako odległy cel, prawdopodobnie nigdy całkowicie osiągnąc się niedający. Dążenie jednak do podobnego celu, oparte na niewzruszonych zasadach, daje rękojmię, że się nigdy nie potkniemy i nie staniemy w sprzeczności z wymaganiami etyki.

A to także jest chyba coś warte.

Jestem też najmocniej przekonany, że wierność zasadom pozwoli nam od czasu do czasu zdobyć niejedną pozycję i osiągnąć korzyści realne.

Jedna korzyść jest niezaprzeczona i nie ulega najmniejszej wątpliwości. Oto Żyd równouprawniony, Żyd, któremu na ziemi polskiej wolno będzie pozostawać Żydem, z którego nikt nie będzie się z tego powodu wyśmiewał, którego nikt nie będzie za to prześladował, którego nikt nie będzie zmuszał do przebierania się za „Polaka”, będzie się czuł na tej ziemi jak u siebie i przez wdzięczność za tę wolność, powoli i mimo woli stanie się Polakiem, jeżeli nie narodowościowo, to przynajmniej terytorialnie. A to nam powinno wystarczyć. 
Pamiętajmy, że Niemiec Kalkstein był gorącym patriotą polskim.

[Kraków 1911. Odbitka z „Krytyki”. Nakładem autora]

1 Z listu Baudouina do W. Feldmana, z Petersburga 27 XII 1910 (9 I 1911 r.): [...] Jednocześnie wysytam rękopis... przerażajacy. Jestem zty na siebie. Zawsze sie dam skusić, a potem żatuje. Tak oto i teraz. Robota zabrata mi wiele czasu, oderwata mie od moich zajęć specjalnych, nie sprawiata najmniejszej przyjemności, a ostatecznie rozrosta sie tak straszliwie, ze nie wiem, czy Pan będzie mógt z niej skorzystać. [...] Jest to cate, mocno nieudatne studium o "antysemityzmie postepowym" w zwiazku z kwestia żydowska w ogóle. Nie wiem, jak Pan spojrzy na te robote, czy ja Pan zużytkuje. Gdyby nie, miatbym dobra nauczke, że nie należy się brać do rzeczy, w których sie jest profanem. [...]. J. N. B a u d o u in d e C o u r t e nay, Listy..., s. 69. 


\section{KWESTIA ŻYDOWSKA W PAŃSTWIE POLSKIM}

\section{Uwaga przedwstępna}

Na broszurę tę złożyły się moje odczyty, które w sprawie żydowsko-polskiej wygłaszałem w ostatnich czasach w Łodzi, w Łomży i w Warszawie. Nie powtarzałem ich dosłownie; ale tu oczywiście nadałem im jednolitą postać. Do tego ujednostajnionego odczytu miałem zamiar dodać kilkanaście artykułów bądź to ogłoszonych w pismach warszawskich i łódzkich, bądź też nawet z tych lub owych powodów niemogących być ogtoszonymi, a dotyczących kwestii żydowskiej w państwie polskim. Chciałem bowiem w ten sposób sprawę tę dla siebie osobiście wyczerpać i więcej już do niej nie powracać, gdyż zdaje mi się, że dalsze jej poruszanie przeze mnie byłoby jałowym rzucaniem grochu na ścianę. Wobec strasznej drożyzny wszelkich wydawnictw, urzeczywistnienie tego zamiaru okazało się bezwzględnie niemożliwym. Zamiast przedrukowania owych artykułów podaję w Bibliografii ich tytuły. Odsyłacze do tekstu podaję nie pod każdą stroną osobno, ale wszystkie razem na końcu ${ }^{1}$.

Zwykła tolerancja mnie nie zadawalnia. Żądam zupełnego i bezwzględnego równouprawnienia wszystkich bez wyjątku wspótobywateli każdego państwa i wszysstkich bez wyjątku ludzi w wielkiej rzeczypospolitej wszechświatowej. Rzecz prosta, że do wspótobywateli i do ludzi zaliczam także Żydów.

W końcu października r. 1918 miałem wykład wstępny w Uniwersytecie Warszawskim. Chociaż w wykładzie tym o Żydach nie tylko ani jednym słówkiem nie wspomniałem, ale nawet 0 nich ani razu nie pomyślałem, pomimo to niektóre organy stronnictwa utożsamiającego siebie z Polską i polskością i uważające siebie za jedynie uprawnione do przemawiania w imieniu upaństwowionego narodu polskiego, nazwały mię żydolubem na katedrze, rozgorzały świętym oburzeniem i domagały się od władz polskich, ażeby przez usunięcie

1 Zachowuję te odsyłacze, ujmując je w nawiasy kwadratowe - M.S. 
mnie z Uniwersytetu uniemożliwiły mi szkodliwy wpływ na młodzież uczącą się i na społeczeństwo w ogóle. Tym bardziej oczywiście muszą być traktowane w ten sposób moje wyraźne wystąpienia w sprawie żydowskiej oraz w sprawach innych „mniejszości narodowych”. Szlachetni „patrioci” i rycerze narodowego kościoła wojującego nie szczędzą mi kłamliwych oszczerstw, plugawych obelg i zaliczania mnie do wrogów Polski.

Mnie osobiście bardzo mało to wzrusza. Przeciwnie, moge być z tego dumny; znajduję się bowiem we wcale dobranym towarzystwie. Przecież obryzguje się jadowitą śliną i odsądza się od czci i wiary nawet tych ludzi, bez których działalności nie byłoby prawdopodobnie Polski dzisiejszej i nie wolno byłoby bezkarnie napadać w sposób zuchwały i zajadły na przedstawicieli państwa i na inne władze naczelne polskie, ale stałoby się na tylnych łapkach i podlizywałoby się władzom zaborczym i okupacyjnym.

Jeżeli zaś napadani i lżeni zachowują się wobec napastników i oszczerców spokojnie i obojętnie, to nie jest to wcale objawem ich „gruboskórności”, jak głoszą zarówno szlachetne osobniki, ćwiczące się w sporcie fałszerstw i oszczerstw, jako też idące za nimi na oślep naiwne stado ich zwolenników i wyznawców. Napastowani i lżeni nie reagują na ujadania i oszczerstwa po prostu w imię bezwzględnej wolności słowa. Guarda e passa (patrz i idź dalej). Der Hund bellt und die Karavane marschiert (Pies szczeka, a karawana kroczy naprzód). Wolnoć psu na Pana Boga szczekać.

Zresztą o ile to mnie osobiście dotyczy, posądzanie mnie 0 „żydolubstwo" nie ma najmniejszej podstawy realnej i dla tego nie przyjmuję na swój rachunek ani skierowywanych w moją stronę wymysłów i połajanek, ani też wypowiadanych z tego powodu pod moim adresem zachwytów i komplementów.

Nie czuję w sobie specjalnego żydowstrętu ani też nie jestem zakochany w żydostwie. Co najwyżej czuję wstręt ideowy i odruchowy do głupoty i podłości ludzkiej, bez względu na to, czy wytryskaja one z głów i serc semicko-żydowskich, czy też z głów i serc aryjskochrześcijańskich.

Nie jestem ani „żydolubem”, czyli ,judofilem”, ani też „żydożercą” czyli „judofobem” lub nawet ,judofagiem”. I w ogóle nie jestem 
ani „człowiekolubem”, czyli „antropofilem”, ani też „człowiekonienawistnikiem”, czyli „antropofobem” lub nawet „człowiekożercą”, czyli „antropofagiem”. Moimi sądami o sprawach ludzkich nie kieruje ani miłość, ani nienawiść. Do znakomitej większości ludzi, włączając do tej czcigodnej kompanii także własną osobę, mogę czuć tylko pogardę.

Uczucie pogardy wywołują ci, co wszczynali wojny zaborcze i pędzili na rzeź całe stada ludzkie bez krzty litości dla cierpiących z tego powodu istot ludzkich. Ale obok tego uczucie pogardy ogarnia na widok tych stad baranich, bezmyślnych i pozbawionych poczucia godności, a dających się prowadzić na rzeź, nie wiadomo za co i po co, i uczestniczących bez oporu i bez szemrania we wszechświatowych jatkach ludzkich. Uczucie pogardy budzą obłudni głosiciele szczytnych haseł, błogosławiący rękę popełniającą na komendę różnorakie zbrodnie przeciw podstawowym przykazaniom boskim i ludzkim. Tylko uczucie pogardy można żywić zarówno dla tych, co świadomie fałszują i oszukują, jako też dla tych, co dzięki swej bezdennej głupocie i łatwowierności dają się oszukiwać i przez szacunek dla słowa drukowanego wierzą najbezczelniejszym kłamstwom. Jak tu nie pogardzać tym bydłem dwunogim, tą zgrają bezmyślną, zgrają, która zamiast wspólnie walczyć z przyrodą i w imię solidarności wszechludzkiej opanowywać i zużytkowywać ją dla wspólnych celów ogólnoludzkich, pod różnokolorowymi sztandarami, „w imię idei”, w imię bzdurnych górnolotnych hasel, dla dogodzenia chciwości i próżności różnych ambitników i bandytów wszechświatowych gryzie się zaciekle między sobą, tępi się nawzajem bez litości i niszczy bezmyślnie wielowiekowe dorobki cywilizacji?

Ale ponieważ wszystko to są nędzne bezwolne robaki pozbawione trzeźwego myślenia i silnych podstaw moralnych, więc ich zachowanie się i postępowanie wzbudza obok uczucia pogardy także uczucie głębokiego politowania.

Tak zwana „miłość bliźniego”, głoszona cynicznie przez obłudników różnowyznaniowych, zakrawa na ironię i jaskrawo odbija od jej urzeczywistniania, którego jesteśmy świadkami od niepamiętnych czasów, a zwłaszcza podczas wojny światowej i wściekłej rewolucji 
aż do chwili obecnej. Powoływanie się ziejących nienawiścią obłudników na „miłość bliźniego” wzbudza we mnie wstręt i obrzydzenie.

Czyż nie lepiej więc byłoby wstrzymać się od wszelkiego mieszania się do spraw bieżących, stać sobie na uboczu i kierować się wygodnym hasłem: moja chata s kraju, nyczoho ne znaju. Coś jednak jak gdyby korci i pociąga do zabierania głosu w tych różnych sprawach społecznych i narodowych, między innymi także w kwestii żydowskiej. Przy tym łudzi się człowiek nadzieją, że może wpłynie na zmianę zapatrywania choćby bardzo niewielkiej liczby osób i w ten sposób będzie współdziałał stopniowemu uspokojeniu i zgodnemu współżyciu obywateli tego samego obszaru państwowego.

Pozostawiając wszelkie „kochajmy się” gardłującym i śliniącym się opojom, kieruję się nie obłudnie głoszoną „miłością bliźniego”, ale tylko pragnieniem możliwego do osiągnięcia szczęścia i dobrobytu wszystkich ludzi na całej kuli ziemskiej w ogóle, a szczęścia i dobrobytu w najbliższym otoczeniu, więc w danej chwili w Polsce w szczególności. Przecież od poprawy stosunków w najbliższym otoczeniu i mnie też może być lepiej. A gdyby najbliższe otoczenie stało się jednym z ognisk, z którego rozchodzą się hasła współpracy dla dobra wszystkich, bez różnicy pochodzenia i zabarwienia stadowego, można by być dumnym za to swoje otoczenie.

I to jest mój egoizm narodowy!

Oczywiście mało nadziei na zmianę poglądu w głowach ludzi przywykłych do pewnych nałogów myślowych, zwłaszcza w czasach powojennych, w czasach ogólnego upadku intelektu i moralności. Możemy liczyć co najwyżej na minimalne wpływy, jako przyczynki do stopniowej ewolucji myśli w ciągu całego szeregu pokoleń. Ale jeżeli niepodobna spodziewać się bezpośredniej korzyści dla samych siebie i dla spółczesnego pokolenia, można się pocieszać myślą o naszych potomkach, którzy będą żyli w szczęśliwszych warunkach, rozkoszując się uspokojeniem zażartej walki między różnoimiennymi zbiorowiskami ludzkimi i spokojnym spółżyciem tych różnoimiennych zbiorowisk ludzkich.

I to jest mój altruizm zarówno narodowy, jako też wszechludzki! 
Po długotrwałej przerwie, po wielu latach nieobecności państwa polskiego na arenie dziejowej dziś dopiero zjawia się po raz pierwszy kwestia żydowska w państwie polskim. Przedtem istniała ta kwestia w trzech różnych państwach, które rozdzieliły między siebie spuściznę polską.

Przed upadkiem państwa polskiego istniała w nim oczywiście także kwestia żydowska, którą starało się rozwiązywać prawodawstwo polskie i społeczeństwo polskie. Różnie się na nią zapatrywano. Obok niewielu zajadłych antysemitów zajmowali się tą sprawą ludzie umiarkowani i zapatrujący się także na nią ze stanowiska ogólnie obywatelskiego.

W ostatnich latach chylącej się ku ostatecznemu upadkowi Rzeczypospolitej Polskiej jeden z zażartych antysemitów ówczesnych wystąpił z projektem radykalnego rozważania i ostatecznego pogrzebania kwestii żydowskiej. Oto domagał się, ażeby za pomocą odpowiedniej operacji Żydów mężczyzn uniemożliwić temu szkodliwemu i znienawidzonemu plemieniu reprodukcję, tak że z życiem pojedynczych Żydów, zakażających wówczas swym oddechem czystą atmosferę rdzennej polszczyzny, skończyłoby się też istnienie całej tej wstrętnej „mniejszości narodowej”. Żydówki byłyby oddane do użytku właścicieli rdzennych. Oczywiście ręka w rękę z podobnym zarządzeniem musiałby iść bezwzględny zakaz przekraczania granic Polski przez Żydów zagranicznych. Wytępiwszy bądź to szczury i myszy, bądź też karaluchy i prusaki we własnym mieszkaniu, powinniśmy zapobiegać przedostawaniu się ich do nas z cudzych mieszkań.

Niestety znakomita większość prawodawców Polski upadającej nie dała posłuchu świattym i wysoce etycznym radom tego „chrześcijanina” i prawdziwie polskiego „patrioty”. Przeciwnie, Konstytucja 3 maja chociaż nie dała Żydom pełnego równouprawnienia, to jednak uznała ich poniekąd za obywateli Polski pośledniejszego gatunku i zniosła niektóre ich privilegia odiosa, tj. przywileje in minus, przywileje krzywdzące.

Konstytucji 3 maja nie było sądzonym wejść w życie. Jej miejsce zajęły prawodawstwa trzech państw, które rozdarły Polskę i które były z początku bardzo dalekie od uznania Żydów za pełnoprawnych obywateli. 
W ciagu ostatnich lat wieku XVIII, przez cały wiek XIX i przez 18 lat wieku XX - poza krótkotrwałym Wielkim Księstwem Warszawskim, poza Królestwem Polskim Kongresowym i poza Rzecząpospolitą Wolnego Miasta Krakowa - nie było Polski jako państwa niezależnego; nie było więc też kwestii żydowskiej w państwie polskim. Natomiast była kwestia żydowska w Prusach, w Austrii i w Rosji, a więc także w oderwanych od Polski częściach tych trzech państw.

Dzięki rewolucjom i ewolucjom społecznym dwa z tych państw dały Żydom równouprawnienie obywatelskie, trzecie zaś, Rosja, aż do ostatniego tchnienia praktykowało najrozmaitsze ograniczenia i prześladowania Żydów.

W Prusach i w ogóle w Niemczech, pomimo formalnego równouprawnienia, w rzeczywistości stosowano do Żydów różne ograniczenia i uprawiano otwarcie antysemityzm. Korpus oficerski nie dopuszczał do swego grona Żydów. Między oficerami armii niemieckiej nie było chyba ani jednego Żyda, chociaż żołnierzem musiał być każdy Żyd, na równi z innymi poddanymi cesarza niemieckiego. W niektórych uniwersytetach niemieckich, przede wszystkim w uniwersytetach pruskich, Żyd nie mógł być profesorem zwyczajnym, co prowadziło niekiedy do tragicznych sytuacji i tragicznych rozwiązań.

Austria i Austro-Węgry w ogóle przyznały Żydom zupełne równouprawnienie, Żyd mógł tam być nie tylko oficerem, urzędnikiem sądowym i administracyjnym, profesorem itd., ale również piastować najwyższe godności w państwie, chociaż faktycznie chyba nigdy się to nie zdarzało. Ale uznając zupełne równouprawnienie Żydów jako jednostek, jako pojedynczych obywateli państwa, Austria nie uznawała wcale osobnej narodowości żydowskiej. Przy spisie ludności w Galicji, np. Żyd mógł się podać za należącego do narodowości niemieckiej, polskiej, rusińskiej, francuskiej, arabskiej nawet, ale nie wolno mu było przyznawać się do narodowości żydowskiej, bo w oczach dygnitarzy i biurokratów austriackich taka narodowość wcale nie istniała. Oczywiście był to nonsens i uprawianie małodusznej polityki strusiej.

W Rosji nie tylko lud, nie tylko przeważna część tzw. inteligencji, ale także sfery rządzące odznaczały się wrogim stosunkiem do Żydów 
i otwarcie uprawiały antysemityzm. Nie było tam wcale mowy nie tylko 0 równouprawnieniu, ale nawet o skromnej tolerancji.

Przede wszystkim istniała tam sławetna „linia osiedlenia” (czerta osiodtosti), którą wolno było przekraczać tylko Żydom wyjątkowo uprzywilejowanym, a której zniesienia nie domagali się na serio nawet głoszący równouprawnienie członkowie partii „wolności ludu”, czyli tzw. „kadeci”. Żyd cudzoziemiec, bez Najwyższego, czyli cesarskiego pozwolenia, nie miał prawa przebywać w Rosji dłużej niż 24 godziny. Pewien znakomity przyrodnik amerykański, udający się dla badań naukowych na Syberię, musiał w ciągu dwóch tygodni czekać na okręcie przed Władywostokiem, zanim mu Akademia Nauk wyjednała Najwyższe zezwolenie na postawienie nogi na nieskalanej ziemi rosyjskiej.

W Rosji istniały do ostatnich czasów caryzmu ohydne procenty szkolne, których dzisiejsi swoiści patrioci polscy domagają się dla Żydów w państwie polskim. Rzecz prosta, żaden Żyd nie mógł byé w Rosji oficerem, a szczyty inteligencji żydowskiej, wybitni prawnicy, artyści, autorowie, nauczyciele, pierwszorzędni uczeni, mogli byé tylko szeregowcami i jeździli podczas manewrów lub mobilizacji w bydlęcych wagonach, przeznaczonych dla 8 koni lub 40 dwunogich wojowników. Z gwardii i marynarki Żydzi byli stanowczo wykluczeni. W służbie cywilnej Żyd nie mógł być ani urzędnikiem, ani sędzią, ani nauczycielem, nie mówiąc już oczywiście o karierze uniwersyteckiej.

Cesarz rosyjski i cała rodzina cesarska nie kryła się z nienawiścią do Żydów i współczuła pogromom, urządzanym przy współudziale ministrów i władz gubernialnych. Na podstawie bzdurnych legend o mordzie rytualnym inscenizowano uroczyście proces Bejlisa ${ }^{1}$ [1].

1 Proces Mendela Bejlisa, oskarżonego o dokonanie „mordu rytualnego" na Andrzeju Juszczinskim, toczył się w Kijowie we wrześniu i październiku 1913 r. po trwającym dwa i pół roku śledztwie (Bejlisa aresztowano w czerwcu 1911 r.) Proces ten, nie pierwszy zresztą w Rosji tamtego okresu, do którego doszło na skutek działań m.in. przywódców kijowskiej czarnej sotni oraz ministra sprawiedliwości I. G. Szczegłowitowa, miał miejsce w czasie, gdy III Duma rozważała projekt zniesienia tzw. czerty osiodtosti w Rosji. Co ciekawe, w czasie trwania procesu policja znała już rzeczywistych sprawców zbrodni, kijowskich bandytów. Na polecenie Ministerstwa 
Podczas wojny, po zajęciu Lwowa przez zwycięskie wojska rosyjskie, wywieziono w głąb Rosji cale zastępy Żydów, a w ich liczbie rektora Uniwersytetu Lwowskiego, profesora Becka, którego traktowano jak „Zwykłego Żyda”, a po wywiezieniu do Kijowa umieszczono w chlewie na barłogu, w brudzie i smrodzie.

A jednak dziwną i zagadkową jest psychologia plemienia prześladowanego. Pomimo tych wszystkich znęcań się i prześladowań znaczna część Żydów rosyjskich lgnęła ku Rosji, grała rolę rusyfikatorów i w sporze pomiędzy Polską a Rosją stawała, a nawet dotychczas staje, po stronie tej ostatniej. Psychologia psa smaganego, a jednak liżącego rękę, która go smaga i katuje. Zresztą Żydzi nie potrzebują się rumienić za tę swoją wierność sobaczą. Taką samą psychologią odznaczali się także inni inorodcy, łącznie z Polakami, którzy zarówno przez swych przedstawicieli w Dumie petersburskiej, jako też u siebie, na ziemi ojczystej, stawali entuzjastycznie po stronie cara, po stronie rządu rosyjskiego i po stronie wspólnej ojczyzny Rosji nie tylko przeciwko Niemcom i Austrii, ale także przeciwko legionom Józefa Piłsudskiego, co nawet trwa dotychczas pod postacią „rozwiewania legendy” i pod postacią innych, nie mniej szlachetnych sposobów walki.

$$
* * *
$$

W stosunku do kwestii żydowskiej w państwie polskim, jak i we wszystkich innych państwach, należy rozróżniać jej, tej kwestii żydowskiej, stronę prawnopaństwową a stronę zwyczajową, stronę społeczną. Zwyczaj bywa silniejszy od wszelkich norm prawnych. Zwyczaj urąga wszelkim prawom i przepisom.

Całość kwestii żydowskiej w państwie polskim rozpada się na trzy główne działy:

1. Unormowanie położenia Żydów przez konstytucję i związane z nią prawa i przepisy.

Sprawiedliwości zostali oni uwolnieni. Ostatecznie Bejlis został uniewinniony i wyemigrował z rodziną najpierw do Palestyny, potem do USA, gdzie w $1926 \mathrm{r}$. wydał swoje pamiętniki, pt. Historia moich cierpień. 
2. Stosowanie prawa, tj. traktowanie Żydów, jak i w ogóle wszystkich innych obywateli, przez władze wykonawcze.

3. Wzajemne stosunki polsko-żydowskie, czyli żydowsko-polskie w życiu prywatnym i społecznym.

Otóż co do strony prawnej, to najnowsza konstytucja polska dała Żydom prawie zupełne równouprawnienie. Należy ona pod tym względem do najliberalniejszych konstytucji świata. Według brzmienia konstytucji, każdy obywatel Polski, a więc także Żyd, może piastować najwyższe urzędy, z wyjątkiem godności prezydenta Rzeczypospolitej, bo to jest wykluczone choćby przez tekst przysięi składanej przez prezydenta. Sądzę jednak, że ambicje Żydów nie sięgają tak wysoko i że bez wielkiego bólu godzą się oni z tym ograniczeniem. Ze względu na ogromną większość członków Sejmu i Senatu nie-Żydów trudno przypuszczać, ażeby mogli oni kiedykolwiek wybrać prezydenta Żyda. Musiałby to byé istotnie jakiś Żyd wyjątkowy. Zresztą i pod innymi względami można stwierdzić w konstytucji polskiej pewne sprzeczności i zamachy na istotne równouprawnienie i wolność obywatelską.

Ponieważ konstytucja dała Żydom równouprawnienie, więc teraz chodzi jedynie o to, ażeby władze państwowe stały na straży konstytucji i bez żadnych wykrętów i nadużyć wcielały w życie zasady równouprawnienia. Niestety, przedstawicielami władzy są ludzie ułomni, obciążeni dziedzicznie i przez wychowanie różnymi wstrętami rasowymi, przesądami, ulegający rozmaitym popędom i emocjom przeciwspołecznym, indywidualnie i zbiorowo egoistycznym, a więc skłonni do obchodzenia i naruszania prawa. Objawem tego są dosyć liczne nadużycia urzędników w tak zwanej Małopolsce Wschodniej i „na kresach” w stosunku do ludności obcoplemiennej.

Otóż jeżeli Żydzi słusznie czy niesłusznie czują się pokrzywdzonymi, mają wszelką możność otwartej i legalnej walki o własne prawa. Mają nie tylko prawo, ale także obowiązek obywatelski dopominać się przestrzegania prawa.

Żydzi pojedynczy, doznający krzywd, w ten lub ów sposób obrażani i poddawani ubliżającym ich godności ludzkiej operacjom [2], niechaj się ujmują za sobą i niechaj domagają się zadośćuczynienia w ten lub ów sposób, jak to jest właściwe ludziom niepozbawionym poczucia godności własnej. 
Jeżeli zaś Żydzi jako Żydzi doznają krzywd zbiorowych, to przecież mają zabezpieczone prawo reagowania na to we właściwy sposób. Mają przede wszystkim do rozporządzenia niektóre organy prasy. Nie tylko zaś ich właśni przedstawiciele w Sejmie i w Senacie, ale także inni członkowie tych izb prawodawczych, niepozbawieni poczucia prawa i sprawiedliwości, mogą wnosić interpelacje, które przecież zwykle nie pozostają bez skutku.

Te walkę o urzeczywistnienie równouprawnienia należy prowadzić wytrwale, cierpliwie, zbliżając się powoli i stopniowo do zamiany Polski na kraj istotnie praworządny, a nie tylko udający praworządność.

Należy walczyć o prawo wewnątrz państwa, nie wzywając interwencji czynników obcych, pozapaństwowych.

Klauzulę traktatu wersalskiego o zabezpieczeniu praw „mniejszości narodowych” odczuto w Polsce przeważnie jako obrażające suwerenność państwa polskiego mieszanie się do jego spraw wewnętrznych $^{1}$.

Ja osobiście nie jestem wcale przeciwnikiem takiej interwencji zagranicznej. Przeciwnie, pragnąc stosowania przykazań i norm moralności prywatnej i społecznej także do spraw państwowych, do spraw międzynarodowych i międzypaństwowych, uważam taką interwencję za całkiem usprawiedliwioną, a nawet pożądaną. Dawniej wolno było rodzicom i opiekunom znęcać się bezkarnie nad dziećmi i wychowańcami. Dziś w razie krzywdzenia dzieci jest obowiązkiem każdego sąsiada i współobywatela wkraczać czynnie i ograniczać samowolę okrutnych rodziców i opiekunów. Co więcej, istnieją przecież towarzystwa opieki nad zwierzętami, nad którymi nie wolno się znęcać bezkarnie.

W niektórych krajach o wysokiej kulturze rozszerzono tę opiekę nad dziećmi i nad zwierzętami na obrządki i przesądy wyznaniowe

1 „Traktat mniejszościowy”, będący uzupełnieniem tzw. Małego Traktatu Wersalskiego z 28 VI 1919 r., zawartego między Gtównymi Mocarstwami Sprzymierzonymi i Stowarzyszonymi a Polska, dokładniej Artykuł 12, dawał państwom członkom Ligi Narodów prawo kontrolowania, jak Polska realizuje prawa mniejszości narodowych. 
bądź to połączone z niebezpieczeństwem dla operowanych osobników, bądź też równoznaczne z całkiem zbędnymi katuszami. Ze względu na antyseptykę prawo szwajcarskie wkracza w dziedzinę rytualną i reglamentuje obrządek obrzezania niemowląt, który to obrządek przy braku zachowania wymagań antyseptyki zagraża bezbronnym pacjentom zakażeniem i zaszczepieniem im różnych chorób. Ponieważ zaś przygotowywanie mięsa koszernego poddaje mordowane zwierzęta okrutnym mękom przedśmiertnym, więc w kantonach szwajcarskich nie wolno pod odpowiedzialnością karną fabrykować mięsa koszernego, tak że Żydzi prawowierni muszą je za drogie pieniądze sprowadzać z krajów sąsiednich, w których toleruje się to okrucieństwo wyznaniowe.

W ten sposób rozciąga się opiekę zarówno nad dziećmi, jako też nad zwierzętami, w imię haseł humanitarnych, w imię miłosierdzia i sprawiedliwości. Podobnie, jeżeli w jakim państwie bądź to większość, bądź też mniejszość jest krzywdzona przez tych, co się uważają za wyłącznych „gospodarzy” tego państwa, jest nie tylko prawem, ale także obowiązkiem „obcych” zaprotestować przeciwko temu, położyć tamę bezprawiu i uniemożliwić urąganie godności ludzkiej.

Chodzi jednak o to, czy ci zagraniczni opiekunowie mają do tego prawo, czy sami nie uprawiają krzywdzenia „mniejszości narodowych" i w ogóle podwładnych im zbiorowisk ludzkich.

Czy ma do tego prawo, np. Anglia, która przez długie wieki pastwiła się nad Irlandezykami i dotychezas nie uporała się z kwestią irlandzką, która w Indiach Wschodnich traktuje tuziemców jak niższy i zasługujący na pogardę gatunek ludzki, która w różnych swych koloniach patrzyła i patrzy na tubylców jak na zwierzynę do polowania, a za pomocą różnych wyrafinowanych środków skazuje tych tubylców na powolne konanie i zagładę?

Czy może ma do tego prawo dzisiejsza Ameryka, która pomimo zagwarantowanego przez konstytucję równouprawnienia traktuje Negrów jak coś niższego i godnego pogardy? A cóż dopiero, jeżeli weźmiemy pod uwagę stosunek przybyszów z Europy i ich potomków do potomków pierwotnej czerwonoskórej ludności Ameryki. A i co do Żydów nie wszyscy Amerykanie przestrzegają przepisów choćby najskromniejszej tolerancji. Na niektórych hotelach amerykańskich 
widniał do niedawna, a może i dziś widnieje napis: No Jews admitted (nie wpuszczamy żadnych Żydów).

Czy może ma do tego prawo Francja, która do niedawna stosowała, a może i dziś stosuje ograniczenia administracyjne do używania języka bretońskiego, baskiego ${ }^{1}$ i która $\mathrm{z}$ pewnością sprzeciwiłaby się uznaniu w Alzacji języka niemieckiego za równouprawniony $\mathrm{z}$ francuskim?

Czy mają do tego prawo Włosi, którzy całkiem otwarcie prześladują swych inorodców, Słowian, Niemców i innych, jeżeli podtrzymują kulturalną i literacką łączność ze swymi językowymi współplemieńcami w innych krajach?

Czy mają do tego prawo Niemcy, którzy w stosunku do swych „mniejszości narodowych” starają się dotychczas kontynuować metody eksterminacyjne, a co najmniej nietolerancyjne, swych przodków, ostatnimi czasy Bismarcka i bismarckistów, hakatystów i innych „egoistów narodowych"?

Czy mają do tego prawo Madziarowie, którzy w swym państwie węgierskim nie uznają dotychczas żadnej innej narodowości oprócz madziarskiej?

Czy może mają do tego prawo Czesi, którzy starają się ignorować prawa narodowo-kulturalne tak licznej i silnej kulturalnie „mniejszości”, jaką są Niemcy, i którzy zamykają oczy na istnienie osobnego poczucia narodowego w Słowakach?

I tak dalej, i tak dalej.

A nawet Belgia wyglądająca z pozoru całkiem niewinnie pod tym względem, właśnie w załatwianiu sporu narodowościowego między Walonami a Flamandami daje się kierować emocjom nacjonalistycznym i szowinistycznym zarówno jednej, jak i drugiej strony. Pod względem zaś traktowania tubylców w koloniach afrykańskich Belgia również nie jest chyba bez zarzutu.

Obok Belgii Holandia zdaje się wyglądać niewinnie pod względem gwałcenia praw „mniejszości narodowych” i poniewierania ich godności ludzkiej. Przypomnijmy sobie jednak handel niewolnikami praktykowany nie tak dawno przez handlarzy holenderskich, a tak

1 Tj. baskijskiego. 
dosadnie uplastyczniony przez Heineg $0^{1}$, a obok tego gospodarkę holenderską w koloniach azjatyckich, przeciwko której podniósł tak gorący protest człowiek wrażliwy i sprawiedliwy, Multatuli.

Otóż okazuje się, że wszyscy podobnego rodzaju łaskawcy i opiekunowie Żydów i innych „mniejszości narodowych” państwa polskiego nie mają prawa do interwencji, dopóki sami nie załatwią własnych spraw „mniejszościowych” i „większościowych”.

Medice, cura te ipsum (lekarzu, wprzód sam sie wylecz).

Kociot garnkowi przygania, a sam smoli.

Widzisz źdźbto w oku blizniego, a we wtasnym belki nie widzisz.

Kto z was bez grzechu, niech na nia kamieniem rzuci.

Do obrony mniejszości narodowych w państwie polskim i wszelkim innym mogłyby rościć sobie prawo dzisiejsze państwa skandynawskie (Szwecja, Norwegia, Dania), Szwajcaria i może jeszcze to lub owo państwo. Przede wszystkim zaś mają do tego prawo pojedyncze indywidua we wszystkich krajach, protestujące przeciwko uciskowi narodowościowemu, przeciwko nadużyciom, gwałtom i przemocy we własnych państwach.

W każdym razie ze strony prawnej kwestia żydowska w Polsce została tymczasem rozwiązana. Na podstawie konstytucji dającej im równouprawnienie Żydzi sami mogą walczyć o swoje prawa i nie potrzebują pomocy ujmujących się za nimi wujaszków całego świata.

Ale konstytucje i prawa istnieją niekiedy po to tylko, ażeby je naruszać i łamać. Niektórzy przewódcy partii wojujących twierdzą, że nierównie wyżej niż prawa pisane i konstytucje stoją prawa niepisane, wyryte w sercach i sumieniach „patriotów”, a zwłaszcza patriotów „narodowo-chrześcijańskich”. Do czego mogą prowadzić podobne hasła i zasady, widzieliśmy niedawno, kiedy przeciwko aktom państwowym, dokonanym bez zarzutu zgodnie z konstytucją i prawem, wystąpiły bandy uliczników, starannie zorganizowane i umiejętnie

1 Mowa o wierszu Statek niewolników ze zbioru o tym samym tytule. 
kierowane ręką warchołów i demagogów, na szkodę państwa i społeczeństwa, dzięki pobłażliwemu traktowaniu tych zbrodniczych i zdradzieckich wybryków przez władze bezpieczeństwa publicznego.

Otóż pomimo wszelkich gwarancji prawnych ze strony Konstytucji i praw obowiązujących takie nadużycia i pogwałcenia prawa mogą być stosowane przede wszystkim do Żydów zarówno przez przedstawicieli państwa, zarażonych jadem szowinizmu i wyłączności narodowej, jako też tym bardziej przez zdeprawowane i ogłupiałe jednostki.

Jedynym lekarstwem na to nieuniknione zło są energiczne protesty ze strony nie tylko samych poszkodowanych, ale także wszystkich tych obywateli, którym leży na sercu praworządność i autorytet państwa. Jak już zaznaczyłem, walkę o przestrzeganie prawa należy prowadzić zarówno drogą protestów i skarg indywidualnych i zbiorowych, jako też za pomocą interpelacji zwracanych do naczelnych władz krajowych przez członków izb prawodawczych.

$$
* * *
$$

Wobec wskazanych przez konstytucję legalnych sposobów walki 0 wcielanie w życie zasady równouprawnienia, wszelkie prywatne narady polsko-żydowskie zmierzające do tego samego celu są zabawką zbędną i bezcelową. Co innego, jeżeli przedmiotem tych narad jest osiągnięcie zgodnego i spokojnego współżycia obywateli różnoimiennych że strony społecznej i towarzyskiej. Tutaj podobne narady graja taką samą rolę, co wszelka propaganda ustna i piśmienna, propaganda słowem żywym i piórem.

Oddziaływując [sic!] na społeczeństwo w duchu uspokajania i zagajania odwiecznych ran, trzeba się liczyć z psychologią, z historią, tj. z tradycją, z przekazywaniem od pokolenia do pokolenia rozmaitych przesądów wydeptanymi ścieżkami i w kierunku najmniejszego oporu. Tylko uwzględniając to wszystko, można się kusić o stopniowe przerabianie ludzi i o przygotowywanie gruntu dla lepszej przyszłości przez wychowywanie przyszłych pokoleń.

Człowiekowi wrodzona jest, a przez wychowanie starannie wszczepianą, potrzeba nienawidzenia innych ludzi, a do zadośćuczy- 
nienia tej potrzebie doskonale się nadają szyldy wyznaniowe, narodowe, klasowe itp. Nienawidzi się nie tyle indywidualnie, ile raczej gromadnie, zbiorowo, a taka nienawiść jest najokrutniejszą i zarazem najgłupszą, chociaż psychologicznie całkiem zrozumiałą.

Wzajemna nienawiść to główny motyw historii ludzkości, a występuje ona nadzwyczaj jaskrawo w stosunkach między zbiorowiskiem żydowskim a innymi zbiorowiskami ludzkimi.

Dla braku czasu pomijam tu stronę historyczną sprawy żydowskiej. Wskażę tylko na wprost potworną megalomanię narodowo-wyznaniową narodu żydowskiego, „narodu wybranego”, mającego prawo do tępienia innych narodów, a co najmniej do panowania nad nimi. Bóg żydowski jest bogiem wyłącznie narodowym, przejawiającym prawdziwie małpią mitość (Affenliebe) do swych dzieci ulubionych i mający do nich pretensję, jeżeli w stosunku do innych ludów nie kierują się bezwzględnym okrucieństwem. Nie zapominajmy jednak, że ten Bóg żydowski stał się następnie Bogiem chrześcijańskim, a połączenie imperializmu rzymskiego z megalomanią żydowską spłodziło katolicyzm, dążący do opanowania świata całego.

Antysemityzm jest dzieckiem Starego Testamentu i wytworem samych Żydów. Antygoizm dał początek antysemityzmowi występującemu nader wyraźnie w bardzo dawnych czasach, w każdym razie na wiele wieków przed ukrzyżowaniem Jezusa Chrystusa, zamordowanego dzięki podszeptom reakcjonistów żydowskich i przy aplauzie rozszalałej tłuszczy, rozagitowanej przez tych reakcjonistów drżących 0 swój wpływ i władzę nad duszami ludu.

Skutkiem prześladowania ich na ich własnej ziemi Żydzi rozproszyli się po całym świecie i zostali skazani na tułaczkę, inną wprawdzie aniżeli koczownictwo cygańskie, ale zawsze tułaczkę, 0 ile utrzymuje się ciągłość narodowa tego zbiorowiska ludzkiego. W różnicy od innych emigracji masowych, w rodzaju choćby niedawnej emigracji polskiej i dzisiejszego wychodźstwa rosyjskiego, Żydzi dzięki swej odporności plemiennej i dzięki spójni za pomocą swoistego wyznania narodowego utrzymali się w swej odrębności i tylko niewielki ich procent asymilował się i tonął w morzu innych zbiorowisk plemiennych i narodowych. 
Jednakże dziwną ironią losu, pomimo swej odrębności, Żydzi zatracili w życiu potocznym swój język narodowy i przyjęli języki swych wrogów i prześladowców: z jednej strony Niemców, z drugiej zaś Hiszpanów. Osiedlając się masowo na ziemiach polskich i przyległych, Żydzi obok swej swoistej religii przynosili ze sobą jako znamię swej odrębności przyswojony przez nich w Niemczech dialekt górnoniemiecki, tzw. „żargon”.

Jak zaznaczyłem na początku, w Polsce niepodległej, przedrozbiorowej, istniała kwestia żydowska rozwiązywana w rozmaity sposób. Zaznaczyłem też, że po upadku Polski w trzech zaborach rozmaicie traktowano kwestię żydowską.

W państwie rosyjskim przed samą wojną wszechświatową kwestia żydowska niezmiernie się zaogniła i doszła do bardzo wysokiego napięcia.

Zaraza bestialskiego antysemityzmu rozszerzała się z Rosji na Kongresówkę, czyli Priwislinskij kraj, w związku z tym godnym podkreślenia faktem, że jak Żydzi przybywający z Zachodu bez wielkich trudności stawali się germanizatorami, tak znowu Żydzi chroniący się do Polski ze Wschodu pomimo pogromów i innych prześladowań rosyjskich pomagali rdzennym obrusitielom do rusyfikowania ziem polskich, będących integralną częścią tego potwora państwowego, rozkładającego się, zdemoralizowanego i demoralizującego. Zresztą zgnilizna moralna i zaćmienie umysłów były przed wojną właściwością nie tylko Rosji, ale także innych państw zatrutych jadem szowinizmu, imperializmu i krwiożerczej zachłanności.

Podczas wojny, kiedy to bakterie nienawiści i ludożerstwa coraz bardziej potężniały, także sprawa żydowska zaostrzyła się do najwyższego stopnia.

$$
* * *
$$

Pomimo zaciętych prześladowań naród żydowski wykazał zadziwiającą odporność jako osobne i wyodrębnione zbiorowisko ludzkie, a Żydzi oraz ludzie pochodzenia żydowskiego u różnych narodów grali wybitną rolę w historii kultury, w literaturze, w poezji, w sztuce i nauce, w ogóle w dziejach ludzkości jako całości niepodzielnej. 
Przede wszystkim chrześcijanizm wyrósł na gruncie żydowskim. Poza tym niektórzy Żydzi biorą żywy udział w życiu rozmaitych narodów, wyznań, sekt, stronnictw itd., a nawet najzajadlejszymi, najfanatyczniejszymi antysemitami i żydożercami bywają ludzie pochodzenia żydowskiego.

Kwestii żydowskiej w Polsce nie można oddzielać od kwestii żydowskiej w ogóle. A ta kwestia ogólnożydowska, w związku z megalomanią narodowo-wyznaniową Żydów ciągnie się co najmniej od czasów rzymskich, przetrwała wieki i ciągnąé się chyba będzie bez końca. Jej ostateczne rozwiązanie na tle społecznym znajduje się w nieskończonej odległości i przypomina asymptoty i krzywe hiperboli, coraz bardziej zbliżające się do siebie, ale nigdy zejść się niemogące.

Porównajmy położenie Żydów w Polsce z ich traktowaniem w innych krajach. Przypomnijmy sobie antysemityzm rumuński, austriacki, francuski, niemiecki, czeski, finlandzki, grecki, gruziński, ormiański, litewski..., nawet amerykański, a to porównanie nie wyjdzie chyba już tak bardzo na niekorzyść Polski.

W ciągu wielu lat przed wojną wiedeńscy studenci christlich-soziale urządzali obławy na Żydów i bili wszystkich bez wyjątku spotkanych Żydów.

Słuchacze uniwersytetu niemieckiego w Pradze protestują przeciw nowo obranemu rektorowi Steinherzowi jako Żydowi i starają się w sposób brutalny zmusić go do podania się do dymisji. Zestawmy z tym fakt, że kilka lat temu rektorem Uniwersytetu Lwowskiego był profesor Beck, o którym przedtem wspomniałem. Dziś, w czasie powojennym, na tle ogólnego ogłupienia i zwyrodnienia może by to już nie było możliwe. W każdym razie jednak w danej chwili rektorem Uniw. Krakowskiego jest profesor Natanson, wprawdzie już nie Żyd urzędowo, ale „rasowo” należący do plemienia żydowskiego, a przecież rdzenni stróze pamiątek narodowego kościota głoszą bezwzględną, nieubłaganą krucjatę przeciw żydostwu na tle „rasowym”, nie zaś wyznaniowym.

Za dni naszych $\mathrm{w}$ niektórych uniwersytetach niemieckich, między innymi w uniwersytecie berlińskim i jenajskim, słuchacze „chrześcijańsko-aryjscy” uchwalają, ażeby, zwłaszcza na wydzia- 
le medycznym, Żydom nie wolno było siadać w trzech lub ezterech pierwszych ławkach. Ławki te powinny być zarezerwowane dla rdzennych Germanów.

W Wiedniu zażądano numerus clausus nie tylko dla słuchaczów, ale także dla profesorów. Liczba zarówno jednych, jako też drugich nie powinna przewyższać 10 procentów [3].

W ostatnich dniach, tj. już na początku r. 1923, czytaliśmy, że w Monachium i w innych miastach Bawarii nacjonaliści biją Żydów i grożą, że wszystkich Żydów powywieszają. Przypuśćmy, że im się to nie uda, ale w każdym razie chęć stanie za uczynek.

Oszczędzając czasu i nie wdając się w szczegóły, zapytuję zacietrzewionych syjonistów i narodowców żydowskich w Polsce:

Czy tzw. „żargon” jest w jakimkolwiek państwie równouprawniony z innymi językami?

Czy szabas jest gdziekolwiek obserwowany z większą gorliwością i sumiennością aniżeli w Polsce?

Czy w innych krajach wolno zastawiać podwórza szałasami kuczkowymi i, zagarniając ciasne podwórza na swój wyłączny użytek, krępować w ten sposób innych mieszkańców tych samych domów?

Czy Żydzi w innych państwach w czasie swych świąt otaczają drutem całe miasteczka i osady, nadając im w ten sposób charakter osad wyłącznie żydowskich?

\section{$* * *$}

Przy traktowaniu kwestii żydowskiej ze stanowiska dobra państwa i społeczeństwa należałoby unikać kierowania się tylko uczuciem i histerią zarówno z jednej, jak i z drugiej strony. Ze względu nie tylko na dobro państwa i społeczeństwa, ale nawet na własne dobro i dobro swych bliskich należy okiełznać swą wybuchowość i popędliwość, traktując tego rodzaju sprawy rozumowo i stojąc na stanowisku utylitarnym, na stanowisku użyteczności.

Niektórzy „,hrześcijanie” i „aryjczycy”, nawet spomiędzy wysoko stojących pod względem umystowym i moralnym, powiadają, że czują do Żydów wstręt $i$ pogardę i wskutek tego nie mogą 0 nich mówić spokojnie. 
Można by się ich zapytać, czy czują wstręt i pogardę także do Chrystusa, do jego matki i do jego pierwszych uczniów i apostołów, którzy przecież wszyscy byli Żydami. „Rasowo” Chrystus był w każdym razie Żydem, przynajmniej po kądzieli, a chyba także i po mieczu, bo przecież w owe czasy jego ojciec był bogiem wyłącznie żydowskim.

Delikatne i dystyngowane damy oświadczają, że patrzyłyby $\mathrm{z}$ rozkoszą na pogromy żydowskie i może same nawet brałyby w nich udział.

A z drugiej strony, z jaką rozkoszą Żydzi prawowierni rozsmakowują wspomnienia 0 pogromach, urządzanych niegdyś przez ich przodków nad wyznawcami innych bogów. Świadezy 0 tym wymownie święto Purim, odgłos pogromu, w którym zamordowano 75000 niewiernych.

W imię antygoizmu i antysemityzmu tępią się wzajemnie różnoimienne bestie ludzkie, a to tępienie się wprawia w zachwyt nieopisany i sprawia im niewymowną rozkosz. Cały świat ludzki przedzierzga się w menażerię gryzących się zwierząt różnogatunkowych.

Za pogromy odpowiedzialni są ci zaślepieńcy lub też niegodziwcy, co zaciekle i bezkrytycznie szczują i podjudzają na wszystkich bez wyjątku Żydów. Propaganda zajadłego ryczałtowego antysemityzmu tak się ma do krwawych pogromów, jak się ma stałe szczucie i podjudzanie czytającej i słuchającej gawiedzi oraz gorliwe dyskredytowanie naczelnika państwa i rządu państwa polskiego do zamiarów krwiożerczych i nareszcie do czynu „patriotycznego” „bohatera” chrześcijańsko-narodowego, p. Eligiusza Niewiadomskiego. Są to tylko następstwa, dalsze ciągi i doprowadzenie do ostatecznych naturalnych konsekwencji.

Kierowanie się nerwami i histerią jest egoizmem na krótką metę, ze szkodą zarówno dla obu stron, jako też dla wielonarodowego i wielowyznaniowego społeczeństwa.

Miejsce nerwów i histerii powinny zająć rozum, rozwaga i zimna krew. Ale i one nie wystarczą, jeżeli umysł jest zanieczyszczony fałszywymi przesłankami, jeżeli pojęcie „goja” lub też „Żyda” stało się kategorią myślenia na podobieństwo czasu, przestrzeni, jakości, celowości, przyczyny, skutku itp. Otóż dla pomyślnego i celowego roz- 
wiązywania podobnych kwestii trzeba usunąć z głów zzoologizowanie, zbiologizowanie i zantropologizowanie mózgu w zakresie myślenia 0 kwestiach społecznych i politycznych.

Otóż pozbywszy się tych niepożądanych naleciałości w naszym aparacie myślowym, rozpatrzmy sprawę żydowską z różnych stron, ze stanowiska prawa i sprawiedliwości, ze stanowiska dobra państwa i różnoplemiennego społeczeństwa Polski.

Przede wszystkim spotykamy na każdym kroku dzielenie od dawna osiadłych mieszkańców danego państwa na „gospodarzy” i „gości”.

Dążność do upaństwowienia jednej jedynej narodowości i jednego jedynego wyznania, dążność do unarodowienia i uwyznaniowienia państwa wielonarodowego i wielowyznaniowego, dążność do wyłączności w tej dziedzinie, do stworzenia państwa koszernego, państwa folblutów rasowych, dzielenie ludności, mieszczącej się w granicach tego samego państwa, na narodowość panującą i na narodowości jej podwładne i poddane, na wyznanie panujące i na wyznania drugorzędne, dzielenie na właścicieli, lokatorów i sublokatorów, na uprzywilejowane rodzone dzieci i na upośledzonych pasierbów - taka dążność i takie zachcianki są wynikiem koncepcji z gruntu fałszywej, pociągającej za sobą nieustanne tarcia i walki bezpłodne, podtrzymującej wrzenie, które przeszkadza zgodnemu współżyciu i współpracy, a natomiast szkodzi państwu i społeczeństwu, bo osłabia je i na wewnątrz, i na zewnątrz.

Rozróżnianie wyznania panującego a wyznań tylko tolerowanych jest złagodzoną starotestamentową wyłącznością żydowską.

Może się też zdarzyć taki wypadek, że tak zwani goście zachowują się poprawnie, szanują konstytucję i prawa obowiązujące, dążą do zgodnej współpracy na pożytek ogółu, ci zaś, co uważają siebie za wyłącznych gospodarzy kraju, łamią prawa, urządzają bunty i rokosze, targają się na majestat Rzeczypospolitej i szkodzą jej niepomiernie pod każdym względem.

W każdym razie zamachu na prezydenta Rzeczypospolitej, symbolizującego państwowość polską i majestat Polski, dokonał nie żaden Żyd, nie żaden członek tej lub owej „mniejszości narodowej”, ale 
tylko rdzenny, najrdzenniejszy Polak, uznany przez wielu za „bohatera narodowego", walczącego w ten sposób o polskość Polski.

Korzystając z bezwzględnej wolności prasy, zohydzają, zniesławiają i dyskredytują naczelnika państwa, pierwszego prezydenta Rzeczypospolitej i rząd polski, starają się szkalować Polskę dzisiejszą zarówno wewnątrz państwa, jako też za granicą, podkopują się pod byt niezależny Polski, solidaryzują się z mordercą prezydenta, urządzają orgie manifestacyjne ku uczezeniu mordercy, zbierają składki na pomnik dla niego ... nie żadni „Żydzi”, nie żadne „mniejszości narodowe”, nawet nie „komuniści”, ale ci, co się podają za jedynych rdzennych Polaków, skupiających się pod hasłem sprawy narodowej.

Do tej bezwzględnej opozycji przeciwko rządowi przyłączyli się w Sejmie także posłowie żydowscy. Uważam to za rażący błąd z ich strony. Mają oni jednak tę wielką zasługę wobec Polski, że swym akcesem do „Targowicy” współczesnej strefili czystość koszerną Związku Chrześcijańskiej Jedności Narodowej. Rzuca to swoiste światto na wściekłość „stronnictw narodowych” i na urządzane w grudniu r. 1922 awantury z powodu skalania Polski przez udział w wyborze pierwszego prezydenta Rzeczypospolitej także postów i senatorów z tona „mniejszości narodowych”. Wzorując się na hasłach Francja dla Francuzów, Anglia dla Anglików, Niemcy dla Niemców, Rosja dla Rosjan, głosi się dumnie i wyzywająco: Polska dla Polaków. Tak, istotnie Polska dla Polaków, jeno że nie narodowo, ale tylko państwowo, podobnie jak Ameryka dla Amerykanów, Polska dla obywateli Polski. Państwo powinno być pozawyznaniowym i pozanarodowym.

$$
* * *
$$

W związku z dążeniem do upaństwowienia w Polsce jednej tylko narodowości pozostaje lęk żywiołowy przed tak zwaną Judeo-Polska, gdzie pierwsza część tego złożenia ma być dla uczucia polskiego obraźliwą, a nawet hańbiącą.

Jest to nieporozumienie i nieumiejętność zaglądania prawdzie w oczy. 
Polska jest już od dawna Judeo-Polską i taką też i nadal pozostanie. Za pośrednictwem chrześcijaństwa żydostwo wżarło się głęboko w polskość. A nawet musimy przyjąć aż trzy Judeo-Polski.

Pierwsza Judeo-Polska to wytwór historii ze śladami w kulturze, literaturze, światopoglądzie i nastroju religijnym. Mniej więcej lat temu tysiąc przywędrowała ona z Zachodu. Wyszła niegdyś z Palestyny, usadowiła się w Rzymie, a przez Niemcy i Czechy trafiła do Polski. Pierwsza Judeo-Polska to Judeo-Polska organistów, pastuszków, kantyczek, kolęd itd. Judeo-Polska chrześcijaństwa.

Druga Judeo-Polska to Judeo-Polska rozdarcia, wzajemnego szczucia, nienawiści, waśni, Judeo-Polska żarcia się, gryzienia się, Judeo-Polska podszczuwaczy i sfanatyzowanej gawiedzi.

Nareszcie trzecia Judeo-Polska to Judeo-Polska opamiętania się, pogodzenia się, zgodnego i spokojnego współżycia i wspólnej pracy obywatelskiej, Judeo-Polska Kościuszki i Berka Joselewicza, Towiańskiego i Mickiewicza, Judeo-Polska Asnyka, Gomulickiego, Adama Szymańskiego, Orzeszkowej i Konopnickiej, Judeo-Polska roku 1861 i w ogóle krótkotrwałej epoki reform Wielopolskiego, Judeo-Polska przyszłości.

Taka Judeo-Polska będzie właśnie Polską w najczystszym, najszlachetniejszym, najpodnioślejszym znaczeniu tego wyrazu, Polską równouprawnienia i współpracy obywatelskiej, Polską kroczącą w przednich szeregach ludzkości. To będzie już Polska bez Judei, to będzie prawdziwe spolszczenie Polski [4].

Dziś sroży się druga Judeo-Polska, Judeo-Polska rozdarcia, Judeo-Polska walki na śmierć i życie. Fanatycy jednego i drugiego obozu gdyby mogli, wzajemnie by się wytępili lub co najmniej wypędzili. Niestety, zapędy w tym kierunku są bzdurną chimerą. Ani rdzenni Polacy nie mogą wyrżnąć Żydów, ani też odwrotnie, Żydzi rdzennych Polaków. Nie pozostaje więc nic innego, jak albo ujadać i żreć się w dalszym ciągu, albo też dla wspólnego dobra wynaleźć jakiś modus vivendi, to jest sposób spokojnego współżycia.

Zawodne są też nadzieje na marzenia syjonistyczne. Najgorliwszy syjonizm nie usunie z Polski wszystkich Żydów [5].

Na podłożu owej drugiej Judeo-Polski zaogniła się teraz sprawa tak zwanego numerus clausus w wyższych uczelniach, przypomina- 
jąca świętej czy też błogosławionej pamięci procenty szkolne w Rosji, łącznie z Priwislinskim Krajem, nad którymi to procentami niegdyś mocno wydziwiano i kłuto nimi oczy Rosji barbarzyńskiej.

Przy tym z góry ogłasza się ryczałtowo wszystkich Żydów za wrogów państwa. W ten sposób pcha się ich, nawet wbrew ich własnej woli i chęci, do obozu wrogów.

Zresztą psychologia krucjaty podjętej pod sztandarem numerus clausus jest całkiem zrozumiała. Wyrosła ona na gruncie ekonomicznym. Jest to jeden z objawów tak zwanej walki 0 byt, tylko że prowadzonej niezaradnie i bezcelowo. Można by przeciwdziałać tej liczebnej przewadze Żydów, ale w inny sposób. A tym szamotaniem się, tymi awanturami i burdami szkodzi się Polsce na wewnątrz i na zewnątrz.

Na wewnątrz, bo wstępuje się na zgubną drogę praw wyjątkowych. Uchwały zrozpaczonej mtodzieży chrzescijansko-narodowej, zresztą do niczego nieprowadzące, nawołują do bezprawia, do łamania konstytucji i do wprowadzania stanów wyją̧tkowych, czyli do legalizowania bezprawia drogą uchwał doraźnych, wbrew prawu ogólnie obowiązującemu.

Na zewnątrz, bo tego rodzaju krzykliwe manifestacje, wzywające do unicestwienia zagwarantowanego przez konstytucję równouprawnienia wszystkich obywateli Rzeczypospolitej, wyzyskuje się za granicą na szkodę Polski, a to prowadzi nie tylko do spadku waluty, ale także do upadku powagi i uroku państwa. Z takim państwem coraz mniej będą się liczyć [6].

Tak zwana „asymilacja” Żydów jako osobnego zbiorowiska ludzkiego jest i pozostanie jeszcze przez długie lata mrzonką nie do urzeczywistnienia. 0 asymilowaniu ciemnych i przesądnych, a wzajem sobie niechętnych mas mowy być nie może. Co najwyżej mogą się asymilować tymczasem pojedyncze jednostki i nieliczne grupy, co w dalszym ciągu prowadzi do równouprawnienia, a raczej wspótżycia towarzyskiego.

Zresztą dzisiejsi „rdzenni Polacy” o zabarwieniu „chrześcijańsko-narodowym", i to nawet tacy rdzenni Polacy, którzy, obiektywnie biorąc, „rasowo”, są podejrzani co do swej czystości aryjskiej, którzy bądź to z pochodzenia w mniej lub więcej odległej przeszłości, bądź 
też przez małżeństwo, powinowactwo i inne koligacje mocno zalatują żydostwem; otóż tacy „rdzenni Polacy” nie chcą wcale asymilacji. Co więcej, uważają oni zarówno przechrztów, mechesów, jako też Żydów-Polaków, za nierównie niebezpieczniejszych dla Polski aniżeli Żydów ortodoksów i Żydów narodowców odżegnujących się od polszczyzny. Celem ich dążeń jest bezwzględne, nieubłagane odżydzenie Polski. Ze wzgardą i nienawiścią odpychają oni od siebie wszelką współpracę kulturalną i społeczną Żydów miłujących Polskę i uważających ją za swą ojczyznę.

Chcieliby nawet rozszerzyć to odżydzanie na całe chrześcijaństwo, na całą kulturę chrześcijańską w ciągu wielowiekowej historii.

Jeżeli tak, to przede wszystkim należałoby to odżydzanie zacząć od usunięcia Chrystusa, Marii, świętego Pawła i innych Żydów, zasłużonych około utrwalenia chrześcijaństwa.

Całkowite odżydzenie kultury chrześcijańskiej równałoby się jej unicestwieniu.

Z drugiej strony istotne, nie obłudne „odżydzenie chrześcijaństwa" prowadzi prostą drogą do wyrzeczenia się antysemityzmu jako naleciałości żydowskiej.

Fanatyczne odżegnywanie się od wszelkiej współpracy z Żydami, bzdurne i tępogłowe twierdzenie, że wszelkie dotknięcie żydostwa, wszelki udział Żydów, np. w pracy nad budową państwa polskiego, kala „aryjskość” i „chrześcijaństwo” - zawdzięczające zresztą swój początek Palestynie żydowskiej - otóż ten wściekły fanatyzm „chrześcijańsko-narodowy” przypomina legendę średniowieczną o wypadku, który podobno miał miejsce we Frankfurcie nad Menem.

Oczywiście Żydzi mieszkali tam w ghetto odgrodzonym wysokim murem od dzielnicy chrześcijańskiej. Pewnej nocy młody Żyd usłyszał za murem wołanie o pomoc człowieka napadniętego przez zbójców. Idąc za popędem prostego ludzkiego uczucia, w dobrym znaczeniu tego wyrazu, wdrapał się na mur, przesadził go, pośpieszył na pomoc mordowanemu chrześcijaninowi i spłoszył rabusiów. Spotkała go swoista nagroda. Za to, że ośmielił się przekroczyć mur oddzielający chrześcijan od Żydów, za to że swą plugawą stopą skalał świętą ziemię chrześcijańską, skazano go na śmierć i spalono na stosie. 
Podobnie, choć nie tak okrutnie, został wynagrodzony chłop, co uratował tonącego szlachcica, schwyciwszy go za włosy i w ten sposób wyciągnąwszy z wody. Dostał dukata za wyratowanie, ale dostał też w skórę za to, że ośmielił się dotknąć swą chamską ręką czupryny szlacheckiej.

W związku z palącą w oczach „chrześcijańsko-narodowych” kwestią „odżydzania” Polski nie od rzeczy będzie przytoczyć zakończenie mego przemówienia, które miałem na zjeździe byłych wychowańców Szkoły Głównej w Warszawie 25 listopada 1912 roku:

Szkoła Główna nie była instytucją wyznaniową, nie była przeznaczona dla młodzieży tylko jednego wyznania, z upośledzeniem innych. Nie znaliśmy ograniczeń procentowych. Szkoła Główna była instytucją przede wszystkim wszechludzką, a następnie polską w najobszerniejszym znaczeniu tego wyrazu, polską nie tylko narodowo, ale także terytorialnie. Zgodnie z tym nie robiliśmy różnicy między kolegami ze względu na ich pochodzenie. Wszyscy byliśmy równi. Nikt z nas nie ośmieliłby się zaproponować koledze Żydowi, ażeby dla uzyskania praw obywatelskich przyjmował katolicyzm. Szanując godność osobistą swoją i cudzą, uważalibyśmy podobną propozycję za taką samą zniewage, jaką byłoby zaproponowanie nieprawosławnernu, ażeby dla uzyskania równouprawnienia w państwie rosyjskim przyjmowat prawosławie.

Dziś jest inaczej. Stanąwszy na gruncie tutejszym, uczułem się boleśnie dotkniętym tym, co się tu dzieje. Dziś rozbrzmiewają inne hasta:

Przybyszu i zaledwie cierpiany gościu! Ochrzcij się, bo tego wymaga „pan i odwieczny dziedzic” tej ziemi. Ale pamiętaj, że ci nigdy nie zapomną twego pochodzenia i że ci je wypomną w najdalszym pokoleniu. Choćbyś nawet ukochał tę ziemię miłością chorobliwą, przeczuloną, choćbyś poświęcił wszystkie swe siły, czas i środki pracy społecznej polskiej, choćbyś niósł wszystko w ofierze społeczeństwu polskiemu, choćbyś brał wybitny udział w fundowaniu instytucji narodowych polskich... nic ci to nie pomoże. Zawsze będziesz tylko Żydem, ale nigdy Polakiem.

I to jest także patriotyzm.

(J. Baudouin de Courtenay, Wkwestii żydowskiej, Warszawa, 1913. str. 108-109). 
Ponieważ nie można się rozejść, ponieważ fatalność historyczna skazuje Żydów i innych inorodców na pozostawanie i nadal w tym samym państwie co i rdzenni Polacy zarówno „chrześcijańsko-narodowi”, jako też sprzeniewierzający się „chrześcijaństwu” i „narodowości” polskiej, więc nie pozostaje nic innego, jak starać się o sposoby zapewniające zgodne wspótżycie. Za wzór można by wziąc mieszkańców tego samego domu lub tej samej miejscowości. Bez względu na swe pochodzenie, na swe poglądy, na swe przekonania polityczne mają oni jednak pewne wspólne, niezmiernie ważne interesy gospodarcze, ekonomiczne, prawne itd. Muszą więc wspólnie zabiegać o to, ażeby pod tymi wszystkimi względami działo się jak najlepiej. Przy tym nie potrzebują składać sobie wizyt i obcować towarzysko.

Jak w domach mogą istnieć komitety domowe, w miastach rady miejskie, tak w państwach współczesnych posiadamy wspólne ciała prawodawcze, wspólne władze wykonawcze, wspólny rząd, wspólne sądy, wspólną administrację, wspólną sitę zbrojną dla obrony granic państwa itd., a w tym wszystkim cała ludność państwa jest jednakowo zainteresowana, bez względu na swe pochodzenie, na swą narodowość, na swe wyznanie, na swe poglądy polityezne.

Zasada sprawiedliwości, uznanie godności ludzkiej wszystkich obywateli, wierność zasadom samookreślania się każdej jednostki uświadomionej wymagają uznania także narodowości żydowskiej nie tylko de iure, ale także de facto. Nie wolno trzymać się wspomnianej na początku metody strusiej, stosowanej niegdyś w Austrii, która po prostu ignorowała narodowość żydowską.

I jak tu nie uznawać narodowości żydowskiej? Odrębność gromadna Żydów jest więcej niż narodowością. Mamy przed sobą naród nad narodami, ,naród wybrany” i przeciwstawiony wszystkim innym narodom. Mamy wcielony w żydostwo pierwowzór wszelkich megalomanii narodowych. Bliższym jest Polakowi Niemiec, Anglik, Hiszpan itd. aniżeli Żyd narodowiec żyjący wspomnieniami o minionej wielkości, 0 swym posłannictwie wszechświatowym, opartym między innymi 0 antygoizm nieubłagany. $\mathrm{W}$ porównaniu $\mathrm{z}$ tą napęczniałą do ostatecznych granic megalomanią żydowską niczym są inne megalo- 
manie państwowo-narodowe: megalomania rzymska, megalomania bizantyjska, megalomania angielska, megalomania francuska, megalomania niemiecka, megalomania rosyjska, megalomania madziarska itd., itd.

Wobec tego osobna narodowość żydowska musi być nie tylko tolerowana, ale także równouprawniona, z tym jednak zastrzeżeniem, że nie będzie nadużywać tego równouprawnienia na szkodę państwa i innych współobywateli. Zresztą przy ścisłym przestrzeganiu praw i stosowaniu odpowiedzialności osobistej takie szkodnictwo jest całkiem wykluczone.

Uznanie osobnej narodowości żydowskiej nie jest równoznaczne z przymusowym zaliczaniem do niej osobników pochodzenia żydowskiego. Na zasadzie równouprawnienia obywatelskiego, w imię wolności osobistej i godności ludzkiej każdemu człowiekowi powinno być wolno przyznawać się do takiej narodowości, jaką sam uznaje za własną, a nawet albo przyznawać się do dwóch i więcej narodowości jednocześnie, albo też nie przyznawać się do żadnej narodowości. Podobnie co do wyznania: człowiek ma prawo zaliczać siebie do tego lub owego wyznania według upodobania albo też nie przystawać do żadnego wyznania i ogłosić się za bezwyznaniowca. Tylko - w różnicy od narodowości subiektywnej - człowiek nie może należeć jednocześnie do dwóch lub kilku wyznań albo też być jednocześnie wyznaniowcem i bezwyznaniowcem, gdyż jest to sprzecznością samą w sobie.

Dopóki istnieją państwa, człowiek pojedynczy może być poddanym czy też obywatelem tylko jednego państwa. Dwupaństwowość, a tym bardziej kilkopaństwowość, jest obiektywnie niedopuszczalna.

Tak więc fanatyzm żydowski, stosujący przymus, a nawet terror do odstępców od zbiorowiska żydowskiego, powinien być ukrócony, a wszelkie zamachy na wolność jednostek surowo karane.

$$
* * *
$$

Dla ortodoksów żydowskich jest bolączką pierwszorzędnej doniosłości zakaz prowadzenia handlu w niedzielę i w inne święta „wyznania panującego". Tak, istotnie jest to bardzo niedogodne, a nawet smutne, jeżeli jednocześnie święci się sobotę i inne święta wyłącznie 
żydowskie. Ale na to nie ma rady, o ile się uznaje tzw. etatyzm, tj. wtrącanie się państwa do życia prywatnego i społecznego. Takimi ustawami i przepisami kieruje zasada większości. Ponieważ w Polsce jest najwięcej katolików, więc uwzględnia się co do handlu święta katolickie.

Ja w tych sprawach jestem przeciwnikiem wszelkiego etatyzmu i uważam go za krępowanie wolności osobistej. Ale rozstrzyganie o tych sprawach nie ode mnie zależy.

Pamiętam, że dawniej wolno było handlować w niedzielę zarówno Żydom, jak i nie-Żydom. A nawet po wsiach właśnie w święta, po nabożeństwie, podczas odpustów i bez odpustów, najruchliwszy handel odbywał się właśnie w niedziele i święta. Dziś jest inaczej. Dziś panuje i wciela się w życie zasada „socjalizacji”, „nacjonalizacji”, normowania godzin pracy i próżnowania itp.

Jeżeli zaś Żydzi czują się pokrzywdzonymi przez zakaz handlowania w niedzielę i w święta katolickie, to niech idą za przykładem tych, co styl kalendarzowy juliański zmienili na styl gregoriański. Niechaj szabas przeniosą z soboty na niedzielę. Podobno w Ameryce już się to praktykuje.

Mocno przepraszam, jeżeli ta moja propozycja dotknie kogo niemile.

$$
* * *
$$

Dla umożliwienia zgodnego pożycia we wspólnym państwie bardzo jest pożądane wzajemne poznanie się wrogich sobie obozów. Pod tym względem Żydzi przeciętnie mają znaczną przewagę nad rdzennymi Polakami. Wielu z nich bowiem zna polską historię, polską literaturę, uczestniczy w życiu umysłowym, artystycznym i kulturalnym Polski. Rdzennych zaś Polaków mogących się pochwalić znajomością życia umysłowego i kulturalnego Żydów można by chyba na palcach policzyć. Z pisarzów polskich mało kto wstępuje w ślady Elizy Orzeszkowej. 
Obiektywna znajomość życia żydowskiego nie da się osiągnąć przez swoisty „instytut żydoznawczy”, zapoczątkowany przez jednostronnych i fanatycznych żydożerców. Żydzi nie sprawiali sobie żadnego ,instytutu gojoznawczego", a jednak i bez niego zaznajamiaja się z życiem współobywateli innowyznaniowych i innoplemiennych, bo w życiu tym sami uczestniczą. Środkiem dążącym do tego celu ze strony nieżydowskiej byłoby przede wszystkim stworzenie w uniwersytetach katedr żydoznawczych, tj. katedr zaznajamiających nie tylko z hebrajszczyzną, ale także z późniejszą i wspótczesną kulturą, literaturą i folklorem żydowskim.

Godząc się, chcąc nie chcąc, ze smutną teraźniejszością, powinni byśmy myśleć cokolwiek o przyszłości, tj. 0 wychowywaniu przyszłych pokoleń i o przygotowywaniu ich do wzajemnej tolerancji i do zgodnego wspótżycia w ramach jedności państwowej. Wiele szkół dzisiejszych wychowuje uczniów we wzajemnej nienawiści, przygotowuje z nich bojowców partyjnych, prowadzi ich do zdziczenia, do ogłupienia i do zatrważającego stępienia poczucia obywatelskiego przez ignorowanie praw obowiązujących.

I szkoła, i dom, i całe otoczenie ćwiczy dzieci i młodzież w stosowaniu dzikich sylogizmów, czyli rozumowań, uznających odpowiedzialność zbiorową, gromadną zamiast odpowiedzialności osobistej, indywidualnej.

Przy tym z jednej strony goizm, z drugiej strony żydostwo stają się podstawą myślenia 0 stosunkach międzyludzkich w rodzaju czasu, przestrzeni, jakości, ilości itd. Logika rozumu i obiektywizmu ustępuje miejsca logice wyrazowej, logice menażeryjnej, zoologiczno-antropologicznej, logice baranich głów, matołków i tępogłowców. Zresztą poza fałszywym punktem wyjścia, oparte na takiej logice wyrazowej sylogizmy są bez zarzutu.

W związku z tym są umyślne fałszerstwa polegające na utożsamianiu Żydów z bolszewikami, z socjalistami, z masonami. Przez wmawianie młodzieży podobnych fałszerstw narzuca się jej umysłom

1 Mowa 0 Instytucie Żydoznawstwa założonym w 1920 r. przez Andrzeja Niemojewskiego. 
beznadziejne pomieszanie pojęć i utożsamianie pojęć należących do różnych dziedzin myślenia.

Wielką szkodę i spustoszenia w duszach ludzkich sprawia też bezkrytyczne uczenie niektórych przedmiotów szkolnych, jak np. „historii świętej”, historii powszechnej, historii ojczystej, literatury itd.

Otóż tego rodzaju wychowywanie w ciemnocie i w duchu przeciwspołecznym powinno być zastąpione przez przyuczanie do krytycznego traktowania tego, o czym się mówi i co się przyswaja z książek i czasopism oraz przez wychowanie prawdziwie obywatelskie w najobszerniejszym znaczeniu tego wyrazu.

Z drugiej strony ludzie dążący do zmniejszenia niepożądanych antagonizmów społecznych powinni by oddziaływać na masy żydowskie w kierunku usuwania specyficznych cech żydowskich, działających wprost wyzywająco na innych współmieszkańców. Przede wszystkim należy walczyć ze specyficznym brudem mas żydowskich. Podobno zawiązują się w łonie inteligencji żydowskiej stowarzyszenia mające na celu rozszerzanie wśród mas żydowskich przekonania o tym, że zgodnie z wymaganiami higieny i antyseptyki koniecznym jest dla zdrowia przestrzeganie elementarnej czystości ciała, odzieży i mieszkania.

Streszczając swe z pewnością przydługie i zbyt rozwlekle wywody, wskazuję w skróceniu na główne działy kwestii żydowskiej w państwie polskim.

1. Na pierwszym miejscu stoi zaznajomienie się z Konstytucją i z prawami obowiązującymi, zabezpieczającymi wszystkim obywatelom państwa, a więc także Żydom, prawie zupełne równouprawnienie.

2. Dalej idzie domaganie się kar na urzędników nadużywających swej władzy dla naruszania praw obowiązujących.

3. Następnie, ze względu na uspokojenie społeczeństwa i na wcielenie w życiu towarzyskim poczucia praworządności i szacunku dla zasady równouprawnienia obywatelskiego, powinniśmy rozsze- 
rzać zdrowe poglądy oparte na rozumie i rozwadze, a nie na nieokiełznanych afektach, nie na nerwach odruchowych, nie na histerii.

4. Nareszcie powinniśmy pamiętać o wychowywaniu przyszłych pokoleń w duchu solidarności obywatelskiej.

Wcielając w życie zasadę równouprawnienia, czego mamy prawo wymagać od Żydów?

0 wymaganiu „patriotyzmu” uczuciowego nie może być tymczasem mowy. Uczucia są ukryte w głębi dusz ludzkich. Miłości takiej lub owakiej nie można ani ślubować, ani nakazywać, ani wymagać. Na miłość trzeba przede wszystkim zasłużyć. Kiedy państwo stanie się faktycznie dla wszystkich swych „dzieci” sprawiedliwą matką, a nie legendarną złą macochą, wtenczas przyjdzie kolej także na „miłość ojczyzny”.

Tymczasem powinniśmy się zadawalniać wymaganiem od Żydów daleko idącej a nierównie solidniejszej solidarności ogólnopaństwowej, nawet bez przysięgi na wierność państwu.

Poruszone tu przeze mnie oraz wszelkie inne środki, mające na celu uspokojenie i zgodne współżycie, obliczone są na długie lata. Trzeba się uzbroić w cierpliwość, pamiętając, że nie od razu Kraków zbudowano. Takich wielkich przeobrażeń nie wytrząsa się z rękawa.

Jeżeli nie zdziczejemy i nie spodlejemy ostatecznie, co zresztą bardzo jest możliwe, musimy, zacisnąwszy zęby, pracować dla przyszłych pokoleń w imię dobra państwa, społeczeństwa i całej ludzkości.

Ale to wszystko wygląda tak pięknie w teorii osnutej na złotych marzeniach. Nie zapominajmy, że tak zwane rozwiązywanie kwestii społecznych i politycznych dokonywa się „żywiołowo”, z minimalnym udziałem świadomości. A my sobie to tylko post factum uświadamiamy i wszechstronnie oświecamy.

Dzieje toczą się pomimo nas, a na placu boju pozostają: $z$ jednej strony gryzienie się bestii ludzkich, z drugiej zaś strony wygodny frazes: „jakoś to będzie”. 
Dla każdego z nas męka istnienia kończy się z jego życiem i przejściem do stanu nieboszczyków ś.p. lub bł.p., a dla bezwyznaniowców bez tych zbytecznych dodatków.

Niechaj się gryzą dwunogie, bylem tylko ja, pogrążywszy się w Nirwanie, nie widział tego gryzienia się i nie słyszał tych kwików, pisków, wycia i ujadania.

I to jest mój egoizm osobisty.

\section{Odsyłacze do tekstu}

N[ume]ry odnoszą się do tytułów podanych w Bibliografii. [1] Nr 4; [2] Nr 6 i 7; [3] Nr 9; [4] Nr 8; [5] Nr 1; [6] Nr 9.

\section{Bibliografia}

Swe własne broszury i artykuły sprzed roku 1913, które albo wyłącznie były poświęcone „kwestii żydowskiej”, albo też dotykały jej tylko między innymi, wyliczam w broszurze $W$ „kwestii żydowskiej”, Warszawa 1913, str. 109-112.

Później potrącałem o te kwestie w różnych wydawnictwach i czasopismach rosyjskich aż do r. 1918, między innymi w broszurze Nacionalnyj i tierritorialnyj priznak w awtonomii. Poswiaszczajetsa wsiem „patriotam”, S-Pietierburg 1913, która uległa konfiskacie i zniszczeniu, a ja za jej wydanie zostałem skazany w marcu r. 1914 na dwa lata twierdzy. Karę tę zmniejszono mi do trzech miesięcy, które, przy zamianie „twierdzy” na „więzienie celkowe” (odinocznoje zakluczenije), tj. z potrąceniem 25\%, odsiedziatem w ciągu dwóch miesięcy i jednego tygodnia (od początku listopada r. 1914 do połowy stycznia r. 1915) w petersburskich „Krestach”.

Po przesiedleniu się z Petersburga do Warszawy we wrześniu r. 1918, już w nowo wskrzeszonym Państwie Polskim poruszałem „kwestię żydowską” w czasopismach polskich. Oto wykaz, zdaje się, wyczerpujący tych moich artykułów:

1. Państwowość polska a Żydzi w Polsce, „Gazeta Polska” 1919, nr 272, 275, 276, Warszawa, 20, 23 i 24 lipca. Artykuły te były przeróbką jednego z czterech memoriałów ułożonych przeze mnie dla Biura 
Kongresowego w Warszawie, które je przesłało Konferencji Pokojowej w Wersalu.

2. W sprawie ksiegi zbiorowej ku uczczeniu nieboszczyka W. Feldmana, „Kurier Polski” 1920, nr 333, Warszawa, 6 grudnia). W zmienionej i uzupełnionej postaci dałem ten artykuł, jako Stowo wstepne, do samej ksiegi zbiorowej Pamieci Wilhelma Feldmana, Kraków 1922, str. 1-6.

3. Z moich wspomnień o W. Feldmanie, „Głos Polski”, Łódź, 23 października 1921, nr 260.

4. Antysemityzm monarchów rosyjskich a „antysemityzm” polski, „Gazeta Polska” 1919, nr 294, 11 sierpnia.

5. Antysemityzm a nauka uniwersytecka w Polsce, „Gazeta Polska” 1919, nr 283, 31 lipca.

6. Epidemia pogonotomii, „Kurier Polski” 1919, nr 182, 18 lipca.

7. Jeszcze z powodu „brodobórstwa”, „Gazeta Polska” 1919, nr 317, 3 września.

8. Judeo-Polska, „Głos Polski”, Łódź 1923, nr 5, 5 stycznia.

9. Numerus clausus, „Głos Polski”, Łódź 1923, nr 6, 6 stycznia.

10. Blok mniejszości narodowych, „Głos Polski”, Łódź 1923, $\mathrm{nr} 50$ i 51,20 i 21 lutego.

11. Sprawy polsko-żydowskie, „Dziennik Poranny”, Warszawa 1919, nr 21, 24 i 35; 23 i 26 stycznia, 6 lutego.

Inne moje artykuły, napisane na usilną prośbę redakcji „Dziennika Porannego", nie zostały wydrukowane, bo redakcja ta, jako partyjna i jednostronna, nie chciała się kompromitować w oczach czytelników ogłaszaniem artykułów krytykujących postępowanie Żydów.

Z powodu sławetnej Jabłonny ${ }^{1}$ napisałem we wrześniu r. 1920 dla „Narodu” artykuł pt. Nie moge uwierzyć, ale srożąca się wówczas cenzura wojskowa uniemożliwiła jego wydrukowanie.

Zwracam też uwage na dwie broszury w „kwestii żydowskiej”, napisane ze stanowiska humanitarnego i prawdziwie obywatelskiego:

$1 \quad$ W Jabłonnie k. Warszawy zorganizowano podczas wojny 1920 r. obóz koncentracyjny dla polskich żołnierzy „wyznania mojżeszowego”. 
1. Antoni Lange, O sprzecznościach sprawy żydowskiej, Warszawa 1911.

Choć nie ze wszystkimi zdaniami autora można się zgodzić, trzeba jednak uznać czystość jego pobudek i oryginalność jego zapatrywań.

2. Dr S. Rubinrot, $W$ imie prawdy..., W sprawie żydowskiej z powodu uchwalenia odnośnej Komisji w Sejmie polskim, Warszawa 1919.

[Warszawa 1923. „Biblioteka Wolnomyśliciela” nr 1] 


\title{
W KWESTII NARODOWOŚCIOWEJ
}

\author{
Uwaga przedwstępna
}

Pod tym tytułem wygłosiłem w r. 1924 cały szereg odczytów publicznych: 1) w Warszawie 17 lutego, w lokalu stowarzyszenia „Strzecha” (Nowy Świat, 21); 2) w Tarnowie 26 marca; 3) w Krakowie 27 marca; 4) w Zgierzu 8 maja; 5) w Brześciu nad Bugiem (w dawnym Brześciu Litewskim) 28 czerwea; 6) w Wilnie 21 grudnia. Za każdym razem odczyt mój brzmiał cokolwiek inaczej. Obecnie wydaję go w znacznie zmienionej i rozszerzonej postaci.

Nie pochlebiam sobie, ażeby moje odezwanie się mogło wywrzeć choćby najmniejszy wpływ. Ale srożący się obecnie nierozum polityczny, kierowanie się jedynie nieokiełznanymi i wyuzdanymi emocjami i afektami, nie zaś dobrze zrozumianym interesem państwowym i spotecznym - niechaj usprawiedliwią moje wystąpienie.

\section{Co to jest narodowość i gdzie istnieje?}

Ażeby usłyszany lub też przeczytany wyraz narodowość wywart odpowiednie wrażenie, czy to słuchacz, czy też czytelnik musi być odpowiednio przygotowany, przygotowany zarówno pod względem umysłowym, intelektualnym, jako też pod względem uczuciowym, emocjonalnym, Przede wszystkim dla uruchomienia narodowości w jej postaci polskiej potrzeba znać język polski, tj. mieścić w swej głowie myślenie językowe polskie. Oczywiście dla zrozumienia skojarzonych z podobnymi wyobrażeniami i wywołujących podobne emocje wyrazów innojęzykowych, nationalité, Nationalität, nacional'nost' itd., konieczną jest znajomość odpowiednich języków.

To jednak nie wystarcza. Nie dla każdego mówiącego po polsku wyraz narodowość jest sam przez się zrozumiały. Dla wielu jest to tylko wyraz bez treści, co najwyżej rzeczownik rodzaju żeńskiego, należący do pewnego typu gramatycznego. Dopiero po rozbudzeniu w duszy własnej poczucia narodowościowego dana jednostka może uczestniczyé w zbiorowym życiu narodowym. Dopiero po wzniesieniu 
się na pewien poziom umysłowy można dojść do pojęcia narodowości.

Ale nawet na najwyższym stopniu umysłowym i przy najsubtelniejszym przeżywaniu pewnych wzruszeń, czyli emocji, uruchomienie językowe i znaczeniowe wyrazu narodowość wysuwa na pierwszy plan jego cechy formalne. Dzięki urodzajowieniu języka polskiego, urodzajowieniu będącemu odbiciem uptciowienia w świecie zwierząt i roślin, narodowość świadczy o sobie jako o istocie rodzaju żeńskiego. W różnicy od męskich naród, lud, rzad i nijakich państwo, spoteczeństwo, a na równi z przesztościa, pomystowościa, obrzędowościa, wytwórczościa, prawościa, sprawiedliwościa, mitościa, ztościa, jednościa, wielościa, mnogościa, pięknościa itd., przy pewnym polocie fantazji twórczej, narodowość staje się jakąś panią, damą, boginią.

Gdzie jednak istnieje, gdzie mieści się ta pani, ta dama, ta bogini? Czy możemy jej szukać poza człowiekiem?

Nie. Narodowość mieści się i żyje tylko w pojedynczych duszach ludzkich, skąd jednak może się wydobywać na zewnątrz w postaci obrazów, symbolów i świadczących o niej czynów ludzkich. Narodowośc istnieje i działa tam, gdzie istnieją i działają wszystkie tego rodzaju chwiejne, nieokreślone, ogólnikowe wyobrażenia substancjalne, czyli rzeczownikowe, od języka, czyli mowy ludzkiej, do państwa, bóstwa itd. włącznie. Tam to, w tej jednostkowej duszy ludzkiej, żyją i działają; język, czyli mowa ludzka zarówno wymawianiowo-słuchowa, jako też pisaniowo-wzrokowa, czyli pismo; tam żyje i działa wszelka twórczość umysłowa w nauce, w poezji i w sztuce; tam żyje i działa państwo wraz z rządem, z poddanymi, z obywatelami; tam żyje i działa gospodarstwo społeczne wraz z przemysłem, handlem i spekulacją; tam żyje i działa prawo wraz z jego wykonywaniem, obchodzeniem i naruszaniem, wraz z sądami i karami; tam żyje i działa moralność wraz z cnotami, grzechami i zasługami; tam żyją i działają mitologia i religia wraz z bożyszczami i bóstwami; tam żyją i działają zwyczaje i obyczaje itd.

I tutaj stwierdzamy zasadniczą różnicę między obiektem, czyli przedmiotem badań nauk przyrodniczych, a obiektem badań nauk psycho-socjalnych, „filologicznych”, „humanistycznych”. Przedmio- 
ty badań nauk przyrodniczych istnieją poza ludźmi, przedmioty zaś badań nauk psycho-socjalnych istnieja jedynie tylko w duszach ludzkich.

Gdy ginie człowiek pojedynczy, z nim razem ginie cały jego świat, świat wyobrażeń, uczuć i popędów; następuje koniec świata osobistego. Ale wszystko to, co stanowi przedmiot badań nauk psycho-socjalnych, nie przestaje istnieć w innych głowach. Gdy zginie cała ludzkość, wszystko to również zginie, zginie ostatecznie i raz na zawsze, ale świat chemiczno-fizyczny pozostanie. Pozostanie też świat fizjologiczno-biologiczny, 0 ile pozostaną inne zwierzęta i rośliny. Gdy zginą też inne zwierzęta i rośliny, pozostanie już tylko świat chemiczno-fizyczny oraz oczywiście wszechświatowy element psychiczny, czyli duchowy. Boć byłoby objawem szalonej zarozumiałości i megalomanii, czyli obłędu wielkości, przypuszczać, że poza człowiekiem nie ma we wszechświecie elementu psychicznego; tylko że ten wszechświatowy element psychiczny jest niedostępny dla ograniczonej i znikomej myśli ludzkiej. Ten wszechświatowy element psychiczny nie jest wcale bogiem ludzkim, bogiem stworzonym na obraz i podobieństwo człowieka, ale jest czymś z myślą ludzką niewspółmiernym, czymś niedoścignionym, niepojętym, jak niepojętą jest nieskończoność czasu i przestrzeni, bezpoczątkowość i bezkońcowośé czasu i przestrzeni we wszystkich kierunkach.

Inaczej jest ze światem psychiczno-socjalnym jako przedmiotem badania. Zginą nie tylko psychologia, socjologia, filologia, historia, ale także same psyche, czyli dusze ludzkie, same societates, czyli ugrupowania ludzkie, zginą w ogóle wszystkie przedmioty badań tych nauk. Zginą wyrazy, wyobrażenia, pojęcia. Zniknie wszelka twórczość ludzka; znikną odkrycia, wynalazki. Znikną ludzie, więc zniknie to wszystko. Będzie to absolutny koniec świata ludzkiego.

Znikną plemiona, szczepy, ludy, narody, narodowości, kraje, państwa, części świata, federacje i różne inne zrzeszenia, ugrupowania i zbiorowiska ludzkie i zwierzęce. Znikną kasty, warstwy społeczne, klasy. Zniknie walka klas. Zniknie nawet „klasowy ruch robotniczy”. Znikną walki zarówno w imię interesu, jak i z pobudek idealnych.

Co więcej, znikną nie tylko nauki i w ogóle całe myślenie ludzkie 0 świecie, ale nawet zniknie cały świat chemiczno-fizyczny i as- 
tronomiczny, uporządkowany na modłę ludzką. Pozostanie to coś, co skłoniło człowieka do wytworzenia pojęć fizycznych, chemicznych, mechanicznych i innych, ale nie będą to już po ludzku ujęte zjawiska świetlne, czyli optyczne, słuchowe, czyli akustyczne, chemiczne, mechaniczne, cieplne, czyli termiczne; nie będzie to ludzka elektryczność, nie będzie to ludzka przemiana materii, nie będzie to ludzkie ujawnianie energii.

W wielkiej papierni wszechświatowej łachmany naszych zdobyczy umysłowych i kulturalnych, wszelkie ślady naszego istnienia zostaną roztarte na miazgę, przetworzone na nową masę, dla wytworzenia nowego papieru, na którym może z czasem jakieś nowe istoty żywe, w charakterze naszych nieświadomych spadkobierców i nosicieli historii i kultury, będą wypisywać od początku ślady życia i rozwoju społecznego.

Czyż wobec tego nie należałoby się upamiętać i, zamiast wzajemnie zatruwać sobie życie, wykorzystać to krótkie i skazane na zagładę istnienie do wspólnej walki z przyrodą i do osiągnięcia możliwego szczęścia i dobrobytu?

Zamiast tego gryziemy się i tępimy się nawzajem, a jednym z pretekstów do tej orgii tępicielskiej jest tak zwana narodowość w jej różnorodnych odmianach.

\section{Pochodzenie narodowości}

Skąd powstała narodowość, tj., ściślej mówiąc, wyobrażenie i poczucie narodowości?

Narodowość wiąże się ściśle, nie tylko językowo, ale także pozajęzykowo, z narodem.

Zarodek i początek narodu tkwi przede wszystkim w języku, czyli w wyodrębnionej, różnej od innych, wspólnej mowie pewnego zbiorowiska ludzkiego oraz we wspólnym życiu, we współżyciu takiego zbiorowiska ludzkiego. Stwierdzamy następnie stopniowe podnoszenie się od takiego stada prawie zwierzęcego na coraz wyższe poziomy. Przy tym dokonywa się stopniowe przechodzenie od stanu koczownictwa do stanu osiadłości. 
Stado zwierzęce staje się społeczeństwem ludzkim. Współżycie stadowo-egoistyczne przechodzi we wspótżycie zbiorowo-indywidualne (kolektywnie indywidualne). Na niższym stopniu mamy wąski egoizm, na wyższym stopniu indywidualizm. Na niższym stopniu komunizm pierwotny, dziki, na wyższym stopniu komunizm rozumowy i oparty na poczuciu sprawiedliwości jako wykwit cywilizacji, jako kolektywizm i solidaryzm.

Tylko proszę nie dawać się porywać myśleniu wyrazowemu. To, co w danej chwili szaleje pod nazwą komunizmu, nie odpowiada wcale wymaganiom uspołecznienia nowoczesnego, ale jest po prostu powrotem do stanu dzikości, jest rabunkiem pod hasłem rabuj to, co zrabowano (grab' nagrablennoje), jest karykaturą na komunizm w wyższym stylu, czyli na kolektywizm. Jest to skutek rozpasania przez wojnę najdzikszych instynktów, nie zaś wcielania w życie zasad solidarności wszechludzkiej.

Podobnie też i praktykowanie narodowości albo może być dzikie i barbarzyńskie, albo też odpowiada wysokiemu poziomowi rozwoju kulturalnego i cywilizowanego. Oczywiście istnieje cała skala stanów mieszanych i przejściowych.

\section{Cechy narodowości}

Jak wszelkie inne hasła i sztandary, pod którymi grupują się krzyżujące się rozmaicie zbiorowiska ludzkie, tak i czy to narodowość w ogóle, czy też pewna ściśle określona narodowość muszą posiadać pewne cechy, czyli właściwości, uprawniające nas do używania tej nazwy w stosunku do ludzi.

Cechy te sprowadzają się do dwóch głównie źródet: albo są to cechy obiektywne, całkiem niezależne od woli i świadomości ludzkiej, albo też jest to samookreślenie subiektywne. Zresztą i na samookreślenie możemy patrzyć jak na cechę obiektywną.

Cechami obiektywnymi ludzi pojedynczych i całych gromad ludzkich, cechami niezależnymi od niczyjej woli ani od woli cudzej, ani od woli własnej, są np. płeć, wiek, różne cechy antropologiczne w rodzaju koloru skóry, włosów, oczu, wymiarów czaszki i ciała w ogóle, język, czyli mowa danego indywiduum, używanie tego lub 
owego pisma, takie lub owakie zwyczaje, podania, tradycje, wierzenia, wspólne ideały społeczne i polityczne, pewien odziedziczony i nabyty stan umysłowości i skłonności etyczno-socjalnych (wrodzony sadyzm, wrodzone współczucie do innych ludzi), do pewnego stopnia wspólne terytorium.

Za pomocą cech obiektywnych, mniej lub więcej ściśle określanych, rozróżniamy lud polski, naród polski, narodowość polską.

Stwierdzamy przy tym rozmaite szczeble (stopnie) unarodowienia, uświadomienia narodowego. Tak np. trudno mówić o narodowości w pełnym znaczeniu tego wyrazu u dzieci, u mas ludowych.

Nareszcie przynależność państwowa, nawet wbrew życzeniom i sympatiom danej jednostki, stanowi jej cechę obiektywną, niezależną od woli ludzkiej.

Od cech czysto obiektywnych i od cech subiektywnych, samookreśleniowych, należy odróżniać trzecią kategorię, kategorię pośrednią, stojącą na pograniczu tych dwóch dziedzin krańcowych. Są to cechy obiektywno-subiektywne, kiedy człowiek bywa zaliczany do pewnego zbiorowiska dzięki nie własnej, ale cudzej woli, dzięki rozkazowi, nominacji lub wyborowi.

Tu należy przede wszystkim przymusowa służba wojskowa oraz wszelkie inne formy niewolnictwa, np. więzienie przymusowe kobiet w domach publicznych, zaliczanie przy praktykowaniu tzw. „dyktatury proletariatu” całych rodzin i całych skupień ludzkich do pozbawionych praw, poniewieranych i ogałacanych z mienia „burżujów”, skazywanie przez sądy i w ogóle przez innych ludzi na takie lub owakie kary, itd. Tutaj własna wola pacjenta nie ma nic do powiedzenia. Ażeby się uwolnić od skutków stosowania cudzej woli do jego osoby nie pozostaje mu nic innego, jak albo uciec, albo też odebrać sobie życie.

Natomiast w wielu innych wypadkach wola cudza jest wprawdzie głównym czynnikiem rozstrzygającym, ale do jej ostatecznego wcielenia w życie niezbędną jest także zgoda samego osobnika mianowanego lub też obieranego.

Urzędnikiem państwowym lub prywatnym, nauczycielem, profesorem, kawalerem orderu tego lub owego stopnia, radcą miejskim, posłem do sejmu lub senatu staje się człowiek bądź to z nominacji zwierzchności, bądź też przez głosowanie, ale może nie przyjąć ofia- 
rowanej mu godności. Bywają wprawdzie wypadki, kiedy nie wolno zrzekać się takiej godności, ale te należą do wyjątków.

Prezydent rzeczypospolitej lub też król elekcyjny osiąga ten zaszczyt przez stosowanie arytmetycznej zasady większości, gdy tymczasem monarcha „Z bożej łaski” jest przeznaczony do piastowania swego urzędu przez sam fakt urodzenia się.

Istnieją próby przymusowego zaliczania do tej lub owej narodowości, ale to są objawy przemocy i gwattu.

Jak wyznanie religijne, tak i wyznanie narodowe, czyli narodowość człowieka, stanowi jedną z jego cech wyłącznie subiektywnych, zależnych jedynie od świadomości, od własnej woli, od własnego uznania i samookreślenia. Wszelkie zamachy na wolność sumienia czy to wyznaniowego, czy też narodowego $\mathrm{w}$ państwie praworządnym i nie niewolniczym są zbrodnią przeciw godności ludzkiej i przeciw prawom zasadniczym, zabezpieczonym przez konstytucję.

Świadomość narodowa bywa o różnym natężeniu i napięciu, wahając się (oscylując) między zerem a $n$, tj. pewnym maximum, pewną normą najwyższą. To, co wybiega ponad zwykłą normę, staje się hipertrofią, staje się przerostem poczucia narodowego.

Możliwą jest też narodowość wmówiona, sugestionowana przez rodziców lub choćby tylko przez jednego z rodziców, przez ojca lub matkę, pomimo to, że się urodziło i że się żyje na obczyźnie, w innojęzykowym i innonarodowym otoczeniu. Znane są osoby urodzone np. w Turcji, w Danii, w Ameryce itp. i pomimo całkowitej nieznajomości języka polskiego odznaczające się przeczulonym patriotyzmem polskim.

\section{Różnorakie „narodowości”}

Poczucie narodowe może się stać energią pobudzającą do czynów bądź to wzniosłych i szlachetnych, bądź też nikczemnych i ohydnych. Fanatyzm partyjny w zastosowaniu do wyznania i narodowości wywołuje zachłanność, napastniczość (agresywność) i fatalne pomieszanie pojęć.

Istnienie Rzymu, tego potwora wiecznie imperialistycznego, z pretensjami do panowania $\mathrm{w}$ ten lub ów sposób nad całym świa- 
tem, nie tylko ziemskim, ale nawet pozaziemskim, doprowadziło do powstania „narodu katolickiego”, wypierającego z głów zamroczonych poczucie innych wyodrębnionych istotnych narodowości i przeciwstawiającego się czupurnie i zaczepnie innym tego rodzaju „narodowościom” z szyldem wyznaniowym. W Polsce cierpiącej na obłęd upaństwowienia narodowości i unarodowienia państwowości oraz na obłęd uwyznaniowienia narodowości i unarodowienia wyznań, w tej Polsce cierpiącej w nierównie wyższym stopniu niż wiele innych społeczeństw na brak umysłów silnych i samodzielnych, katolicyzm utożsamia się z polskością, wyznanie ewangelickie z niemieckością, prawosławie z rosyjskością, czyli z moskiewskością, wyznanie unickie z rusińskością, „narodowość żydowską” z wyznaniem mojżeszowym, starozakonnym, izraelickim.

„Naród katolicki”, jako zbiór poddanych i niewolników wszechwładcy rezydującego w Rzymie, powstał ze zmieszania imperialistycznych dążności Rzymu Cezarów ze swoistymi dążeniami Żydów zreformowanych, czyli chrześcijan, do narzucenia swych wierzeń całej ludzkości. Obok tego „narodu katolickiego”, wytworzonego z odszczepieństwa od pnia żydowskiego, nie przestaje istnieć pierwotny, prawowierny, ortodoksyjny „naród żydowski”, rozsiany po całym świecie.

\section{„Narodowość żydowska” I}

Tutaj wypada zapytać:

Czy istnieje osobna „narodowość żydowska” na podobieństwo takich narodowości, jak niemiecka, francuska, angielska, włoska, hiszpańska, polska, czeska, rosyjska, ukraińska itd., narodowość nieutożsamiana z wyznaniem mojżeszowym? Przy tym mamy do czynienia tylko z dwoma pojęciami, wyznaniem i narodowością, bo przyjmowanie jakiejś osobnej „rasy” żydowskiej ze stanowiska obiektywnie-naukowego nie ma żadnej podstawy.

Otóż wszystkie dane historii i obserwacji tego, co mamy przed oczyma, skłaniają nas do twierdzenia, że osobna swoista „narodowość” żydowska istnieje i odznacza się w ogóle daleko wyraźniejszymi cechami aniżeli inne, ogólnie uznane narodowości. 
Przede wszystkim znakomitą większość osobników nazywanych Żydami łączy w jedno zbiorowisko tradycyjna religia, jedna z najbardziej upartych, wyodrębniających się i nietoleracyjnych religii, łączy uświęcony od tysiącoleci rytuał. Następnie znakomitą większość Żydów łączy w wyodrębniające się od innych zbiorowisko ludzkie potworna megalomania „narodu wybranego”, wybranego przez Stwórcę na pana i władcę nad innymi narodami, a tylko czasowo upośledzonego i skazanego na tułaczkę, dla tym świetniejszego tryumfu w przyszłości pod wodzą oczekiwanego z utęsknieniem Mesjasza. To poczucie niezmiernej potęi pod opieką rozmiłowanego w swych wybrańcach Jehowy utrzymuje w całej sile swoisty patriotyzm żydowski i swoistą narodowość żydowską, pomimo zatracenia przez Żydów własnego języka. Osobny język narodowy Żydów ustąpił miejsca językom ich prześladowców, a te języki prześladowców podniesiono do godności ,języków żydowskich”. Okrutnie prześladowani przez Hiszpanów i wypędzeni z Hiszpanii Żydzi ponieśli ze sobą w inne kraje język hiszpański, jako język różniący ich od tuziemców. Są to tak zwani spanioli, Żydzi języka hiszpańskiego. W otoczeniu znowu niemieckim Żydzi przyswoili sobie pewne gwary niemieckie, przetwarzając je na swoisty język żydowski, zwany lekceważąco i pogardliwie „żargonem”, a właściwie, ze stanowiska obiektywnego, tak dobry język, jak i wszelki inny. 0 ile ten język pozostaje w sferze wymawianiowo-słuchowej, należy do świata językowego germańskiego. 0 ile zaś posługuje się zmodyfikowanym alfabetem hebrajskim, z odwrotnym sposobem pisania, nie z lewa na prawo, ale z prawa na lewo, wyodrębnia się od całego świata europejsko-amerykańskiego i przenosi Żydów do Azji Zachodniej, do świata semickiego.

Dziś ten ,język żydowski” jest jednym z narzędzi, za pomocą których Żydzi oddzielają się od współmieszkańców innych narodowości i zasklepiają się w swym narodowym ghetto.

Pewna część Żydów mieszkających w dawnej Rosji przyjęła język rosyjski i trzyma go się jako swego języka, w różnicy od innych języków miejscowych, Np. Żydzi wileńscy mówią dziś w znacznej części po rosyjsku, wywołując oburzanie się przeczulonych patriotów polskich. Oburzanie się to jest oczywiście objawem patologicznym, ale i bez oburzania się może się wydawać dziwnym i rażącym trzyma- 
nie się języka byłych prześladowców, nawet z uszczerbkiem własnych interesów. Gra tu z pewnością rolę swoisty konserwatyzm żydowski, godzący się wyśmienicie z drugą ostatecznością, z rzucaniem się bez zastrzeżeń w objęcia najnowszych i najskrajniejszych prądów politycznych i społecznych.

Wyodrębnieniu Żydów jako osobnej narodowości współdziałało wtłaczanie ich w średniowieczu w osobne dzielnice żydowskie, tzw. ghetto, uznawane zresztą z lubością przez samych Żydów. W sposób zmodyfikowany trwa to po dziś dzień.

\section{„Narodowość żydowska” II}

Przyjrzyjmy się jeszcze nieco uważniej „narodowości” żydowskiej.

Na dobrą sprawę, ze stanowiska obiektywnego, ze stanowiska ściśle naukowego, w świetle logiki porządkującej i klasyfikującej, swoista odrębność wszechżydowska, poczucie solidarności wszechżydowskiej i związany z tym specyficzny patriotyzm żydowski jako następstwo wspólnych wierzeń i tradycji religijnych, jako następstwo fanatycznie przestrzeganego rytuału, mogą być postawione jedynie obok odrębności wszechkatolickiej, obok poczucia solidarności wszechkatolickiej i obok specyficznego patriotyzmu katolickiego, jako też obok odrębności i solidarności wszechmuzułmańskiej i obok specyficznego patriotyzmu muzułmańskiego albo obok odrębności, solidarności i wyznaniowego patriotyzmu wszystkich buddystów itp. Jest to odrębność, solidarność i kosmopolityczny patriotyzm wszelakich międzynarodówek powstałych pod najrozmaitszymi hasłami i szyldami. Tutaj należą: międzynarodowa i wszechludzka solidarność wszystkich monarchów, wszystkich arystokratów i tzw. wyższych sfer społecznych, wszystkich kupców, przemysłowców i wszelkiego rodzaju kapitalistów, wszystkich ludzi pracy, wszystkich proletariuszy; międzynarodowa i wszechludzka solidarność wszystkich artystów i wszystkich uczonych zarówno w ogóle, jak i według pojedynczych specjalności; międzynarodowa i wszechludzka solidarność wolnomularzy, czyli masonów, faszystów, komunistów; międzynarodowa i wszechludzka solidarność esperantystów i innych zwolenników ję- 
zyków pomocniczych międzynarodowych; międzynarodowa i wszechludzka solidarność bezwyznaniowców, wolnomyślicieli, itd., itd.

Międzynarodowa i wszechludzka odrębność i solidarność wszystkich powyżej wymienionych zrzeszeń i zbiorowisk ludzkich, bez względu na przynależność państwową, narodową i językową, jest faktem niezaprzeczonym. Ale też i Żydzi, uważając się za wyodrębnione od reszty ludzkości wspólne zbiorowisko ludzkie, stanowiące jedną całośé, pomimo że są obywatelami czy też poddanymi różnych państw, pomimo że używają różnych języków ojezystych czy też macierzystych, należą do kategorii owych międzynarodowych zrzeszeń i zbiorowisk ludzkich w różnicy od narodowości w ścisłym znaczeniu tego wyrazu.

Tak by się zdawało w świetle logiki, ze stanowiska obiektywnego, bez udziału woli i świadomości osobników klasyfikowanych. Ale przecież, jak wyżej zaznaczyłem, nikt nie ma prawa czy to narzucać innym tę lub ową narodowość, czy też odmawiać prawa zaliczania siebie do tej lub owej narodowości, zgodnie z własną nieprzymuszoną wolą i $\mathrm{z}$ własnym uświadomieniem narodowym, i przy tym jest zupełnie obojętne, czy dany osobnik zalicza siebie do jednej z narodowości uznanych i istniejących, czy też zalicza siebie do jakiejś nowej, dotychczas nieprzewidzianej narodowości, czy też nareszcie nie chce należeć do żadnej narodowości.

Jeżeli więc wielu Żydów nie zadawala się przeciwstawianiem siebie jako starozakonnych, „nowozakonnym”, ale obok tego swą solidarność wszechżydowską, polegającą na odwiecznych tradycyjnie przekazywanych wierzeniach i na zaciekle, fanatycznie przestrzeganym rytuale, chce przemalować na kolor narodowościowy i np. w Polsce wystąpić jako osobna narodowość obok innych narodowości państwa, tj. obok narodowości polskiej, ukraińskiej, białoruskiej, rosyjskiej, litewskiej, niemieckiej, to nikt nie ma prawa zabraniać im tego.

W ciągu kilku ostatnich dziesięcioleci Europę ogarnął ogólny obłęd narodowościowy. Obłęd ten znalazł oddźwięk także w środowisku żydowskim. Jemu to przede wszystkim zawdzięczamy zrodzenie się syjonizmu, podtrzymującego nader skutecznie poczucie narodowe Żydów w różnicy od innych narodowości. 
Jeżeli syjonizm ma się oprzeć na podłożu geograficznym, to musi on także ustalić jeden wspólny język dla wszystkich Żydów upaństwowionych. Żydzi syjoniści dopiero szukają wspólnego języka. Ale zdaje się, że cały syjonizm pozostanie w dziedzinie marzeń nie do urzeczywistnienia, podobnie jak i cały mesjanizm żydowski. Żydzi i nadal będą musieli pozostawać we Francji, we Włoszech, w Anglii, w Ameryce, a na wschodzie Europy tworzyć nadal osobną odmianę, tzw. Osteuropäische Juden. Będą więc i nadal pozostawali w Polsce, a to narzuca nam problemat ich zgodnego wspótżycia z innymi obywatelami państwa.

0 tzw. „asymilacji” ryczałtowej mowy tymczasem być nie może. „Patrioci” albo raczej „partyjoci” z obozu utożsamiającego Polskę z własną partią i jej bardzo poziomymi interesami uprawiają zajadłe szczucie i nagankę na Żydów i wszelakimi siłami starają się przeciwdziałać asymilacji, choćby tylko szczytów inteligencji obustronnej. Zbliżeniu się i spokojnemu zgodnemu współżyciu przeszkadzają obustronni nacjonaliści zarówno żydowscy, jak i rdzenni.

Wobec tego wszystkiego pytam: czy mamy uznać narodowość żydowską, czy też nie? Czy mamy iść za przykładem Austrii w ogóle, a Galicji w szczególności, gdzie przy spisie ludności Żyd miał prawo pod względem narodowościowym podać się za Niemca, Polaka, Rusina, Czecha, Madziara, Araba, Turka, Chińczyka, ale nie wolno mu było przyznać się do narodowości żydowskiej.

Zdrowy rozsądek i poczucie sprawiedliwości nie pozwalają nam upośledzać nikogo pod względem jego prawa do samookreślania się. Jeżeli Żyd czuje się narodowo Żydem, ma nie tylko prawo, ale także obowiązek podać się za Żyda,

Przy tym małe zastrzeżenie:

Jak przynależność do wszelkiego innego wyznania i narodowości, tak też przynależność do wyznania mojżeszowego i do narodowości żydowskiej może być tylko dobrowolna, nigdy zaś przymusowa. Wara wszelkim gminom żydowskim, wszelkim kahałom, wszelkim zarządom bóżnicznym od zmuszania osób pochodzenia żydowskiego do tego, ażeby koniecznie zaliczały się do Żydów i opłacały podatki związane z przynależnością formalną do tego wyznania. 


\section{Myślenie wyrazowe i mieszanie pojęć \\ w stosunku do narodowości}

Skończywszy z narodowościa żydowską, przechodzę do rozpatrywania kwestii narodowościowej w ogóle.

Jak wszędzie w dziedzinie myśli trzeźwej, tak i tu należy starannie unikać myślenia wyrazowego, tj. mieszania pojęć na podstawie bądź to tożsamości lub podobieństwa wyrazów, bądź też przypadkowego zbiegu, czyli koincydencji cech różnowartościowych. Jeśli np. spostrzeżenie poucza nas, że większość, choćby nawet znaczna, brunetów odznacza się niższym wzrostem aniżeli większość blondynów, to jednak nie uprawnia nas to do utożsamiania niższych z brunetami, a wyższych z blondynami.

Poprzednio dotknąłem prostackiego mieszania narodowości z wyznaniem. Nie mniej niedorzeczne i szkodliwe jest upaństwowienie narodowości i unarodowienie państwa, tj, mieszanie państwa z narodem, państwowości z narodowością.

Przede wszystkim niech mówią oczywiste fakty.

Zanim powstało unarodowione cesarstwo niemieckie, istniały państwa takie jak Prusy, Bawaria, Saksonia, Wirtemberg, Baden, Hessen jedno i drugie, Hannover, Oldenburg, Nassau, Schlezwig, Holstein itd., znaczna część Szwajearii, znaczna część Austrii, a wszystkie one były zamieszkane, z pewnymi wyjątkami, przez naród niemiecki. Przy jednolitej narodowości włoskiej (narodowości nie tyle językowej, ile historycznej) Włochy liczyły kilkanaście państw i państewek różnoimiennych, Anglii i Stanom Zjednoczonym wspólna jest narodowość kulturalna anglosaska, Portugalii i Brazylii portugalska, a narodowość hiszpańska panuje nie tylko w Hiszpanii, ale także w republikach południowoamerykańskich.

Z drugiej strony państwo Szwajcaria, czyli Helwecja, ma trzy a nawet cztery lub pięć narodowości językowych i literackich, a np. obywatel kantonu Ticino władający doskonale językiem włoskim obraża się, kiedy go zapytać, czy jest Włochem. No, sono Svizzero (nie, jestem Szwajearem) - odpowiada dumnie. Tu jednolitość państwowa przeważa nad różnorodnością językowo-narodową. Nieboszczka 
Austria stanowiła jedno państwo, mieszczące w sobie kilkanaście narodowości różnoplemiennych i różnojęzykowych.

Dla rozróżniania państwa rosyjskiego od narodu rosyjskiego, czyli wielkoruskiego, stosowano po pierwszej tzw. rewolucji rosyjskiej terminy rossijskij do państwa, a russkij do narodu, przyjmując w zasadzie równouprawnienie innych narodowości państwa z narodowością liczebnie przeważającą i rezygnując z zachcianek ruszczenia, czyli rusyfikacji inorodców. Dawniej mieli to być nie tylko państwowo, ale także narodowo Rosjanie polskogo, niemieckogo, litowskogo, armianskogo, jewrejskogo, tatarskogo proischożdienija. Był to w oczach „patriotów” rosyjskich surowy materiał do zwiększania kadr narodowości rosyjskiej.

Podobnie istnieli dawniej w Galicji o panującym zabarwieniu polskim gente Rutheni, natione Poloni (z pochodzenia Rusini, z narodowości Polacy).

Przed laty mniej więcej 60 (1861-1863), za czasów Wielopolskiego, Szkoły Głównej i drgnień powstaniowych r. 1860 i nast., przeważna część inteligencji żydowskiej w Królestwie Polskim uważała siebie za gente Judaei, natione Poloni. Byli to późniejsi „Polacy wyznania mojżeszowego”. Epoka ta dawno minęła, a późniejsi działacze z obozu chrześcijańsko-narodowego zaczęli uprawiać gorliwie „odżydzanie Polski”.

\section{Beznarodowość i wielonarodowość}

W związku z pojęciem „narodowości” świadomej, opartej na samookreślaniu się, muszę poruszyć kwestię „beznarodowości” i „dwunarodowości” lub nawet „wielonarodowości”.

Beznarodowymi obiektywnie, beznarodowymi z konieczności są niemowlęta i dzieci w pierwocinach ich życia społecznego. Beznarodowymi są też indywidua z ludu nieuświadomione i obojętne pod tym względem. Ale tego nie dosyć.

Przy ścisłym przestrzeganiu wolności sumienia i poszanowaniu dla godności ludzkiej możliwe jest świadome niezaliczanie siebie do żadnej narodowości, jako też świadome zaliczanie siebie i uczuciowe należenie do dwóch i więcej narodowości. 
Beznarodowość staje obok bezwyznaniowości. Wielonarodowość zaś nie może mieć odpowiednika w dziedzinie wyznaniowej, bo uznawanie dogmatów i wierzeń jednego wyznania nie da się pogodzić z dogmatami i wierzeniami innych wyznań.

Mieszkając bądź to na pograniczu etnograficznym dwóch narodowości, bądź też w dzielnicy etnograficznie i narodowo mieszanej, można nie tylko mówić od samego początku dwoma językami, ale także brać udział w życiu kulturalnym jednej i drugiej narodowości i czuć się kulturalnie solidarnym i z jedną, i [z] drugą narodowością, a nawet kochać i miłować twórczość kulturalną i jednej, i drugiej narodowości.

Z jakiego powodu ma człowiek we własnej duszy toczyć zaciętą walkę i, należąc nie tylko obiektywnie, ale także subiektywnie do dwóch zbiorowisk narodowych, np. do żydowskiego i do polskiego, albo też do litewskiego i polskiego, jako Żyd lub Litwin nienawidzić w sobie samym Polaka albo też jako Polak nienawidzić w sobie samym Żyda lub Litwina? Tylko takie obmierzłe czasy jak nasze zmuszają ludzi do staczania takich tragicznych walk we własnej duszy.

Doskonale kwestię tę rozstrzygnął pewien szewe w Jaswojniach b. guberni kowieńskiej.

W lecie r. 1885 bawiłem chwilowo w tym mieście razem z Janem Juszkiewiczem, profesorem gimnazjalnym w Kazaniu, zasłużonym pracownikiem na polu filologii litewskiej i gorącym patriotą litewskim, pomimo że w domu w obcowaniu ze swą rodziną używał języka polskiego. Otóż temu propagatorowi litewskości szewe miejscowy przyniósł zamówione buty. Załatwiwszy tę sprawę życiową, Juszkiewicz zwrócił się do szewca z zapytaniem:

- Jakiego jesteś plemienia? (Kokies gimines esi?)

- Jestem katolik (Asz esmu katalikas) - odpowiada szewe.

Na to Juszkiewicz, nieco zirytowany:

- Nie 0 to chodzi; ja pytam, czy jesteś Polak, czy Litwin.

Szewe odpowiada:

- Jestem Litwin, jestem Polak (Esmu lietuvininkas, esmu lenkas).

- To nie może być; musisz być albo Polakiem, albo Litwinem. 
To nieporozumienie i niezrozumienie dwunarodowości ze strony zacietrzewionego doktrynera narodowościowego człowiek prosty, ale obdarzony zdrowym rozsądkiem, rozwiązał spokojną i rozumną odpowiedzią: „Mówię po litewsku, mówię po polsku” (kalbu lietuviszkai, kalbu lenkiszkai).

Takim dwunarodowym prostym człowiekiem był Jankiel cymbalista w Panu Tadeuszu Mickiewicza. Takim gorącym Żydem przywiązanym jednocześnie równie gorąco do narodu polskiego był Mendel Gdański Marii Konopnickiej.

Znałem osoby o wyższym poziomie umysłowym, należące i świadomie, i uczuciowo do dwóch narodowości, dokładniej mówiąc, do dwóch zbiorowisk ludzkich, wyodrębniających się od innych takich zbiorowisk pod względem wierzeń, tradycji i wspólności kulturalnej.

W latach 1905-1907, w czasach pierwszej „rewolucji” rosyjskiej, poznałem w Petersburgu inżyniera Hirschsohna, pochodzącego z Warszawy. Opowiadał mi, że, należąc do rodziny żydowskiej, czuł się solidarnym ze społeczeństwem żydowskim w ogóle; jednocześnie jednak od najmłodszych lat czuł się Polakiem i uważał siebie za Polaka. Kiedy jednak po r. 1880 fala pogromów rosyjskich, zapoczątkowanych w Niżnim Nowgorodzie, dotarła do Warszawy i kiedy i w Warszawie poczęto rabować sklepy żydowskie, rozpruwać pierzyny i poduszki żydowskie i w ogóle niszczyć mienie żydowskie, przeciwstawił się polskości jako Żyd prześladowany. Przeniósłszy się następnie do Petersburga i widząc tam prześladowanie zarówno Żydów, jak i Polaków, powrócił do dawnej dwoistości narodowej i poczuł się na nowo i Żydem, i Polakiem.

Zasłużony działacz w dziedzinie równouprawnienia wszystkich narodowości Rosji i obrońca odrębności ukraińskiej, nieboszczyk Aleksander Russow, zapewniał, że czuje się jednocześnie solidarnym z dwiema narodowościami: ukraińską i wielkoruską, czyli rosyjską.

Jeden $\mathrm{z}$ wybitnych językoznawców mieszkający przed laty w Warszawie pisał do mnie, że dopiero moje wywody o możliwości należenia jednocześnie do dwóch i więcej narodowości objaśniły mu jego stan psychiczny pod tym względem. Poczuwa się on jednocześnie do solidarności z narodowością niemiecką i polską. 
Poznałem też w Dorpacie znakomitego poliglotę, doktora Sauerweina, tłumacza przy Brytyjskim (Angielskim) Towarzystwie Biblijnym. W swym poliglotyzmie przeszedł on swego słynnego poprzednika, kardynała Mezzofantiego. Niemiec, hanowerczyk z urodzenia, rozumiał prawie 200 języków; władał zaś mniej lub więcej biegle chyba przeszło 70 językami. W wielu z tych języków układał utwory wierszowane. Niektóre z nich, jak np. litewskie, weszły do skarbca odnośnej literatury. Twierdził on, że, przyswajając sobie nowy język, zdobywa nową duszę. Z niektórymi z narodów, których język sobie przyswoił i używał go za narzędzie własnej twórczości literackiej, zespolił się do tego stopnia, że wspótezuł jego dążeniom politycznym i np. w czasie wyborów do parlamentu niemieckiego agitował na korzyść kandydatów narodowych litewskich w okolicach Tylży, a serbołużyckich w okolicach Budziszyna i Chociebuża. Spraw narodów uciśnionych bronił z zapałem jak spraw własnych. Nawoływał do zgody i pokojowego wspótżycia wszystkich narodów. Człowiek ten był prawdziwym wielonarodowcem w najszlachetniejszym znaczeniu tego wyrazu.

Od łączenia w swej duszy zarówno uczuciowej, jak i uświadomionej przynależności do dwóch narodowości należy odróżniać inne objawy, tylko pozornie podobne, ale w każdym razie szwankujące pod względem etycznym.

Do takich swoistych objawów rozdwojenia czy też podwojenia należało np. dawane poddanym niemieckim pozwolenie urzędowego przyjmowania poddaństwa innych państw, np. państwa rosyjskiego, pod warunkiem, ażeby jednocześnie pozostawali nadal poddanymi niemieckimi. Było to w razie konfliktów uświęcaniem „zdrady” albo w jednym, albo też w drugim kierunku.

Byłoby też nadużyciem wskazanej przeze mnie „dwunarodowości” w szlachetnym znaczeniu tego wyrazu, gdyby podszywać się pod nią usitowali, tak świetnie scharakteryzowani przez satyryka rosyjskiego Sałtykowa-Szczedrina, Taszkientcy rosyjscy ${ }^{1}$, którzy

1 Mowa o cyklu szkiców satyrycznych M. Sałtykowa-Szczedrina Panowie taszkientczycy (1869-1872). Taszkientczyk jest w nich uosobieniem cynicznego tępego i ślepo posłusznego władzy wykonawcy, urzędnika, policjan- 
przy zmienionych okolicznościach przedzierzgnęli się bez żadnego trudu w „Taszkientców” polskich i jak dawniej rusyfikowali inorodców rosyjskich, tak dziś polonizują „mniejszości narodowe” polskie. Również możliwe jest nadużywanie pojęcia „dwunarodowości” przez szpiegów służących dawniej rządowi rosyjskiemu, a dziś bez najmniejszych skrupułów służących rządowi polskiemu.

Pewien osobnik, który niegdyś w roli jednego z policmajstrów petersburskich pomagał ministrowi Kasso gromić i ujarzmiać Uniwersytet Petersburski, po przewrocie bolszewickim wstąpił na służbę polską i jako jeden z dygnitarzy policji polskiej trzymał w ryzach inorodców polskich na kresach. Może się on powoływać na swą „dwunarodowość”; dusza jego mieści w sobie dawniejszą rosyjskość i dzisiejszą polskość.

W Poznańskiem i na dzisiejszym Pomorzu polskim grasują osobniki, które za czasów pruskich były gorliwymi hakatystami, a dziś są nie mniej gorliwymi „patriotami” polskimi, członkami „Ligi obrony wiary i ojczyzny".

Otóż powoływanie się takich podejrzanych indywiduów na ich rzekomą „dwunarodowość” byłoby bezczelnością i szyderstwem. Nie są to wcale „dwunarodowcy”, ale tak dobitnie napiętnowane przez język włoski figure porche (postacie świńskie), czyli po polsku „szuje” lub „szubrawcy”.

Natomiast wobec niezaprzeczonych i bijących w oczy faktów musimy uznać obiektywną dwunarodowość, a nawet wielonarodowość pewnych miejscowości bądź to z ludnością pod względem narodowym różnorodną, bądź też będących stolicami krajów dwunarodowych lub wielonarodowych. Takimi miejscowościami są np. Praga czeska, będąca, pod względem narodowym stolicą kraju niemiecko-czeskiego; Strasburg - francusko-niemiecki; Gorica, Triest, Rijeka-Fiume itd. miasta włosko-słowiańskie; w Polsce Lwów, Wilno, Poznań, itd., itd.

Przy uznawaniu i zachowywaniu stworzonych przez wypadki dziejowe granic politycznych, państwowych i administracyjnych,

ta, „krzewiciela oświaty” i rusyfikatora, który - jak pisze Szczedrin - nie ma żadnych narzedzi cywilizacyjnych - ale - ma za to suche, żylaste i nadzwyczaj chwytliwe rece. 
choćby ze względu na niewywoływanie widma nowej rzezi wszechświatowej, nie tylko zdrowy rozsądek, nie tylko poczucie sprawiedliwości, ale po prostu względy utylitarne - i państwowe, i społeczne, powinny skłaniać nas do uznawania podobnych dwunarodowości i wielonarodowości.

Spokojne współżycie dwóch i więcej uczuć narodowych w jednostkowej duszy ludzkiej może znaleźć odbicie w spokojnym wspótżyciu obywateli tego samego kraju i wszystkich mieszkańców całej kuli ziemskiej.

\section{„Narodowość panująca” a „narodowości podwładne”}

Pomieszanie narodowości z państwowością, uznawanie tylko jednej narodowości za panującą, a innych za narodowości jej podwładne, minderwertige Nationalitäten ${ }^{1}$, prowadzi do naruszania zasady równouprawnienia obywatelskiego i pociąga za sobą fatalne skutki zarówno dla jednej, jak i dla drugiej strony, jako też dla mieszczącej je w sobie całości państwowej.

Prowadzi to przede wszystkim do nadużywania pojęcia narodowości, utożsamianego z państwowością, przez dzielenie obywateli tego samego kraju na „rdzennych” i na „przybyszów”, na „gospodarzy” i „gości” lub też na panów i podwładnych, a nawet poddanych. „Gospodarzami” w Niemezech, aż do Kalisza, Katowic, Olsztyna i Tylży, byli tylko rodowici Niemcy, w Wegrzech tylko Madziarowie, w Rosji tylko Rosjanie, Dwornik lub izwozczik rosyjski wyrażał się o inorodcach, w tej liczbie także o Polakach: oni naszi poddannyje; my im awtonomii nie dadim (oni to nasi poddani; my im autonomii nie damy).

Tutaj stosuje się zasadę większości, zasadę narodowości liczebnie przeważającej. Ale panować i uważać innych za swych poddanych może także uprzywilejowana mniejszość narodowa. Tak było w Kraju Nadbałtyckim Rosji, tak było na Ukrainie, tak było w Polsce etnograficznej, należącej czy to do Prus, czy też do Rosji.

1 Minderwertige Nationalitäten (niem.) - mniej wartościowe narodowości. 
Takie panowanie mniejszości nad większością jest zresztą zjawiskiem powszechnym w innych dziedzinach życia politycznego i społecznego. Do tego sprowadza się w ogóle ustrój państwowy. A nawet rzekome panowanie narodowości liczebnie przeważającej nad innymi narodowościami sprowadza się właściwie do panowania niewielkiej liczebnie grupy jednostek uprzywilejowanych nad ogółem nie tylko narodowości upośledzonych, ale także samej narodowości naczelnej i wysuwającej się na plan pierwszy.

W naszych czasach uprzywilejowanie jednych a upośledzenie drugich urzeczywistnia się u wschodnich sąsiadów państwa polskiego w dziedzinie społecznej. Rzekoma „dyktatura proletariatu” jest właściwie praktykowaniem dyktatury partyjnej zarówno nad „burżuazjatem”, jak i nad „proletariatem”, przy mniej lub więcej zręcznym wyzyskiwaniu haseł narodowych.

W każdym razie uważanie np. w Polsce jednej tylko narodowości polskiej za panującą, a wszystkich innych za narodowości podwładne jest dyktaturą narodowości uprzywilejowanej, a taka dyktatura staje godnie obok dyktatury kapitału, obok dyktatury proletariatu, obok dyktatury faszystów, obok dyktatury endecji, jednym słowem obok dyktatury partyjnej lub klasowej.

Panowanie czy to mniejszości nad większością, czy też choćby nawet rzekome panowanie większości nad mniejszością może trwać bardzo długo, ale zwykle się kiedyś kończy. Wystarczy, ażeby poddani i ubezwładnieni zapytali, dlaczego to oni mają być tylko poddanymi i służyć za narzędzie do przeprowadzania wrogich im zamierzeń, a wtedy hört die Gemütlichkeit auf (nastaje koniec idylli).

Znane jest powiedzenie, że Ameryka dla Amerykanów. Ukute według tego samego wzoru twierdzenia, że Rosja dla Rosjan albo też Polska dla Polaków polegają na nieporozumieniu, o ile Rosjanie lub Polacy mają oznaczać ludzi narodowości rosyjskiej lub polskiej. Mają one sens i uzasadnienie tylko o tyle, o ile Rosjanie znaczą wszystkich mieszkańców państwa rosyjskiego, a Polacy wszystkich obywateli Rzeczypospolitej Polskiej. Jak widzimy, wyraz Polacy jest dwuznaczny i kiedy się go używa, należy przede wszystkim umieć myśleć logicznie i sprawiedliwie. 
Na pomieszaniu pojęć i na wyzyskiwaniu bezmyślności tłumów polegały awantury urządzane przez Polskę partyjną w grudniu r. 1922. Prezydent, skalany braniem udziału w jego wyborze także przez „mniejszości narodowe”, w oczach tego obozu popełnił zbrodnię i zasługiwał na śmieré, a ten, co ten wyrok wykonał, urósł do roli „bohatera” i świętego narodowego. Dziwne tylko, że obranie tymi samymi głosami z udziałem „wrogów Polski”, tj. jej „mniejszości narodowych", drugiego prezydenta nie wywołało już żadnych objawów nienawiści, a nawet choćby tylko najlżejszych protestów.

Takie zacięte prześladowanie innych narodowości pogardzanych i pomiatanych wywołuje opłakane i szkodliwe dla państwa skutki, wywołuje dążności odśrodkowe i skierowane ku rozbiciu i rozsadzeniu jednolitego państwa. Jaskrawym przykładem świecą nam Rosja, Niemcy, Węgry, a nieco dawniej także Austria.

Gdyby kierownicze sfery nowo powstałej Polski i ludzie wodzący rej w ugrupowaniach partyjnych byli w stanie rozumieć interes państwowy, zapobiegliby byli w samym początku dążeniom odśrodkowym i państwowoburezym. Tymczasem zaślepienie samobójcze ciasnych głów stworzyło rozmyślnie groźną sprawę kresów i „mniejszości narodowych”. Przez ścisłe i nieubłagane przestrzeganie równouprawnienia narodowego, nie tylko de jure, ale także de facto, sprawę tę można było w samym zarodku unieszkodliwić i całkowicie ją usunąć ku wzajemnemu pożytkowi. Ale cóż, kiedy w Polsce mają przewagę polskie Bismarcki i polskie bismarczęta, polscy głosiciele krótkowzrocznego egoizmu narodowego, polscy hakatyści.

\section{Ojezyzna i patriotyzm. Patriotyzm narodowościowy, dzielnicowy i ogólnopaństwowy. \\ Polska marzenie a Polska rzeczywistość}

W związku z narodowością pozostaje wyobrażenie i pojęcie ojczyzny, a z ojczyzny, patria, wywodzi się patriotyzm, jak znowu od partii może pochodzić „partyjotyzm”.

Patriotyzm może byé zaściankowy (patriotisme du clocher), dzielnicowy, krajowy, narodowy, państwowy. W każdym zaś razie na- 
leży rozróżniać patriotyzm narodowy a solidarność ogólnopaństwową.

W Szwajcarii i w Belgii solidarność ogólnopaństwowa ma przewagę nad patriotyzmem narodowym.

W Austrii ostatnich dziesięcioleci (nie w Węgrzech oczywiście) patriotyzm pojedynczych narodowości godził się wyśmienicie z patriotyzmem państwowym austriackim, z solidarnością ogólniepaństwową. I gdyby nie megalomania Habsburgów rzucająca meine Völker na pastwę rzezi wszechświatowej, Austria mogłaby była stać się wzorem państwa zbudowanego nie w imię instynktów zoologieznych, ale na podstawie interesów gospodarczych i solidarności międzynarodowej. Stoweńcy np. mogli rozwijać się pomyślnie pod względem narodowym przede wszystkim w Austrii. Nie tylko zachłanne i denacjonalizatorskie Włochy, które po wojnie zagrabiły znaczną część terytorium słoweńskiego, ale nawet słowiańska Jugosławia nie mogą im tego wynagrodzić.

We Francji pojęcie rzekomo jednolitej nation française nie może zatrzeć wrażenia mozaiki narodowościowej, dzięki wchodzeniu do składu jednolitego państwa francuskiego niemieckich Alzatczyków i Lotaryńczyków, Bretończyków, Basków. Żydzi francuscy, jak np. Dreyfus i tylu innych, są pod względem nie tylko państwowym, ale także narodowym, Francuzami.

Ojczyzna w języku polskim była pierwotnie synonimem ojcowizny, a dopiero z czasem wyszła z ciasnego koła zagrody ojców, zagrody ojczystej i stała się równoznaczną z łacińską patria, niemieckim Vaterland, rosyjskim otieczestwo w różnicy od węższego pojęcia rodina (kraj rodzinny, zakątek rodzinny).

Związany z „,jezyzną” rosyjską patriotyzm rosyjski, obejmujący mitośnie wszystkie części państwa rosyjskiego od Kamczatki do Kalisza, był zamierzony na zbyt wielką skalę i skutkiem tego brak mu było głębi uczucia i podstawy realnej. Był to patriotyzm czynowników gotowych do wyzyskiwania na swą korzyść tego potwora państwowego.

Czysty patriotyzm narodowy bez oparcia 0 własną państwowość i w ogóle 0 jakieś jednolite terytorium znalazł ujście między innymi w syjonizmie Żydów narodowców i w ich marzeniach o Palestynie. 
Różnica patriotyzmu dzielnicowego, uzgodnionego z patriotyzmem ogólnienarodowym, uwydatnia się w początkowych wierszach Mickiewiczowskiego Pana Tadeusza:

Litwo, ojezyzno moja! ty jesteś jak zdrowie,

Ile cię trzeba cenić, ten tylko się dowie,

Kto cię stracił. Dziś piękność twą w całej ozdobie

Widzę i opisuję, bo tęsknię po tobie.

Dzielnicowy patriotyzm „litewski” odnoszący się do Litwy historycznej nie przeszkadzał Mickiewiczowi być jednym z najczystszych, najgorętszych, przeczulonych patriotów polskich. Dziś prawdopodobnie zawahałby się on nazwać Litwę swoją ojczyzną.

Prócz tego zwróćmy uwagę na ujawnioną w tym wierszu tęsknotę do straconej ojczyzny, tak drogiej właśnie dlatego, że podobnie jak zdrowie została utraconą. Ale ta Polska wyśniona, wymarzona, żyjąca w duszach i sercach Polaków (Wyspiański), była 0 wiele realniejszą i potężniejszą aniżeli dzisiejsza Polska „zmartwychwstała” i upaństwowiona, zrodzona ze zbrodniczej wojny światowej i w wytworzonej przez tę wojnę kloace wszechświatowej.

Polacy rozproszeni po całym świecie i tęskniący do straconej ojczyzny mieli prawo wołać: Jeszcze Polska nie zginęta, póki my żyjemy ..., a z pewnością znaczna większość dzisiejszych Polaków, którzy się doczekali „wskrzeszenia ojczyzny”, może co najwyżej powiedzieć: Jeszcze Polska nie zginęta, chociaż my żyjemy.

Dziś, po odzyskaniu niepodległości państwowej, nie umieją uszanować tej Polski zmartwychwstałej, urządzają na nią zamachy, zagrażające jej bytowi:

1. szkalują i obryzgują jadowitą śliną tych, co położyli największe zasługi w sprawie stworzenia państwa polskiego;

2. podkopują się pod podwaliny bytu niepodległego przez urządzanie zamachów na najwyższych dostojników i przedstawicieli państwa, wybranych zgodnie z prawem, zgodnie z konstytucją, zgodnie z sumieniem;

3. wychowują młodzież, tj. przyszłych czynnych obywateli, w bezprawiu i w pogardzie do ustaw zasadniczych;

4. starają się stwarzać jak najwięcej wrogów Polski zarówno na zewnątrz państwa, jako też wewnątrz przez potęgowanie, a nawet 
wywoływanie w „mniejszościach narodowych” dążności odśrodkowych.

Narodowość polska przechowywana w duszach i sercach wygnańców, rozproszonych niegdyś po całym świecie, kontynuuje się dziś w wyższego polotu narodowości kulturalnej, ideowej, a obok niej pełza i chrząka napastliwa narodowość życia codziennego, wichrząca i warcholąca pod hasłem egoizmu narodowego.

Traktowanie ludności „kresowej” jest najlepszym dowodem rozpanoszenia się tej kołtuńskiej i prostackiej narodowości życia codziennego.

Ignoruje się przede wszystkim aspiracje narodowe Ukraińców. A tymczasem dzisiejsze położenie Ukrainy, żjącej w duszach i sercach uświadomionych Ukraińców, przypomina bardzo nie tak dawne położenie Polski, żyjącej tylko w duszach i sercach Polaków. Polskę przedrozbiorową rozdarły trzy państwa zaborcze. Ukraina jest rozdzielona aż pomiędzy cztery państwa: Bolszewię, Polskę, Rumunię i Czechosłowację.

Polaków krzepiła pieśń: Jeszcze Polska nie zginęta... Ukraińców krzepi pieśń: Szcze ne wmerta Ukraina...

Zdaniem ciemnogrodzkich patriotów polskich należy mścić się na wszystkich Ukraińcach aż do najdalszego pokolenia za urządzenie przez Ukraińców lwowskich i w ogóle wschodniogalicyjskich rewolty w końcu r. 1918. Stosuje się zasadę wendetty, zasadę odpowiedzialności zbiorowej, tak zwanej przez Rosjan krugowoj poruki. Więc za ten bunt przemijający nowe pokolenia ukraińskie, nowo narodzone dzieci i młodzież podrastająca mają być karane przez zatruwanie ich dusz jadem nienawiści do Polaków jako do nieprzejednanych wrogów. Nie wolno im pozbywać się tego wstrętnego uczucia. Muszą, tak jak i ich przodkowie, widzieć w Lachach prześladowców i gnębicieli.

Podobnie po powstaniu r. 1863 i 1864 patrioci rosyjscy mścili się na wszystkich Polakach (i wszystkich Litwinach), stosując do nich okrutne środki eksterminacyjne i godząc w samo istnienie narodu polskiego (i narodu litewskiego). A co z tego wyszło?

Z aspiracjami narodowymi Ukraińców należy się poważnie liczyć, ażeby nie wywoływać w mniej lub więcej odległej przyszłości widma buntu i separatyzmu politycznego. 
Pytanie: „gdzie ma się zrodzić Piemont ukraiński?”

Rolę Piemontu dla Polski odegrała austriacka część Polski przedrozbiorowej. Byłoby pożądanym, ażeby Piemontem Ukrainy była jej część wchodząca do składu państwa polskiego, jednakże z następującym zastrzeżeniem i ostrzeżeniem: Należy postępować tak, ażeby zjednoczenie Ukrainy nie przyniosło szkody państwu polskiemu. Przy bezwzględnym szanowaniu przez państwo dążności narodowych i kulturalnych można pod względem politycznym pozostawać tymezasem w granicach tego państwa, mając tylko zapewniony jak najszerszy samorząd i autonomię. Bez krwawych staré można się obejść, zwłaszcza po wymownych lekcjach ostatniej wojny światowej.

Niestety, ciasne i zakute głowy nie chcą tego zrozumieć. Szykanują i obrażają Ukraińców między innymi przez to, że stale i uparcie nazywają ich „Rusinami”, nie racząc nazywać ich tak, jak tego żądają sami Ukraińcy. Niech sobie przypomną, jak słodko było Polakom należącym do Rosji, kiedy Polskę kongresową przezwano Priwislinskim krajem lub Priwislinijem, a zamiast Polak mówiono i pisano Priwislinskij urożeniec, warszawskij urożeniec. Zmuszanie Ukraińców nawet przez władze miejscowe do używania w podaniach urzędowych terminu ruski lub rusinski zamiast ukrainski jest drażnieniem i prowokacją, nie mówiąc już o tym, że podobne ignorowanie życzeń samych Ukraińców jest na rękę Rosji czy to carskiej, czy też bolszewicko-sowieckiej.

W sprawie uniwersytetu ukraińskiego postępuje się niekiedy wprost wyzywająco (prowokująco).

Naradzanie się gospodarzy i panów polskich w sprawach „mniejszości" narodowych (tj. Ukraińców, Białorusinów, Rosjan, Niemców i Żydów) odbywa się bez ich udziału, jak gdyby to były narodowości małoletnie i niedojrzałe.

Okazuje się, że narody upaństwowione skutkiem wojny mogą sprawiać wrażenie niewolników, co zerwawszy się z łańcucha, usiłują gnębić swych dawnych spółtowarzyszy niedoli.

Rozumny patriotyzm narodowy polega na obronie własnych praw bez zamachów na cudze prawa. Patriotyzm narodowy nie może byé równoznaczny z nacjonalizmem kąsającym i obrażającym. 
„Narodowość słowiańska”. Solidarność wszechludzka. Języki pomocnicze międzynarodowe

W związku z pojęciem narodowości niektórzy politycy i marzyciele wysuwają potrzebę solidarności ogólnosłowiańskiej. Wszechsłowiańskość i wzajemność słowiańska ma być ogniwem pośrednim między narodowościami pojedynczych zbiorowisk stowiańskich, zbiorowiska polskiego, czeskiego, słowackiego, serbołużyckiego, rosyjskiego, ukraińskiego, bułgarskiego, serbskiego, chorwackiego, słoweńskiego..., a solidarnością wszechludzką całej ludzkości jako zjednoczonej całości.

Przed laty sześćdziesięciu slawista rosyjski W. Łamanskij w broszurze Nacionalnost' stawianskaja i italjanskaja stawiał na równi „narodowość” słowiańską a narodowość włoską i twierdzit, że, jak różne narodowości Półwyspu Apenińskiego zlały się w jednej narodowości włoskiej z jednym językiem ogólnowłoskim, tak samo wszystkie obecne narodowości słowiańskie znikną, ustępując miejsca narodowości ogólnosłowiańskiej z jednym językiem wszechsłowiańskim, którym oczywiście będzie język rosyjski.

Podobne zestawienie jest błędem logicznym i kłóci się z historią. Słowiańskość i włoskość nie są weale pojęciami współrzędnymi. Włoskość, francuskość, hiszpańskość itd. mogą byé zestawione z polskością, rosyjskością, czeskością itd., słowiańskości zaś jako pojęciu ogólnemu, obejmującemu pojęcia szczegółowe polskości, rosyjskości, czeskości itd., odpowiada pojęcie ogólne romańskości, mieszczące w sobie włoskosśe, francuskośé, hiszpańskośé itd. Historia zaś nie dała nam i nigdy nie da poczucia jakiejś jednej narodowości wszechsłowiańskiej. Wprawdzie bliskość i podobieństwo języków słowiańskich bije w oczy i wyodrębnia Stowian w osobny szczep w różnicy od innych równorzędnych szczepów w rodzaju szczepu romańskiego, germańskiego itd. Wprawdzie w różnych krajach, w Niemczech, w Austrii, w Węgrzech, czyli w Madziarii, we Włoszech, czyli w Italii, z obawy przed "panslawizmem” praktykowano prześladowanie własnych Słowian. Wprawdzie działały w kierunku zjednoczenia wszystkich Słowian, w kierunku zlania się strumieni słowiańskich w wielkim morzu rosyjskim apetyty zachłanników i zaborców zawodowych. 
To wszystko jednak nie było w stanie unicestwić poczucia odrębności narodowej pojedynczych narodów słowiańskich. Jak dawniej nic tu nie pomogły gruchania mitosne i gołąbkowania rozanielonych marzycieli w tonie różnych narodów słowiańskich, tak dziś również daremne są wznowione flirty i umizgi słowiańskie. A jak się wciela w życie wypieszczona idea „wzajemności słowiańskiej”, dają nam wymowną odpowiedź stosunki bułgarsko-serbskie, macedońsko-serbskie, serbsko-chorwackie, polsko-czeskie, czesko-słowackie, polsko-ukraińskie, polsko-białoruskie, polsko-rosyjskie, ukraińskorosyjskie itd.

Nie zawracajmy więc sobie głowy i dajmy pokój naiwnej mrzonce, jakoby dla przejścia od jedności narodowej pojedynczych narodów słowiańskich do poczucia solidarności wszechludzkiej, czyli do szlachetnie pojętego kosmopolityzmu, był konieczny etap przejściowy roztopienia się narodowości słowiańskich w jednej ogólnej narodowości słowiańskiej. Od istniejących faktycznie narodowości do wszechludzkości prowadzi droga wprost, bez żadnych ogniw pośrednich. A ściśle biorąc, istnieją tylko dwa krańce tego łańcucha przejść stopniowych: z jednej strony człowiek pojedynczy ze swymi prawami i obowiązkami, ze swą godnością i wartością indywidualną, a z drugiej strony ludzkość cała jako zbiorowisko wszystkich ludzi w walce z przyrodą i z antyspołecznymi instynktami własnej natury. Wszystko inne, wszystkie owe narodowości, ojczyzny itp. to tylko mala necessaria (zła konieczne), to tylko przeszkody na drodze do wcielenia w życie solidarności wszechludzkiej.

Swoiści marzyciele i wyznawcy języków pomocniczych międzynarodowych głoszą, że rozpowszechnienie takiego języka międzynarodowego w rodzaju volapüka, esperanto, ido itp. może się w znacznej mierze przyczynié do pogodzenia narodów i do przewagi jednoczącego poczucia solidarności wszechludzkiej nad rozbieżnością kłócących się i walczących ze sobą narodowości. Sami twórcy sztucznych języków międzynarodowych, Schleyer, Zamenhof..., marzyli i śnili 0 braterstwie narodów.

Chociaż język pomocniczy międzynarodowy jest rzeczą wielce pożądaną, to jednak przypisywanie mu takiej roli pacyfikatorskiej, czyli pokojowej, należy do złud pochodzących z nieuwzględnienia 
historii i z optymistycznego poglądu na naturę ludzką. Doświadczenia zaczerpnięte z dziejów ludzkości uczą nas, że język wspólny nie zapobiega wcale walkom religijnym, dynastycznym i państwowym. Nie zapobiega on również walkom klas, partii i w ogóle różnorakim tzw. wojnom domowym. W łonie tego samego narodu, zjednoczonego wspólnością języka, istnieją osobne rasy psychiczne, uważające siebie za przeznaczone do panowania nad innymi współobywatelami. Takimi są np. endecy, komuniści, faszyści itp.

Jako swoista utopia, jako ideał mogący się urzeczywistnić w odległej przyszłości daje się pomyśleć sfederalizowanie (sfederowanie) całej ludzkości. Przy takim ustroju państwa dotychczasowe stałyby się prowincjami świata ziemskiego zamieszkałego przez ludzi. Granice państw zostałyby wtedy wykreślone w zależności od interesów ekonomicznych i od warunków geograficznych. Wybrzeże morskie musiałoby wtedy wchodzić w skład tego samego państwa prowincji, co związany z nim interesami gospodarczymi hinterland ${ }^{1}$. Tak samo stoki gór stanowiłyby jedno państwo z rozciągającymi się u stóp tych gór nizinami. Wszyscy mieszkańcy wszystkich państw byliby zabezpieczeni od prześladowań narodowych, jak i od wszelkich innych prześladowań. Obowiązkiem państw byłoby popieranie wszelkich narodowości, szerzenie oświaty i kultury we wszystkich bez wyjątku językach.

Narodowości istniałyby obok siebie jako świadome grupowania się ludzi, uznających swoją wspólność pod tym względem. Dzisiejsze ojczyzny stałyby się wtedy ojcowiznami, zakątkami rodzinnymi, $k r a-$ jami lat dziecinnych w wielkiej ojczyźnie wszechświatowej.

A nie tylko wtedy, po wcieleniu w życie utopii kosmopolitycznej, ale już teraz należałoby wzorować współżycie obywateli tego samego państwa na współżyciu różnorodnych pod względem wyznaniowym, narodowym, klasowym, partyjnym mieszkańców tego samego domu, tej samej miejscowości. Pomimo różnic ideowych, przekonaniowych, narodowych, wyznaniowych, wszyscy mieszkańcy danego domu i danej miejscowości mają wspólne interesy w zakresie życia codzienne-

$1 \quad$ Hinterland (niem.) - tu: zaplecze. 
go. Wszystkim powinno chodzić o usuwanie smrodu i nieczystości, o zapobieganie epidemiom i wszelkim innym klęskom żywiołowym, sprawne funkcjonowanie wodociągów, gazowni, elektryczności itp. Na takich też wspólnych interesach życia praktycznego powinna się opierać jedność i solidarność państwowa wszystkich współobywateli danego państwa, bez względu na ich różnoraką przynależność wyznaniową, narodową i wszelką inną.

Posłannictwa, czyli misje dziejowe

(narodów, państw i władców)

Dla wytłumaczenia i usprawiedliwienia jatek ludzkich i wszelkich gwałtów popełnianych na arenie dziejowej, usłużni historycy i poeci wymyślili misje, czyli posłannictwa dziejowe narodów, państw i władców stojących na ich czele.

Zygmunt Krasiński (w Psalmie wiary) woła: Garść im powotań sypnąeśs z wysoka, wmawiając w ten sposób w swego Boga, jakoby dał on ludom, narodom i państwom pewne zadania do wykonania, a to przede wszystkim drogą rzezi i obracania w perzynę całych osad, miast i krajów.

Takie specjalne posłannictwa miały do spełnienia trzy Rzymy: Rzym pierwszy, owo gniazdo zbójeckie, dążące do podboju całego świata i do stworzenia wszechwładnego Imperium Romanum; Rzym drugi, Rzym Konstatynopola, Rzym bizantyjski; wreszcie Rzym trzeci, Moskwa, jako spadkobierczyni i kontynuatorka Rzymu bizantyjskiego, Rzymu carogrodzkiego. Do tych trzech Rzymów dołącza się Rzym czwarty, Rzym papieski, roszczący pretensje do zawładnięcia duszami świata całego i do zaprzęgnięcia ich w swe jarzmo.

Przypisuje się też misje dziejowe wszystkim megalomanom i psychopatom, dążącym do ujarzmienia jak największej ilości bliźnich, a więc Aleksandrowi Macedońskiemu, Cezarowi, Karolowi Wmu, Napoleonowi i innym bandytom wszechświatowym, porywającym za sobą całe ludy i narody. Do takich wymyślonych i wmawianych posłannictw dziejowych należą też: idea jagiellońska Polski od morza do morza, idea habsburska, idea hohenzollernska itd. 
Megalomani niemieccy czasów najnowszych narzucali Niemcom, jako zawodowym „organizatorom”, posłannictwo organizacji świata całego pod przewodem Germanii.

Pod hasłem rule, Britannia! (panuj, Brytanio!) imperialiści angielscy uważali i uważają Anglię za władczynię wszystkich mórz i za państwo mające prawo do hegemonii, czyli przodownictwa wszystkim innym państwom.

Italia, ta regina del mar (królowa morza), rości pretensję do wyłącznego panowania na Adriatyku, a może nawet na całym Morzu Śródziemnym. Stąd to wcielanie do Włoch przemocą nadbrzeży Morza Adriatyckiego z ludnością niewłoską i wrogą Włochom.

Rosja carska pretendowała do roli trzeciego Rzymu, któremu sądzone jest podbić Carogród i cieśniny, i zapanować niepodzielnie nad Morzem Czarnym i nad Morzem Egejskim. Rosja najnowsza powojenna głosi ludzkości „nowe słowo”, streszczające się w groźnej obietnicy:

My na gorie wsiem burziujam,

Mirowoj pożar razdujem.

(My, ku utrapieniu wszystkich burżujów, rozniecimy pożar wszechświatowy) ${ }^{1}$.

Na myśl 0 wszystkich tych i im podobnych misjach, czyli posłannictwach dziejowych, aż ciarki przechodzą po skórze. Wszelkie te górnolotne hasła pachną krwią, łzami, dymem pożarów i męczeństwem maluczkich. Drogo za nie płacą maluczcy, tj. ludzie cisi i prości. A mnie osobiście chodzi przede wszystkim o szczęście i spokój cichych i prostych.

Niech będą przeklęte wszelkie misje dziejowe oprócz misji ogólnego pokoju i zgodnego współżycia ludzi i ludów! Owe wielbione i gloryfikowane posłannictwa i misje dziejowe są objawami megalomanii, są objawami fanatyzmu i sadyzmu wyznaniowego, narodowościowe-

$1 \quad 0$ psychozę posłannictw dziejowych rozmaitych zbiorowisk ludzkich potrąca świetna i głęboko pomyślana praca profesora Jana St. B y s t r 0 n i a , Megalomania narodowa. Źródta - teorie - skutki, Gebethner i Wolff, Warszawa - Kraków - Lublin - Łódź - Poznań - Wilno - Zakopane 1924 [przyp. BdeC]. 
go, klasowego i partyjnego. Uznając je za zjawisko psychopatyczne, powinniśmy im wszelkimi sposoby zapobiegać i leczyé międzynarodowy i wszechświatowy dom obłąkanych.

W człowieku pojedynczym i zbiorowym zakiełkowała i zrodziła się potrzeba religii, sztuki i nauki, potrzeba miłości, poczucie wspólności i solidarności - a zaspakajanie tych potrzeb daje mu rozkosz, pociechę, ukojenie. Ohydna bestia ludzka potrafiła zrobić z tego wszystkiego narzędzia męki i katuszy.

Te pocieszycielki ludzkości, religia, sztuka, nauka, miłość, narodowość, dostawszy się do rąk krwiożerców, zwyrodnialców i sadystów, tj. potworów ludzkich rozkoszujących się cierpieniami bliźnich, stają się dręczycielkami i biczami ludzkości.

\section{„Nie sprzeciwiać się złu”}

Na zakończenie parę słów w sprawie poniekąd osobistej.

Dusze pobożne i lękliwe mają mi za złe, że ośmielam się poruszać podobne kwestie, które w oczach ogólu prawomyślnego należą do kwestii, 0 których nie powinno się mówić. Troskę o rozwiązywanie tych kwestii należy pozostawić administracji miejscowej, policji i związkom „obrony wiary i ojezyzny”.

Pogłębiajmy więc przepaść, jaka dzięki napastniczemu i drażniącemu postępowaniu „patriotów” spod ciemnej gwiazdy wytworzyła się między obywatelami tego samego państwa.

Kto nie pomaga swoistym patriotom przy pogłębianiu tej przepaści, kto nie pochwala ich pracy niszczycielskiej, kto im przeciwdziała, tego piętnują mianem co najmniej „żydoluba”, jeżeli nie „wroga Polski”.

Mnie podobne wyzwiska nie przestraszają. Przeciwnie, uważam za swój obowiązek pomagać zasypywaniu tej przepaści wyrytej przez nacjonalistów obustronnych i zmniejszać przeciwieństwa zrodzone dzięki fanatyzmowi i złej woli. Sądzę, że czas najwyższy podać rękę do zgody, a pierwszy krok w tym kierunku powinien wyjsé od strony silniejszej; tą zaś w danym wypadku jest strona rządząca, strona ludności utożsamianej z państwowością polską. 
Uważając wszelkie zakusy polonizacyjne za bzdurną chimerę, pragnąłbym zaszczepić Polskę państwo w duszach obywateli kresowych i obcoplemiennych. To zaś daje się osiągnąć:

1. przez wcielenie w życie i nieubłagane przestrzeganie zasady równouprawnienia obywatelskiego, przez bezlitosne poskramianie i wykorzenianie poniewierania, pogardliwego traktowania i prześladowania narodowości niepolskich i wyznań niekatolickich;

2. przez używanie wszelkich możliwych środków, zmierzających do zwiększenia dobrobytu ludności kresowej, a w liczbie tych środków niepoślednie miejsce zajmuje przeprowadzenie rozumnej reformy rolnej;

3. przez niczym niekrępowane szerzenie oświaty we wszystkich językach miejscowych, zgodnie z niezależnie wypowiedzianym życzeniem ludności miejscowej.

Zapytuję więc:

Kto działa na korzyść ogółu obywateli państwa polskiego, a kto jest „wrogiem Polski”: czy ja i moi wspótideowcy, czy też ci, co pracują usilnie nad otaczaniem Polski od zewnątrz i od wewnątrz pierścieniem coraz bardziej potężniejącej nienawiści i dążności odśrodkowych, i rozsadzających całość państwową?

Nic tu nie pomogą ani towarzystwa obrony kresów z wyraźną tendencją polonizacyjną, ku zgnębieniu i wytępieniu uświadomionych narodowo obcoplemieńców, czyli „mniejszości narodowych”, ani też żadna straż pograniczna, choćby nawet wielomilionowa.

Styszymy nawoływania do zaprowadzania stanów wyją tkowych, tj. do oddawania ludności na łaskę i niełaskę znarowionej administracji miejscowej. Zastanówmy się jednak, do czego doprowadzity Rosję, Prusy i Węgry stany wyjątkowe czy to otwarcie ogłaszane, czy też zamaskowane.

W Rosji przedwojennej pomrukiwał i pęczniał „patriotyzm żywiołowy”. Wyszczerzano kły dzikiej świni, grożąc wragam $i$ supostatam $^{1}$ na wszystkie strony świata; uważano inorodców, w tej liczbie także Polaków, za naszich poddanych; uznawano tylko jeden

1 Supostat (a. sopostat) (ros.) - nieprzyjaciel, przeciwnik, także złoczyńca, niegodziwiec (obecnie wyraz przestarzały). 
naród panujący, naród rosyjski, utożsamiając narodowość wielkoruską z państwowością rosyjską; słowami Puszkina w Klewietnikam Rossii ${ }^{1}$ rzucano zuchwałe wyzwanie całemu światu europejskiemu. I cóż to pomogło? Do czego doprowadziło?

Kto pomimo tych pouczających przykładów będzie szedł śladami Rosji i hakatystów pruskich, doczeka się takiego samego końca.

Dziś straż pograniczna jest konieczna. Ale najskuteczniejszą obroną granic jest nie szczecina bagnetów z dodatkami na lądzie, na wodzie i w powietrzu, ale głęboko tkwiące w duszach ludności różnoplemiennej poczucie solidarności ogólnopaństwowej.

[Warszawa 1926]

1 Oszczercom Rosji. Wiersz A. Puszkina, będący poetycką odpowiedzią na europejskie protesty przeciwko stlumieniu powstania listopadowego. Wojnę polsko-rosyjską widzi w nim autor jako domowy spór Stowian o to, czy strumienie stowianskie zleja się w jedno morze, czy też ono wyschnie. 


\section{TOLERANCJA, RÓWNOUPRAWNIENIE, WOLNOMYŚLICIELSTWO, WYZNANIE PASZPORTOWE}

(Odezyt miany w Warszawie w Związku Zawodowym

Pracowników Handlowych

13 marca 1922 r.,

a urządzony staraniem

Stowarzyszenia Wolnomyślicieli Polskich)

Chociaż wrażenia lat ostatnich, lat grozy wojennej, lat zbrodni bez liku i miary, lat otwartego i cynicznego deptania przez hordy uzbrojone wszelkich przykazań boskich i ludzkich powinny były chyba zatrzeć w naszych duszach wspomnienia epoki przedwojennej, to jednak i te wspomnienia jaskrawo jeszcze występują i kierują naszymi pragnieniami i dążeniami. Dotychczas żywe są wspomnienia przedwojenne, wspomnienia z dawnych czasów, z czasów gospodarki rosyjskiej i pruskiej na ziemiach polskich, gospodarki madziarskiej na Węrzech. Przecież chyba dotychczas pamiętamy brutalne, bezlitosne, a czasem nawet krwawe prześladowania religijne unitów, katolików, żydów, mahometan, sektantów, prześladowania narodowe Polaków i Duńczyków w Prusach, Polaków, Finlandczyków obu narodowości, fińskiej i szwedzkiej, Estończyków, Łotyszów, Gruzinów, Ormian, Tatarów, Kirgizów, Buriatów oraz pozostałych inorodców w państwie rosyjskim. Pamiętamy tortury unitów, pamiętamy hakatę i rugi bismarckowskie.

To w przeszłości. A dziś znowu czy nie dochodzą nas odgłosy znęcania się nad kościołami różnych wyznań, tępienia, wyrywania z korzeniem i unicestwiania wszelkiej myśli wolnej i opozycyjnej, odgłosy niezliczonych objawów okrucieństwa połączonego z sadyzmem i dochodzącego wprost do krańców obłędu w państwie bolszewików?

W Polsce chełpiącej się swą tradycyjną tolerancją stwierdzimy też, choć w słabszym stopniu niż w Rosji carskiej i w Prusach hohenzol- 
lernskich, objawy krzywdzenia innowierców i innoplemieńców, unitów, prawosławnych, żydów; stwierdzamy zabieranie cerkwi prawosławnych i przerabianie ich na kościoły katolickie; słyszymy i wyczytujemy w czasopismach szczucie na innowierców i inorodców, dopuszezanych do urzędów na „kresach” państwa polskiego. (Zob. m.in. „Tydzień Polski” $1922 \mathrm{nr}$ 10, art. Wobronie tolerancji).

Stwierdzamy nawracanie inowierców na katolicyzm przemocą i podstępem. W związku z tymi zamachami na wolnośé sumienia i z tym poniewieraniem godności ludzkiej stwierdzamy konfiskaty, areszty, bezmyślne Jabłonny i znęcania się nad więźniami politycznymi.

A już nie ma co mówić o prześladowaniu bezwyznaniowców i brutalnym, iście inkwizytorskim zmuszaniu ich do obłudnego udawania, że należą do tego lub owego wyznania bądź to panującego, bądź choćby tylko tolerowanego.

Wobec tych wszystkich zamachów na wolność sumienia wywieranych przez wszechwładne państwa zaprzedane klerowi różnowyznaniowemu tolerancja wydaje się szczytem marzeń. Ale co to jest tolerancja?

Jest to znoszenie, cierpienie obok siebie. Człowiek tolerowany jest to człowiek znoszony, cierpiany obok tych, co mają prawo rozporządzać losem własnym i cudzym.

Toleruje albo uprzywilejowana mniejszość, albo też liczebnie przeważająca większość.

Najjaśniejszy naród polski, dokładniej katolicko-polski, tj. pewne stado istot dwunogich a bezskrzydłych, 0 swoistym zabarwieniu, jako pan i władca ziemi polskiej i państwa polskiego raczy najmitościwiej znosić obok siebie innych, tj. inaczej nazywane narodowości i wyznania, nie tępiąc ich i nie wypędzając, z tym jednak zastrzeżeniem, że pewne godności w państwie są dostępne tylko katolikowi, a inne znowu (np. stopnie oficerskie) tylko osobnikowi należącemu (tj. podającemu się za należącego) do narodowości polskiej.

Pomyślmy jednak, że tolerowanymi nazywane są także prostytutki. Z drugiej strony tolerowani są łapownicy, fałszerze, obłudnicy. Co więcej, nie tylko tolerowani, ale także uznawani i popierani są obłudnicy udający patriotów, Polaków, chrześcijan, katolików lub prawosławnych, zależnie od czasu i od stopnia szerokości i długości geograficznej. 
Tak więc wobec najnowszych zapatrywań, wobec potrzeby szanowania godności ludzkiej w każdym bez wyjątku człowieku, zwykła tolerancja zbankrutowała i nie może nas zadowolnić.

Fanatyzm narodowości upaństwowionej i państwowości unarodowionej, właściwy nawet ludziom skądinąd światłym i wybitnym, uznaje tylko folblutyzm państwowy i żąda, ażeby wszyscy obywatele danego państwa należeli do jednej i tej samej narodowości. We Francji mają prawo mieszkać tylko Francuzi, w Niemczech tylko Niemcy, we Włoszech tylko Włosi, w Rosji tylko Rosjanie, w Litwie tylko Litwini, w Polsce tylko Polacy itd. A kto się ośmieli pokazać nos na cudzej ziemi, kulą w łeb.

- A cóż pan zrobisz z Żydami, pomimo należenia do tego ludowego państwa uznającymi siebie za odrębną narodowość?

- Powinni wynaleźć sobie jakiś kawałek ziemi w tej lub owej części świata i tam założyć państwo narodowe żydowskie, bez przymieszki żywiołów obcych.

- A jakże pan pogodzisz ze swym żądaniem istnienie Austrii (wtenczas istniała jeszcze Austria), Belgii, Holandii, Szwajcarii, Ameryki Północnej, Brazylii, Argentyny, Peru itd.?

- Wszelkie tego rodzaju państwa powinny być zniesione, a ich mieszkańcy wcieleni do państw narodowych, zgodnie z ich przynależnością plemienną. 0 ile zaś pewien naród (jak np. Czesi lub Słowacy, wówczas także i Polacy) nie posiada osobnego państwa, należy takie państwo stworzyć i dany naród państwowo wyodrębnić.

Ta kołowacizna folblutyzmu rasowego, czyli raczej plemiennonarodowego w państwach jako całościach politycznie niezależnych i suwerennych, była zapowiedzią tego szału nacjonalistycznego, jakim po wojnie zostały opętane prawie wszystkie narody europejskie.

Objawem tego w Polsce np. są ograniczenia i prześladowania innowierców i innoplemieńców, tj. Żydów, unitów, Rusinów, czyli Ukraińców. Objawem tej kołowacizny nacjonalistycznej jest żądanie, ażeby oficer w wojsku polskim należał koniecznie do narodowości polskiej, tj. w pewnych razach był obłudnikiem udającym Polaka z narodowo- 
ści. Takie podejrzane indywiduum, zmieniające narodowość stosownie do okoliczności, ceni się nierównie wyżej aniżeli lojalny obywatel Rzeczypospolitej Polskiej, przyznający się otwarcie do narodowości niepolskiej.

Tego absurdu nawet w Rosji carskiej nie było. Oficerem armii rosyjskiej mógł być nie tylko Rosjanin, ale także Polak, Łotysz, Estończyk, Fin, Szwed, Niemiec, Tatar, Kirgiz, Gruzin, Ormianin itd. Tylko Żyd nie mógł dostąpić tego zaszczytu. Ale tu chodziło nie tyle o narodowość, ile raczej 0 wyznanie z metryki i paszportu.

Ale jak można byłoby stosować zasadę wyłączności narodowościowej mającą obowiązywać w stosunku do oficerów w armii szwajcarskiej, belgijskiej, byłej austriackiej i tylu, tylu innych?

Idąc za przykładem byłej Rosji, Niemiec, Wegier, Włoch itp. i pozwalając rozpasanemu i rozpanoszonemu czynownictwu kresowemu i obskurnemu kołtuństwu prześladować, a choćby tylko ograniczać inorodców i „inowierców”, Polska wstępuje na ścieżki, wprawdzie wydeptane i utorowane, ale, jak się okazało, w wielu wypadkach prowadzące do rozkładu i do zguby państwa.

Konstytucja Rzeczypospolitej mówio równouprawnieniu wyznań i narodowości. Znajdują się jednak w niej furtki, którymi przemyca się uprzywilejowanie narodowości liczebnie panującej i wyznania liczebnie panującego, i w ten sposób wyciska się na Konstytucji piętno mimowolnej obiektywnej obłudy.

Zresztą nie powinno to nas ani dziwić, ani oburzać. Wszelkie konstytucje jako dzieło ludzkie są wynikiem albo eklektyzmu historycznego, albo też kompromisów, kompromisów z sumieniem, z sumieniem partyjnym ludzi umysłowo ograniczonych i etycznie nieprzodujących. Takimi są też konstytucje innych państw, a konstytucja polska nie stoi na szarym końcu.

Faktycznie trudno nie zauważyć panoszenia się w Polsce klerykalizmu z jego wielorakimi objawami. Tym tylko można objaśnić natarezywe umizgi do Watykanu oraz spór o to, kto w państwie polskim ma mieć pierwszeństwo, czy nuncjusz papieski, czy też naczelnik państwa. Prawdopodobnie wypada się nad tym zastanawiać ze względów oportunistycznych. Razi to jednak w państwie, w którym niby to istnieje równouprawnienie wyznań. 
Tym uprzywilejowaniem katolicyzmu i jego przewaga nad poczuciem państwowości polskiej objaśnia się to, że katolicy uważają siebie za wyłącznych gospodarzy w państwie polskim, a inne wyznania tylko łaskawie tolerują.

Przewagą zaś liczebną narodowości polskiej, a jeszcze bardziej żądzą odwetu za prześladowania, którym ulegali Polacy pod rządami zaborczymi, objaśnia się nacjonalizm państwowy Polaków i wszelakie ograniczenia w stosunku do innych narodowości. Niewolnik zerwany z łańcucha mści się na innych niewolnikach.

Jeżeli są pożądane i uprawnione towarzystwa opieki nad zwierzętami, to nie mniej pożądane i uprawnione powinny być stowarzyszenia opieki nad ludźmi upośledzonymi, stowarzyszenia w rodzaju Ligi Obrony Praw Człowieka i Obywatela ${ }^{1}$ Taka liga jest zarazem ligą obrony samego państwa przed zamachami samobójczymi.

Państwo kierujące się nie względami oportunizmu przemijającego i „egoizmu narodowego” na krótką metę, ale przewidującym, sięgającym w odległą przyszłość rozumnym egoizmem państwowym, powinno się stać państwem nie tyle bezwyznaniowym, ile raczej pozawyznaniowym, nie tyle beznarodowym, ile raczej pozanarodowym. Jednocześnie takie państwo bezstronne i będące jednakowym opiekunem wszystkich obywateli powinno zapewniać i gwarantować zupełną, absolutną swobodę wyznań indywidualnych i swobodę zaliczania siebie do tej lub owej narodowości, jako też absolutną swobodę wszelakich zrzeszeń bądź to wyznaniowych, bądź to narodowych, bądź też innych, byle tylko niezagrażających spokojowi i niewystępujących zaczepnie wobec innych takich zrzeszeń. A to pociąga za sobą absolutną wolność propagandy własnego wyznania w granicach pokojowych, nienapastniczych, nieobrażających. Wolno oddziaływać na innych przekonywaniem, ale nie wolno terroryzować ich ani przymusem policyjnym, ani też groźbą kary w tej lub owej postaci.

To żądanie wprowadza nas wprost do dziedziny wolnomyślicielstwa.

$1 \quad$ LOPCi0 - organizacja działająca w latach 1921-1937, założona dla obrony swobód demokratycznych, walki z nietolerancją i prześladowaniami politycznymi. 
Wolnomyślicielstwo wiąże się ściśle zarówno z myślą, jako też Z wolnością.

Nawet w głowie skończonego matołka, skończonego idioty myśl jest myślą indywidualną. Wobec tego utożsamianie wyznania zbiorowego, znanego pod tą lub ową nazwą (np. wyznanie rzymskokatolickie, wyznanie mojżeszowe itp.), z wyznaniem tego lub owego człowieka, zaliczanego według metryki lub paszportu do tego lub owego stada, czyli zbiorowiska wyznaniowego, jest stanowezo wykluczone. Nauki, wierzenia, przesądy itd. związane z tym lub owym wyznaniem urzędowym w każdej głowie indywidualnej układają się w sposób indywidualny i stanowią osobny zespói, niemogący się powtarzać bez zmiany w innych głowach. Każdy osobnik ludzki ma swą osobną historię, ma swe osobne przeżycia, ma osobne przygotowanie, ma osobne uzdolnienie itd., a wszystko to razem wzięte stwarza jego osobiste wyznanie i jego osobisty światopogląd, różniący je, choćby tylko w minimalnych rozmiarach, od wyznania i światopoglądu innych osobników.

Oprócz tego pojęcie wolnomyślicielstwa łączy się ściśle z pojęciem wolności.

A cóż to takiego jest wolność?

Jeden z profesorów b. uniwersytetu rosyjskiego w Warszawie, pojechawszy do Lwowa, pokłócił się ze służącym hotelowym, zwymyślał go i uderzył go w twarz. Stużący zaskarżył go do sądu, który skazał go na kilka tygodni kozy i zapłacenie grzywny. Oburzony tem do głębi, szanowny profesor zawołat: wot tie swoboda! po mordam bit' nie pozwolajut! (Piękna mi wolność! Po mordzie bić nie pozwalają!).

Ze swego stanowiska miał on zupełną słuszność, podobnie jak czują się ograniczonymi w swych prawach wolnościowych uwodziciele kobiet karani za swe czyny bohaterskie na tym polu.

Podobnie czuliby się pogwałconymi w swych prawach zdobywców wojacy, którym by zabroniono niewolić, rabować, zabijać, palié. Przecież żołnierzowi na wojnie wszystko wolno. A jakżeby zawyli z oburzenia na ograniczenie ich wolności krzewiciele nowego porządku społecznego w Europie Wschodniej', gdyby im nie dano rozstrzeliwać, torturować i znęcać się wszelkimi sposoby.

\footnotetext{
1 Tj. bolszewicy.
} 
Rozmaici inteligenci i inteligentki ignorują napisy zabraniające palenie w wagonach, w biurach itd. i, uważając je za ograniczenie wolności, palą pomimo to, że innym osobom może to nie tylko sprawiać przykrość, ale nawet szkodzić. Są to po prostu bydlęta w ludzkiej postaci.

Urządzający orgie samochodowe i tratujący przechodniów kawalerowie i damy wszelkie ograniczenia tego szalonego sportu uważają za zamach na ich wolność.

Wyznawcy pewnika filozoficznego „tańczę, więc jestem”, tańcząc całymi nocami i nie pozwalając spać sąsiadom, twierdzą, iż są w swoim prawie i protestują uroczyście przeciwko wszelkiemu ograniczeniu ich pląsów i hołubców.

Tak, to jest także wolność, ale wolność dzikich, wolność barbarzyńców i chamów wszelakiego autoramentu. Jest to wolność tabunu dzikich koni.

W oczach takich obrońców wolności typowym wolnomyślicielem jest sławetny Kamarinskoj muzizik1.

Zdawałoby się, że co jak co, ale myśl powinna być zawsze wolną i nieskrępowaną. A jednak, kiedy w r. 1848 w jednym z miast Austrii, zdaje się w Trieście, lud się burzył i żądał konstytucji, miejscowy wielkorządca wyszedł na balkon i zawołał: Obywatele! cesarz daruje wam wolność myśli. Tłum przyjął to oświadczenie z zapałem i uspokoił się. Czuł on bowiem, że myśl jego nie jest wolną i dopiero powinna być uwolniona z więzów.

1 Bohater ludowej pieśni Kamarinskaja, którego prototypem był ponoć uczestnik bitwy pod wsią Dobruń stoczonej między oddziałami Dymitra I Samozwańca i Borysa Godunowa, Rassukin syn, Kamarinskij muzik. Zapewne popularność tej pieśni spowodowała powstawanie nowych wariantów, parafraz i ewolucję postaci do pijanego chłopa. (Ach ty, sukin syn, Kamarinskoj muzik! / Pijanyj, biez sztanow po ulice biezit. Inny wariant: Ach, ty, mityj moj, kamarinskij muzik;; Ty zaczem biez sztanow po ulice bieżisz?). Sama melodia stała się tematem fantazji orkiestrowej rosyjskiego kompozytora Michała Glinki, pt. Kamarinskaja. Postać kamarinskiego mużika, pojawia się też w wierszu Piesnia o kamarinskom muzikie (1867) poety Leonida Triefolewa. Fraza kamarinskij mużik jako wyzwisko pojawia się w Martwych duszach Gogola, można ją także spotkać w utworach współczesnej prozy rosyjskiej. 
Dobroczyńcy ludzkości tępiący „burżujów” i utożsamiający inteligenta z burżujem starają się wytępić myśl, bo uważają ją za niebezpieczną. Kto myśli, jest wrogiem ludu, wrogiem proletariatu. Odsłania on bowiem i demaskuje obłudę i szalbierstwo proroków, głosicieli i apostołów nowych ewangelii, podobnie jak i dawniejszych.

Ta wojna tępicielska wypowiedziana obecnie inteligencji jest historycznie i psychologicznie zrozumiała. Od początku wojny i dawniej tzw. intelekt zrezygnował z wolności myśli. Zaprzągł się do jarzma państwowego i wyznaniowego i oto teraz jęczy w niewoli u tyranów bolszewickich i komunistycznych, a na pewnym stopniu upodlenia czciciel potęgi schlebia swym dzisiejszym panom i posiadaczom, podobnie jak dawniej schlebiał carowi i jego sługom.

Inteligent wydał wyrok śmierci na samego siebie i popełnił samobójstwo.

Tak jest u naszych sąsiadów ze wschodu. U nas za to, obok różnych ograniczeń za grzech pierworodny przynależności do upośledzonego zbiorowiska ludzkiego, panuje w pewnych razach nieograniczona wolność słowa i druku. Wymyśla się niestworzone rzeczy, a oszczerstwa z palca wyssane puszeza się w kurs na użytek ludku czytającego.

Należę do tych, którzy mają zaszczyt być celem takich napaści, na niczym nieopartych. Kiedy moi znajomi namawiają mię do reagowania w ten lub ów sposób na te plugastwa, przypominam im powiedzenie pana Bergeret Anatola France’a.

Było to za czasów dreyfusjady. P. Bergeret, rozumiejąc krzywdę wyrządzoną Dreyfusowi, bronit jego sprawy, a jego, pana Bergeret, kolega szkolny i przyjaciel, jako zaciekły antysemita, miał mu to za złe. Kiedy jednak jakiś plugawy świstek wydrukował niesłychane oszczerstwa na p. Bergeret, przyjaciel ów skłaniał go do wytoczenia procesu 0 dyfamację. Zastanowiwszy się chwilkę, p. B. uśmiechną się i odpowiedział mniej więcej w ten sposób:

- Kiedy sobie pomyślę, ile to mąk musiała wycierpieć ludzkość, nim zdobyła sobie wolność stowa, kiedy sobie pomyślę, ilu to ludzi spalono na stosie, ilu to ludziom powyrywano języki za to, że się ośmielali krytykować możnych tego świata..., to ten plugawy świstek, uprawiający szczucie i szkalowanie, jest dla mnie świętością. Uosabia mi on bowiem wolność słowa i wolność druku. 
Pan Bergeret był prawdziwym wolnomyślicielem.

Bo tzw. wolnomyślicielstwo nie zawsze jest prawdziwie wolnomyślicielstwem. Nierównie częściej bywa ono wolnomyślicielstwem rzekomym, wolnomyślicielstwem udanym, wolnomyślicielstwem fałszowanym.

Przecież wolnomyślicielstwo jest synonimem myśli niepodległej. A przypomnijmy sobie, na jakie to manowce zboczyła w Polsce „Myśl Niepodległa”1, „Myśl Niepodległa” oklaskiwana w końcu przez najzajadlejszych wsteczników i obskurantów. Ta myśl wolna, czyli niepodległa, została pojęta w ten sposób, że wolno bezkarnie przekręcać, fałszować, szczuć i podjudzać. Była to myśl niepodległa, ale niepodległa wymaganiom sumienia i uczciwości.

Inni znowu pod flaga wolnomyślicielstwa chcieliby przemycać nienawiść klasową i fanatyzm partyjny; chcieliby przemycać dogmat „Walki klas” i nieomylności klasowej, dogmat wyłączności i sprawiedliwości tylko dla swoich, a nie dla obcych, obcych partyjnie i klasowo, chcieliby przemycać różne maniactwa i kołowacizny w rodzaju obowiązkowego próżnowania; chcieliby przemycać hasło koszarowego „ugrium-burczejewskiego”² ustroju społeczeństwa; chcieliby przemycać podeptanie i zabicie wszelkiej indywidualności.

Pod firmą wolnomyślicielstwa starano się przemycać adorację przenajświętszego Sownarkomu i przenajświętszej czrezwyczajki³

Pod hasłem wolnomyślicielstwa próbowano przemycać rozmaite „dyktatury”: dyktatury proletariatu, tj. dyktatury demagogów i warchołów, bałamucących ciemne masy i bezczelnie je wyzyskujących.

1 Zob. W sprawie „antysemityzmu postepowego” w niniejszym wyborze.

$2 \quad$ Ugrium-Burczejew - jeden z gradonaczalników we wspaniałej satyrze Sałtykowa-Szczedrina Istorija odnogo goroda [przyp. BdeC].

3 Sownarkom, skrót od: Sowiet Narodnych Komissarow (Rada Komisarzy Ludowych), w Rosji bolszewickiej (potem ZSRR) w latach 1917-1946, odpowiednik rady ministrów. Czrezwyczajka (także Czeka), potoczna nazwa bolszewickiej policji politycznej zorganizowanej w 1917 r. przez F. Dzierżýskiego (Wsierossijskaja czriezwyczajnaja komissija po bor'bie s kontrriewolucjej $i$ sabotażem - Ogólnorosyjska Nadzwyczajna Komisja do Walki z Kontrrewolucją i Sabotażem). 
Niewiele więcej warte są ,dyktatury pracy”, ,dyktatury inteligencji” i inne tp. objawy obłędów dyktatorskich.

Pod hasłem wolnomyślicielstwa próbowano przemycać komunizm, pojmowany po współczesnemu, w interpretacji marksiąt rosyjskich, polsko-rosyjskich, żydowsko-rosyjskich i międzynarodowo-rosyjskich, swoisty komunizm, tj. wolnośé wywłaszczania i przekładania cudzej własności do własnej kieszeni, wolność bandytyzmu, rabunku, kradzieży, wolność rozpusty i wszeteczeństwa.

Nie, wolnomyślicielstwo nie ma nic wspólnego z jakąkolwiek bądź dyktaturą. Wolnomyślicielstwo a dyktatura wyłączają się nawzajem.

Wolnomyślicielstwo wychodzi z zasady solidarności wszechludzkiej jako ze swego założenia i nie uznaje żadnego gwałtu, żadnej przemocy czy to nad pojedynczym człowiekiem, czy też nad całymi zbiorowiskami ludzkimi.

Fatalność dzisiejszego ustroju ludzkości „cywilizowanej” stanowi głównie to, że uprywatniono dobra materialne, leżące poza człowiekiem, a ze skwapliwością, godną lepszej sprawy, upaństwowiono i uspołeczniono najindywidualniejsze i najnietykalniejsze tajniki duszy ludzkiej, poddając je bezmyślnej mustrze i tresurze. (Myśli nieoportunistyczne, Kraków 1898, nr 59).

W ten sposób powstały stada wyznaniowe, zbiorowiska ludzkie podprowadzone pod jeden strychulec i noszące wspólną nazwę wyznaniową.

Wolnomyśliciel prawdziwy nie może należeć do żadnej sekty.

Niedawno temu jeden ze znajomych winszował mi, że utworzyłem nową sektę. Oczywiście związał on moje nazwisko ze Stowarzyszeniem Wolnomyślicieli ${ }^{1}$ i stąd powstało to nieporozumienie.

1 Stowarzyszenie Wolnomyślicieli powstało w 1920 r., zawieszone decyzją władz w r. 1928. Baudouin był z nim przez jakiś czas związany, redagując organ Stowarzyszenia „Myśl Wolną”. W 1924 r. zerwał i z gazetą, i z organizacją na skutek działań komunistycznej grupy Jana Hempla, która doprowadziła do przegłosowania votum nieufności wobec Baudouina. 0 sprawie tej Baudouin pisał m.in. w liście do H. Ułaszyna: Jestem bardzo kontent, że nie potrze- 
Czułem się z lekka dotkniętym tym powinszowaniem i wyttumaczyłem owemu znajomemu, że nie należę i nie chcę należeć do żadnej sekty, a tworzenie nowej sekty jest sprzeczne z moją naturą i z moim światopoglądem.

Wolnomyślicielstwo nakłada przede wszystkim obowiązek obrony wolności sumienia w jakiejkolwiek bądź formie. Wolnomyśliciel może być absolutnie bezwyznaniowym, może być jednak także wierzącym, byle tylko nie uważał swego wyznania za nieomylne i uznawał prawo do życia i równouprawnienia wszystkich innych wyznań.

Nie może więc być wolnomyślicielem wyznaniowiec widzący zbawienie jedynie w swoim wyznaniu i twierdzący, że innowiercy są skazani na wieczne potępienie. A więc ci wszyscy, którzy nie z własnej winy nie mogli poznać wszechzbawczego wyznania, np. tzw. poganie przed epoką nawracania ich ogniem i mieczem albo też dzisiejsze ludy Afryki, do których nie dotarli jeszcze misjonarze, podlegają karze wiecznego potępienia. Harmonizuje to wprawdzie z bezecną i okrutną maksymą, że nikt nie może sie wymawiać nieznajomościa prawa, ale pomimo to jest absurdem i tępym okrucieństwem.

Nie mogą należeć do wolnomyślicieli ortodoksi żydowscy i megalomani „narodu wybranego”.

Nie mogą rościć pretensji do wolnomyślicielstwa marksięta wierzące ślepo w nieomylność mistrza.

Z wolnomyślicielstwem trudno pogodzić stosy i różnorakie tortury (buty hiszpańskie, dziewice żelazną itp.), tortury, tj. ową poezję czynną średniowiecza katolickiego, jako też męki i tortury poezji

buje tracić czasu na „Myśl Wolna”. Uwolnitem sie od tego pisma, a prócz tego wyjaśnitem potożenie. Nie lubie dwuznaczności, przemycania kontrabandy pod fatszywym tytutem $i$ stużenia za parawan osobnikom, którzy stoja od myśli prawdziwie wolnej nierównie dalej, aniżeli najzajadlejsi klerykali i chasydzi. Dość tej ciuciubabki! [...] Banda, która opanowata teraz „M[yśl] W[olna]” i w ogóle „Stow[arzyszenie] Wolnom[yślicieli] Polskich", należy do najzawziętszych wrogów socjalistów. P[an] Hempel i jego zwolennicy (hempleta) zwalczaja najzacieklej socjalizm i socjalistów. Sa to jednym stowem zwolennicy „myśli karnej $i$ zorganizowanej” i narzucania gwattem „bezbożnictwa” $i$ innych kwiatków komunistycznych. [...] List z 24 VI 1925 r., rkps. Archiwum PAN Warszawa, sygn. III-162, poz. 263. 
czynnej chamstwa wschodnioeuropejskiego czasów obecnych, owo zakopywanie żywcem, zdzieranie pasów, wbijanie na pal itp.

Z wolnomyślicielstwem nie licuje ani Święta Hermendada, owa czrezwyczajka katolicyzmu średniowiecznego, ani też autentyczna czrezwyczajka czasów obecnych.

Panowie sympatyzujący z czrezwyczajkami niechaj się nie podszywają pod wolnomyślicielstwo.

W połowie ósmego lat dziesiątka ubiegłego stulecia, około r. 1875, była słynną w Krakowie zakonnica Barbara Ubryk, którą jej siostry klasztorne więziły w ciągu lat dwudziestu w podziemiu, nie wypuszczając jej stamtąd ani na chwilę. Wykryło się to przypadkowo, dzięki listowi bezimiennemu do policji. Barbarę Ubryk, zrujnowaną fizycznie i całkiem zidiociałą, uwolniono, ale bogobojne siostry nie zostały pociągnięte do odpowiedzialności. Uszło im to na sucho. Przebywający wówczas w Krakowie Aleksander Świętochowski, który bawił się wtedy i potem jeszcze dość długo w wolnomyślicielstwo i nie przystał jeszcze do kościoła panującego pod godłem ND [Narodowej Demokracji], poruszał w swych odczytach te zbrodnię klerykalną i występował ostro przeciw duchowieństwu. Za to modny wówczas kaznodzieja, ksiądz Golian, wyklinał Świętochowskiego z kazalnicy i grzmiat: Gdyby sie wrócity dawne czasy, rzucitbym na niego czarna świece, tj. spalitbym go na stosie.

Tak się odzywa urzędowy głosiciel „miłości bliźniego”.

A i dziś są tacy, co by chętnie i z rozkoszą rzucali czarne świece na krnąbrnych i opornych. No, ale nie dał pan Bóg świni rogów, boby ludzi bodła.

Wolnomyśliciel powinien brać do serca sprawę rozwodów, których niektóre wyznania wcale nie uznają, dopuszczając jednak „unieważnienia małżeństwa”. Przy ceremoniach wymaganych dla „unieważnienia małżeństwa”, kobietę traktuje się jak krowę lub kobyłę i poddaje się ją poniżającym i hańbiącym oględzinom oraz eksperymentom wkraczającym w dziedzinę pornografii. Zresztą łapówki konsystorskie sprawy te znacznie ułatwiają i procedurę łagodzą.

Otóż zadaniem wolnomyśliciela jest przeciwdziałać podobnemu poniżaniu godności ludzkiej. 
Wolnomyśliciel nie może w żaden sposób uznawać grzechu pierworodnego. On może uznawać odpowiedzialność jedynie osobistą, nigdy zaś stadową.

Kiedy urzędowi głosiciele „miłości bliźniego” nie tylko rozgrzeszają zabójstwo, ale nawet do niego zachęcają i głoszą zemstę i wendettę, wolnomyśliciel powinien wytykać im obłudę i sprzeczność z najelementarniejszymi wymogami moralności.

Pozostawiając wolnym związkom i zrzeszeniom wyznaniowym urządzanie szkół wyznaniowych, wolnomyśliciel powinien się domagać, ażeby szkoły państwowe były bezwyznaniowymi. Wyznaniowa bowiem nauka religii, jako oparta na megalomanii wyznaniowej i na przesłance, że zbawienie jest możliwe tylko w łonie danego wyznania, wpaja w uczniów nienawiść i pogardę dla innych wyznań.

Nauki wyznaniowe o sprawiedliwości, miłosierdziu, o karze i nagrodzie, o zemście bezgranicznej, o wiecznych mękach, o konieczności pochlebstwa i obłudy pozostawiają wiele do życzenia, bo demoralizują uczniów i wpajają w nich przewrotne i bluźniercze pojęcia 0 „istocie najwyższej”, tak czy owak pojmowanej.

Nauka religii oparta na katechizmie i na tzw. historii świętej, w rękach nieumiejętnych i fanatycznych może się stać źródłem zgorszenia i demoralizacji. Moralność przedajna, łapówkowa, choćby tylko oparta na handlu zamiennym, nie jest wcale pożądaną ze stanowiska solidarności społecznej i wszechludzkiej.

Traktowanie uczniów przez nauczycieli religii bywa niekiedy sprzeczne z wymaganiami pedagogiki. Znam wypadek, kiedy pewną uczennicę za to, że prosiła 0 wyjaśnienie tego, czego nie rozumiała, ksiądz wypędził z klasy i nie chciał jej puszczać na swoje lekcje, które były obowiązujące i bez których nie można było przejść z klasy do klasy. Oczywiście wypadek ten nie jest odosobniony.

Klerykalizm szkolny wymaga, ażeby uczniowie i uczennice odbywali 4 razy do roku przymusową spowiedź. Jest to religijność na komendę, religijność czysto formalna, zdawkowa, zabijająca religijność prawdziwą, religijność indywidualną.

Im więcej przepisów i obrządków, tym mniej miejsca na cnoty indywidualne. (Myśli nieoport., nr 57). 
Wobec tego wszystkiego, ze stanowiska wolnej myśli wcielanej w życie należy się domagać, ażeby ze szkół państwowych usunięto obowiązkową naukę religii i moralności wyznaniowej, a na jej miejsce wprowadzono naukę moralności ogólnej, wszechludzkiej, opartej na podstawie solidarności wszechludzkiej, bez różnicy wyznania. Przykładem godnym naśladowania świeci nam tu Japonia.

Poza tym każdemu uczniowi powinno być wolno drogą prywatną zaznajamiać się z zasadami tego lub owego wyznania, a nawet kilku wyznań.

W ogóle ze szkoły państwowej i społecznej powinien być usunięty wszelki przymus wyznaniowy.

Moralność, głosząca obłudnie „miłość bliźniego”, a w życiu uprawiająca szczucie i nienawiść, bliską jest ostatecznego bankructwa. Jej miejsce musi zająć moralność, niewmawiająca w ludzi sprzecznej z naturą ludzką miłości „bliźniego”, ale za to oparta na rozumie, oraz na pielęgnowaniu i umiejętnym rozwijaniu poczucia sprawiedliwości wrodzonego każdemu ani nieupośledzonemu od urodzenia, ani też niespaczonemu przez wychowanie i otoczenie, człowiekowi. (Myśli nieoport., nr 65).

Usunięcie ze szkół przymusu wyznaniowego wynika samo przez się z wymaganej przez wolnomyślicielstwo pozanarodowości i pozawyznaniowości państwa. Ostateczne oddzielenie wszelkich kościołów od państwa i zaprowadzenie stanu cywilnego w pełnym znaczeniu tego wyrazu jako jeden z słownych celów wolnomyślicielstwa rozumie się samo przez się.

Wolnomyślicielstwo może być dwojakie: jedno wolnomyślicielstwo wąsko egoistyczne, bierne, kontemplacyjne, prowadzące do niesprzeciwiania się złu, drugie zaś - wolnomyślicielstwo czynne, altruistyczne.

Wolnomyślicielstwu grożą rozmaite zboczenia i zwyrodnienia. Tutaj należą: nieomylność wolnomyślicielska oraz fanatyzm wolnomyślicielstwa i bezwyznaniowości.

Trzeba się strzec fanatyzmu prawdy, tj. fanatyzmu w głoszeniu i przeprowadzaniu, tego, co się samemu uważa za prawdę. Czasem 
wzgląd na szczęście ludzkie wymaga, ażeby zataić prawdę, przemilczeć, a nawet skłamać. Kłamstwo niekiedy jest nakazem moralnym, a bezwzględne głoszenie prawdy może graniczyć ze zbrodnią.

Przy wszelkich okolicznościach powinna przyświecać wolnomyślicielowi myśl o szczęściu i dobrobycie jednostek, a nad wszystkim górować poczucie solidarności wszechludzkiej.

Religia serc naiwnie wierzacych zasługuje na uznanie i szacunek choćby dla tego, że wprawia duszę do dążeń idealnych i uszlachetniających.

W licznych utrapieniach życia jedynymi stałymi pocieszycielkami powinny by być: religia, nauka i sztuka, każda z nich w mniejszym lub większym stopniu, stosownie do indywidualności cierpiącego. Jednakże nawet $\mathrm{z}$ tych pocieszycielek potrafiono zrobić narzędzia męki i katuszy. (Myśli nieoport., nr. 8 i 9).

Prawdziwy wolnomyśliciel jest obowiązany występować zawsze jako obrońca wszystkich wierzących i niewierzących, o ile są maltretowani bądź to przez władze policyjne, bądź też przez napastników z łona społeczeństwa. Dla wyjaśnienia, jak ja to pojmuję, przytoczę przykłady z własnej praktyki wolnomyślicielskiej.

Mieszkając w Petersburgu, około r. 1910 miałem służącą, Malwinę Dąbrowską, właściwie Białorusinkę, ale mówiącą także po polsku i gorliwą katoliczkę. Miała ona brata Ignacego, służącego w jednym z pułków gwardii i po wypuszczeniu go z wojska starającego się o paszport cywilny. Kiedy mojej służącej wypadło zmieniać paszport, urzędnik policyjny wpisał do rubryki wyznaniowej: prawostawnogo (tj. wieroispowiedanija), pomimo że w poprzednim paszporcie i w metryce stało: rimsko-katoliczeskogo. Kiedy zaprotestowała, policjant odpowiedział cynicznie: nie wsio-li wam rawno? Przyszła więc do mnie z płaczem i poskarżyła się. Napisałem tedy ostry protest, powołując się na prawo i inne motywy, i zmusiłem policjantów do zapełnienia rubryki wyznaniowej w paszporcie zgodnie z żądaniem pokrzywdzonej. To samo miało miejsce z jej bratem, którego również wyrwałem ze szpon prawosławia i ocaliłem dla katolicyzmu. 
Nie uczyniłem tego dla siebie, bo dla mnie osobiście i katolicyzm jako taki, i prawosławie jako takie były jednakowo obojętne. Uczyniłem to, szanując godność ludzką każdego człowieka i uznając jego prawo do podawania się za tego, kim jest we własnym przekonaniu. Ochroniłem świętość duszy ludzkiej od poniewierania jej przez cynizm brutalnego policjanta.

W ten sam sposób broniłbym prawosławnego, żyda, mahometanina i wszelkiego innego wyznaniowca, gdyby się udał do mnie z prośbą o obronę przed przemocą policyjną lub też przed podstępem gorliwców innego wyznania. A nawet miałem sposobność już w Warszawie występować z protestem przeciw przemocy i podstępowi wykonanym nad osobą wyznania prawosławnego. Prócz tego wróciłem narodowości polskiej Polkę, którą policja zarejestrowała jako Litwinkę dlatego, że mąż jej jest Litwinem.

Znakomita większość tzw. inteligentów podkpiwa sobie z takiej donkiszoterii wolnomyślicielskiej. I nic to dziwnego. Przecież te indywidua, te „sympatyki” katolicyzmu, prawosławia, mozaizmu itp. zapatrują się na swe własne rzekome wyznanie jako na rzecz czysto formalną, do niczego właściwie nieobowiązującą. I na tym też polega ich religijność!

Prawdziwy wolnomyśliciel powinien się wystrzegać zaćmienia i zamglenia umysłu egoizmem i egocentryzmem. Pod wpływem pewnych czynników paraliżujących krytycyzm i jasny sąd o meczach, wolnomyśliciel i bezwyznaniowiec może się stać równie zaślepionym, jak i wszelki wyznaniowiec.

Prawdziwy wolnomyśliciel powinien umieć wczuć się i wmyślić się w cudze dusze, w dusze innych ludzi, nawet w duszę wroga. Niezbędnym warunkiem wolnomyślicielstwa jest rozumieć stanowisko przeciwnika i znaleźć wspólny z nim język.

To jest prawdziwe wolnomyślicielstwo w szerokim znaczeniu tego wyrazu.

Ten postulat wzajemnej wyrozumiałości umożliwia załatwianie kwestii spornych drogą pokojową, bez uciekania się do aktów przemocy i do prześladowania. Wychodzi to na dobre obu stronom.

W imię godności jednostkowej duszy ludzkiej prawdziwy wolnomyśliciel walczy za uszlachetnienie i uwolnienie wszelkiej wyzna- 
niowości i bezwyznaniowości od uwłaczającego jej kontrolowania ze strony władz policyjnych różnej barwy i różnego autoramentu.

Na zakończenie kilka słów o tak zwanym wyznaniu urzędowym, wyznaniu paszportowym.

Wyznanie to narzuca się przemocą już małym dzieciom, niemowlętom, narzuca się je embrionowi człowieka. Jest to jednocześnie i gwałt nad sumieniem, i fałszowanie statystyki.

W ogóle cała statystyka ludnościowa polega na fałszowaniu. Jak można zaliczać do mówiących pewnym językiem tych, którzy jeszcze wcale nie mówią, bo są niemowlętami? Jak można zaliczać do pewnej narodowości tych, którzy albo nie mogą mieć jeszcze poczucia narodowego, albo też którzy w ogóle nie zdają sobie sprawy z tego, co to takiego jest narodowość? Jak można zaliczać do pewnego wyznania tych, którzy albo jeszcze nie mogą mieć żadnego wyznania, bo pozostają w stanie nieświadomości, albo też tych, którzy świadomie nie chcą należeć do tego wyznania?

Jak psu ucina się ogon, jak zwierzęta domowe piętnuje się znakami przynależności do ich właścicieli, tak dwunogi niewolnik bądź to pojedynczego pana, bądź też zbiorowiska wyznaniowego ulega pewnym operacjom mającym zaznaczyć jego przymusowe zaliczanie do tego lub owego wyznania.

Jest to swoista fabryka aniołków różnowyznaniowych.

W paszportach wydawanych przez władze polskie istnieje rubryka wyznanie, którą koniecznie trzeba zapełniać. Rubryka ta została odziedziczona po nieboszczce Rosji, gdzie człowiek składał się z ciała, z duszy i z paszportu. Dziś składa się on z tych trzech elementów prawie we wszystkich państwach.

W paszportach wydawanych przez władze okupacyjne niemieckie i austriackie rubryka wyznaniowa nie istniała. Wprowadziło ją dopiero wolne, niezależne państwo polskie, zapatrzone w swą dawną panią, Rosję, i naśladujące jej brutalność w stosunku do poddanych. 
Zapytuję: jakie prawo ma pierwszy lepszy drab z ulicy grzebać w mojej duszy i domacywać się, jakiego jestem wyznania? A wara od tego! A zasię od mych wierzeń, od moich świętości spoczywających w głębi mego ducha! Paszport, cyrkuł a najdroższa świętość człowieka - jakaż to profanacja! Daje się ona objaśniać tylko frywolnym, powierzchownym traktowaniem spraw poważnych i niepodlegających kontroli wywiadowców i inkwizytorów, nazwanych dowcipnie przez Szczedrina sierdcewiedami.

Ja osobiście zapytanie, jakiego jestem wyznania, odczuwam jako obrazę osobistą, jako zniewagę, jako ubliżenie godności ludzkiej.

Jeszcze w Rosji przedwojennej, kiedy w celu przygotowania spisu kandydatów na sędziów przysięgłych zapytywano mię w kancelarii uniwersytetu, jakiego jestem wyznania, odpowiadałem albo nikakogo, albo też swojego sobstwiennogo .

Również przyjeżdżając do Łodzi na odczyty, bywałem zaraz na wstępie indagowany przez portiera hotelowego lub jego zastępcę, jakiego jestem wyznania. Odpowiadałem: Żadnego, jestem bezwyznaniowy. To nie mogło im się w głowie pomieścić, ale ja znowu nie mogłem podawać 0 sobie fałszywego świadectwa. Za drugim razem jeden z pomocników portiera chciał mię zaliczyć do wyznania „mojżeszowego”, bo oczywiście w jego oczach bezwyznaniowiec a Żyd to mniej więcej to samo. Jeden i drugi należą do ludzi pośledniejszego gatunku. Ja jednak przeciw swej „mojżeszowości” stanowezo zaprotestowałem, podobnie jak przeciw swej „rzymskokatolickości”.

Inny wypadek tego samego rodzaju. Do Warszawy przyjechała na studia córka prawdziwego i konsekwentnego bezwyznaniowca łódzkiego ani „świętej”, ani „błogosławionej pamięci”, a po prostu nieboszczyka doktora Mieczysława Kaufmana. Mieszkała ostatnimi czasy w Krakowie, gdzie należała do zrzeszenia bezwyznaniowego i przywiozła świadectwo o tym, wydane jej przez starostwo krakowskie. W Warszawie jednak rządea domu nie chciał tego uwzględnić i narzucił jej wyznanie „mojżeszowe”, kierując się oczywiście nazwiskiem, bo delikwentka z fizjonomii na Żydówkę wcale nie wygląda. Nie dała jednak za wygraną, wystąpiła ze skargami do władz odpowiednich i może jej się nareszcie uda zmusić pana rządcę do wykreślenia „mojżeszowości” z jej karty pobytu. 
W głowach Maćków spod ciemnej gwiazdy możliwość bezwyznaniowości za nic się nie mieści. Są to dusze niewolnicze i zahukane.

Wobec krzyczącego bezsensu wyznania paszportowego i związanej z nim obrazy godności ludzkiej należy wymagać jego usunięcia.

W związku ze zniesieniem wyznania paszportowego pozostaje usunięcie obowiązkowości przysiąg i zastąpienie ich uroczystą obietnicą mówienia prawdy. Wymaganie przysięgi jest lekceważeniem człowieka, który staje się istotą wiarogodną dopiero pod ochroną jakiegoś wierzenia stadowego.

W r. 1907 czy też 1908 miałem jedyny raz w swoim życiu występować jako sędzia przysięgły (prisiażnyj zasiedatiel) w jednym z oddziałów Sądu Okręgowego petersburskiego. Przy składaniu przysięgi przez przysięgłych przewodniczący sądu zwrócił się do mnie z zapytaniem: wy katolik, sogtasny-li wy priniat' prisiagu u naszego swiaszczennika? (pan jesteś katolikiem, czy pan się zgadza złożyć przysięgę na ręce naszego, tj. prawosławnego duchownego?). (Inaczej trzeba by było sprowadzać księdza katolickiego).

Odpowiedziałem: Prosze mie uwolnić od przysiegi jako sprzecznej z mymi przekonaniami $i$ zastapić ja uroczysta obietnica mówienia prawdy.

Po tym oświadczeniu przyłączył się do mnie inny przysięgły, Jakowlew, profesor Instytutu Górniczego.

Wtedy przewodniczący zwrócił się do prokuratora, żądając jego opinii. Prokurator zaproponował, ażeby nas osztrafowat' (obłożyé grzywną) i usunąć z sądu, tj. pozbawić prawa uczestniczenia w zgromadzeniu sędziów przysięgłych. Wtedy sąd oddalił się na naradę i naradzał się całe półtorej godziny, ku wielkiemu zgorszeniu i oburzeniu na nas jako sprawców tej zwłoki zarówno ze strony podsądnych, jako też ze strony świadków i innych przysięgłych. Po naradzie sąd wrócił na salę, a przewodniczący ogłosił wyrok skazujący każdego z nas na 25 rubli grzywny (suma, jak na owe czasy, dość pokaźna) i natychmiastowe wydalenie z sali sądu.

Oddaliliśmy się z wielką radością, bo nie potrzebowaliśmy tracić czasu na kilkunastodniowe branie udziału w czynnościach wątpliwej wartości moralnej. 
Nawiasem mówiąc, kara ta była objawem samowoli, sprzecznym z przepisami obowiązującej wówczas procedury sądowej. Ówczesne prawo rosyjskie pozwalało uchylać się od przysięgi, a nawet jednocześnie w innym oddziale Sądu Okręgowego jakiś przysięgły również odmówił przysięgi i nie spotkała go za to żadna kara. Ale co do nas dwóch, co do mnie i co do prof. Jakowlewa, działał oczywiście wzgląd na nasze stanowisko społeczne. Uchylanie się od przysięgi profesorów wyższych zakładów naukowych było w oczach sędziów zgorszeniem publicznym.

Ja jednak nie dałem za wygrane. Podałem do Izby Sądowej jako do instancji wyższej sprzeciw, czyli protest, przeciw wyrokowi Sądu Okręgowego i wygrałem. Izba Sądowa skasowała ten wyrok i uwolniła nas od grzywny. Ja zaś nie tylko że nie zapłaciłem 25 rubli, ale - przeciwnie - zarobitem, gdyż w jednej z gazet (zdaje się „Nasza Żizń”) wydrukowałem artykuł $K$ naszej swobodie sowiesti, za który dostałem honorarium więcej niż 25 rubli.

Wkrótce potem byłem w Paryżu dla wzięcia udziału w zjeździe delegatów w sprawie języka pomocniczego międzynarodoweg 0 . Kiedy opowiadałem 0 swych przygodach w Sądzie Okręgowym Petersburskim jednemu z najznakomitszych uczonych francuskich, znalazł on postąpienie sądu całkiem prawidłowym i zauważył, że we Francji za odmówienie przysięgi również by nas skazano na grzywnę.

A więc pomimo usunięcia krucyfiksów z urzędów francuskich, pomimo bezwyznaniowości magistratury i sądownictwa francuskiego, obłudnicy urzędowi zmuszają groźbą grzywien do przysięgania w imieniu jakiejś bezwyznaniowej Istoty Najwyższej (Être Supréme). Obłudnicy i cynicy urzędowi patrzą na przeżytki obrządków religijnych jak na obowiązkowy, a nawet przymusowy konwenans, jak na kłamstwo konwencjonalne, jak na zdawkowy flirt z Panem Bogiem czy też z jego niefortunnym erzacem, Être Supréme. Dla nich przysięga i wykonywanie innych praktyk państwowo-religijnych jest taką

1 Baudouin de Courtenay był jednym z dwunastu członków komitetu wyłonionego z Delegacji do przyjęcia języka powszechnego, utworzonej w Paryżu w 1900 r., która powstała dla ocenienia esperanta na tle istniejących już innych języków sztucznych. Komitet zebrał się w październiku 1907 r. 
samą oznaką dobrego wychowania, jak używanie chustki do nosa, niekładzenie przy jedzeniu noża do ust, niekrajanie nożem ryby, pisanie bez błędów ortograficznych itp.

Podobno nawet główny inicjator przewrotu w poglądach na historię świata organicznego, Charles Darwin, chadzał co niedziela do kościoła z książką do nabożeństwa pod pachą, bo nie chodzić nie wypadało, bo gdyby nie manifestował swej zdawkowej pobożności, byłoby to shocking, nie byłoby comme il faut.

Dla tych osób patrzących na praktyki religijne i na udawanie pobożności jako na jeden z obowiązków przyzwoitości towarzyskiej, nazwa Bóg należy do rzędu takich samych wyrazów konwenansowych, jak honor, jak obrona obrażonego honoru za pomocą pojedynków itp. Przede wszystkim należy zachowywać pozory, a co się pod tym kryje, to już rzecz, właściwie mówiąc, całkiem obojętna.

Zresztą może to mieć nawet swoją dobrą stronę. Sprowadziwszy swego Boga czy też jego sobowtóra, Istotę Najwyższą, do poziomu formalności towarzyskich i kłamstw konwenansowych i zautomatyzowawszy wszelkie z nim stosunki w postaci wyczytywanych z książki i bezmyślnie klepanych modlitw, przypominających używane w Indiach kołowrotki modlitewne, nie potrzeba się już kłopotać o swój świat wewnętrzny, o głębię swego ducha, swą poważnie i sumiennie pojmowaną religijność. Oszczędza się bardzo wiele czasu, który można użyć na co innego, a przede wszystkim na różne spekulacje bądź to w dziedzinie handlu i geszeftu, bądź też w dziedzinie myślenia teoretycznego, tj. w dziedzinie nauki.

Jak przy spotkaniu ze znajomymi uchyla się kapelusza i mówi się dzień dobry panu (lub pani), tak też i panu Bogu należy oddać zwyczajowy, przez tradycje przekazywany ukłon. Podobno któryś ze znakomitych dowcipnisiów francuskich, zdaje się Voltaire, zapytany, jaki jest jego stosunek do Boga, odpowiedział): nous nous saluons, mais nous nous ne parlons pas (kłaniamy się sobie ale nie rozmawiamy ze sobą).

A przy tym to konwenansowe uznawanie bóstwa ma cel praktyczny pierwszorzędnej wagi. Jak powiedział znakomity poeta i publicysta czeski Karol Havliczek, w swym tryskającym humorem utwo- 
rze Kržest svateho Vladimira: Bez Boha se sprostym lidem neni $k$ vydrženi (bez Boga z prostym ludem niepodobna wytrzymać).

Ten nonsens i tę hańbę, jaką jest wyznanie paszportowe, Polska odziedziczyła po śp. Rosji carskiej. Tam, w Rosji carskiej, wyznanie paszportowe miało pewien sens, sens wprawdzie ohydny, ale zawsze sens. Przecież w Rosji istniała linia osiedlenia (czerta osiodtosti) dla Żydów, którym nie wolno było przekraczać tej linii. W stolicach Żyd przyjezdny mógł przebywać nie więcej jak 24 godzin. Żydowi obcopaństwowcowi nie wolno było przyjeżdżać do Rosji, chyba tylko za specjalnym pozwoleniem władzy najwyższej. Wobec tego policja musiała mieć dokładne dane wyznaniowo-paszportowe, ażeby nie dozwalać Żydowi naruszać tego swoistego „prawa”. Zresztą wszechwładna łapówka pozwalała obchodzić to prawo. Niektórzy Żydzi przyjezdni całymi miesiącami mieszkali w hotelach petersburskich, opłacając tylko od czasu do czasu organom policji po 10 rubli lub może trochę więcej.

Ależ w Polsce nie mamy linii osiedlenia. W Polsce mamy niby to równouprawnienie urzędowe obywateli, choć faktycznie go nie ma. Więc po kiego licha owa rubryka wyznaniowa w paszportach „wolnej Rzeczypospolitej Polskiej”? Konstytucja 17 marca zniosła podobno tytuły i rangi. Należałoby więc chyba znieść także tytuły wyznaniowe.

Dla państwa liczącego się z obiektywnym stanem rzeczy każdy człowiek jest swego własnego wyznania. Jest tyle wyznań, ilu jest ludzi świadomych i myślących. Oprócz tego istnieją wolne związki, czyli zrzeszenia ludzi, którym się zdaje, że są tego samego wyznania, tj. którzy spełniają lub też powinni spełniać te same obrządki religijne.

Precz więc $\mathrm{z}$ wyznaniem paszportowym! Państwo powinno znieść tę hańbiącą, ubliżającą, uwłaczającą godności ludzkiej rubrykę.

Odmowa przysięgi ze strony ludzi nieuznających jej znaczenia i otwarte deklarowanie przez nich bezwyznaniowości oraz wyrzucenie z paszportów rubryki wyznaniowej są konieczne właśnie ze stanowiska religii traktowanej poważnie, a nie powierzchownie, nie formalnie, nie policyjnie. 
Zniesienie wyznania paszportowego i obowiązkowych szkół wyznaniowych, które powinny ustąpić miejsca szkołom państwowym, tylko bezwyznaniowym, unikającym przemocy nad sumieniem uczniów i ich rodziców, jest konieczne dla umocnienia w społeczeństwie prawdziwej religijności, spoczywającej w głębi dusz ludzkich, a nie na papierze.

To będzie właśnie zadokumentowaniem szacunku dla religii, dla czystych i nieskalanych dotknięciem brutalnej łapy kontrolera wyznaniowego uczuć ludzkich, będzie zdjęciem przymusu religijnego z najświętszych i najdroższych dla każdego tajników duszy ludzkiej, będzie emancypacją duszy ludzkiej od kleszczy dozoru policyjnego i żandarmskiego.

Powyższe wywody streszczam w pięciu tezach:

1. Tolerancja jako uwłaczająca tolerowanym i krzewiąca megalomanię bądź to niesłusznie uprzywilejowanych, bądź też liczebnie przeważających nam już nie wystarcza.

2. Odrzucając podział współobywateli danego państwa na uprzywilejowanych gospodarzy i na upośledzonych gości, żądamy bezwzględnego równouprawnienia zarówno pojedynczych ludzi, jako też wszelkich związków i zrzeszeń kulturalnych.

3. Wolnomyśliciel nie powinien pozwalać nadużywać swego szyldu dla przemycania nauk i dążności nic wspólnego z wolnomyślicielstwem niemających.

4. Wolnomyśliciel staje w obronie wszystkich wierzących i niewierzących przed wszelkimi skierowanymi przeciwko nim ograniczeniami i prześladowaniami.

5. Rubryka wyznaniowa w paszportach jest anachronizmem i hańbą dla państwa, które ją uznaje lub choćby tylko toleruje. Wobec tego należy się domagać stanowczo jej usunięcia.

\section{Konspekt odezytu}

Bankructwo tolerancji.

Bezwzględne równouprawnienie.

(Zdjęcie przymusu policyjnego z najgłębszych i najświętszych tajników duszy ludzkiej). 
(Emancypacja duszy ludzkiej od kleszczy dozoru policyjnego i żandarmskiego).

Wolne zrzeszenia wyznaniowe.

Bezwyznaniowość.

Wolnomyślicielstwo — wątpliwe a istotne.

(Fanatyzm wolnomyślicielstwa i bezwyznaniowości).

Prawdziwy wolnomyśliciel jako obrońca wszystkich wierzących i niewierzących.

(Obłuda w Konstytucji).

(Państwo bezwyznaniowe i pozawyznaniowe).

Oddzielenie kościołów od państwa. Uszlachetnienie wyznań.

Usunięcie ze szkolnictwa przymusu wyznaniowego.

Zniesienie (usunięcie) obowiązkowości przysiąg.

Zniesienie wyznania paszportowego. Jego, wyznania paszportowego, bezsens i obraza godności ludzkiej.

(W imię godności jednostkowej duszy ludzkiej wolnomyśliciel walczy za uszlachetnienie i uwolnienie wszelkiej wyznaniowości i bezwyznaniowości od uwłaczającego im kontrolowania ze strony władz policyjnych wszelakiego autoramentu).

[Warszawa 1923. „Biblioteka Stowarzyszenia Wolnomyślicieli Polskich" nr 1] 


\title{
WYZNANIOWE I POZAWYZNANIOWE ŚLUBY I ROZWODY
}

\section{(Z powodu oczekiwanej reformy prawa małżeńskiego)}

\author{
Uwaga wstępna
}

Ponieważ w różnych dzielnicach nowo powstałej Polski, zależnie od ich poprzedniej przynależności do tego lub owego państwa zaborczego panują dotychczas różne kodeksy kryminalne i cywilne, a w prawodawstwie cywilnym różny stosunek kościołów do państwa, zjednoczenie zaś państwowe pociąga za sobą konieczność usunięcia tej rozmaitości i uzgodnienia prawodawstwa na całym obszarze państwa, więc utworzono w tym celu Komisję Kodyfikacyjną ${ }^{1}$, od której oczekujemy zniesienia różnic dzielnicowych i zastąpienia praw i przepisów rosyjskich (w dwóch odmianach: „Królestwa Kongresowego” i Cesarstwa w ścisłym znaczeniu), austriackich i pruskich jednakowymi dla całej Polski prawami i przepisami polskimi. Obecnie opracowuje się dział prawodawstwa cywilnego dotyczący zawierania małżeństw, ich „unieważniania” i rozwodów. Chodzi o to, czy przy określaniu stosunku kościołów do państwa prawodawstwo postępowe, oparte na rozróżnianiu pojęć ma ustąpić prawodawstwu zacofanemu, opartemu na pomieszaniu pojęć, nieuznającemu praw osobistych i uragającemu godności ludzkiej, czy też odwrotnie.

W związku z tym „Nowy Kurier Polski” urządził w marcu r.b. „specjalną ankietę" pt. Dookota prac Komisji Kodyfikacyjnej. Reforma prawa matżeńskiego w Polsce. Co o niej sadza rzeczoznawcy? Nie trzymano się jednak zastrzeżenia co do „rzeczoznawców”, bo na samym początku zwrócono się między innymi do mnie, a ja, nie będąc wcale prawnikiem, nie mogę uważać siebie za rzeczoznawcę nie tylko

1 W chwili powstania niepodlegtej Polski na jej poszczególnych ziemiach obowiązywały systemy prawne: niemiecki, pruski, austriacki, węgierski (na Spiszu i Orawie), francuski i rosyjski. Sejm Ustawodawczy powołał 3 VI 1919 r. Komisję Kodyfikacyjną, której powierzył przygotowanie kodeksów prawa karnego i cywilnego. 
wybitnego, ale nawet jak najskromniejszego. Mam prawo do zabierania głosu w tej sprawy na równi z każdym obywatelem niepozbawionym zdolności myślenia.

Przy tym w stosunku do mnie zaszło małe nieporozumienie. Nie zastawszy mnie w domu, wywiadowca „N[owego] Kur[iera] Pol[skiego]" zostawił mi list, prosząc mię w nim wyraźnie nie 0 wywiad-rozmowę, ale tylko 0 artykut. W swej naiwności zrozumiałem to dosłownie, przypuszczając, że to, co napiszę, będzie uważane za moją własność i zostanie wydrukowane jako mój artykuł. Tymczasem współpracownik gazety skorzystał z mej pracy jedynie jako z materiału do własnego artykułu („Nowy Kurier Polski”, nr 30, z 2 marca). Nie przeinaczył wprawdzie moich zapatrywań, przepisując dosłownie moje własne zdania, ale wyrzucił całe ustępy i nadał memu artykułowi niepożądany dla mnie wygląd fikcyjnego wywiadu z pytaniami i odpowiedziami, które oczywiście nie mogły mieć miejsca, ponieważ ja p. wywiadowcy w żywe oczy nie widziałem.

Prócz tego zaopatrzył on swój „wywiad” w całkiem zbyteczną i niesłuszną uwagę, jakobym ja ujmował niektóre zagadnienia $w$ sposób krańcowy, gdy tymczasem ja jestem daleki od wszelkiej „krańcowości” zarówno z prawa, jak z lewa, odgradzając się wyraźnie zarówno od komunistów, jak od faszystów, zarówno od zamachowców w imię „dyktatury proletariatu”, jako też od zamachowców w imię „monarchy z Bożej łaski”. Wypowiadam się w sposób, według mego zdania, całkiem obiektywny, a mam zawsze na widoku pożytek obustronny na dalszą metę.

No, ale tak czy owak, powinien bym był zadowolnić się tym, co się stało, i nie zabierać więcej głosu w tej obcej mi sprawie. Będąc jednak niedawno w Krakowie, dałem się skusić namowom osób biorących tę sprawę gorąco do serca, a zwłaszcza prof. 0. Bujwida, który mi zaproponował wydanie osobnej broszury w tej sprawie. 0statecznie podnoszę jeszcze raz głos jako jeden z tłumu.

\section{Mój punkt wyjścia}

Wypowiadając się w tej sprawie, kieruję się jedynie zdrowym rozsądkiem oraz poczuciem sprawiedliwości i godności ludzkiej. 
Instytucja małżeństwa zrodziła się, rozwijała się i rozwija się w dalszym ciągu, podobnie jak tyle innych instytucji społecznych, w związku z potrzebami naturalnymi człowieka, w związku z jego instynktami, namiętnościami itd. Około niej nagromadziły się nawarstwienia z różnych epok cywilizacji, przeżytki dawno minionych wieków, urządzenia uzgodnione z późniejszymi zapatrywaniami itd. Stąd sprzeczności, spory i starcia (konflikty). Wchodzą tu w grę elementy życia badane przez biologię, psychologię, socjologię, folklorystykę itd.

Źródłem pierwotnym i stałym jest tu popęd do rozmnażania się, wspólny człowiekowi ze wszystkimi zwierzętami, a dający silne wrażenia swoistej rozkoszy. Od objawów czysto zwierzęcych człowiek posunął się w dwóch różnych kierunkach: z jednej strony upodlenie i zohydzenie instynktu płciowego w rozpuście i prostytucji wszelkiego rodzaju, z drugiej uszlachetnienie i uspołecznienie instynktu przez miłość dwóch osobników różnej płci, pragnących wspólnego pożycia. I jedno, i drugie zostało wyzyskane zarówno przez teokrację, przez znachorów i kapłanów wszelkiego rodzaju, jako też przez przemyst, handel i w ogóle rozmaite manipulacje z dziedziny ekonomii społecznej i organizacji państwowej.

Niegdyś znachor, szaman, cadyk lub inny tego rodzaju pośrednik między człowiekiem a bóstwem całkowicie wystarczał i ostatecznie wyrokowal, i w sprawach higieny, i lecznictwa, i w sprawach obcowania społecznego w sferze własności, w sferze stosunków międzypłciowych itd. Stopniowo jednak zjawiało się coraz większe różniczkowanie funkcji społecznych, coraz większa specjalizacja. Natchnienie i jasnowidzenie znachora przestało wystarczać. W sprawach zdrowia, żywienia się i w ogóle higieny zaczął zabierać głos przyrodnik-lekarz, w sprawach społecznych specjalista prawnik, w sprawach wychowania i uczenia specjalista pedagog i nauczyciel. Potężniało coraz bardziej uwalnianie się od opieki sił pozaziemskich, uświecczanie, czyli laicyzacja życia. Zjawił się konflikt, czyli starcie organizacji teokratycznej, czyli kościoła, z organizacją świecką, czyli z państwem, w którego ramach narastają również rozmaite inne swoiste konflikty. 
Rozgraniczenie interesów Kościoła

a państwa i społeczeństwa

Konflikt interesów kościelnych z interesami państwowymi występuje bardzo wyraźnie przede wszystkim w regulowaniu i reglamentowaniu życia społecznego, związanego z takimi etapami życia jednostek, jak urodzenie się, śmieré, zawieranie związków międzypłciowych, dających początek nowemu życiu. Każda z tych walczących ze sobą instytucji chce nałożyé właściwe sobie piętno na kierowanie życiem społecznym we wzmiankowanych dziedzinach, a to prowadzi do zgorszenia, do fanatycznego zacietrzewienia, do obłudy, do stosowania gwałtu i przemocy. Jedynym wyjściem z gorszących konfliktów, prowadzących do kompromisów z sumieniem i do nieszczerości, jest oddanie każdemu tego, co mu się należy, oddanie Bogu tego, co boskie a cesarzowi tego, co cesarskie, jest absolutny rozdział kościołów od państwa, jest oddanie strony społecznej, ogólnie obywatelskiej, małżeństwa i związanych z nim wydarzeń w życiu jednostek i rodzin urzędom świeckim, a strony wyznaniowej, religijnej, o ile jej potrzebują zainteresowane jednostki, urzędom duchownym. Jest to jedyne wyjście, umożliwiające spokojne wspótżycie kościołów i państw, bez podporządkowywania jednych pod władzę drugich. Toteż państwa, którym chodzito o ostateczne usunięcie wszelkich drażniących konfliktów, wprowadziły u siebie prawdziwy „stan cywilny”, tj. rejestrację ruchu ludności w urzędach świeckich, nie zabraniając nikomu zwracania się także do sankcjonowania zmian zaszłych w ich życiu przez dobrowolnie uznawane duchowieństwo.

Wobec tego i ja też muszę stać na stanowisku bezwzględnego rozdziału kościołów i państwa, na stanowisku bezwzględnego uświeczczenia, czyli laicyzacji, naszego życia indywidualnego i spotecznego. Wymaga tego dobrze zrozumiany interes zarówno państwa i społeczeństwa jako też przede wszystkim samych kościołów. Każdy szanujący siebie kościót powinien zyskiwać wyznawców i zwolenników jedynie drogą przekonywania i spokojnej propagandy, nie uciekając się do przymusu policyjno-żandarmskiego. W oczach niefanatyka, w oczach człowieka szanującego godność ludzką własną i cudzą, wyznanie jest rzeczą sumienia jednostki i nie wolno go narzucać za 
pomocą bądź to terroru, szantażu i prześladowania, bądź też przekupstwa czy to na tym, czy choćby nawet na tamtym świecie.

Dzisiejsze metody zmuszania ludzi do udawania wyznawców tego lub owego kościoła są tylko rozcieńczonym terrorem wyznaniowym, praktykowanym w dawnych czasach przez Inkwizycję Święta za pomocą wymyślnych tortur, owej poezji czynnej katolicyzmu wojującego w wiekach średnich. Zalatuje od nich mięsem smażonym na stosach, dochodzą echa wycia skazańców wijących się w mękach piekielnych, urządzanych przez ecclesia militans. Nie przelewano przy tym krwi, ale przecież i Mikołaj I, wieszając dekabrystów, również „krwi nie przelewał”.

Dzisiejszy kościół katolicki nie może odpowiadać za okrucieństwa i zbrodnie swego historycznego poprzednika i imiennika, ale też swym uporem, swym zaślepieniem i swą nieustępliwością nie powinien wywoływać widm haniebnej przeszłości i wytwarzać wrogiego dla siebie nastroju.

Za to ma on niezaprzeczone prawo i obowiązek domagania się, ażeby jego prawdziwi i szczerzy wyznawcy - a tacy przecież istnieją i istnieć będą - mogli bez żadnych przeszkód odbywać wszelkie praktyki religijne, a więc także zawierać śluby małżeńskie przed ołtarzem, ze wszelkimi wynikającymi stąd następstwami wyznaniowymi.

\section{Równouprawnienie państwowe wszystkich obywateli}

Chodzi więc o zupełne równouprawnienie wszystkich obywateli bez różnicy wyznania czy to zbiorowego, stadowego, czy też indywidualnego. Wszystkich obywateli musi obowiązywać wspólne jednakowe prawodawstwo czysto świeckie, pozawyznaniowe, niegwałcące zresztą ich sumień pod względem religijnym, tj. nienarzucające im obowiązkowej „bezwyznaniowości” lub pozawyznaniowości. A ze stanowiska takiego prawodawstwa państwowego, pozawyznaniowego, małżeństwo nie może być traktowane ani po katolicku, ani po żydowsku, ani po mahometańsku, ale tylko po świecku, pod kątem ogólnieludzkiej sprawiedliwości społecznej i ogólnieludzkiej moralności pozawyznaniowej. Ma ono być ulegalizowaniem naturalnego związku między indywiduami różnopłciowymi, które postanowiły zawrzeć 
umowę stałego współżycia na dłuższy czas, możliwie do końca życia jednego z kontrahentów. Jest to taka sama umowa cywilna, czyli świecka, między równouprawnionymi jednostkami jak wszelka inna.

W obliczu prawa cywilnego ani stosunek wyznaniowy osób zawierających umowę małżeńską, ani strona uczuciowa i sposób pożycia nie mogą byé przedmiotem prawodawstwa. Zgodnego lub kłótliwego pożycia, wzajemnej miłości lub wstrętu i nienawiści małżonków nie może, nie jest w stanie i nie ma prawa reglamentować żadna władza, ani prawodawcza, ani wykonawcza, chociażby to nawet była władza samego wielkiego nieomylnika lub też samego wielkiego inkwizytora. Uczynki i mowy nieprawomyślne i buntownicze mogą byé kontrolowane i „karane”, ale na myśli i uczucia nieprawomyślne i buntownicze nie posiadamy, niestety, dotychczas żadnego kagańca, ani nawet żadnych promieni prześwietlających. Można wprawdzie ślubować „wierność małżeńską", ale niepodobna ślubować dozgonnej, a choćby nawet krótkotrwałej miłości, o ile oczywiście nie pojmujemy „miłości" po prostacku, w znaczeniu francuskiego faire l'amour, o ile nie utożsamiamy miłości z jej rzekomym uzewnętrznianiem w postaci wymuszonego brutalnego aktu płciowego, jednakowego zarówno dla prawdziwej miłości, jako też dla gwałtu i płatnej prostytucji.

\section{Prawdziwie wierzący a niedowiarki udające wierzących}

0 ile szanujący siebie kościót chce zachować czystość i nieskazitelność, o ile chce się opierać na prawdziwych potrzebach serca swych wyznawców, na ich uczuciach, tęsknotach i pragnieniach związku bezpośredniego z odezuwanymi i uznawanymi przez nich potęgami zaświatowymi, o tyle powinien unikać wszelkiej przemocy, wszelkiego fałszu i obłudy, wszelkiego salonowego rozkosznego flirtu z Panem Bogiem, praktykowanego przez światowców rzekomo religijnych. Boć owe „wyższe sfery towarzyskie” trzymają się księżej rewerendy lub cycełe cadyka dla panowania nad naiwnie wierzącym gminem, z którym „bez Boga nie można sobie dać rady”. Niedowiarki zawierają w tym celu konkordaty, a kościót prowadzący konszachty polityczne z państwem dla oddawania sobie wzajemnych usług plugawi siebie i zohydza. Przy tej sposobności jegomoście uprawiający 
przelotne motylkowate małżeństwa sezonowe gardłują za sakramentalnością i nierozerwalnością małżeństwa wyznaniowego.

Obowiązkowe śluby i rozwody jedynie cywilne, czyli świeckie

Reforma prawa małżeńskiego czyniąca zadość dzisiejszym zapatrywaniom i nastrojom powinna opierać się jedynie i wyłącznie na uznaniu obowiązkowych ślubów i rozwodów cywilnych, jednakowych dla wszystkich bez wyjątku obywateli i obywatelek państwa, bez różnicy wyznania i narodowości. 0 ile zaś wstępujący w związek małżeński zechcą go sankcjonować w świątyni tego lub owego wyznania, to już powinno być rzeczą ich gustu i bądź to sumienia, bądź też naginania się do panujących zwyczajów i konwenansów.

Równouprawnienie małżonków

Równouprawnienie obojga małżonków pod każdym względem jest absolutnie nie do osiągnięcia. Przede wszystkim stoi mu na przeszkodzie sama przyroda w dziedzinie płciowej. Sam akt płciowy wyklucza równouprawnienie. Tym bardziej jego zwykłe naturalne następstwa. Kobieta jako matka nie jest równouprawniona z mężczyzną jako ojcem. Mężczyzna uczestniczy tylko w rozkoszach życia międzypłciowego, a kobieta jako rodząca musi poza rozkoszami znosić także wszelkie bóle i cierpienia. Jeżeli zaś jest matką nieślubną, oprócz cierpień fizycznych wystawioną jest na swoiste cierpienia moralne.

Ten stan rzeczy, o ile zależy od przyrody, jest nie do zmienienia. Ale za to człowiek może i powinien wprowadzać ulepszenia w tych sferach życia, gdzie pozaludzki proces przyrody uspołecznia się. Poczucie sprawiedliwości wymaga przeciwdziałania krzywdom spotykającym kobietę jako matkę nieślubną. Jeżeli nie można ustalić i odnaleźć ojca, powinno go zastąpić społeczeństwo.

W umowach małżeńskich jako aktach społecznych powinno być przestrzegane bezwzględne równouprawnienie. Jeżeli uznajemy równouprawnienie polityczne, to tym bardziej powinniśmy domagać się absolutnego zrównania małżonków tak pod względem rozporządzal- 
ności majątkiem osobistym, jako też pod względem swobody ruchów. Grasujący niegdyś w Rosji carskiej przepis i zwyczaj uzyskiwania przez żonę pozwolenia mężowskiego dla otrzymania osobnego paszportu był haniebną potwornością, przeżytkiem niewolnictwa, zgodnym zresztą z Dekalogiem (z Dziesięciorgiem Bożego Przykazania), w którym żona - czy to jednoosobowa przy monogamii, czy też wieloosobowa przy poligamii - figuruje obok wołu, osła, domu innych przynależności mienia mężowskiego.

\section{Wspólne nazwisko małżonków}

Ale i w sferze równouprawnienia społecznego, cywilno-prawnego nie da się tymczasem usunąć pewien wyjątek, a mianowicie co do wspólnego nazwiska małżonków. Mąż zachowuje swoje kawalerskie nazwisko, a żona traci nazwisko ojca, nazwisko panieńskie, zamieniając je na mężowskie. Zwyczaj ten zawdzięczamy epoce, kiedy to obok mater semper certa (matka zawsze jest wiadoma) stawał pater (ojciec) jako pan i władzca [sic!] matki, uznający jej dziecko za swoje, epoce przejścia od matriarchatu, określanego przez samą przyrodę i właściwego całemu światu zwierzęcemu, do patriarchatu, od luźnego związku biologicznego do instytucji wyraźnie społecznej. Jako symbole uznawania dziecka przez ojca zjawiły się ongi kuwada, tj. odbywanie połogu przez ojca zamiast matki; patronymica, dotychczasowe rosyjskie otczestwa, czyli dodatki do imion własnych, utworzone od imienia ojca. Początkowo, w dobie matriarchatu, dodatki te tworzono od imienia matki, a w epoce przejściowej od matriarchatu do patriarchatu zarówno od imienia matki, jak i od imienia ojca. Kiedy żony kupowano, stanowiły one część składową inwentarza żywego w gospodarstwie mężczyzny, a więc oczywiście musiały się nazywać według imienia czy też nazwiska właściciela. Zresztą same nazwiska w dzisiejszym rodowym ich rozumieniu są zjawiskiem nowszym.

Znamieniem przejściowości jest zwyczaj nazywania żony nazwiskiem męża i jej własnym imieniem osobistym z dodatkiem $z$ domu albo urodzona (co chyba jest nowszym bądź to rusycyzmem, bądź też germanizmem), np. Maria Kowalska z domu (lub urodzona) Malecka (albo krócej: Maria z Maleckich Kowalska). We Włoszech panuje zwy- 
czaj stawiania naprzód nazwiska panieńskiego a po nim nazwiska męża, np. Eleonora Fumigalli (po ojcu) maritata (za mężem) Sarto. Przy wypisywaniu na biletach wizytowych, na drzwiach itd. Marianowie Sokołowscy, Janowie Baliccy itp. (niby dwóch lub więcej Marianów Sokołowskich, Janów Balickich itp. rodzaju męskiego) mąż pochłania żonę bez reszty. Łagodzi się to przez zamianę dwuznacznych Marianowie, Janowie itd. na Marianostwo, Janostwo itd.

Dziś mamy już próby wolnego wyboru: albo zachowania przez żonę nazwiska panieńskiego, albo przybrania przez nią nazwiska mężowskiego, albo nawet przyjęcia przez męża nazwiska żony. Ta wolność wyboru stosuje się także do dzieci albo za obopólną zgodą rodziców, albo też z wyboru samych dzieci.

\section{Rozwody}

Uznanie rozwodu jest konieczną konsekwencją liczenia się z godnością ludzką i z zasadą wolności osobistej. Jeżeli dwoje ludzi różnopłciowych, poznawszy się bliżej, nie może się znosić i woli się rozejść, tylko brutalna przemoc może ich zmuszać do mieszkania pod jednym dachem. W stopniu nie mniejszym odnosi się to także do jednej ze stron. Żona poniewierana i maltretowana przez męża lub odwrotnie, mąż dręczony przez żonę, ma nie tylko prawo, ale nawet obowiązek przed własnym sumieniem uwolnić się od tyrana i chama, albo też od jędzy i sekutnicy. Przykuwać kogoś do zbrodniarza, zwyrodnialca, nikczemnika lub w ogóle osobnika psychopatycznego jest zbrodnią i cynizmem, a prawo czy to kościelne, czy państwowe, które, stosując zasadę nierozerwalności małżeństwa, skazuje niewinnych na dożywotnią katorgę, wystawia sobie jak najgorsze świadectwo i zasługuje na pogardę - choćby to nawet było prawo kanoniczne Kościoła Świętego rzymskokatolickiego. Szczególnie okropnym jest położenie żony skazanej na zadawalanie się rolą ścierki lub też naczynia pośledniejszego gatunku ku pożytkowi i wygodzie maltretującego ją pana i ,prawowitego” "nieoderwalnego” małżonka.

0 ile z takiego nieszczęśliwego małżeństwa zrodziły się dzieci, to powoływanie się na ich istnienie nie zmienia w niczym prawa do rozwodu. Przeciwnie, właśnie ze względu na dzieci, dla niezatruwa- 
nia ich dusz i dla niegorszenia ich widokiem objawów wzajemnego wstrętu rodziców, dla unikania choćby tak zwanej „obrazy boskiej” związanej z takimi widowiskami i gorszącymi scenami, należy je wyrwać z tego piekła „rodzinnego” i przenieść do środowiska spokojnego i pogodnego.

\section{Dokąd przenieść dzieci}

Ale w takim razie, przy kim mają pozostać małoletnie i niepełnoletnie dzieci?

To zależy od bardzo wielu najróżnorodniejszych okoliczności: czy przy jednym z rozwiedzionych małżonków, czy przy innych krewnych, czy też w zakładach społeczno-państwowych. Jeżeli rodzice tylko w stosunku do siebie są niemożliwi, a poza tym dają rękojmię przyzwoitego zachowania się, dzieci mogą być im pozostawione bądź to wszystkie przy jednym z rodziców, bądź też rozdzielone między oboje. W każdym razie koniecznością państwowo-społeczną jest istnienie zakładów wychowawczych dla dzieci niemogących pozostawać przy rodzicach lub krewnych.

Jeżeli dzieci są już starsze i uświadomione, należy je same zapytać, czy chcą pozostawać przy jednym z rodziców, o ile oczywiście on sam również nie będzie miał nic przeciwko temu.

Kwestię kosztów utrzymania dzieci opuszczonych przez rodziców powinno rozstrzygnąć prawodawstwo.

\section{Rozwód a „unieważnienie małżeństwa”}

Rozwód czy separacja - o tym powinni stanowić sami rozstający się ze sobą różnopłciowi obywatele. Niektórym, zwłaszcza w późniejszym wieku, może wystarczyć separacja, tj. rozejście się bez formalnego rozwodu; znaczna jednak większość będzie z pewnością żądała zupełnego zerwania wszelkich więzów małżeńskich, nie tylko fizycznych, ale także społeczno-prawnych. Tak zwane „unieważnienie małżeństwa” ze wszystkimi jego konsekwencjami, praktykowane con amore przez kler katolicki, jest potwornością urągającą zdrowemu rozsądkowi i godności ludzkiej. 
Oczywiście „małżeństwo” zawarte tylko na papierze a niespełnione (matrimonium non consummatum), samo się unieważnia bez niczyjej sankcji. Bywają jednak wypadki , unieważniania małżeństwa” po kilkudziesięciu latach wspólnego pożycia i istnieniu całej kupy wspólnych dzieci, które w ten sposób stają się „nieprawymi”. Bo jowialne twierdzenia urzędników konsystorskich i pomagających im adwokatów, że „unieważnienie małżeństwa” nie sprzeciwia się „prawości” dzieci zrodzonych z takieg 0 „nieprawego toża” jest bezczelnym wykrętem urągającym wszelkiej logice i poczuciu prawa.

Procedura „unieważniania małżeństw” połączona jest częstokroć z całym szeregiem brudów i skandali. A nie potrzebuję chyba wspominać 0 urządzaniu przez władze konsystorskie w związku $\mathrm{z}$ „unieważnieniami małżeństw” eksperymentów pornograficznych (kiedy idzie o zarzut impotentiae), o patrzeniu na kobietę jak na krowę lub kobyłę i poddawaniu jej poniżającym i hańbiącym oględzinom (kiedy chodzi 0 stwierdzenie matrimonii non consummati), 0 magicznym wreszcie wpływie bądź to łapówek, bądź też wysokich protekcji przy prowadzeniu procesów 0 ,unieważnienie małżeństwa” nie tylko w konsystorzach miejscowych, ale nawet w samej urbs aeterna.

Wiem od ludzi całkiem wiarogodnych, którzy się z tym blisko stykali, że urzędnicy konsystorscy miewali znaczne dochody poboczne, że istnieją adwokaci zajmujący się wyłącznie tego rodzaju sprawami i doskonale zarabiający. Znam osobiście pewnego adwokata Włocha, który się wyuczył po polsku i osiedlił w Polsce dla ułatwiania, dzięki swym stosunkom rzymskim, „unieważniania małżeństw” obywateli i obywatelek polskich.

Co się zaś tyezy skutecznego wpływu tapówek lub też osobistych znajomości i wysokich protekcji, to przede wszystkim nie da się zaprzeczyć, że biedacy nieposiadający gotówki nie mogą nawet marzyć 0 ,unieważnieniu” swych małżeństw, choćby najbardziej się do tego nadających, a ludziom bogatym i ustosunkowanym zawsze się to udaje. 
Oto

dwa wymowne przykłady

Przed laty pewien znakomity pisarz polski ${ }^{1}$, wdowiec, wstąpif w powtórny związek małżeński. Odbyło się to nadzwyczaj uroczyście, z błogosławieństwem samego Ojca Świętego, uniemożliwiającym podobno „unieważnienie małżeństwa”. Pomimo to małżeństwo na samym wstępie zrobiło fiasko i na wyraźne nieodwołalne postanowienie panny młodej trzeba było prosić 0 ,unieważnienie”, które też uzyskano, dzięki oczywiście wysokim wpływom w samem centrum katolicyzmu.

A oto drugi przykład jeszcze bardziej wymowny.

Pewien słynny filozof polski², wierny syn Kościoła broniący gorliwie wszystkich jego dogmatów, jakiś czas codziennie przystępujący do Stołu Pańskiego, a co tydzień się spowiadający, utożsamiający polskość z katolicyzmem, po przeszło dwudziestoletnim pożyciu z pierwszą żoną porzucił ją, ażeby wstąpić w związek małżeński z inną osobą. Przez wysokie koligacje i znajomości w sferach rzymskokatolickich uzyskał „unieważnienie” pierwszego małżeństwa i mógł uzyskać ponowne błogosławieństwo również dla drugiego. Znaleziono jakieś nieformalności i „unieważniono” pomimo wyraźnego i stanowczego sprzeciwu pierwszej małżonki. A trzeba dodać, że filozof ten jest wyznawcą i głosicielem dogmatu nierozerwalności małżeństwa nie tylko na tym, ale także na tamtym świecie. Z drugiej strony posiada on podobno tę godną zazdrości odwagę, że kilkoro dzieci swoich, spłodzonych z pierwszego, „unieważnionego" małżeństwa, uważa za „bękartów”. Wnioskowanie ściśle logiczne i bez zarzutu.

Do takich bezeceństw i krzywd prowadzi nieuznawanie rozwodów a praktykowanie „unieważniania” małżeństw.

Temu wszystkiemu nowe prawodawstwo powinno położyé koniec, o ile oczywiście panowie kodyfikatorowie nie są obłudnikami i spiskowcami przeciwko moralności publicznej i szczęściu współobywateli.

1 Mowa o Henryku Sienkiewiczu i jego nieudanym małżeństwie z Marią Wołodkowiczówną.

2 Mowa o Wincentym Lutosławskim. 
Sądy wyznaniowe

Przy istnieniu ogólnopaństwowych ślubów i rozwodów cywilnych, jednakowych dla wszystkich współobywateli, nie ma miejsca dla sądów wyznaniowych, uprawnionych do rozstrzygania spraw z natury rzeczy i w oczach prawodawstwa państwowego pozawyznaniowych. Oczywiście w imię bezwzględnej tolerancji sądy wyznaniowe mogą pozostać, ale tylko jako instytucje prywatne tego lub owego wyznania. Kto w sprawach świeckich uznaje nad sobą władzę kościoła, ten oczywiście i nadal będzie się zwracał do sądów wyznaniowych. Przecież dla Żyda prawowiernego autorytet cadyka lub rabina jest jedynym uznawanym przezeń autorytetem.

Stanowisko duchowieństwa - duchowieństwo katolickie

Przy obecnie przeprowadzanej kodyfikacji prawa małżeńskiego chodzi o to, czy państwo jako państwo ma zapobiec mięszaniu się kościoła do spraw społecznych pozawyznaniowych, tj. czy ma być uznana i wcielona w życie zasada uświecczenia, czyli laicyzacji życia społecznego, czy też po dawnemu życie to ma być regulowane przez przemawiających w imieniu bóstwa pośredników: księży, rabinów, muftich, szamanów i innych tp. Wobec tego ciekawą jest rzeczą, jak na te sprawy zapatruje się samo duchowieństwo. W Polsce pod względem liczebnym naczelne miejsce zajmują wyznawcy Kościoła katolickiego; a więc należy się przede wszystkim zapoznać ze zdaniem duchowieństwa katolickiego. Ułatwia nam to znakomicie podana do wiadomości publicznej odezwa biskupów (wydrukowana m.i[n]. w „Kurierze Warszawskim” nr 68, z wtorku dnia 9 marca 1926 r., „Dodatek poranny”). Przytaczam ją w całości.

Odezwa biskupów Polski do rządu i narodu w obronie sakramentu małżeństwa

Niepokój wielki ogarnął duchowieństwo i szerokie koła naszego katolickiego społeczeństwa wskutek poważnych wieści, że przygotowywana kodyfikacja prawa małżeńskiego dla katolików opiera się na poglądach niezgodnych z zasadą Kościoła świętego. Wobec tego 
zwracają się biskupi katoliccy wszystkich trzech obrządków, zebrani z całej Polski na narady w sprawach kościelnych w Warszawie d. 2, 3, 4 i 5 marca 1926 r., do przedstawicieli rządu i stronnictw poselskich 0 zabezpieczenie katolickim związkom małżeńskim ich charakteru sakramentalnego.

Świętość rodzinnego życia, religijne wychowanie dzieci są podstawą nie tylko rodziny chrześcijańskiej, ale także trwałości i pomyślnego rozwoju życia narodowego i państwowego. Podstawa ta atoli jest uwarunkowana uświęceniem związków katolickich przez Kościół i przez nierozerwalność ich węzła.

Od tych zasad Kościół katolicki ustąpić nie może i nie ustąpi. A my biskupi, będący stróżami przekazanych nam nauki i nakazów Chrystusowych, wymagać musimy i wymagamy, aby także wszyscy katolicy w tej sprawie sumienia mocno stali w obronie zasad Kościoła katolickiego i przeciwdziałali ustawowemu sankcjonowaniu tak zwanych ślubów i rozwodów cywilnych. Związek małżeński, zawarty przed urzędnikiem stanu cywilnego, jest nieważny, bo sprzeciwia się prawu Bożemu.

Żaden też poseł katolik nie powinien głosować za tym, co jest sprzeczne z prawem Bożym, a wyborcy mają prawo i obowiązek zażądania od swych posłów, ażeby nie współdziałali w uchwaleniu ustaw szkodliwych nierozerwalności i świętości węzła małżeńskiego. Prócz tego mają posłowie obowiązek użycia całego swojego wpływu w celu zapobieżenia wyrządzeniu tak niesłychanej krzywdy zasadzie katolickiej.

Powyższe oświadczenie Episkopatu wręczone będzie przedstawicielom rządu i zarządom stronnictw sejmu i senatu, a xx. proboszczowie ogłoszą je z ambon w najbliższą niedzielę.

Warszawa, dnia 5 marca $1926 \mathrm{r}$.

$\dagger$ Aleksander kardynat Kakowski, † Józef Teodorowicz, arcybiskup lwowski obrz. orm., † Adam Sapieha, książę-arcybiskup metropolita krakowski, † Bolestaw Twardowski, arcybiskup metropolita lwowski obrz. łac., † Anatol Nowak, biskup przemyski obrz. łac., † Leon Watega, biskup tarnowski, † Stanistaw Zdzitowiecki, biskup włocławski, $\uparrow$ Antoni-Julian Nowowiejski, biskup płocki, † Grzegorz Chomyszyn, biskup stanisławowski, $\dagger$ Marian Ryx, biskup sandomierski, $\uparrow A u$ gustyn Łosinski, biskup kielecki, † Zygmunt Łozinski, biskup piński, 
† Józefat Kocytowski, biskup przemyski obrz. grecko-katolickiego, $\dagger$ Henryk Przeździecki, biskup podlaski, † Stanistaw Gall, biskup wojsk polskich, sufragan warszawski, $\dagger$ Wincenty Tymieniecki, biskup łódzki, † Romuald Jałbrzykowski, biskup łomżyński, † August Hlond, biskup śląski, † Teodor Kubina, biskup częstochowski, †Karol Fischer, biskup sufragan przemyski, † Jakub Klunder, biskup sufragan chełmiński, † Wtadystaw Krynicki, biskup sufragan włocławski, $\uparrow$ Pawet Kubicki, biskup sufragan sandomierski, $\uparrow$ Adolf-Józef Jetowiecki, biskup sufragan lubelski, † Stanistaw Eukomski, biskupwikariusz kapitulny archidiecezji poznańskiej, † Kazimierz Michalkiewicz, biskup-wikariusz kapitulny archidiecezji wileńskiej, † Józef Bocian, biskup sufragan lwowski obrz. grecko-katolickiego, $†$ Antoni Laubitz, biskup-wikariusz kapitulny archidiecezji gnieźnieńskiej, $\dagger$ Wtadystaw Szcześniak, biskup sufragan warszawski, † Stanistaw Okoniewski, biskup-nominat koadiutor chełmiński.

Jak widzimy, przedstawiciele katolicyzmu w Polsce stoją na stanowisku nieprzejednanych (intransigeants), nie chcą w niczym ustąpić wymaganiom nowoczesnym, nie chcą też wiernych istotnie wierzących, ale wolą obłudników udających wiarę, żądają współpracy państwa w zmuszaniu obywateli do wykonywania obrządków i ceremonii, które dla nich, dla tych obywateli, są co najwyżej tradycyjnym konwenansem.

Gdyby autorowie odezwy rozróżniali pojęcia, gdyby zgodnie z rzekomo uznawanym przez nich Pismem Świetym oddawali to, co boskie, Bogu, a to, co państwowe i społeczne, państwu i społeczeństwu, nie ośmieliliby się twierdzić, ̇̇e przygotowywana kodyfikacja prawa matżenskiego (chyba nie dla samych tylko katolików, a dla wszystkich obywateli państwa polskiego) opiera sie na pogladach niezgodnych z zasada Kościota świętego. Sądzę, że właśnie taka kodyfikacja ułatwia Kościołowi współżycie ze społeczeństwem, po części innowyznaniowym, a po części pozawyznaniowym, w całym państwie, podobnie jak już dawniej miało to miejsce w „zaborze pruskim” jako cześsi państwa niemieckiego. Po przeprowadzeniu laicyzacji, czyli uświecczenia życia społecznego, nie tylko prawdziwi, szczerzy katolicy, ale nawet obłudnicy udający katolików nie będą w niczym krępowani i będą mogli w dalszym ciągu wykonywać swe praktyki 
wyznaniowe. 0 ile obywatele i obywatelki pozostaną katolikami lub o ile w dalszym ciągu będą udawali katolików, nikt nie będzie odbierał ich związkom małżeńskim charakteru wyznaniowego i sakramentalnego; ale obok tego, jako zwykli obywatele będą musieli dopełnić formalności wymaganych przez państwo.

Co do świętości rodzinnego życia, religijnego wychowania dzieci itd., trzeba przede wszystkim liczyé się ze smutną rzeczywistością. Te tak patetycznie głoszone hasła przedzierzgają się w życiu w obłudną praktykę, a świętość rodzinnego życia z przyległościami znajduje się prawie bez wyjątku pod wielkim znakiem zapytania.

Trudno też zrozumieć, dlaczego ta podstawa nie tylko rodziny chrześcijanskiej, ale także trwatości i pomyślnego rozwoju życia narodowego $i$ panstwowego ma być uwarunkowana uświęceniem zwiazków katolickich (dlaczego tylko katolickich?) przez Kościót $i$ przez nierozerwalność ich węzta. Same odbyte w kościele ceremonie i skucie dwojga ludzi kajdanami nierozerwalności nie gwarantują ani „świętości”, ani „wychowania moralnego”. Trzeba się liczyé z realnie istniejącymi ludźmi, z ich psychologią, z ich popędami i nałogami oraz z oddziaływaniem na nich otoczenia. Piękne frazesy i wzniosłe hasła nie wystarczą.

Jeżeli mowa 0 „wszystkich” katolikach, to niechaj to będą istotnie katolicy, katolicy naiwnie i głęboko wierzący, katolicy wyrzekający się własnego myślenia i zastępujący je wmówionymi w nich i narzuconymi im przez Kościół twierdzeniami, nie zaś „katolicy” udający tylko wierzących, udający bądź to dla kariery, bądź też dla niezrażania sobie i dla niemartwienia krewnych i bliskich znajomych.

Zwiazek matżenski, zawarty przed urzędnikiem stanu cywilnego, jest nieważny, bo sprzeciwia sie prawu Bożemu. Ale w Poznańskiem i na Pomorzu jakoś nie sprzeciwia się i jest ważny. A nawet i w b. „Królestwie Polskim” ksiądz dający ślub, w obliczu prawa byt i jest przede wszystkim „urzędnikiem stanu cywilnego”, a dopiero potem dawcą sakramentu. Po co więc te próżne i puste frazesy?

A jakiemu to „prawu Bożemu” ma się sprzeciwiać ślub cywilny? Prosilibyśmy o dokładne sformułowanie tego „prawa Bożego”.

Śluby cywilne nie są przewidziane w Piśmie Świętym Starego $i$ Nowego Testamentu. To prawda. Ależ tam wiele rzeczy nie jest 
przewidzianych. Gdyby ograniczać się tylko tym, co jest przewidziane w Piśmie Świętym, należałoby wyrzec się nie tylko aeroplanów, kolei żelaznych, telegrafów, telefonów itd., ale także druku, powozów, lamp naftowych itp., a używać jedynie poczty pantoflowej, lampek olejnych lub łojówek, własnych nóg lub co najwyżej koni, mułów i osiołków. A jednak najprawowierniejsi katolicy, żydzi i inni starowyznaniowcy korzystają z kolei żelaznych, z oświetlenia elektrycznego i innych tp. bezbożnych, czartowskich, szatańskich wymysłów.

Przeciwnicy uświecczenia życia lubią powoływać się na „objawienie boskie”, na „słowo boże”, na siły nadprzyrodzone, na natchnienia „wielkich wtajemniczonych”. Ale skąd się o tym wszystkim dowiedzieli? Przecież od takich samych ludzi jak i oni. Jest to tylko nieprzerwany łańcuch przechodzących z ust do ust podań, jest to powtarzanie pacierza za panią matką lub też za panem ojcem wielebnym. Któryż to z powołujących się na Objawienie obcował bezpośrednio z Bóstwem? Czy urządzano wywiady z istotami nadprzyrodzonymi, na które się tak chętnie powołujemy?

To powoływanie się na „wielkich wtajemniczonych”, to nadużywanie „objawienia” cieszy się takim powodzeniem z dwóch powodów: z jednej strony czynnie i napastniczo występuje zuchwała megalomania proroków i ich naśladowców, z drugiej strony idzie im na spotkanie bierna łatwowierność i bezmyślność tłumów. Przywidzenia i widzenia natchnionych „wielkich wtajemniczonych” bierze się za dobrą monete, a, jak wiadomo, mundus vult decipi, decipiatur ergo (świat chce być oszukiwanym, niech go więc oszukują).

W dzisiejszych czasach trudno budować na tym coś trwałego, chociaż z drugiej strony musimy uznać pełne prawo ludzi istotnie wierzących i egzaltowanych do tudzenia siebie i innych.

Głosi się zawzięcie nierozerwalność $i$ świętość węzta matzeńskiego, a na zdrowie przyszłych pokoleń, na możliwość zaszczepiania im chorób chronicznych, chorób zaraźliwych, popędów zwyrodnialczych nie zwraca się uwagi. Niech gniją i giną niewinne istoty, byle święciła tryumfy zasada nierozerwalności!

Nic więc dziwnego, że wobec nieustępliwości kleru katolickiego wielu katolików, chcąc znaleźć wyjście z pułapki, jaką staje się dla nich nierozerwalność małżeństwa katolickiego, szuka ocalenia, tj. 
rozwodu, w przejściu na jakieś inne wyznanie, liczące się z indywidualnością ludzką, a więc nie tak okrutne i zapamiętałe.

Ta nieustępliwość, ten upór, ta tępość przypomina nieustępliwość caratu i innych despotii niechcących uwzględnić nowych prądów społecznych. Do czasu się to udaje, ale ostatecznie następuje krach. Dziś oczywiście przy ogólnym cofaniu się wstecz nie ma obawy, ażeby nastąpił upadek Kościoła, który niczego nie zapomniał i niczego się nie nauczył. Należałoby jednak patrzyé dalej niż na koniec swego nosa. Egoizm na krótką metę należałoby zastąpić egoizmem przewidującym, nie odstręczającym od siebie, ale zyskującym życzliwych i wyrozumiałych.

\section{Stanowisko Kościoła ewangelickiego}

Poznaliśmy fanatyczne, nieustępliwe i nieuznające innych zapatrywań stanowisko kleru katolickiego. Rażąco odbija od niego stanowisko świattego i godzącego się z duchem czasu duchowieństwa ewangelickiego.

Z zapatrywaniami nie tylko duchowieństwa, ale także wybitnych przedstawicieli gminy ewangelickiej zapoznają nas wywiady „Nowego Kuriera Polskiego”:

1. Gtos kościota ewangelickiego, tj. wywiad z superintendentem generalnym kościoła ewangelickiego w Polsce, księdzem Juliuszem Bursche („NKP” nr 41, z 13 marca),

2. Gtos gminy ewangelickiej, tj. wywiad z przedstawicielem Polaków wyznania ewangelickiego, prezesem zboru ewangelickoaugsburskiego w Warszawie, p. Józefem Ewertem („NKP” nr 42, z 14 marca),

3. Gtos prasy ewangelickiej, tj. wywiad z księdzem pastorem Zygmuntem Michelisem, redaktorem „Zwiastuna Ewangelicznego”(„NKP” nr 45, z 17 marca).

Choćby dla wytchnienia po ponurym nastroju, wywołanym przez odezwę dostojników Kościoła katolickiego warto poznać szczegółowo wynurzenia wybitnych przedstawicieli Kościoła ewangelickiego. Dlatego przytaczam je in extenso, tylko gdzieniegdzie skracając i usuwając pytania wywiadowcy. 


\section{Zdanie ks. Juliusza Burschego}

Kościót ewangelicki, acz odrzuca sakramentalny charakter małżeństwa jako nieuzasadniony w Ewangelii, widzi jednak w małżeństwie moralną podstawę rodziny chrześcijańskiej i dlatego oczekuje od swoich wyznawców, że zawrą swój związek małżeński z modlitwą i wezwaniem Boga o łaskę, czyli, że wezmą ślub kościelny. Ale małżeństwo jest też instytucją cywilno-prawną i dlatego państwo ma nie tylko prawo, ale i obowiązek baczenia, by małżeństwa były zawierane zgodnie z istniejącym prawem cywilnym.

W idei małżeństwa chrześcijańskiego i według zasad Ewangelii leży jego nierozerwalność. Niemniej uważamy, że tam, gdzie małżeństwo w rzeczywistości przestało istnieć, gdzie serca i ciała małżonków odwróciły się od siebie i kościót, i państwo mają prawo skonstatowania istniejącego faktu oczywistego, czyli że możliwy jest rozwód; orzeczenie rozwodu jednak winno się opierać na specjalnie ważnych powodach, określonych przez prawo, by nie folgowano lekkomyślności ludzkiej.

Odmawianie rozwodu prowadzi: 1) albo do wykrętnych sofizmatów, które po większej części są podstawą tzw. „unieważniania” małżeństw w kościele katolickim, które zresztą niczym innym nie jest, jeno zakapturzonym i nieszczerym rozwodem (wiadomą jest rzeczą, że w tym kościele, który nie uznaje rozwodów, a przecież znaleźć musi wyjście z tragicznych nieraz sytuacji, za pieniądze, zazwyczaj za wielkie pieniądze, prawie każdy może otrzymać unieważnienie małżeństwa, bo zawsze znajdzie się jakiś pozorny wykręt); 2) albo do jawnej, nawet przez kościół tolerowanej niemoralności, kiedy mąż idzie w jedną stronę, żona zaś w inną, a dzieci demoralizują się w zatrutej atmosferze wzajemnego wstrętu rodziców, która szerzy wokoło siebie zgorszenie; 3) albo wreszcie ludzie doprowadzeni do ostateczności handlują wiarą, przechodząc na kalwinizm (kościót ewangelicko-augsburski w Polsce dla rozwodów nikogo nie przyjmuje), na prawosławie, ba! nawet na mahometanizm, byle osiągnąc swe cele. W ogóle zaś zmuszanie ludzi, którzy w rzeczywistości już nie są małżeństwem, do tego, by wobec prawa stanowili małżeństwo, prowadzi do obłudy, do zgnilizny, a można 0 tym to samo powiedzieć, co 
Szujski (Dzieje Polski, t. III, § 90) mówi o wychowaniu jezuickim, że prowadziło do „pozornej religijności” i dewocji faryzeuszów, do lekkomyślnego zaufania w przebaczenie win publicznych i prywatnych za pomocą hipokryzyjnego nabożeństwa, a wszystko to jest śmiercią prawdziwej religii. Dlatego to w Polsce mamy tylu świętoszków, tylu „religijnych ateuszów”.

Projekt nowego prawa o małżeństwie wygotowany przez komisję kodylikacyjną oświadcza się podobno za ślubem cywilnym fakultatywnym i za rozerwalnością każdego małżeństwa wobec państwa, z tem jednak zastrzeżeniem, że małżeństwa, tzw. (w projekcie) „czysto katolickie”, czyli zawarte tylko w kościele katolickim, nie będą mogły uzyskać rozwiązania in foro civili. Gdyby tak rzeczywiście być miało, to projekt ów nie rozstrzygnąłby kwestii, bo po dawnemu zmuszałby katolików do przechodzenia na inne wyznanie dla celów rozwodowych, czyli popierałby frymarczenie religią. Gdyby zaś kto mniemał, że katoliccy małżonkowie, którzy - dajmy na to - przeszli na wyznanie ewangelickie, już przez to, że niegdyś byli katolikami, i nadal muszą podlegać przepisom katolickiego prawa kanonicznego, to byłoby to jawnym pogwałceniem wolności sumienia i zasady równouprawnienia wyznań, zagwarantowanego nam przez konstytucję, na co my, ewangelicy, nigdy byśmy zgodzić się nie mogli: kościół katolicki nie może mieć żadnej zgoła władzy nad byłym swym członkiem, który, przeszedłszy na inne wyznanie, zerwał z nim wszystkie stosunki; i na odwrót, kościół ewangelicki nie ma i nie może rościć sobie żadnych praw do tego, kto z ewangelika stał się katolikiem. Są to elementarne prawdy, których gdzie indziej nawet dowodzić by nie potrzeba.

Państwo nie ma i nie może mieć prawa narzucania kościołowi swoich postanowień w sprawach rozwodowych, nie może więc zmuszać go do uznawania rozwodów cywilnych, zmuszać do dawania ślubu tym, którzy w cywilny sposób zostali rozwiedzeni. Jest to sprawa wewnętrzna danego kościoła.

Jestem zwolennikiem ślubów kościelnych, a cywilnych dla tych, którzy ślubu kościelnego nie chcą, czyli ślubów cywilnych fakultatywnych.

Jestem zwolennikiem rozwiązalności każdego małżeństwa wobec państwa i przez sądy państwowe, bez względu na to, czy ślub 
zawarty został w kościele, czy cywilnie. Ale te rozwody cywilne nie moga obowiązywać kościołów w tym sensie, że je muszą uznawać i dawać nowe śluby.

Jeżeli która z rozwiedzionych przez sądy państwowe stron żąda pobłogosławienia przez kościół nowego małżeństwa, musi wprzód uzyskać aprobatę danego kościoła; w kościele katolickim przez ewentualne unieważnienie przez kościół poprzedniego małżeństwa, w kościele ewangelickim - przez rozwód kościelny. Kto tego nie chce lub nie może, temu zostaje otwarta droga cywilnego ślubu powtórnego.

Dziwić się należy, że „odezwa biskupów Polski do rządu i narodu w obronie sakramentu małżeństwa” głosi, iż „Związek małżeński zawarty przed urzędnikiem stanu cywilnego jest nieważny”. Przecież tenże kościół katolicki uznaje śluby cywilne gdzie indziej, uznaje je także w b. zaborze pruskim i nie może nigdzie dawać ślubu kościelnego z inną osobą człowiekowi, który zawarł poprzednio związek małżeński cywilny.

U nas w Polsce pod względem zawierania małżeństw, rozwodów i unieważniania małżeństw panuje dotychczas istna anarchia: kościoły ewangelickie, zgodnie z prawem o małżeństwie z 1836 roku, rozwodzą małżeństwa zawarte w kościele katolickim, jeżeli jeden z małżonków przeszedł na jedno z wyznań ewangelickich; kościół katolicki, wbrew prawu z 1836 roku dotychczas obowiązującemu, opierając się na prawie kanonicznym, sprzecznym z prawem cywilnym, unieważnia małżeństwa prawnie w kościele ewangelickim zawarte, jeżeli jedna ze stron była wyznania katolickiego, czyli tzw. małżeństwa mieszane, a rząd toleruje to bezprawie!

Jeżeli my, ewangelicy taki wprost horrendalny stan, aczkolwiek z bólem serca znosimy, jeżeli krom platonicznych protestów nie przedsiębierzemy żadnych innych środków, to powoduje nami jeno miłość ojczyzny, która i bez tego w tak w ciężkim jest położeniu, oraz nadzieja, że przecież wreszcie praworządność w Polsce zwycięży i że nowe prawo małżeńskie sprawę tę w duchu sprawiedliwości i równouprawnienia wyznań definitywnie załatwi.

Muszę się przyznać, że wprost nie rozumiem, jak może nawet chcieć kościół katolicki, aby obywatel, który nie wierzy w kościół i jego zasady, musiał kłamać wobec niego, a tym samym tracić pod- 
stawy moralności we własnym sumieniu. Powie sobie, że kościót i państwo każą mu kłamać, i ostatecznie dojdzie do tego, że z lekkim sercem będzie okłamywał i państwo, i kościót. Niech mi kto wytłomaczy, że jest grzechem korzystanie z wolności sumienia czy to przy zawieraniu małżeństwa, czy przy wyborze wyznania. Niech mi kto wyttomaczy, że to jest w intencjach nauki Chrystusowej, aby człowiek niewierzący w dogmaty kościoła koniecznie musiał brać ślub w kościele. Przecież to absurdy potworne.

\section{Zdanie p. Józefa Ewerta}

Jestem zwolennikiem zupełnego rozdziału kościoła od państwa ze wszystkimi konsekwencjami stąd wyptywającymi.

Jako człowiek wierzący pragnąłbym gorąco, żeby życie religijne w Polsce rozwijało się tak pomyślnie i biło takim tętnem jak w Ameryce lub nawet we Francji, nie mówiąc już 0 krajach skandynawskich. Podkreślić tu muszę z naciskiem, że życzenia moje odnoszą się w równej mierze zarówno do rozwoju życia religijnego w tonie kościoła ewangelickiego, jak i katolickiego, gdyż jako Polak miłujący swą ojczyznę w spotęgowaniu życia religijnego w państwie w ogóle widzę dobro, do którego winniśmy dążyć. Ten bujny rozkwit życia religijnego osiągniemy wówczas, gdy urzeczywistni się rozdział dwóch odrębnych sfer: państwa i kościoła.

Uznając z całą wiarą, że rodzina jest podstawą ładu społecznego i państwowego, stwierdzić muszę, że małżeństwa kościelne nie dają gwarancji dobroci. Na poparcie tego twierdzenia przytoczę jeden tylko argument: gdyby małżeństwa zawierane w kościołach stanowiły o wartości rodziny, to ze względu na istniejący w Polsce sakramentalny charakter małżeństw musiałyby one stwarzać wzorowe rodziny. Tak jednak nie jest, niestety.

Przytoczony argument dowodzi niezbicie, że żeby rodzina odpowiadała tym wymaganiom, jakie jej stawiamy, musi być oparta na wysokiej moralności i wysokim poziomie etycznym. Te warunki dadzą się osiągnąc przez zrealizowanie dwóch czynników: 1) oświaty pojętej jak najszerzej; 2) rozwoju życia religijnego - nie klerykalizmu i obrzędowości, lecz wiary twórczej i prawdziwej religijności w życiu. 
Rodzina, w której wygasła miłość i przestała istnieć wzajemna harmonia między małżonkami, rodzina, w której małżonkowie patrzą na siebie jak na wrogów, mu si być rozwi ązana. Wymaga tego zarówno sprawa Królestwa Bożego, jak i ładu społecznego.

Raz jeszcze podkreślam, że tylko intensywny rozwój całego życia religijnego w Polsce, niezależnie od wyznań, w jakich się koncentruje, sprowadzić może nową erę w rozwoju życia społeczeństwa i państwa.

\section{Zdanie księdza pastora Zygmunta Michelisa}

Meritum poruszonej przez „Nowy Kurier Polski” sprawy zostało wyczerpująco a wszechstronnie wyłożone w oświadczeniach ks. biskupa Bursche i p. prezesa Ewerta. Dodam tylko, że wywody ks. biskupa Burschego są jednomyślnym programem całego społeczeństwa ewangelickiego w Polsce.

Krzywdzącego nas podwójnie, jako Polaków i jako ewangelików, załatwienia sprawy prawa małżeńskiego nie uznamy. Był czas, okres plebiscytu, kiedyśmy wiele rzeczy, acz z tłumionym oburzeniem, znosili. Ofiara milczenia była potrzebna dla ojczyzny, która nie tylko mieczem, lecz i w dyplomatycznej walce ustalała granice państwa. Dziś ta sama miłość ojezyzny nakazuje nam protestować i walczyć, aby uchronić Polskę od powrotu XVIII wieku, no i jego konsekwencji.

Zarówno nasze przekonania religijne, jak i nasza tradycja społeczna wskazują nam miejsce w szeregach demokracji. Jej zwycięstwo jest naszym zwycięstwem, nasza sprawa powinna być jej sprawą. Boli nas milczenie postępowej prasy. Prócz „Nowego Kuriera Polskiego" tylko tu i ówdzie odezwie się dorywczy, jakby nieśmiały głos w tak przecież społecznie doniosłej sprawie. Jest to niepokojący objaw, że prawo o małżeństwie załatwia się przed forum „sług katolickich” spod znaku św. Zyty oraz za kulisami targów partyjnych, ba, osobistych. Gdzie nie świeci słońce publicznej dyskusji i publicznej odpowiedzialności, tam się tworzy bagno wstecznictwa i demoralizacji.

Dla prasy ewangelickiej jest to zagadnienie siegające poza granice państwa. Nasi świeccy koledzy (dziennikarze) nie zdają sobie 
sprawy, jak kwestie kościelno-religijne i stosunek do nich rządu i społeczeństwa polskiego kształtują o nas opinię w Europie, a zwłaszcza w Ameryce, i jak ta właśnie opinia odbija się także na sprawach politycznych, a nawet finansowych naszego państwa. Z bolesną satysfakcją czytam nieraz artykuły „Zwiastuna” smagające rodzime wstecznictwo, w światowych dziennikach teologicznych niemieckich, a z nich przedruki w amerykańskich, angielskich i skandynawskich.

Acz z bólem serca, prasa ewangelicka jest zdecydowana dla dobra ojczyzny i w imię prawdy chrześcijańskiej spełnić swój ciernisty obowiązek, jeżeli zajdzie potrzeba, także i w sprawie prawa małżeńskiego.

Znaczy to, że poruszymy opinię ewangelicką w całym kraju, odwołamy się do całej demokracji polskiej, przemówimy tak donośnie, że usłyszy nas nie tylko głuchy na innowiercze ucho minister wyznań religijnych, lecz także premier, a nade wszystko minister spraw zagranicznych. Liczymy przede wszystkim na sukurs zrywającego powoli, ale konsekwentnie pęta klerykalne ludu polskiego oraz wszystkich ludzi z poczuciem godności państwowej i nieobłudnej moralności publicznej.

\section{Świecki głos lekarza}

To były głosy kościołów: z jednej strony w odezwie biskupów katolickich echo dawno minionych czasów, echo legendarnego fanatycznego średniowiecza podporządkowującego życie społeczne pod wszechwładzę kleru; z drugiej zaś strony głosy kościoła rozumiejącego potrzebę dostosowywania się do postępu idei i uznającego wolność sumienia. A teraz zwrócmy uwagę na głos specjalisty lekarza, rozpatrującego tę sprawę ze stanowiska eugeniki, ze stanowiska zdrowia społeczeństwa, lekarza pragnącego zapobiegać zwyrodnieniu fizycznemu i psychicznemu. Jest to nie wywiad, ale artykuł napisany samorzutnie przez dr. med. W. Łuniewskiego pt. W sprawie oczekiwanej ustawy o matżństwie. Gtos lekarza psychiatry umieszczony w $\mathrm{nr} 38$ i 39 „Nowego Kuriera Polskiego” z 10 i 11 marca rb. Zawiera on tak cenne wskazówki, że uważam za pożądane przedrukować go prawie w całości: 
Zdarza się, że do sakramentalnie zupełnie prawidłowego małżeństwa wkradnie się czasem choroba jednego z małżonków. Jeżeli jest to choroba krótkotrwała i choroba, która istoty psychicznej człowieka zasadniczo nie zmieni, małżeństwo trwa jak za czasów zdrowia i żadne trudności osobliwe stąd nie powstają. Zdarza się przecież, i to nierzadko, że jeden z małżonków zapada na chorobę psychiczną trwającą długie nieraz lata, niedającą widoków na wyleczenie. Osoba dotknięta taką chorobą staje się nieraz innym zupełnie człowiekiem, mimo że nie przestaje być tą samą jednostką prawną. Z dawnego czułego męża i ojca robi się tyran i wróg rodziny; z dawnej tkliwej i kochającej żony i matki robi się istota obojętna, bezuczuciowa, zatruwająca życie mężowi, dręcząca i katująca swoje własne dzieci. Kto nie zna wypadków, kiedy psychicznie chory mąż zamordowuje w okrutny sposób najniewinniejszą, najlepszą żonę; kiedy psychicznie chora żona z urojonych motywów truje lub zabija swego męża, zamordowuje dzieci. 0 ile do tych tragicznych rozwiązań nie doszło, chory lub chora dostają się do zakładu i tu powstają po pewnym czasie kwestie, kwestie natury moralnej i prawnej, kwestie bezkrwawe wprawdzie, ale nie mniej tragiczne.

Związek małżeński nie da się rozerwać. Zdrowy małżonek, nieraz z gromadą dzieci, pozostaje w faktycznym wdowieństwie. Nie wolno mu się żenić, by znaleźć opiekunkę dla pozostających w faktycznym sieroctwie dzieci; nie wolno żonie wyjść za mąż, żeby znaleźć uczciwe środki egzystencji dla siebie i ojczyma dla dzieci pozostających pod jej opieką. Gdyby to zrobili, popełniliby bigamię lub biandrię i dostaliby się do więzienia.

Z praktyki zakładu psychiatrycznego znam duży szereg wypadków zupełnej ruiny materialnej i moralnej całych rodzin spowodowanej chorobą ich członka.

Uczucie sympatii wtedy nie wygasa już tylko (z czym można by się było jeszcze pogodzić), ale przeradza się w pozostałej przy zdrowiu części rodziny w nienawiść - a ta podszeptuje nieraz bardzo niedobre pomysły. Nie zapomnę z pierwszych lat mojej praktyki zakładowej przypadku, kiedy biedny robotnik fabryczny, ojciec pięciorga drobnych dzieci, któremu żona zachorowała na nieuleczalną chorobę psychiczną, po kilku latach cierpliwego wyczekiwania na jej powrót 
do zdrowia, a potem po wielomiesięcznych bezcelowych zabiegach w konsystorzu o rozwód, usiłował podstępnie otruć chorą żonę przy okazji odwiedzania jej w szpitalu. Ten biedny człowiek wyobrażał sobie może, że mniej zgrzeszy, kiedy otruje chorą żonę, niż gdyby zmienił wyznanie i w legalny sposób uzyskał rozwód w konsystorzu innego wyznania, gdzie znalazłby posłuch dla trapiącej go niedoli. Może nie umiał on sobie tylko poradzić.

Znam nie jeden, ale setki, wiele setek przypadków, gdzie nie dochodzi do takich zbrodni, ale gdzie podobne myśli zbrodnicze wkradają się do dusz czystych i szlachetnych, kiedy stają wobec niemożności rozwiązania sakramentalnego węzła małżeńskiego z nieuleczalnie chorym psychicznie mężem lub chorą psychicznie żoną. Wierzący może nieraz pobożnie modlą się o szybką śmieré dla tych, od których im się odłączyć legalnie niepodobna.

Paniom, które w prasie i na wiecach ludowych tak gorąco dziś bronią zasady bezwzględnej nierozerwalności małżeństwa, moglibyśmy - lekarze zakładów psychiatrycznych - pokazać błagalne listy naiwne wieśniaków i wieśniaczek, w których proszą nas o to, byśmy przyśpieszyli z upragnieniem przez nich oczekiwaną śmieré ich chorych mężów lub żon.

Nie mam najmniejszej wątpliwości, że jeden taki list, pisany naprawdę krwią serdeczną cierpiącego członka rodziny, człowieka z ludu, wzruszyłby serca tych pań więcej, niż zdołają wzruszyć redagowane przez nie uchwały wiecowe wieśniaczek, domagające się z patosem utrzymania tego sakramentalnego status quo, który sprawia, że mąż żonie, a żona mężowi stają się wilkami, kiedy jedno z nich zachoruje.

Ten okropny dramat znienawidzenia osoby kochanej za to, że stała się chorą, jest wytworem specyficznym u ludności tych wyznań, które nie uznają rozwodu.

Nie dotykam tu komplikacji prawnych i ekonomicznych tej sprawy przeraźliwej, której nie ma dziś już w żadnym państwie w Europie, która nie dusi też obywateli naszego państwa, należących szczęśliwie do wyznań liberalnych, jak również tych warstw społeczeństwa, które ze zmiany wyznania skrupułów sobie nie robią. Tam nie kwestionuje się prawa do życia chorego, nie wyczekuje się jego śmierci, nie 
złorzeczy się mu - tu błaga się o jego szybką śmieré, bez której nie ma wyzwolenia dla skutej z jego losami zdrowej reszty rodziny.

Kodeksy kanoniczne wyznań nieuznających rozwodów uznają wprawdzie unieważnienie małżeństwa; ta przecież forma rozłączenia nieszczęśliwego stadła małżeńskiego może mieć zastosowanie tylko wyjątkowe tam, gdzie choroba zaistniała przed ślubem.

W obecnym stanie rzeczy mamy przecież obowiązującą ustawę z dnia 28 III 1836 r., która w $\$ 14$ stawia wyraźną tamę do unieważnienia małżeństwa nawet osoby obłąkanej. Strach pomyśleć, że $§ 92$ tej samej ustawy nakłada na prokuratorów obowiązek zaskarżania nieważności małżeństw różnowierców, które ustawa uważa za nieważne.

W państwie polskim istnieją więc grupy wyznaniowe, których kanony ignorują zjawiska patologiczne w psychice ludzkiej; tak samo ignorują prawa wyznawców innych wyznań. Z drugiej znów strony w tym samym państwie istnieją krańcowo odmienne grupy, dla których kaprys męża wystarczy do uzyskania rozwodu, gdzie nie potrzeba do tego powodów prawnych ani specjalnych uzasadnień.

Tylko kodeks cywilny jednakowy dla wszystkich obywateli państwa, bez różnicy dzielnic i wyznań, kodeks oparty na doświadczeniach nie bolszewickich, ale na wieloletnich doświadczeniach państw Europy Zachodniej, może uporządkować panujący w dziedzinie praw o małżeństwie chaos i zabezpieczyć duszę ludu polskiego od trującego jadu nienawiści względem nieszczęśliwych chorych.

Jednym z czynników, którego skutki psychopatologiczne ujawniają się w pierwszym rzędzie w pożyciu małżeńskim, jest alkoholizm. Nawet łagodne postacie tego nałogu odbijają się na czułym barometrze życia rodzinnego.

Postacie cięższe prowadzą do psychoz niewątpliwych.

Współczesne prawodawstwo karne i cywilne ma duży kłopot z alkoholikiem, który czasami w oczach prawodawcy jest chorym, czasami zaś tylko po prostu - „pijakiem” lub „pijanym”. Kłopotu tego nie może uniknąć przyszła ustawa dotycząca małżeństw. Kwestia jest zbyt jaskrawa i zbyt demokratyczna (?), żeby ją mogła pominąć ustawa współczesna. 
Streszczam się. Z lekarskiego punktu widzenia dążyé musimy do praw o małżeństwie, które by dawały dostęp argumentom życia oraz doświadczenia lekarskiego. Nie możemy w sprawach tak życiowo doniosłych i powszechnych żonglować, jak dotąd, wśród kilkunastu odmiennych ustaw kanonicznych musimy dążyć do jednej, jednolitej dla wszystkich obywateli Rzeczypospolitej ustawy cywilnej. W stosunku do omawianych tutaj zagadnień lekarskich ustawa ta winna oprzeć się na zasadach następujących:

1) Zawieranie małżeństw nie tylko przez osoby „umysłowo chore", ale także przez osoby umystowo upośledzone powinno być zasadniczo zakazane. Wyjątek mogłyby stanowić małżeństwa, w których z góry dałoby się przewidzieć, że potomstwa mieć nie będą. W wypadkach wątpliwości co do stanu psychicznego kandydatów do stanu małżeńskiego powinni byé wzywani rzeczoznawcy psychiatrzy.

2) Małżeństwa zawarte przez osoby psychicznie chore powinny podlegać unieważnieniu, względnie rozwodowi, a to na żądanie jednej ze stron zainteresowanych bezpośrednio, jak i na żądanie władzy publicznej. W przypadkach, kiedy małżeństwo miałoby już potomstwo, byłby wskazany raczej rozwód, niż unieważnienie.

3) Rozwód powinien byé ulegalizowany.

4) Choroba psychiczna jednego z małżonków, powstała po zawarciu prawomocnego małżeństwa, powinna byé uznana za powód do rozwodu, o ile trwa czas dłuższy i nie daje widoków na wyleczenie w czasie dającym się przewidzieć.

5) Nałóg pijacki jednego z małżonków, ze względu na nieporozumienia, jakie budzić mogłaby ewentualnie jego ocena psychiatryczna wobec sądów, powinien być wymieniony w szeregu powodów do rozwodu jako punkt osobny.

\section{Echa ankiety}

Urządzona przez „Nowy Kurier Polski” ankieta przebrzmiała prawie bez echa, chociaż zwróciła na siebie uwagę niektórych osób. Tak np. ja osobiście, z powodu swej opinii w tej sprawie, otrzymałem następujący list (z Brzeżan pod Tarnopolem, 16/3 1926): 
W imieniu wielu a wielu prosimy w unifikacji prawodawstwa naszego wprowadzić w prawie małżeńskim rozwody i śluby cywilne w duchu nowoczesnym. Wszak ile z tego powodu złamanych egzystencji, ile mordów, sądy najlepiej wiedzą. Prosimy i domagamy się tego! Motywy aż nadto znane. W razie potrzeby wyślemy petycję.

Oczywiście zaszło tu nieporozumienie. Autor listu zwraca się do mnie jak do osoby mogącej mieć wpływ na ten lub ów wynik narad Komisji Kodyfikacyjnej, gdy tymczasem ja w danym razie jestem tylko jednym $\mathrm{z}$ tłumu.

Inny znowu pan (z Krakowa), dotychczas całkiem mi nieznany, zwrócił mi uwagę na wydrukowane w krakowskim „Głosie Narodu” (nr 52 z 5 marca) bezwzględne potępienie mego oświadczenia. Czy w innych pismach także napadano na mnie, nie wiem i nie starałem się dowiadywać.

„Głos Narodu” przypisuje mi patologiczny natóg korzystania z każdej sposobności dla rozprawienia się z „klerykalizmem”. Zarzut, że ani jednym przykładem nie popieram swych cynicznych oskarżen, odpieram powyżej, przytaczając dwa wymowne przykłady i powołując się na świadectwo osób ocierających się z bliska 0 zakulisowe manewry związane z procesami o „unieważnienie małżeństwa”.

Twierdząc, że obowiązkowe śluby cywilne i rozwody oraz bezwagledne uświecczenie jest równoznaczne ze zbolszewizowaniem matżenstwa, „Głos Narodu” wykazuje albo rozbrajającą naiwność, albo też mniej już rozbrajającą złą wiarę. Śluby cywilne w państwach zachodnioeuropejskich zostały zaprowadzone przed przeszło stu laty, kiedy na „bolszewików” jeszcze się muchy nie goniły. Przecież i Francja, i Włochy, i Niemcy..., nawet Wielkie Księstwo Warszawskie toć to państwa „burżuazyjne”, a jednak wprowadziły one śluby cywilne, które dotychczas trwają w Polsce: obowiązkowo w b. zaborze pruskim, a fakultatywnie w b. zaborze austriackim.

Wyrażenie nierozerwalny sakrament jest istotnie niefortunne. Ale przecież Kościół katolicki uważa małżeństwo i za „sakrament”, i za „związek nierozerwalny”. Z tych dwóch określeń, drogą tak zwanej w językoznawstwie kontaminacji, powstał nierozerwalny sakrament. 
Moje poglądy nie są wcale antykatolickie. Przeciwnie, bronię katolicyzmu przeciw wszelkim zamachom na wolność sumienia katolików, a przede wszystkim przeciw samobójczym zamachom Kościoła katolickiego na siebie samego.

Rozróżnianie pojęć - tresura wyznaniowa a żywa wiara

Pierwszym warunkiem zdrowego trzeźwego myślenia jest przestrzeganie ścisłości w rozróżnianiu pojęć, tj. w niemięszaniu ze sobą rzeczy różnorodnych i niewspółmiernych. I to zarówno w stosunku do świata w ogóle, jak i do człowieka i społeczeństwa ludzkiego w szczególności. Otóż w stosunku do człowieka pojęcia z zakresu lecznictwa, czyli medycyny, i higieny swoją drogą, sprawy przepisów prawnych, regulujących współżycie wszystkich obywateli swoją drogą, a sprawy wiary czy to indywidualnej na własną ręką, czy też zbiorowej, zgodnie z narzuconymi przez innych wskazówkami, również swoją drogą.

0 ile człowiek wierzy istotnie w rzeczy nadprzyrodzone, 0 ile istotnie tęskni do Wielkiego Nieznanego, ma prawo wyodrębnić tę swoją wiarę i uniezależnić ją od spraw świeckich i powszednich. A że myśleć własną głową jest w ogóle trudno, a nawet niebezpiecznie, więc nic dziwnego, że, nie mając odwagi stanąc 0 własnych siłach i bojąc się własnej inicjatywy, szuka podpórek i wskazówek od specjalistów w dziedzinie narzucania wierzeń i objaśniania spraw boskich i bogoczłowieczych - a to tym bardziej, że już od najwcześniejszego dzieciństwa uderzono go obuchem w łeb i kazano powtarzać bezmyślnie to, do czego stosuje się formuła credo quia absurdum (wierzę, bo kłóci się ze zdrowym rozsądkiem). Jest to swoiste ius primae noctis praktykowane przez patentowanych znachorów i ich naśladowców nad świeżą kiełkującą dziewiczą myślą ludzką.

Przy tym należy stwierdzić, że przez tresurę wyznaniową unieruchomione i skostniałe $\mathrm{w}$ dogmatach myślenie teologiczne jest śmiercią wiary żywej, rodzącej się pod ożywczym oddziaływaniem na nas uduchawianej (animizowanej) i uczłowieczonej (personifikowanej) przyrody. 
Pojęcie sakramentu związane jest $\mathrm{z}$ wiarą w potęge słowa, w skuteczność błogosławieństwa i przekleństwa. Dziedziczymy tradycyjnie nawarstwienia pojęciowe różnych epok, od najdawniejszych do najpóźniejszych. Dotychczas trzyma w kleszczach tłumy wierzące wiara w złego ducha, w żydowskie wcielanie się w ludzi żywych Dybuka ${ }^{1}$, w chrześcijańskie opętanie od diabła i wypędzenie go bądź to kropidłem, bądź też zaklęciami. Dotychczas zabezpieczamy się przez na psa urok. Dotychczas Słońce dla nas wschodzi i zachodzi, pomimo że jednocześnie powtarzamy wmówione w nas twierdzenie, że Słońce stoi, a Ziemia się koło niego obraca. Z epoki wiary w siłę zaklęcia, błogosławieństwa i przekleństwa pochodzi wiara w sakramenty w ogóle, a w sakrament małżeństwa w szczególności.

Są ludzie, co takiej wiary potrzebują i takich ludzi jest bardzo dużo. Nikt nie ma prawa krępować ich w tym, a tym mniej szydzić $\mathrm{z}$ nich i naigrawać się. Ale, korzystając $\mathrm{z}$ wyrozumiałości innych współobywateli i z opieki prawa, ludzie wierzący w sakramenty nie powinni naśladować partyjników (endeków, bolszewików, faszystów i in.), dążących do ujarzmienia wszystkich mieszkańców państwa i poddania ich pod terror partii rządzącej, ale, odwzajemniając się, oddając pięknem za nadobne, powinni stosować wyrozumiałość i tolerancję do wszystkich inaczej wierzących lub też wcale niewierzących.

Konieczność obowiązkowego uświeczczenia związków małżeńskich wynika z następujących powodów:

1. Są ludzie - może zresztą bardzo rzadcy - którzy przy zawieraniu małżeństwa nie tylko nie potrzebują błogosławieństwa kościelnego, ale nawet uważają je za gwałt zadawany ich sumieniu. Nie wolno zadawać im tego gwałtu gwoli uporowi i kaprysom kleru różnowyznaniowego.

2. Bywają wypadki, że osoby różnowyznaniowe chcą się pobrać bez gwałcenia własnych sumień, bez udawania, bez obłudy, a więc bez formalnej zmiany wyznania i bez zobowiązań, że będą wychowywały dzieci na poddanych tego lub owego kleru.

1 W żydowskim folklorze dusza zmarłego w grzechu, która, skazana na wieczne potępienie, wchodzi w ciało żyjącego człowieka, by zapanować nad jego duszą. 
3. Po zawarciu małżeństwa kościelnego możliwą jest zmiana wierzeń i „przekonan” religijnych jednego lub nawet obojga małżonków, a więc zmiana zapatrywań na „sakramentalność” i „nierozerwalność". Wskutek tego związek małżeński traci podstawę wyznaniową, gdy tymczasem jego strona świecka czyli cywilna pozostaje nienaruszoną.

Gdybym był wrogiem Kościoła

Gdybym był wrogiem Kościoła, byłbym jego pochlebcą, a więc złym doradcą. Widząc jego błędy, widząc krzywdy przezeń wyrządzane i wytwarzające w krzywdzonych złowrogi dla niego nastrój, zacierałbym ręce z radości i nie tylko nie przestrzegałbym przed błędami, ale, przeciwnie, przyklaskiwałbym wszelkiej kompromitacji i zachęcałbym do trwania w błędach (perseverare in errore) i do stosowania metod zaślepieńców uważających siebie za nieomylnych i dążących do zabicia w innych wszelkiej samodzielności myślenia.

Przeciwnik ideowy niekoniecznie jest wrogiem. Przeciwnik Kościoła wykazuje brak podstaw logicznych w narzucanych dogmatach i nakazach nieomylników, ale obok tego pragnie, ażeby ci, których zwalcza, byli szlachetni i zasługiwali na szacunek. Widząc nadużycia i zboczenia, wytyka je, a przez to samo chce podnieśé zwalczanego w oczach własnych i cudzych. Nie chce więc demoralizacji ani we własnym obozie, ani w obozie przeciwnika, bo wie, że zaraza szerzona w domu sąsiada i współmieszkańca musi się przedostać także do jego domu, do jego mieszkania.

Wiadomo, jak szkodliwie oddziaływa na zbiorowisko katolickie obowiązkowy celibat, czyli bezżeństwo księży. „Wróg” katolicyzmu powinien się z tego cieszyć i gardłować za utrzymaniem tej instytucji, tak wysoce szkodliwej dla samego katolicyzmu. Kto zaś wskazuje na te praktyki hańbiące i zohydzające katolicyzm, kto nie chce się zabawiać kosztem księży i anegdotycznych księżych gospodyń, ten nawotuje do usunięcia chronicznego zgorszenia i do zastąpienia go legalnymi związkami małżeńskimi kapłanów katolickich ${ }^{1}$.

1 P. mój artykuł Dobrodziejstwa celibatu, czyli bezżeństwa księży („Myśl Wolna” nr 12 (20), grudzień 1923 r.) - Warto by się zastanowié, o ile 
Klerowi katolickiemu chodzi o panowanie świeckie nad terroryzowanymi policyjnie poddanymi, o mięszanie się do wszystkich objawów życia społecznego, wbrew życzeniom samych rządzonych, o stałe naruszanie głoszonego ostentacyjnie hasła ne misceantur sacra profanis (nie należy mieszać rzeczy świętych ze świeckimi). Ja zaś dążę do uniemożliwienia profanacji Kościoła, do uniemożliwienia „obrazy boskiej” przez przymusowe zaliczanie do stada rządzonego przez jedynego pasterza jedynej owczarni także bezczelnych obłudników i szalbierzy, kpiących sobie w duszy z wszelkiej religii i wyzyskujących względy kleru dla kariery lub też z innych powodów, niemających nic wspólnego z prawdziwą wiarą. Co po psie w kościele, kiedy pacierza nie mowi, a więc precz ze światowcami, podszywającymi się pod wierzących i uprawiającymi lekki flirt z wyzyskiwanym przez nich „Panem Bogiem”! Precz z cynicznym wymaganiem, wygłoszonym niegdyś przez jednego z namiestników galicyjskich do podwładnych mu urzędników: $W$ co sobie panowie wierzycie, to mi jest catkiem obojętne, byle byście tylko spetniali obrzadki religijne i przez nieuczeszczanie do kościota $i$ wstrzymywanie sie od spowiedzi nie wywotywali publicznego zgorszenia!

Należy oczyścić Kościół od „wilków w owczej skórze”. Ci, co do niego formalnie należą, powinni należeć także z przekonania, powinni należeć duszą i sercem. Lepiej mało, ale prawdziwych wiernych, aniżeli dużo podejrzanych i obłudnie schlebiających. Nie ilość, lecz jakość.

Nieustępliwa, autokratyczna odezwa biskupów katolickich jest jednym z objawów bezdusznego, drewnianego, czysto formalistyczne$\mathrm{g}_{0}$, biurokratycznego traktowania cierpiących ubogich i maluczkich. Bo dla możnych i potężnych, chcących zerwać krępujące ich więzy, znajdą się zawsze sławetne „unieważnienia” i inne furtki do wyjścia $\mathrm{z}$ ciemnicy.

Dbający o podległe mu duszyezki Kościół powinien by być dla nich matką współczującą, kojącą i łagodzącą cierpienia, nie zaś dozorcą więziennym, zmuszającym do udawania i gwałcenia sumień.

pojęcie „nierozerwalności małżeństwa”, według profesora Lutosławskiego nawet na tamtym świecie, da się zastosować także do „księżych gospodyń” [przyp. BdeC]. 


\section{Zakończenie}

We wszystkich dziedzinach życia społecznego, a więc także w dziedzinie zawierania i zrywania związków małżeńskich powinno nastąpić zupełne zrównanie wszystkich obywateli państwa, bez różnicy narodowości i wyznania. Wyznanie każdego człowieka jest jego sanctissimum (świętość nad świętościami), w którym nie ma prawa grzebać łapa policjanta i żandarma; a policjantem i żandarmem staje się też każdy duchowny, plugawiący duszę ludzką przez zmuszanie jej do udawania wiary, której w istocie nie ma. Wpisywanie do paszportów tego lub owego „wyznania” jest bezczelnością urzędową. Stawiane urzędowo pytanie, jakiego dany osobnik jest wyznania, jest policzkiem wymierzonym godności ludzkiej.

Szanujący siebie ludzie różnowyznaniowi i pozawyznaniowi powinni zawrzeć „koalicję” dla wspótpracy mającej na celu zabezpieczenie sobie wolności wyznania i zgodnego wspótżycia w granicach wspólnego państwa. Nikt nie ma prawa unieszczęśliwiać ludzi, chociażby nawet w imię Boga Wszechmogącego i Miłosiernego. Nikt nie ma prawa skazywać czy to wierzących, czy też niewierzących na dożywotnie męczarnie.

Powinniśmy nareszcie przestać patrzyć na obywateli i obywatelki jak na bydło będące własnością bądź to monarchy, bądź też wielogłowego, nieuchwytnego władcy, zwanego tym lub owym narodem. Człowiek musi mieć prawo do zachowania godności ludzkiej i do urządzania swego osobistego życia według własnych pragnień i zapatrywań, byle tylko nie ze szkodą innych wspótobywateli.

[Warszawa 1926']

1 Na ten temat wypowiadał się Baudouin także na łamach „Dziennika Ludowego” (1926, nr 53) - Jakim powinno być prawo matżenskie w Polsce. Gtos prof. Baudouin de Courtenay. 


\section{MÓJ STOSUNEK DO KOŚCIOŁA}

\section{PAMIECCI}

mojej matki, JADWIGI z Dobrzyńskich,

zmarłej w Radomiu w r. 1870 w 50-ym roku życia, mojej siostry BRONISŁAWY,

zm. w Radomiu w r. 1919 w 72-im roku życia,

oraz moich dwóch wnuczek,

TERENI Małachowskiej-Łempickiej,

zm. w Warszawie 3 sierpnia r. 1926 w trzy miesiące po urodzeniu,

i KRZYSI Ehrenkreutzówny,

zm. w Wilnie 19 maja r. 1927 w dziesiątym roku życia,

POŚWIECAM

\section{R0ZDZIAŁ I, wstępny}

Punkt wyjścia. „Fałszywa fasja”

Za punkt wyjścia biorę kapitalne głupstwo popełnione przeze mnie przed trzydziestu laty. Mieszkałem wówczas w Krakowie, do którego w r. 1893 przeniosłem się z Dorpatu-Juriewa, nie wysłużywszy pełnej emerytury rosyjskiej, ażeby móc pracować w jednym z istniejących wówczas uniwersytetów polskich. Wkrótce po przybyciu do tego miasta zostałem niemile dotknięty zwyczajem praktykowanym przez wszystkich mieszkańców Galicji, któremu to zwyczajowi ja również musiałem się poddać, bo inaczej zostałbym pozbawiony dachu nad głową.

Oto wynająwszy mieszkanie i opłaciwszy umówione ustnie komorne za pierwszy kwartał, powinienem był po niejakim czasie w osobnej księdze domowej stwierdzić własnoręcznym podpisem oświadczenie, równające się pod względem prawnym zeznaniu pod przysięgą, a więc w razie wykrycia urzędowego nieprawdziwości zeznania karane na równi z „krzywoprzysięstwem”, ile mianowicie wynosi moje roczne komorne.

Przy tym gospodarz domu oświadczył mi, że za nic w świecie nie moge zmieniać figurującej w księdze sumy na istotnie umówioną i opła- 
caną, ale że muszę w swym zeznaniu „pod przysięgą, czyli w „fasji mieszkaniowej” uznać zredukowane mniej więcej do połowy komorne. Kiedy próbowałem protestować, mój „kamienicznik” oświadczył mi stanowczo, że jednak muszę się na to zgodzić, że jest to obowiązujący wszystkich lokatorów zwyczaj, a gdybym się chciał spod niego wyłamać, zostanę wyrzucony z zajmowanego mieszkania i nie znajdę mieszkania w żadnym innym domu, bo mnie żaden właściciel domu do siebie nie puści. Nie było więc rady i trzeba było ostatecznie popełnić to uświęcone zwyczajem „krzywoprzysięstwo”.

Zapytywałem wszystkich swoich kolegów i znajomych krakowskich, prosząc ich o wyjaśnienie. Wszyscy dziwili się mojej naiwności, zapewnili mię, że mój gospodarz miał słuszność, i radzili mi, ażebym się poddał bez szemrania zwyczajowi, który tu nikogo nie razi. Praktykuje się zaś ten bogobojny zwyczaj dla ulżenia właścicielom domów przy opłacaniu podatku dochodowego, który od komornego wynosi 45\% sumy wymienionej w „fasji”. Co innego bowiem jest 45\% od istotnie pobieranej sumy komornego, a co innego 45\% od mniej więcej połowicznego nominalnego komornego, wnoszonego do księgi fasji podatkowej i stwierdzanego podpisem samego lokatora.

Po takim wyjaśnieniu stuliłem uszy, zrezygnowałem z wszelkich protestów i zgodziłem się być szubrawcem i oszustem, popełniającym rokrocznie zawodowe fałszerstwo, równoznaczne $\mathrm{z}$ „krzywoprzysięstwem”.

A trzeba wiedzieć, że władze skarbowe wcale się nie krępowały zeznaniami fasyjnymi lokatorów ulegających terrorowi właścicieli domów i całkiem dowolnie, według widzimisię powiększały sumę nominalnego komornego, niekiedy nawet ponad sumę komornego faktycznego. Ponieważ każdy urzędnik galicyjski był albo lokatorem, albo „kamienicznikiem”, więc też każdy urzędnik skarbowy popełniał sam owo zwyczajowe fałszerstwo i „krzywoprzysięstwo” i mógł śmiało powiększać sumy „fałszywej fasji”, bo wiedział, że nikt nie będzie protestował przeciw temu samowolnemu powiększaniu. Gdyby bowiem protestowat, zarządzono by dochodzenie i dowiedziono by fałszerstwa i krzywoprzysięstwa, tj. występków przewidzianych przez kodeks karny. Owa możność dowolnego powiększania sum zeznanych w fałszywej fasji była w rękach urzędników doskonałym środkiem faworyzowania prawomyślnych oby- 
wateli, a prześladowania obywateli podejrzanych o nieprawomyślność i „przewrotowość”.

Obywatele prawomyślni, bogobojni, pobożni, gorliwcy wyznaniowi, praktykujący wszelkie nakazane przez Kościół obrządki, spełniający w przepisanych terminach wszelkie sakramenty zarówno sakrament pokuty, jak i ciała i krwi Pańskiej, wylegujący się całymi godzinami krzyżem w kościele Panny Marii i we wszystkich innych kościołach krakowskich i w ogóle galicyjskich, nie wahali się podpisywać rok w rok zeznania krzywoprzysięskie. A do tych nieświadomie, podświadomie i świadomie cynicznych obłudników należeli w polskiej Galilei nie tylko zwykli śmiertelnicy i śmiertelniczki, ale także luminarze i świeczniki społeczeństwa, przodownicy hierarchii kościelnej, biskupi i arcybiskupi, artyści, literaci pierwszorzędni, profesorowie wyższych zakładów naukowych, członkowie Akademii Umiejętności z jej prezesem na czele, jednym słowem kwiat różnonarodowej inteligencji galicyjskiej (dziś „małopolskiej”).

Duchowieństwo różnowyznaniowe, kler żydowski, katolicki i wszelki inny uczestniczył w tym okłamywaniu, w tym fałszowaniu, w tym nagminnym oszustwie i ani jednym słówkiem nie protestował przeciwko niemu. Jeżeli „fałszywa fasja” należała do „grzechów”, toć oczywiście każdy prawowierny katolik powinien był się spowiadać z tego „grzechu” i oczywiście za każdym razem otrzymywał rozgrzeszenie wraz z pozwoleniem powrotu do grzechu i kontynuowania utartego zwyczaju „fałszywej fasji”.

Zdaje się jednak, że „fałszywa fasja” nie należała do grzechów przewidzianych przez moralność żydowsko-chrześcijańsko-katolicką. Przecież w Dekalogu, czyli w Dziesięciorgu Bożych Przykazań, nie znajdujemy wcale przykazania: „nie kłam, nie udawaj, nie oszukuj, nie fałszuj, nie bądź obłudnikiem”, boć nie mów fatszywego świadectwa przeciwko bliźniemu twemu (pierwotnie przyk. 9, później 8) znaczy właściwie co innego. Tak więc kler różnowyznaniowy, patrząc pobłażliwie na „fałszywą fasję” i sam w niej uczestnicząc, był w porządku ze swym sumieniem wyznaniowym. „Krzywoprzysięstwo” związane z „fałszywą fasją" było pojęciem tylko świecko-prawniczym, obcym dziedzinie religii. 
W mojej jednak etyce pozawyznaniowej wołało gromkim głosem owo przykazanie, nieprzewidziane ani w etyce żydowsko-chrześcijańskiej, ani w etyce rzymskokatolickiej. Pomimo to, pod grozą stracenia dachu nad głową, podpisywałem w ciągu kilku lat „fałszywą fasję" w obu moich mieszkaniach krakowskich, i na ulicy Radziwiłłowskiej, i na Pędzichowie, czyli byłem takim samym kłamcą, fałszerzem, oszustem, „krzywoprzysiężcą, jednym słowem szubrawcem, jak wszyscy inni mieszkańcy Galicji i Lodomerii. Ale wstręt do tej ohydy, pragnienie zaprotestowania przeciw kloace moralnej, w której się musiałem nurzać wraz z innymi, wzbierały coraz bardziej w mojej duszy i coraz natarczywiej targały moim sumieniem. Doprowadziło to w końcu do wybuchu i do wystąpienia publicznego. Pod koniec r. 1897 napisałem i wydałem nakładem własnym broszurę Jeden z objawów moralności oportunistyczno-prawomyślnej, Kraków 1898.

Zastrzegtem się w tej broszurze przeciw posądzeniu,

jakoby mi przy tym chodziło głównie 0 szkodę, jaką skutkiem fałszywej fasji ponosi państwo, nierównie bowiem większą szkodę ponosi dane społeczeństwo. Tak zwane „państwo” ma samo dosyć środków do bronienia swoich interesów, ma na swoje rozkazy setki tysięcy bagnetów, ma przymus w formach najrozmaitszych.

Jestem więc przeciwnikiem fałszywej fasji nie ze względów abstrakcyjnych, nie dla tego, że jest ona wysoce niesprawiedliwą wobec opiekuńczego rządu, ale muszę ją potępić dlatego, że demoralizuje społeczeństwo do szpiku kości, że jest nigdy niewysychającym źródłem gangreny moralnej, źródłem zgnilizny i korupcji powszechnej. Przyjąwszy fałszywą fasję za jedną z podstaw działania, mamy prawo, za przykładem jednego z „bohaterów” komedii Dobrzańskiego Ztoty cielec, powtarzać sobie bez ogródki: Pan jesteś ztodziej, ja jestem ztodziej, wszyscy jesteśmy ztodzieje i możemy sobie tego nawzajem powinszować. (str. 28-29).

Zastanawiając się dziś z zimną krwią i w świetle rozsądku praktyeznego, muszę przyznać, że moje wystąpienie przeciwko „fałszywej fasji” pod naciskiem natrętnej autosugestii było objawem lekkomyślnej donkiszoterii, a mogło też sprawiać wrażenie odpychającej megalomanii. „Niespokojny człowiek”, „warchoł”, „zarozumialec”, „chce 
być mędrszym od innych”, ,wyrywa się nieproszony ze swymi reprymendami”, „Zakłóca spokój”, ,należy go obezwładnić i usunącé itp. - oto uwagi, które musiały się nasuwać prawomyślnym, bogobojnym, bogoojezyźnianym obywatelom pod wrażeniem mojej zuchwałej napaści na ich „najświętsze wierzenia” $i$ „prawa zwyczajowe”.

Przyznaję im słuszność, dodając, że za swe nieobywatelskie i nieprawomyślne wystąpienie, za palnięcie kapitalnego głupstwa poniosłem zasłużoną karę.

\section{Opłakane skutki niewczesnej donkiszoterii}

Ukazanie się mojej broszury wywołało powszechne oburzenie. Zawrzało jak w ulu albo jak w mrowisku. Gorliwi stróże narodowego pamiatek kościoła nie posiadali się z gniewu i wzywali odpowiednie władze 0 pomstę za zuchwały napad na ich świętości. Oburzenie ogarnęło wszystkie stronnictwa zarówno „prawicowe”, jak i „lewicowe” oraz wszystkie „organy opinii publicznej” z wyjątkiem, 0 ile pamiętam, socjalistów i dzienników socjalistyeznych. Prócz tego pojedyncze osoby bezpartyjne, a nawet może należące do tej lub owej partii, nie tylko nie oburzały się, ale - przeciwnie - wyrażały mi uznanie i podziw.

Ale te rzadkie objawy ze strony ludzi oceniających przychylnie protest przeciwko chronicznemu i endemicznemu uprawianiu fałszerstwa i oszustwa nikły w powodzi wycia i naszczekiwania nie tylko ze strony zwykłych pismaków i krzykaczy, ale także ze strony patentowanych i przodujących narodowi inteligentów.

Kiedy w r. 1898, będąc wówczas profesorem Uniw. Krakowskiego, w osobnej broszurze Jeden z objawów moralności oportunistyczno-prawomyślnej, zwróciłem uwagę na obniżanie poziomu etycznego publiczności galicyjskiej przez stałe uprawianie fałszerstwa i „krzywoprzysięstwa” przy zeznaniach 0 wysokości płaconego komornego („fałszywa fasja”), p. St. Głąbiński - wówczas tylko profesor Uniw. Lwowskiego, a jeszcze ani ekscelencja austriacka, ani też poseł do sejmu polskiego i minister oświaty Rzplitej Polskiej - napisał w „Słowie Polskim”, że jestem wariatem. Zdaniem p. G., tylko wariat może uznawać szkodliwy wpływ chronicznego fałszer- 
stwa i „krzywoprzysięstwa”, Ówczesny zaś naczelny redaktor „Głosu Narodu”, w związku z tą sprawą zawiadomił swych czytelników, iż jestem „szpiegiem rosyjskim”.

Dwie zaszczytne kwalifikacje!

Ostatecznie dotknięci w swych uczuciach kieszeniowych „patrioci” polsko-galicyjscy zarówno „prawicowi”, jak i „lewicowi” wyjednali u rządu austriackiego usunięcie mnie z Uniwersytetu Krakowskiego. (Redaktor pisma postepowego uznany przez policje za wariata, „M[yśl]W[olna]” 1925, nr 3, str. 125).

Nie raczono przy tym zwrócić najmniejszej uwagi na to, że jednocześnie z broszurą Jeden z objawów moralności oportunistycznoprawomyślnej wypuściłem rosyjską broszurę Cenzurnyja miełoczi. I. Kniaz' Bismark i gonienije „Stawian”, Kraków 1898, w której wystąpiłem przeciwko prześladowaniu Polaków w Prusach przez Bismarcka i jego naśladowców. Nie mogło to zrównoważyć mojego zbrodniczego zamachu na uświęcone tradycją prawo zwyczajowe.

Polsko-galicyjscy posłowie do parlamentu austriackiego zarówno „prawicowi”, jak i „lewicowi” (np. lwowski profesor Roszkowski) żądali od ministra oświaty w Wiedniu, ażeby mię natychmiast uwolnił. On sam był gotów uczynić zadość temu żądaniu wybitnych patriotów polsko-galicyjskich, gdyby nie powstrzymał jego zapędów szef sekcji uwagą: Exzellenz, er ist von dem Kaiser selbst bestatigt (Ekscelencjo, on jest zatwierdzony przez samego cesarza). Załatwiono więc sprawę w ten sposób, że nie odnowiono mego pięcioletniego kontraktu (18941899) na nowe pięciolecie. Niektórzy z profesorów Uniwersytetu Jagiellońskiego (Krakowskiego) jeździli umyślnie do Wiednia, ażeby dopilnować tej sprawy i nie dopuścić do jej załatwienia na moją korzyść.

Później znaczna większość Wydziału Filozoficznego Uniw. Krakowskiego (przeciwko mnie stanowczo było tylko 8 członków Wydziału) chciała mię zatrzymać w Krakowie, ale pod warunkiem (stawianym niejednomyślnie), że odszczekam swe napady na „fałszywą fasje” i przeproszę osobiście p.p. hr. Pinińskiego (namiestnika Galicji), Bobrzyńskiego (wicenamiestnika i przewodniczącego Rady Szkolnej) i hr. Tarnowskiego (profesora i chwilowo rektora Uniw. Jagiell., prezesa Akademii Umiejętności). Przy rokowaniach ze mną zgadzałem się wprawdzie na niektóre 
ustępstwa, ale na odszczekiwanie i przepraszanie zgodzić się nie mogłem. Prof. Creizenach, który prowadził ze mną te rokowania w imieniu Wydziału, powiedział nareszcie dowcipnie: Wissen Sie, Herr Kollege, die Herren möchten, Sie erklären, die falsche Fassion sei eine schöne und edle Volkssitte (Wiesz pan, panie kolego, ci panowie chcieliby, ażebyś pan oświadczyt, że fatszywa fasja jest pięknym $i$ szlachetnym obyczajem ludowym). (Rozmawialiśmy po niemiecku, ponieważ Creizenach, profesor germanistyki, był Niemcem i chociaż mówił biegle po polsku, to jednak jakoś łatwiej nam było porozumiewać się po niemiecku).

Tak więc owe rokowania nie doprowadziły do niczego. Po wyrzuceniu czy też usunięciu mnie za nieprawomyślność z uniwersytetu polskiego nie pozostawało mi nic innego, jak wracać do Rosji.

[ ${ }^{1}$ Przeniostem się więc do Petersburga, gdzie po 18 latach pobytu spotkała mię straszna klęska. Spreparowany przez wojnę, podszczuwany przez fanatycznego i zdeprawowanego inteligenta rozbestwiony cham rosyjski, działający w imię „dyktatury proletariatu” i pod hasłem grab' nagrablennoje (rabuj to, co zrabowano), zrabował i zniszczył prawie całe moje mienie ruchome, w tej liczbie większą część mojej biblioteki, moich zbiorów i materiałów naukowych i uniemożliwił mi systematyczną pracę naukową w ostatnich latach mego marnego żywota. Jest to całkiem zasłużona nagroda za to, że, mając uniemożliwiony dostęp do wszechnic polskich, kilkadziesiąt lat musiałem spędzić w Rosji (w Petersburgu, w Kazaniu, w Dorpacie-Juriewie i znowu w Petersburgu-Pietrogradzie), pracując tam jako profesor uniwersytetu i różnych innych zakładów naukowych, jako autor rozmaitych dzieł naukowych oraz uczestnicząc - zresztą całkiem niepotrzebnie i ze szkodą dla siebie samego - w życiu społecznym i politycznym narodu rosyjskiego i innych narodów państwa rosyjskiego.

Rozczulające jest w stosunku do mnie współdziałanie „patriotów” polskich i podżegaczy komunistycznych. W nagance i szczuciu na mnie idą oni ręka w rękę i dotychczas darzą mię swą nienawiścią, która przy-

1 Fragment umieszczony w nawiasach kwadratowych nie znalazł się na skutek interwencji cenzury w przedruku tej broszury w VI t. Dziet wybranych, Warszawa 1983. W przypisie objaśnienie: Wydawca dokonat koniecznego skrótu. 
nosi mi zaszczyt. To jednak, co mię spotkało dzięki zgodnej współpracy „bogoojczyźniaków” polskich i „proletariackich” chamów rosyjskich, napełniło moją duszę goryczą i wstrętem do życia].

Gdybym był w swoim czasie trzymał język za zębami i nie wywyższał się ponad otoczenie, kornie, ulegle i bez szemrania praktykujące „fałszywą fasję, byłbym może i podczas wojny przebywał w Krakowie, do którego nie zdołały wkroczyć zwycięskie zastępy oswobodzicieli spod sztandarów Mikołaja Mikołajewicza. Wprawdzie warszawscy „patrioci” polscy mogli ofiarowywać jenerałom rosyjskim złote szable za obronę Warszawy ${ }^{1}$ i za wzięcie Lwowa, a co do Krakowa musieli się obejść smakiem, ale ja, mieszkając wtedy w Krakowie, ocaliłbym swoje mienie i mógłbym nadal spokojnie i systematycznie opracowywać swe w ciaggu wielu lat zbierane materiały naukowe.

Na swej megalomanii i donkiszoterii wyszedłem gorzej niż Zabłocki na mydle.

\section{Mądralin}

Ani kara, jaka mię spotkała w Krakowie za „megalomanię” i „donkiszoterię”, ani więzienie, na które mię skazano w r. 1914 w Petersburgu za mieszanie się nie do swoich rzeczy, ani nareszcie wzmiankowana powyżej klęska poniesiona przeze mnie w Petersburgu już po wojnie, w związku jeszcze z krakowskimi podszeptami „megalomanii” i „donkiszoterii”, nie nauczyły mnie rozumu i powściągliwości języka. Już po przeniesieniu się z Pietrogradu do Warszawy świerzbiał mię wielokrotnie język, a uparta autosugestia pchała do bzdurnych i lekkomyślnych wystąpień publicznych, narażających mię „opinii publicznej” i dojrzałemu sądowi „patriotów” i „bogoojczyźniaków”. Zostałem w ich oczach wrogiem Polski, całe życie pracujacym na jej szkode.

Baudouin nawiązuje tu do niezrealizowanego projektu, jaki zrodził się w 1914 r. w środowisku warszawskim, by ofiarować szablę honorową rosyjskiemu generałowi Ruzskiemu, dowodzącemu 3. armią, która zdobyła Lwów i wyparła Niemców spod Warszawy. 
Jednym z tego rodzaju lekkomyślnych i szkodliwych dla mnie wystąpień, podyktowanych tą razą już nie przez „donkiszoterię”, ale prawdopodobnie przez swoistą megalomanię i wstręt organiczny do wszelkiej „fałszywej fasji”, było moje oświadezenie w r. 1924, że jako niechrześcijanin nie mam prawa do korzystania z dobrodziejstw pobytu w Mądralinie. W ten sposób pozbawiłem się możności odpoczynku w warunkach nadzwyczaj pomyślnych, prawdziwie idealnych. Ze stanowiska zdrowego rozsądku i korzyści praktycznych był to krok nierozważny i po prostu głupi. Cóż bowiem mogło się stać złego, gdybym ja swoją „,niechrześcijańskość” zachował dla siebie, nie afiszując się z nią publicznie i nie podkreślając jej jako powód do niekorzystania z dobrodziejstw zapisu śp. Hiszpańskiego Kasie im. Mianowskiego? Tani pobyt w tej uroczej miejscowości byłby z korzyścią dla mojej kieszeni, a wyborne powietrze, doskonałe odżywianie się i w ogóle cały zespół warunków pobytu w Mądralinie z korzyścią dla mego zdrowia. Przecież odwiedzają dość często to wspaniałe sanatorium nawet głośni i oficjalni „wolnomyśliciele”, wykorzystujący swe „rzymskokatolickie” lub w ogóle „chrześcijańskie” wyznanie paszportowe.

Teraz znowu mię świerzbi język, a raczej ręka trzymająca pióro piszące. Autosugestia pchająca mię w danej chwili ku wystąpieniu publicznemu wolna jest całkowicie od „donkiszoterii”, ale nie mogę zaręczyć, czy jest wolną od pewnej przymieszki „megalomanii”. No, ale kto wie, czy niezbędnym warunkiem wszelkiego samodzielnego działania ludzkiego nie jest pewien stopień megalomanii, czyli obłędu wielkości. Bez tego człowiek by się weale nie ruszał, a poddany władzy przeciwnego obłędu, obłędu małości, czyli „mikromanii”, całkiem by zdrętwiał i uległby paraliżowi psychicznemu.

A chodzi mi w obecnej chwili o coś nierównie ważniejszego od „fałszywej fasji” galicyjskiej. Chodzi mi o praktykowanie „fałszywej fasji” co do mej istoty duchowej i wartości społecznej przez przeszło 60 (sześćdziesiąt) lat. 


\title{
ROZDZIAŁ 2
}

\begin{abstract}
Moje pochodzenie katolickie. Mój „katolicyzm”
i moja wyznaniowość w ciągu całego życia.

Dzieciństwo, chłopięctwo i pierwsza młodośé
\end{abstract}

Pochodzę z rodziny katolickiej. Zaraz po urodzeniu (w Radzyminie w r. 1845) ochrzczono mię, nie pytając mnie weale 0 zgodę. Jak w nowoczesnych państwach wszyscy mężczyźni podlegają obowiązkowej służbie wojskowej, tak znowu w państwach bez rozdziału kościołów od państwa wszystkie nowo narodzone dzieci podlegają obowiązkowemu chrztowi albo też (przynajmniej płeć męska) obowiązkowemu obrzezaniu. A nawet przy rozdziele kościołów od państwa większość rodziców trzyma się tego lub owego wyznania. Tak więc w każdym razie bytbym ochrzczony. Do ksiąg „urzędu stanu cywilnego" zostałem wniesiony przez księdza. Moimi rodzicami chrzestnymi byli ksiądz wikary i służąca moich rodziców.

Wychowanie otrzymałem szczerze rzymskokatolickie. Od najwcześniejszego dzieciństwa wpajano we mnie starannie i sumiennie religijność rzymskokatolicką ze wszystkimi jej przynależnościami.

Moja matka była prawdziwą katoliczką, nie damą flirtującą z konwenansowym Bogiem, ale osobą głęboko wierzącą i całą duszą, całym sercem oddaną swemu Bogu, który, chociaż podobnie jak wszystkim innym osobom wierzącym był jej narzucony i w nią wmówiony, stał się jej prawdziwym Bogiem osobistym, czezonym i wielbionym bez zastrzeżeń i bez powątpiewań, zgodnie z nauką Kościoła. Życie mojej matki było życiem męczennicy, poddającej się bez szemrania przeznaczonemu jej losowi, który dla niej był wyjątkowo okrutnym. Doznawała prawie bez przerwy tylko cierpień, a nader rzadko chwilowej przemijającej radości. Urodziła czternaścioro dzieci, z których tylko czworo wychowało się i dorosło; jedna córeczka umarła, mając lat pięć, a wszystkie inne w ciągu pierwszego roku życia. W jej cierpieniach jedyną jej pocieszycielką była głęboko odczuwana i całą istotą przeżywana religia. Za swój najświętszy obowiązek uważała bezwzględne posłuszeństwo Kościołowi, surowe przestrzeganie prze- 
pisów kościelnych i wykonywanie wszystkich bez wyjątku praktyk religijnych.

Uważając swoją religijność za niezbędny warunek szczęścia doczesnego i pozagrobowego, matka moja starała się wszelkimi sposoby wszczepić ją także dzieciom. Ćwiczyła nas w modlitwach, w niedzielę i święta czytywała nam przepisane na każde ze świąt lekcje i ewangelie, prowadziła nas na nabożeństwa, kazała czcić osoby duchowne jako istoty wyższe, jednym słowem wychowywała nas w kulcie religijnym 0 absolutnej czystości i bez zarzutu.

Oczywiście usiłowania wychowawców w kierunku zaszczepienia wychowankom czystej i prawdziwej religijności nie zawsze trafiają na podatny grunt, a wywołują czasami niepożądane skutki.

W małych dzieciach, skazanych na bałamucenie ich opowiadaniami i objaśnieniami całkiem dla nich niezrozumiałymi, można wzbudzić nastrój religijny przez samo powiedzenie „Złóż rączki i pomódl się do bozi”. Jest to zapewne rozrzewniające i rozczulające, ale czy zawsze celowe, czy zawsze da się długo utrzymać, to wielkie pytanie. (Różnoraka „psychologia modlitwy”, „MW” 1923, nr 11, str. 12).

Ja jednak odczuwałem poważny nastrój religijny, pomimo że często przychodziły mi do głowy myśli „grzeszne”, a nawet po prostu wszeteczne.

Pamiętam, że w dzieciństwie byłem bardzo pobożnym, starałem się modlić się ze skupieniem i z uczuciem czci należnej Stwórcy, chociaż nie zabezpieczało mnie to weale przed grzechami i przed kalaniem myśli choćby przez niektóre wyliczane w katechizmach grzechy wołające o pomstę do nieba i inne nie mniej pikantne. Zresztą katechizm tylko współdziałał z wrażeniami odbieranymi od życia, a przede wszystkim od faktu różnicy płci w świecie zwierzęcym w ogóle, a ludzkim w szczególności. („MW” 1923, nr 11, str. 12).

Modliłem się gorąco rano i wieczorem, chociaż wieczorami zwykle przy tym zasypiałem. 
Pamiętam, jak w dzieciństwie przed pójściem spać klękałem do wieczornego pacierza i odmawiałem po kolei Ojcze Nasz, Zdrowaś Maria, Wierze w Boga, Dziesięcioro Bożego Przykazania, a czasami w przystępie niezwykłej gorliwości także inne modlitwy i przykazania. Bywałem często mocno rozespany i klepałem na wpół przytomnie modlitwy uważane za obowiązkowe. Otóż Wierze w Boga bywało dla mnie zadaniem nie do przezwyciężenia. Powtarza się w nim dwa razy „Ducha Świętego": najprzód w połączeniu który sie począt z Ducha Świetego, narodzit sie z Maryi Panny (lub z Maryi Dziewicy), następnie zaś w połączeniu Wierze w Ducha Świętego, święty kościót powszechny... Przejechawszy tedy przez pierwszego „Ducha Świętego" i dojechawszy szczęśliwie do drugiego, nie mogłem za nic ruszyć dalej i wracałem automatycznie do pierwszego, tj. zamiast powiedzieć wierze w Ducha Świętego, swięty kościót powszechny bełkotałem ponownie ...Ducha Świętego, narodzit sie z Maryi Panny. Znowu dochodziłem do wierze w Ducha Świętego i znowu cofałem się do pierwszego „Ducha Świętego” w towarzystwie Maryi Panny. Da capo al fine. Powtarzało się to kilkakrotnie i ani rusz nie mogłem się wydobyć z Wierze w Boga i przedostać się do Dziesięciorga Bożego Przykazania, dopóki nie zdobyłem się na jakiś krok stanowczy, tj. ocknąwszy się ze stanu drzemki, brałem gwałtownie rozbrat z Wierze w Boga i rzucałem się rozpaczliwie na fale Dziesięciorga Przykazań (wraz z cudzotożeniem i pożadaniem żony bliźniego swego). („MW” 1923, nr 11, str. 15).

Z wielkim przejęciem śpiewałem lub recytowałem około Bożego Narodzenia kolędy - w nastroju radosnym, a przed Wielkanocą Gorzkie żale - w nastroju smutnym, przeżywając i odczuwając przy tym do pewnego stopnia męki Chrystusowe.

Kiedy 8 września r. 1855 (w dzień wzięcia Sewastopola przez sprzymierzonych) kazano mi po raz pierwszy iść do spowiedzi, a następnie do komunii, wywarło to na mnie potężne wrażenie. Bardzo sumiennie i skrupulatnie robiłem „rachunek sumienia”. Skupiłem myśl na tym akcie świętym i na łasce, której dostąpiłem. Nie zwracałem uwagi na to, że mój spowiednik - 0 ile pamiętam, jakiś zatabaczony bernardyn czy też reformat - traktował tę sprawę rzemieślniczo, zawodowo, robił mi napomnienia stereotypowe i zadał mi na pokutę odmawianie w cią- 
gu kilku dni pewnej porcji „ojczenaszów” i „zdrowasiek”. Dalsze praktykowanie tych „sakramentów” zarówno w domu, jak później w szkole działało na mnie ochładzająco, a bezduszne klepanie wyznaczanych za pokutę „ojczenaszów” i „zdrowasiek” było bardzo dalekie od podniosłego nastroju modlitewnego.

Boć doprawdy dziwny to pomysł, ażeby łączenia się duszy pobożnej z Bogiem w modlitwie używać jako środka kary, a przez mnożenie modlitwy (5 lub 10 Pater noster i Ave Maria, choćby nawet nie w urzędowym języku Kościoła, ale w języku ojczystym penitenta) nadawać jej cechę bezmyślnego klepania pewnych wyrazów w określonym porządku. Podobnie, używając pracy jako kary dla przestępców, odziera się tę pracę z wszelkiego uroku. Zarówno praca jako też modlitwa powinny być otoczone pewną czcią. Użyte jako narzędzia kary mimo woli wywołują ku sobie odrazę. („MW” 1925, nr 11, str. 12-13).

Prócz tego niektórzy ze spowiedników swoimi pytaniami naprowadzali mię na „grzechy”, o których jeszcze nie wiedziałem, a ponieważ byłem naturą wysoce zmysłową, więc te indagacje czcigodnych ojców duchownych kalały moją wyobraźnię i deprawowały mię stopniowo.

Ten wpływ deprawujący wywierały także niektóre ustępy z $H i$ storii Świętej, niektóre oddziały Katechizmu, a zwłaszcza wyliczania różnych egzotycznych grzechów, których kazano mi się uczyć na pamięć. Wyczytany w liczbie grzechów wotajacych o pomste do nieba (czy też do Boga) grzech sodomski niezmiernie mię zaciekawił, a że byłem dzieckiem myślącym i chcącym rozumieć to, czego każą mu się uczyć, rozpytywałem na wszystkie strony, co to takiego, i dopóty się nie uspokoiłem, dopóki się nie dowiedziałem, nie pamiętam już od kogo, zdaje się że od jakiegoś rówieśnika. A tymczasem mógłbym przez całe życie nie wiedzieć o tym interesującym grzechu, o ile bym nie został lekarzem, zwłaszcza psychiatrą, folklorystą lub - rzecz oczywista - księdzem.

W epoce swego pierwszego dzieciństwa święcie wierzyłem we wszelkie cuda, starotestamentowe, nowotestamentowe i późniejsze, dokonywane przez samego Boga wielopostaciowego i przez jego wybrańców i wybranki, tj. przez różnych świętych, a zwłaszcza przez różne Matki Boskie. Kiedy mi opowiadano o cudach, związanych 
z Matką Boską Częstochowską, o rzekomym napadzie husytów na Jasną Górę i o sponiewieraniu przez nich obrazu cudownego i Hostii Przenajświętszej, dygotałem z oburzenia, a że przy tej sposobności utożsamiano husytów z chasydami i w ogóle z Żydami-masonami i twierdzono, że to Żydzi-husyci zbezcześcili tak świętości katolickie (takie twierdzenia można było słyszeć od niektórych księży, nawet z ambon) ${ }^{1}$, odzywała się w mej duszy ostra niechęć do „Żydów”, którą hodowały też Gorzkie żale, opiewające ukrzyżowanie i męki Chrystusa.

Przecież Chrystus był synem Boga, a zarazem zbawicielem ludzkości, który poddał się mękom za grzechy ludzi zgodnie z przepowiedniami proroków, to jest zgodnie z ułożonym przed wiekami programem. I takiego Boga-człowieka „Żydzi” nie tylko nie uznają, ale oddają go na męczarnie i śmierć hańbiącą. Zgódźcie się sami, że weale nie wyrzutki moralne i potwory moralne spomiędzy chrześcijan, ale właśnie bardzo uczciwi, bardzo szczerzy i bardzo szlachetni ludzie mogą się oburzyć na Żydów i stać się ich wrogami, naturalnie pod warunkiem, że ci uczciwi, szczerzy i szlachetni ludzie są pozbawieni choćby krzty zmysłu krytycznego, ale za to posiadają łatwo zapalającą się wyobraźnię. (J. Baudouin de Courtenay, Ze zjazdu autonomistów, czyli przedstawicieli narodowości nierosyjskich., Kraków 1906. Odbitka z „Krytyki”, str. 24-25).

Ale ten mój „antysemityzm” dziecięcy był bardzo niewinny i nie miał w sobie ani cienia pogromowości. Moje najbliższe otoczenie było również wolne od uczuć antysemityzmu napastniczego i tępicielskiego. W związku z prawdziwą religijnością nakaz „miłości bliźniego” przeważał nad fanatyzmem wojowniczym. Patrzyliśmy nie tylko na Żydów, ale w ogóle na wszelkie inne zrzeszenia innowiercze z poczuciem wyższości katolickiej i co najwyżej litowaliśmy się i ubolewaliśmy nad „poganami” i „heretykami” z powodu, że nie uznając

1 Ze strony ścisłości historycznej to mięszanie czeskich husytów z żydowskimi chasydami przypomina twierdzenie współczesnych nam dygnitarzy kościelnych o tym, że śluby cywilne są wymysłem „bolszewików” [przyp. BdeC]. 
władzy i nieomylności papieża, skazują siebie na wieczne potępienie. I w ogóle w ówczesnym społeczeństwie polskim nie było jeszcze tego wściekłego, fanatycznego i geszefciarskiego antysemityzmu, który w związku z potężniejącym syjonizmem i szowinizmem żydowskim zatruł pod koniec XIX i na początku XX wieku atmosferę społeczną i uniemożliwił znośne, spokojne współżycie różnych „ras” i różnych wyznań.

Również mój „nacjonalizm” dziecięcy nie miał w sobie cech fanatyzmu i nienawiści bezwzględnej. Byłem wprawdzie gorącym patriota polskim, marzyłem o niepodległości Polski i 0 wskrzeszeniu państwa polskiego, uważałem „Niemców” i „Moskali” za wrogów Polski, pragnąłem wypędzenia ich z ziem polskich w granicach przedrozbiorowych z dodaniem do nich reszty ziem zamieszkałych częściowo przez Polaków; snułem senne obrazy wielkiej Polski od morza do morza i od Odry do Dniepru, w połączeniu z przyległymi krajami „słowiańskimi”, ale nieubłaganej nienawiści do „wrogów” nigdy w sercu nie żywiłem. W ogóle zdaje mi się, że uczucie nienawiści jest mi obce; moge je sobie wyobrazić, ale nie mogę go odczuwać.

W dziedzinie życia religijnego wierzyłem bezwzględnie w tzw. „Objawienie”, nie zastanawiając się nad tym, skąd ono pochodzi. Przecież „objawienie” przechodzi drogą tradycji od człowieka do człowieka i tylko od człowieka do człowieka. Cofając się jak najdalej wstecz, nikt nie potrafi wskazać wybrańca i szczęśliwca (oczywiście płci męskiej), któremu udało się rozmawiać bezpośrednio z bóstwem i odbierać od niego wskazówki dla dwunogich, obdarzonych olbrzymią dozą zarozumiałości i megalomanii. Każdy z nas dowiaduje się o „Objawieniu” od swego otoczenia: od piastunek, od rodziców i wychowawców, od kapłanów danego wyznania albo istotnie wierzących w możność „objawienia”, albo też obłudnie udających, że w nie wierzą. Przestawszy być analfabetami, potwierdzenie legendy objawieniowej znajdujemy w książkach partyjnych.

W każdym razie ja osobiście wierzyłem przez pewien czas w „objawienie boskie”.

Byłem też czcicielem kleru i jego wiernym poddanym. W związku z tym 
przypominam sobie $\mathrm{z}$ wczesnego dzieciństwa wrażenia niezbyt budujące. Mieszkałem z rodzicami w Porębie, wsi kościelnej niedaleko od Ostrowia i Pułtuska, w dzisiejszej ziemi łomżyńskiej. Otóż w tej wsi był proboszcz w starszym już wieku, na którego w swej dziecięcej naiwności patrzyłem z wielką czcią, bo zdawało mi się, że głowę jego otacza aureola na podobieństwo promieni i kręgów, okalających na obrazkach głowy świętych płci obojej. Prawdopodobnie memu proboszczowi kurzyło się z czupryny. Otóż o tym czczonym przeze mnie księdzu opowiadano sobie poufnie, ale tak, że opowiadania te obijały się o moje uszy, iż miał on kolejno po sobie dwie gospodynie: najprzód matkę, a potem córkę, która była też jego własną córką. Prawdopodobnie była to potwarz czy też oszczerstwo; ale już możność podobnej potwarzy czy też oszczerstwa przemawia chyba jaskrawo przeciw celibatowi. Ja byłem wówczas jeszcze na tyle naiwny, że w tej kolejności księżych gospodyń nie widziałem nic zdrożnego. (Dobrodziejstwa celibatu, czyli bezżenstwa księży, „MW” 1923, nr 12, str. 4).

Kiedy w r. 1857 wstąpiłem do klasy trzeciej Gimnazjum Realnego w Warszawie, musiałem wraz z całą klasą i wraz z całą szkołą uczęszczać codziennie przed rozpoczęciem lekcji już o wpół do ósmej z rana do kościoła panien Wizytek na nabożeństwo uczniowskie, odprawiane dla nas przez jednego z księży prefektów. To traktowanie nas jak trzody wyznaniowo musztrowanej musiało prawie we wszystkich nas tłumić i zabijać prawdziwy nastrój religijny i modlitewny indywidualny.

Urządzane w szkole rekolekcje przed kontrolowaną w sposób policyjny spowiedzią wielkanocną nie wzbudzały w nas wcale nastroju religijnego, ale, przeciwnie, były traktowane lekceważąco i humorystycznie, jako kinderbale duchowne (przeróbka używanego przez naszych katechetów wyrażenia zabawa duchowna). (Różnoraka psychologia modlitwy, „MW” 1923, nr 11, str. 13).

0 ile sobie przypominam, byliśmy wówczas, przed laty 70, zmuszani do spowiadania się tylko raz na rok, koło Wielkanocy, nie tak jak dziś, w dobie ostentacyjnie głoszonej „sanacji moralnej” i uczciwości, kiedy to okólnik ministerialny nakazuje uczniom szkół średnich spowiadać się trzy razy do roku. Oczywisty postęp jako skutek konkordatu! 
W klasie 5 bierzmowałem się, również u panien Wizytek, korzystając z przyjazdu jakiegoś biskupa. Chciałem uczestniczyć w jednym z sakramentów wprawdzie nieobowiązkowych, ale zalecanych.

Ostatni raz spowiadałem się w klasie szóstej na wiosnę r. 1861 u znanego filozofa polskiego, księdza pijara Franciszka Krupińskiego. Zachowywał się on całkiem poprawnie, wysłuchał mych zwierzeń uważnie, a na pewne dolegliwości „grzechowe” dawał mi bardzo trafne rady higieniczne z zakresu hydroterapii. Oczywiście jako zawodowiec zalecił mi także odmawianie „ojczenaszów” i „zdrowasiek”, boć przecie było to koniecznym przypieczętowaniem spowiedzi wyznaniowej.

Była to moja ostatnia spowiedź, której musiałem się poddać obowiązkowo jako uczeń gimnazjum. Przeszedłszy z szóstej klasy gimnazjum realnego do szkoły przygotowawczej do Szkoły Głównej, nie podlegałem już kontroli szkolnej, a moja ówczesna religijność wykluczała potrzebę spowiedzi dobrowolnej. Obłudnikiem zaś nigdy nie byłem i być nie mogłem.

Wiem o tym, że wielu ludzi, i to nawet pierwszorzędnych myślicieli, których światopogląd kłóci się zasadniczo z nauką Kościoła urzędowego, uważa za konieczne, dla niewywoływania zgorszenia, brać udział w nabożeństwach i udawać pobożnych. Podobno Karol Darwin, wzorem innych uczonych angielskich, chadzał w święta do kościoła z książką do nabożeństwa pod pachą; bo inaczej byłoby to shocking (raziłoby publiczność). Mnie jednak nie stać na takie udawanie pro publico bono. Chcę pozostawać sobą, nie zaś jakimś surogatem własnej osoby. („MW” 1923, nr 11, str. 13-14).

Napoleon I, który nie bardzo był w porządku z przykazaniami boskimi, a zwłaszcza z przykazaniem 5, odbywał podobno praktyki religijne i został uznany przez Kościół Chrystusowy. Za jego przykładem rozmaici dostojnicy, prezydenci, marszałkowie, ministrowie itd. rozmaitych państw, a w tej liczbie Polski, odbywają przepisane przez Kościół praktyki i uczestniczą w obrzędach bądź to jako istotnie wierzący (o czym przeważnie można wątpić), bądź też jako udający wierzących ze względów oportunistycznych. Mnie to jednak ani trochę nie wzrusza. 
Po ostatniej w życiu spowiedzi

Tak więc moja ostatnia spowiedź miała miejsce w r. 1861. Później już ani razu się nie spowiadałem.

Można by o tym powątpiewać choćby ze względu na to, że przed przystąpieniem do „sakramentu” małżeństwa każdy kontrolowany przez zwierzchność duchowną „katolik” musi przejść przez „sakrament” pokuty, tj. wyspowiadać się i przynieść od spowiednika urzędowe zaświadczenie. Dla usunięcia podobnych wątpliwości stwierdzam, że pierwszy mój ślub odbył się w kościele ewangelicko-augsburskim w Warszawie, drugi zaś w kościele katolickim maltańskim w Petersburgu. Ówczesny proboszcz tego kościoła, dziś oczywiście już nieboszczyk, był na tyle delikatny, że się nas wcale nie pytał o spowiedź, pozostawiając widocznie załatwienie się z „sakramentami” przedwstępnymi naszemu sumieniu. Zadowolnił się przyzwoitym honorarium. Sądzę, że nawet ze stanowiska wyznaniowego postąpił on właściwiej aniżeli inni księża, wymagający koniecznie świadectwa o odbytej przed ślubem spowiedzi. Wymuszona bowiem ze względów formalnych obłudna spowiedź bez przekonania uważana jest podobno za „bluźnierstwo”, a nawet za „świętokradztwo”. Dzięki tolerancji ks. Martynoffa uniknęło się tego bądź co bądź ciężkiego „grzechu”. Prócz tego, jego uprzejmość dawała tacite (milcząco) w razie czego doskonały pretekst do unieważnienia zawartego bez poprzedniej spowiedzi małżeństwa; za tę uprzejmość należała mu się prawdziwa wdzięczność.

Już w szkole przygotowawczej do Szkoły Głównej (1861-1862) zaczęły się moje poważne wątpliwości religijne. Stopniowo coraz dalej odchodziłem od Kościoła. Wpływały na to: najprzód obserwowanie postępowania kleru, któremu przede wszystkim chodziło 0 władze i panowanie, o wyzysk i geszeft; po wtóre zaś sama narzucana wierzącym tradycja religijna, sprzeczna z rozumem i z poczuciem sprawiedliwości.

Po skończeniu Szkoły Głównej, mając lat 21, nie wierzyłem już nie tylko w „nieomylność” papieską i w „Niepokalane Poczęcie Najświętszej Maryi Panny”, nie tylko w nieśmiertelność duszy, ale nawet 
w Boga wyznaniowego; stałem się, jak to mówią, „ateuszem”, czyli „bezbożnikiem” i dotychczas być nim nie przestałem.

Pomimo to dzieci swoje chrzciłem, przez konwenans, a także dlatego, że mnie osobiście było to obojętne, a dla drugiej strony miało znaczenie, choćby dlatego, że niechrzczenie byłoby shocking. Zreszta nie należy zapominać o stronie prawnej: przy braku w Rosji stanu cywilnego wniesienie nowo narodzonego dziecka do ksiąg ludności nie mogło się obejść bez jakiegoś obrządku wyznaniowego.

Sam też figurowałem w spisach ludności jako wyznania rzymskokatolickiego. Moje „wyznanie paszportowe” było „rzymskokatolickie”. To samo wyznanie było wpisane w odpowiedniej rubryce mego formularnego spiska, czyli urzędowego „stanu służby”, Chcąc nie chcąc tedy, musiałem się godzić z tą sprzecznością między mymi przekonaniami, między moim światem wewnętrznym a między szyldem, pod którym byłem wniesiony do inwentarza poddanych z jednej strony Najjaśniejszego Cesarza Wszechrosji i „Króla Polskiego”, z drugiej zaś strony Jego Świętobliwości Papieża Rzymskiego.

Ulegając stale temu przymusowi, gdzie tylko mogłem i kiedy tylko mogłem, wyłamywałem się spod niego. Przy powtarzających się co kilka lat spisach ludności, dla celów statystyki na przeznaczonej dla mnie kartce w rubryce wyznaniowej wpisywałem albo bezwyznaniowy albo też żadnego. Podobnie przy sporządzaniu listy kandydatów na sędziów przysięgłych, kiedy w kancelarii Uniwersytetu Petersburskiego zapytywano mię o wyznanie, odpowiadałem albo nikakogo (żadnego), albo też swojego sobstwiennogo (swego wtasnego).

Od pełnienia w Petersburgu funkcji sędziego przysięłłego starałem się zawsze w ten lub ów sposób się wykręcić. Raz jednak nie udało mi się i musiałem się zjawić na posiedzenie sądu. Podczas odbierania przysiąg przez duchownego prawosławnego (katolickiego przy tym nie zaproszono), przewodniczący sądu zwrócił się do mnie z zapytaniem: Pan jest katolik, czy pan sie zgodzi przysiac przed naszym duchownym? Ja na to: Prosze uwolnić mie od wszelkiej przysiegi, ponieważ przysiega jest sprzeczna z mymi przekonaniami. Do mnie przyłączył się drugi przysięgły, profesor Instytutu Górniczego Jakowlew. Na wniosek prokuratora sąd po półtoragodzinnej naradzie obłożył nas grzywną dwudziestopięciorublową i wydalił z sali posiedzeń. 
Byliśmy bardzo zadowoleni, bo nie potrzebowaliśmy tracić czasu na zajęcie wątpliwej wartości moralnej. Ponieważ jednak postanowienie Sądu Okręgowego o ukaraniu nas grzywną było sprzeczne z obowiązującym wówczas prawem i praktyką sądową, więc zaskarżyłem je (a za mną mój wspóttowarzysz niedoli, prof. Jakowlew) przed Izbą Sądową i wygratem.

Nie przysięgałem też, występując parę razy jako świadek, a zamiast przysięgi składałem tylko uroczyste przyrzeczenie, że będę zeznawał prawdę.

W ostatnich latach,

przyjeżdżając do Łodzi na odczyty, bywałem zaraz na wstępie indagowany przez portiera hotelowego lub jego zastępcę, jakiego jestem wyznania. Odpowiadałem: Żadnego, jestem bezwyznaniowy. To nie mogło im się w głowie pomieścié, ale ja znowu nie mogłem podawać o sobie fałszywego świadectwa. Za drugim razem jeden z pomocników portiera chciał mię zaliczyé do wyznania „mojżeszowego”, bo oczywiście w jego oczach bezwyznaniowiec a Żyd to mniej więcej to samo; jeden i drugi należą do ludzi pośledniejszego gatunku. Ja jednak przeciw swej „mojżeszowości” stanowezo zaprotestowałem, podobnie jak przeciw swej „rzymskokatolickości”. (Tolerancja. Równouprawnienie. Wolnomyślicielstwo. Wyznanie paszportowe, Warszawa, 1923, str. 18-9).

Jeszcze w r. 1926, zwróciwszy się do policji ze skargą na piekarnię, z której pochodził nabyty przeze mnie chleb trujący, zostałem zapytany przez urzędnika spisującego protokót, między innymi także o to, jakiego jestem „wyznania”. Chociaż trudno zrozumieć, jaki może istnieć związek między moim „wyznaniem” a jakością chleba, to jednak, zapytany, odpowiedziałem: żadnego. Protokólista określił mię jako bezwyznaniowego.

Chociaż sam osobiście stoję poza wszelkimi wyznaniami sankcjonowanymi i legalizowanymi, to jednak, szanując godność człowieka i jego prawo być tym, czym chce, broniłem wierzących katolików przeciwko zamachom na nich ze strony prawosławnych, bronitem wierzących prawosławnych przeciwko katolikom, wierzących żydów przeciwko zamachom ze strony prawosławnych lub katolików. 
Każdy z tych wierzących chciał mieć swego boga wyznaniowego, nie zaś boga przemocą narzuconego. (Komu i na co potrzebny jest Bóg? „MW” 1925, nr 1, str. 11).

Dla tych ludzi ich religia, utożsamiana z wyznaniem, była jedynym elementem uszlachetniającym i uszczęśliwiającym, jedynym elementem wznoszącym ich w ich własnych oczach ponad poziom bydlęcia, i tylko brutalny cham z instynktami sadystycznymi mógł ich tego pozbawiać.

Ale co do mnie osobiście, to również tylko brutalny cham i cynik klerykalny może mi narzucać jakieś wyznanie, pomimo że jestem człowiekiem absolutnie pozawyznaniowym. Niestety, ja sam w stosunku do siebie samego grałem rolę takiego chama i cynika, nie zrywając z siebie sprzecznych z moimi przekonaniami pęt wyznaniowych. Był to jeden z objawów ludzkiej podłości i tchórzostwa.

Poczucie ohydy podobnego udawania rośnie stopniowo, coraz bardziej potężnieje i w końcu staje się nie do zniesienia, tak że nareszcie człowiek sobie powiada: Trzeba z tym raz skończyć.

\section{Moje współdziałanie z klerem katolickim}

Chociaż ze swych uczuć, zapatrywań i przekonań pozareligijnych nie robiłem tajemnicy, jednakże, pozostając oficjalnie w łonie Kościoła katolickiego, uchodziłem i byłem uważany za wiernego syna tego Kościoła, a przynajmniej za jego sympatyka.

Nawiasem mówiąc, w Rosji carskiej moje położenie pod tym względem było położeniem bez wyjścia. Ponieważ bezwyznaniowość i pozawyznaniowość były tam niedopuszczalne, a nawet uważane za występek, więc wystąpić z Kościoła katolickiego mogłem jedynie przez zmianę wyznania, tj. wstępując do jednego z innych kościołów chrześcijańskich: albo do jednego z wyznań protestanckich, albo też do Kościoła prawosławnego. To ostatnie byłoby krokiem, pozbawiającym wszelkiej swobody ruchów w tej dziedzinie: lasciate ogni speranza voi ch'entrate (porzućcie wszelką nadzieję wy, którzy tu wstępujecie); boć przecie próba zerwania z prawosławiem była karana w Rosji jako przestępstwo kryminalne. 
Niektórzy dostojnicy kościelni, chociaż z pewnością wiedzieli o moim indyferentyzmie wyznaniowym, zwracali się jednak do mnie z prośbami o załatwianie pewnych spraw poufnych.

Przez cały czas swego pobytu w Kazaniu (1875-1883) wcale nie uczęszczałem do kościoła i w ogóle stałem z dala od proboszcza miejscowego i jego otoczenia. Głównymi filarami Kościoła katolickiego, syndykami itp. byli Polacy z intendentury wojskowej lub z leśnictwa, z których niektórzy mieli procesy o rozmaite nadużycia pieniężne. (Ja sam w charakterze sędziego przysięgłego uczestniczyłem raz w sądzie nad takimi łapownikami i złodziejami, ale oczywiście bardzo pobożnymi i prawowiernymi katolikami). Pomimo to pod koniec mego tam pobytu pisał do mnie internowany w Jarosławiu (nie galicyjskim, ale rosyjskim) arcybiskup Feliński, prosząc o pośrednictwo w doręczaniu zapomóg dwóm wracającym z zesłania syberyjskiego, a przebywającym czasowo w Kazaniu księżom (jeden z nich był w domu dla obłąkanych). Dodał przy tym Feliński, że zwraca się do mnie, ponieważ do miejscowego proboszcza z powodu jego prowadzenia się nie ma zaufania. Wymieniliśmy ze sobą kilka listów w tej sprawie, a, o ile sobie przypominam, ksiądz arcybiskup przysłał na moje ręce dla swych pupilów kilkaset rubli.

W Dorpacie (1883-1893) zastałem słynnego księdza Pietkiewicza, proboszcza i wykładającego w uniwersytecie religię katolicką dla studentów katolików. Swoimi kazaniami niemieckimi, a nawet swymi mowami pogrzebowymi kapłan ten wzbudzał ogólną wesołość. Na pogrzebie jednego z nieboszczyków nawet jego rodzony syn, prorektor uniwersytetu Wikszemski, musiał się śmiać, a niektórzy z obecnych, dusząc się od śmiechu, dla niewywoływania zgorszenia pochowali się do rowu. Podczas zaś jednego ze swych kazań czcigodny ksiądz „profesor", polemizując z Darwinem, wskazał ręką na krucyfiks i zawołał: Ist das ein gekreuzigter Affe? (Czyż jest to ukrzyżowana matpa?). 0 ile było to z korzyścią dla Kościoła rzymskokatolickiego, niech rozstrzygnie łaskawy czytelnik.

Ponieważ opowiadano 0 tych występach pajacowskich szanownego duszpasterza, więc, chociaż nie miałem w ogóle zwyczaju chodzić do kościoła, to jednak pozwoliłem sobie parę razy pokazać się w kościele dorpackim dla wysłuchania humorystycznych popisów 
Pietkiewicza. Jeden raz zjawiłem się w białym letnim ubraniu. To dało asumpt złotoustemu kaznodziei do wypowiedzenia (oczywiście po niemiecku) następującego zwrotu: masz na sobie szate biata, a dusze masz czarna.

Podobnie w latach przedpowstaniowych, 1861 i 1862, uczęszczałem pilnie, jako na curiosa, na wygłaszane w katedrze św. Jana w Warszawie słynne „konferencje” polityczne ajentów walczącego wówezas z „podziemnym” „rządem narodowym” arcybiskupa Felińskiego, mianowicie na „konferencje” głośnego później także w Krakowie księdza Goliana, a następnie na „konferencje” młodziutkiego wówczas, ale bardzo uczonego i karmiącego słuchaczów cytatami z Objawienia Świętego Jana w oryginale greckim księdza Jażdżewskiego, późniejszego posła do sejmu pruskiego i, zdaje się, także do parlamentu niemieckiego. Przy wysluchiwaniu pikantnych ekspektoracji i wynurzeń tych obdarzonych bojowym temperamentem obrońców istniejącego porządku w „duchownej sukience” nie chodziło mi weale 0 ich budujący wpływ na moją religijność, ale tylko 0 odbieranie silnych wrażeń od ich wojowniczych i bądź co bądź prowokacyjnych występów.

Zastrzegam się przy tym, że, zestawiając warszawskich kaznodziejów z ich dorpackim kolegą, czynię to jedynie ze swego subiektywnego stanowiska jako widza i słuchacza. Obiektywnie rzecz ujmując, nie wolno stawiać na równi bardzo subtelnych i wysoce wykształconych pomocników margrabiego Wielopolskiego i arcybiskupa Felińskiego ze sprośnym Falstaffem dorpackim, chociaż według nauki Kościoła, ten sprośny Falstaff jako kapłan katolicki posiada nadprzyrodzoną moc zarówno „związywania” i „rozwiązywania” na ziemi tego, co automatycznie musiało się „związywać” i „rozwiązywać" w niebie, jako też moc przymusowej transsubstancjalizacji chleba i wina w ciało i krew bóstwa.

Kiedy po kilku latach mego pobytu w Dorpacie przedstawiciel uniwersytecki i syndyk kościoła katolickiego z ramienia uniwersytetu, profesor matematyki Helmling, wskutek staré z ks. Pietkiewiczem zrzekł się tej godności, uniwersytet, dzięki memu nominalnemu „katolicyzmowi”, postanowit powierzyć ją mnie. Również sam ks. Pietkiewicz prosił 0 zamianowanie mnie syndykiem. Liczył bowiem na 
to, że jako nieuczęszczający na nabożeństwa i w ogóle obojętny pod względem religijnym nie będę również wtrącał się do spraw zarządu majątkiem kościelnym i będę patrzył przez palce na jego, Pietkiewicza, nadużycia.

Ja jednak nieco inaczej zapatrywałem się na wzięte na siebie obowiązki wobec parafian. Choć mi się to weale nie uśmiechało, ustąpiłem naleganiom zarządu uniwersytetu i zostałem syndykiem kościoła katolickiego w Dorpacie. Biedny Pietkiewicz zawiódł się na mnie. Zaraz po objęciu urzędu przystąpitem do zaznajomienia się ze stanem majątku kościelnego i zażądałem od proboszcza zdania sprawy i pokazania mi ksiąg i rachunków. To usposobiło go względem mnie wrogo, tak że zaczął walczyé ze mną za pomocą oszczerstw i denuncjacji, wskazując władzom na mój „demoralizujący wpływ” na młodzież uniwersytecką.

Wkrótce spłonął drewniany budynek mieszczący w sobie obok „kościoła” na dole mieszkanie księdza i wynajmowane prywatne mieszkanie na pierwszym piętrze, także nad samym ołtarzem. Prowadząca śledztwo początkowe policja zakomunikowała mi poufnie, że wszelkie poszlaki naprowadzają ją na podejrzenie, że sprawcą pożaru był sam Pietkiewicz, ale że dla uniknięcia skandalu umorzyła sprawę. 0 ile to podejrzenie policji było usprawiedliwione, nie wiem. W każdym razie ciążyło ono nad czcigodnym kapłanem.

Pietkiewicz tryumfował, urządził składkę na odbudowę kościoła i plebanii w Dorpacie i miał zamiar zająć się sam tą odbudową. Niestety znalazł we mnie niepożądanego i nienawistnego kontrolera, który sprawdzał wszystkie wpływy i wydatki i nie pozwalał samemu odbudowcy na nadużycia. Pietkiewicz musiał przede wszystkim ułożyé plan odbudowy, który to plan powinien był być zatwierdzony przez konsystorz metropolitalny w Petersburgu. Ponieważ plan był sprzeczny z obowiązującym prawem kanonicznym (Pietkiewicz dla zwiększenia swoich dochodów chciał zatrzymać w nowym budynku wynajmowane mieszkanie prywatne, umieszczone na pierwszym piętrze nad ołtarzem), więc Konsystorz nie mógł tego zatwierdzić i zwrócił się do mnie, jako do syndyka, ażebym z całą energią bronił prawa przeciw jego gwałcicielowi. Otrzymałem w tej sprawie od kanoników i członków Konsystorza kilka listów, w których przy charakterystyce 
Pietkiewicza użyto bardzo ostrych wyrazów, w rodzaju tajdak, infamis itp. Ostatecznie musiał się on obejść smakiem i nie mógł przystąpić do odbudowy. Kościół murowany, oddzielony od plebanii, stanął już po jego śmierci.

Niepowodzenie doprowadzało go do wściekłości. W walce z Konsystorzem i ze mną nie przebierał w środkach. Mnie starał się szkodzić wszelkimi sposoby, oczerniając mię przed kuratorem, przed gubernatorem, przed naczelnikiem żandarmów. Z polecenia kuratora rektor wzywał mię do siebie i robił mi urzędowe wymówki. Sam kurator, przyjechawszy z Rygi i widząc się ze mną, czuł się jakoś nieswojo i nie dotykał wcale tej drażliwej sprawy.

Nareszcie pułkownik czy też jenerał żandarmów, wsławiony we wspomnieniach Kennana o Syberii okrutnik znęcający się nad „katorżnikami” w Karze, Nikolin, przeniesiony wówczas z Kary do Dorpatu, pod wpływem stałych „donosów” Pietkiewicza na moją „nieprawomyślność polityczną” wezwał mię do siebie i radził mi, ażebym się ukorzył przed Pietkiewiczem, bo inaczej mogę to srogo odpokutować. (Dodam tu, że w sam dzień mego wyjazdu z Juriewa, tj. z dawniejszego Dorpatu, do Krakowa, 25 czerwea r. 1893, żandarm Nikolin rozstał się z tym światem).

Nie zadawalniając się denuncjowaniem mnie przed władzami carskimi, szanowny mój antagonista starał się zgubić mię także w oczach „opinii publicznej”. Wydrukował w warszawskim „Przeglądzie Katolickim” korespondencję z Dorpatu, w której po prostu oskarżał mię o kradzież pieniędzy kościelnych. Chociaż unikam wszelkiego prawowania się, w danym jednak razie nie mogłem jakoś milczeć i wytoczyłem Pietkiewiczowi proces o oszczerstwo. Rozprawa sądowa odbyła się w Dorpacie na jednej z sesji wyjazdowych Sądu Okręgowego Ryskiego. Gdybym się był uparł, Pietkiewicz byłby skazany. Jednakże prezes sądu zaproponował nam pogodzenie się. Pietkiewicz chwycił się tego skwapliwie: Ja sogtasien (Zgadzam się). Na zwrócone do mnie pytanie przewodniczącego odpowiedziałem: Ja takize sie zgadzam, o ile ten pan odwota swoje oszczerstwo i przyzna sie do winy. Ja otkazywajus' i proszu izwinienija (Wyrzekam sie i prosze o przebaczenie) - odrzekł Pietkiewicz i wyciągnął do mnie rękę, której ja nie uścisnąłem i cofnąłem swoją. Kiedy zaś przewodniczący 
zapytał mię z pewnym wyrzutem: Czto $\dot{z} e$ wy eto tak (Dla czegóż pan

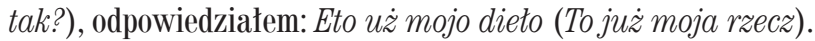

Wtedy nie byłem tak wyrozumiały i tolerancyjny jak dzisiaj. Dziś uścisnąłbym prawdopodobnie dłoń Pietkiewicza, bo jestem tego zdania, że największy nikczemnik i niegodziwiec zasługuje na litość i wyrozumiałość.

W miesiąc po tej rozprawie sądowej Pietkiewicz umarł. Zdaje się, że wojna ze mną silnie podkopała jego zdrowie i przyśpieszyła jego śmierć.

Kompromitując Kościół katolicki, ksiądz Pietkiewicz działał, może nawet pomimo woli, na korzyść wojującego z katolicyzmem prawosławia.

Na jednym z zebrań profesorskich duchowny prawosławny i profesor teologii prawosławnej Uniwersytetu Dorpackiego zwierzał mi się, że poprzedni kurator Kapustin, dla położenia końca skandalom związanym z osobą Pietkiewicza, chciał go usunąc z uniwersytetu i zapytywał o radę mego rozmówcę. Ten zaś, dbały o interesy prawosławia, zauważył: Pomitujtie, Michait Nikotajewicz, wied' my gtupieje jego nie najdiom, a eto dla nas wies'ma żetatielno (Zmiłuj się pan, Michale Mikołajewiczu, przecież my głupszego od niego nie znajdziemy, a to dla nas bardzo pożądane).

Tak więc brałem udział w bezkrwawej wojnie, w której po jednej stronie stałem ja wraz z arcybiskupem-metropolitą mohylewskim i wraz z Konsystorzem rzymskokatolickim, po drugiej zaś stronie sprzymierzeni: ksiądz Pietkiewicz, kurator okręgu naukowego, gubernator, Kościół prawosławny i żandarmi.

Na polu świeckim w walce o prawo i własność publiczną święciłem braterstwo broni z klerem katolickim.

\section{ROZDZIAŁ 3}

Moje dotychczasowe wystąpienia „przeciw Kościołowi”

Były to wystąpienia „przeciw Kościołowi” tylko ze stanowiska kleru, żądnego nieograniczonej władzy i dążącego w tym celu do tumanienia ludku bożego i do zyskiwania sobie poparcia u kierujących 
się obłudą i geszeftem władz świeckich zarówno cywilnych, jak i wojskowych. Jeżeli zaś nam chodzi o prawdziwą wiarę, 0 oczyszczenie Kościoła od parszywych owiec, to te moje wystąpienia byly wystąpieniami na korzyś́ć Kościoła.

Na dowód tego przytaczam niektóre ustępy z moich broszur i artykułów.

1.

Może i ja łudzę się co do stanu swego umysłu, ale zdaje mi się, że mam prawo uważać siebie i za zdecydowanego „ateusza” i za „wolnomyśliciela” jednocześnie. (Czy Ateizm $i$ „Myśl Wolna” wykluczaja sie nawzajem, „MW” 1924, nr 1, str. 9).

2.

Ateizm ma być negacją, twierdzi bowiem jakoby, że nie istnieje żadna istota wywierająca wpływ na bieg wszechświata. Zapytuję tedy: Skąd wiemy o tej „istocie”? Przecież dowiadujemy się zarówno o niej samej, jako też 0 wszelkich „objawieniach boskich”, 0 „naukach i wskazaniach bogów” itd. jedynie tylko od takich samych ludzi, jakimi my sami jesteśmy, od ludzi powtarzających te rzekome prawdy za swymi poprzednikami. Wiarę w tę , istotę" z przyległościami wpojono w nieodporny i niekrytyczny umysł dziecka i w ogóle słabogłowca, i to ma nam wystarczać. Należałoby żądać nie bezmyślnego powtarzania pacierza za panią matką, nie przysięgania na słowa mistrza (iurare in verba magistri), ale dowodów istotnie przekonywających. Takich dowodów nie ma i być nie może. Ani ,ateusz”, ani nikt inny nie może negować tego, czego istnienia nie da się racjonalnie udowodnić. Najprzód dowiedźcie, ale dowiedźcie rozumowo, nie zaś frazesami zabarwionymi poezją i sentymentem, a dopiero później pomówimy. Co więcej, ,ateusz” wcale nie neguje; on powiada jedynie, że nie wie, bo to jest niedostępne dla jego umysłu. (ib., str. 9).

3.

Jakim prawem ja, niebędący wcale „chrześcijaninem”, pozwoliłem sobie nadużyć prawa gościnności? (Mqudralin, „MW” 1924, nr 4 , str. 17). 
Śp. profesor Eligiusz Niewiadomski jako z jednej strony pracownik naukowy, z drugiej zaś nie tylko jako chrześcijanin i katolik wierzący i praktykujący, ale także jako „nieśmiertelny bohater” i „święty narodowy" posiadał wszelkie kwalifikacje do tego, ażeby korzystać w całej pełni z odpoczynku w Mądralinie. Mnie zaś jako „niedowiarkowi”, niewyznającemu żadnych dogmatów ani „chrześcijańskich”, ani jakichkolwiek bądź innych, wara od tego. (ib. 17-18).

Wykluczeni z niego (tj. z Mądralina) Żydzi, jak również karaici (karaimowie), muzułmanie, buddyści, szintoiści, szamaniści itd., w ogóle wszelcy ludzie uznający dogmaty tego lub owego wyznania są bliżsi „chrześcijaństwu” aniżeli absolutni bezwyznaniowcy, do jakich ja, niestety, należę. Jako człowiek całkowicie pozakościołowy, pozawyznaniowy i nieczujący potrzeby uznawania jakiegokolwiek bóstwa stworzonego na obraz i podobieństwo człowieka (a innego bóstwa nie ma i byé nie może), stoję od chrześcijaństwa bez porównania dalej aniżeli wszyscy wierzący jakiegokolwiek bądź gatunku i odmiany.

Oczywiście zarówno wszelcy „poszukiwacze boga” na własną rękę, jako też wszelcy wyznawcy „myśli karnej i zorganizowanej” mają daleko więcej prawa do korzystania z raju mądralińskiego aniżeli ja. Co więcej, ponieważ dogmaty polityczne i społeczne są kwiatkami z tego samego ogródka co i dogmaty wyznaniowe, a fanatyzm partyjny staje godnie obok fanatyzmu religijnego, więc wszelcy rewolucjoniści i kontrrewolucjoniści, wszelcy „komuniści”, „bolszewicy” itd., o ile są Polakami i pracownikami naukowymi, mogą z większym prawem upominać się o przytułek w Mądralinie aniżeli taki „niedowiarek” jak ja. Samo przez się się rozumie, że mają przede mną pierwszeństwo wszelcy obrządkowcy i komedianci w rodzaju „masonów”, czcicieli szatana, odprawiaczy czarnych mszy i innych tego rodzaju praktyk budujących. (ib. 18).

Chodzi nie o metrykę, nie o świadectwo policyjne, ale 0 to, czym jest człowiek we własnym przekonaniu; chodzi o jego istotę psychiczną, 0 jego indywidualność. Jestem zasadniczym wrogiem wszelkiego udawania, wszelkiej obłudy, wszelkiej „fałszywej fasji”. Nie cheę się podszywać pod to, co mi się zgodnie z prawdą nie należy.

Jak dawniej Polak udający Rosjanina i przyjmujący prawosławie dla dostania posady lub zyskania pewnych przywilejów, a dziś znowu jak Rosjanin podszywający się dla tych samych celów pod polskość, jest 
tak zwaną przez Włochów figura porca (postać świnska), czyli po polsku szubrawcem, tak samo ja byłbym we własnych oczach szubrawcem, gdybym przestawał być sobą, a stawał się jakąś podstawioną osobistością.

Jak prezydent Rzeczypospolitej Wojciechowski ani w aktach sprawy, ani we własnym sumieniu nie mógł znaleźć pobudek do ułaskawienia obłąkańca i fanatyka Niewiadomskiego, tak też ja ani we własnym sumieniu, ani w żadnych innych okolicznościach nie znalazłbym dla siebie usprawiedliwienia, gdybym sobie pozwolił korzystać z tego, co mi się pod żadnym pozorem nie należy.

Chrystus zabraniał rzucać szczeniętom chleb, przeznaczony dla dzieci. Gdybym ja za pomocą fałszywego świadectwa przeszwarcowywał się do Mądralina, byłbym właśnie jednym ze szczeniaków krzywdzących dzieci prawdziwie „chrześcijańskie”. Samozwańczo zabierałbym miejsce zasłużonemu, mającemu na to niezaprzeczone prawo

Ze względu na moje przekonania, dla mego trupa nie ma miejsca ani na Powązkach, ani na Bródnie, ani na Woli, ani na żadnym w ogóle cmentarzu wyznaniowym. Co najwyżej może on być pochowany częścią w słojach ze spirytusem, mieszczących pewne części ciała krajanego na stołach sekcyjnych, częścią zaś w dołach dla trupów krajanych. Jest to prosta konsekwencja, czyli następstwo moich żądań, wypowiedzianym w artykule Orientacje trupie. („MW”, 1924 nr 3; ib. str. 18-19).

4.

Mnie osobiście - a może także i niektórym innym osobom - Bóg jest całkiem niepotrzebny.

Ze strony rozumowej zwykły dotychczasowy Bóg, czy też zwykli dotychczasowi bogowie nie mogli być niczym innym, jak tylko ludźmi, ludźmi powiększonymi i rozrosłymi do olbrzymich rozmiarów, ale zawsze tylko ludźmi. Może to być nadczłowiek, ale zawsze tylko z właściwościami ludzkimi zarówno w dziedzinie intelektualnej, jak i moralnej. Nazwa, wyraz Bóg, bogowie, bóstwa i im podobne prowadzi do wytworzenia mitu teogonicznego (tj. objaśniającego powstanie boga), a wrodzony myśleniu ludzkiemu antropomorfizm obdarza Boga ciałem i duszą na podobieństwo człowieka i tylko człowieka. W ten sam 
mniej więcej sposób powstają pojedynczy bogowie politeistyczni, powstają anieli, anioły stróże, diabły kusiciele i inne istoty rzekomo nieziemskie. Boć człowiek nie może się nigdy wznieść ponad człowieka. Z jednej strony porządkuje przyrodę na wzór i podobieństwo własne, z drugiej zaś strony rozszerza siebie w sfery rzekomo nadziemskie i niebieskie również na wzór i podobieństwo własne.

Przyjęcie Boga jako hipotezy naukowej nie posuwa ani na krok naszej prawdziwej wiedzy o wszechświecie.

Uczuciowo również nie potrzebuję Boga. Widzę w świecie tyle zła, tyle niesprawiedliwości, tyle okrucieństw, że nie mogę odpowiedzialnością za te wszystkie ohydy obarczać nie tylko sprawiedliwego, ale także dobrotliwego i miłosiernego Ojca. Zwalanie win popełnianych przez bestię ludzką na stwórcę i opatrzność jest wprawdzie bardzo wygodne, ale zarazem bezmyślne i niemoralne. (Komu $i$ na co potrzebny jest Bóg?, „MW” 1925, nr 1, str. 13-14).

[...] modlić się do takiej istoty niepojętej i we wszystkich kierunkach nieskończonej, traktować ją za pan brat, przypuszczać, że to coś, napełniające i ogarniające świat cały, nigdzie i nigdy, tj. w przestrzeni i w czasie, ani się zaczynający, ani się kończący, że to coś może się interesować nędznym robakiem ludzkim na kuli ziemskiej, że może się stawać do niego podobnym, jest również objawem szalonej, potwornej, prawdziwie ludzkiej megalomanii.

Dla mnie zwykły „Bóg” jest tylko wyrazem, wyrazem wprawdzie wcielanym i antropomorfizowanym, wyrazem kojarzonym z najróżnorodniejszymi wyobrażeniami zjawisk z życia przyrody, społeczeństwa i psychiki ludzkiej, ale zawsze tylko wyrazem i niczym więcej.

Takie jest moje osobiste zapatrywanie, podzielane może przez niektóre inne osobniki dwunogie a bezskrzydłe. To mi jednak nie przeszkadza uznawać i szanować potrzebę Boga w innych ludziach, nie tylko niższych, ale także wyższych umysłowo, wyższych, głębszych i nierównie bardziej twórczych w dziedzinie wiedzy, nauki i sztuki.

Z całą żarliwością bronię ich prawa do wierzenia w Boga bądź to wyznaniowego, bądź też pozawyznaniowego, bronię ich zarówno przed zamachami ze strony nawracaczy obcowyznaniowych, jako też przed terrorem tępogłowych prawomyślnych „bezbożników”, lubują- 
cych się w dręczeniu i pastwieniu się dlatego tylko, że dręczenie i pastwienie się rozkosz im sprawia.

W zamian za to żądam uznania mej bezwyznanioweści czy też pozawyznaniowości, żądam uznania mego prawa do niewierzenia, tj. do abstynencji od marzeń sennych, przekraczających dosięgalność ograniczonego umysłu ludzkiego. (ib. 14).

5.

Pani przypuszcza, że ja wierze „w Istote wyższa, która my zwiemy Bogiem". Muszę temu stanowczo zaprzeczyé.

Wszystkie te wyrazy: wierzyć, istota, bóg, zwać itp. powstały w myśleniu ludzkim i przez obcowanie ludzi między sobą oraz przez obcowanie ludzi z otaczającą ich przyrodą. Wszelkie rzeczy, istoty, bóstwa itd. stworzył sobie człowiek na obraz i podobieństwo własne. „Bóg”, tak jak jest on ujmowany przez umyst ludzki, nie może byé niczym innym, jak tylko wyrazem, wyrazem, wprawdzie substancjalizowanym (rzeczownikowionym) i antropomorfizowanym (człowieczonym), ale tylko wyrazem.

Świat pozaludzki oczywiście istnieje, ale jest on wielkością z myśleniem ludzkim całkiem niewspółmierną. Szkoda czasu i energii umysłowej na zagłębianie się w to, czego zgłębić niepodobna.

Swój pogląd na te sprawy rozwinąłem w artykule Коти i na co potrzebny jest Bóg? („MW” 1925, nr 1, zwłaszcza str. 13-4).

Ja mogę być przekonanym, mogę sądzié, mogę przypuszczać, może mi się zdawać, mogę mniemać, mogę wierzyć komuś, a nawet grzeszyć pod tym względem łatwowiernością i naiwnością, ale wierzyé w kogo lub w co dziś już nie potrafię. Wierzenie w cokolwiek bądź, a więc także w jakiekolwiek bądź bóstwa, należy u mnie do przeszłości, jest to dla mnie überwundener Standpunkt (stanowisko, którego się pozbytem).

Wierzę innym, że wierzą w Boga, ale sam nie wierzę ani w Boga, ani w człowieka.

Nie jest to jednak „nihilizm” prowadzący do bezwzględnej anarchii intelektualnej i moralnej. Przeciwnie, pomimo tylu rozczarowań i dowodów nikczemności ludzkiej, jestem na tyle naiwny, że widzę możność oparcia moralności na drzemiących w duszy ludzkiej pierwiastkach współczucia, solidarności społecznej i rozumnego, na daleką metę obli- 
czonego egoizmu, moralności, niepotrzebującej straszaków, zwanych czy to bogami, czy też diabłami.

Dotychczasowa moralność oparta na wierze w Boga nie zapobiega takim zbrodniom, jak wojny, jak „kara śmierci”, jak „niewolnictwo” i inne tym podobne ohydy. (Wierzyć w kogo lub w co, a wierzyć komu. Odpowiedź pani Helenie Mycielskiej, „WM” 1925, nr 2, str. 75-76).

Obchodzę się całkowicie bez Boga, wywodząc wszystkie swe postulaty i ideały etyczne z ukrytych w duszy ludzkiej pierwiastków współczucia i solidarności rodzaju ludzkiego. (Z niewydrukowanej odpowiedzi redakcyjnej p. A. Wojcieszakowi w Poznaniu).

6.

Jestem na tyle naiwny, po prostu praktycznie głupi, że nie mogę udawać wierzącego, kiedy nim nie jestem. Nie chcę być ani farbowanym lisem, ani też osobistością podstawioną. W „Myśli Wolnej” z r. 1924 w artykule Madralin wyłuszczyłem, że, nie wierząc w żadne dogmaty ani katolickie, ani żydowskie, ani żadne inne, będąc bezwzględnym pozawyznaniowcem, popełniłbym czyn zdrożny, a nawet nikczemny, gdybym chciał korzystać z dobrodziejstw przysługujących jedynie prawowiernym chrześcijanom. Prawdziwemu chrześcijaninowi nierównie bliższy jest żyd wierzący, muzułmanin wierzący, buddysta wierzący, bezwyznaniowiec wierzący aniżeli taki absolutny pozawyznaniowiec, taki „metateusz" (tj. ani czciciel tego lub owego bóstwa, ani panteista, ani deista, ani „poszukiwacz boga”, ani ateusz) jak ja. Podobnie do uczestniczenia w towarzystwie chrześcijańskim zwalczającym antysemityzm mają nierównie większe niż ja prawo wszyscy inni wierzący, czy to chrzczeni, czy też niechrzczeni, czy to obrzezani, czy też nieobrzezani, czy to należący do wyznań gromadnych, czy też głęboko religijni na własną rękę. (Towarzystwo Opieki nad... Żydami, „Życie Wolne” 1927, nr 1, str. 10).

$$
* * *
$$

W „Myśli Wolnej” 1925, nr 1, str. 1-4 w artykule „Od Redakcji” dałem określenie zadań „myśli wolnej”, tak ja je pojmuję.

Za moje „antykatolickie” artykuły Konkordat na zimno („MW” 1925, nr 4, str. 150-152), Tryumf przemocy, tchórzostwa i obtudy („̇̇y- 
cie Wolne” 1927, nr 4, str. 12-13), za cały szereg innych artykułów, za moje broszury, Myśli nieoportunistyczne (Kraków 1898), Tolerancja, równouprawnienie, wolnomyślicielstwo, wyznanie paszportowe (Warszawa 1923), Wyznaniowe $i$ pozawyznaniowe śluby $i$ rozwody (Z powodu oczekiwanej reformy prawa matzenskiego) (Warszawa 1926) i inne, za to, że jako niekatolik jestem przeciw zawieszaniu krzyżów w audytoriach i zakładach uniwersyteckich, za to, że jako niekatolik stoję za absolutny rozdział kościołów od państwa, za to, że zarówno okólnik p. ministra Bartla o przymusie pełnienia obrządków wyznaniowych przez uczniów szkół średnich, jako też odmówienie bezwyznaniowej p. Irenie Stróżeckiej, pomimo że zdała wszystkie egzaminy z wyjątkiem egzaminu z religii, wydania świadectwa dojrzałości nie tylko przez Min. WRiOP, ale także przez Najwyższy Trybunał Administracyjny (!!), uważam za szkodliwe dla państwa, dla społeczeństwa i dla samego Kościoła (p. mój artykuł Śladami Rosji carskiej „Życie Wolne” $1927 \mathrm{nr}$ 2, str. 9-10), za wszystkie powyżej przytoczone wyjątki z moich broszur i artykułów, jednym słowem za wszelkie podobne oświadczenia i wystąpienia publiczne „przeciw Kościołowi”, jako za zuchwale objawy krnąbrności i nieposłuszeństwa zwierzchności kościelnej, Kościół Święty, matka nasza, powinien był sam wyrzucié mię ze swego łona.

0 ile Kościół dba 0 swoją godność, o czystość swego zespołu, o ile jest uczciwy, powinien sam usuwać obłudników i zdrajców, a zatrzymywać w swym łonie tylko prawdziwie wierzących i wiernych. Powinno mu chodzić nie o liczbę rzekomych wyznawców, ale o czystość wiary szczerych i nieobłudnych zwolenników. Inaczej grozi mu martwota, zgnilizna, rozkład i upadek.

\section{ROZDZIAŁ 4}

Czy ja, będąc takim jakim jestem, mam prawo uchodzić za katolika. Ogólna moja charakterystyka pod względem wyznaniowości i religijności

Nie jestem nie tylko katolikiem, nie tylko w ogóle chrześcijaninem, nie tylko jakimkolwiek bądź wyznaniowcem, nie tylko człowiekiem osobiście religijnym, ale w ogóle stoję poza wszelkim wyznaniem, poza 
wszelką religią czy to stadową, zbiorową, czy też jednostkową, indywidualną, a to zarówno ze strony zewnętrznej, powierzchownej, jako też ze strony wewnętrznej, ze strony uczuć, myśli i przekonań.

Ze strony zewnętrznej nie jestem praktykantem wyznaniowym i nigdy, ze względu na „opinię publiczną” i dla zyskania sobie łaski zwierzchników nie udawałem praktykanta. Po ostatniej w życiu spowiedzi nigdy nie odmawiałem żadnych modlitw, nie uczęszczałem na nabożeństwa kościelne, ani razu się nie spowiadałem, nie całowałem biskupów w rękę, nawet samego nieomylnego nie pocałowałbym w pantofel. 0 posłuszeństwie matce naszej Kościołowi Świętemu mowy u mnie byé nie może; nigdy się na to nie zgodzę, ażeby nie tylko Macoch częstochowski, Pietkiewicz dorpacki, carosławny biskup Żyliński wileński, ale nawet najporządniejszy i najuczciwszy ksiądz mógł kierować moim postępowaniem i dawać mi wskazówki moralności.

Co zaś do strony wewnętrznej, to, o ile siebie pamiętam, po ostatniej spowiedzi w r. 1861 nigdy nie znajdowałem się w nastroju pobożnym i dewocyjnym, nigdy nie odczuwałem tęsknoty religijnej i pędu mistycznego do jednoczenia się i zlewania się z „bóstwem”. Gdybym za pomocą modlitwy chciał nawiązywać styczność z Panem nad Pany, pretensja do obcowania z tak wielkim panem byłaby z mej strony dowodem potwornej megalomanii. Może jest to swoiste kalectwo, próżnia i pustka w rodzaju braku słuchu muzykalnego, w rodzaju przytępienia i ostatecznego zamarcia zmysłów: słuchu, wzroku, smaku, powonienia, dotyku. Być może. Na to nie ma rady. Pozwolę sobie jednak zauważyć, że w gminach górskich, w których wszyscy mieszkańcy mają wole pod gardłem, człowiek pozbawiony tej koniecznej ozdoby uważany jest za kalekę.

Obce mi są wszelkie wierzenia osobiste, obcą mi jest wiara w jakiekolwiek dogmaty zarówno wyznaniowe, jak i polityczno-partyjne. Nie uznaję żadnych sakramentów. Nie uznaję, rzecz oczywista, żadnych objawień i proroctw, wiedząc, że wszelkie tzw. objawienia i proroctwa dostają się od człowieka do człowieka za pomocą wmawiania, sugestii, a pierwotne ich źródło sprowadza się do „natchnień” i zboczeń umystowych, do atrofii i hipertrofii, stanowiących przedmiot badania psychiatrów.

Co zaś do bóstw i w ogóle co do sił rządzących rzekomo światem, to przede wszystkim są to językowo ochrzczone uogólnienia i scałkowa- 
nia (zintegrowania) mnóstwa wrażeń i wyobrażeń powstających w nas dzięki oddziaływaniu na nas przyrody i społeczeństwa. Nie powinniśmy też zapominać, że w stosunku do ogółu wszechświata znajdujemy się jak w studni, nie mogąc wyjrzeć po za jej krawędzie, że nasze zmysły mogą odbierać wrażenia tylko w nader szczupłych granicach, poza którymi znajduje się nieskończona ilość objawów zmysłom naszym niedostępnych. Do stwierdzenia zjawisk pozazmysłowych prowadzą nas ścisłe badania naukowe. Dostępne naszemu uchu szmery i tony mieszczą się tylko między pewnymi minimami i maksymami wibracji, czyli drgań. W dziedzinie optyki odkryto promienie ultrafioletowe, oku naszemu niedostępne. W dziedzinie akustyki działają fale pozadźwiękowe (ondes ultrasonores). Podobnie w dziedzinie zjawisk i oddziaływań psychicznych, w sferze intelektu ludzkiego (i zwierzęcego) musimy przyjąc we wszechświecie nieskończoną ilość zjawisk, leżących poza jak najdalej idącą rozszerzalnością i rozciągalnością intelektu.

Przypuszczać, że poza człowiekiem i zwierzęciem nie ma w świecie pierwiastku psychicznego, byłoby objawem szalonej megalomanii, czyli obłędu wielkości. Coś takiego musi być, ale co to jest, nie wiem. Jestem na to za głupi, zanadto ograniczony. I śmiem twierdzić, że inni ludzie są również za głupi i za ograniczeni i nigdy nie potrafią zrozumieć owego wszechświatowego pierwiastku psychicznego. (Komu i na co potrzebny jest Bóg?, „MW” 1925, nr 1, str. 14).

To, co się opowiada o tym świecie tajemniczym, niedostępnym umysłowi ludzkiemu, to, co się wmawia w siebie i w innych, są to senne widziadła i bajdurzenia bądź to powtarzane z dobrą wiarą, bądź też wyzyskiwane dla tumanienia łatwowiernych.

Z mnóstwa kwestii, których traktowanie przeze mnie jest sprzeczne z nauką Kościoła i - ponieważ wyznanie biorę na serio, głęboko, przekonaniowo, nie zaś policyjnie, metrycznie (nie od metra, ale od metryki) i paszportowo - nie pozwala mi uchodzić za katolika, zastanowię się tu nieco obszerniej tylko nad trzema: nad kwestią „sprawiedliwości boskiej”, nad kwestią „nieśmiertelności duszy” i nad kwestią wmawianej w Boga próżności i żądzy sławy. 


\section{Sprawiedliwość}

Czy dopuszczenie przez Stwóreę do grzechu pierworodnego i karanie za niego wszystkich ludzi jako potomków dwojga grzeszników daje się pogodzić z ludzkim poczuciem sprawiedliwości? Czy w ogóle odpowiedzialność zbiorowa bądź to całych zrzeszeń ludzkich, bądź też w nieskończonym następstwie pokoleń nie jest nonsensem urągającym zdrowemu rozsądkowi normalnego, niezwyrodniałego człowieka? Wprawdzie rozmaici tyrani i degeneraci znajdują sadystyezną rozkosz w uprawianiu ohydnej vendetty $\mathrm{i}$ w prześladowaniu ludzi pojedynezych za przynależnośé do znienawidzonego zbiorowiska ludzkiego, przy czym grają główną rolę uogólnienia myślenia językowego. Nikczemne bydlę ludzkie wmawia w stworzonego na obraz i podobieństwo własne Boga swe zbrodnicze i sadystyczne popędy, nazywając jednocześnie tego swego Boga nie tylko Sprawiedliwym, ale także Miłosiernym. Człowiek, który by sobie pozwalał na coś podobnego, byłby uznany za zbrodniarza, ale Bóg jest czczony właśnie za to, że jest Bogiem zemsty.

Dzięki umężczyźnieniu naszego myślenia i naszej wyznaniowości, dzięki upłciowieniu naszego Olimpu, każemy Bogu byé mężczyzną. Tylko mężczyzną może być również zastępea Boga na ziemi, Namiestnik Chrystusowy. Tylko mężczyznami mogą być działający w imieniu boskim kapłani. Bóstwa i pótbóstwa płci żeńskiej grają podrzędną, choć nieraz bardzo zaszezytną rolę. Być niebianką nie jest to to samo, co byé bogiem czy to jednopostaciowym, czy też wielopostaciowym. Być mniszką, choćby nawet westalką, nie jest to to samo, co być kapłanem. A proszę mi odpowiedzieć, tylko szczerze i uczciwie, czy podobne upośledzenie płci żeńskiej można uważać za sprawiedliwe, zwłaszcza wobec tego, że kobiety są główną podporą Kościoła. To upośledzenie kobiet jest przeniesieniem do Królestwa Niebieskiego naszych ziemskich i ludzkich urządzeń i zwyczajów, aleć chyba tych naszych zwyczajów i obyczajów nie możemy uważać za doskonałe, a podobno w państwie Wszechmocnego i Wszechwiedzącego ma panować bezwzględna doskonałość.

Czy ze stanowiska ludzkiego, ze stanowiska sprawiedliwości, odczuwanej po ludzku, tj. nie zbrodniczo, ale uczciwie po ludzku, można uważać za sprawiedliwe skazywanie jedynie kobiet na cierpienia i męki połączone z rodzeniem dzieci? 
Czy sprawiedliwym jest skazywanie niektórych niemowląt na bezustanne choroby i cierpienia, bez jednej chwili odpoczynku, bez jednej chwili radości w ciągu ich kilkotygodniowego lub nawet tylko kilkodniowego istnienia? Przyszły biedactwa na świat jedynie po to, ażeby bez przerwy cierpieć i w cierpieniach skonać.

Przypomnijmy też sobie niemowlęta, duszone przez własne matki lub usłużne akuszerki, przez uprawiające tę specjalność swoiste opiekunki i wychowawezynie.

Uprzytomnijmy sobie Ewę Pobratymską z Dziejów grzechu Żeromskiego, która rodzi swoje niemowlę w wychodku, każąc niewinnemu stworzeniu dusić się w otchłani nieczystości kloacznych. To także ma być objawem sprawiedliwości opatrznościowej. A przecież takie dziecko jako niechrzczone jest skazane po śmierci na męki wiekuiste.

Jeżeli chodzi o powiększanie grona aniołków, mających sławić Pana Zastępów, to można by przecież uciec się do jakiegoś innego, mniej okrutnego sposobu ich fabrykacji.

Niemowlęta zmarłe bez chrztu, na równi z „poganami” i wszystkimi niekatolikami są skazane na potępienie wieczne. Czy zgadza się to ze sprawiedliwością wmawianą w stworzonego na obraz i podobieństwo ludzkie Stwórcę? Taką sprawiedliwość spod ciemnej gwiazdy każe uprawiać swemu dobrotliwemu 0jcu marne i plugawe bydlę ludzkie.

Niektóre ludy „dzikie” czczą zwierzęta jako bóstwa. Tak np. Gilacy w Syberii Wschodniej ubóstwiają psów, a na dowód czci zarzynają je i pożerają, chcąc wraz z ich mięsem i krwią wessać w siebie ich boską moc i potęgę. Oddając pięknym za nadobne, zwierzęta pożerają ludzi, ale już bez przymieszki czci boskiej. Również ludożercy, pożerając misjonarza, nie kierują się pobudką okazania mu w ten sposób czci boskiej.

[ ${ }^{1}$ Przed kilku laty w Bolszewii okrutny głód zmusił ludzi do pożerania „bliźnich”, a nawet własnych dzieci. Pewien ojciec, zarżnąwszy swego syna kilkoletniego i sporządziwszy z niego pieczeń, posłał niezjedzoną jeszcze córeczkę do sąsiadki po musztardę, bo był przyzwyczajony

$1 \quad$ Fragment umieszczony w nawiasach kwadratowych nie znalazł się w przedruku tej broszury w t. VI Dziet wybranych (Warszawa 1983). W przypisie objaśnienie: Wydawca dokonat koniecznego skrótu. 
do spożywania pieczeni z musztardą. Czy to także mieści się w ramach rozlanej we Wszechświecie i wmawianej w Opatrzność Sprawiedliwości?]

Czy przy sprawiedliwości praktykowanej przez miłosierne bóstwa możliwe by było istnienie chorób, śmierci przedwczesnej, nędzy, niewoli wszelakiej, hańbiącej człowieczeństwo prostytucji itd., itd?

Czy Ojciec kochający naprawdę swoje dzieci, a będący zarazem Wszechmocnym, mógłby je skazywać na wzajemną nienawiść, na wzajemne tępienie się i prześladowanie, na popełnianie wszelakich zbrodni pojedynczych i zbiorowych, na prowadzenie wojen, na orgie rewolucji itd., itd.? Czy 0jciec kochający a wszechmocny nie urządziłby swym umiłowanym życia w sposób uniemożliwiający wszelkie cierpienia, wszelką nędzę i zbrodnię?

Czy Ojciec kochający swoje córki, będąc wszechmocnym, mógłby skazywać je na hańbę prostytucji?

Czy Ojciec wszechmocny, mający choćby ździebełko miłości ku swym dzieciom będącym rodzicami na ziemi, mógłby te swoje umiłowane dzieci pogrążać w bezbrzeżnej rozpaczy po stracie ich dzieci duszonych w sposób równie bezmyślny, jak okrutny?

Oczywiście takie pytania można stawiać, jedynie przyjmując sprawiedliwość we Wszechświecie i wmawiając ją w Boga osobistego, stworzonego na obraz i podobieństwo ludzkie. Stają się zaś one całkiem bezprzedmiotowymi, jeżeli staniemy na stanowisku, że sprawiedliwość jest wytworem ludzkim i że nie ma podstawy do szukania jej we wszechświecie, niewspółmiernym z psychiką ludzką, we wszechświecie, którym „rządzą” „ściśle określone” „prawa”, ale nigdy ani „sprawiedliwość”, ani „litość”, ani „miłosierdzie”.

Wspaniałą ilustracją „miłości” Ojca niebieskiego do jego ziemskich dzieci są wiwisekcje urządzane przezeń nad biblijnym Hiobem, coś w rodzaju wiwisekcji, o której z dumą opowiadał mi fizjolog i patolog rosyjski, Wiktor Wasiljewicz Paszutin, profesor Uniwersytetu Kazańskiego, a następnie profesor i naczelnik (rektor) Akademii MedykoChirurgicznej w Petersburgu.

Chciał zbadać eksperymentalnie duszę psa. Nabył więc psa, obłaskawił go; pies się do niego przywiązał i lizał mu ręce. Wtedy Paszu- 
tin oblał psa ukropem. Z psa zlazła skóra, ale pies lizał ręce swego oprawcy. Wtedy Paszutin po raz drugi oblał psa ukropem. Można sobie wystawić jego (psa, a nie Paszutina) męczarnie. A pomimo to nie przestawał lizać ręki kapłana nauki. Jeszcze raz oblano psa ukropem, ale tu już nie wytrzymał i wyzionął ducha. Dopóki jednak żył, lizał rękę swego pana. Był „do zgonu wierny jak sobaka”. A może rozumiał, że cierpi i poświęca życie dla dobra nauki. (Rehabilitacja psubrata i sukinsyna, „MW” 1924, nr 8, str. 9)1 .

Chociaż główną pobudką do tego zarówno głupiego, jak okrutnego „eksperymentu” był cyniczny sadyzm „badacza”, to jednak „badacz” mógł się zasłaniać pretekstem, że chce się czegoś dowiedzieć. Gdyby był wszechwiedzącym jak Jehowa, to nawet Paszutin powstrzymałby się chyba od okrucieństwa bezcelowego. Chcąc więc zrozumieć wiwisekcje urządzane przez Jehowę nad Hiobem, nie pozostawałoby chyba nic innego, jak przypuścić, że z jednej strony wszechmoc i wszechwiedza, z drugiej zaś strony wszechsprawiedliwość, wszechmiłosierdzie i wszechmiłość godzą się doskonale z mściwością bezgraniczną i z sadyzmem bezgranicznym.

1 Do tego wątku, nawiązał M. Zdziechowski w swojej książce 0 okrucienstwie (Warszawa 1928), polemizując z wnioskami wyciągniętymi przez Baudouina: Prof. Baudouin de Courtenay ogtosit w r. 1927, pt. Mój stosunek do Kościota, rzecz straszna przez swoja nieustraszona, totstojowska, niecofajaca się przed żadnymi konsekwencjami logicznośc. [...] Rozprawe swoja prof. Baudouin de Courtenay byt taskaw mnie przystać. Dziękujac, odpowiedziatem mu, że zgadzam sie na wiele rzeczy, które tam sa, tylko inny wyciagam wniosek, podyktowany Galileuszowskim e pur si muove. Wprawdzie moje e pur si muove ma podstawe swoja nie w nauce, lecz $w$ potrzebie serca, niemniej jednak jest mocne. Rozmyślania nad zagadnieniem religii doprowadzaty mnie zawsze $i$ tak samo utwierdzaja dzis we wniosku, że wiara jest gwattem zadanym rozumowi; zbyt gtośno to, co sie na świecie dzieje, świadczy, krzyczy przeciw Bogu. Silniejsza jednak nad to wszystko jest tęsknota za Pięknem przedwiecznym, absolutnym, którego blaski pociecha sa nam i otucha wżyciu; głód rzeczy wiecznych, gtód Boga, w którym tęsknota nasza ma ujście, staje sie fundamentem wiary. Religia zaś nie daje sie pomyśleć bez spoteczności religijnej, bez Kościota, Kościót bez wspólnej modlitwy i kultu. 
Dlaczegoż tedy wmawiacie w swego Ojca Wszechmocnego, a zarazem nie tylko sprawiedliwego, ale także miłosiernego, takie okrucieństwa, jakie z człowieka na ziemi robiłyby potwora, wyrodka i zbrodniarza?

Wprawdzie pocieszają nas rozkoszami czekającymi nas rzekomo po śmierci. Ci bądź to naiwni, bądź też obłudni pocieszyciele powinni by chyba zrozumieć, że największe rozkosze pozagrobowe nie mogą zrównoważyé i zatrzeć wspomnienia o mękach doznanych za życia na tym świecie.

Nie szukajmy więc Sprawiedliwości poza sobą, nie wmawiajmy jej w stworzone przez nas bóstwa. Jak to wspaniale wykazał Maeterlinck (Le temple enseveli), sprawiedliwości obiektywnej, sprawiedliwości poza psychiką ludzką nie ma ani w przyrodzie, ani w wymyślonych przez człowieka istotach ludzkich i nadludzkich. Sprawiedliwość mieści się bez reszty w duszy ludzkiej i zwierzęcej zarówno odosobnionej, jako też współżyjącej z innymi duszami, ale i tutaj była dotychczas i pozostanie na zawsze ideałem niedoścignionym.

\section{Nieśmiertelność duszy ludzkiej (i zwierzęcej)}

Przyjmowanie nieśmiertelności duszy i wiara w nią jest objawem potwornej megalomanii nędznych robaków ziemskich. Urodziło się to, ponieważ miało rodziców, i wydaje mu się, że powinno żyć wiecznie. Że jednak podświadomie odczuwa się cały absurd podobnej pretensji, więc owa niby-wiara w nieśmiertelność duszy wygląda bardzo podejrzanie. Gdyby ludzie naprawdę wierzyli we własną nieśmiertelność, nie baliby się śmierci, ale, przeciwnie, wyglądaliby z upragnieniem uwolnienia od cierpień na tym padole płaczu i zastąpienia ich rozkoszami związanymi z nieustającym wpatrywaniem się w oblicze Pana nad Pany.

Według mego niekompetentnego rozumienia przymus nieśmiertelności bytby największą karą, jaką byłby w stanie wymyślić wyrafinowany okrutnik. Byłoby to prawdziwe piekło przeżywane czy to w piekle, czy w czyśćcu, czy też w samym raju. Urzędowe patentowane „piekło” stałoby się zbytecznym. Wystarezyłaby prosta nieśmiertelność. Bo czyż może byé większe piekło, jak stała, nieustająca, nigdy się niekończąca świadomość krzywd wyrządzonych przez nas innym i doznanych przez 
nas samych za życia? Dosyć chyba tego, że ta przeklęta świadomość zatruwa nam życie za życia, że dzięki piekielnemu bólowi przez nią sprawianemu mamy wstręt do życia, tęsknimy do Nirwany, do absolutnego niebytu, aż tu nagle pocieszają nas zapewnieniem, że ta męka istnienia przeciągnie się za grobem w nieskończoność. Jakąż straszną rzeczą byłaby ta wieczna, nigdy niekończąca się świadomość przeżytej nędzy, świadomość krzywd wyrządzonych i doznanych!

Z głębin udręczonego serca wznosi się okrzyk pani L. Ackermann w jej wierszu Les malheuereux z cyklu Poesies philosophiques:

Laisse nous oublier que nous avons vé c u!

(Pozwól nam zapomnieć, żeśmy żyli!).

Nasze istnienie osobiste jest buntem przeciw jedności wszechświata; za tę zbrodnię jesteśmy skazani na śmierć ${ }^{1}$, na śmierć prawdziwą, na śmierć absolutną.

I to jest prawdziwa łaska.

Śmierć porównywamy ze snem. Śmierć nazywamy snem wiecznym. A o śnie prawdziwym, o śnie głębokim myślimy dlatego z taką błogością, że pozwala on nam zapominać o troskach i zgryzotach życia.

Pieśń ludowa nazywa sen stodkim. Litewskie saldżei miegoti, serbski sladki sanak.

W zastosowaniu do śmierci Havliczek-Borovsky powiada: Vierzim, že velmi tiežce jest umrziti, nic sladsziho pak, neż umrlym byti (Wierzę, że bardzo ciężko jest umrzeć, nic słodszego jednak niż być umarłym).

Humorystycznie traktuje tę sprawę poeta publicysta wiedeński Oskar Blumenthal w czworowierszu Auf mein eigenes Grab (na mój własny grób):

Nun bin ich ledig aller Erdenplag,

Mich kann kein Glück, kein Hoffen mehr betrügen,

Und wenn einst kommt der Auferstehungstag,

Ich bleibe liegen.

(Oto jestem wolny od wszelkich dolegliwości ziemskich, nie może mnie już oszukać żadne szczęście, żadna nadzieja; a jeżeli kiedyś nadejdzie dzień zmartwychwstania, ja się nie poruszę).

1 Własny aforyzm [przyp. BdeC]. 
Innego rodzaju „nieśmiertelność”, nieśmiertelność w cudzysłowie, nieśmiertelność ludzi głośnych i sławnych, których imiona żyją w pamięci pokoleń i są przekazywane przez tak zwaną historię, jest również objawem megalomanii, i to megalomanii obustronnej: $\mathrm{z}$ jednej strony subiekt dwunogi szumiący i zwracający na siebie uwage czy to swymi zbrodniami lub cnotami, czy też swymi czynami lub utworami pragnie żyć „nieśmiertelnie” w pamięci takich samych dwunogich, z drugiej zaś strony ci inni dwunodzy w swej zarozumiałości sądzą, że mogą swym wybrańcom zapewnić nieśmiertelność.

Ja czuje nieśmiertelność, nieśmiertelność tworze (Adam Mickiewicz).

Marna to nieśmiertelność, nieśmiertelność zapewniana marniakom przez takich samych marniaków. Nieśmiertelność prochów i pyłów, nieśmiertelność pluskiew, wszy i innego robactwa. Niech z ziemią jako z miejscem pobytu robactwa ludzkiego stanie się jakaś radykalna a zbawcza dla rodu Kainów katastrofa, a wszystkie owe wielogębne nieśmiertelności rozwieją się i znikną na wieczne czasy.

Jeżeli uznajemy nieśmiertelność duszy ludzkiej, jesteśmy obowiązani uznać także nieśmiertelność duszy zwierzęcej. Co więcej, mierząc prawo do nieśmiertelności cnotami i zasługami osobnika, powinniśmy się zgodzić, że pies, górujący swą wiernością i przywiązaniem, ma więcej prawa do nieśmiertelności niż nikczemne, okrutne i znęcające się nad psem bydlę ludzkie. Ale sądzę, że i pies zaprotestowałby przeciw swej nieśmiertelności związanej z pamięcią o krzywdach doznanych, a więc równającej się piekłu.

A jak też stoi sprawa z dziećmi-embrionami, które nie mogły się urodzić i udusiły się w łonie matki? Czy one także mają być nieśmiertelne? Bo co do niemowląt, które przeżyły kilka tygodni lub nawet kilka dni w nieustających cierpieniach, to sprawa jest jasna i rozstrzygnięta: skazane są one na nieśmiertelność i na wieczną pamięć takiej strasznej krzywdy.

Ale uspokójmy się. Nie ma obawy. Nie grozi nam nieśmiertelność. Do tego wystarczy trochę zastanowienia się i pomyślenia na zimno, 
bez ulegania emocjom, bez ulegania irracjonalnym tęsknotom i bezpodstawnym nadziejom.

1. Bez ciała nie ma warunków dla istnienia psychy, dla istnienia tego, co nazywamy duszą ludzką i zwierzęcą. Co się urodziło, musi mieć też koniec. Jak mówi Mefistofel w Fauście Goethego:

Denn alles was entsteht

ist wert, dass es zu grunde geht;

drum besser wäres, wenn nichts entstünde.

(Bo wszystko, co powstaje, zasługuje na to, ażeby ginęło; dlatego byłoby lepiej, gdyby nic nie powstawało.)

2. Wszystko, co ludzkie, jest skończone zarówno w przestrzeni, jak i w czasie. Wszelka wieczność i w ogóle wszelka nieskończoność znajduje się poza sferą ludzkiego bytowania i ludzkiego ścisłego myślenia. Jest ona nie do uchwycenia i nie do przeżycia. Można o niej marzyć i bajdurzyć, ale myśleć niepodobna. Przy tym nieskończoność w jedną stronę związana jest ze swym przeciwstawieniem w druga stronę. Nieskończoność przyszłościowa jest niemożliwa bez nieskończoności przeszłościowej. Nieśmiertelność jednostkowej duszy ludzkiej i zwierzęcej byłaby nieskończonością jedynie przyszłościową, a więc w logicznym myśleniu ludzkim niedopuszczalną.

\section{Wmawianie w Boga próżności i żądzy sławy}

Modląc się czy to pojedynczo, czy też zbiorowo, czy to w domu na osobności, czy też w świątyniach, czy to na pamięé, czy też z książek do nabożeństwa, klepiąc różańce, godzinki, nowenny, litanie, pacierze za pokutę, uprawiając żebraninę w stosunku do Boga, pochlebiając mu, wmawiając w niego litość i miłość do „dzieci”, traktujemy tego Boga jak sobie równego, obarczonego wadami i ułomnościami ludzkimi. Tak też być powinno, bo Bóg osobowy, stworzony na obraz i podobieństwo człowieka, może się wprawdzie różnić od człowieka ilościowo, ale nigdy jakościowo. Bóg-człowiek jest wrażliwy na pochlebstwa, ma oczy i uszy, lubuje się widokiem tłumów modlących się, ustępuje natrętnym i wrzaskliwym prośbom zbiorowym, jednym słowem przypomina łaskawego władcę ziemskiego, monarchę lub wpływowego dygnitarza. 
Opanowanemu żądzą sławy nie wystarczają chóry dwunogich chwalców na ziemi; dodaje do nich chóry anielskie i archanielskie z rozmaitymi „szarżami” oficerskimi i jeneralskimi. Chwalcie Pana, zastępy.

Na wzór sykstyńskiej kapelli papieskiej w przybytku Boga na niebiesiech rozbrzmiewają dźwięczne głosy aniołków, aniołów i archaniołów.

Ja ze swej strony uważam to za obmawianie Boga, za oszczerstwo. Nie wierzę w próżność Istoty Najwyższej, w jej kabotynizm, w jej żądzę sławy u robaków ziemskich i wybrańców niebieskich.

Kilka uwag 0 wszechwiedzy i wszechwładzy kleru

Dotychczas dla prawdziwie wierzących ksiądz jako spadkobierca znachora jest ostateczną wyrocznią w sprawach higieny, w sprawach pożywienia, w sprawach życia osobistego i społecznego. To uznawanie uniwersalności kapłańskiej i uprawnienia kapłanów do wyrokowania we wszelkich kwestiach spornych pochodzi z epoki niezróżniczkowania specjalności, z epoki spełniania wszelkich funkcji społecznych przez jedną i tę samą osobę. Z dzisiejszym poglądem na ustrój społeczeństwa nie da się to w żaden sposób pogodzić.

W stosunku do Boga ksiądz jest obdarzony niesłychaną mocą. Jest on potężniejszy od Boga. Kiedy bowiem przy odprawianiu Mszy Świętej rozkazuje Bogu Wszechmogącemu wcielić się w opłatek i w wino, Bóg nie może mu odmówić i musi się wcielić. A takim nadboskim potentatem, potężniejszym od samego Boga (coś w rodzaju przewodniczącego Trójcy Świętej), jest każdy osobnik odznaczony sakramentem kapłaństwa, a więc także wzmiankowany powyżej Pietkiewicz dorpacki, Macoch częstochowski i tylu, tylu innych sąsiadujących z kryminałem.

Dla wiernych synów Kościoła jest to całkiem w porządku. Ja zaś, 0 ile wmyślę się i wczuję się w duszę prawdziwie wierzącego i dbałego o czystość wyznaniową, podobne uznawanie potęgi „sług bożych” muszę uważać za bluźnierstwo.

Inny dowód megalomanii hierarchów kościelnych. Oto papież mianuje błogosławionych i świętych, awansuje z niższej rangi „bło- 
gosławionego” na wyższą rangę „świętego”, a Bóg nie może się temu sprzeciwić. Jest on bowiem tylko ściśle ograniczonym monarchą konstytucyjnym, a papież autokratycznym, samowładnym premierem i ministrem wojny.

Nie tylko papież, ale także niżsi dostojnicy, urzędnicy i funkcjonariusze kościelni udzielają odpustów na tyle i tyle dni, a Bóg, stosując się do ich rozporządzeń, musi przenosić delikwentów z czyśćca do raju. Bo do autonomicznego piekła rządzonego przez Lucyferów, Mefistofelesów, Belzebubów, biesów, szatanów, diabłów i cały zastęp piekielnej Czrezwyczajki, nawet Bogu Wszechmogącemu wtrącać się nie wolno. Odpusty w mniejszej lub większej porcji nie mogą się odnosić do piekła.

A ten kler wszechwładny, rządzący ziemią i niebem, uprawia otwarcie obłudę. Głoszone przezeń zawodowo przykazanie nie zabijaj w życiu praktycznym do niczego go nie obowiązuje. Nie walczy on ani z wojną, ani z „karą śmierci”, z tą chroniczną zbrodnią legalizowaną, błogosławi ręce bratobójcze, odbiera od żołnierzy przysięgi bluźniercze. Co więcej, sam skazuje na śmieré, sam torturuje, sam pali na stosie (przynajmniej praktykował to niezbyt dawno). Rozsmakowując szóste przykazanie, nie przeciwstawia się ani prostytucji, ani innym objawom niewoli płciowej.

Na podobieństwo własne zaleca obłudę swym owieczkom i barankom. Byle nie występować otwarcie, byle nie manifestować, byle udawać pobożność i w razie potrzeby uczestniczyć w uroczystych urzędowych obchodach i nabożeństwach; poza tym można sobie wierzyć lub nie wierzyć. Na praktykowanie obłudy skazują już dzieci szkolne, sekundowani usłużnie przez panów ministrów i władze szkolne.

Może dla braku przykazania „nie kłam, nie oszukuj, nie fałszuj, nie uprawiaj obłudy” nie tylko nie zabraniają uprawiania różnych „fałszywych fasji”, ale sami w nich uczestniczą. Komu zaś „fałszywa fasja” wydaje się grzechem, ten bez trudności dostaje rozgrzeszenie z niemą zgodą na kontynuowanie grzechu: da capo al fine. Klerowi miłe są fałsz i obłuda, bo sam je gorliwie uprawia.

Degenerat, fanatyk i szaleniec Eligiusz Niewiadomski, morderca prezydenta Narutowicza, został uznany przez znaczną część kleru katolickiego w Polsce za bohatera, męczennika i nieomalże za świętego. 
Odprawiano na jego intencję demonstracyjne nabożeństwa i z głębi duszy aprobowano jego czyn patriotyczny, dokonany, można powiedzieć, pod skrzydłem opiekuńczym Kościoła. Trzeba oddać sprawiedliwość klerowi innych wyznań w Polsce. 0 ile wiem, ani ewangelicy, ani prawosławni, ani Żydzi nie pochwalali czynu Niewiadomskiego. W danym wypadku przykazanie nie zabijaj traktowali bardziej na serio.

Niedawno jeden (a może i niejeden) ksiądz na kresach wschodnich dowodził na kazaniu, że obecny rząd zaprowadzi nowe porządki, że nie wolno będzie brać ślubów w kościele, a że śluby będą dawali Żydzi. Są to dalsze konsekwencje z twierdzenia dostojników kościelnych, że śluby cywilne wymyślili bolszewicy.

W Wadowicach istnieje i działa zakon księży Pallotynów, protegowany przez kurie biskupie, a ziejący nienawiścią, zatruwający serca i ogłupiający słabe głowy ludzkie. Wpadł mi w ręce wydany przez tych trucicieli i podżegaczy Kalendarz Królowej Apostotów, Nakładem Kongregacji misyjnej ks. ks. Pallotynów w Wadowicach, 1927.

W Kalendarzu tym przeważają artykuły, pełne bądź to nieuctwa, bądź też umyślnego fałszowania historii, a uprawiające agitację pogromową. Pozwalam sobie z artykułu Żyd (szp. 105-114) przytoczyć następujące ustępy, zawierające $\mathrm{w}$ sobie bądź to prawdziwe lub też rzekome cytaty z dzieł i okolicznościowych wypowiedzeń różnych znakomitości, nawet Woltera, bądź też samodzielne wywody szanownego autora:

1. Rozrzuceni po całym globie, a jednak ściśle z sobą złączeni Żydzi - to istoty podstępne, niebezpieczne i wrogo usposobione do reszty ludzi. Nie wolno patrzeć obojętnie, gdy podnoszą oni łeb do góry, lecz natychmiast wybijać ich tak, jak wybija się jadowite żmije. W przeciwnym razie kąsać będą - a ukąszenie żydowskie jest śmiertelne. (szp. 105).

2. Nie rozumiem, czemu dotąd nie wytępiono doszczętnie tych jadowitych wężów. Wszak zabija się drapieżne zwierzęta pożerające ludzi. A kimże jest Żyd jak nie ludożercą. (szp. 105). 
3. Ta zadra w żywych organizmach innych narodowości wywołuje choroby, gnicie i śmierć. Wśród narodów europejskich żydostwo jest elementem obcym, wnoszącym jedynie rozkład.

Z trychinami i bakcylami nikt nie zawiera paktów - ani też usiłuje przerobić drogą wychowania, lecz stara się jak najprędzej wytępić. Przede wszystkim odebrałbym Żydom to, co stanowi ich siłe - mianowicie pieniądz. (szp. 106-107).

4. Należałoby Żydów pozbawić praw cywilnych i stworzyć dla nich prawa specjalne. (szp. 107).

5. Zjawisko zrozumiałe: Żyd wzgardził pracą fizyczną. U siebie - na własnej ziemi - i pod własnym niebem nie chciał on ani orać, ani siać - ani przy fabrycznym młocie, kowadle, warsztacie tkackim. Porzucił własną ziemię, jął się włóczęgostwa z najmocniejszym postanowieniem unikania wszelkiej roboty - a życia cudzym wysiłkiem, cudzym potem - na cudzy koszt. Jak wesz, pluskwa, szarańcza, zarazek tyfusu, bakcyl cholery i dżumy. (szp. 107).

6. Ale gdy z zarośli wychodzi na cię tygrys, czołga grzechotnik, a z mętnych ujść Missisipi aligator - wolno ci strzelać: siła na siłę, zręczność za zręczność - twoja śmieré lub jego. Nie usypia cię on swym człowieczeństwem - nie powołuje na dyplom uniwersytecki - na przykazania boskie - na etykę i prawo - nie żąda, byś - w imię miłości bliźniego - rzucił na ziemię lub jemu oddał strzelbę, kłonicę, widły czy też oszczep - i własnoręcznie bez wszelkiej obrony wytoczył dlań swą krew.

Aby nie żebrać - lecz bez pracy na cudzy rachunek dostatnio żyć musiał on wykląć wszelką uczciwość i cnotę - a nadto rozgrzeszyć całą masę „wybranego ludu” z kradzieży, fałszerstwa, rabunku, krzywoprzysięstwa, podpaleń, lichwy, kontrabandy tudzież zabójstwa. Jego księgi święte świadczą, iż uczynił to bez wahań. Więcej nawet: zażądał równouprawnienia i „tolerancji”. Jakiego równouprawnienia i „tolerancji” - nie mówi. Jego księgi święte dały mu wszelkie prawa do takich nawet potworności, o jakich pomyśleć nie wolno chrześcijaninowi, stworzył on więc dla siebie najwyższą tolerancję - nie ma bowiem zbrodni, której by nie uznawał. Zatem przez „równouprawnienie” i „tolerancję” rozumieć należy żydowskie ultimatum do całkowitego poddania się świata chrześcijańskiego żydowskiej nawale i abdykuj, chrześcijaninie - wyrzekaj się wiary, narodowości, ziemi, nieba - oddaj coś nagromadził - spal Pismo święte, obal Papiestwo, przebuduj kościoły na synagogi, za- 
puść pejsy, włóż „cycełe” - i pójdź na żydowskiego parobka. (szp. 108).

7. Szanujmy ohydne zbrodnie wyłuszczone w cytowanych protokółach ${ }^{1}$ : więc gwałtem, siłą, podstępem, obłudą, korupcją pieniężną, oszustwem, zdradą, rozbojem, zwyradnianiem przeciwnika, osłabieniem jego rozumu, oduczaniem od rozważań, niszczeniem wpływu rodziny oraz jej wartości wychowawczej, mąceniem stosunków narodowych, przemęczeniem, ogłupianiem, demoralizacją, głodem, nędzą i szczepieniem chorób. Oto jakim jest arsenał narodu żydowskiego do walki z innymi narodami - oto środki, którymi powalono taką wielką potęgę, jaką była Rosja.

Lecz samego arsenału za mało - potrzeba ludzi. Któż to zająć się ma wprowadzeniem programu żydowskiego w czyn - kogo wyznaczył Zyd do zwyradniania gojów, osłabiania ich rozumu, oduczania od rozważań, niszczenia wpływu rodziny, mącenia stosunków narodowych, ogłupiania, demoralizacji - komu wypadła rola ogładzania tudzież szczepienia wśród narodów nieżydowskich takich plag jak choroby? Odpowiedź krótka: pozostawiając w swym ręku naczelne kierownictwo, Żyd gojom powierzył misję wytępienia gojów. Nieprawdopodobne, a jednak prawdziwe. Cóż znaczyłoby 447 Żydziaków w Rosji, gdyby dawniejsi kadeci tudzież partie wywrotowe nie podważyły ustroju państwowego, nie zdemoralizowały cara - a dziki mużyk rosyjski nie sformował czerwonej armii do wytępienia rosyjskiej arystokracji, rosyjskiego ziemiaństwa, rosyjskiego duchowieństwa i rosyjskiej inteligencji narodowej - gdyby pod naczelną komendą żydowskich komisarzy nie palił, zabijał, niszczył - pozostawiając za sobą cmentarze i zgliszcza - zgliszcza i cmentarze? (szp. 109-110).

8. Nie od dziś - i nie od wezoraj żydostwo demoralizowało sferę inteligencką, wszelkimi sposobami wciąganą do lóż masońskich. (szp. 110).

9. Nikczemnym jest Żyd. Ale po stokroć, po tysiąckroć nikczemniejszym jest goj wysługujący się w lożach masońskich Żydowi. Tamten niszczy państwa cudze, by na ruinach wznosić gmach państwowości własnej. Ten zaś dla pieniędzy lub stanowiska sztylety wbija w serce 0jezyzny własnej, by jej trupa w prezencie zanieść na szabas Judejczykowi. Jeżeli Żyd jest wampirem - na określenie goja

1 Mowa o Protokotach Mędrców Syjonu. 
w służbie żydowskiej słownictwo nie zna odpowiedniego wyrazu. (szp. 113).

10. Całe legie zdrajców własnego kraju, duszami i mózgiem zaprzedanych judaizmowi, dziesiątkami lat popełniają nieustającą zbrodnię zaprzaństwa narodowego ambasadorów, prezesów najwyższych instytucji, delegatów kraju na międzynarodowe kongresy, sędziów wojennych, profesorów, wydawców, redaktorów. Całe to zbiegowisko opryszków najgorszego gatunku wyciska na masach narodowych odpowiednie piętno, kieruje tak zwaną „opinią”, a co najważniejsza - decyduje. Zmasonizowana reprezentantka płci „nadobnej” rozsiadła się w ministerium wyznań i oświecenia publicznego, ściga uczciwych Polaków, rozdaje stanowiska dyrektorów szkół chłopcom z kilkuklasowym wykształceniem, wydziera najzasłużeńszym Polakom szkoły przy pomocy zamaskowanych oraz bezmaskich prowokatorów z Wiednia i Petersburga, by poprzez szumowiny rosyjskie odzierać dziatwę polską z wszelakich świętości. W ciągu czterech lat niepodległości rozdarło żydostwo kraj, zniszczyło jego pieniądz, skupiło kopalnie i fabryki w akcjach, spółkach tudzież obligacjach - i pociągnęło naród cały na krawędź nieuniknionej zagłady. To samo co w Rosji - i tak samo jak w Rosji. (szp. 114).

Oto kilka kwiatków uszczkniętych w ogródku wielebnych „ojców” czy też „braciszków”, występujących w imieniu Jezusa i jego matki, „królowej apostołów”, którzy oboje byli Żydami, urodzonymi w ziemi żydowskiej i wywodzącymi się z rodu króla żydowskiego Dawida.

A nie zapominajmy, że Kalendarze Królowej Apostotów rozchodzą się tysiącami pomiędzy ludem wchłaniającym w siebie tę zatrutą strawe.

Sprzedający trujące pożywienie dla ciała bywają karani; handlarzom trucizną dla duszy, o ile są protegowani przez władze duchowne, przy życzliwej neutralności władz świeckich, uchodzi to na sucho. Im wolno bezkarnie szczuć, podjudzać i jątrzyć ${ }^{1}$.

1 Zob. także J. B a ud ou in de Courtenay, Czarny terror, „Robotnik” 1927, nr 199. 
W ogóle daje się stwierdzić, że powszechność kościelna jest w znacznej części bandą bądź to zaślepionych fanatyków, bądź też cynicznych obłudników i oszustów. Szczerze wierzących, a zarazem niesfanatyzowanych jest tylko nieznaczny procent. Obłudnicy duchowni i obłudnicy świeccy podają sobie ręce, oddają sobie wzajemne usługi, zawierają konkordaty i inne umowy w celu ujarzmienia i ogłupiania mas biernych i posłusznych. Rozczulająca wzajemna asekuracja. Ręka rękę myje, noga nogę wspiera. 0 godność ludzką, o wolność sumień nikt się nie troszczy; chodzi przede wszystkim 0 władzę, panowanie i wyzysk.

Z klerem czy to fanatycznym, czy też obłudnym nic mnie wiązać nie może. Więc już z tego powodu - choćbym nawet był religijnie usposobiony i tęsknił do jakiegoś bóstwa - nie mógłbym być katolikiem. A cóż dopiero będąc chemicznie oczyszczonym z wszelkiej religijności, z wszelkich tęsknot do Boga, z wszelkiego mistycyzmu.

Dla mnóstwa ludzi Bóg osobisty, tj. wyobrażenie stworzone przez człowieka na obraz i podobieństwo człowieka, jest przedmiotem wiary. Dla mnie to różnopostaciowe, jednopostaciowe i wielopostaciowe wyobrażenie, zależnie od czasu, od umiejscowienia na kuli ziemskiej i od indywidualności ludzkiej, wraz ze wszystkimi innymi związanymi z nim wyobrażeniami jako też wraz z przeżyciami religijnymi, z nastrojami modlitewnymi, z wierzeniami osobistymi i gromadnymi, z wiarą w objawienie itd., stanowi jedynie ciekawy przedmiot badania. Istnieją też takie nauki i dyscypliny naukowe, jak religioznawstwo, historia kultury i umysłowości ludzkiej (i zwierzęcej), socjologia, psychologia, psychiatria poświęcona badaniu zboczeń umysłowych itp.

\section{Wolnomyślicielstwo}

Swój pogląd na myśl ludzką wolną od wszelkich dogmatów, przesądów i zabobonów, czyli na tak zwane wolnomyślicielstwo w prawdziwym znaczeniu tego wyrazu, wyłożyłem m.in. w artykule Od Redakcji w „Myśli Wolnej” z r. 1925 nr 1, str. 1-4. Przytaczam tu dosłownie główne ustępy tego artykułu: 
Myśl wolna to myśl badaweza, myśl naukowa. Jedynie tylko oczyszczona od wszelkich przesądów i narzuconych wierzeń myśl wolna wydziera tajemnice przyrodzie, przyrodzie w najobszerniejszym znaczeniu tego wyrazu, a więc nie tylko przyrodzie tzw. materialnej, ale także psychicznej, duchowej. Specjalności myślicielskie, czyli „nauki” wychodzące z założeń dogmatycznych, są sprzeczne z myślą wolną i niezależną, a więc nie są naukami.

W wydzieraniu tajemnic przyrodzie myśl wolna, myśl naukowa nie może się wznieść ponad człowieka. Najwspanialsza, najdalej sięgająca hipoteza może być ujęta tylko po ludzku. „Nadludzkość”, a raczej pozaludzkość jest przy tym stanowezo wykluczona.

Myśl wolna opiera się na logice, na myśleniu logicznym. W zastosowaniu do etyki, do wspótżycia ludzi, myślenie logiczne prowadzi do poczucia sprawiedliwości, do uznania równouprawnienia we wszystkich kierunkach, równouprawnienia różniczkowanego warunkami indywidualnymi.

Myśl wolna porusza wszystkie tematy, roztrząsa wszystkie kwestie, a czyni to sine ira et studio, tj. bezstronnie, bez namiętności, bez uprzedzeń czy to osobistych, czy też zbiorowych. Myśl wolna wystrzega się działania na wyobraźnię, kierowania się afektami i emocjami, podniecania namiętności. Przy roztrząsaniu kwestii spornych prawdziwy wolnomyśliciel chowa do szuflady i zamyka na klucz wszelkie swoje wstręty i pociągi, wszelkie swoje antypatie i sympatie.

Przez zawiłe zagadnienia intelektualne i etyczne prowadzą wolnomyśliciela czysty rozum i, w sferze etyki, wzgląd na dobro ogólne, które ze swej strony rozkłada się na dobro jednostek należących do danego zbiorowiska społecznego, a na wyższym stopniu do całej ludzkości.

Jeżeli szczęście danego człowieka zależy od ignorancji, od pozostawania w dziecinnej wierze, wolnomyśliciel nie jest na tyle okrutnym, ażeby burzyć to szczęście, wyrywając z duszy błogie i uszczęśliwiające iluzje.

Ze względu na szczęście ludzi wolnomyśliciel stoi tymczasem na gruncie danego ustroju politycznego i społecznego. Kieruje nim przy tym nie ubóstwienie molocha państwowości, nie bzdurne powiedzenie, że wszelka wtadza pochodzi od Boga, ale ta jasna i zdobyta 
przez doświadczenie prawda, że wszelki przewrót, wszelka wojna, wszelka rewolucja związane są z tępieniem mnóstwa istnień ludzkich, z waleniem w gruzy dobytków kultury, a więc prowadzą do klęski i nieszczęścia niezliczonej rzeszy cichych i maluczkich, poniewieranych przez wszechświatowych krwawych „ideowców” i zbrodniarzy.

Wobec tego spokojna myśl wolna, myśl krytyczna, myśl indywidualna, niepozwalająca okiełznać się zaciekłym i na nic się nieoglądającym doktrynerom, nie uprawia żadnego szczucia, nie głosi konieczności poświęcenia milionów ludzi współczesnych dla chimery raju mającego uszczęśliwić przyszłe, mniej lub więcej odległe pokolenia.

Prawdziwy wolnomyśliciel nie może być tłumicielem żadnej myśli ludzkiej i nikomu ust nie knebluje. Nie patrzy on ani na twarz ludzką jak na pysk do nakładania kagańca, ani też na ręce ludzkie jak na piszczele do pętania i zakuwania w kajdany. Nie uważa on żadnej myśli, 0 ile jest tylko myślą, za objaw zbrodniczy. Nie zionie nienawiścią i nie wpada we wściekłość na widok „heretyka”. Nie woła ani „na stos!”, ani „pod topór kata!”, ani „pod ścianę!”.

Wolnomyśliciel nie może się uważać za nieomylnego. Pozostawia on uprawianie tego procederu zawodoweom i ochotnikom, poczynając od urzędowo uznanego nieomylnika, rezydującego w Rzymie, a kończąc niezliczoną zgrają pospolitych głupców nieomylnych.

Zgodnie z tym „Myśl Wolna” będzie i nadal starannie unikała wszelkich napaści osobistych, wszelkich wyzwisk, wszelkich obelg. W arsenale polemicznym „Myśli Wolnej” brak pocisków, utkanych czy to z „rozmiękczenia mózgu”, czy też z pomawiania przeciwnika ideowego o rozmaite bezeceństwa z zakresu kryminalistyki, niemoralności i antypaństwowości, wypominane zwykle w celach denuncjatorskich.

Co innego jednak, jeżeli chodzi nie o przekonania i argumenty, ale 0 akty gwałtu i przemocy, o rozmaite nadużycia i objawy „dyktatury”, o zamachy na wolność sumienia, 0 wyrafinowane ogłupianie podwładnych i 0 wszelkie inne tego rodzaju czyny praktykowane przez inkwizytorów, przez bandytów, przez obrońców wiary $i$ ojczyzny i innych tp. W takich razach „Myśl Wolna” uważa za swój obowiązek 
występować otwarcie i stawać w obronie wszystkich ofiar przemocy, wyzysku i fanatyzmu.

Poza tym „Myśl Wolna” uznaje zasadę bezwzględnej wyrozumiałości i tolerancji. Chce ona być wolną trybuną dla myśli wolnej we wszystkich kierunkach. Pod warunkiem przestrzegania przyzwoitości i powściągliwości w wyrażeniach zapraszamy do wymiany myśli wszystkich ludzi szczerych i nieobłudnych, od jezuitów i rabinów do komunistów włącznie.

Możemy się różnić diametralnie w zdaniach, ale obok tego możemy się szanować i dążyć do wzajemnego przekonywania się drogą rozumową, bez obelg i bez zacietrzewienia.

Zestawiam tę daną przeze mnie definicję myśli wolnej z obowiązującymi każdego prawdziwego, niefarbowanego katolika dogmatami i zapytuję: czy, będąc wyznawcą i głosicielem myśli wolnej, mogę być jednocześnie katolikiem? A nie jest to kwestia gustu. Z jednej strony prawdziwa indywidualna myśl wolna, z drugiej zaś zdogmatyzowane i sfanatyzowane myślenie, „myśl karna i zorganizowana”, będąca podstawą judaizmu, katolicyzmu, komunizmu i wszelkich innych wyznań opartych na pochodzeniu, na przymusie partyjnym itd.

Kto ma takie jak ja wyznanie wiary, „wyznanie pozawyznaniowe”, nie może być ani katolikiem, ani żadnym innym wyznaniowcem, a chcąc być człowiekiem uczciwym, nie może udawać wyznaniowea i uchodzić za niego w oczach innych ludzi.

\section{ROZDZIAŁ 5}

Moje zerwanie z Kościołem nie tylko de facto, ale także de iure.

Pobudki do otwartego wystąpienia z Kościoła

Przytaczam niektóre swoje oświadczenia, obowiązujące mię do wyciągania z nich koniecznych konsekwencji.

Stosując swój sposób traktowania spraw wyznaniowych, uważałbym za właściwe radzić wszystkim Żydom, którzy przestali wierzyé w nakazy swego wyznania, ażeby, 0 ile nie są przekonani 0 wyższości czy to katolicyzmu, czy też jakiego innego wyznania, nie zmieniali urzę- 
dowo wyznania na wyznanie, ale tylko ażeby po prostu występowali z gminy wyznaniowej żydowskiej i ogłaszali się za bezwyznaniowych. Taką samą radę daję ludziom, figurującym w spisach ludności jako katolicy lub też jacy inni wyznaniowcy. Jeżeli przestali wierzyé, jeżeli nie uznają dogmatów swego rzekomego wyznania i jeżeli nie chcą uprawiać kłamstwa i obłudy, powinni otwarcie wykreślić się z listy wyznaniowców i przejść do bezwyznaniowców. Należy mieć odwagę do walki 0 swe najświętsze prawa. (Przechrzta $i$ neofityzm z przylegtościami, „MW” 1924, nr 12, str. 9).

Do tego lub owego zrzeszenia wyznaniowego człowiek może należeć szczerze i uczciwie tylko o tyle, o ile sam w głębi duszy uznaje siebie za wyznającego zasady tego wyznania. Jeżeli zaś żadne z istniejących wyznań go nie zadawalnia, ma on nie tylko prawo, ale także obowiązek wobec państwa i współobywateli ogłosić się za bezwyznaniowego. Udając takiego lub innego wyznaniowca, a nie będąc nim w samej rzeczy, człowiek staje się publicznym kłamcą, obłudnikiem i oszustem.

Ludzie zmuszający nas do udawania, ludzie nieuznający bezwyznaniowości, ludzie niechcący między innymi uprawnić statutu gminy bezwyznaniowej, każą obywatelom wolnej Rzeczypospolitej być kłamcami, obłudnikami i oszustami. (Zagajenie wiecu protestacyjnego z dn. 1 czerwca r. 1924, „MW” 1924, nr 7, str. 8).

Jeżeli takie rady i wskazówki daję innym, powinienem także sam się do nich stosować. Pozwólcie i mnie nie być kłamcą, obłudnikiem i oszustem.

Sprawę tę traktuję poważnie, na serio, a nie konwenansowo, nie salonowo. Przecież zaszczytna nazwa katolika, rycerza Marii, czciciela Boga w Trójcy Świętej Jedynego chyba do czegoś obowiązuje. Noblesse oblige. Przynależność do tego lub owego wyznania nie może być stawiana na równi z przeznaczaniem przez władze wojskowe bezwolnych rekrutów do różnej broni. Jak są przymusowi infanterzyści, kawalerzyści, artylerzyści, tak też mają być przymusowe chrześniaki, obrzezaki, jednopostaciowcy, dwupostaciowcy i inni niewolnicy przymusu wyznaniowego. Rekrut pod batem i pod groźbą kary składa zbrodniczą kainową przysięgę; nad niewinnym i nieświadomym niemowlęciem popełnia się gwałt chrztu, obrzezania i innych tego rodzaju obrządków. 
Przestrzegana przez ewangelików konfirmacja ma byé świadomym potwierdzeniem przez dane indywiduum popełnionego na nim w niemowlęctwie gwałtu. Oczywiście sprowadza się to zwykle do pustej formalności.

Jeżeli brać rzeczy nie powierzchownie, nie konwenansowo, nie formalnie, nie policyjnie, ale zgodnie z prawdą, to ja wystąpiłem z Kościoła katolickiego przed przeszło sześćdziesięciu (60) laty. Moje milczenie 0 tym fakcie, a więc obłudne, kłamliwe, fałszywe przyznawanie się do katolicyzmu, dające mi możność korzystania z przywilejów, które mi się nie należały, było po prostu nieuczciwością i podłością.

Wprawdzie moje dotychczasowe występy publiczne świadczyły dostatecznie 0 moim faktycznym wystąpieniu z Kościoła; ale do takich junackich występów ludzie są przyzwyczajeni i uważają je za rodzaj fanaberii i swoistego sportu. Objaśnia się je błazeńską donkiszoterią, żakowskim popisywaniem się, brawurą, megalomanią, tym, że świerzbi język, a ręka pisząca jest mu posłuszna. I istotnie, jeśli się trochę zastanowić i pomyśleć spokojnie, można zapytać: czy warto tracić czas i energię umysłową na wynurzenia, które nikomu nie są potrzebne i pozostają głosem rozlegającym się w pustyni?

Obecnie mogę zapewnić, że przy zgłoszeniu mego urzędowego wystąpienia z powszechności rzymskokatolickiej powodują mną nie próżność, nie megalomania, ale nakazy mojej etyki osobistej, między którymi jedno z czołowych miejse zajmuje niezawarte w Dekalogu przykazanie: nie ktam, nie udawaj, nie oszukuj, nie fatszuj, nie badź obtudnikiem.

Jeżeli fałszowanie materiałów spożywczych, fałszowanie pieniędzy itd. uważane jest za grzech i występek, to tym bardziej powinno być uważane za grzech i występek, i okrywane pogardą fatszowanie sumien wtasnych $i$ cudzych.

Zastrzegam się przy tym, że nie jestem fanatykiem prawdy. Rozróżniam prawdę w nauce a prawdę w życiu. W nauce obowiązuje prawda bezwzględna, dla której należy być gotowym nawet na męczeństwo. W życiu obowiązek głoszenia prawdy wygląda nieco inaczej. Są sprawy ważne, sprawy społeczne, sprawy polityczne; a są też sprawy prywatne, osobiste, sprawy mniej ważne, a przynajmniej względnie ważne. W stosunku do spraw osobistych zatajenie „praw- 
dy” bywa czasem obowiązkiem, a mówienie prawdy może graniczyć ze „zbrodnią”.

W danym wypadku, gdy chodzi o mój stosunek do Kościoła, prawda naukowa zbiega się z prawdą społeczną, a więc ma się do czynienia ze sprawą ważną. Kontynuowanie milczenia i tłumienia prawdy byłoby fatszowaniem istotnego stanu rzeczy. Niech inni fałszują, ale ja nie cheę i nie mogę dłużej fałszować.

Od dłuższego czasu trapiły mię wyrzuty sumienia, które (tj. nie wyrzuty, ale sumienie) na swoje nieszezęście posiadam. Doznawałem nieustającego dręczącego niepokoju. Wzmagała się we mnie dokuczliwa i bolesna pogarda dla samego siebie za tchórzostwo i za brak odwagi do zdobycia się na krok stanowczy. Musiałem sobie ulżyć. Musiałem odbyć tę „spowiedź powszechną”. Musiałem dać świadectwo prawdzie.

W ciągu swego bezmyślnego, głupiego, splugawionego, ludzkobydlęcego życia popełniłem mnóstwo nieuczciwości, „grzechów”, występków, łajdactw, objawów tchórzostwa, wykroczeń przeciw człowieczeństwu w podniosłym znaczeniu tego wyrazu. Bezcześciłem godność ludzką, cudzą i własną. Wyrządzałem niepowetowane krzywdy innym i samemu sobie. Marnotrawiłem i trwonitem posiadane skarby pod każdym względem.

Wiem na pewno, że ani katolicyzm, ani żadne inne wyznanie nie uchroniłoby mnie od tych wszystkich zdrożności i błędów. Nie uchroniła mnie moja własna etyka osobista. Przemogła natura, przemogły zdrożne nałogi i bydlęce popędy.

Od przeszło sześćdziesięciu lat praktykowałem chroniczne oszustwo co do swej przynależności wyznaniowej. Cheę przynajmniej pod koniec życia oczyścić się, byé uczciwym, nie obłudnym, nie mówić fałszywego świadectwa 0 samym sobie.

Nie chcę uprawiać flirtu z Panem Bogiem obowiązującego „katolików” z inteligencji i z „towarzystwa”. Niech pozostają „katolikami” różni światowcy czy to obłudnie „praktykujący”, czy to wcale niepraktykujący, ale podtrzymujący przyjazne stosunki z klerem dla oddawania sobie wzajemnych usług.

Odgraniczam się od „katolików”, odgraniczam się od obrońców wojny, od obrońców kary śmierci, od obrońców wszelkiego rodzaju niewolnictwa, odgraniczam się od jegomościów twierdzących, że śluby cy- 
wilne wymyślili bolszewicy i że obchodzenie się bez ślubu kościelnego jest sprośnym konkubinatem. Odgraniczam się od zbiorowiska, do którego należą i którego bronią tępi, bezduszni, pozbawieni logiki i poczucia sprawiedliwości biurokraci (urzędnicy Min. WRiOP i członkowie Najwyższego Trybunału Administracyjnego), wbrew wyraźnym nakazom konstytucji pozbawiający praw osobę, która zdała bardzo dobrze egzamin maturalny ze wszystkich przedmiotów naukowych, ale, jako urzędowo bezwyznaniowa, nie mogła zdawać z wypowiadającej walkę nauce „religii”. Takiego pozbawiania praw nie było nawet w Rosji carskiej.

Uznaję słuszność przysłowia co po psie w kościele, kiedy pacierza nie mówi; nie chcę być „parszywą owcą” zanieczyszczającą kościół i dlatego wychodzę.

Gorliwcy „katolicy” obawiający się zgorszenia, niech się pocieszą. Nie ma się co martwić. I beze mnie pozostaną w łonie Kościoła katolickiego tysiące, miliony obłudników, fałszywych katolików, farbowanych lisów, a przecież o nich przede wszystkim chodzi Kościołowi wojującemu i roszczącemu pretensję do wszechwładzy, do panowania nad całą ludzkością.

Przez moje wykreślenie ze spisu rzymskich katolików statystyka urzędowa nic nie ucierpi. Będzie to kropla w morzu.

Rozstając się publicznie z mymi rzekomymi współwyznawcami, współobywatelami wszechświatowej monarchii papieskiej, nie żywię do nich żadnych nieprzyjaznych uczuć. Przeciwnie, żegnam ich z prawdziwą wdzięcznością za to, że mnie nie prześladowali i nie wymagali ode mnie obłudnych praktyk wyznaniowych.

Słyszałem, że w czasie mojej ostatniej choroby w niektórych kongregacjach modlono się za mnie. Jest to bardzo rozczulające i rozrzewniające. Dziękuję gorąco tym życzliwym dla mnie osobom. Tym bardziej jestem względem nich obowiązany do szczerości i do nieudawania katolika.

Zanadto szanuję ludzi prawdziwie wierzących, ażebym ich miał nadal oszukiwać. A o obłudników, umizgających się do kleru i flirtujących z „Panem Bogiem” nie dbam.

Może jeszcze będę współpracował ze szczerze wierzącymi w obronie prawdy i sprawiedliwości. Gdyby jednak żądano ode mnie 
„pojednania się z Bogiem”, uważałbym to za objaw potwornej megalomanii. Byłoby śmieszne, gdyby np. wesz lub pluskwa chciały się pojednać z człowiekiem, a przecież odległość między człowiekiem a Bogiem, choćby nawet stworzonym na obraz i podobieństwo człowieka, jest nieskończenie większa aniżeli odległość między wszą lub pluskwą a człowiekiem.

Gdyby po sześćdziesięciokilkoletniej nieobecności powróciła wiara i ja wrócę do Kościoła. Nie ma jednak o to obawy. Jak powiedział jeszcze Goethe w Aus meinem Leben Wahrheit und Dichtung, powrót do istotnie utraconej wiary jest absolutną niemożliwością. Łysa głowa włosiem nie porasta. Chyba żebym dostał rozmiękczenia mózgu.

\section{Argumenty przeciw memu postanowieniu}

Niektóre osoby, którym wspominałem 0 zamiarze wystąpienia z Kościoła, stanowczo przeciwko temu protestowały, twierdząc, że byłoby to „zgorszeniem publicznym” i krokiem szkodliwym pod każdym względem. A trzeba dodać, że osoby te weale nie należą do prawdziwie wierzących.

Tak więc jawne i otwarte stwierdzenie faktu, że się nie jest tym, za kogo się uchodzi, ma byé „zgorszeniem”. A praktykowanie obłudy, zawieranie konkordatów i robienie ustępstw klerowi wbrew zdrowemu rozsądkowi i ze szkodą dla społeczeństwa nie jest zgorszeniem? A popieranie mordercy Niewiadomskiego przez kler nie jest zgorszeniem? A twierdzenie dostojników kościelnych, że śluby cywilne to wymyst bolszewików, nie jest zgorszeniem? A ciągłe naruszanie 5 przykazania przy błogosławieństwie zawodowych głosicieli „miłości bliźniego” nie jest zgorszeniem? A cyniczne praktykowanie kłamstwa i obłudy nie jest zgorszeniem?

Jak już powiedziałem, owe osoby obawiające się zgorszenia nie należą weale do osób wierzących. Im chodzi tylko o zachowanie pozorów, jako też o panowanie, do spótki z klerem, nad ludkiem gtupiutkim i pokorniutkim, boć, jak mówi Karol Havliczek-Borovsky, bez boha se sprostym lidem neni vydrženi (bez boga z prostym ludem nie podobna wytrzymać). (Komu i na co potrzebny jest Bóg, „MW” 1925, nr 1, str. 7). 
Stara to, od wieków znana polityka. Dość wspomnieć kapłanów egipskich, augurów rzymskich i innych zawodowych okpiwaczów. Ja jednak nie potrzebuję nikogo durzyé, tumanić i okpiwać.

Inni znowu byli przeciwko memu wystąpieniu, ponieważ przez wystąpienie traci się wpływ na rzekomych współwyznawców.

Uważam za pożyteczniejsze pozostanie i walczenie wewnątrz. Pisze Pan: „dość obłudy i udawania”, ale w danym wypadku nie ma ani obłudy, ani udawania, gdyż Pan nigdy z swoimi poglądami się nie krył... Ja staram się nie zrywać z moimi „bliźnimi”, tylko stwierdzać, że 0 wiele więcej byłoby między nami zgody i bliskości, gdyby nas nie różniły kościelne przesądy, a więc są one przeszkodą, a więc usuwajmy je stopniowo razem, obopólnie. Tylko w ten sposób można ścierać „kanty”. Inna sprawa masowe wystąpienie. Na to oczywiście jeszcze u nas za wcześnie, ale agitować można. Ale wszystko na nic wobec roli, jaką odgrywa katolicyzm u nas; musi być zrównany z innymi wyznaniami, a wszystkie wyznania muszą być oddzielone od państwa; winny być prywatnymi religijnymi stowarzyszeniami.

Tak pisał do mnie jeden z bardzo mi życzliwych wolnomyślicieli. Jego zarzuty odpieram następującymi uwagami:

Mój przyjaciel twierdzi, że przez wystąpienie urzędowe z łona danego wyznania traci się wpływ i pozbawia się możności oddziaływania na innych rzekomych współwyznawców. Ależ ja nie chcę wywierać żadnego wpływu, nie chcę na nikogo oddziaływać. Nikogo nie tylko nie zmuszam, ale nawet nie namawiam do udawania niewierzących. Nie wdzieram się nieproszony do tajników duszy ludzkiej. Chcę być sam i nawet najbliższych mi osób nie namawiam do naśladowania mnie. Żądam tylko od nich absolutnej tolerancji dla samego siebie. Obcy mi jest duch prozelityzmu, propagandy, nawracania. Nie chcę odbierać duszom wierzącym pociechy i osłody, jaką znajdują w religii. Co więcej, jestem tego zdania, że Religia serc naiwnie wierzacych zastuguje na uznanie $i$ szacunek choćby dlatego, że wprawia dusze do dażen idealnych i uszlachetniajacych. (Myśli nieoportunistyczne, Kraków 1898, nr 8). Wierzcie sobie, w co chcecie, przestrzegajcie nauk i wskazówek swych duszpasterzy, tylko mnie dajcie święty spokój i nie troszczcie się o zba- 
wienie mojej duszy, które mnie samego nic nie obchodzi. Pozwólcie mi być tym, czym jestem. Nie zmuszajcie mnie i nie namawiajcie mnie do udawania katolika, kiedy nim nie jestem. Nie stosujcie do mnie gwałtu i przemocy. Stosujcie do mnie tolerancję.

Inkwizytorowie palili na stosach setki i tysiące dla zbawienia duszy smażonych. Krzewiciele katolicyzmu i „chrześcijaństwa” tępili ogniem i mieczem całe ludy przez „miłość bliźniego”, dla zbawienia grzęznących w „pogaństwie” i w „herezji” dusz. Z powierzchni zdobytej przez „chrześcijan” Ameryki zniknęły całe ludy ze swoistą kulturą i z odrębnymi wierzeniami. Wytępiono albigensów, wytępiono arian. Wszystko ad maiorem Dei gloriam (na większą chwałę Boga). Ja nie mógłbym uczestniczyé w podobnych ezynach apostolskich. Pod tym względem nie czuję w sobie ani krzty sadyzmu niezbędnego do krwawych całopaleń na chwałę Boga żydowsko-chrześcijańskiego. Nie chcę nikogo nawracać ani mieczem, ani stosem, ani słowem.

Mego absolutnego indyferentyzmu co do wierzeń innych ludzi nie można zestawiać z postępowaniem Żydów asymilatorów, a raczej zasymilowanych, którzy, zlawszy się ze społeczeństwem ich otaczającym, wyrzekli się wszelkiej styezności z żydostwem. Przecież nie stawali się oni pozawyznaniowcami, ale, przeciwnie, przechodzili do obozu innego wyznania, wrogiego ich poprzedniemu wyznaniu, a więc nakładali na siebie piętno odszczepieńców i już przez to samo zamykali sobie drogą do kulturalnego oddziaływania na swych dawnych, pogrążonych w ciemnocie współwyznawców. Ja zaś nie bawię się w namawianie kogokolwiek bądź do zmiany wyznania na wyznanie, narodowości na narodowość. Wszystkie one posiadają w moich oczach jednakową wartość.

Według zdania mego przyjaciela, należy dążyé do zbiorowego, gromadnego występowania z Kościoła, coś w rodzaju stadowego chrzczenia „pogan”. Ja wcale do tego nie dążę. Liczba mi nie imponuje. Jeden Kopernik wart w moich oczach nierównie więcej aniżeli całe miliony wspótczesnych mu dwunogich. Sam sobie wystarczam. Sam zrywam z Kościołem, by choć pod koniec życia nie być oszustem i nikczemnym tchórzem.

Mój przyjaciel powiada, że katolicyzm musi byé zrównany z innymi wyznaniami, a wszystkie wyznania oddzielone od państwa. Bardzo to 
piękne pia desideria (pobożne życzenia), ale kto się zajmie ich zrealizowaniem? Kto będzie zrównywał, kto będzie oddzielał wyznania od państwa? Przecież chyba nie my; vanae sine viribus irae (próżne bezsilne gniewy). Więc może sejm i senat, instytucje prawodawcze złożone w większości z obłudników i obskurantów? Może rząd, grający w tych sprawach rolę pokornego służki Rzymu i kleru miejscowego? A może nareszcie Komisja Kodyfikacyjna, której pojedynczy członkowie w cztery oczy czupurzą się, są niezmiernie wolnomyślni i żądają uświecczenia życia społecznego, a gdy przyjdzie co do czego, tulą uszy i przy głosowaniu kierują się względami oportunizmu i obawą narażenia się klerowi i „opinii publicznej”.

Dajmy więc pokój tym „musom”. W Polsce współczesnej nie może być mowy ani o zrównaniu katolicyzmu z innymi wyznaniami, ani o oddzieleniu kościołów od państwa. Konstytucja jest na pokaz, a życie idzie swoją drogą. Zresztą i konstytucja przyznaje katolicyzmowi pierwszeństwo. A cóż dopiero konkordat, przed którym wszelka „sanacja moralna” i inne obiecanki-cacanki stają na baczność lub też chowają się w kąt i nie śmieją pisnąć. Więc ze swymi zuchwałymi żądaniami możemy czekać do sądnego dnia.

Posiadając zmysł rzeczywistości, ja tak daleko nie sięgam i nie dążę do masowych wystąpień. Sam chcę być wolnym i we własnych oczach uczciwym, a inni nic mnie nie obchodzą.

Ale mój przyjaciel namawia mię do czegoś bardzo szpetnego i nagannego, mianowicie do tego, ażebym pozornie należał do Kościoła, a w duszy knuł podstęp, oszustwo i zdradę. Boć przecie chyba zdradą należy nazwać podkopywanie się pod całość, do której jest się zaliczanym. Byłaby to zaszczytna rola konia trojańskiego, albo, co gorzej, rola Azefa będącego jednocześnie spiskowcem-rewolucjonistą i szpiclem, ajentem Ochrany carskiej. Inni znowu jednocześnie służą w defensywie polskiej i są ajentami komunistów bolszewików. Jest to niecna, podła robota.

Należąc do Kościoła, choćby tylko nominalnie, nie wolno działać na jego szkodę. Jeżeli walczyć, to walczyć otwarcie, a nie podstępem i zdradą.

To, co tylko co powiedziałem, brzmi szlachetnie i wspaniale. Ale istnieje także odwrotna strona medalu i, jeżeli ona bierze górę, mój przyjaciel będzie miał słuszność. Rycerskość i gra w otwarte karty 
obowiązuje tylko wtedy, kiedy i przeciwnik przestrzega tych samych metod. Jeżeli zaś przeciwnik walczy za pomoca gwałtu, przymusu, represji, prześladowania za przekonania, za pomoca więzienia, konfiskat, pozbawiania praw itp., nie moge go uważać za zasługującego na szacunek i otwartą walkę i muszę zamiast tego uciekać się do podstępu i roboty tajemnej. Ja sam to praktykowałem. Ponieważ w Rosji carskiej nie wolno było sprowadzać z zagranicy wielu wydawnictw, choćby tylko z powodu używanego w nich alfabetu (np. alfabetu łacińskiego w wydawnictwach z tekstem litewskim, ukraińskim, białoruskim), ponieważ szalała tam cenzura i żandarmeria graniczna, więc uważałem za swój święty obowiązek, ile razy wyjeżdżałem za granicę, przemycać kontrabandą pewną ilość wydawnictw zakazanych i przez cenzurę prześladowanych. Było to nielojalne wobec państwa, ale państwo oparte na podstawach kłócących się z wymaganiami etyki, państwo, tłumiące myśl, słowo, wszelką wolność obywatelską nie zasługiwało na zachowywanie wobec niego lojalności; przeciwnie, prowokowało najdalej idące zamachy „wywrotowe”, a cóż dopiero niewinną kontrabandę książek zakazanych.

Wychodzimy z różnych założeń. Mój przyjaciel zapatruje się na nasze obecne położenie pesymistycznie i stoi na stanowisku przedwojennym, kiedy państwo kneblowało usta i krępowało ręce i kiedy jedynym skutecznym sposobem walki z tym potworem były spiski i zamachy. Ja zaś jestem naiwnym optymistą wierzącym konstytucji, która podobno zabezpiecza wolność sumienia, wolność wyznania i inne niezbędne w życiu nowoczesnym wolności. Oczywiście gdyby Kościół miał nieograniczoną i niczym niekrępowaną władzę, inaczej wyglądałyby te nasze wolności. Może wtedy ziściłyby się marzenia niektórych przedstawicieli kleru o powrocie dawnych czasów, kiedy to Kościół krwi nie przelewał, ale za to smażył na stosach mięso heretyków i wszelkich swoich wrogów.

Około roku 1875 Aleksander Świętochowski, bawiący się wówczas w wolnomyślicielstwo i jeszcze daleki od ideałów endeckich, występował w Krakowie przeciwko klerowi katolickiemu z powodu głośnej sprawy Barbary Ubryk. Gromiący wrogów Kościoła słynny kaznodzieja ksiądz Golian zagrzmiał wtedy w kościele Panny Marii: Gdyby sie wrócity dawne czasy, rzucitbym na niego czarna świece! 
Niestety ręce za krótkie. Kościół wojujący musi się dostosowywać do zmienionych warunków życia i zapatrywań społeczeństwa, z którego też sam się rekrutuje. Takich amatorów smażonego mięsa ludzkiego jak ksiądz Golian jest chyba niewielu. Więc pomimo wszelkich konkordatów konstytucja gwarantuje do pewnego stopnia wolność sumienia, tak że można bez obawy wojować ustnie i piśmiennie nawet z Kościołem świętym. A ja nie wojuję z nim, tylko, nie chcąc go oszukiwać, w najlepszej komitywie z nim się rozstaję i wyjaśniam powody rozstania. Co więcej, chodzi mi przy tym o podniesienie poziomu moralności w ogóle, tj. nie tylko poza Kościołem, ale także w łonie samego Kościoła. Dążę do uzdrowienia moralnego, do oczyszczenia i do uszlachetnienia zarówno osób wierzących, jak i niewierzących.

Niestety po ostatnich występach najwyższych interpretatorów i realizatorów konstytucji dochodzi się do wniosku, że ja łudzę się, a słuszność ma mój przyjaciel, odradzający traktowanie Kościoła i jego obrońców jako uczciwych przeciwników. Przypomnijmy sobie głośną sprawę panny Ireny Stróżeckiej, która uczyła się w gimnazjum jako urzędowo bezwyznaniowa, więc, zdając maturę, nie mogła zdawać z tzw. religii, który to przedmiot jako co do swych „prawd” zależny od pochodzenia wyznaniowego osoby egzaminowanej, jest sprzeczny z wszelką prawdziwą nauką. Zdawszy bardzo dobrze egzamin, miała prawo na otrzymanie świadectwa maturalnego. Ministerstwo jednak odmówito zatwierdzenia świadectwa, ponieważ brakuje $\mathrm{w}$ nim stopnia $\mathrm{z}$ religii. Matka abiturientki, pani Estera Stróżecka, zaskarżyła tę decyzję Ministerstwa WRiOP do Najwyższego Trybunału Administracyjnego, uważając go za obiektywnego i bezstronnego stróża prawa, konstytucji i zaprzysiężonych przez Prezydenta Rzeczypospolitej i przez cały rząd praw i swobód obywatelskich. Tymezasem Najw. Tryb. Adm. za pomocą różnych rozumowań, kłócących się poniekąd z logiką i z poczuciem sprawiedliwości i praworządności, skargę pani Stróżeckiej oddalit, zatwierdzając orzeczenie ministerstwa.

Okazuje się, że odziedziczone po najeźdźcach ze Wschodu przyzwyczajenie do gwałcenia sumień i poniewierania godnością ludzką ma przewagę nad konstytucją niepodlegtego państwa polskiego, że konstytucja jest sobie tymczasem tylko próżnym marzeniem i obiecanką ca- 
canką, że ułożono ją jedynie na eksport, dla mydlenia oczu zagranicy i naiwnym prostakom w samej Polsce. Po dawnemu najwyższe instancje rządowe każą obywatelom cheącym korzystać z przynależnych im praw uciekać się do łapówek, do kłamstwa, oszustwa i obłudy. Zapewniano mię, że za 60 złotych czy coś około tego można dostać świadectwo o zdaniu egzaminu z ,religii”, o ile się nie uczęszczało na wykłady tej swoistej nauki. Tak to rząd sanacji moralnej i walki ze ztem pracuje nad umoralnieniem i uzdrowieniem społeczeństwa.

Pod tym względem w Polsce dzisiejszej jest gorzej, niż było w Rosji carskiej. Przed wojną sam widziałem kilkanaście matur, czyli prawomocnych świadectw dojrzałości, bez stopnia z „religii”. Jeżeli w danej szkole nie było nauczyciela pewnej religii, zwalniano eo ipso abiturienta czy abiturientkę od obowiązku składania egzaminu z tego „przedmiotu”. Między tymi świadectwami widziałem nawet kilka wydanych katolikom, ponieważ w ich szkole średniej nie było katechety katolickiego. Tylko prawosławny nie mógt się obejść bez stopnia z „religii” uprzywilejowanej i przodującej innym.

Chociaż jestem stanowezym przeciwnikiem wszelkiej walki za pomocą gwałtu, to jednak odczułem to orzeczenie Najwyższego Trybunału Administracyjnego jako wyzwanie rzucone wszystkim obywatelom walczącym 0 wolność sumienia i o poszanowanie godności ludzkiej. A cóż dopiero mówić o ludziach mało krytycznych, tatwo zapalnych i gotowych do walki czynnej. Tacy ludzie mogą dojść do wniosku, że w Polsce drogą legalną niepodobna korzystać z zawartych w konstytucji praw obywatelskich i że konieczną jest walka konspiracyjna, spiskowa, zamachowa, krwawa. Wniosek błędny, ale nastroju tych ludzi nie wolno lekceważyé i bagatelizować. Same zaś represje mogą zawieść i zwykle zawodzą.

Otóż wobec tego wszystkiego mój przyjaciel, zalecający mi granie roli kreciej i dwulicowej, może mieć słuszność.

\section{Sprawa „powłoki cielesnej”}

Mnie osobiście niewiele się już należy: tylko w „proch się obrócié”.

Mam prawo uważać siebie za prawdziwego wolnomyśliciela i bezwyznaniowca, chociaż nie obnoszę się z tą swoją charakterystyką 
jak kura z jajkiem. I właśnie jako „wolnomyśliciel” i „bezwyznaniowiec" chcę tu określić swój stosunek do własnego ciała po śmierci, której jakoś nie mogę się doczekać i muszę ciągle jeszcze znosić gorycz i mękę istnienia.

Mnie samego już wtedy nie będzie. Ten najsubtelniejszy wytwór i szczyt istnienia rozwojowego, jakim jest „dusza” jednostkowa, jakim jest świadomość, myślenie, chcenie, odczuwanie itd. zniknie absolutnie, pozostawiając na placu tylko swe martwe podłoże organiczne, skazane na rozkład i zlanie się ze światem chemicznofizycznym. Właściwie więc powinno by mi być całkiem obojętne, co się stanie po śmierci z tymi moimi zwłokami, z tym moim trupem. Jeżeli jednak pozwalam sobie wypowiedzieć co do tego jakieś żądania i wymagania, to kierują mną przy tym z jednej strony względy oszczędnościowe, z drugiej zaś strony chęć przysłużenia się nauce, badającej ciało ludzkie zarówno ze stanowiska teoretycznego, jako też dla potrzeb praktycznych.

Dla swego tzw. ciała mam za życia wstręt i pogardę. Gdyby nie ono, nie popełniałbym wielu tzw. grzechów, przestępstw, a nawet zbrodni, nie ulegałbym szkodliwym dla siebie samego i dla innych podszeptom i autosugestiom, nie wyrządzałbym niepowetowanych krzywd zarówno sobie samemu, jako też innym osobom. Jeżeli więc nie mam dla swego ciała najmniejszego szacunku za życia, to z jakiego powodu miałbym zmieniać ten swój do niego stosunek po śmierci, kiedy ja sam już istnieć nie będę?

Gdybym żył „w pierwszych wiekach chrześcijaństwa”, może by mnie przedzierzgnięto całkiem darmo w jedną z „pochodni Nerona”. Gdybyśmy żyli w „wiekach średnich”, kiedy to „Kościół święty”, „matka nasza”, wojująca a dbała o zbawienie dusz, „krwi nie przelewała”, może by ksiądz Lutosławski i Spółka urządzili mi darmowe krematorium na stosie. Gdybym żył we Francji w czasie „Wielkiej Rewolucji” „wielkiego narodu”, może by mi całkiem darmo oddzielono głowę od kadłuba i pochowano kosztem skarbu u stóp gilotyny. Gdybym żył dziś w Europie Wschodniej „pozakresowej”, może bym jako „burżuj” i „kontrrewolucjonista” został najprzód postawiony „pod ścianką”, a następnie znalazł darmowy „wieczny odpoczynek” w dole własnymi rękoma wykopanym.

Niestety, nie mogę chyba liczyć na żaden z tanich sposobów przeniesienia się na tamten świat. Czeka mię prawdopodobnie (o ile nowy wybuch sztucznie przez władze wojskowe urządzonych w Cy- 
tadeli warszawskiej wulkanów ${ }^{1}$ nie przyśpieszy mego „przeniesienia się do wieczności”) tzw. „śmierć naturalna”, bez szczególnych względów ze strony „świętych hermandad”, patriotycznych „komitetów ocalenia publicznego” i „czrezwyczajek” przenajróżniejszego autoramentu.

Dla tego, co zostanie po mnie, a nie będzie mną, nie chcę ani spalenia w krematorium, ani też uroczystego pogrzebu. Zarówno jedno, jak drugie pociągnęłoby za sobą ogromne koszta, a narażanie czy to rodziny, czy też kogo innego na takie zbędne wydatki byłoby głupotą lub przestępstwem. Lepiej te pieniądze użyć na co innego. Nie należy krzywdzić żywych na korzyść cmentarzy i krematoriów.

W razie tedy mego „przeniesienia się do wieczności” wymagam stanowezo:

1) ażeby nie robiono o tym żadnych ogłoszeń ani w dziennikach, ani na ulicach, bo szkoda tych „milionów”' na nekrologi i klepsydry;

2) ażeby nie wystawiano ciała „na pokaz”;

3) ażeby nie urządzano żadnych ceremonii ani religijnych, bo te same przez się są wykluczone przy zwłokach bezwyznaniowca, ani też świeckich;

1 Mowa 0 wybuchu w prochowni Cytadeli, który miał miejsce 13 X 1923 r., w czego wyniku zginęło 25 osób. Oskarżono wówczas o podłożenie bomby dwóch oficerów, por. W. Bagińskiego i ppor. A. Wieczorkiewicza. Sformułowanie sztucznie przez wtadze wojskowe urzadzonych jest zapewne aluzją do całej tej sprawy. Oskarżeni w czasie, kiedy nastąpił wybuch, przebywali w więzieniu, co jednak nie przeszkodziło sądzić ich i skazać na śmierć. Prowokacyjny charakter tego zdarzenia wykryli dwaj członkowie komisji sejmowej (główny świadek okazał się policyjnym konfidentem, a raporty policyjne sfałszowano). Obaj oficerowie zostali ułaskawieni od kary śmierci przez prezydenta Wojciechowskiego i mieli być wymienieni na osoby znajdujące się w więzieniach sowieckich. Do wymiany nie doszło, ponieważ oficerowie zostali zastrzeleni w pociągu przez policjanta, notabene potem skazanego za to zabójstwo na 2 lata więzienia i zwolnionego po roku. Baudouin pisał o tej sprawie w artykule Niewiadomski a Baginski, Wieczorkiewicz i Spótka, „Głos Polski” 1924, nr 112.

2 Pisano to za czasów panowania marki, kiedy to dzisiejszemu złotemu polskiemu odpowiadały co do wartości prawie dwa miliony marek [przyp. BdeC]. 
4) ażeby nie marnowano żadnych ubrań przez nakładanie ich na trupa, który przecież żadnych ubrań nie potrzebuje. Co najwyżej można go zawinąć w jaką starą płachtę.

Rozumie się samo przez się, że wszelkie nabożeństwa żałobne i „za spokój duszy” są stanowezo wykluczone. W zastosowaniu do takiego „niedowiarka” jak ja byłyby one po prostu śmieszne. Niech się nikt nie niepokoi o spokój duszy, która nie będzie istniała.

Zwłoki moje należy oddać do całkowitego rozporządzenia prosektorium anatomicznemu i innym związanym z nim instytucjom, pod warunkiem oczywiście, że transport tej ruchomości z mieszkania do miejsca badań odbędzie się ich kosztem.

Sądzę, że moja śmiertelna powłoka z jej mózgiem, z jej nerwami, muskułami, gruczołami, kośćmi i innymi częściami składowymi może przedstawiać pewien interes naukowy. Tyle nieraz trudności przedstawia dla prosektorium uzyskanie trupów przeciętnych śmiertelników kończących żywot w szpitalach. Niedostępnymi dla badań sekcyjnych są przede wszystkim trupy żydowskie. Rzadkością zaś bywa na stole sekcyjnym trup profesora, a w dodatku „niedowiarka”, wprawdzie nie „żydomasona”, ale coś około tego.

Dzięki własnemu niedołęstwu i niepomyślnym okolicznościom, niewiele mogłem przynieść pożytku nauce za życia jako subiekt badający. Niechże to choć w części wynagrodze po śmierci, każąc swym zwłokom występować w roli obiektu badanego. (Orientacje trupie. W zwiazku ze sprawa krematorium), „MW” 1924 r., nr 3, str. 5-8).

„Odwaga cywilna” tylko do pewnych granic

Być może, iż niektórzy ojcowie duchowni z gatunku śp. księdza Goliana nie uznają mej pokojowości, będą mię uważali za krnąbrnego heretyka i rzucą na mnie klątwę. Perspektywa klątwy wcale mnie nie trwoży. Klątwa i ja są to rzeczy niewspółmierne. Klątwa mnie wcale nie ugodzi i przejdzie mimo moich uszu. Szkoda więc na nią czasu i fatygi. I w ogóle klątwy, anatemy, chajremy itp. wyszły teraz z mody.

Prawdopodobnie w wiekach średnich, za panowania Inkwizycji Świętej i Świętej Hermandady zabrakłoby mi odwagi do uczynienia podobnego kroku. Perspektywa powolnego smażenia się na stosie 
wcale by mi się nie uśmiechała. Jestem w ogóle wytrzymały na ból fizyczny, ale tylko do pewnego stopnia. Pomimo więc, żeby mię może świerzbiał język, trzymałbym go za zębami, a nawet nikomu bym się nie zwierzał ze swymi wątpliwościami i heretyckimi zapatrywaniami na Kościót rządzący a mściwy.

Podobnie w Bolszewii zachowywałbym się skromnie i potulnie, nie zdradzałbym się ze swą „łobuzerką wolnomyślicielską” i, stuliwszy uszy, podporządkowałbym się nowoczesnej „myśli karnej i zorganizowanej”. Działająca w imieniu „dyktatury proletariatu” Inkwizycja święta naszych czasów, sowiecko-socjalistyezna Czrezwyczajka czy to pod właściwym szyldem, czy też pod pseudonimem GPU, nie przebaczyłaby mi mych buntowniczych myśli i jako „burżuja” i „kontrrewolucjonistę” postawiłaby „pod stienku”. Gdybym był pewny, że rozstrzelanie spowoduje śmieré natychmiastową, nie miałbym nic przeciwko temu. Ale śmieré może nastąpić nie od razu, tak że jakiś czas wypadłoby męczyć się i doznawać dotkliwego bólu. Nie zapominajmy też, że, za przykładem swych siostrzyc, Inkwizycji Świętej i Hermandady Świętej, i święta Czrezwyczajka uciekała się do tortur.

Zważywszy to wszystko, trzeba być wyrozumiałym i nie rzucać kamieniem na tych nieszczęśliwców, co, pozostawszy w państwie terroru, ugięli karki przed komunistami i bolszewikami, a przedtem przed hordami uzbrojonymi, przed rozzbrodniczonymi przez wojnę, rozwścieczonym i rozbestwionym żołdactwem i przed zgrają towarzyszy, wcielających w życie zawiet Iljicza: grab' nagrablennoje. Będąc przykutym do łańcucha, trudno się bawić w „odwagę cywilną” i w „wolnomyślicielstwo”.

Jest jeszcze jeden kraj europejski, gdzie prawdopodobnie nie odważyłbym się wypowiadać szczerze i otwarcie swych myśli o stosunku do Kościoła: kraj tyrana imperialisty, kraj czarnych koszul, kraj band faszystowskich.

Może się mylę, ale zdaje mi się, że w Polsce pomimo wszystkiego tolerowaną jest jeszcze tolerancja, tolerowaną jest pewna swoboda sumienia, wolność słowa i wypowiadania się. Można więc sobie pozwolić na takie tanie „bohaterstwo”, jak publiczne, urzędowe zerwanie z Kościołem, zwłaszcza pod koniec życia, kiedy mi się już niewiele należy. 
Gdybym się zawiódt, gdyby władze decydujące nie uwzględniły mego żądania, musiałbym w dalszym ciągu stosować metody niewolnicze, tj. głosząc zasady przez Kościół potępione, pozostawać oficjalnie w jego tonie, a więc uprawiać fałsz i obłudę.

Zobaczymy.

Podania do władz

\section{1) Do Zarządu parafii rzymskokatolickiej kościoła św. Krzyża w Warszawie}

Od przeszło sześćdziesięciu lat przestałem być katolikiem. Nie odprawiam żadnych modłów, nie uczęszczam na nabożeństwa, w ogóle nie uczestniczę w żadnych praktykach religijnych. Ostatni raz spowiadałem się w roku 1861.

Nie wierzę w żadne dogmaty ani katolickie, ani żadne inne, łącznie z głoszonym przez „dyktatorów proletariatu” dogmatem bezbożnictwa.

Nie mam żadnych tęsknot religijnych, nie potrzebuję żadnych pociech religijnych.

Wobec tego pozostawanie formalne w łonie Kościoła rzymskokatolickiego było z mej strony obłudą i nikczemnością. Dłużej wytrzymać nie mogę. Urzędowe wystąpienie z Kościoła jest nakazem mego sumienia.

Aby przynajmniej pod koniec życia dać świadectwo prawdzie i choćby przez szacunek dla Kościoła, pojmowanego nie jako instytucja żandarmsko-policyjna, ale jako zrzeszenie ludzi prawdziwie wierzących i istotnie potrzebujących wskazówek od duszpasterzy, postanowiłem wystąpić z niego otwarcie i z całą odwagą.

Na podstawie art. 111 i 112 Konstytucji Rzeczypospolitej Polskiej proszę o wykreślenie mnie z listy parafian i w ogóle wyznawców Kościoła rzymskokatolickiego.

Dr Jan Baudouin de Courtenay, profesor Uniwersytetu Warszawskiego

Warszawa, 1 czerwea r. 1927. Ul. Smolna No 28 m. 6. 
2) Do II Ekspozytury Komisariatu Rządu na m. st. Warszawę (0boźna 4)

Zwróciłem się do Zarządu parafii rzymskokatolickiej św. Krzyża w Warszawie z następującym oświadczeniem:

(Tutaj powtarzam powyżej, przytoczony tekst oświadczenia).

Na dowód wysłania przeze mnie tego oświadezenia i otrzymania go przez Zarząd parafii załączam zwrotne poświadczenie odbioru z 2 czerwea r. 1927.

Zawiadamiając 0 tym Ekspozyturę Komisariatu i załączając swój dotychezasowy dowód osobisty z 30 kwietnia r. 1922 pod $\mathrm{Nr}$ $6633 / 7710$, proszę 0 wpisanie w rubryce 6 . „Wyznanie” zamiast „rz. katolickie" - pozawyznaniowy.

Załączam też:

1) wypis z ksiąg ludności domu nr 26/28 przy ul. Smolnej,

2) odpis mojej metryki chrztu z 25 marca r. 1845,

3) odpis przysposobienia (adoptacji) mego ojca Aleksandra przez jego stryja,

Kacpra Baudouin de Courtenay, z 5 lipea r. 1859.

Dr Jan Baudouin de Courtenay, profesor Uniwersytetu Warszawskiego

Warszawa, 15 czerwca r. 1927. ul. Smolna 28 m. 6.

Uwaga: W końcu lipea r.b. 1927 sprawa ta została załatwiona pomyślnie. Otrzymałem nowy dowód osobisty bez określenia wyznania.

[Warszawa 1927. Nakładem Spótdzielni Wydawniczej „Bez Dogmatu”] 


\section{TEKSTY DROBNIEJSZE}

\section{OBEEDD KOMUNISTYCZNY}

W tych dniach zwracał się do mnie z prośbą o radę jeden z moich młodych znajomych. Wobec najnowszych wypadków znajduje się on w rozterce i nie wie, co począć. Jest on z jednej strony antymilitarystą, z drugiej zaś komunistą nieuznającym własności prywatnej. Przed wojną bawił w Petersburgu i przystał tam do „bolszewików”, tj. do odłamu bolszewickiego w obozie socjalno-demokratycznym. Wróciwszy do Warszawy, zachował sympatię do „bolszewizmu” i do „komunizmu”, chociaż w ogóle trzyma się z dala od polityki i czynnie nie występuje, zada-walniając się kontemplacją i rozmyślaniem filozoficznym. Jego przekonania nie pozwalają mu zgłaszać żadnych „Świadczeń” wojennych. Z początku przypuszczał, że byłoby najlepiej, gdyby się kazał aresztować jako komunista, ale później odstąpił od tego zbyt stanowczego kroku. Dusza jego znajduje się na rozdrożu. 0 tej swej tragedii mówił z wielkim wzruszeniem i ze łzami w oczach. Prosił o radę i o wskazówki, do których mógłby się zastosować.

Z pewnością nie jest to wypadek odosobniony. Przypuszczam, że takich jak ów mój znajomy jest między młodzieżą inteligentną pewna liczba, tylko że nie wszyscy są tak i otwarci i tak poważnie sprawę tę traktują. Ze względu tedy na przypuszczalną mnogość głów w ten sposób spreparowanych sądzę, że nie będzie bez znaczenia zastanowienie się nad tą sprawą i oświecenie jej w ten mniej więcej sposób, jak starałem się ją oświecić w prywatnej rozmowie z moim znajomym.

Nie będę oczywiście powtarzał szczegółów tej rozmowy. Rozpatrzę tylko w ogóle kwestie potrącone przez mego znajomego i rozwinę motywy, za pomocą których starałem się zbijać jego zdania. 
Nieuznawanie własności prywatnej jest sprzeczne z naturą ludzką. Bez poczucia pewnej własności osobistej nie da się pomyśleć nie tylko człowiek, ale nawet zwierzę. Jeżeli kto nie uznaje własności prywatnej, powinien się zgodzić na to, że mu zabiorą jego ubranie, jego mieszkanie, jego narzędzia pracy czy to fizycznej, czy to umystowej, a w ten sposób uniemożliwią mu samą tę pracę. Czy to nazwiemy własnością, czy też prawem używalności, toć to wszystko jedno. W każdym razie z życiem człowieka kończy się także jego własność.

Kto nie uznaje „własności prywatnej”, ten powinien uznawać prawo wszystkich mężczyzn do wszystkich kobiet i przyklaskiwać gwałtom dokonywanym na kobietach przez hordy uzbrojone. Cały świat ludzki zamienia się wtedy na wszechświatowy dom publiczny.

Tym zagwożdżonym głowom niepodobna wytłumaczyć, że zabór, gwałt i przymusowe pozbawienie rzeczy niezbędnych do życia nie jest wcale „komunizmem”, pojmowanym idealnie jako dobrowolne wyrzeczenie się części swojej własności na korzyść ogółu. Co więcej, pod hasłem rzekomego „komunizmu” rozpasała się orgia najwyuzdańszego kapitalizmu, kapitalizmu najskrajniejszego, bo barbarzyńskiego. Najlepszym tego dowodem jest chyba to, że typowi wyraziciele bezwzględnego kapitalizmu, bezduszni handlarze Wielkiej Brytanii zwąchali się i pokumali się z rosyjskimi głosicielami „zniesienia własności prywatnej” i „komunizmu”. Zrabowana „własność prywatna” „burżujów” znalazła się w kieszeniach „komunistów” jako ich „własność prywatna".

W zamroczonych i słabo funkcjonujących głowach niepokonaną jest potęga wyrazów. Posiadacze takich głów czują nieprzeparty pociąg do „bolszewizmu”, ponieważ jest on jakoby wcieleniem w życie skrajnego kierunku „lewicowego”. Nie wszystko co „lewe” jest bezwzględnie dobre. A ponieważ Polska broni się przeciwko najazdowi w czasie istnienia rządu „prawicowego” $i$ „reakcyjnego”, więc szanujący się „komunista” nie może brać udziału w tej obronie o charakterze „kontrrewolucyjnym”.

Niepoczytalny dzięki swemu zaślepieniu „komunista” nie jest w stanie zrozumieć, że to, co się dzieje obecnie we wschodniej Europie i w północnej Azji, jako cofnięcie się do stanu barbarzyństwa i zapanowanie najokrutniejszej tyranii i despotyzmu jest chyba naj- 
straszniejszą, najczarniejszą reakcją. Dalej wstecz nie podobna się już cofnąć. Ale pan „komunista” zachwyca się, bo dzieje się to pod hastem „lewicowości” i „rewolucji”.

Gdyby taki niewolnik wyrazów ubóstwianych miał w głowie choć trochę zdrowego sensu i trzeźwego patrzenia na rzeczy, musiałby przyjść do wniosku, że w danym wypadku nie chodzi wcale o żadne zasady i teorie, nie chodzi nawet 0 „komunizm” i „bolszewizm”, ale chodzi po prostu o fakt najścia barbarzyńców, pustoszących i zamieniających w perzynę wszystko, co spotkają po drodze, a więc chodzi o stawianie oporu niszczycielom, podpalaczom, dręczycielom, gwałcicielom. W sławetnej kawalerii Budionnego ma być około 50 proc. zarażonych chorobami wenerycznymi (por. art. F. Wolskiego w „Warszawskim Słowie”, nr 149), a zuchy te, z którymi sympatyzują panowie komuniści warszawscy, nie darują żadnej kobiecie.

\section{II}

Nawiasem mówiąc, te szlachetne zastępy jenerała Budionnego miały być podobno skierowane ku Indiom przeciwko Anglii; na skutek konszachtów dyplomatycznych rzucono je na Polskę. To powodzenie okrutnych bezdusznych handlarzy doskonale oświetla „komunizm” ich obecnych sprzymierzeńców.

Ów mój znajomy, o którym wspominam na początku tego artykułu, nie może brać udziału w akcji obrony Polski przed najazdem bolszewickim także z tego powodu, że jest antymilitarystą, czyli przeciwnikiem wojny, co jednak nie przeszkadza mu sympatyzować z jedną ze stron wojujących, mianowicie z Rosją bolszewicką.

Otóż ja także jestem antymilitarystą i to do tego stopnia, że wszelką wojnę jako wojnę uważam za zbrodnię. Zastrzegam się jednak, że w moich oczach wojna prowadzona dla odparcia napastnika niosącego zniszczenie i grożącego zagładą przestaje być zbrodnią, a nawet staje się obowiązkiem każdego niezwyrodniałego obywatela.

Ja jestem antymilitarystą przede wszystkim dlatego, że dla mnie na pierwszym planie stoi człowiek i jego prawo do szczęścia, do dobrobytu i do możności korzystania z dobrodziejstw kultury. Dla- 
tego też w czasie wojny uważam za obowiązek korzystanie z wszelkiej nadarzającej się sposobności rozpoczęcia rokowań pokojowych, a omijanie podobnych sposobności jest w moich oczach albo umyślną zbrodnią, albo też objawem głupoty.

Kiedy kilka miesięcy temu „bolszewicy” wystąpili z propozycją rozpoczęcia rokowań pokojowych, umieściłem w „Trybunie” (nra 15, 16 i 17) artykuł pt. Chwila stanowcza: albo..., albo..., w którym dowodziłem, że koniecznie trzeba z tego skorzystać.

Wówczas można było zawierać pokój, a przynajmniej rozpocząć rokowania pokojowe, całkiem świadomie, bez cudzej łaski i opieki, jako państwo całkiem niezależne. W każdym razie wytworzono by atmosferę pokojową i zrzucono by z siebie odium dalszego krwi rozlewu. Tymczasem trzymano się Borysowa jak pijany płotu i doprowadzono do tego, że dziś trzeba błagać o pomoc i 0 interwencję.

Do tego przyczynili się także rosyjscy „antybolszewicy” oraz inni podszczuwacze, którym chodzi o to, ażeby Polacy walczyli w ich interesie do ostatniej kropli krwi.

Obecny smutny wynik owego krótkowidztwa politycznego ma może jednak pewną dobrą stronę. W każdym razie kiełkujący i rozrastający się, zwłaszcza w kierunku wschodnim imperializm polski został stłumiony w zarodku; a to Polakom jako ludziom może wyjść tylko na dobre. Straszno tylko pomyśleć, jakimi to ofiarami okupuje się tę zbawienną nauczkę.

W każdym razie ówczesna dyplomacja polska, dawszy tak potężny atut w ręce wroga, wystawiła sobie wymowne świadectwo ubóstwa. Być może, iż po skończeniu wojny i po zawarciu pokoju wypadnie wyświetlić tę sprawę, oddać winowajców pod sąd i przeprowadzić dokładne śledztwo.

Teraz jednak nie czas na skargi, na żale i wyrzuty. Teraz trzeba skupić się i odpierać wroga wszelkimi siłami.

Malkontenci twierdzą, że rząd obeeny niewiele jest wart, że trzeba by go zastąpić przez inny. Ale czy nowy rząd byłby w danej chwili lepszy? W ogóle brak jest ludzi. Ale gdzie są w ogóle ludzie dorośli do dzisiejszych wypadków i stojący na wysokości zadania? Czy może krętacze i bezlitośni handlarze w rodzaju układających się z „Rosją sowiecką” 0 wymianę towarów? Na ten „brak ludzi” nie ma rady. 
Kiedy pali się dom, trzeba go ratować, a nie kłócić się o to, kto mógłby w nim lepiej gospodarować.

Jestem wrogiem wszelkiego militaryzmu, wszelkiego imperializmu, wszelkiego posuwania się naprzód w celach zaborczych, w celach ujarzmiania w ten lub ów sposób narodów i krajów ościennych. W danej jednak chwili obraz się zmienił. Trzeba bronić siebie, trzeba bronić bliskich i dalekich.

Gdybym był młodszym, zapisałbym się do szeregów obrońców czynnych, a nie potrzebowałbym do tego pobudek patriotycznych. Wystarczyłaby mi solidarność ogólnie ludzka, wystarczyłaby potrzeba ocalenia ludzkości, potrzeba ocalenia człowieka w lepszym znaczeniu tego wyrazu.

Jest to jedna z tych nader rzadkich w historii ludzkości chwil, kiedy „patriotyzm” brzmi unisono z uczuciami ogólnoludzkimi, kiedy sprawa „ojczyzny” staje się sprawą ludzkości. Tylko bezduszne kłody, tylko automaty nakręcone rękami „bolszewickimi”, tylko głowy obałamucone i serca zatrute jadem uczuć antyspołecznych nie są w stanie tego zrozumieć i mogą jeszcze się wahać.

Te wykolejone i wynaturzone indywidua, których mózgi przesiąkły „zasadami” „komunizmu”, nie mają litości nad swym otoczeniem skazanym na zagładę przez prącą ze wschodu dzicz wszechplemienną, ale za to współczują właśnie tej dziczy i nie mogą z nią walczyć.

Owszem, i ja „współczuję” tej dziczy. Nie mogę mieć do niej żalu za to, że jest głodna, zdeprawowana, wyuzdana i moralnie niepoczytalna. Ależ tak samo są głodne i moralnie niepoczytalne wilki, szczury, szarańcza, a jednak staramy się je ubezwładnić i, o ile się da, tępić. A przecież dwunogie dzikie bestie są 0 wiele straszniejsze od wszelkich szczurów, wilków, tygrysów.

Memu znajomemu „antymilitaryście” i „komuniście” dałem następującą radę praktyczną:

Ponieważ pańskie przekonania i pańskie sumienie nie pozwalają panu brać udziału w obronie kraju i społeczeństwa przed najściem dziczy wschodniej pod sztandarem „bolszewizmu”, więc nie zgłaszaj pan żadnych „świadczeń”. Nikt pana do tego nie zmusza. Gdyby zaś chciano brać pana do wojska drogą poboru przymusowego, możesz pan wytrwać na swym stanowisku i jako konsekwentny antymilita- 
rysta przyjąć wszelkie konsekwencje, a nawet dać się rozstrzelać. Zginąłbyś pan „śmiercią bohaterską” w obronie zasad „komunizmu”, „nieuznającego własności prywatnej”.

W n. 153 „Warszawskiego Słowa” ukazał się świetny felieton A. Buchowa pt. Towariszcz Anglija. Kończy się on następującym zwrotem (w polskim przekładzie):

Ach, towarzyszu Anglio, towarzyszu Anglio, czyż to uchodzi w nasze dni być tak cynicznym aż do naiwności, albo też tak naiwnym aż do cynizmu, ażeby na widok krewnej, gwałconej przez watahę chuliganów, oświadczać z całym spokojem: Ja w ogóle nie mięszam się do spraw mitosnych bliskich mi osób.

Tak samo zachowują się, nasi „komuniści”, nieuznający własności prywatnej. Jako wyznawcy zasady „niesprzeciwiania się złu” patrzą oni spokojnie i obojętnie na niszczenie kraju i obracanie go w pustynię, na katowanie, torturowanie i mordowanie tysięcy ludzi bez różnicy płci i wieku, na gwałcenie kobiet itd., a to tym bardziej, że zło, dokonywane przez „rycerzy” walczących pod świętym dla nich znakiem „komunizmu” i „bolszewizmu”, musi się im wydawać dobrem.

[,Kurier Polski” 1920, cz. I, nr 196; cz. II, nr 209]

\section{NIEWINNE FAESZYWE ŚWIADECTWA W WYŻSZYCH UCZELNIACH}

Jak wiadomo, w wyższych uczelniach słuchacze dostają tak zwane indeksy, do których co semestr wpisują tytuły wykładów, na które mają zamiar uczęszczać, a odnośni wykładający nasamprzód w odpowiednich rubrykach wpisują swe nazwiska oraz datę na dowód, że pozwalają słuchaczowi uczęszczać na swe wykłady (tak zwane nomen receptum), następnie zaś, pod koniec semestru, w innych rubrykach wpisują znowu swe nazwiska oraz datę, jako poświadczenie, że słuchacz istotnie 
uczęszczał na te wykłady (tak zwane testa). Tak jest w uniwersytecie, tak jest na politechnice, tak jest w Wolnej Wszechnicy Polskiej, a może i w innych zakładach.

Nie jest to wcale wynalazek warszawski ani nawet polski. Praktykuje się on przede wszystkim w Niemezech, jako też w krajach wzorujących się pod względem szkolnictwa wyższego na Niemcach: w byłej i obecnej Austrii, w Szwajcarii, a dziś prawdopodobnie w Czechostowacji i w innych państwach, związanych tradycjami ze światem germańskim. Datuje się zaś ten sławetny zwyczaj od wieków średnich, w których słuchacze uniwersytetu praktykowali u profesorów tak, jak w ogóle terminatorzy i czeladnicy u majstrów. Profesor-majster nasamprzód przyjmował słuchacza-ucznia do terminu, a następnie po przepisanym zwyczajowo przeciagu czasu wyzwalał go.

Bez wątpienia organizacja nauczania wyższego w porównaniu z innymi krajami stała w Niemczech w ogóle na najwyższym stopniu.

Do szkół niemieckich udawali się zwolennicy studiów wyższych ze wszystkich krajów europejskich, z Ameryki, z Japonii, z Chin. W Niemczech bowiem to, co się nazywa „szkoła”, ,wyszkoleniem”, a co się nabywa pod kierunkiem profesora w zakładach naukowych, w seminariach itp., uchodziło za doskonałe. I całkiem słusznie. Ale obok tych dobrych stron dzięki wiadomemu i gorliwie uprawianemu konserwatyzmowi konserwowano też i uprawiano w Niemczech różne, całkiem zbędne, ze stanowiska nowszych pojęć nieuzasadnione, a niekiedy nawet wprost szkodliwe przeżytki.

Do takich przeżytków należą honoraria profesorskie, czyli tak zwane czesne, opłacane przez pojedynczych słuchaczów od godziny wykładów, a idące nie do ogólnej kasy uniwersyteckiej, ale do kieszeni danego profesora. W ten sposób najznakomitszy uczony i profesor, mający z natury swego przedmiotu niewielu słuchaczów, dostawał niewielkie wynagrodzenie, dochody zaś niejednej miernoty naukowej, ale wykładającej przedmiot obowiązkowy dla prawników lub medyków, mogły dochodzić setek tysięcy marek lub koron. Zwyczaj bez wątpienia niesprawiedliwy i demoralizujący. Toteż w Austrii uznano go za taki i w końcu ubiegłego stulecia zniesiono, zastapiwszy go wyłącznie stałym wynagrodzeniem profesorskim. Natomiast w Rosji, starającej się małpować „zagranicę” nie tyle w dobrym, ile raczej w złym, wprowadzono czesne profesorskie 
dopiero w ustawie uniwersyteckiej z r. 1884, podczas gdy dawniej nie znano tam tego zwyczaju.

0 ile osobne wynagrodzenie za prace indywidualne, jak np. za zajęcia w laboratoriach, w gabinetach itd., za egzaminy i inne nadetatowe zużycie czasu jest całkiem usprawiedliwione, to natomiast nie ma najmniejszej racji bytu mnożenie dochodów profesorskich za wykłady, które wymagają jednakowego zawsze przygotowania i jednakowej ilości czasu, bez względu na liczbę słuchaczy.

Do przeżytków średniowiecznych należą też zresztą całkiem niewinne, kolorowane (z czapeczkami i wstęgami) korporacje studenckie, niezwiązane z jakąśs specjalnością, ale stanowiące luźne kluby towarzyskie.

Przeżytek notowania w „indeksach” czy też „matrykułach” przyjmowania słuchaczów na wykłady oraz testowania pilności frekwencji, czyli uczęszczania na wykłady, przyjął się np. w Rosji jako coś tchnącego aromatem nowości dopiero w ostatnich dziesiątkach lat. Praktykuje się on obecnie w Polsce na chwałę i pociechę endemicznego wzajemnego okłamywania się i podkpiwania sobie z prawdy i ze zdrowego rozsądku. Ile to papieru, atramentu, czasu i innych tp. lekceważonych wartości marnuje się bez najmniejszej potrzeby! Ile to razy nieszczęśliwy profesor musi uwieczniać swe nazwisko, przeklinając w duszy ten głupi wynalazek! Jeszcze pół biedy, kiedy profesor wykłada przedmiot mało uczęszczany, obowiązkowy dla niewielkiej ilości słuchaczy. Ale jak musi się czuć medyk, prawnik lub choćby historyk wykładający nie tylko „filozofom”, ale także „prawnikom”! A z drugiej strony ile to czasu muszą tracić biedni słuchacze, wystający całymi godzinami dla zdobycia upragnionego podpisu, raz na początku, drugi raz na końcu semestru!

I jakiemu to bóstwu przynosi się te ofiary z czasu i energii umysłowej?

Czy znajdzie się choć jeden wykładający, który by odmówił słuchaczowi lub słuchaczce podpisu wyrażającego zgodę na to, ażeby dawny słuchacz lub słuchaczka mieli prawo wstępu na jego wykłady? A taki podpis w indeksie jest konieczny, bo bez niego kwestura nie przyjmie opłaty za dany kurs lub też za udział w éwiczeniach praktycznych.

A następnie, czy zaświadczenie pilności uczęszczania, czyli frekwencji, ma jakiekolwiek poważne znaczenie? Ażeby profesor mógł 
zgodnie z sumieniem zaświadczyć, że słuchacz istotnie uczęszczał na jego wykłady, powinien by posiadać listę, za każdym razem odczytywać i odnotowywać sobie wszystkich nieobecnych. Profesor mający kilkaset albo nawet przeszło tysiąc słuchaczów, potrzebowałby na samo sprawdzanie frekwencji nie trzech kwadransy, ale kilku godzin, czyli że nie tylko cały czas przeznaczony na wykład schodziłby na kontrolowaniu obecności, ale jeszcze musiano by go przedłużać aż do zupełnego wyczerpania listy. 0 samym wykładzie nie mogłoby być mowy; cały czas mający być poświęcony wykładom schodziłby na policyjnym kontrolowaniu.

Nie bytby to jednak pedantyzm, ale tylko chęć sanicznego świadczenia, zgodnie z przepisami obowiązującymi. Jeżeli bowiem własnym podpisem stwierdzam, że ktoś chodził na moje wykłady, a ten ktoś wcale nie chodził, popełniam kłamstwo i fałszerstwo.

A z drugiej strony wielu studentów i studentek pomimo najszczerszej chęci nie może wcale uczęszczać na wykłady, bo właśnie w tych godzinach są zajęci pracą zarobkową, bez której nie mogliby istnieć.

Inni znowu mogą zastąpić słuchanie wykładów czytaniem dzieł specjalnych, z których częstokroć mogą się nauczyć daleko więcej, aniżeli odsiadując godziny obowiązkowe na wykładach. Przecież bywają indywidua roztargnione, niezdolne do słuchania ze skupieniem, a natomiast wybornie umiejące korzystać z dzieł uważnie czytanych. Czy wobec tego nie byłoby naganną pedanterią a nawet okrucieństwem odmawiać swego podpisu?

A więc mamy do wyboru: albo świadome oszukiwanie i fałszerstwo, albo też okrucieństwo. Tertium non datur (nie ma do wyboru nic trzeciego). Albo pereat mundus, fiat iustitia (niech zginie świat, byle się działa sprawiedliwość), albo też pereat iustitia, fiat mundus (niech przepadnie sprawiedliwość, byle istniał świat). I jedno, i drugie jest głupie, wstrętne i ohydne, tym głupsze, tym wstrętniejsze i tym ohydniejsze, że można by z wielką łatwością pozbyć się obu alternatyw.

Na dowód, jak pilną bywa frekwencja słuchaczów ubiegających się o „testę” mogę przytoczyć dwa przykłady z własnej praktyki w Uniwersytecie Warszawskim.

Parę tygodni temu w szatni profesorskiej uwieczniał swe imię w indeksach profesor Smoleński, szczycący się nieskończonymi ogona- 
mi „filozofów” i „prawników” spragnionych sławetnej testy. Zbliżyłem się do tego samego stołu i wpisałem „testę” do indeksu jednego z własnych słuchaczów. Wtedy przystępuje do mnie jakiś nieznany mi młodzieniec i podaje mi swój indeks. Zobaczywszy w indeksie nazwisko prof. Cybichowskiego, Łyskowskiego i innych prawników, a nie widząc wcale własnego przedmiotu, zapytuję pacjenta: „Za kogo mię pan bierze?”. Odpowiedź: „Pan profesor Smoleński”. Jakże pilnie uczęszczał na wykłady profesora Smoleńskiego ten spragniony „testy” słuchacz!

Inną znowu razą wzięto mię za profesora Szerękowskiego, któremu, jako młodemu przystojnemu brunetowi, gdyby się o tym dowiedział, nie byłoby to chyba bardzo przyjemne. Pomięszanie z prof. Smoleńskim usprawiedliwia przynajmniej ta okoliczność, że obaj jesteśmy w wieku sędziwym i mamy włosy przyprószone siwizną lat, co najmniej szpakowate, chociaż w każdym razie wyglądamy cokolwiek inaczej.

Czy więc wszystkie owe „nomina” i „testy” nie są po prostu niedorzeczną komedią?

Te fałszywe świadectwa w indeksach studenckich przypominają poniekąd „fałszywą fasję” mieszkaniową, uprawianą ongi, a może i dotychczas w Galicji alias w Małopolsce, która to fałszywa fasja polega na tym, że w ksiegach mieszkaniowych lokator musi stwierdzić własnym podpisem, równoważnym przysiędze, że płaci komornego znacznie mniej, aniżeli płaci istotnie. Jeżeli odmówi podpisu, nie znajdzie nigdzie mieszkania. Owa „fałszywa fasja” jest ściśle związana z moimi losami, gdyż za zwrócenie uwagi na demoralizację będącą skutkiem podobnego endemicznego kłamstwa i krzywoprzysięstwa zostałem wyrzucony z Uniwersytetu Krakowskiego i w ogóle z Krakowa; musiałem wracać do Rosji.

Kłamstwo i krzywoprzysięstwo tkwiące w „fałszywej facji” mieszkaniowej miało charakter poważny, bo godziło w interesy skarbu krajów i państw. Usankcjonowane i wymagane przez władze uniwersyteckie kłamstwo i fałszywe świadectwo, ujawniające się w indeksach studenckich, jest sobie niby niewinnym sportem uprawianym za pomocą pióra i kałamarza. Ale między tymi dwoma objawami moralności konwenansowej i prawomyślnej zachodzi różnica jedynie ilościowa. Jakościowo są to jagody z tego samego ogródka, z tego ogródka, gdzie wystarczy spełniać przepisane obrządki, a nawet, nie spełniając obrządków, tylko 
siedzieć cicho i nie protestować, ażeby uchodzić za wierzącego katolika lub tė̇, zgodnie z metryką i z paszportem, za innego wyznaniowca. Jest to stałe przyuczanie do myśli, że należy iść przez świat, uprawiając kłamstwo i obłudę, a wyrzekając się prawdy i stosowania się do wymagań etycznych. Jak przystało na wszelkie instytucje i zwyczaje obowiązujące, wyłonione $\mathrm{z}$ głębin światopoglądu i wytycznych moralnych społeczeństw istniejących, również zwyczaj uwieczniania podpisów profesorskich w indeksach studenckich związany jest z pewnego rodzaju łapówkami lub, co najmniej, napiwkami. Oto niektórzy słuchacze, niemający czasu lub nawet nieobecni w Warszawie, oddają swe indeksy woźnym, a ci załatwiają wymagane formalności, dostając od sztuki pewną ilość marek. Jest to zarobek godziwy, ale niekonieczny.

Głównym zaś złem jest bezmyślne marnowanie czasu na kontrolę powierzchownie policyjną, uwłaczającą godności tak zwanych wyższych uczelni.

Czas położyć koniec tej bezmyślności choćby dlatego, ażeby nie dawać powodu do mniemania, że uczeni stanowią kategorię ludzi odznaczających się wprawdzie brakiem zdrowego rozsądku, ale za to przedziwną umiejętnością trwonienia czasu i energii umysłowej na rzeczy bezużyteczne, a nawet szkodliwe.

[„Naród” 1921, nr 189]

\section{NIE SKANDAL, A PO PROSTU OBJAW ZNAMIENNY I POUCZAJĄCY}

Przeczytawszy w „Narodzie” (nr 43, z dn. 13 lutego, art. pt. Nowy skandal w świecie naukowym) dotyczącą mojej osoby wiadomość, sprawdziłem ją u źródła i tam dowiedziałem się, że istotnie Wydział Filozoficzny Uniwersytetu Warszawskiego, przyjąwszy do swego grona innych „profesorów honorowych”, mnie osobiście jako indywiduum niepożądane zabalotował. Podana więc przez „Naród” wiadomość jest zgodna z faktycznym przebiegiem sprawy, chociaż przy tej sposobności 
straszliwie przeceniono moje zasługi naukowe. Mój dorobek naukowy jest znikomo mały, w każdym razie bez porównania mniejszy od tego, który mógłby mieć miejsce, gdyby mojej działalności naukowej nic paraliżowały z jednej strony moja nieumiejętność koncentrowania się, rozpraszanie się na wszystkie strony, marnotrawstwo pod każdym względem, jednym słowem moja nieudolność, z drugiej zaś strony, przeważnie przeze mnie samego stworzone, opłakane warunki życia, zmuszające mię do stałego szukania różnorakiej pracy zarobkowej.

Posiadam bardzo wiele szpetnych i ohydnych właściwości; do ich liczby jednak nie należy zarozumiałość. Powinien bym więc i w danym razie nie zajmować czytelników swoją osobą, tj. pominąć całą tę sprawę bezwzględnym milczeniem, gdyby nie ta okoliczność, że to, co w związku ze mną stało się ostatnimi czasy w Uniwersytecie Warszawskim, charakteryzuje dosadnie poziom umysłowy i etyczny znacznej części „Szczytów inteligencji” warszawskiej i indywiduów, które zawodowo niosa przed narodem oświaty kaganiec.

Zresztą wykreślając mię ostatecznie ze składu Wydziału Filozoficznego, spełniono, niestety tylko częściowo, życzenia licznego odłamu „młodzieży uniwersyteckiej”, która już dość dawno w swym organie „Prąd” domagała się całkowitego usunięcia mnie z Uniwersytetu Warszawskiego.

Obok stałych oszczerstw i potwarzy rzucanych na mnie przez różnorodnych „patriotów” i ,zasłużonych obywateli” Rosji i Polski, obok zaciekle prowadzonej nagonki i ujadania rozmaitych pismaków oskarżających mię o najrozmaitsze zbrodnie i wykroczenia przeciw uznawanym przez ogół prawdom i dogmatom, doznaję po raz trzeci „prześladowania za przekonania” w ostrej urzędowej formie.

Bawiąc przez siedem lat (1893-1900) w Krakowie, zmuszony stale do uczestnictwa w endemicznym oszustwie zwanym „fałszywą fasją” mieszkaniową, nie mogłem w końcu wytrzymać i wypuściłem w świat broszurę Jeden z objawów moralności oportunistyczno-prawomyślnej (Kraków 1898), w której starałem się udowodnić, że podobny zwyczaj powszechny zeznawania pod przysiega (bo podpisywanie „fałszywej fasji” było równoważne przysiędze), że się płaci znacznie mniej, aniżeli się istotnie płaci, że podobny zwyczaj, przy którym wszyscy bez wyjątku mieszkańcy kraju są oszustami i krzywoprzysiężcami, musi ooddziały- 
wać nader ujemnie i zgubnie na moralność i uprawniać do powiedzenia: ja jestem ztodziej, pan jesteś ztodziej; wszyscy jesteśmy ztodzieje i możemy sobie tego nawajem powinszować.

To moje wystąpienie wywołało straszne oburzenie „patriotów” polsko-galicyjskich. Nazwano mię ptakiem, co wtasne gniazdo kala, boć wolno kraść i oszukiwać, byle tylko o tym nie mówić. Jeden z wielkich mężów galicyjskich, później minister austriacki, a dziś poseł do sejmu polskiego zakwalifikował mię w „Słowie Polskim” jako wariata. Matadory administracji krajowej i gwiazdy wiedzy miejscowej potępity mię z kretesem, a posłowie galicyjscy do parlamentu wiedeńskiego zarówno z „prawicy”, jak i z „lewicy” żądali od ministra oświaty, ażeby mię stante pede wyrzucono z Uniwersytetu Krakowskiego. Pan minister chciał im dogodzić, ale szef sekcji wyttumaczył mu, że jako zatwierdzony na pięć lat przez samego cesarza, mogę być usunięty dopiero po upływie tych pięciu lat przez nieodnawianie kontraktu. Tylko znikomo mała cząstka inteligencji galicyjskiej widziała w moim wystąpieniu nie zbrodnię i nie błąd ale czyn obywatelski.

Później wahano się i chciano mię zatrzymać w Krakowie, ale pod warunkiem, że odszczekam zarówno publicznie, jako też prywatnie, przed panami hr. Tarnowskim (prezydentem Akademii Umiejętności i dyktatorem uniwersytetu), hr. Pinińskim (namiestnikiem Galicji) i prof. dr. Bobrzyńskim (wiceprezydentem Rady Szkolnej) niecne potwarze rzucone przeze mnie na Galicję i uznano, że „fałszywa fasja” nie tylko nie jest oszustwem, ale przeciwnie, jest cnota obywatelska obowiązującą każdego patriotę.

Na to się jakoś zgodzić nie mogłem, tak że po upływie pięciu lat kontraktowych wypadło zbierać manatki i wracać do Rosji.

W ciąga kilku dziesiątków lat, przebywając w Dorpacie (18831893), w Krakowie (1893-1900) i w Petersburgu (1900-1917), gdzie tylko mogłem i jak tylko mogłem, występowałem stale i wytrwale w obronie uciśnionych i protestowałem przeciwko gwałtom spełnianym czy to na jednostkach, czy też na całych zbiorowiskach ludzkich za ich wyznanie i narodowość.

W Dorpacie broniłem Estończyków i Łotyszów przeciw poniewieraniu ich przez Niemców, a następnie w imię równouprawnienia obywatelskiego i narodowego broniłem zarówno Niemców, jako też Łotyszów 
i Estończyków przeciw brutalnej rusyfikacji. Później Niemcy bałtyccy przyznali mi, że miałem słuszność.

W Krakowie, jednocześnie z broszurą, za którą mnie wyrzucono z Uniwersytetu Krakowskiego, wydałem broszurę rosyjską Cenzurnyje „mietoczi”. Kniaz' Bismark i gonienije „Stawian”, w której występowałem przeciwko gwałtom dokonywanym na Polakach przez Niemców, wyznawców Bismarcka. Na tę broszurę ci, co mię poddali ostracyzmowi za cios wymierzony w ich kieszenie, nie raczyli zwrócié najmniejszej uwagi.

W Petersburgu wyrywałem katolików wierzących ze szpon policji, która wbrew ich oświadezeniu i wbrew ich metrykom zapisywała ich w księdze paszportowej jako prawosławnych. I walkę tę prowadzitem z powodzeniem.

Nie pretenduję z tego powodu do orderu Świętego Grzegorza, bo robiłem to nie jako katolik, partyjnie zainteresowany, ale jako człowiek szanujący godność ludzką i przekonany, że ani policjant i żandarm, ani popi jakiegokolwiek wyznania, łącznie z bezwyznaniowością, nie mają prawa zapuszczać swej brudnej tapy do głębi duszy ludzkiej i wyrywać z niej to, co dany człowiek uważa za swe sanctissimum i co częstokroć stanowi jego jedyny pierwiastek idealny, przemieniając go ze zwykłego zjadacza chleba i bydlęcia dwunogiego na człowieka w szlachetnym znaczeniu tego wyrazu. Z równą energią i z równym uporem broniłbym prawosławnego przeciw zachłanności katolickiej, żyda przeciw zamachom ze strony tych lub owych „chrześcijan” oraz wszelkiego innego człowieka szczerze wierzącego przeciwko napaściom ze strony innowyznawców. Ale za to wymagam, ażeby również bezwyznaniowca nie ograniczano w jego prawach obywatelskich i pozwalano mu być otwarcie tym, czym jest w głębi duszy, a nie jakimś fałszowanym subiektem.

W ciągu ostatniego lat dziesiątka przed zbrodniczą wojną wszechświatową, kiedy to niektórzy uczeni warszawscy - nie tyle starsi, ile raczej młodsi i dopiero poczynający - godzili się najzupełniej z uprawianą przez Uniwersytet Warszawski rusyfikacją i, stojąc na tylnych łapkach, nadskakiwali rusyfikatorom, ja, nie hołdując zasadzie nieinterwencji i spokojnego stania na uboczu, protestowałem w miarę sił i możności przeciwko wszelakim zamachom rusyfikatorskim na prawa Polaków i innych inorodców Rosji. A robitem to czy to jako członek kolegium pro- 
fesorskiego Uniwersytetu Petersburskiego, czy to jako członek rozmaitych związków i stowarzyszeń, a zwłaszcza jako członek i czasowo przewodniczący Związku Autonomistów-Federalistów, czy też nareszcie jako człowiek występujący publicznie bądź to na wiecach i zgromadzeniach, bądź też w szeregu broszur i artykułów dziennikarskich.

Nareszcie kiedy w r. 1913 wypuściłem broszurę Nacjonalnyj $i$ terrritorialnyj priznak $w$ awtonomii, w której przepowiadałem, ̇̇e jeżeli Rosja nie zejdzie z drogi prześladowania wyznań i narodowości, jeżeli nie uzna zasady jak najszerszej autonomii i federacji, będzie musiała rozpaść się i w gruzy się rozwalić, „czynniki miarodajne”, cenzura i sądownictwo carskie dopatrzyły się w niej cech zbrodni, a Izba Sądowa petersburska skazała mię na dwa lata twierdzy, czyli półtora roku więzienia. Dzięki zabiegom Akademii Nauk w Petersburgu i osób wysoce wpływowych miano mię „ułaskawié”, ale, korzystając z wojny, zmniejszono tylko dwa lata na trzy miesiące czyli półtora roku na dwa miesiące i tydzień, którą to „karę” odsiedziałem w „Krestach” petersburskich. Oczywiście w związku z tym wyrzucono mię z Uniwersytetu Petersburskiego.

A teraz trzeci wypadek „prześladowania za przekonania”. Większość Wydziału Filozoficznego Uniwersytetu Warszawskiego poddaje mię ostracyzmowi za to, że pozwalam sobie mieć własne zdanie, nie poddając się cenzurze senatu akademickiego i samozwańczych „stróżów pamiątek narodowego kościoła”.

Warto porównać zachowanie się „szczytów inteligencji” i „świata uczonego" w tych trzech wypadkach.

W Krakowie potępiono mię wprawdzie powszechnie, ale pomimo to uniwersytet chciał mię w ten lub ów sposób zatrzymać. Z dwudziestu kilku czy też nawet więcej niż trzydziestu członków Wydziału Filozoficznego tylko ośmiu było za bezwzględnym usunięciem mnie z uniwersytetu, reszta głosowała za mną. Nie poparto wprawdzie energicznie tego wyniku głosowania, ale w każdym razie ujawniono dobrą wolę.

W Petersburgu gwałt dokonany nade mną przez sądy carskie wywołał w łonie inteligencji nie tylko miejscowej, ale nawet pozamiejscowej, powszechne oburzenie. Zarówno profesorowie uniwersytetu i innych zakładów naukowych, zarówno słuchacze i słuchaczki tych zakładów, jako też działacze społeczni i inni przedstawiciele inteligencji 
nie mogli się z tym pogodzić i wyrażali mi uznanie. Nawet niektórzy tzw. „czarnosecińcy”, naznaczając, że się ze mną nie zgadzają i potępiają moje wystąpienia, wyrażali mi wspótczucie, oburzali się na wyrok Izby Sądowej i ofiarowywali mi swą pomoc.

Kiedy zaś upadł rząd carski, jednym z pierwszych kroków Uniwersytetu Petersburskiego było powołanie mnie na nowo do swego grona. Trwało to niedługo, bo już w r. 1918, nie mogąc wytrzymać pod rządami „bolszewików”, pozostawiłem w Petersburgu całe moje mienie wraz z biblioteką i ze wszystkimi materiałami naukowymi i uciekłem do Warszawy, przypuszezając, że tu będę mógł być użyteczny jako jeden $\mathrm{z}$ wykładających $\mathrm{w}$ uniwersytecie. Istotnie przyjęto mię i dano mi możność pracowania w charakterze wykładającego.

Obecnie większość Wydziału Filozoficznego uznała, że jako człowiek innych przekonań, a więc dla tych panów „niesympatyczny", a może nawet niebezpieczny, nie powinienem byé dopuszczony do przyzwoitego prawomyślnego towarzystwa.

Słyszałem od niektórych prawników, jakoby owo głosowanie w Wydziale Filozoficznym nie daje się obronić ze stanowiska prawnego. Nie wchodzę w to, ale zdaje mi się, że był to tylko dalszy ciąg całego szeregu omyłek i nieporozumień zasadniczych.

Utworzenie w Uniwersytecie Warszawskim osobnej kategorii upośledzonych „profesorów honorowych” było pomysłem arcyniefortunnym. Przy tym tak zw. „komisja stabilizacyjna” pozwoliła sobie bez ceremonii naruszyć instrukcję wyraźnie ją obowiązującą. W instrukcji powiedziane było, że komisja stabilizacyjna nie ma prawa kwalifikować tych wykładających tymczasowego Uniwersytetu Warszawskiego, którzy już przedtem wykładali w jednym z uniwersytetów czy to polskich, czy też zagranicznych. Tymczasem wbrew instrukcji komisja stabilizacyjna pozwoliła sobie usunąć kilku wykładających, degradując ich na „honorowych”. Powiadają, że w ten sposób chciano się pozbyé niepożądanych gości, osładzając im pigułkę „honorowością”.

Działało też oczywiście zapatrzenie się na praktyki austriackie, które przeważyło instrukcję, daną komisji stabilizacyjnej przez Ministerstwo Oświecenia. Zapomniano jednak, że w Austrii, usuwając profesorów z powodu wieku, pozostawiano im pełną pensję wraz z rozmaitymi dodatkami, ale za to nie nazywano ich „honorowy- 
mi”. W Warszawie zaś „honorowi” dostali tylko niewielkie odczepne. A tymczasem co po tytule, kiedy pustki w szkatule. Później starano się zaradzić częściowo temu pokrzywdzeniu finansowemu, pozostawiając jednak „honorowych” poza wydziałami. Dziś samowolnie jednych się wprowadza do grona uprzywilejowanych, innych zaś uznaje się za niegodnych tego zaszczytu.

Chociaż nieboszczka Rosja carska nie może nam w ogóle służyć za wzór, to jednak w danej kwestii urządziła się ona chyba bardzo racjonalnie. Profesor, przesłużywszy lat 30, nie mógł już zajmować katedry, ażeby nie przeszkadzać młodszym uczonym; zachowywał jednak swe całkowite wynagrodzenie, a za wykłady pobierał osobny dodatek. Oprócz tego pozostawał dożywotnim członkiem kolegium profesorskiego, ze wszystkimi prawami, a przede wszystkim prawem obieralności na dziekana, rektora i inne urzędy uniwersyteckie. To oczywiście wykluczało możność tego rodzaju „kazusów paskudeusów” jak ten, który się niedawno wydarzył na Wydziale Filozoficznym Uniwersytetu Warszawskiego.

Ja osobiście nie mam najmniejszego żalu do tych panów, którzy mnie nie dopuścili do uczestnictwa w prawach wydziału. Głosowali według wskazówek własnego sumienia, które im nie pozwalało cierpieć w swym gronie człowieka „innych przekonań”. Co więcej, jestem im bardzo wdzięczny za to że nie będę potrzebował tracić czasu na branie udziału w zgromadzeniach, których większość uważałaby mię za niepożądanego i nienawistnego intruza ${ }^{1}$.

[„Naród” 1921, nr 48]

1 W kilka miesięcy później tenże Wydział Filozoficzny UW nadał Baudouinowi doktorat honoris causa, o czym sam zainteresowany pisał tak: A po kilku miesiacach [od nieprzyjęcia w skład Wydziału - M.S.] takiego profesora watpliwej wartości naukowej robi się doktorem honorowym. Czyż nie jest to krzyczqcy btad logiczny, czy to nie rażaca niekonsekwencja? [...] Ale to jeszcze nic. Ów zaszczytnie odznaczony jegomość zostat przedtem napiętnowany przez większość decydujacych jako "wróg Polski”, „cate życie dziatajacy na jej szkode". I to, zdaje sie, byto głównym powodem wykluczenia go z grona wydziatu. J. B a u d o u in d e C o u r t e nay, Zaszczytne odznaczenie „wroga Polski”, „Robotnik” 1922, nr 55. 


\section{Mały fejleton ZE WSPOMNIEŃ 0 P.P. METONIE}

Ludzie w Polsce dzielą się na takich, którzy po śmierci stają się „ś.p.”, i na takich, którzy po śmierci stają się „b.p.”. Ponieważ sam nie należę ani do jednych, ani do drugich, więc wymawiam sobie, ażeby po śmierci nie tytułowano mnie ani „s..p.”, ani „b.p.”. Jak nie byłem nigdy spragniony orderów i rang, tak też nie chcę mieć i po śmierci żadnych zaszczytnych dodatków.

Podobnie też wymagam, ażeby nie marnowano grosza na ogłoszenia 0 moim „przeniesieniu się do wieczności” ani też nie wyrzucano pieniędzy na ceremonie pogrzebowe. Dlatego to zapisuję swoje tak zwane zwłoki do prosektorium, pod warunkiem atoli, że zostaną one sprowadzone z domu na miejsce krajania przez sam zakład bądź to anatomii normalnej, bądź też anatomii patologicznej. Przypuszczam bowiem, że badania makroskopijne i mikroskopijne zwłok osobnika patentowanego przez rzeczoznawców od patriotyzmu na wroga Polski, działajacego cate życie na jej szkode mogą przedstawiać pewien interes naukowy.

Jestem wprawdzie człowiekiem, z czego, mówiąc nawiasem, nie jestem wcale dumny; wolałbym bowiem być psem, a choćby nawet wilkiem. Zwłaszcza w dzisiejszych czasach ze względów moralności nierównie zaszczytniej jest należeć do rzędu takich lub owakich czworonogów, dwunogów skrzydlatych, płazów, gadów, insektów, robaków i innych istot tego rodzaju aniżeli do dwunogich a bezskrzydłych bestii ludzkich.

Zazdroszczę p.p. Metonowi, że był właśnie psem, psem zarówno rozumnym, jak zacnym i szlachetnym.

Podobnie jak i ja był on bezwyznaniowym i beznarodowym. A ja muszę byé nie tylko bezwyznaniowym, ale także beznarodowym, bo nie mogę się solidaryzować z zachłannością, imperializmem, nietolerancją i megalomanią żadnego narodu upaństwowionego. Mogę należeć tylko do całej ludzkości, czyli do całego świata ludzkiego, podobnie jak Meton należał do całego świata psiego. Tylko że mnie należenie 
do świata ludzkiego nie przynosi wcale zaszczytu, gdy tymczasem p.p. Meton nie potrzebował się wstydzić tego, że był psem.

Jako bezwyznaniowemu, nie należałby się właściwie Metonowi żaden dodatek przed imieniem. Dlaczego jednak pozwalam sobie używać dodatku „p.p.”?

Nie jest to skrócona nazwa partii, w rodzaju ND, LND, Ch-D, PPS, SD itp., gdyż psy na szczęście do żadnych partii nic należą.

Ten zagadkowy skrót objaśnia się bardzo prosto: „p.p.” znaczy, zgodnie z faktem, „psiej pamięci”. Wprawdzie, mówiąc o nieboszczykach rodzaju ludzkiego, nie piszemy „l.p.”, tj. „ludzkiej pamięci”. Ależ za to mamy rozpadnięcie się całej ludzkości na „ś.p.” i „b.p.”, a przy bezwyznanioweach powinniśmy się obchodzić bez takich ozdób dwuliterowych, czyli używać dodatku zero. No, ale co innego człowiek, a co innego pies.

Prawdę powiedziawszy, „psia pamięce” jest bardzo krótka i nie przechowuje imion nieboszczyków. „Psia pamięć” sprowadza się właściwie do „ludzkiej pamięci” o psach.

Znałem pewną panią, która swemu ulubionemu pieskowi kazała wystawić wspaniały pomnik i na tym pomniku uwieczniła imię swego ulubieńca. Same psy są na szczęście wolne od tej próżności i megalomanii i nic tracą czasu na pamiętanie o tym, czego pamiętać nie warto.

P.p. Meton był przede wszystkim pudlem, z gęstą i obfitą szerścią koloru habitu kapucyńskiego. Był pudlem rozumnym i pojętnym. Odgadywał myśli ludzkie, a spojrzawszy człowiekowi w oczy, wiedział od razu, czego od niego wymaga.

P.p. Meton był stałym mieszkańcem Warszawy. Mnie zaś, pomimo że młodość spędziłem w Warszawie, pomimo że zostałem niegdyś zapisany do ksiąg stałych mieszkańców Warszawy i posiadałem odpowiednią „książeczkę legitymacyjną”, dziś, po powrocie ostatecznym na „ziemię ojczystą” z wieloletniej tułaczki, policja warszawska odmawia tego zaszczytu i każe mi być „mieszkańcem niestałym”.

P. p. Meton nie należał do nikogo osobiście; należał do całego domu, a mianowicie do jednego $\mathrm{z}$ domów na Tamce wprost Solca. Odwiedzał różnych mieszkańców tego domu i był przez nich żywiony i łaskawie traktowany. Chociaż ja tylko przejazdem 
z Kazania i z Dorpatu za granicę i odwrotnie bywałem w tym domu, gdzie zatrzymywałem się zwykle tylko po kilka dni, był jednak do mnie bardzo przywiązany. Kiedy, bawiąc na podwórzu, ujrzał mię pierwszy raz po moim przyjeździe przez okno pierwszego piętra, wpadał w szał radości, przybiegał na górę i witał się ze mną jak z najlepszym przyjacielem.

P.p. Meton był nie tylko rozumnym i pojętnym, ale także szlachetnym; kierował się wzniosłymi pobudkami altruizmu. Kiedy w tym domu oszczeniła się do nikogo nienależąca suka i żyła ze swymi szczeniętami w wielkiej nędzy, szlachetny Meton odwiedzał ją stale i przynosił jej otrzymywane ochłapy i inne smakołyki. A proszę nie myśleć, że mogły tu działać jakieś uczucia małżeńskie i ojcowskie. Jak mnie zapewniano, Meton żył w bezwzględnym celibacie i był osamotnionym starym kawalerem. Jego postępowanie z ową ubogą suką było objawem czystej „miłości bliźniego”, według zasady: res sacra miser.

Kiedy podczas ogromnych upałów dających się we znaki kudłatemu zwierzęciu moje kuzynki mieszkające w tym domu ostrzygły Metona, po paru dniach przyprowadził on do nich swego kolegę i wspóttowarzysza upalnej niedoli, dając wymowne znaki, ażeby jego także uwolniono od dokuczającej mu wełny.

W uznaniu tych zasług p.p. Metona ozdobiłem jego szyję będącym w moim posiadaniu orderem. I muszę przyznać, że jedwabna wstęga ciemnoczerwona z białymi brzegami była Metonowi daleko bardziej do pyska aniżeli mnie do twarzy. Doskonale odbijała od jego brunatnego owłosienia. Niestety, niedługo cieszył się Meton tą zaszezytną odznaką; musiałem mu ją zabrać, bo pokazywanie się tak udekorowanego czworonoga na ulicach ówczesnej Warszawy mogło pociągnąc za sobą niepożądane dla mnie następstwa.

Ale i do Metona musiała się stosować gadka starość nie radość. Dożywszy sędziwego psiego wieku, doznawał objawów sklerozy, artretyzmu starczych dolegliwości, oślepł, po części ogłuchł, owrzodział i wzbudzał ku sobie wstręt fizyczny. A że nie należał do nikogo, kto by się za nim ujął, więc stróż domu, czyli po dzisiejszemu dozorca, zawlókł go do Wisły i tam przemocą utopit. Tak więc w „tragiczny sposób” przeniósł się biedny Meton do lepszego psiego świata. 
Pochodzę wprawdzie z kraju, gdzie podobno ...do pana przywiazańszy stuga, niż w innych krajach matżonka do męza; gdzie

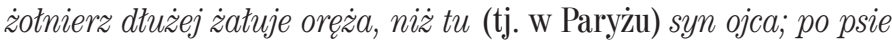
ptacza szczerze i dtu̇iej, niż tu lud po bohaterze; nie moge jednak odtworzyć w sobie uczuć przypisywanych Polakom przez Mickiewicza. Zostawmy na boku pana i sługę, małżonkę i męża, żołnierza i oręż, syna i ojca..., a ograniczmy się psem, ludem i bohaterem.

Po „bohaterze” nie byłbym w stanie płakać, a tym mniej po uwielbianym przez Mickiewicza, a przelewającym potoki krwi i wyciskającym strumienie łez Napoleonie, gdyż jego to właśnie miał nasz poeta na myśli. Nie jestem jednym z dwóch grenadierów i nie moge przejąć się psią wiernością dla ubóstwianego cesarza.

Po psie jednak prawie że płakałem. Smutny los mego kudłatego przyjaciela głęboko mię wzruszył.

[„Tydzień Polski” 1921, nr 32]

\section{PRAWDZIWA WOLNOMYŚLICIELKA}

W pewnej szkole była dziewczynka, która za nic nie chciała powtarzać za nauczycielem, że Ziemia obraca się dookoła Słońca.

Przecieżja widze, że Stońce sie porusza, a Ziemia stoi.

Dawano jej za to złe stopnie. Nic to nie pomogło. Dziewczynka trwała uparcie w „błędzie”, potępionym przez prawowierną naukę.

A ponieważ było to w czasach, kiedy za taki upór karano cieleśnie, więc nareszcie oćwiczono biedną dziewczynkę za nieposłuszeństwo i za lekceważenie nauki szkolnej.

Zalana łzami, dzielna dziewczynka oświadczyła: Ponieważ mnie bijecie, wię już bede powtarzata, że Ziemia obraca sie koto Stońca, ale nigdy temu nie uwierze.

Jej własny umysł mówił jej wyraźnie, że słońce zmienia położenie w ciągu dnia, od wschodu do zachodu, a tymczasem kazano jej powtarzać bezmyślnie oczywisty dla niej nonsens. Wymagała ona 


\section{przekonania jej dowodami niezbitymi, a nie nakazem i terro- rem. Gdyby ją przekonano, zgodziłaby się i zmieniłaby zda- nie.}

Był to umysł samodzielny a nie papuga powtarzająca bądź to utarte i przez tradycję i konwenans uświęcone zdania, bądź też modne i powabne dzięki swej nowości hasła.

Była to prawdziwa wolnomyślicielka, stojąca godnie obok Galileusza.

[„Myśl Wolna” 1922, nr 2]

\section{„DOBRY POLAK” A „WRÓG POLSKI”}

W artykule Zaszczytne odznaczenie „wroga Polski"1 opowiadałem dzieje swego „doktoratu honorowego” i związanych z nim nieporozumień i sprzeczności. Ale czytelnik nie dowiedział się, kto właściwie miał słuszność: czy ci, co mię napiętnowali niezbyt zaszczytną i niezbyt honorową nazwą wroga Polski, czy też ci, co pomimo tych napaści i oskarżeń, nadali mi całkiem szczerze i z czystym sumieniem istotnie zaszczytny tytuł doktora honorowego.

Jednym słowem powstała niewyjaśniona kwestia, jakim sposobem w oczach ludzi skądinąd niegłupich i uczciwych, a nawet niepospolitych i społecznie, i naukowo zasłużonych cieszę się opinią wroga Polski, cate życie dziatajacego na jej szkode.

Pierwsze moje wystąpienie publiczne w r. $1865^{2}$ było w obronie polskości, nad którą dokonywano eksperymentów rusyfikacyjnych. Następnie, o ile tylko miałem sposobność, broniłem polskości i walczyłem (oczywiście tylko słowem i piórem) zarówno z rusyfikacją, jak

\footnotetext{
1 „Robotnik” 1922, nr 55.

2 Chodzi 0 broszurę pt. Kilka stów z powodu wzmianki Tygodnika Ilustrowanego o rozprawie dr J. Ew. Purkyniego „O korzyściach z ogólnego rozprzestrzenienia tacińskiego sposobu pisania $w$ dziedzinie języków stowianskich", Warszawa 1865.
} 
też z germanizacją. Występowałem z odpowiednimi protestami i żądaniami na posiedzeniach rad uniwersyteckich, na zgromadzeniach publicznych, na zjazdach, w prasie, w artykułach dziennikarskich, w osobnych broszurach itd. Odgłosy moich wystąpień w latach wojny japońskiej i następnych, umieszczone w gazetach amerykańskich, zjednały mi entuzjastycznych wielbicieli między Polakami w Stanach Zjednoczonych.

Kiedy w marcu r. 1914 sądzono mię za broszurę 0 pierwiastku narodowym i terytorialnym $\mathrm{w}$ autonomii ${ }^{1}$ i skazano na dwa lata twierdzy, jednym z motywów, które wprawiały we wściekłość przewodniczącego izby sądowej Kraszeninnikowa, była właśnie moja „polskość”, której zresztą w swej broszurze nie wyodrębniatem i nie przeciwstawiałem prawom innych narodowości. W swym votum separatum, skierowanym do senatu z powodu, że skazano mię tylko za jedno przestępstwo, a uniewinniono co do drugiego, ten zacny mąż, Kraszeninnikow, nazwał mię etot pychtiaszczij nienawistju k' Rossii inorodiec (ten ziejący nienawiścią do Rosji innoplemieniec). Ten wybuch „patriotyzmu”, wprawdzie tylko rosyjskiego, powinien by znaleźć przyjazny oddźwięk w pokrewnych duszach "patriotów” polskich, widzących we mnie wroga Polski, cate życie dziatajacego na jej szkode.

Skąd więc taka charakterystyka dawana mi przez znaczny odłam inteligencji polskiej, a w tej liczbie także przez wielu uczonych i profesorów? Spróbuję dać wyjaśnienie.

Oto przede wszystkim nigdy nie byłem wyznawcą „egoizmu narodowego", uważając go za obłęd szkodliwy i zgubny.

Nigdy nie byłem wielbicielem Bismarcka i jemu podobnych zbrodniarzy wszechświatowych.

Nigdy nie uznawałem konszachtów ${ }^{2}$ i w tej liczbie także narodu polskiego za naród wybrany, uprzywilejowany i mający prawo do pomiatania innymi narodami i do uważania ich za materiat etnograficzny.

1 Nacjonalnyj $i$ territorialnyj priznak $w$ awtonomii, Pietierburg 1913.

$2 \quad$ Oczywisty błąd zecera. 
Nie należałem do kościoła panującego w Polsce na polu politycznym, tj. nie należałem do „Endecji” (obecnie „Luendecji”) ${ }^{1}$, a przeciwnie, byłem jej stanowczym przeciwnikiem, uważając jej metody za zgubne dla Polski.

Nigdy nie zaznawałem ${ }^{2}$ konszachtów i szachrajstw politycznych mających na celu wytargowywanie jakichś ustępstw dla Polaków z pominięciem, a nawet z upośledzeniem innych narodów. Nigdy nie wyodrębniałem sprawy Polski, ale zawsze traktowałem ją w związku ze sprawą wszystkich innych narodów uciśnionych.

W czasie wojny wszechświatowej nie plułem na legionistów galicyjskich, nie nazywałem ich lancknechtami Wilhelma, nie przyklaskiwałem formowaniu w Warszawie legionów, walczących po stronie rosyjskiej3.

Nie stałem na tylnych łapkach przed „Koalicją”, widziałem bowiem jej egoizm i jej lekceważenie sprawy polskiej, która w jej oczach była tylko sprawa wewnętrzna panstwa rosyjskiego. Nie potępiałem bezwzględnie Niemców i nie uważałem tylko ich za wyłącznych sprawców wojny i za barbarzyńców. Mieszkałem bowiem w Rosji i widziałem, co się tam dokoła działo i dzieje.

Nie mogłem też potępić „aktywistów”, bo widziałem w nich ludzi starających się wykorzystać nowe warunki dla kładzenia podwalin pod państwowość polską.

Nie zachęcałem ludności Polski i ziem przyległych do uciekania przed Niemcami i do towarzyszenia ustępującej armii rosyjskiej

1 Tak nazywa Baudouin Związek Ludowo-Narodowy (od 1919 r.), czyli wcześniejszą Narodową Demokrację (endecję).

2 Błąd zecera, powinno być: uznawatem.

3 Chodzi o plany utworzonego w listopadzie 1914 r. przez Narodową Demokrację Komitetu Narodowego Polskiego, kierowanego przez R. Dmowskiego.

4 Tj. państwami Ententy.

5 Tak nazywano w okresie okupacji Królestwa Polskiego przez wojska austriacko-niemieckie zwolenników wspólnego działania z Austro-Węgrami i Niemcami przeciwko Rosji, w przeciwieństwie do zwolenników orientacji prorosyjskiej, których nazywano pasywistami. 
w charakterze jej inwentarza dwunogiego, skazanego na zagładę lub upodlenie.

Ośmieliłem się od czasu do czasu wskazywać na zgniliznę moralną toczącą społeczeństwo polskie dzięki fałszom i kłamstwom konwencjonalnym. Za to zostałem wyrzucony z Uniwersytetu Krakowskiego. Osiadłszy w Warszawie w r. 1918, pomimo niepowodzeń i klęsk doznanych nie uspokoiłem się.

W wykładzie wstępnym w Uniwersytecie Warszawskim (28 października 1918 r.), mówiąc o prostytuowaniu nauki, wyraziłem nadzieję, że odradzająca się Polska nie stanie się nowym gniazdem zbójeckim, zagrażajacym pokojowi świata i powiększajacym liczbe bestii apokaliptycznych w menażerii wszechświatowej („Tydzień Polski” 1920 r., nr 4). Za to zostałem nazwany żydolubem na katedrze, pomimo że o Żydach nie tylko wcale nie wspomniałem, ale nawet o nich podczas całego wykładu ani razu nie pomyślałem. Nie mogłem wraz z prof. Zdziechowskim nie protestować przeciwko przyłączeniu się polskiej Akademii Umiejętności do postanowienia o niedopuszczeniu Niemców i ich sprzymierzeńców do Rady Międzynarodowej Badań Naukowych (Paroksyzm zemsty i nienawiści w światyni nauki, „Tydzień Polski”1920, nr 15 i 16).

Ośmieliłem się bez dostatecznego szacunku mówić i pisać o togach z biretami, o sztandarach, o krzewieniu militaryzmu i innych tp. świętościach ${ }^{1}$.

Następnie w artykułach o Uniwersytecie Wileńskim („Tydzień Polski” 1920, nr 20 i 31; 1921, nr 21) wypowiedziałem zdanie, że uniwersytet ten powinien unikać podejrzenia o tendencje polonizacyjne. Otóż te moje artykuły wywołały święte oburzenie także pośród pewnego odłamu inteligencji warszawskiej, z niektórymi wybitnymi uczonymi włącznie. Oświadczano prywatnie i urzędowo, że Polak nie powinien tak pisać. „Dobry Polak” ma prawo pisać tylko to, co przejdzie przez cenzurę senatu akademickiego, zwierzchności uniwersyteckiej i areopagu uczonego. „Polak” powinien, jak za panią matką

1 Mowa 0 artykule Togi profesorskie, „Kurier Polski” 1921, nr 23 oraz Sztandar, „Naród” 1921, nr 161, 162, 169, w których Baudouin pisał o niewłaściwości wydawania pieniędzy na rzeczy zbędne w zrujnowanym kraju.. 
pacierz, powtarzać tylko mdłe banalności, powinien byé zaopatrzony w powagi narodowe i basować im pokornie i bez żadnej krytyki. „Polak” powinien iść śladem tych gęsi w bajce Franciszka Morawskiego, które, zapytane o przyczynę podjętego przez nie wrzasku, ustami jednej z nich, lecącej w odwodzie, oświadczyły:

Alboż my wiemy, co się dzieje z nami,

My tylko lecim za temi gessiami,

Które tam krzyczą na przodzie.

„Dobry Polak” powinien być typem Lechity scharakteryzowanego tak dosadnie przez Ślaza w Lilii Wenedzie.

W związku z oburzaniem się na mnie za moje zdanie o Uniwersytecie Wileńskim twierdzono, że całe życie byłem wrogiem Polski, że całe życie działałem na szkodę Polski, że nawet w ostatnich czasach ośmieliłem się obrazić paskarzy francuskich (art. Spustoszenia w duszach ludzkich, „Tydzień Polski” 1921, nr 3), a to może być powodem wielkiego nieszczęścia. Oto szlachetna i bezinteresowna Francja, solidaryzując się ze swymi paskarzami, wypowie nam swą przyjaźń i opiekę i pozostawi na łaskę losu oraz innych wypróbowanych opiekunów i łaskawców, Anglików i Włochów. A czyż to nie kryminał zasługujący na bezwzględne potępienie?

Oceniając samego siebie całkiem obiektywnie i bezstronnie, pozwalam sobie twierdzić, że ci, co mię uważają za wroga Polski:

1) albo wcale nie czytali moich broszur i artykułów i nie znają odnośnych faktów mego życia, powtarzając bezmyślnie złośliwe plotki i oszczerstwa, a w takim razie postępują lekkomyślnie i niesumiennie;

2) albo czytali moje prace publicystyczne, ale ich nie byli w stanie zrozumieć. Byłoby to jednym dowodem więcej, że można byé znakomitym uczonym w zakresie pewnych specjalności, do królowej nauk, matematyki, włącznie, a pomimo to w zakresie spraw społecznych i etycznych być niezdolnym do samodzielnego orientowania się;

3) albo nareszcie sami czytali i zrozumieli, ale ze względów partyjnych lub innych tego rodzaju, udają głuptasków i wypowiadają swe sądy ze złą wiarą. W takim razie zasługują na osobną kwalifikację, której tu nie będę rozwijał. 
Jakoś mi doprawdy nieswojo, że wciąż drepczę około własnej osoby i zajmuję nią cierpliwego czytelnika. Ale jak powiedziałem na początku artykułu Zaszczytne odznaczenie wroga Polski, swej osoby używam tylko jako materiału do roztrząsań ogólnych. A doprawdy rzadko kto tak jak ja doznawał tylu napaści i był ogłaszany za wroga przez „patriotów” różnonarodowych: i przez Polaków, i przez Rosjan, i przez Niemców, i przez Madziarów, i przez Włochów, i przez Francuzów...

Innych pozostawiam na boku, a określę tylko swój stosunek do polskości.

Obiektywnie i z urodzenia, i ze stosunków rodzinnych, i z wychowania, i ze wspomnień dzieciństwa i młodości, i z późniejszego życia, jestem Polakiem i niczym innym byé nie mogę. Byłoby śmiesznie wypierać się tego, a byłoby podle zaprzeczać temu dla kariery, jak to robili niektórzy priwislinskije urożency, uważani zresztą za całkiem porządnych ludzi. Co zaś do mej polskości świadomej, subiektywnej, to rzecz się ma, jak następuje.

Idę z Polską, dopóki walczy o swoje prawa, dopóki broni się. Chociaż jestem zdecydowanym antymilitarystą i przeciwnikiem wszelkich wojen, to jednak w roku 1920, podezas najścia „bolszewików”, wstąpitbym sam do szeregów, gdyby nie wiek cokolwiek spóźniony. Bo była to nie zwykła wojna, ale obrona przed barbarzyńcami, obrona przed grożącym nie tylko Polsce, ale i całej Europie ostatecznym zaćmieniem kultury i cywilizacji.

0 ile by jednak Polska czyhała na cudze, krzywdziła, zabierała przemocą i podstępem, robiła zamachy na prawa ludzi pojedynczych i całych zbiorowisk ludzkich, powiedziałbym: wara od tego! i nie mógłbym się solidaryzować z taką Polską napastniczą i zbójecką. Wtedy stałbym się istotnie „wrogiem Polski”; ale taki wróg to właśnie przyjaciel. Bo to, co by Polska wtedy robiła, byłoby nie tylko zbrodnią, ale czynem dla niej samej zgubnym i zabójezym. Zemściłoby to się na niej czy prędzej, czy później.

Polska szłaby wtedy torem swych dawnych gnębicieli i innych zachłanników, wyznawców zasady: oderint dum metuant (niech nie- 
nawidzą, byle się tylko bali). W najwyższej potędze trzymają się tej zasady dzisiejsi władcy Rosji, fałszerze Marksa; ale chyba i im nie ujdzie to na sucho.

Uganianie się za taką „wielkością” i „potęgą” jest zgubne dla każdego państwa. Niegdyś przy innej sposobności, wypowiedziałem zrównanie: wielikaja Rossija -nieszczastnaja Rossija (wielka Rosja - nieszczęśliwa Rosja). Tak samo myśl 0 „potężnej Polsce” w znaczeniu straszydła dla innych i gniazda zbójeckiego (w rodzaju Rzymów różnorakich) wstręt we mnie budzi.

Czuje się solidarnym z Polską tam, gdzie chodzi 0 obronę niezaprzeczonych praw Polski i Polaków, gdzie polskość bierze udział w twórczości umysłowej, w wytwarzaniu nowych zdobyczy ducha ludzkiego, w pielęgnowaniu uszlachetniających ideałów wszechludzkich.

Do żadnego zaś społeczeństwa, które by uprawiało politykę „egoizmu narodowego", polityke gęsią i baranią, politykę głupią, zaślepioną i samobójczą należeć bym nie chciał i nie należałbym.

Nie chcę być „dobrym Polakiem”, jeżeli to wymaga wyrzeczenia się rozumu i poczucia sprawiedliwości. Przyjmuję chętnie nazwę wroga Polski, jeżeli wrogiem Polski jest ten, kto przestrzega przed nadymaniem się na wielkopaństwowośé i przed poświęcaniem względnego szczęścia i dobrobytu ludzi zarówno we własnym kraju, jako też gdzie indziej, na ołtarzu histerycznych i zbrodniczych zachcianek niepoczytalnych ambitników i megalomanów narodowości upaństwowionej.

Nie mogę się solidaryzować z Polską, która brutalnie odtrąca od siebie tych, co się do niej garną. Nie mogę iść ręka w rękę z „patriotami”, którzy nie tylko dla osobników istotnie podejrzanych, ale także dla tych, co ukochali Polskę miłością przeczuloną i nieśli jej życie w ofierze, urządzają Jabłonny, i którzy wolą głuptasa folbluta, aniżeli rozumnego „inorodca”, czyli „allogena”. choćby całym sercem oddanego sprawie publicznej państwa polskiego.

Jestem wrogiem Polski tam, gdzie Polska sama jest sobie wrogiem. 


\section{POZIOM MORALNY I UMYSŁOWY SPOŁECZEŃSTWA}

Trudno wydawać ryczałtowe, uogólniające wyroki, nie zbadawszy sumiennie szczegótów. Jeżeli jednak pozwalamy sobie wypowiadać na poczekaniu sądy o stanie umysłowym, moralnym i innym danego społeczeństwa lub nawet kilku społeczeństw, to czynimy to jedynie na podstawie impresji, na podstawie wrażeń przemijających. Przy tym zjawiska pewnej kategorii występują nierównie jaskrawiej aniżeli inne, może nierównie donioślejsze.

To, co się wylewa na ulicę i daje o sobie krzykliwe świadectwo, usuwa na dalszy plan pracę cichą, zamkniętą w sobie, a jednak zwykle dającą nierównie trwalsze wyniki.

Zwłaszcza w ostatnich dniach ulica wzięła stanowczo górę nad tym, co dzieje się wewnątrz domów, w gabinetach, w warsztatach, fabrykach itd. Niedawno mieliśmy hałaśliwe wybory do sejmu i senatu, następnie hałaśliwe i wprost bandyckie protesty przeciw wyborowi pierwszego Prezydenta Rzeczypospolitej, a nareszcie zakończenie tego wszystkiego przez mord dokonany na osobie Prezydenta, znienawidzonego bez żadnego rozumnego powodu. A wszystko to odbywało się przy akompaniamencie wynurzeń w „organach opinii publicznej”, wynurzeń świadczących w znacznej części o nader niskim poziomie etycznym i intelektualnym ich autorów.

Przede wszystkim okres wyborezy nasuwa smutne refleksje i podszeptuje wnioski ,reakcyjne” 0 bezsensie tak zwanego parlamentaryzmu. Przecież z jakie dziewięć dziesiątych wyborców płci obojej szło do urn wyborczych jak ślepe, odurzone i niezdające sobie sprawy stado bydląt dwunogich a bezskrzydłych. Sami nie wiedzieli, po co ich tam pędzono i co miała znaczyć cała ta komedia.

Niektórzy wyborcy, a właściwie wyborczynie zapytywali, czy nie będą karani w razie, jeżeli wstrzymają się od głosowania. Znakomite uświadomienie i nie mniej znakomite rozumienie swych praw i obowiązków obywatelskich! A przecież takich obywateli i obywatelek uprawnionych do głosowania jest wcale pokaźna porcja.

Prawdopodobnie wszystkie partie zacietrzewione i dążące wszelkimi sposoby do zmiażdżenia swych przeciwników, dopuszczały 
się nadużyé, oszustw i fałszerstw. Tak można z góry przypuszezać, znając naturę ludzką. Trzymając się z dala od zgiełku walk toczonych językiem i nożem, mam bardzo mało konkretnych danych na poparcie tego przypuszczenia. Mimo woli jednak uszczknąłem parę kwiatków działalności agitacyjnej sympatyków partii zblokowanej', której się wydaje, że wydzierżawiła na swój wyłączny użytek prawdziwą ,polskośc”, prawdziwy „patriotyzm” i istotną troskę 0 ,jedność państwową” w duchu „chrześcijańskim” i „narodowym”.

Niektórym wyborczyniom „Z ludu” grożono, że zostaną wyrzucone z mieszkania, jeżeli nie będą głosowały na „ósemkę”. Musiały dać słowo, że spełnią to żądanie, a że dały słowo, więc uważały się za obowiązane do jego dotrzymania. Dały zaś słowo dzięki poziomowi swego uświadomienia politycznego i dzięki swoistej znajomości praw obowiązujących w Rzeczypospolitej Polskiej. W swej bezdennej naiwności nie wiedzą one, że nie mogą byé wyrzucone $z$ mieszkania, że nikt nie ma prawa wymuszać na nich zobowiązania do głosowania na taką lub owaką liczbę, że głosowanie jest tajne i że nikomu nie wolno wywierać nacisku w kierunku tej lub owej liczby. Ale tym zahukanym i sterroryzowanym posługaczkom i innym „proletariuszkom” chodzi 0 dach nad głową i o nienarażenie się osobom, które im imponują pod tym względem. Niestety na tym samym poziomie w zakresie polityki stoją nie tylko proste praczki i posługaczki, ale także osoby niby to wykształcone i śmiało zabierające głos w kwestiach politycznych.

W pewnej fabryce zagrożono robotnikom, że jeżeli nie będą głosowali na „ósemkę”, fabryka zostanie zamknięta, a oni stracą zarobek. Był to oczywisty nonsens i tzw. strachy na lachy. A jednak podobno niektórzy robotnicy uwierzyli temu i dali się sterroryzować, co świadczy nader pochlebnie o stopniu ich „uświadomienia politycznego”.

Wszelkie tego rodzaju groźby, wymuszania, szantaże należą do przestępstw, za które można być skazanym na mniej lub więcej surową karę więzienną. Gdyby więc obywatele lub obywatelki, którym ktokolwiek bądź groził represjami za niegłosowanie na tę lub ową

1 Tj. Chrześcijańskiego Związku Jedności Narodowej (popularnie zwanego „Chieną”), koalicji Narodowej Demokracji, Chrześcijańskiej Demokracji i Narodowo-Chrześcijańskiego Stronnictwa Ludowego. 
liczbę, czyli listę, znali przepisy o wyborach do sejmu i senatu i gdyby posiadali choć odrobinę poczucia godności osobistej i obywatelskiej, powinniby byli 0 każdej takiej próbie wymuszania donosić do władz kierujących wyborami lub choćby tylko do policji, a wtedy może ostygtby nieco zapał w obrabianiu „bydła wyborczego”.

Nie mamy prawa obwiniać 0 nadużycia kierowników tej lub owej partii, ale że znaczna liczba gorliwców mogła się posuwać za daleko i nie tylko naruszać przykazania moralne, ale także popełniać przestępstwa kryminalne, to nie ulega najmniejszej wątpliwości.

Wprost anegdotycznie wygląda pogtoska, jakoby agitatorowie „piątki” zdołali wmówić niektórym dewotkom, ażeby głosowały na „piątkę", czyli na „komunistów”, ponieważ „komuniści” to tacy, co przystępują co tydzień do „komunii” świętej.

Wszystko to są wymowne świadectwa 0 wysokim poziomie moralnym i umysłowym przeciętnego społeczeństwa.

0 tym samym poziomie świadezy także stosunek ludku bożego do wyboru przez sejm i senat, czyli przez Zgromadzenie Narodowe, pierwszego Prezydenta Rzeczypospolitej.

Szczegóły objawów „gniewu narodu” za „wyrządzoną mu zniewagę” przez obiór „żydowskiego elekta” są aż nadto znane. Dopełnię je paru drobnostkami, niemniej charakterystycznymi.

Pewnej damie „z towarzystwa” powiedziano, że Narutowicz był „Szwajcarem” (obywatelem Szwajearii). Zrozumiała to ona po swojemu i bardzo się dziwiła, że nie mogli wybrać jakiego inteligenta, ale zatrzymali się na człowieku, który drzwi otwiera.

Kumoszki na rynkach warszawskich miały za złe panom wyborcom, że nie wybrali hrabiego Zamoyskiego. Hrabia jest przecież bogaty; nie tylko nie brałby nic od ludzi, ale, przeciwnie, sam by dawał. Nie byłoby więc wcale podatków, a ludzie biedni dostawaliby zapomogi od magnata. Tak zaś, jak się stało, wszystko pójdzie po staremu i w dalszym ciągu panować będzie „rząd złodziei”. Piłsudski kradt, a teraz Narutowicz będzie kradł, tj. będzie pobierał podatki i chował do własnej kieszeni.

A nie zapominajmy, że tego rodzaju kumoszki królują nie tylko na rynkach i w halach za Żelazną Bramą. Ich siostrzyce znajdą się również w salonach i w tonie tak zwanej „inteligencji”. Jeżeli np. po- 
psuły się rury gazowe i gaz wydobywał się na schody, jeżeli w ogóle coś się gdzieś popsuło, osoby wykształcone wybuchały oburzeniem: to wszystko rzady Pitsudskiego!

Agitatorowie partyjni czy to ze złą wiarą, czy też dzięki ciasnocie umysłowej wypisywali na rozlepionych afiszach, że coraz bardziej rosnącą drożyznę zawdzięczamy rzadom Belwederu i lewicy. Dodawano przy tym, że dla zwalczenia drożyzny trzeba koniecznie głosować na tę lub ową liczbę. Jestem w posiadaniu nalepki na bochenku chleba $z$ tekstem następującym: $\mathrm{Nr}$ 8. Chcecie mieć chleb tanszy, głosujcie na liste $\mathrm{Nr} 8$.

Ale co tu dziwić się ludziom przeciętnym. Przecież jeden z „Nestorów" postępu polskiego wyrzucał niewdzięczność Piłsudskiemu, ponieważ ongi przed laty, kiedy Piłsudski musiał się tułać i ukrywać, on go przytulił i pozwolił mu nocować w swym własnym mieszkaniu, a teraz po wskrzeszeniu państwa polskiego temu, kto się niegdyś zlitował nad Piłsudskim, rekwirują mieszkanie. Jaka czarna niewdzięczność!

I jaki zarazem dowód światłości i siły umysłu!

Kwiatkami z tego samego trzęsawiska są wypadki, wywołane wyborem pierwszego Prezydenta. Grożono nawet wojna domowa i morzem krwi. W tej kołowaciźnie i w tym zamęcie beznadziejnym nie tylko nadymano się na najmroczniejsze średniowiecze, ale po prostu tkwiono w mroku średniowiecza. Powinniśmy się pogodzić z myślą, że cofnęliśmy się do najciemniejszych wieków średnich, które zresztą może nie były tak straszne, jak je malują, i które może nawet pod niejednym względem stały wyżej od czasów przez nas przeżywanych.

Bluźnierstwem, właśnie ze stanowiska ludzi szczerze wierzących, było nadużywanie palca bożego i zrzadzenia Opatrzności.Z powodu mordu dokonanego na pierwszym Prezydencie pisano między innymi:

Palec Boży. Fakt zabójstwa uczynił na ludzie warszawskim głębokie wrażenie. W czynie niepoczytalnego szaleńca widzi się palec Boży, twierdząc, że składanie zaprzysiężenia przez człowieka niewierzącego było krzywoprzysięstwem, które nie mogło pozostać bez kary. 
Fakt ten stanowić będzie niewątpliwie koniec jednego rozdziału walki o narodowe zwycięstwo.

Jak się wam podoba to grzebanie w duszy nieboszczyka? Skąd ta pewność, że był on cztowiekiem niewierzacym?

A niepoczytalny szaleniec odegrał rolę narzędzia kary za krzywoprzysięstwo. Kiedy za pogrzebem Prezydenta ciągnął się długi orszak z duchowieństwem katolickim na czele, widząca to obywatelka prawowierna i odpowiednio spreparowana, miała zawołać: Patrzcie no, Żyda księża chowaja!. A takich obywatelek i obywateli jest cały legion.

$\dot{Z} y d$, przechrzta, mason, socjalista, bolszewik - wyrazy te działają, zapadają głęboko do duszy i wywołują odpowiedni nastrój i ferment, potężniejący w atmosferze beznadziejnego pomieszania pojęć.

Nasz (to jest nie tylko nasz polski, ale także nasz wszechświatowy) poziom umysłowy i moralny) obniżył się ogromnie, ale nie doszedł jeszcze do stopnia odpowiadającego ogromowi zbrodni wszechświatowej, jaką była ostatnia wojna i jej dalsze ciągi. Należy oczekiwać coraz większego obniżania się i upadku.

Czy się podźwigniemy, podejmując syzyfową pracę przemijającej odbudowy? Na to pytanie trudno dać odpowiedź.

[„Głos Polski” 1922, nr 371]

\section{NIE WOLNO KALAĆ UST MILCZENIEM}

W życiu powszednim słuszną jest zasada, wyrażona w niemieckiej gadce: Sprechen ist silber, Schweigen ist gold (mówienie jest srebrem, milczenie złotem). Bywaja jednak wypadki nadzwyczajne, kiedy milczenie byłoby objawem obojętności na sprawy społeczne pierwszorzędnej wagi, obowiązkiem zaś obywatela jest zabierać głos, jeżeli to, co się dzieje, jest sprzeczne w jego oczach z nakazami najwyższej moralności i z wymaganiami dobra powszechnego. Taką właśnie jest chwila obecna. 
Przed ostatecznym rozstrzygnięciem losu Eligiusza Niewiadomskiego zwracano się do prezydenta Rzeczypospolitej z różnych stron i w różny sposób z prośbami o ulżenie losowi skazańca, tj. o zamianę „kary śmierci” na inną, nie tak już bezwzględną i uniemożliwiającą, choćby w mniej lub więcej odległej przyszłości, wszelką skruchę i uświadomienie sobie całej ohydy popełnionego „zbrodniczego czynu”. Leo Belmont wydał List otwarty do pana prezydenta Rzeczypospolitej w sprawie Eligiusza Niewiadomskiego. Ukazały się też artykuły w prasie poruszające tę samą sprawę. Grono osób podpisało prośbę do p. prezydenta o złagodzenie wyroku. Nawet najbliższa rodzina zamordowanego prezydenta Narutowicza oświadczyła, że pomna aktu miłosierdzia, który był pierwszym aktem jego urzędowania, nie pragnie odwetu i prosi o darowanie życia zabójcy ojca i brata.

Należałem do tych, co podpisali zbiorową prośbę o niezatwierdzanie wyroku śmierei. Uważam więc, że mam prawo i obowiązek wypowiedzieć zdanie 0 tym, co się stało. Mam też nadzieję, że nie będzie mi to wzięte za złe i że ani ja osobiście, ani to, co powiem, nie ulegnie żadnym represjom.

Jeżeli zasadę bezwzględnej wolności słowa stosowano i dotąd stosuje się do tych, co pozwalali i pozwalają sobie w sposób ulicznikowski zniesławiać, znieważać i zohydzać naczelnika państwa ${ }^{1}$, rząd i najwyższe władze państwowe, jeżeli wolno było pisać lekceważąco i pogardliwie o panu Narutowiczu, już jako o Prezydencie Rzeczypospolitej, jeżeli z drugiej strony wolno gloryfikować i apoteozować jego mordercę, toć chyba należałoby stosować tę samą zasadę wolności słowa do poważnej i pełnej uszanowania krytyki wyroków i postanowień władzy, zwłaszcza jeżeli ta krytyka wypływa z pobudek zarówno humanitarnych, jako też utylitarnych, utylitarnych nie w stosunku do własnej osoby piszącego, ale w znaczeniu dobra ogólnego, dobra państwa i społeczeństwa.

Schylając głowę z należytym szacunkiem zarówno przed wyrokiem sądu, jako też przed potwierdzającą ten wyrok decyzją przed-

1 Baudouin ma na myśli ataki prasy endeckiej na Piłsudskiego, prowadzone, mówiąc oględnie, w stylu rynsztokowym, acz charakterystycznym dla tego nurtu. 
stawiciela państwa, nie mamy jednak ani obowiązku, ani tym mniej prawa do uważania tych władz za nieomylne. Chociaż dla każdego wiernego poddanego wszelka wtadza pochodzi od Boga, to jednak nie może być uważana za nieomylną. Ani sędziowie, ani głowa państwa nie są papieżami. A nawet „dogmat nieomylności papieskiej” nie dla wszystkich jest obowiązującym.

Wszystkim tym, co starali się w ten lub ów sposób wpłynąć na złagodzenie wyroku, wydawało się to tak naturalnym i tak samo przez się rozumiejącym, iż ani na chwilę nie przypuszczali, ażeby mogło być inaczej. Dowiedziawszy się zaś, że decyzja wypadła wbrew ich pragnieniom i przewidywaniom, nie wierzyli własnym oczom i uszom. Był to dla nich taki cios, jak gdyby wydarto im coś bardzo drogiego i świętego. A drogą i świętą jest wiara w tryumf ideałów humanitarnych.

Wiadomość o zatwierdzeniu wyroku przyjęli z zadowoleniem z jednej strony osobniki stosujące zasadę zęba za zab, oka za oko, z drugiej zaś strony ci, co, wypowiedziawszy wojnę państwu polskiemu, o ile nie jest ono przez nich rządzone, pragną mieć własnych „męczenników”, „bohaterów” i „patronów”.

Ludzie marzący o złagodzeniu wyroku znajdowali dostateczne do tego motywy zarówno w aktach sprawy, jako też we własnym sumieniu.

Akta sprawy mówiły im, że wyrok śmierci zapadł niejednogłośnie. Jeden z trzech sędziów był stanowczo przeciwko niemu i podał votum separatum. Przecież samo prawo obowiązujące nie przewiduje kary śmierci; mogła ona być zastosowaną tylko na podstawie przepisów dodatkowych, wydanych przez niemieckie władze okupacyjne. W każdym razie kwestia to sporna i niedostatecznie wyjaśniona, a podobnoć w razach wątpliwych prawo tłumaczy się na korzyść obwinionego.

Co zaś do sumienia, to sumienie niegodzące się na wygłaszanie pięknych haseł i przykazań przy jednoczesnym postępowaniu według całkiem innych wskazówek, sumienie takie zna w podobnych razach tylko jedno jedyne przykazanie: nie zabijaj.

Nie zabijaj: ani indywiduów, ani grup; ani ludów, ani ras; ani życia, ani szczęścia; ani ciała, ani myśli; ani dobrobytu, ani ideałów. Nie zabijaj: ani nielegalnie, ani legalnie; ani „niehonorowo”, ani „ho- 
norowo"; ani skrytobójczo, ani też z całą paradą, przy odgłosie trąb i bębnów.

Nie ulega wątpliwości, że mord dokonany przez Niewiadomskiego był czynem okropnym, był zamachem godzącym w majestat Polski, a może nawet w jej istnienie, zamachem, który przy odpowiednim napięciu mógłby był wywołać zamęt ogólny, wojnę domową i nieobliczalne następstwa wynikłego stąd chaosu, przy akompaniamencie wszechnienawiści. Jeżeli tak zwana „zbrodnia tchórzostwa”, równoważna prawie ze „zbrodnią” zdenerwowania lub rozstroju żołądka, bywała karana śmiercią, to chyba „zbrodnia” dokonana przez Niewiadomskiego zasługiwała na wielokrotnie pomnożoną „karę śmierci”.

A jednak i jedna, i druga „zbrodnia” należą do dziedziny niepoczytalności. Nie mówiąc już o naukowym traktowaniu winy i kary, wykluczającym pojęcie „kary”, gdyż nikt nie może postępować inaczej, jak postępuje, to nawet ze stanowiska prawnego, ze stanowiska odpowiedzialności i poczytalności należało uznać Niewiadomskiego za niepoczytalnego. Przypuszczam, że z tym zapatrywaniem zgodzą się psychiatrzy i psychologowie.

Niewiadomski był niepoczytalny nie w tym sensie, że nie wiedział, co czyni, że nie rozumiał, iż morduje człowieka całkiem niewinnego i niepospolitego zarówno pod względem umysłowym, jako też moralnym. Niewiadomski był niepoczytalny, ponieważ znajdował się pod wszechpotężnym wpływem autosugestii, podsycanej przez to, co dokoła widział i słyszał, ponieważ naładował się nienawiścią i żądzą pomszczenia krzywdy wyrządzonej rzekomo Polsce, a naładował się w tak wysokim stopniu, że mógł się uspokoić dopiero po wyładowaniu tego rozpierającego jego istotę uczucia przez dokonanie morderstwa na symbolu znienawidzonej przez niego Polski dzisiejszej.

Uczucie sprawiedliwości w połączeniu z naukowym poglądem na rzeczy nie pozwalało stosować kary śmierci do takiego człowieka.

Ale podobno kara śmierci ma działać odstraszająco i zapobiegać powtarzaniu przestępstw. Niestety, jest to złudzenie i kłamstwo konwencjonalne, w które nie wierzą sami ci, co je sentencjonalnie wygłaszają. Jeżeli kara śmierci stosowana do zwykłych złodziei, zabójców i bandytów nikogo z nich nie odstrasza i nie zmniejsza wcale ilości przestępstw, to tym mniej może ona wpływać odstraszająco na 
tego rodzaju „zbrodniarzy” jak Niewiadomski, którzy uważają się za powołanych do robienia porządku na świecie, którzy „w imię idei” pełnią samozwańczo rolę oskarżycieli, sędziów i wykonawców wyroku.

Przeciwnie, ostentacyjne wykonanie na Niewiadomskim wyroku śmierci wraz z towarzyszącymi mu okolicznościami może działać tylko zachęcająco na wyobraźnię osobników, w których kiełkuje żądza stania się swoistymi „bohaterami narodowymi”.

Powiadają, że sam Niewiadomski żądał dla siebie kary śmierci, że więc było obowiązkiem spełnić to jego żądanie. Dziwna doprawdy uprzejmość! Potępia się stanowczo „zbrodnię”, ale uwzględnia się „kabotyńskie” zachcianki „zbrodniarza”, pozującego na „bohatera”.

W oczach swoistych entuzjastów Niewiadomski miał „piękną śmieré”, śmierć z paradą, śmierć z kwiatami; mógł sobie pozwolić na „wspaniały gest” i na wykrzyki piętnujące znienawidzonych przeciwników i oczywiście nawołujące współideowców do zgładzenia ludzi, którzy „gubią Polskę”. Czyż to nie zachęcające?

Wszystko to wygląda tak, jak gdyby Niewiadomski zabił jednego ze swych głównych przeciwników politycznych, a za to spotkał go odwet ze strony tych przeciwników. Takich pozorów należałoby unikać ze względów dobrze zrozumianego interesu państwowego.

Następstwem tego czynu nieopatrznego, jakim jest zabicie Niewiadomskiego, mogą być próby urządzania manifestacji ku uczczeniu „męczennika i bohatera”, „pielgrzymki” do jego grobu itp. niepożądane wybryki. Przemówienia straconego w ten sposób przestępcy urastają do znaczenia „testamentu” przekazanego narodowi do rozważania, zapamiętania i naśladowania.

Jeżeli zaś w ogóle „kara śmierci” ma być aktem wysoce moralnym i przywracającym naruszoną równowagę społeczną, to należałoby wymagać, ażeby sami sędziowie wykonywali własnoręcznie wyroki śmierci, nie zmuszając młodych chłopców w mundurach wojskowych do łamania na komendę górującego nad wszystkim przykazania boskiego: nie zabijaj! Na te nieszczęsne ofiary, zmuszone wbrew woli spełniać rolę katów, branie udziału w zabójstwie zbiorowym musi działać demoralizująco.

Przeciwko zabiciu Niewiadomskiego należy zaprotestować jeszcze w imieniu nauki. Nie ulega chyba wątpliwości, że Niewiadomski 
był człowiekiem jeżeli nie niepospolitym, to w każdym razie niezwykłym, a więc przedstawiającym pierwszorzędny interes naukowy. Jako taki, zasługiwał na dokładne i wszechstronne badanie. Ciało jego było mniej interesujące niż dusza ${ }^{1}$. A znowu w ciele najbardziej zajmującą częścią był mózg. A tego właśnie nie można by było zbadać, bo mu roztrzaskano czaszkę i mózg uszkodzono.

Nauce w danym wypadku chodzi głównie o duszę. Siedząc w więzieniu, Niewiadomski pisałby z pewnością pamiętniki, nie do pogardzenia dla psychiatry i psychologa. Można na pewno przypuszczać, że po niejakim czasie ten zacięty „zbrodniarz” uświadomiłby sobie całą ohydę swego czynu, ujawniłby skruchę i żal, a to by było prawdziwą ekspiacją, prawdziwym zadośćuczynieniem, nierównie pożądańszym aniżeli proste zgładzenie ze świata zatwardziałego i zaciętego przestępcy.

Jednym słowem, dalsza ewolucja duszy takiego człowieka, jak Niewiadomski dostarczyłaby nauce nadzwyczaj cennego materiału, który dziś został uniemożliwiony.

W każdym razie wolno chyba zaprotestować przeciwko temu, o czym można powiedzieć: c'est plus qu'un crime, c'est une faute. Tak, jest to więcej niż zbrodnia; jest to błąd, niestety, nie do poprawienia.

Napisałem to jeszcze przed ostentacyjnym i demonstracyjnym przeniesieniem zwłok „nieśmiertelnego bohatera narodowego” ze stoków cytadeli na cmentarz Powązkowski. Przewidywania moje sprawdziły się i to nawet w nierównie wyższym stopniu, aniżeli przypuszczatem.

Pogrzeb nosił na sobie wszelkie znamiona uwielbienia i hołdu złożonego przez ojczyzne jej wielkiemu synowi. Odbywał się on przy akompaniamencie łkań, płaczu i ryku, wydobywającego się z piersi

1 Baudouin w swych pismach używa wyrazu dusza także w znaczeniach 'psychika' oraz, co widać w jego pismach językoznawczych, 'mózg'. 
i z gardeł „patriotek” i „patriotów”, czcicieli i czcicielek niewinnie zgtadzonej ofiary.

Jakiś posiadacz krzyża zasługi wojskowej zerwał go sobie z piersi i rzucił na trumnę bohatera nad bohaterami, wojownika za polskość Polski.

Młodzież uniwersytecka wartowała po nocach przy grobie Niewiadomskiego, a ludek boży opowiadał sobie ze skupieniem, że to aniołowie pełnią straż przy zwłokach meczennika.

Jeżeli po wyborze Narutowicza duchowieństwo niektórych parafii urządzało żałobną „czarną mszę”, „mszę sataniczną”, to po zabiciu Niewiadomskiego, który zrobit dobrze i zastużyt sie ojczyźnie, zgładziwszy ze świata Żyda i wybranca Żydów, zapraszano patriotów na niezliczoną ilość mszy żałobnych za spokój świetlanej duszy sp. Eligiusza Niewiadomskiego, który wtasnym życiem obudzit ducha narodu.

Niewiadomski jest „nieśmiertelny”. Do niego to przede wszystkim stosuje się powiedzenie Mickiewicza: Ja czuje nieśmiertelność, nieśmiertelność tworze, oraz Krasińskiego: Nieśmiertelny ten na ziemi, kto swa śmiercia życie pleni.

Dla widomego unieśmiertelnienia tego zacnego męża w niektórych miastach zakładają się biblioteki-czytelnie imienia Niewiadomskiego, a na pomnik dla niego zbiera się składki dawane z zapałem nawet przez urzędników państwowych. Kto zaś nie chce ich dawać, bywa do tego zmuszany.

Jeden z „wielkich pisarzów polskich” skomponował antycypando, tj. w oczekiwaniu wykonania wyroku śmierci, Testament tego, o którym wolno pisać tylko przez dużą literę: On, Jego, Jemu, Niego itd. Sam zaś wielki męczennik, święty, a co najmniej btogostawiony Eligiusz zwrócił się z kolportowaną w wielu tysiącach egzemplarzy odezwą Do wszystkich Polaków1.

1 Odezwę tę zamieścił w swojej broszurze pt. Proces Eligiusza Niewiadomskiego o zamach na życie prezydenta Rzeczypospolitej Polskiej Gabriela Narutowicza [...], odbyty w sadzie okregowym w Warszawie..., opracował i wydał Stanisław Kijeński, Poznań 1923. Na ten temat pisał Baudouin w artykule „Nil nisi veritas”, „Głos Polski” 1923, nr 326. 
Odezwa ta, pod nazwą Ewangelia narodowa Nieśmiertelnego Bohatera, krąży po kraju w niezliczonych odpisach, z dodaniem na końcu uwagi: Naucz się na pamięć zdan podkreślonych $i$ daj drugim.

W taki to sposób obłąkańcy lub też udający obłąkańców starają się zatruwać umysły i sumienia narodu.

Jacy wyznawcy, taki też „prorok” i taka też „ewangelia”, ewangelia „bohatera narodowego”, który zaćmił Kościuszkę i stał się największym „patriotą polskim”, ponieważ zamordował pierwszego Prezydenta Rzeczypospolitej Polskiej.

Z tej swoistej ewangelii świetlanej pamięci nieśmiertelnego proroka $i$ bohatera narodowego zionie nieubłagana nienawiśé do Polski, rządzonej nie przez spółkę „ND et Co”, a w związku z tym zachęcanie i wzywanie do mordowania ludzi według własnego widzimisię. Można się spodziewać, że nowo upieczony „święty Eligiusz” znajdzie chętny posłuch i gorliwych naśladowców.

Najwymowniejsze i najgorętsze nawoływania do zbrodni ze strony Niewiadomskiego odsiadującego karę w więzieniu nie miałyby nigdy tego uroku i nie wywierałyby takiego wpływu, co głos zza grobu meczennika sprawy narodowej.

Ongi podszczuwacze, a dziś czciciele i wyznawcy Niewiadomskiego przelicytowują się w uwielbieniu dla niego. W łódzkiej gazecie „Rozwój” nr 47 (z niedzieli, dn. 18 lutego 1923 r.) czytamy:

0 Polsko! Ty nie zginiesz, chociaż czarne moce oplotty Cię intrygą i trądem, co plami Święte imię Ojczyzny. Chwałę Twoją pogrą̨zý pragną złe syny w pomroce, a niepomni na świeże i krwawiące blizny, od łańcucha niewoli i knutów siepaczy, niepomni lat ucisku, co w tajgi Sybiru słały tysiące braci na żywot tułaczy, cheą Cię strącić do grobu, pod osłoną kiru, który czerwoną płachtą, hasłem bratniej walki, chce zasłonić ludowi białych Orłów skrzydła, narodowego Znicza strzegącej Westalki, chę zająć miejsce jakieś upiorne straszydła, szydzące z polskiej mowy, z starej Ojców wiary, z Polską ojezyzną żadnym czuciem nie związane, obce hasłu złożenia z krwi własnej ofiary; za ordery - zaszczyty. Dusze zaprzedane!!!

Z tej pomroki grożącej Ojezý́nie zapadnią, wyłonił się duch ezysty, duch wielkiej świattośei, bolał nad jej upadkiem i zapragnął nad nią, mocnym ezynu piorunem zbudzié do ezujności, 
wielkie serce narodu. Dobry syn 0jezyzny w chrzcie ofiarnym krwi własnej nie wzdragał się spławié, rzucając razem z życiem w grunt jej święty, żyzny, hasło walki o Polskę - zginąć lub ją zbawić!

I zginął tak jak Chrystus, w odkupienia męce. I umierał jak mocarz bez skargi i trwogi ezystego ducha oddał w Boga Ojea ręce, a krwią swą obmył tej świątyni progi, gdzie honor Matki Polski na ołtarzu stoi, gdzie się ezyni cudowne misterium miłości. Duch jego trzymać będzie straż u tych podwoi. Duch i imię, co przejdą do nieśmiertelności.

Przez rodaków przelanej krwi Twojej rubiny, odrodzonej Ojczyzny wieńczyć będą skronie, głosząc prawdę, że mając takie jak Ty syny, w chaosie i bezprawiu Polska nie zatonie.

Tego tylko brakowało. Niewiadomski - chociaż przez ostrożność wyraźnie niewymieniony - został zestawiony z Chrystusem. Ale między Niewiadomskim a Chrystusem zachodzi choćby ta niewielka różnica, że Chrystus nikogo nie nienawidził i nikogo nie mordował, a Niewiadomski dyszał jadem nienawiści i za główny cel swego życia uważał morderstwo. Nie mówię już w ogóle o całej potworności i ohydzie podobnego zestawienia.

$$
* * *
$$

Na zakończenie zapytuję:

Czy tej gloryfikacji, tej apoteozy mordercy życzyli sobie ci, co wydawali i zatwierdzali wyrok śmierci?

Jeżeli tak, to ich życzeniom stało się w całej pełni zadość.

Jeżeli zaś nie życzyli sobie tych wstrętnych objawów bądź to szczerej, bądź też tylko udawanej kołowacizny, to mści się na nich sprzeniewierzenie się wymaganiom moralności zarówno chrześcijańskiej, jak i ogólnoludzkiej, i pogwałcenie jedynie obowiązującego przykazania: nie zabijaj!.

Ostatecznie zwyciężą chyba ci, co porzucą drogę krwawych odwetów i zemsty zaślepionej. 


\section{KANDYDATURY DEMONSTRACYJNE}

Zbliża się 9 grudnia, pierwsza rocznica wyboru pierwszego prezydenta Rzeczypospolitej Polskiej. Osoby obchodzące rocznicę doznają różnych uczuć, zależnie od przynależności partyjnej. Wątpię jednak, czy w kimkolwiek rocznica ta wywoła radość. Jedni bowiem będą się złościć na wspomnienie, że nie mogli przeprowadzić swego kandydata, drugich zaś ogarnie smutek przy myśli, że, wybierając Narutowicza, skazali go mimo woli na śmieré.

Warto uprzytomnić sobie okoliczności towarzyszące temu wyborowi.

Tylko prawica, czyli tzw. popularnie „Chiena”, miała tylko jednego kandydata, przy którym wytrwała do końca. „Lewica”, do której wówczas należał także „Piast”, rozstrzeliła swe głosy i wystawiła aż cztery kandydatury: dwie poważne, a dwie tylko dla demonstracji i ze względów taktyki wyborczej. Na podstawie bowiem ordynacji, obowiązującej przy wyborze prezydenta, wybory się powtarzały, przy czym kandydat. który otrzymał najmniejszą ilość głosów, odpadał przy następnym wyborze. Dawało to możnośé stopniowego koncentrowania się aż do skutku.

Poważnymi kandydatami byli Wojciechowski i Narutowicz. Przy pierwszym wyborze Narutowicz otrzymał czterdzieści kilka głos[ów] i był drugim od końca kandydatem między dwoma kandydatami demonstracyjnymi. Wojciechowski był przy pierwszym wyborze drugim od początku i szedł zaraz po hrabim Zamoyskim, wystawionym jednogłośnie przez prawicę. Demonstracyjny kandydat PPS Daszyński jako ten, co otrzymał najmniejszą ilość głosów przy pierwszym wyborze, odpadt przy drugim wyborze, a przy trzecim wyborze odpadł demonstracyjny kandydat „mniejszości narodowych”. Przy piątym i ostatnim wyborze walka toczyła się tylko między zwolennikami hr. Zamoyskiego a zwolennikami Narutowicza, na korzyść tego ostatniego.

Dzięki jakiemuś nieporozumieniu i przypadkowi, i mnie także wypadło figurować w liczbie kandydatów. Stało się to absolutnie bez mojej wiedzy i woli. 
Kiedy w gazetach porannych wyczytałem swoje nazwisko jako nazwisko kandydata upatrzonego przez „mniejszości narodowe”, pomyślałem, że są to kpiny albo też taki sobie pomysł którego z posłów. Nie przypuszczałem, że sprawa ta będzie traktowana poważnie. Kiedy zaś w południe, będąc przypadkowo w administracji jednej z gazet, wyczytałem zakomunikowany przez telefon rezultat pierwszego wyboru i znalazłem swoje nazwisko na trzecim miejscu, między Wojciechowskim i Narutowiczem, to chociaż pogłaskało to moją próżność, doznałem jednak niemiłego uczucia przy myśli, że pozwolono sobie nadużyć mego nazwiska. Gdyby mię bowiem zapytano o zgodę, stanowczo bym odmówił, nie chcąc grać roli figuranta.

Następnego dnia przychodzili do mnie dwaj przedstawiciele klubów, które mię zaszczyciły wyborem, przepraszając mię za nadużywanie mego nazwiska. Powiedziałem im, że właściwie powinien bym czuć do nich urazę, ale rozumiem pobudki, które ich do tego skłoniły.

Chcieli mi w ten sposób złożyć hołd uznania za moje wystąpienia przedwojenne w Rosji w obronie wszystkich „mniejszości narodowych”, w tej liczbie przede wszystkim Polaków. Zaprowadziło mię to nawet przed sąd carski i do więzienia, które odsiadywałem w końcu r. 1914 i na początku roku 1915.

0 ile mogłem wyrozumieć, inicjatywa mojej kandydatury wyszła wcale nie od Żydów, ale tylko od Białorusinów i Ukraińców, w każdym razie od „wrogów Polski”, do których przyłożyli się Żydzi i Niemcy, również „wrogowie Polski”. A to wystarcza.

Ponieważ dotychczas niektóre pisma pozwalają sobie nazywać mię, przeważnie dla ubliżenia mi „kandydatem na godność prezydenta”, więc oświadczam, że świadomie i subiektywnie podobnej kandydatury nie wystawiałem.

Zresztą gdyby nawet wbrew wszelkiemu prawdopodobieństwu wybrano mię ostatecznie, nie byłoby żadnego niebezpieczeństwa, ażebym wybór ten przyjął.

Przede wszystkim nie przyjąłbym go ze względu na to, że mnie nie pytano 0 zgodę.

Po wtóre nie przyjąłbym ze względów zasadniczych. Nie mogę się podejmować zadań, do których nie dorosłem. 
Następnie wiek mój mówi przeciwko podejmowaniu się pracy obliczonej na kilka lat.

Nareszcie, nie należąc do żadnego wyznania, nie mógłbym składać przysięgi wyraźnie wyznaniowej. Sumienie nie pozwala mi byé obłudnikiem i korzystać z praw, które mi się nie należą.

Oczywiście gdybym pomimo to zgodził się, miałbym po kilku dniach wspaniały pogrzeb; boć „bohater narodowy” z nierównie większym prawem mógłby skierować kule w moje plecy aniżeli w plecy Bogu ducha winnego Narutowicza. Tego morderstwa nikt nie mógt przewidzieć i obawa przed nim nie mogła byé w moich oczach czynnikiem przeciwdziałającym.

Powinien bym mieć wyrzuty sumienia, że pośrednio stałem się przyczyną śmierci Narutowicza. Boć przecie moja „kandydatura” ujawniła wyraźnie liczbę głosów „mniejszości narodowych”, a te głosy padły ostatecznie na Narutowicza. Czuję jednak ulgę przy myśli, że tępy fanatyk noszący się z zamiarem zamordowania Piłsudskiego byłby wykonał swój zbrodniczy zamiar i bez skoncentrowania głosów „mniejszości narodowych” na mojej „kandydaturze demonstracyjnej”.

Dziwna jednak rzecz, że dokonany tymi samymi głosami w kilka dni potem wybór Wojciechowskiego nie wywołał wściekłości w kołach większości narodowej, nie wywołał wrogich manifestacji przeciw nowemu prezydentowi, nie wywołał żadnych zamachów. Wybór ten przyjęto z rezygnacją.

Przy wyborze drugiego prezydenta „prawica” wystawiła jako swego kandydata znakomitego uczonego, Kazimierza Morawskiego. Zdaje mi się, że z jej stanowiska wybór ten nie był wcale odpowiedni. Jako człowiek prawdziwie światty i wysoce kulturalny K. Morawski nie popierałby wybryków zdziczenia, tępości moralnej, nienawiści i kołowacizny nacjonalistycznej. 


\section{ŁYSINA WYZNANIOWA}

Jeden z moich znajomych, którego głowa jest goła jak kolano, musiał wyrabiać sobie paszport. Urzędniczka sporządzająca ten dokument, bez którego człowiek nie może być człowiekiem-obywatelem w pełnym znaczeniu tego wyrazu, układała między innymi „rysopis” pacjenta. Gdy przyszła kolej na włosy, panna ta czy też pani zapytata: Jakie pan ma wtosy? Zgodnie z faktycznym stanem rzeczy odpowiedź brzmiała: Żadne; nie mam żadnych wtosów.

- Ale ja muszę panu napisać włosy.

- Ależ kiedy ja nie mam żadnych włosów.

- To nic; w rysopisie muszą być włosy.

- To niech sobie pani pisze, jakie się pani podoba.

Chociaż ani na głowie, ani na twarzy nie było ani śladu jakiego bądź włosa, twarz bowiem goli mój znajomy bardzo starannie, urzędniczka paszportowa zaliczyła go do jednego ze zbiorowisk ludzkich określanych według uwłosienia. W „rysopisie” figuruje on, zdaje się, jako „szatyn” czy też „brunet”, chociaż w czasach swego dzieciństwa, chłopięctwa i młodzieńczości był podobno jasnym blondynem.

Mój znajomy przyjął bez szemrania ten podarek uwłosieniowy z rąk bądź to uroczej, bądź też czcigodnej paszporcistki.

Przypomina to obdarzanie bezwyznaniowców obowiązkowym wyznaniem paszportowym. Chociaż pod tym względem dusza danego indywiduum jest absolutnie łysa, to jednak gorliwiec paszportowy nie uznaje tego i gwałtem wpisuje czy to „rzymsko-katolickość”, czy „mojżeszowość”, czy też jaką inną „wyznanio-wość”. Bo w oczach tych panów i pań bezwłosy ma włosy, bezręki ma ręce, beznogi ma nogi, a bezwyznaniowy ma wyznanie.

Przeciwko wpisywaniu koloru włosów do paszportu osobnika włosów pozbawionego można nie protestować. Przeciwko jednak narzucaniu przemocą i gwałtem tego lub owego wyznania stanowczy protest obowiązuje każdego człowieka, traktującego swe własne przekonania nie lekkomyślnie i frywolnie, ale poważnie i sumiennie. 


\section{BIBLIOGRAFIA PISM PUBLICYSTYCZNYCH BAUDOUINA DE COURTENAY ${ }^{1}$}

1865

1. Kilka stów z powodu wzmianki Tygodnika Ilustrowanego o rozprawie dr J. Ew. Purkyniego „O korzyściach z ogólnego rozprzestrzenienia tacinskiego sposobu pisania w dziedzinie jezzyków stowianskich", Warszawa 1865 .

1866

2. Odpowiedź p. Aleksandrowi Makowieckiemu na jego recenzje dzieta: „Franciszka Bolemira Kwieta. Popularnej nauki wychowania”, „Rodzina" $1866, \mathrm{nr} 3$.

3. [Inc.:] W numerze 3 „Rodziny” w Rozmaitościach czytamy mieddzy innymi..., „Rodzina” 1866, nr 5.

\section{2}

4. Hilferding czy ksiadz Malinowski, Moskale czy Polacy dadza Stowianom wszechstowiańskie abecadto? Pytania na które czytelnik znajdzie odpowiedź w niniejszym ttumaczeniu broszury... pt. Kilka stów z powodu „Wszechstowiańskiego abecadta”, Poznań 1872.

5. Petrograd, „Soča” 1872, nr 23, 25.

6. A. F. Hilferding, „Soča” $1872, \mathrm{nr} 32$.

7. [Noty] „Soča” 1872, nr 26, 42, 49.

1 Opracowano na podstawie: Bibliografia prac Jana Ignacego Niecistawa Baudouina de Courtenay, zestawionej przez M. J a s i ń s k ą , [w:] J. N. B a ud ou in d e C ourt en ay, Dzieta wybrane, t. 1, Warszawa 1974; dane bibliograficzne [w:] J. M u g d e n, Jan Baudouin de Courtenay (1845-1929). Leben und Werk, München 1984; R. A. R o th s te i n, Poprawki i dodatki do „Bibliografii prac Jana Ignacego Baudouina de Courtenay”, „Poradnik Językowy” 1976, nr 1 oraz częściowej kwerendy własnej. To zestawienie mimo wszystko nie jest zapewne kompletne, a całościowa bibliografia publicystyki Baudouina wciąż czeka na opracowanie. 
8. Odprto pismo, „Soča” 1872, nr 34.

9. Poslano, „Soča” 1872, nr 51/52.

10. Nektere opazke ruskega profesorja, „Soča” 1872, nr 75 [przedr. brosz. Gorica 1872].

11. Listek, „Slovenski Narod” 1872, nr 90, 106.

12. Z Gorycy, „Niwa” 1872, nr 17-18, 21-22.

\section{4}

13. Erudycja lingwistyczna „Tygodnika Ilustrowanego”, „Przegląd Tygodniowy” 1874, nr 40.

14. Slovenskim prijateljem, „Slovensky Narod” 1874, nr 138.

1875

15. Do redakcji „Niwy”, „Niwa” 1875, t. VI.

16. Przyczynek do historii blagi warszawskiej, „Przegląd Tygodniowy” 1875 , nr 33.

17. Groch na ściane, „Przegląd Tygodniowy” 1875, nr 42.

18. Pis'mo w redakciju, „Nowoje Wriemia” 1875, nr 203.

1877

19. Polityczne drgnienia Stowian austriackich, „Przegląd Tygodniowy" 1877 , nr 36-51.

1879

20. P. Ch. Mayreder, „Nowiny” 1879, nr 349.

21. Mate sprostowanie, „Nowiny” 1879, nr 350.

1880

22. Sprostowanie, „Nowiny” 1880, $\mathrm{nr} 70$.

23. Z listów lekarza ziemskiego Polaka, „Nowiny” 1880, nr 78. 
24. Ksiadz Antoni Juszkiewicz, „Nowiny” 1881, nr 35.

25. Kongres geograficzny, „Nowiny” 1881, nr 259, 261-264, 268, 281282, 284-285, 287-288.

26. Mieżdunarodnyj gieograficzeskij kongress i wystawka w Wenecii, „Zagranicznyj wiestnik” 1881, t. I.

27. Doktoryzacja. Literatura litewska, „Prawda” 1881, nr 25.

28. 0 prawde, „Prawda” 1881, nr 43.

\section{4}

29. Statija o stawianach w Italii, „Slovansky sbornik” 1884.

\section{6}

30. List zaprzeczajacy, „Kraj” 1886, nr 13.

31. Za i przeciw. Odwaga "Warty" na polu ktamstw i przekręcań, „Kraj” 1886, nr 50.

32. W sprawie kościota katolickiego w Dorpacie, „Kraj” 1886, nr 52. 33. Z powodu jubileuszu profesora Duchinskiego. Przez..., Kraków 1886.

\section{7}

34. W sprawie kościota katolickiego w Dorpacie, „Kraj” 1887, nr 5, 26.

\section{8}

35. In Sachen der hiesigen römischkatolischen Kirche, „Neue Dörptsche Zeitung" 1888, nr 219.

36. W sprawie kościoła katolickiego w Dorpacie, „Kraj” 1888, nr 19.

1889

37. List do redaktora, „Przegląd Tygodniowy” 1889, nr 45. 
38. Odgtos drugiego zjazdu historyków polskich we Lwowie, „Kraj” $1890, \mathrm{nr} 30$.

39. List zapraszajacy, „Kraj” 1890, $\mathrm{nr} 44$.

1891

40. In Sachen der hiesigen römischkatolischen Kirche, „Neue Dörptsche Zeitung” 1891, nr 129, 208.

41. W sprawie kościoła katolickiego w Dorpacie, „Kraj” 1891, nr 16, 30.

42. [Nota] Zur Judenfrage: Zeitgenössische Originalaussprüche, herausgegeben von C. E. Klopfer, München 1891, s. 47.

43. Wspomnienia z podrózy przelotnej po Czechach, „Dziennik P0znański” 1891, nr 153-154, 156, 158-159, 162, 171-172.

44. Sąd naganny o Elizie Orzeszkowej, „Dziennik Poznański” 1891, nr 174.

45. Z Dorpatu. Sprostowanie (w sprawie funduszu miejscowego kościota), „Przegląd Katolicki” 1891, nr 45-46.

46. Franciszek Bolemir Kwiet, „Athenaeum” (Praha) 1891, nr 4.

47. In Sachen der hiesigen römischkatholischen Kirche, „Neue Dörptsche Zeitung” 1891, nr 129, 208.

1892

48.Zur Frage der Russiefizierung der Universität Dorpat, „HochschulNachrichten” (München) 1892, nr 22; [replika BdeC na komentarz redakcji: Zur Dorpater Denunciations-Affaire. Erklärung, tamże 1892, nr 27].

49. O stawjanach $w$ Italii. Publicznaja lekcija, czitannaja $w$ polzu gotodajuszczich 14 marta 1892 g. w aktowom zale Derptskogo un-ta, „Russkaja mysl” 1893, ijun'.

1893

50. Aforyzm, „Dziennik Poznański” 1893, nr 293. 
51. Sprawa przyjecia jednolitej pisowni, proponowanej przez Akademie Umiejętności, „Tydzień” 1894, nr 32.

52. Sprawa przyjecia jednolitej pisowni, proponowanej przez Akademie Umiejętności, „Pamiętnik zjazdu literatów i dziennikarzy polskich”, t. I, Lwów 1894.

53. W sprawie pisowni, „Kraj” 1894, nr 32-33.

54. Ksiadz Michat Hórnik. Wspomnienie pośmiertne, „Czas” 1894, nr 45; także: „Nowa Reforma” 1894, nr 45;

55. Spomnjenje wo Mich. Hórniku, „Lužica” (Budišyn) 1894, nr 5-6.

1895

56. Myśli-miedziaki: Dwa Ślaska, Lwów 1895.

1898

57. Cenzurnyje „mietoczi”. 1. Kniaz' Bismark i gonienije „Stawian”, Kraków 1898.

58. Jeszcze o liście D, „Kraj” 1898, nr 40, 44.

59. Jeden z objawów moralności oportunistyczno-prawomyślnej, Kraków 1898. [wyd. nast.: Kraków 1928].

60. Myśli nieoportunistyczne, Kraków 1898.

1899

61. Na ziemi stowianskiej. (Przygody i wrażenia), „Kraj” 1899, nr 3-5.

62. Stowianie we Wtoszech, „Kraj” 1899, nr 45-46.

63. Puszkin w Krakowie, „Dziennik Poznański” 1899, nr 142-144.

64. Stowacy i korona św. Stefana, „Dziennik Poznański” 1899, nr 145146. 
65. Slovaci a korůna sv. Štepána, „Slovansky Přehled” R. I, 1899, s. 2-9; 73-78; 125-129; 170-176.

66. Stowacy i korona św. Stefana, „Tydzień” 1899, nr 203, 211, 220, 227, 268.

67. Wspomnienia z niedawnej wycieczki do Stowaków, „Przegląd Tygodniowy" 1899, nr 18-19.

\section{0}

68. Wspomnienia z miedzynarodowego kongresu historycznego, odbytego na poczatku września r. 1899 w Cividale, na pamiatke 1100 rocznicy śmierci Pawta Djakona, historyka Longobardów, „Ateneum” 1900, nr 2.

\section{2}

69. Gtos w sprawie konfiskat w ogóle a konfiskaty „Legend” A. Niemojewskiego w szczególności, „Krytyka” 1902, z. 11-12.

70. Uwagi na czasie i nie na czasie. (Z powodu ankiety „Krytyki” $w$ sprawie konfiskat $w$ ogóle a konfiskaty "Legend” A. Niemojewskiego w szczególności), „Krytyka” 1902, z. 11-12 [odb., Kraków 1903].

\section{3}

71. Kaprysy ttumicieli myśli ludzkiej, „Krytyka” 1903, z. 5 [odb., Kraków 1903].

72. 0 panslawiźmie platonicznym. (Odczyt wygtoszony $w$ Krakowie w czerwcu 1903), „Krytyka” 1903, z. 8-9.

73. 0 zjeździe slawistów i o panslawiźmie „platonicznym”. Dwa odczyty wygtoszone w Krakowie 16 i 18 czerwca 1903 r. na korzyśc Towarzystwa Pomocy Naukowej dla Polek im. Kraszewskiego, Wydawnictwo „Krytyka”, Kraków 1903.

74. Po powodu „sjezda slawistow”, „Wiestnik Jewropy” 1903, t. 38, ijul.

75. Zamietki o minuwszem i predstojaszczem "sjezdie slawistow” I, „Birżewyje Wiedomosti” 1903, nr 200. 
76. Zamietki o minuwszem i predstojaszczem „sjezdie slawistow” II, „Birżewyje Wiedomosti” 1903, nr 204.

1904

77. Zjazd slawistów a „głos mtodzieży”, „Kraj” 1904, nr 1.

78. Zjazd slawistów. Jeszcze z powodu zjazdu slawistów i "gtosu mtodzieży”, „Kraj” 1904, $\mathrm{nr} 3$.

79. Jeszcze o „zjazd slawistów”. Niezbędne wyjaśnienie, „Kraj” 1904, nr 5 .

80. 0 zjazd slawistów. Wyjaśnienie nowych nieporozumień w sprawie zjazdu, „Kraj” 1904, $\mathrm{nr} 12$.

81. Krzewiciele zdziczenia, „Ogniwo” 1904, nr 1.

82. Kwestia alfabetu litewskiego w panstwie rosyjskim i jej rozwiazanie, Kraków 1904.

\section{5}

83. Kamień na drodze. I, „Ogniwo” 1905, nr 1.

84. Luźne uwagi, „Ogniwo” 1905, $\mathrm{nr} 6,8$.

85. Z powszedniej logiki mitośników bliźniego, „Ogniwo” 1905, nr 10.

86. Pljatonicznyj panslawizm, „Literaturno-Naukowij Wistnik” 1904, kn. 1.

87. $Z$ logiki ttumów, „Krytyka” 1904, z. 5.

88. Professora i politika, „Syn Otieczestwa” 1905, nr 43.

89. Dwie kultury, „Syn Otieczestwa” 1905, nr 113.

90. Niedoumenije, „Syn Otieczestwa” 1905, nr 122.

91. Po powodu pisma G. Sienkiewicza, „Syn Otieczestwa” 1905, $\mathrm{nr} 243$.

92. Kak ja byt milicjonierom. (Iz prof. wospominanij), „Birżewyje Wiedomosti” 1905, nr 8720.

93. Gdie na Rusi konserwatory, „Birżewyje Wiedomosti” 1905, nr 8747.

94. Pod wpieczatlenijem sjezda professorow wysszich uczebnych zawiedenij, „Birżewyje Wiedomosti” 1905, nr 8755. 
95. Wospitatielnoje $i$ „odobriennoje” podstriekatielstwo, „Birżewyje Wiedomosti” 1905, nr 8788.

96. K woprosu ob uczeniczeskich zabastowkach, „Birżewyje Wiedomosti” 1905, nr 8791.

97. O procentnych btagodiejanijach $i$ mitostijach, „Birżewyje Wiedomosti” 1905, nr 8797.

98. „Kontrabanda” w zakrytych pismach, „Birżewyje Wiedomosti” $1905, \mathrm{nr} 8830$.

99. Christiansko-dworjanskij ftot, „Birżewyje Wiedomosti” 1905, $\mathrm{nr} 8845$.

100. Żetatielny-li posriedniki i zastupniki?, „Birżewyje Wiedomosti” 1905, nr 8853.

101. Powyszenije psichiczeski-socialnoj tiempieratury w obtasti szkolnogo dieła, „Birżewyje Wiedomosti” 1905, nr 8857.

102. Woinstwiennyj zud „istinnych christian”, „Birżewyje Wiedomosti” 1905, nr 8873.

103. Niegodowanije "niemieckogo patriota”, (Pis'mo w redakciju), „Birżewyje Wiedomosti” 1905, nr 8885.

104. „Pozornyj” mir i malen'kaja sprawoczka. (Otwiet po powodu statii w nr 8873), „Birżewyje Wiedomosti” 1905, nr 8893.

105. Obraszczenije „partii”, „Birżewyje Wiedomosti” 1905, nr 8897.

106. Pereat mundus, fiat vajatka! Iz uniatskoj epopiei, „Birżewyje Wiedomosti” 1905, nr 8941.

107. Umirotworienije uczenikow „sriednej szkoty”, „Birżewyje Wiedomosti” 1905, nr 8959.

108. Pamjati muczenikow, „Birżewyje Wiedomosti” 1905, nr 9124.

109. Iz moich wojennych wospominanij, „Naszi Dni” 1905, nr 30.

110. Nacjonalisticzeskoje mrakobiesie w tielegrafnom wiedomoste, „Nowaja Żizn’” 1905, nr 103.

111. Pora pierestat' tgat' i licemerit', „Nowaja Żizn” 1905, nr 116.

112. Po powodu tak nazywajemoj „zabastowki” w wysszich uczebnych zawiedenijach, „Nowaja Żizn’” 1905, nr 119.

113. Profiessorskoje bessilie, „Nowaja Żyzn’”1905, nr 130.

114. Iz polskich diet, „Nowaja Żizn’” 1905, nr 131/132.

115. Pis'mo w redakciju, „Nowaja Żizn’” 1905, nr 148.

116. Zagadocznaja kartinka, „Nowaja Żizn’” 1905, nr 335. 
117. Zabastowka, „Prawo” 1905, nr 23.

118. Polskij wopros w swjazi s drugimi okrainnymi i inorodczeskimi woprosami. Riecz', skazannaja 27 marta (9 aprelja) 1905 g. w sekcii obszczich diet sjezda profiessorow $i$ prepodawatielej wysszich uczebnych zawiedienij, „Prawo” 1905, nr 32.

119. Kwestia polska w Rosji w zwiazku z innymi kwestiami kresowymi i „innoplemiennymi”, „Świat Słowiański” 1905 [odb., Kraków 1905].

120. Uniwersitietskaja nauka i pasportnaja sistiema, „Rus’” 1905, nr 197.

\section{6}

121. Autonomia Polski. Odczyt wygtoszony w sali Muzeum Techniczno-Przemystowego w Krakowie 9 lipca 1906, Kraków 1906 [powtórnie wyd. Kraków 1907].

122. Graf S. Ju. Witte i „kadiety” (Iz pis'ma w riedakciju), „Dwadcatyj wiek" $1906, \mathrm{nr} 8$.

123. Pytki w Warszawie (Uspokoitielnyj reżim Witte-Durnowo), „Rus’ $" 1906, \mathrm{nr} 44$.

124. „Bojkot” profiessorow, „Birżewyje Wiedmosti” 1906, nr 9598.

125. Smiertnaja kazn' sobaki, „Birżewyje Wiedomosti” 1906, nr 9600.

126. My was wsiech pierierieżem, „Birżewyje Wiedomosti” 1906 , nr 9615 .

127. Opjat' pochoronnyje wienki, „Birżewyje Wiedomosti” 1906 , nr 9627.

128. Po polskomu woprosu. Warszawskij uniwiersitiet $i$ drugije wysszyje szkoty w carstwie Polskom, „Nasza Żizn’” 1906, nr 408, 411, 414, 418.

129. Po voprosu ob awtonomii i rawnoprawii nacionalnostiej, „Ukrainskij Wiestnik" 1906, $\mathrm{nr} 1$.

130. Projekt osnownych potożenij dla rieszenija polskogo woprosa, St. Pietierburg 1906.

131. Ze Zjazdu autonomistów czyli przedstawicieli narodowości nierosyjskich w Petersburgu, „Krytyka” 1906, z. 2- 3 [odb., Kraków 1906].

132. Konfiskata „Krytyki”, „Krytyka” 1906, z. 3.

133. List do Redakcji w zwiazku z konfiskata ustepu w artykule autorawz. 3 z 1906 r., „Krytyka” 1906, z. 5 . 
134. Punkt zwrotny w historii Rosji, „Krytyka” 1906, z. 5 .

135. Tępość moralna spoteczeństwa rosyjskiego, „Krytyka” 1906, Z. 11.

136. Wszechrosyjskie święto konstytucyjne, „Krytyka” 1906, z. 11.

137. Uniwersytet w Wilnie, „Kraj” 1906, nr 1.

138. Szanujmy jezzk ojczysty, „Kraj” 1906, nr 11.

139. Z powodu Ligi oświaty, „Kraj” 1906, nr 11.

140. Z powodu frakcji parlamentarnej zwiazku autonomistów, „Kraj” 1906, nr 18.

141.Z ruchu osvoboženského v Rusku, „Slovansky Přehled”, R. 9, 1906, č. 1-2.

\section{7}

142. Margrabia Wielkopolski jako zbrodniarz, [w:] Elizie Orzeszkowej Polacy znad Newy, Petersburg 1906.

143. Illustracija k naszej „swobodie sowiesti”, „Towariszcz” 1907, nr 236.

144. Z ciemni wszechrosyjskiej, „Krytyka” 1907, z. 5.

145. Z niedawnych wspomnien, „Wolne Słowo” 1907, nr 2.

146. Język pomocniczy międzynarodowy, „Kraj” 1907, $\mathrm{nr}$ 40-45.

\section{8}

147. Wyroki „sankiulotów”, „Wolne Słowo” 1908, nr 5.

148. Kilka uwag przelotnych z powodu "neoslawizmu" $i$ "neopolonizmu”, „Wolne Słowo” 1908, nr 36-37.

149. Wrażenia z Poznania, „Wolne Słowo” 1908, nr 38- 39.

150. Po powodu wolnostuszatielnic, „Sojuz Żen'szczin” 1908, nr 9.

151. Do charakterystyki ś.p. Kazimierza Jawnisa, „Draugija” (Kowno) 1908 , t. IV, nr 16.

152. W sprawie porozumienia sie ludów stowianskich. (Odczyt publiczny urzadzony przez „Polskie Stowarzyszenie Przyjaciót Pokoju” a wygtoszony w Warszawie w wielkiej sali Muzeum Przemystu i Rolnictwa 30 kwietnia 1908 roku), Warszawa 1908. 
153. 0 języku pomocniczym miedzynarodowym. Odczyt publiczny, wygtoszony w Warszawie 5 maja 1908 r., „Krytyka” 1908, z. 10-12 [odb.]

1909

154. Epidemia krwiożerczości, „Krytyka” 1909, z. 6 [nadb.] 1910

155. Z panstwa anarchii i chronicznego bezprawia, „Krytyka” 1910 , Z. $7-8$.

156. Derpt - Juriew. K woprosu o „rawnoprawii”, [w:] W Pribattijskom kraje. Esty i tatyszy, ich istorija $i$ byt, pod red. prof. M. A. Rejsnera, Moskwa 1910.

157. Sport $i$ kultura, „Ruch Warszawski” 1911, nr 52.

158. W sprawie „antysemityzmu postepowego”, „Krytyka” 1911, z. 26 [odb., Kraków 1911].

159. Z powodu zamachu na Stotypina, „Krytyka” 1911, z. 10 [odb. Kraków 1911].

160. Grjaduszczije profiessora, „Szkoła i Żizn’” 1911, nr 52.

\section{2}

161. Baudouin de Courtenay Jan, [Feldman Wilhelm] W. F., O panu Andrzeju Niemojewskim stów kilka, „Krytyka” 1912, z. 1 [odb., Kraków 1912].

162. Wimie prawdy faktycznej, „Krytyka” 1912, z. 3.

163. W sprawie języka sztucznego międzynarodowego w ogólności a esperanto w szczególności, „Ilustrowany Kurier Codzienny” 1912, nr 187.

164. Wychowanie wspótczesne jako stata przyczyna zdenerwowania, Książnica „Ruchu”, t. 1, Warszawa 1912.

165. Przemówienie na „uczcie” b. wychowanców Szkoty Gtównej w Warszawie 25 (12) listopada 1912, „Dziennik Petersburski” 1912, nr 805.

166. Dziś inaczej: Echa rocznicy Szkoty Gtównej, „Słowo” 1912, nr 332. 


\section{3}

167. Bracia Stowianie, „Krytyka” 1913, z. 9; z. 10 [nadb.]

168. Nacjonalnyj i territorialnyj priznak $w$ awtonomii, Pietierburg 1913.

169. „Ukrainskij wopros” s wnienacjonalnoj toczki zrienija (po povodu ankiet „Ukrainskoj Żizni”), „Ukrainskaja Żizn' ” 1913, nr 7-8 [odb. 1913].

170. W,kwestii żydowskiej”. Odczyt wygtoszony w Warszawie 7 lutego 1913, Warszawa 1913.

171. [Artykuły o pomocniczym języku międzynarodowym], „Gołos Biełostoka” 1913.

\section{4}

172. Stowo $i$ „stowo”, „Otkliki” 1914, nr 7 [dodatek do gazety „Dien”, $\mathrm{nr} 56]$.

173. Z sennych widziadet ludzkości, [w:] Priwit Iwanowi Frankowi w sorolite jogo pis'mennoj praci 1874-1914, „Literaturno-naukowij zbirnik”, Lwiw 1914.

\section{6}

174. Jedność stowiańska $i$ stosunki wszechstowiańskie, „Myśl Polska” 1915, z. 3 [przedr. w: Polski Kalendarz Piotrogradzki na rok przestepny 1916, Piotrogród 1916].

175. Gienrich Sienkewicz, „Dien’” 1916, nr 305.

176. Myślenie wyrazowe w polityce, „Kurier Nowy” 1916, nr 75-76.

177. Z powodu otwarcia Wyższych Kursów Polskich, „Kurier Nowy” $1916, \mathrm{nr} 78$.

178. „Niemieckośc” Uniwersytetu Krakowskiego, „Kurier Nowy” 1916, nr 128.

179. Po powodu uczebnikow russkogo jazyka, „Birżewyje Wiedomosti” 1916, nr 15791, 15889, 15987. 
180. Rok 1863 a Szkota Gtówna Warszawska, [w:] Odgtosy. Ksiażka zbiorowa wydana staraniem i nakladem Stowarzyszenia „Dom Polski w Moskwie", Moskwa 1916, s. 9-17 [odb.]

181. Stosunek „Kaszubów” do „Polaków”, „Echo Polskie” 1916, nr 29.

182. Wozmożno li mirnoje sożitelstwo raznych narodnostiej w Rossii?, [w:] Otieczestwo. Puti i dostiżenija nacionalnych literatur Rossii. Nacionalnyj vopros, t. 1, Petrograd 1916, s. 19-31.

183. Jedność stowianska i stosunki wszechstowiańskie, [w:] Polski Kalendarz Piotrogradzki na rok przestepny 1916, Piotrogród-Moskwa-Kijów 1916.

\section{7}

184. Chotmszczyna, „Nowaja Żizn’” 1917, nr 85.

1918

185. „Stawjanskoje jedinienije” $i$ Rossija, „Jewropa” 1918, nr 3.

186. Wyższe Kursy Polskie, „Dziennik Narodowy” 1918, nr 125.

187. Pod wrażeniem walnego zebrania PTS, „Dziennik Narodowy” 1918, nr 190.

188. [List do Redakcji], „Kurier Warszawski” 1918, nr 327.

\section{9}

189. Państwowość polska a Żydzi w Polsce, „Gazeta Polska” 1919, nr 272, 275-276 [przedruk w: Adolf Nowaczyński, Mocarstwo anonimowe, Warszawa 1921].

190. Antysemityzm a nauka uniwersytecka w Polsce, „Gazeta Polska” 1919, nr 283.

191. W sprawie granic Polski na wschodzie i potudnia-wschodzie, „Gazeta Polska” 1919, nr 288, 290-291, 293.

192. Antysemityzm monarchów rosyjskich a „antysemityzm” polski, „Gazeta Polska” 1919, nr 294.

193. Jeszcze z powodu „brodobórstwa”, „Gazeta Polska” 1919, nr 317.

194. Epidemia „pogonotomii”, „Kurier Polski” 1919, nr 182, 
195. Sprawy polsko-żydowskie, „Dziennik Poranny” 1919, nr 21, 24, 35.

\section{0}

196. O „zasadzie etnograficznej” w ogóle i o „Polsce etnograficznej” w szczególności, „Przymierze” 1920, nr 19.

197. Obted komunistyczny. I, „Kurier Polski” 1920, nr 196.

198. Obted komunistyczny. II, „Kurier Polski” 1920, nr 209.

199. W sprawie ksiegi zbiorowej ku uczczeniu nieboszczyka W. Feldmana, „Kurier Polski” 1920, nr 333.

200. Paroksyzm zemsty i nienawiści w światyni nauki, „Tydzień Polski” 1920, nr 15-16.

201. „Polska etnograficzna”, „Tydzień Polski” 1920, nr 24.

202. Uniwersytet Wileński. I, „Tydzień Polski” 1920, nr 29.

203. Uniwersytet Wileński. II, „Tydzień Polski” 1920, nr 31.

204. Chwila stanowcza: albo..., albo, „Trybuna” 1920, nr 15-17.

1921

205. Jazykonienawistijczestwo i mirnoje sozitielstwo jazykow, „Warszawskie Słowo” 1921, nr 2.

206. „Diktatura proletariata” w obtasti nauki, „Warszawskie Słowo” 1921, nr 23.

207. Spustoszenia w duszach ludzkich, „Tydzień Polski” 1921, nr 3.

208. „Dyktatura proletariatu” w dziedzinie nauki, „Tydzień Polski” 1921, nr 12.

209. W sprawie prof. Baudouina de Courtenay, „Tydzień Polski” 1921, nr 16.

210. O Uniwersytet Wileński. Odpowiedz krytykom, „Tydzień Polski” 1921, nr 21.

211. List do Redakcji, „Tydzień Polski” 1921, nr 22.

212. Togi profesorskie, „Kurier Polski” 1921, nr 23.

213. Maty fejleton. Ze wspomnień o p.p. Metonie, „Tydzień Polski” 1921, nr 32.

214. Sentymenty a zmyst rzeczywistości, „Tydzień Polski” 1921, nr 35. 
215. Spetnianie obowiazków a ordery, „Głos Polski” 1921, nr 224.

216. Kamarinskij muzik, „Głos Polski” 1921, nr 225.

217. Z moich wspomnień o W. Feldmanie, „Głos Polski” 1921, nr 269.

218. Straszak kiereńszczyzny, „Głos Polski” 1921, nr 325.

219. Nie skandal, a po prostu objaw znamienny i pouczajacy, „Naród” $1921, \mathrm{nr} 48$.

220. Sztandar. I, „Naród” 1921, nr 161.

221. Sztandar. II, „Naród” 1921, nr 162.

222. Sztandar. III, „Naród” 1921, nr 169; także: „Naprzód” 1921, nr 141, 145.

223. Niewinne fatszywe świadectwo w wyższych uczelniach, „Naród” 1921, nr 189.

224. Nawracanie niewiernych przemoca i podstepem, „Naród” 1921, nr 193.

225. Jeszcze w sprawie tzw. "testowania” w wyższych uczelniach, „Naród” 1921, nr 196.

226. Samowolne zaliczanie do innej narodowości, „Naród” 1921, $\mathrm{nr} 206$.

227. Delikatni jatmużnicy a harde i zuchwate dziady, „Naród” 1921, nr 217.

228. „Wolny Chrześcijanin”, „Naród” 1921, nr 220.

229. Sprostowanie, „Kurier Polski” 1921, nr 65.

230. „Niedoszty prezydent” czyli dyssekcja „madrej gtowy”, „Hasło” $1922, \mathrm{nr} 10$.

231. Wimié ścistości i sprawiedliwości, „Robotnik” 1921, nr 90.

232. Diktatura proletarijata nad naukoju, „Syn Ukrainy” 1921, nr 5-6.

1922

233. W zwiazku z wyznaniem paszportowym, „Myśl Wolna” 1922 , $\mathrm{nr} 1$.

234. Zadania etyczne do rozwiazania, „Myśl Wolna” 1922, nr 1. 235. Prawdziwa wolnomyślicielka, „Myśl Wolna” 1922, nr 2.

236. „Tolerancja” ludowa, „Myśl Wolna” 1922, nr 3.

237. Wyznaniowo nieprzyzwoite cześci ciata, „Myśl Wolna” 1922, nr 6. 
238. W sprawie „Zwierciadta chamstwa”, „Myśl Wolna” 1922, nr 7.

239. Zatrważajacy serwilizm, „Myśl Wolna” 1922, nr 8.

240. Jeszcze z wypraw naukowych polskich, „Trybuna” 1922, nr 15-16.

241. Uniwersytet ukrainski $w$ państwie polskim, „Trybuna” 1922, nr 17.

242. Czecho-Stowacja spadkobierczynia Austro-Wegier, „Trybuna” 1922 , nr 18.

243. Szczerość czy obtuda w dziedzinie „etyki ptciowej” "Głos Polski” $1922, \mathrm{nr} 4$.

244. Jeszcze o Stanistawie Rożnieckim, „Tydzień Polski” 1922, nr 1516.

245. Ist noch eine Rettung möglilch?, „Neue Lodzer Zeitung” 1922, nr 93.

\section{3}

246. Judeo-Polska, „Głos Polski” 1923, nr 5.

247. Numerus clausus, „Głos Polski” 1923, nr 6.

248. Blok mniejszości narodowych, „Głos Polski” 1923, nr 50-51.

249. „Nil nisi veritas”, „Głos Polski” 1923, nr 326.

250. Eligiusz Niewiadomski a Karolina Corday, „Głos Polski” 1923, nr 329.

251. Kandydatury demonstracyjne, „Głos Polski” 1923, nr 332.

252. Poziom moralny i umystowy spoteczeństwa, „Głos Polski” 1922, $\mathrm{nr} 371$.

253. Dusze stużalcze i niewolnicze, „Robotnik” 1922, nr 46; także: „Naprzód” 1922, nr 42.

254. Czyja wina? „Robotnik” 1922, nr 47.

255. Zaszczytne odznaczenie „wroga Polski”, „Robotnik” 1922, nr 55.

256. „Dobry Polak” a „Wróg Polski”, „Robotnik” 1922, nr 58.

257. Cmentarz a kolebka, „Robotnik” 1922, nr 275.

258. „Polak i katolik”, „Naród” 1922, nr 54.

259. Co nas ominęto, „Rzeczpospolita” 1923, nr 8.

260. Kwestia żydowska w państwie polskim, „Biblioteka Wolnomyśliciela”, 1., Warszawa 1923.

261. Eysina wyznaniowa, „Myśl Wolna” 1923, nr 1. 
262. Wzwiazku z wyznaniem paszportowym, „Myśl Wolna” 1923, nr 1.

263. Nie wolno kalać ust milczeniem, „Myśl Wolna” 1923, nr 3.

264. Chrystus i indyjski Krszna, „Myśl Wolna” 1923, nr 4.

265. Dwa morderstwa, „Myśl Wolna” 1923, nr 5.

266. Szabas przenajświętszy, „Myśl Wolna” 1923, nr 6.

267. „Mtodziė̇ ukrainska” a „mtodziė̇ polska”, „Myśl Wolna” 1923, nr $7 / 8$.

268. Święty Eligiusz Morderca, „Myśl Wolna” 1923, nr 9.

269. Różnoraka psychologia modlitwy, „Myśl Wolna” 1923, nr 10.

270. Usprawiedliwienie, „Myśl Wolna” 1923, nr 10.

271. Militaryzm a wolnomyślicielstwo i bezwyznaniowość, „Myśl Wolna” $1923, \mathrm{nr} 10$.

272. Dobrodziejstwa celibatu czyli bezżenstwa księży, „Myśl Wolna” $1923, \mathrm{nr} 12$.

273. Tolerancja, równouprawnienie, wolnomyślicielstwo, wyznanie paszportowe, Biblioteka Stowarzyszenia Wolnomyślicieli Polskich, t. 1, Warszawa 1923.

\section{4}

274. Rozbrojenie i uspokojenie, „Głos Poznański” 1924, nr 2-3.

275. Co to jest narodowość i gdzie istnieje, „Głos Poznański” 1924, grudzień.

276. Cechy narodowości, „Głos Poznański” 1924, nr z 20 XII.

277. Czy Ateizm $i$ „Myśl Wolna” wykluczaja sie nawzajem? Artykut dyskusyjny, „Myśl Wolna” 1924, nr 1.

278. Mieszanie pojęć, „Myśl Wolna” 1924, nr 1.

279. W zwiazku z „kwestia żydowska” w Państwie Polskim, „Myśl Wolna” 1924, nr 2.

280. Orientacje trupie. (W zwiazku ze sprawa krematorium), „Myśl Wolna” 1924, nr 3.

281. Madralin, „Myśl Wolna” 1924, nr 4.

282. Jeszcze o militaryzmie a wolnomyślicielstwie i bezwyznaniowości, „Myśl Wolna” 1924, nr 5-6.

283. Zagajenie wiecu protestacyjnego z dn. 1 czerwca r. 1924, „Myśl Wolna” 1924, nr 7. 
284. Rehabilitacja psubrata $i$ sukinsyna, „Myśl Wolna” 1924, nr 8.

285. Przechrzta $i$ neofityzm z przylegtościami, „Myśl Wolna” 1924, nr 11-12.

286. Niewiadomski a Baginski, Wieczorkiewicz i Spótka, „Głos Polski” 1924, nr 103.

287. Prowokatorzy i ptatni ajenci, „Głos Polski” 1924, nr 112.

288. Albo pokój i rozbrojenie moralne, albo też zawalenie się w gruzy „świata cywilizowanego”, „Głos Polski” 1924, nr 151.

289. Czy istnieje naród i język czesko-stowacki? „Głos Polski” 1924, nr 158.

290. Fabryka świętych, „Głos Polski” 1924, nr 161.

291. Zacietrzewienie narodowościowe a głos rozsadku. I, „Głos Polski” 1924, nr 186.

292. Zacietrzewienie narodowościowe a gtos rozsadku. II, „Głos Polski” 1924, nr 187.

293. Krzewiciele bezprawia, „Naprzód” 1924, nr 38.

1925

294. Kilka ogólników objektywnej i subjektywnej odrębności „Ukrainy" pod waględem językowym, plemiennym, narodowym i państwowym, [w:] Album Societatis Scientiarum Ševcenkianae Ucrainensium Leopoliensis ad sollemnia sua decennalia quinta 1873-1923, Lwów 1925, s. 1-19.

295. Od Redakcji, „Myśl Wolna” 1925, nr 1.

296. Komu i na co potrzebny jest Bóg, „Myśl Wolna” 1925, nr 1.

297. W zwiazku z istnieniem odrębnej gminy wyznaniowej żydowskiej, „Myśl Wolna” 1925, nr 2.

298. Masowe nawracanie na „bezbożność”, „Myśl Wolna” 1925, nr 2.

299. Przyczynek do naszej wolności druku, „Myśl Wolna” 1925, nr 2.

300. Wierzyć w kogo lub wierzyć w co a wierzyć komu, „Myśl Wolna” $1925, \mathrm{nr} 2$.

301. Odpowiedzi Redakcji, „Myśl Wolna” 1925, nr 2.

302. Sierota jako pojecie wszechludzkie, pozawyznaniowe i pozanarodowe, „Myśl Wolna” 1925, nr 3 [przedruk w przekł. na jidisz w jednodniówce „Dos einste kind”, Warszawa 1925.] 
303. Rozbrojenie moralne jako warunek pokoju i wolności myśli, „Myśl Wolna” 1925, nr 3.

304. State nieporozumienie, „Myśl Wolna” 1925, nr 3.

305. Ze spraw bieżacych. 1. Konkordat. 2. Studium teologii prawostawnej. 3. [Poprawka]. 4. Redaktor pisma postepowego uznany przez policje za wariata, „Myśl Wolna” 1925, nr 3.

306. Ze spraw bieżacych. 1. Zmniejszenie liczby świat. 2. Krzyże $w$ Uniwersytecie Poznanskim. 3. Skazanie „Rosyjskiej grupy akademickiej”, „Myśl Wolna” 1925, nr 4.

307. Odpowiedzi Redakcji. Do wszystkich prenumeratorów i czytelników, „Myśl Wolna” 1925, nr 4.

308. Przypis Redakcji do artykutu M. I. Salomona "Homo Vorax”, „Myśl Wolna” 1925, nr 4.

309. Aforyzmy, potracajace o mord legalny, „Myśl Wolna” 1925, nr 4.

310. Konkordat na zimno, „Myśl Wolna” 1925, nr 4.

311. Lekkomyślność i bezmyślność samobójcza, „Myśl Wolna” 1925, nr 4.

312. Uwagi Redakcji, „Myśl Wolna” 1925, nr 4.

313. [List do Redakcji], „Myśl Wolna” 1925, nr 5.

314. Zwierciadto chamstwa, „Myśl Wolna” 1925, nr 8.

315. Czy istnieje osobna kultura stowianska?, „Przegląd Warszawski” 1925 , z. 44.

316. Die hebraeische Universitet in Iruszlim, „Lodzer Tageblat” 1925, $\mathrm{nr}$ z 8 kwietnia.

\section{6}

317. W kwestii narodowościowej, Warszawa 1926.

318. Jakiem powinno być prawo matżenskie w Polsce. Gtos prof. Baudouin de Courtenay, „Dziennik Ludowy” 1926, nr 53.

319. Wyznaniowe i pozawyznaniowe śluby i rozwody. (Z powodu oczekiwanej reformy prawa matżenskiego), Warszawa 1926.

320. Do wspóttowarzyszy niedoli, „Kurier Warszawski” 1926, nr 93.

321. W sprawie mienia obywateli polskich zwróconego z Rosji czyli z ZSRR. I, „Nowy Kurier Polski” 1926, nr 182. 
322. W sprawie mienia obywateli polskich zwróconego z Rosji czyli z ZSRR. II, „Nowy Kurier Polski” 1926, nr 183.

323. Ostrzeżenia, „Nowy Kurier Polski” 1926, nr 188.

\section{7}

324. Mój stosunek do kościota, Warszawa 1927.

325. Towarzystwo opieki nad... Żydami, „Życie Wolne” 1927, nr 1.

326. Śladami Rosji carskiej, „Życie Wolne” 1927, nr 2.

327. Triumf przemocy, tchórzostwa $i$ obtudy, „Życie Wolne” 1927, $\mathrm{nr} 4$.

328. Jeszcze o krzyżach w Uniwersytecie Poznanskim, „Życie Wolne” 1927, nr 5.

329. Czy istotnie szczerość?, „Epoka” 1927, nr z 5 lipca.

330. „Czarny terror”, „Robotnik” 1927, nr 199.

1928

331. Męczennik tajemnicy spowiedzi, „Wolnomyśliciel Polski” 1928, nr 1.

332. Powitanie, „Wolnomyśliciel Polski” 1928, nr 1.

333. Dowcip ś.p. Piusa IX, „Wolnomyśliciel Polski” 1928, nr 2.

334. Obiecujaca mtodziėं, „Wolnomyśliciel Polski” 1928, nr 3.

335. Zacięte konflikty oceniane ze stanowiska wolnomyślicielskiego czyli obiektywnego. 1. Wzajemna wyrozumiatośc. 2. Przywilej nieuctwa dla prawodawców. 3. Nietykalność suwerennych awanturników, „Wolnomyśliciel Polski” 1928, nr 3; nr 4; nr 5.

336. Eańcuch dziekanski, „Wolnomyśliciel Polski” 1928, nr 7.

337. „Wandalizm” jezykowy, „Wolnomyśliciel Polski” 1928, nr 7.

338. Rosja, Biatoruś i Ukraina, „Przegląd Wileński” 1928, nr 3-5.

339. Z legend o Waldemarasie, „Robotnik” 1928, nr 218.

340. Profesor Jan Baudouin de Courtenay o sporcie $i$ zagadnieniach aktualnych. Rozmowa..., „Znicz” 1928, nr 1. 
341. Oddźwiekki na zgrzyty $i$ kwiki $w$ menażerii dwunogich a bezskrzydtych. 1. [bez tytułu]. 2. „Honor” pojedynkowiczów. 3. Bez batwochwalstwa $i$ ubóstwiania, bez pielgrzymek $i$ procesji, bez mauzoleów i relikwii ani rusz. 4. Komunizm w zastosowaniu do stosunków ptciowych $i$ do rodziny, „Wolnomyśliciel Polski” 1929, nr 1-2, 4-5.

342. Zbrodnie i niegodziwości Mikotaja Mikotajewicza, „Wolnomyśliciel Polski” 1929, nr 7.

343. Pogadanki szkolne o „Bogu” $i$ o innych sprawach pokrewnych a drażliwych, „Wolnomyśliciel Polski” 1929, nr 11-12.

344. Czy kler jest nam potrzebny, „Wolnomyśliciel Polski” 1929, nr 2021.

345. Ze wspomnień i rozmyślań o Stoweńcach $i$ Stowianach w Italii, „Wiedza i Życie” 1929, nr 6 [odb., Warszawa]. 


\section{INDEKS OSOBOWY}

Ackermann Luiza (1813-1890), poetka francuska uprawiająca lirykę filozoficzną. 488.

Aleksander Macedoński, 385.

Aleksander II, car Rosji. 171.

Aleksiejew, poseł do Dumy. 289.

Andrejew Leonid (1871-1919), rosyjski pisarz i dramaturg. 23, 118.

Annuzio Gabriele D’ (1863-1938), poeta włoski. 198.

Appel Karol Ludwik (1857-1930), polski językoznawca, wykładowea Towarzystwa Kursów Naukowych (1906-1915), od 1920 r. prof. Uniwersytetu Warszawskiego, jeden z założycieli Towarzystwa Naukowego Warszawskiego, członek PAU. 266-268, 271.

Apuchtin Aleksander L. (1822-1904), w latach 1879-1897 kurator warszawskiego okręgu szkolnego prowadzący politykę rusyfikacji szkolnictwa w Królestwie Polskim przez zmianę programów szkolnych i podręczników, wprowadzenie policyjnego systemu nadzoru nad uczniami i bezwzględną walkę z językiem polskim. 271.

Arbues de Epila Piotr, inkwizytor Aragonii, zabity przez Żydów 15 IX 1485 r., u stóp głównego ołtarza katedry w Saragossie. 65.

Askenazy Szymon (1866 a. 1867-1935), historyk polski, profesor Uniwersytetu Lwowskiego, członek Akademii Umiejętności. 306.

Asnyk Adam, 344.

Auerbach S., autor artykułu w „Prawdzie”. 286, 314.

Azef Jewno F. (1869-1918), działacz partii socjalistów-rewolucjonistów, zarazem tajny współpracownik policji. Zdemaskowany po 15 latach (1908), skazany na śmieré przez sąd partyjny, zdołał się ukryé i wyjechać do Niemiec. 175, 285.

Babiański Aleksander (1853-1931), generał, adwokat i sędzia wojskowy. Po dymisji z wojska w 1899 r. działacz społeczny i polityczny, poseł do III Dumy z ramienia partii kadetów. Czynny był także jako działacz w petersburskim środowisku polskim; był prezesem kulturalno-oświatowego „Ogniska”, stowarzyszenia robotniczo-inteligenckiego „Promień”, a podczas I wojny założył Polskie Towarzystwo Pomocy Ofiarom Wojny. Wydawca i redaktor „Dziennika Narodowego (później „Dziennika Pietrogradzkiego”). Od 1915 r. był członkiem Zrzeszenia Niepodległoś- 
ciowego w Petersburgu. Znajomy Baudouina, bywał u niego w domu, a w roku 1914 był jego obrońcą w procesie wytoczonym uczonemu za broszure Nacional'nyj i tierritorialnyj priznak w awtonomii. 10.

Badeni Kazimierz, hr. (1846-1909), konserwatywny polityk, w latach 1888-1895 namiestnik Galicji, prezes rady ministrów i minister spraw wewnętrznych w ck monarchii. Jego działalność na rzecz ugody z Ukraińcami doprowadziła do utworzenia na uniwersytecie lwowskim katedry historii Ukrainy. 42, 92.

Bagiński W., ppor., jeden z oskarżonych o spowodowanie wybuchu w Cytadeli warszawskiej w 1923 r. 513.

Baliński Jan (1827-1902), profesor petersburskiej Akademii Medyko-Chirurgicznej. Pierwszy w Rosji wykładał psychiatrię jako odrębny przedmiot. Był współzałożycielem Towarzystwa Psychiatrycznego, założycielem pierwszej kliniki psychiatrycznej w Rosji, zaprojektował m.in. szpital w Tworkach k. Warszawy. 85.

Baranow Mikolaj M. (1837-1901), od 1883 do 1897 r. gubernator Niżnego Nowogrodu, wcześniej naczelnik Petersburga, znany z rządów twardej ręki. 129.

Bartel Kazimierz (1882-1941), matematyk, polityk. Profesor Politechniki Lwowskiej od 1913. W wolnej Polsce poseł na sejm i w l. 1926-1930 minister WRiOP, potem wicepremier, (trzykrotnie) premier. W latach 1937-1939 senator. Rozstrzelany przez Niemców we Lwowie w akcji AB. 480.

Baudouin de Courtenay Bronisława (1847-1919), młodsza siostra Jana. 448.

Baudouin de Courtenay Jadwiga z Dobrzyńskich (1822 a. 1823-1870), matka Jana. 448.

Beaufront Louis de właśc. Louis Chevreux, (1855-1935), pierwszy francuski esperantysta, założyciel Société Pour la Propagation de l'Espéranto (1888), później jeden z projektodawców języka ido. 267.

Beaupré Antoni (1860-1937), publicysta i działacz polityczny, w latach 1901-1914 redaktor „Głosu Narodu”, potem współpracownik „Czasu”. Od 1910 r. członek Rady Naczelnej Stronnictwa Prawicy Narodowej. 83.

Beck Adolf (1863-1942), fizjolog, profesor uniwersytetu we Lwowie, od 1912 r. rektor. 330, 339. 
Bejlis Mendel (1873-1934 a. 1937) pracownik cegielni w Kijowie, oskarżony 0 rytualny mord na rosyjskim chłopcu Andrieju Juszynskim. Ostatecznie uniewinniony. 329, 330 .

Belmont Leo (Leopold Blumental) (1865-1941), adwokat, obrońca w procesach politycznych, literat, tłumacz, redaktor „Wolnego Stowa” (19071913), założyciel Polskiego Towarzystwa Esperantystów, autor powieści psychologicznych i sensacyjnych, przekładów z literatury rosyjskiej i niemieckiej oraz tłumaczeń na esperanto. 267, 272-275, 305, 315, 551.

Bismarck 0tto von (1815-1898), niemiecki polityk, minister spraw zagranicznych, premier Prus, pierwszy kanclerz zjednoczonych Niemiec od 1871 r. 65, 160, 163, 164, 168, 334, 453, 531, 540.

Bliziński Józef (1827-1893), komediopisarz nawiązujący w swych utworach do tradycji komedii A. Fredry, autor m.in. Marcowego kawalera, Rozbitków, Pana Damazego. 287.

Blumental Leopold zob. Belmont Leo.

Blumenthal Oskar (właść. Oskar Schötau) (1852-1917), austriacki publicysta, krytyk teatralny. 488.

Bobrzyński Michał (1849-1935), historyk, wspóttwórca krakowskiej szkoły historycznej, profesor honorowy Uniwersytetu Lwowskiego, członek Akademii Umiejętności. Także konserwatywny polityk, przywódca stańczyków, poseł do Sejmu Krajowego, członek austriackiej Rady Państwa. Od roku 1891 był wiceprezydentem Rady Szkolnej Krajowej; położył duże zasługi dla rozwoju oświaty w Galicji. W latach 1908-1913 był namiestnikiem Galicji, a w 1917 r. ministrem dla Galicji. 288, 453, 530.

Bocian Józef, biskup. 428.

Sydaczoff Bresnitz von (pseud.) 83, 288.

Buber Rafal, działacz PPS. 24.

Buchow Arkadij. S. (1889-1937), pisarz, satyryk, od 1922 wydawca rosyjskiej gazety „Echo” na Litwie, poświęconej literaturze litewskiej i emigracyjnej literaturze rosyjskiej. $\mathbf{5 2 3}$.

Budiłowicz Anton S. (1846-1908), slawista, profesor uniwersytetów w Warszawie i Dorpacie, publicysta, działacz polityczny, propagator poglądów prof. W. Łamanskiego o jedności świata słowiańsko-greckiego i idei zwierzchnictwa Rosji nad Słowianami. Czynny rusyfikator narodowości nierosyjskich w Rosji. Jako rektor uniwersytetu w Dorpacie 
(1892-1901) prześladował Niemców. Jako członek rady Ministerstwa Oświecenia zwalczał w 1905 r. Związek Wykładowców Szkół Wyższych. 288.

Budionny Siemion M. (1883-1973), w latach 1919-1921 dowódca bolszewickiej I Armii Konnej, w późniejszych latach (od 1935) marszałek ZSRR. 520.

Bujwid Odo (1957-1942), lekarz, bakteriolog, immunolog, twórca polskiej szkoły mikrobiologii, profesor Uniwersytetu Jagiellońskiego, także działacz społeczny. Uczeń Pasteura, pierwszy w Polsce wprowadził jego metody leczenia wścieklizny i zapobiegania jej. Zorganizował w Warszawie drugi w świecie instytut pasteurowski oraz stację badania żywności, zaś w Krakowie uniwersytet ludowy. Ze swą żoną, Kazimierą, działał na rzecz praw kobiet do kształcenia się. Wspólnie założyli pierwsze gimnazjum żeńskie (w Krakowie), a w tych działaniach Bujwidów wspomagali zaprzyjaźnieni z nimi Baudouinowie. 415.

Burcew Włodzimierz L. (1862-1942), początkowo czynny w Narodnoj Woli, aresztowany i skazany na zesłanie, skąd uciekł za granicę. Na emigracji zajął się działalnością wydawniczą i pisarską. Wrócił do Rosji, gdy objęła go amnestia. Wydawał gazetę „Byłoje”. Od roku 1906 jego głównym zajęciem stało się „polowanie na prowokatorów”. Ujawnił wielu agentów Ochrany, m.in. E. Azefa. W 1907 r. emigrował ponownie, tym razem do Francji, gdzie powrócił do działalności wydawniczej. Jego próba przedostania się do Rosji w 1914 r. zakończyła się aresztowaniem i krótkim zesłaniem na Syberię, Po powrocie (do Piotrogrodu) wydawał gazety, „Obszczeje Dieło” i „Buduszczeje”, tym razem o profilu antybolszewickim. Aresztowany po przewrocie bolszewickim, zwolniony dzięki interwencji M. Gorkiego, wyjechał do Francji. 275.

Bursche Juliusz, superintendent polskiego kościoła ewangelickiego. 431, $432,436$.

Bystroń Jan Stanisław (1892-1964), etnolog, socjolog, profesor Uniwersytetu Jagiellońskiego, Poznańskiego, Warszawskiego. 22, 386.

Černy Adolf, pseud. Jan Rokyta (1864-1939), czeski slawista, stowianofil i poeta, tłumacz polskiej poezji, zaprzyjaźniony z Baudouinem. Černy założył także pismo „Slovansky Přehled” (wychodziło w latach 1898-1914 i 1925-1932), z którym Baudouin de Courtenay współpracował. Listy A. Černego do Baudouina wydał T. Bešta (Wrocław 1972). 68. 
Campoamor Ramon de (1817-1901), hiszpański poeta uprawiający poezję filozoficzną. 65.

Cezar Gaius Iulius, 385.

Chałubiński Tytus (1820-1889), przyrodnik, lekarz, profesor Akademii Medyko-Chirurgicznej w Warszawie, potem Wydziału Lekarskiego Szkoły Głównej. Był współzałożycielem i pierwszym przewodniczącym Kasy im. Mianowskiego. 306.

Chmielnicki Bohdan (ok. 1595-1657), hetman kozacki. 161.

Chmielowski Piotr (1848-1904), historyk i krytyk literatury, w l. 1881-1897 redaktor „Ateneum”, od 1903 r. profesor historii literatury polskiej na Uniwersytecie Lwowskim. Był także współredaktorem Wielkiej encyklopedii powszechnej ilustrowanej, Encyklopedii wychowawczej i Poradnika dla samouków. 7.

Chomyszyn Grzegorz, biskup. 427.

Cotourat Louis (1868-1914), francuski matematyk, profesor na uniwersytecie w Tuluzie i w College de France, esperantysta. 267.

Creizenach Wilhelm (1851-1919), germanista i anglista, profesor języka i literatury niemieckiej w Uniwersytecie Jagiellońskim. 454.

Cybichowski Zygmunt (1879-1946), prawnik, profesor Uniwersytetu Lwowskiego, od 1916 r. Uniwersytetu Warszawskiego, specjalista w zakresie prawa międzynarodowego. $\mathbf{5 2 7}$.

Cywiński Bohdan, historyk, publicysta. 27.

Czerkawski Euzebiusz, inspektor szkolny. 44.

Darwin Karol (1809-1882), angielski przyrodnik, twórca teorii ewolucji gatunków. 60, 410, 464, 469 .

Daszyński Ignacy (1866-1936), polityk, publicysta, założyciel i przywódca Polskiej Partii Socjalno-Demokratycznej Galicji i Śląska Cieszyńskiego. Od 1897 r. poseł do austriackiej rady Państwa. Współpracował z PPS (potem z PPS-Frakcją Rewolucyjną), współdziałał w tworzeniu Legionów Polskich. W 1918 r. był premierem Rządu Tymczasowego w Lublinie, potem wicepremierem Rządu Obrony Narodowej 1920/21. Poseł na sejm II Rzeczypospolitej, wicemarszałek i marszałek sejmu. Po 1926 r. w opozycji wobec polityki J. Piłsudskiego. 310, 559.

Dąbrowska Malwina, służąca w petersburskim domu Baudouinów. 404.

Dąbrowski Ignacy, brat Malwiny. 404.

Diamand Herman (1860-1931), prawnik, socjolog, publicysta, działacz Polskiej Partii Socjalno-Demokratycznej Galicji i Śląska Cieszyńskie- 
go, współpracownik I. Daszyńskiego. Od 1904 delegat PPS w Międzynarodowym Biurze Socjalistów. Był też posłem do austriackiej Rady Państwa. W wolnej Polsce poseł na sejm. Był zwolennikiem asymilacji i polonizacji Żydów. W latach 1902-1905 wydawał wspólnie z L. Krzywickim i S. Stempowskim tygodnik „Ogniwo”. 274, 307.

Dickstein Samuel (1851-1939), polski matematyk, pedagog i historyk, profesor Uniwersytetu Warszawskiego. 7, 276, 306.

Dmowski Roman (1864-1939), działacz niepodległościowy, polityk, publicysta, ideolog polskiego nacjonalizmu i współzałożyciel Narodowej Demokracji. Był delegatem polskim na konferencję paryską w 1919 i sygnatariuszem traktatu wersalskiego. $\mathbf{5 4 1}$.

Dobrzański Stanisław (1847-1880), aktor, komediopisarz, reżyser. Występował we Lwowie, Krakowie i Poznaniu. Autor m.in. Żotnierza królowej Madagaskaru, wodewilu grywanego też w naszych czasach w opracowaniu J. Tuwima. Komedia Ztoty cielec wystawiana była w 1880 r. we Lwowie. 53, 451.

\section{Dostojewski Fiodor, 23, 118.}

Dreyfus Alfred (1859-1935), francuski oficer, z pochodzenia Żyd, oskarżony w 1894 r. o szpiegostwo na rzecz Niemiec i skazany na degradację oraz dożywotnie więzienie. Jego proces wywołał wzburzenie, zwłaszcza gdy okazało się, że Dreyfus był niewinny, a do skazania go przyczyniły się m.in. nacjonalistyczne i antysemickie nastroje w armii i w części środowisk politycznych. W akcji protestów przeciwko procesowi brał udział także Emil Zola, którego za list otwarty do prezydenta skazano na rok więzienia i który ostatecznie zmuszony schronić się w Anglii. W 1906 Dreyfus został uwolniony i zrehabilitowany. 54, 70, 269, 397.

\section{Dygasiński Adolf, 7 .}

Dubrowin Aleksander I. (1855-1918 a. 1921), lekarz i działacz polityczny, zwolennik tezy o obronie interesów narodu rosyjskiego przed Żydami. W 1905 r. współzałożyciel nacjonalistycznego i antysemickiego Związku Narodu Rosyjskiego. Założył gazetę „Russkoje Znamia”, inicjował wydawanie broszur i ulotek propagujących antysemityzm. Zamordowany w bolszewickim więzieniu. 273.

Duchiński Franciszek (1816-1893), historyk, etnograf, publicysta, nauczyciel. Pochodził ze spolszczonej rodziny ukraińskiej lub polskoukraińskiej. Od 1834 r. prawdopodobnie studiował w Kijowie, na pewno zaś obracał się w kręgach liberalnej inteligencji, wśród której 
żywe były hasła zbliżenia Polaków i Ukraińców. W 1846 r., obawiając się aresztowania, Duchiński wyjechał do Turcji, potem do Włoch. Podczas wojny krymskiej był w intendenturze brytyjskiego korpusu ekspedycyjnego. Po zakończeniu wojny osiadł we Francji, gdzie został profesorem historii w Szkole Polskiej w Paryżu. Od 1872 był kustoszem Muzeum Polskiego w Rapperswilu. Główne jego prace to: Zasady dziejów Polski i innych krajów stowianskich (t. I-II, 1858-1861); Polacy w Turcyi (1858); Treść lekcyi historyi polskiej wyktadanych w Paryżu (1860); Pologne et Ruthenie. Origines slaves (1861); Dopetnienie do trzech czesści zasad dziejów etc. (1863); Necessité des reformes dans l'exposition de l'histoire des peuples Aryas-Européens et Tourans (1864); Peuples Aryas et Tourans, agriculteurs et nomades (1864). Duchiński zasłynął dzięki stworzonej przez siebie teorii o pochodzeniu Rosjan, którzy (w przeciwieństwie do Polaków, Ukraińców i Białorusinów) nie są Słowianami, a nawet nie należą do rasy „aryjskiej”, ale są jednym z plemion „turańskich”, podobnie jak Mongołowie. 0 języku rosyjskim sądził, że jest to zapożyczony i zepsuty język cerkiewno-słowiański, używany zamiast właściwego języka „turańskiego”. Duchiński oparł się na teorii o nierówności ras głoszonej przez Josepha G0binau (Essai sur l'inégalité des races humaines (1853-1855)). Sądził także, że w interesie „aryjskiej” Europy jest powstanie wolnej Polski, która, skupiając w sobie Polaków Ukraińców i Białorusinów, stałaby się tamą dla wielkorosyjskiego (moskiewskiego) turanizmu. Teoria Duchińskiego zdobyła duże uznanie u części środowisk polskich, ale i w środowisku francuskich historyków. Wzbudziła natomiast sprzeciw Rosjan (np. polemika historyka Mikołaja I. Kostomarowa publikowana w piśmie „Osnowa”, z artykułami opublikowanymi w „Czasie” i „Revue contemporaine” w roku 1861). 140-173, 289.

Dymitr Samozwaniec (?-1610), właśc. Grogorij Otrepjew, w 1604 r. podał się za nieżyjącego syna Iwana Groźnego, a zyskawszy pomoc polską, zasiadł na tronie moskiewskim. Zabity podczas powstania przeciwko Polakom okupującym Moskwę. 396.

Dzieduszycki Wojeiech, hr. (1845-1913), polityk, literat i filozof, prof. estetyki Uniwersytetu Lwowskiego, także jeden z przywódców partii konserwatywnej w Galicji, poseł do sejmu i parlamentu, prezes Koła Polskiego, minister dla Galicji. 288. 
Dzierżyński Feliks (1877-1926), polski i rosyjski działacz komunistyczny. 398.

Ehrenberg Kazimierz (1870-1932), dziennikarz i publicysta piszący najpierw w krakowskim „Czasie” i „Głosie Narodu”, później sekretarz redakcji w warszawskim „Wieku”. Redaktor „Kuriera Porannego (od 1905 r.), dalej „Echa Polskiego” i „Dziennika Polskiego”, od 1918 r. redaktor polityczny w „Gazecie Polskiej”. Od 1931 r. był jej korespondentem w Genewie i członkiem zarządu Międzynarodowego Związku Dziennikarzy przy Lidze Narodów. 269, 283, 288.

Ehrenkreutzówna Krzysia (1917-1927), wnuczka Jana, córka Cezarii z Baudouinów de Courtenay i Stefana Ehrenkreutza. 448.

Ewert Józef, prezes zboru ewangelicko-augsburskiego w Warszawie. 431, $435,436$.

Feldman Wilhelm (1868-1919), historyk literatury, krytyk literacki, publicysta, pisarz i polityk związany z galicyjskimi socjalistami. Był jednym z założycieli Uniwersytetu Ludowego im. A. Mickiewicza w Krakowie. W 1. 1901-1914 redagował „Krytykę”, w której publikował także Baudouin de Courtenay, który z kolei kolportował to pismo wśród Polaków mieszkających w Rosji. Baudouin napisał słowo wstępne do księgi opracowanej dla uczczenia pamięci Feldmana i wydanej w 1922. 9, 105106, 121, 305, 322, 355.

Feliński Zygmunt (1822-1895), arcybiskup metropolita warszawski w l. 1862-1863, wywieziony do Rosji, gdzie do roku 1883 przebywał na zesłaniu. 469, 470.

Ferdynand I Koburg (1861-1948), najpierw książę Bułgarii (od 1887 r.) dzięki poparciu Austro-Węgier i Niemiec, potem car od 1908 r. Abdykował w roku 1918 na rzecz swego syna Borysa. 203.

Fischer Karol, biskup. 428.

Forster, 267.

France Anatol (1844-1944), francuski pisarz. 93, 397.

Frankiewicz S., autor listu do „Myśli Niepodległej”. 278.

Franko Iwan (1856-1916), poeta i pisarz ukraiński, działacz polityczny. Jego działalność była przyczyną szykan tak ze strony Ukraińców, jak i Polaków. Tekst nt. A. Mickiewicza, wywołany stosunkiem do Franki strony polskiej i opublikowany w 1897 r. w wiedeńskim czasopiśmie „Die Zeit” stał się powodem szczególnie długiej i ciężkiej nagonki na poetę. $92,93,97$. 
Freitag, autor sztuki Journalisten. 270.

Gall Stanisław, biskup. 428.

Garszyn Wsiewołod M. (1855-1888), rosyjski pisarz, autor m.in. opowiadań 0 wymowie pacyfistycznej. 132.

Gierymski Maksymilian (1846-1874, polski malarz. 7.

Gloger Zygmunt (1845-1910), polski historyk, archeolog, etnograf, folklorysta, krajoznawca, autor m.in. Encyklopedii staropolskiej, 1900-1903. 7.

Glinka Michał I. (1804-1857), rosyjski kompozytor. 396.

Glusker, 269.

Głąbiński Stanisław (1862-0k. 1943), ekonomista, prawnik, polityk, profesor uniwersytetu we Lwowie, ideolog i działacz Narodowej Demokracji. Był posłem na sejm krajowy galicyjski (1902-1918) i do parlamentu austriackiego. W tym ostatnim był prezesem Koła Polskiego. W 1912 r. został austriackim ministrem kolei. W Polsce niepodległej pełnił funkcje ministerialne, był też krótko wicepremierem, potem senatorem. Aresztowany przez NKWD zginął w ZSRR. 288, 452.

Gobineau Joseph A. (1816-1882), francuski myśliciel społeczny, historyk, pisarz, dyplomata, etnolog. Autor m.in. książki Badania nad nierównościa ras. $\mathbf{3 9 6}$.

Godunow Borys (1552-1605), car rosyjski. 396.

Goethe Johann Wolfgang, 41, 490, 505.

Gogol Mikołaj W., 396.

Golian Zygmunt (1824-1885), kaznodzieja walczący z ruchami wolnościowymi, w l. 1862-1867 profesor Akademii Duchownej w Warszawie. Od 1868 r. pracował w Krakowie. 96, 401, 470, 509, 514.

Gomulicki Wiktor (1848-1919), pisarz i publicysta, autor m.in. Wspomnień niebieskiego mundurka. 7, 344.

Gonta Iwan (?-1768), jeden z przywódcow koliszczyzny. 161.

Grabowski Antoni (1857-1921), inżynier chemik, publicysta, działacz ruchu esperanckiego i prezes Polskiego Towarzystwa Esperantystów od 1908 r. Przekładał poezję polską, m.in. Pana Tadeusza na esperanto. 267.

Gregorěič Simon (1855-1906), poeta słoweński. 57.

Gresser Piotr A. (1833-1892), od 1882 naczelnik Petersburga. 257, 275, 276. 
Guriewicz Jurij G. (nie: J., jak w oryginale) (1846-1906), nauczyciel gimnazjalny, wykładowea Wyższych Kursów Żeńskich, na których pracował też Baudouin, redaktor i wydawca od 1890 r. czasopisma „Russkaja Szkoła”. Autor prac historycznych. $\mathbf{2 4 6}$.

Gurland Ilia J. (1868-?), pochodził z żydowskiej rodziny, prawnik, literat, konserwatysta, od 1904 r. w służbie państwowej. Jeden z głównych współpracowników P. A. Stołypina. Od 1907 r. redaktor pisma „Rossija”. Po rewolucji lutowej wyemigrował do Paryża. W wydanej w 1. 90. jego biografii znajdują się zaskakujące informacje na temat jego zażyłych stosunków korespondencyjnych z nacjonalistą i antysemitą W. P. Puryszkiewiczem. 275.

\section{Habsburgowie, 167, 378.}

Haeckel Ernst (1834-1919), niemiecki biolog, filozof i podróżnik. Był zwolennikiem darwinizmu, opracował drzewo genealogiczne wszystkich organizmów. 60.

Haecker Emil (Samuel Haker) (1875-1934), dziennikarz-publicysta, historyk literatury i badacz dziejów socjalizmu, polityk, członek Polskiej Partii Socjalno-Demokratycznej Galicji i Śląska Cieszyńskiego, redaktor gazety „Naprzód”. 275, 277, 307.

Hartmann Karl Robert Eduard von (1842-1906), niemiecki filozof, autor Philosophie des Unbewussten (1869), Phänomenologie des sittlichen Bewusstseins (1879), Religionsphilosophie. I:Das religiose Bewusstein der Menschheit, II: Die Religion des Geistes (1882). 164.

Harusiewicz Mieczysław, deputowany endecki członek Koła Polskiego w Dumie Państwowej. 179.

Hausner Otto (1825 a. 1827-1890), galicyjski działacz polityczny, poseł do Sejmu Krajowego (od 1873), delegat do Rady Państwa (od 1878) i przywódca Koła Polskiego w parlamencie austriackim. Hausner znany był z głośnych wystąpień przeciwko gwałtom rosyjskim i austriackiej okupacji Bośni. Za występowanie w obronie interesów polskich otrzymał tytuł honorowego obywatela Lwowa. 208.

Havliček-Borovský Karel (1821-1856), czeski poeta i publicysta, tłumacz i działacz w czasie Wiosny Ludów. Baudouin de Courtenay bardzo cenił jego twórczość literacką (zob. np. liczne wzmianki w listach do A. Černego), a gdy prowadził w Petersburgu zajęcia z języka czeskiego, korzystał z jego utworów, własnoręcznie przepisując je dla studentów. 43, 410, 488, 505. 
Heine Henryk, 271, 313, 335.

Helmling Ernst, matematyk, profesor uniwersytetu w Dorpacie. 470.

Hempel Jan (1877-1937), publicysta, krytyk literacki. Członek PPS-Lewicy, potem KPRP, ostatecznie działacz KPP. Współpracował z wieloma czasopismami, m.in. z „Myśli Niepodległą”. W 1932 r. wyemigrował do ZSRR. W 1937 został skazany na śmierć (zrehabilitowany w 1956 r.). Hempel i skupiona wokół grupa komunistów zwalczali Baudouina, co doprowadziło do jego wycofania się z redakcji „MN” i do rozłamu w Stowarzyszeniu Wolnomyślicieli Polskich. 23, 399.

Hercen Aleksander (1812-1870), rosyjski myśliciel, pisarz, działacz polityczny. 225.

Heryng Teodor (1847-1925), jeden z pionierów laryngologii polskiej, ordynator w szpitalu Św. Rocha w Warszawie; profesor honorowy Uniwersytetu Warszawskiego (1922). 306.

Herzenstein Michał J. (1859-1906), prawnik, ekonomista, zajmował się kwestiami finansowymi i agrarnymi. Z powodu pochodzenia niedopuszczony do pracy dydaktycznej, pracował przez 15 lat w Moskiewskim Banku Ziemskim. Od 1903 r. docent prywatny Uniwersytetu Moskiewskiego, od 1904 r. profesor pomocniczy ekonomii politycznej w Instytucie Rolniczym. Członek partii kadetów, wybrany do I Dumy Państwowej z Moskwy. Zajmował się w niej zagadnieniami agrarnymi, co przysporzyło mu wrogów w środowiskach właścicieli ziemskich. Po rozwiązaniu Dumy przeniósł się do miejscowości Terijoki w Finlandii, gdzie został zamordowany w 1906 r. 177.

Hilferding Aleksander F. (1831-1872), uczony rosyjski, historyk, slawista, folklorysta, zbieracz ruskich bylin. Jeden z ważniejszych przedstawicieli słowianofilów. Znaczna część jego dorobku poświęcona jest historii i językom Słowian zachodnich i południowych. W roku 1864 był członkiem Komitetu Urządzajacego kierowanego przez namiestnika Królestwa Polskiego F. F. Berga. Był pomysłodawcą wprowadzania grażdanki jako alfabetu dla jezzyka polskiego (także w ogóle jako przyszłego alfabetu ogólnosłowiańskiego), o czym pisał w pracy Obszczestowjanskaja azbuka s pritożenijem obrazcow slawjanskich nareczii, 1871. Baudouin napisał na ten temat broszurę Hilferding czy ksiadz Malinowski. Moskale czy Polacy dadza Stowianom Wszechstowianskie abecadto... Poznań 1872. 288.

Hirschsohn, inżynier 372. 
Hiszpański Stanisław (1872-1939), właściciel znanej bardzo pracowni szewskiej w Warszawie, z wykształcenia prawnik, działacz „Sokoła”, współpracownik „Dziennika Kijowskiego”. Ofiarował Kasie im. Mianowskiego posiadłość w Świdrze pod Warszawą, z przeznaczeniem na fundacje „Mądralin”, mającą utrzymywać dom wypoczynkowy dla polskich uczonych. $\mathbf{4 5 6}$.

Hlond August (1926-1946), arcybiskup metropolita warszawsko-gnieźnieński (1946-1948), prymas Polski, Sługa Boży. 428.

Huzarski, autor artykułu w „Wolnym Słowie”. 272, 275.

Jackan Samuel Jakub (1874-1936), działacz syjonistyczny, dziennikarz, założył w 1908 r. w Warszawie gazetę „Hyant”. 277.

Jakowlew Mikołaj N. (1870-1966) geolog, paleontolog, profesor petersburskiego Instytutu Górniczego, członek Rosyjskiej Akademii Nauk. 408, $409,466,467$.

Jałbrzykowski Romuald, biskup. 428.

Jażdżewski Ludwik (1838-1911), ksiądz, poseł do sejmu pruskiego i do parlamentu Rzeszy. Z przekonań konserwatysta i zwolennik współpracy z niemieckimi katolikami. 470.

Jeleński Jan (1845-1909), dziennikarz, publicysta, wydawca od 1882 r. konserwatywno-klerykalnego tygodnika „Rola” 0 antysemickim nastawieniu. 283.

Jełowiecki Adolf Józef, biskup. 428.

Jespersen 0tto (1860-1943), duński fonetyk i teoretyk języka, profesor uniwersytetu w Kopenhadze. 267.

Joselewicz Berek (1764-1809), kupiec żydowski. W roku 1794 uformował pułk kawalerii złożony z Żydów i walczył w powstaniu kościuszkowskim. Od 1798 r. w Legionach, od 1807 podpułkownik w armii Księstwa Warszawskiego. Zginął w bitwie pod Kockiem. 306, 344.

Juszezinski Andrzej, rosyjski chłopiec, o którego zamordowanie oskarżono Bejlisa. 329, 385.

Juszkiewicz Jan (Jonas Juška) (1815-1886). Baudouin wspólnie z nim badał litewskie dialekty, a także opracował i wydał zbiór ludowych pieśni litewskich, będący dorobkiem życia brata Jana - Antoniego (1819-1866), księdza, leksykografa i etnografa. 371.

Kakowski Aleksander (1862-1938), arcybiskup metropolita warszawski, kardynał. Członek Rady Regencyjnej (1917-1918) Królestwa Polskiego. 427. 
Kalkstein Ludwik Chrystian (ok. 1630-1672), szlachcic z Prus Książęcych, jeden z przywódców opozycji przeciwko elektorowi Fryderykowi Wilhelmowi, porwany z terytorium Polski, następnie skazany na śmieré i stracony. 322.

Kamieński Henryk S., 275, 278.

Kant Immanuel, 163.

Kapustin, kurator okręu naukowego dorpackiego. 473.

Karo Yosef Ben Efraim (1488-1565), żydowski uczony autor kodeksu praw Szulchan Aruch. 280.

Karol I Hohenzollern-Siegmaringen (1839-1914), książę rumuński od 1866 r., król Rumunii od 1881 r. 208.

Karol Wielki, 385.

Kasso Lew A. (1865-1914), prawnik, docent uniwersytetu w Dorpacie, prof. uniwersytetu w Charkowie, potem w Moskwie. Rosyjski minister oświecenia publicznego. Zasłynął z pacyfikacji niepokojów studenckich na Uniwersytecie Moskiewskim i w in. uczelniach w 1911 r., usuwania profesorów, relegowania wszystkich słuchaczek Żeńskiego Instytutu Medycznego w 1912 r. oraz represji w stosunku do uczniów szkół średnich. 374.

Kaufman Mieczysław (1864-1916), lekarz, działacz społeczny, inicjator utworzenia w Łodzi biblioteki miejskiej. 407.

Kawelin Konstantyn D. (1818-1885), filozof, prawnik, profesor uniwersytetów w Moskwie i Petersburgu. 303.

Kennan George (1845-1923), podróżnik, autor m.in. wspomnień z podróży po Syberii. 472.

Kieszkowski Czesław, 42, 43.

Kijeński Stanisław, 556.

Kleingels Michał W., gen. kawalerii, naczelnik Petersburga w l. 1895-1904. 257.

Klingenberg Mikołaj M., gubernator kowieński. 252.

Klunder Jakub, biskup. 428.

Kocyłowski Józefat, biskup. 428.

Konopnicka Maria, 344, 372.

Konstantinow, komisarz policji w Warszawie. 285.

Kopernik Mikołaj, 507.

Kordecki Augustyn (1603-1673), przeor klasztoru częstochowskiego. 315.

Korsakowa, siostra profesora K. D. Kawelina. 303. 
Korzon Tadeusz (1839-1918), badacz historii nowożytnej, przedstawiciel warszawskiej szkoły historycznej. Był nauczycielem w Szkole Handlowej L. Kronenberga, potem dyrektorem Biblioteki Ordynacji Zamoyskich. Członek Akademii Umiejętności. 295.

Kościuszko Tadeusz, 41, 212, 344, 557.

Kotarbiński Tadeusz (1886-1981), filozof, logik, prakseolog, profesor Uniwersytetu Warszawskiego, po II wojnie pierwszy rektor Uniwersytetu Łódzkiego. Członek PAU, PAN. Baudouin znał się z nim z działalności w ruchu wolnomyślicielskim. 12, 24.

Krafft-Ebing Richard von (1840-1902), niemiecki psychiatra, profesor uniwersytetów w Grazu i Wiedniu, zajmował się psychiatrią kliniczną, sądową i seksuologią. 61.

Kramsztyk Zygmunt (1849-1920), okulista, działacz społeczny, założyciel redaktor pisma „Krytyka Lekarska”, redaktor „Medycyny Społecznej” i jeden z założycieli Towarzystwa Higienicznego Warszawskiego. 306.

Krasiński Zygmunt, 184, 385, 556.

Kraszeninnikow, przewodniczący sądu. 540.

Kraszewski Józef Ignacy, 19, 119.

Kraushar Aleksander (1842-1931), adwokat, historyk, wydawca źródeł historycznych, publicysta. Współzałożyciel Towarzystwa Naukowego Warszawskiego w 1907 r., prezes Towarzystwa Miłośników Historii. Zajmował się historią polityczną Polski. Napisał m.in. Historię Żydów w Polsce (t. 1-2, 1865-1866), Towarzystwo Warszawskie Przyjaciót Nauk 1800-1832 (t. 1-8, 1900-1911), Miscellanea historyczne (t. 1-73, 1903-1920). 277, 306.

Kronsztadzki Jan (Iwan I. Siergiejew) (1829-1908), protojerej, pisarz religijny, kanonizowany przez Cerkiew w 1990 r. Zwolennik idei monarchii rosyjsko-prawosławnej i sympatyk nacjonalistycznego Związku Narodu Rosyjskiego W 1903 r. pod wpływem kiszyniewskich pogromów napisał Mys'li moi po powodu nasilii christian s jewrejami w Kiszyniewie. 224.

Krupiński Franciszek Salezy (1836-1898), ksiądz, filozof i jeden z pierwszych polskich pozytywistów. 464.

Kruszewan Paweł A. (1860-1909), deputowany do II Dumy, skrajny reakcjonista i antysemita. W Kiszyniowe wydawał od 1897 r. gazetę „Bessarabiec" o wyjątkowo antysemickim charakterze. Był organizatorem po- 
gromu Żydów kiszyniowskich i inspiratorem szeregu innych. W 1903 r. założył gazetę „Znamia”, w której po raz pierwszy zostały opublikowane Protokoty mędrców Syjonu. 273, 283.

Kruszewski Mikołaj (1851-1887), językoznawca, uczeń Baudouina na uniwersytecie w Kazaniu i od 1883 r. profesor tej uczelni. Obaj weszli do historii lingwistyki światowej jako twórcy tzw. szkoły kazańskiej. 8, 13.

Krynicki Władysław, biskup. 428.

Kryński Antoni A. (1844-1932), kolega Baudouina ze Szkoły Głównej, filolog i językoznawca, profesor filologii słowiańskiej na Uniwersytecie Lwowskim, członek AU, współzałożyciel „Prac Filologicznych”, Towarzystwa Naukowego Warszawskiego. 7, 11.

Krzywicki Ludwik (1859-1941), socjolog, ekonomista, pedagog, działacz społeczny i polityczny, uważany za jednego z najwybitniejszych polskich marksistów. 108.

Kubicki Pawel, biskup. 428.

Kubina Teodor, biskup. 428.

Kulczycka-Saloni Janina, historyk literatury, profesor Uniwersytetu Warszawskiego. 13.

Lange Antoni (1861 a. 1863-1929), poeta, filozof, pisarz, krytyk literacki. Tu przywołany jako autor broszury, w której przedstawił pogląd nt. biologicznego wyeliminowania rasy żydowskiej w drodze przymusowych małżeństw mieszanych, co miała doprowadzić (poza zniknięciem Żydów w Polsce) do wzmocnienia narodu polskiego „nową, obcą krwią". 356.

Lassalle Ferdynand (1825-1864), niemiecki myśliciel, działacz ruchu socjalistycznego, założyciel Powszechnego Niemieckiego Związku Robotników. 61.

Laubitz Antoni, biskup. 428.

Leau Leopold, francuski matematyk; zajmował się zagadnieniem języka międzynarodowego. Współautor (z L. Couturat) Histoire de la Langue Universelle (1903), Les Nouvelles Langues Internationales (1907). 267.

Ludwik XIV, król Francji. 415.

Ludwik XV, król Francji. 242.

Ludwik XVI, król Francji. 85, 145.

Luksemburg (Luxemburg) Róża (1870-1919), działaczka ruchu socjalistycznego. 277. 
Lutosławski Kazimierz (1880-1924), ksiądz, lekarz, ekonomista, pedagog, działacz Narodowej Demokracji i harcerstwa. Był współpracownikiem Romana Dmowskiego, członkiem kierownictwa Związku Młodzieży Polskiej „Zet”, od 1912 członkiem Naczelnej Komendy Harcerskiej na Królestwo Polskie. W wolnej Polsce poseł na sejm. Redagował tygodnik „Sprawa” w l. 1919-1920, współpracował z „Myślą Narodową” i „Gazetą Warszawską". 512.

Lutosławski Wincenty (1863-1954), filozof, wykładał na wielu uniwersytetach polskich i zagranicznych, członek Akademii Umiejętności. Baudouin mówi tu o pierwszym małżeństwie Lutosławskiego z hiszpańską pisarką Zofią Perez Equia y Casanova. W latach, w których Baudouinowie mieszkali w Krakowie, pozostawali w bliskich kontaktach z Lutosławskimi. Kontakty z W. Lutosławskim przerwały się, gdy ten opuścił żonę. Poglądom Lutosławskiego na kwestie moralne w stosunkach między płciami poświęcił Baudouin artykuł Szczerość czy obtuda $w$ dziedzinie „etyki ptciowej”, „Głos Polski” 1922, nr 4. 425, 446.

Lamanski Władimir I. (1833-1914), historyk, slawista, docent, potem profesor w katedrze filologii słowiańskiej Uniwersytetu Petersburskiego, członek Akademii Nauk, wykładowca w Akademii Duchownej i w Akademii Sztabu Generalnego. Badacz historii Rosji i jej kultury, szczególnie XVIII w. historii nauki rosyjskiej, przeszłości i kultury Słowian. 382.

Łopuchin Aleksiej A. (1864-1928), dyrektor departamentu policji (1902), który ujawnił partii socjalistów-rewolucjonistów agenturalną rolę J. Azefa. 224.

Losiński Augustyn, biskup. 427.

Łoziński Zygmunt, biskup. 427.

Łukomski Stanisław, biskup. 428.

Łuniewski W., doktor medycyny, autor artykułu w „Nowym Kurierze Warszawskim”. 437.

Lyskowski Ignacy (1864-1945), prawnik, profesor Uniwersytetu Warszawskiego, rektor UW 1923/24. 527.

Macoch Damazy, zakonnik z Jasnej Góry, aresztowany w 1909 r. za kradzież pieniędzy pochodzących z datków wiernych, wotów z obrazu jasnogórskiego i fałszerstwo oraz za zamordowanie stryjecznego brata, którego żona była kochanką Macocha. 302, 304, 315, 319, 481, 591.

Maeterlinck Maurycy, 487. 
Malinowski Lucjan (1839-1898), kolega Baudouina ze Szkoły Głównej, językoznawca, dialektolog, profesor filologii słowiańskiej na Uniwersytecie Jagiellońskim od 1877, członek Akademii Umiejętności od 1880. Wydawca szeregu zabytków staropolskich. 7.

Małachowska-Łempicka Ewelina z Baudouinów de Courtenay (1892-1985), trzecia córka Jana. Studiowała w Petersburgu historię, potem pracowała tam jako nauczycielka, a od 1917 r. w Warszawie. Jej mężem był Stanisław Małachowski-Łempicki, historyk i prawnik. Podczas II wojny brała udział w tajnym nauczaniu, po 1945 r. była lektorką rosyjskiego w Szkole Inżynierskiej w Częstochowie, a potem lektorką rosyjskiego i angielskiego na Uniwersytecie Warszawskim. 10.

Małachowska-Łempicka Teresa (Terenia), wnuczka Baudouina. 448.

Markow Mikołaj E. (1866-1945), inżynier, jeden z założycieli Związku Narodu Rosyjskiego, deputowany w III i IV Dumie. Wyznawał skrajnie nacjonalistyczne poglądy. 283, 293.

Marks Karol, 61, 91.

Martin Henri (1810-1893), francuski historyk i polityk, profesor Sorbony, usunięty za poglądy polityczne, członek Akademii Francuskiej. Autor m.in. Pologne et Moscovie (1863), La Russie et l'Europe (1866), zwolennik europejskich ruchów niepodległościowych, także powstania styczniowego. 164.

Martynoff, ksiądz. 465.

Meillet Antoine (1866-1936), francuski indoeuropeista i teoretyk języka, profesor Collége de France, a także m.in. członek Akademii Umiejętności. 267.

\section{Messalina, 53.}

Mezzofanti Joseph Caspar (1774-1849), włoski kardynał, znał ponad 38 języków. 373.

Michalkiewicz Kazimierz, biskup. 428.

Michelis Zygmunt, pastor, redaktor „Zwiastuna Ewangelicznego”. 431, 436.

Mickiewicz Adam, 84, 86, 92, 133, 344, 372, 379, 489, 538, 556.

Mienszykow Michał 0. (1859-1917), rosyjski dziennikarz o przekonaniach mnarchistycznych i nacjonalistycznych, od 1901 r. pracował w gazecie „Nowoje Wriemia”. Uważany za zwolennika czarnej sotni. Rozstrzelany przez bolszewików. 273, 275.

Mikołaj I, car Rosji. 179, 418. 
Mikołaj II, car Rosji. 175, 179.

Mikołaj Mikołajewicz (Romanow), wielki książę, (1856-1929), naczelny dowódca wojsk rosyjskich do sierpnia 1915 r. 455.

Mill John Stuart (1806-1873), angielski filozof, logik, ekonomista. 60.

Miniszewski Józef Aleksander (1821-1863), literat i publicysta współpracujący z Aleksandrem Wielopolskim, rzecznik jego polityki, występował w swych publikacjach przeciw ruchom niepodległościowym. Zamordowany przez członków organizacji spiskowej. 91, 93.

Morawski Franciszek (1783-1861), poeta, krytyk literacki, żołnierz. 91, 543.

Morawski Józef Nikodem (1813-1902) poseł, członek austriackiej Izby Panów. 101.

Morawski Kazimierz (1852-1925), filolog klasyczny, historyk, profesor UJ, członek Akademii Umiejętności i jej prezes (1925). 561.

Moszezeńska (-Rzepecka) Izabella (1864-1941), działaczka oświatowa, społeczna, polityczna, publicystka. Była współredaktorem „Przeglądu Pedagogicznego”, współpracowała z „Głosem”, współredagowała w l. 1908-1909 „Prawdę”. Organizatorka strajku szkolnego w 1905 r. W 1913 r. założyła Ligę Kobiet Pogotowia Wojennego, w której działała podczas I wojny światowej; pracowała także w Biurze Prasowym Departamentu Wojskowego Naczelnego Komitetu Narodowego. W 1915 r. była współzałożycielką Ligi Państwowości Polskiej, organizacji głoszącej koncepcję połączenia Galicji i Królestwa Polskiego. 269, 276.

Multatuli (właśc. Eduard Douwes Dekker) (1820-1887), holenderski pisarz, autor m.in. autobiograficznej powieści Maks Havelaar (1860). Polskie tłumaczenia jego utworów wyszły w 1903 r. Występował przeciwko kolonializmowi i kolonialnej polityce Holandii, w czego wyniku musiał emigrować. 335.

Murawiew Michał N. (1796-1866), generał rosyjski, w 1863 r. mianowany naczelnikiem Kraju Północnozachodniego (tj. Litwy), gdzie wsławił się brutalnymi tłumieniem powstania styczniowego, stąd zyskał przydomek ,Wieszatiel”. 214.

Mutermilch Wacław, 266, 268, 275.

Napoleon I, cesarz francuski. 133, 145, 160, 181, 311, 385, 464.

Napoleon III, cesarz francuski. 145, 164, 229.

Narutowicz Gabriel (1865-1922), inżynier konstruktor, profesor politechniki w Zurichu, budowniczy elektrowni wodnych w Europie Zachodniej. 
Podezas I wojny przewodniczył Polskiemu Komitetowi Społecznemu w Zurichu i był jednym z kierujących Komitetem Generalnym Pomocy Ofiarom Wojny w Polsce. Powrócił do Polski po odzyskaniu przez nią niepodległości, stawiając się do dyspozycji odradzającego się państwa. Był ministrem robót publicznych (19219-1922), potem ministrem spraw zagranicznych (1922). W grudniu 1922 r. został wybrany na pierwszego prezydenta RP, głównie głosami centrum, lewicy i mniejszości narodowych. Wybór ten wywołał ordynarne napaści endecji i jej zwolenników na Narutowicza, nieustającą nagonkę prasową, demonstrację w dniu składania przez niego przysięgi prezydenckiej, a nawet czynną napaść na powóz, którym jechał. W tej atmosferze doszło do zamordowania Narutowicza przez Niewiadomskiego. 16, 492, 548, 556, 551, 559, 560, 561.

Natanson Jakub (1832-1884), chemik (zajmował się syntezą związków organicznych), profesor Szkoły Głównej Warszawskiej, współzałożyciel Muzeum Przemysłu i Rolnictwa i Kasy im. Mianowskiego. 306.

Natanson Władysław (1864-1937), syn Jakuba, fizyk, profesor Uniwersytetu Jagiellońskiego, członek Akademii Umiejętności, pierwszy prezes Polskiego Towarzystwa Fizycznego, autor ważnych prac z zakresu termodynamiki procesów nieodwracalnych, optyki, także podręczników i prac z historii nauki. 276, 306, 339.

Neron, cesarz rzymski. 122.

Niemojewski Andrzej (1986-1921), literat, publicysta, działacz społeczny, religioznawca. W l. 1890-1891 w ruchu socjalistycznym w Galicji i Zagłębiu Dąbrowskim, potem w Warszawie (aresztowany w 1899 r.), czynny podczas strajku szkolnego 1905, założył też w tymże roku miesięcznik „Kuźnica”. Wydalony z Królestwa. Po powrocie do Warszawy zajął się religioznawstwem i propagowaniem wolnomyślicielstwa (m.in. Katechizm wolnomyśliciela, 1909). W 1911 r. skazany na rok twierdzy z artykułu kodeksu karnego dotyczącego bluźnierstwa. Założył (z pomocą Baudouina) i redagował (w l. 1906-1931) czasopismo „Myśl Niepodległa”. Miało ono początkowo charakter wolnomyślicielski, z czasem jednak, w miarę ewoluowania poglądów Niemojewskiego ku ideologii nacjonalistycznej i antysemickiej, zmieniło swój profil. Wtedy też rozeszły się drogi Niemojewskiego i Baudouina. W 1920 r. Niemojewski, wówczas już autor wielu publikacji antysemickich, założył Instytut Żydoznawstwa (zob. w niniejszym wyborze $Z$ powodu an- 
tysemityzmu postępowego). Legendy (1902), cykl opowieści nawiązujący do książki E. Renana Żywot Chrystusa (A. Niemojewski przełożył ją na język polski w 1904 r.), w których autor przedstawia Chrystusa jako „pierwszego proletariusza”, wywołały znaczne oburzenie a w końcu decyzję prokuratury o konfiskacie. Decyzja ta stała się przedmiotem interpelacji parlamentarnej, co spowodowało jej złagodzenie - konfiskata objęła tylko tytuł cyklu, stąd utwór funkcjonował też pt. Tytut skonfiskowamy. 82, 86, 93-95, 97, 99, 100, 271, 273-77, 281-83, 285287, 291, 310, 314, 351.

Niewiadomski Eligiusz (1869-1923), malarz, wykładowca i krytyk sztuki, działacz ruchów nacjonalistycznych, zabójca pierwszego prezydenta RP Gabriela Narutowicza. Skazany został w jednodniowym procesie na karę śmierci, zaś prezydent Stanisław Wojciechowski odrzucił jego prośbę o ułaskawienie. Pogrzeb Niewiadomskiego, w którym wzięło udział ok. 10 tys. osób, stał się demonstracją poparcia dla jego czynu, a samego zabójcę część opinii publicznej uznała za bohatera narodowego i meczennika sprawy narodowej. 16, 341, 475, 492, 493, 551, 553-558.

Nikolin, generał żandarmerii rosyjskiej. 472.

Nitsch Kazimierz (1874-1958), językoznawca, dialektolog, profesor Uniwersytetu Jagiellońskiego (od 1910), członek AU (1911), jeden z twórców krakowskiej szkoły językoznawczej, twórca polskiej dialektologii, prezes PAU. Baudouin pozostawał z nim w bliskich stosunkach. 19, 26.

Nowak Anatol, biskup. 427.

Nowowiejski Antoni Julian, biskup. 427.

Nusbaum Henryk (1849-1937), lekarz, fizjolog, filozof, działacz społeczny, autor prac z zakresu deontologii lekarskiej, zwolennik łączenia się kultury żydowskiej z polską. Autor Filozofii medycyny (1926). Był członkiem Warszawskiego Towarzystwa Lekarskiego, Kasy Mianowskiego, prezesem Towarzystwa 0chrony Kobiet, Rady Nadzorczej Towarzystwa Opieki nad Dziećmi, a także Komitetu Obywatelskiego Pomocy Robotnikom w roku 1905. Zaprzyjaźniony z Elizą Orzeszkową, przemawiał na jej pogrzebie w imieniu społeczności żydowskiej. W 1918 r. przeszedł na katolicyzm. W r. 1920 mianowany docentem filozofii i etyki lekarskiej Uniwersytetu Warszawskiego, a w 3 lata potem profesorem honorowym. 276, 306. 
Okoniewski Stanisław, biskup. 428.

Orzeszkowa Eliza, 23, 344, 350.

Ostaszewski-Barański Kazimierz (1862-1913), dziennikarz, pisarz historyczny, statystyk. Współwłaściel i redaktor naczelny „Dziennika Polskiego”, komisarz w magistracie lwowskim, gdzie przyczynił się do powstania biura statystycznego i reaktywacji komisji statystycznej Rady Miasta. Wydał 7 tomów nowej serii Wiadomości statystycznych o Lwowie. Był także współzałożycielem Związku Dziennikarzy Słowiańskich w Austrii. Autor wielu książek, w których opisywał swoje podróże, i opowiadań historycznych. 92.

Ostwald Wilhelm F. (1853-1932), chemik, profesor politechniki w Rydze i Lipsku, jeden z twórców chemii fizycznej. Laureat nagrody Nobla (1909) z dziedziny chemii. 267.

Pasteur Ludwik (1822-1895), chemik, mikrobiolog, tworca imunologii. 41. Paszutin Wiktor W. (1845-1901), fizjolog, jeden z pionierów patofizjologii w Rosji, profesor Uniwersytetu Kazańskiego, autor pierwszego rosyjskiego podręcznika z tego zakresu. 485-86.

Petrażycki Leon (1867-1931), prawnik, socjolog i filozof, był profesorem Uniwersytetu Petersburskiego, od 1918 r. profesorem socjologii Uniwersytetu Warszawskiego. W czasie, którego dotyczy tekst, Petrażycki był członkiem Partii Konstytucyjno-Demokratycznej, potem posłem do I Dumy Państwowej. 11, 177.

Pietkiewicz Krzysztof, ksiądz, proboszcz polskiego kościoła w Dorpacie. 469-473, 481, 491.

Pietuchow, rotmistrz żandarmów. 224.

Piltz Erazm (1851-1929), prawnik, dziennikarz i polityk, do 1882 r. redagował w Petersburgu z W. Spasowiczem polski tygodnik „Kraj”. Był jednym z przywódców ugodowego Stronnictwa Polityki Realnej. 140.

Piłsudski Józef, 330, 548, 549, 551, 561.

Piniński Leon (1857-1938), prawnik, profesor Uniwersytetu Lwowskiego. Namiestnikiem Galicji był w latach 1898-1903. 453, 530.

Platon, 61.

Plehve Wiaczesław K. von (1846-1904), polityk, senator, wiceminister, a od 1902 r. minister spraw wewnętrznych Rosji. Zwolennik rusyfikacji, inspirator pogromów Żydów, działań pacyfikacyjnych. Zginął w zamachu zorganizowanym przez socjalistów-rewolucjonistów. 242 , 257. 
Pobiedonoscew Konstanty P. (1827-1907), prawnik, działacz państwowy, senator, członek Rady Państw, oberprokurator Świętego Synodu, wychowawca Aleksandra III. Zwolennik samowładztwa, reakcjonista, przez wiele lat miał wpływ na decyzje najpierw Aleksandra III, a potem Mikołaja II. Inicjator polityki rusyfikacyjnej wobec mniejszości narodowych w Rosji, prześladowania unitów i Żydów. Wraz z D. Tołstojem i redaktorem „Moskowskich Wiedomosti” M. Katkowem uważany był uosobienie najgorszych tendencji politycznych w Rosji. 83, 283, 288.

Pompadour Jeanne Antoinette Poisson de (1721-1764), metresa Ludwika XV. 242.

Posner Stanisław (Salomon) (1868-1930), prawnik, publicysta, działacz PPS, podezas pobytu w Paryżu współzałożyciel Uniwersytetu Ludowego im. A Mickiewicza. W 1904 r. Posner zwracał się do Baudouina w sprawie podjęcia starań i nagrodę Nobla dla Elizy Orzeszkowej. 306.

Prus Bolesław, 7, 13, 25.

Przeździecki Henryk, biskup. 428.

Przyborowski Walery (1845-1913), pisarz, historyk i publicysta. 7.

Przybyszewski Stanisław (18667-1927), pisarz, autor manifestu Młodej Polski Confiteor. Baudouin znał go z czasów krakowskich. 61.

Puryszkiewicz Włodzimierz M. (1870-1920), działacz polityczny, w 1904 r. urzędnik do specjalnych poruczeń w Ministerstwie Spraw Wewnętrznych. Razem z Dubrowinem zakładał Związek Narodu Rosyjskiego, a po frondzie w 1908 r. założył Rosyjski Związek Narodowy im. Michała Archanioła. Poseł do II, III i IV Dumy Państwowej. Przypuszcza się, że należał do grupy osób, które zabiły G. Rasputina. Po rewolucji październikowej utworzył konspiracyjną monarchistyczną organizację oficerów. Skazany przez „trybunał rewolucyjny” na 4 lata robót przymusowych. 273, 283, 289, 293.

Purkyně Jan Evangelista (1787-1869), czeski uczony, anatom, fizjolog, prof. Uniwersytetu Karola w Pradze. Był także językoznawcą, założycielem Towarzystwa Literacko-Słowiańskiego we Wrocławiu. 288.

Puszkin Alekander S., 389.

Puzyna Jan (1842-1911), biskup krakowski, kardynał (1901). 288.

Radek Karol (1885-1939), w tym czasie działacz SDJPiL. 277.

Radziwiłł Karol zw. „Panie Kochanku” (1734-1790), wojewoda wileński. 268. 
Riazin (Razin) Stienka (Stepan T.) (ok. 1630-1671), Kozak doński i przywódca powstania kozackiego w 1670 r., ujęty i skazany w Moskwie na śmierć. Był bohaterem legend i pieśni ludowych; szczególnie popularnych wśród biedoty kozackiej. 197.

Rokyta Jan zob. Černy Adolf.

Roszkowski Gustaw (1841-1915), prawnik, profesor Uniwersytetu Lwowskiego, poseł do parlamentu austriackiego. $\mathbf{4 5 3}$.

Ryx Marian, biskup. 427.

Russow Aleksander (1847-?), rosyjski etnograf. 372.

Ruzski, generał rosyjski, dowódca 3. Armii w 1914 r. 455.

Rzepecki Ludwik Władysław (1832-1894), księgarz polski, działacz spoteczny, redaktor „Gońca Wielkopolskiego”, założyciel konserwatywnokatolickiego tygodnika „Warta”, przeznaczonego dla inteligencji i wydawanego w latach 1874-1890. 288.

Rzymowski Wincenty (1883-1950), prawnik, literat, publicysta, działacz polityczny. Od 1908 r. pisał artykuły do „Myśli Niepodległej”, w l. 191215 był redaktorem naczelnym „Prawdy”. Był współzałożycielem Klubu Demokratycznego (1937) i Stronnictwa Demokratycznego (1938). Po II wojnie minister kultury i sztuki, potem spraw zagranicznych. 277.

Sade Donatien Alphonse Francois de markiz (1740-1814), pisarz francuski. 117.

Sałtykow-Szczedrin Michał E. (1826-1889), rosyjski pisarz. 23, 41, 231, 242, 373-74, 398.

Sapieha Adam, arcybiskup metropolita krakowski. 427.

Sauerwein Georg (1831-1904), Niemiec z pochodzenia, publicysta, poeta, poliglota, obrońca praw uciskanych narodowości, w tym Polaków, Litwinów, Łużyczan. Znał 62 języki, pisał poezję w ponad 30. Ceniony bardzo przez Litwinów. Współpracował z litewską prasą okresu odrodzenia narodowego. Po litewsku napisał ponad 300 tekstów poetyckich, jeden z nich, Lietuvninkai mes esam gime (1879) uważany nawet za hymn Małej Litwy (in. Pruskiej Litwy, obecnie część obwodu kaliningradzkiego) jest do dziś, w wersji skróconej (Lietuviais esame mes gimę), popularną pieśnią litewską. 373.

Saussure Ferdynand de (1857-1913), szwajcarski językoznawca, profesor uniwersytetu w Paryżu (1881-1891) i w Genewie (1891-1913). Zarys teorii języka i koncepcja językoznawstwa przedstawione przez niego w cyklu wykładów genewskich, a wydane z notatek studentów 
jako Kurs językoznawstwa ogólnego (1916) stały się podstawą rozwoju strukturalistycznych szkół w lingwistyce europejskiej wieku XX. Baudouin korespondował z de Saussurem, którego poznał w Paryżu w 1882 r. 8.

Schleyer Johann Martin (1831-1912), ksiądz katolicki, poeta, filantrop. W 1880 r. opracował projekt międzynarodowego języka o nazwie volapük. 383.

Schuchardt Hugo (1842-1927), austriacki indoeuropeista i romanista, profesor uniwersytetów w Grazu i Halle. 267, 383.

Sienkiewicz Henryk, 7, 23, 120, 306, 425.

Sieroszewski Wacław (1858-1945), pisarz, działacz socjalistyczny, zesłaniec, legionista. 305.

Skałon Georgij A. (1847-1914), generał, od 1905 r. gubernator warszawski, który krwawo stłumił rewolucję 1905 r. w Królestwie Polskim. 181, 190.

Smoleński Władysław (1851-1926), historyk, profesor Uniwersytetu Warszawskiego (od 1919), członek AU, potem PAU. 526, 527.

Spasowicz Włodzimierz (1829-1906), prawnik, publicysta, krytyk literacki, profesor Uniwersytetu Petersburskiego, obrońca w procesach politycznych. Członek Akademii Umiejętności. Był współwydawcą Volumina legum, współzałożycielem i wydawcą warszawskiego „Ateneum” i petersburskiego „Kraju”. Zwolennik zbliżenia polsko-rosyjskiego. 140

Spencer Herbert (1820-1903), angielski filozof i socjolog. 60.

Steinherz Samuel (1857 a. 1859 a. 1867-1942(?)), historyk, autor prac dotyczących historii Żydów w Czechach, profesor niemieckiego uniwersytetu w Pradze. Jego wybór na rektora w roku 1922 wywołał strajk i antysemickie demonstracje zorganizowane przez niemieckie organizacje nacjonalistyczne, Związek Narodowy i Ludowy Związek Studentów. Steinherz złożył dymisję, nieprzyjętą przez ministra oświaty. Ostatecznie wziął urlop na okres kadencji rektorskiej. 16 XII 1942 został wywieziony przez Niemców do Oświęcimia. 339.

Stevenson Robert L. (1850-1894), pisarz angielski. 287.

Stróżecka Estera, 511.

Stróżecka Irena, 509.

Sulimierski Filip (1843-1885), geograf i literat, redaktor naczelny „Wędrowca”, jeden z założycieli Kasy Mianowskiego, wydawca Stownika 
geograficznego Królestwa Polskiego i innych krajów słowiańskich. 306.

Swift Jonathan (1667-1745), pisarz angielski. 98.

Szachowski, książę 85.

Szczegłowitow Iwan G. (1861-1918), rosyjski polityk, związany z ruchem nacjonalistycznym, m.in. ze Związkiem Narodu Rosyjskiego, w l. 19061915 minister sprawiedliwości. Zamordowany przez bolszewików. 329.

Szcześniak Władysław, biskup. 428.

Szujski Józef (1835-1883), historyk, pisarz i publicysta, profesor Uniwersytetu Jagiellońskiego, rektor UJ, członek Akademii Umiejętności. Jeden z przywódców stańczyków. Był też posłem do galicyjskiego sejmu krajowego, a następnie do Rady Państwa. 37, 433.

Szulman Baruch (1885-1906), członek Organizacji Bojowej PPS. 285.

Szymański Adam (1852-1916), prozaik i publicysta, także działacz konspiracyjny Konfederacji Narodu Polskiego, aresztowany, zesłany. Autor opowiadań z życia zesłańców syberyjskich Szkice (t. 1-2, 1887-1890). 344.

Świętochowski Aleksander (1849-1938), publicysta i literat, ideolog polskiego pozytywizmu, redaktor pism warszawskich („Przegląd Tygodniowy”, „Nowiny”, „Prawda”). Jeden z założycieli w 1905 r. liberalnego Związku Postępowo-Demokratycznego. Podczas I wojny światowej zbliżył się do Narodowej Demokracji, a w wolnej Polsce pisał do jej gazet. Był kolegą Baudouina de Courtenay ze Szkoły Głównej. 7, 13, 96, 302, 306, 401, 509.

Tarnowski Stanisław (1837-1917), historyk literatury, krytyk, polityk i publicysta, jeden z twórców Teki Stanczyka. Był posłem na sejm galicyjski, członkiem wiedeńskiej Izby Panów. Profesor Uniwersytetu Jagiellońskiego, dwukrotnie rektor, prezes Akademii Umiejętności w l. 1890-1917. 288, 453, 530.

Taxil Leo (Gabriel-Antoine Jogant-Pages) (1854-?), założyciel Unii Antyklerykalnej i wydawca pisma „L'Anticlerical”, autor książek o takiejże wymowie, m.in. Groteskowe sutanny, Świeci pornografowie, Papieskie metresy, Joanna d'Arc, ofiara księży. Te publikacje miały ponoć wpływ na ustawy antykościelne wydawane w okresie III Republiki. W pewnym momencie pozornie nawrócił się na katolicyzm, został nawet przyjęty na prywatnej audiencji przez Leona XIII i zaczął publikować artykuły 
przeciwko wolnomularstwu, w których przypisywał masonom praktyki satanistyczne. Artykuły te wzbudziły ogromną sensację wśród czytelników, dopóki Taxil nie ogłosił, że były one mistyfikacją. Miss Diana Vaugan to fikcyjna osoba, której „wspomnienia” Taxi sprokurował. 88.

Teodorowicz Józef, arcybiskup. 427.

Tichanowskij, ppłk dragonów rosyjskich. 257, 285, 320.

Tołstoj Lew N., 15, 23, 61, 84, 85, 93, 94, 120, 121.

Tomaszewski, ofiara zabójstwa. 118.

Torquemada Tomasz de (1420-1498), dominikanin, organizator inkwizycji, wielki inkwizytor Kastylii i Aragonii. 65.

Towiański Andrzej (1799-1878), reprezentant jednego z nurtów polskiego mesjanizmu. Założył w Paryżu w 1842 r. Koło Sprawy Bożej, zyskując dla swej ideologii osoby z polskiej emigracji, przede wszystkim A. Mickiewicza, na którego wywarł silny i fatalny wpływ. 344.

Traugutt Romuald (1826-1864), generał, dyktator w powstaniu styczniowym. 212.

Trefolew Leonid N. (1839-1905), poeta rosyjski. 396.

Truskier Efroim (późn. Franciszek Fiedler) (1880-1956), w tym czasie działacz SDKPiL. 277.

Turgieniew Iwan S., 23, 120.

Twardowski Bolesław, arcybiskup metropolita. 427.

Tymieniecki Wincenty, biskup. 427.

Ubryk Barbara (1818-1898), zakonnica w klasztorze Karmelitanek w Krakowie. 96, 401, 509.

Ułaszyn Henryk (1874-1956), językoznawca, profesor uniwersytetów we Lwowie, Poznaniu, po wojnie w Łodzi. Uczeń Baudouina podezas jego pracy na Uniwersytecie Jagiellońskim. Kontakty korespondencyjne utrzymywali ze sobą do końca życia Baudouina. 22, 399.

Unszlicht Julian (1883-1944?), z pochodzenia Żyd. Studiował we Francji. Początkowo członek SDKPiL, potem zwalczał tę partię, uważając ją za antypolską. Występował przeciwko rosyjskim Żydom przenoszącym się do Królestwa Polskiego, tzw. litwakom, których nazywał litwacka Targowica. W tej sprawie napisał m.in. książki: Socjallitwactwo w Polsce (1911) i O pogromy ludu polskiego. (Rola socjal-litwactwa w niedawnej rewolucji). W 1914 r. wstąpił do armii francuskiej, dostał się do niewoli niemieckiej, gdzie w obozie jenieckim przyjął chrzest. W 1924 r. po studiach w seminarium duchownym w Meaux przyjął święcenia ka- 
płańskie i był duszpasterzem wychodźstwa polskiego we Francji. 275, 278, 279, 280.

Urusow Siergiej D. książę (1862-1937) wicegubernator tambowski, po pogromie Żydów w Kiszyniowie w 1902 r. mianowany gubernatorem Besarabii. Na tym stanowisku, będąc przeciwnikiem pogromów, represji i prześladowań, przyczynił się do uspokojenia środowisk żydowskich, za co Towarzystwo Pomocy Biednym Żydom guberni besarabskiej wybrało go 12 XI 1905 r. swoim członkiem honorowym. Urusow był następnie (1904) mianowany gubernatorem twerskim, ale po podporządkowaniu, wbrew prawu, gubernatorów D. F. Trepowowi, znanemu ze swych antysemickich poglądów, podał się do dymisji. W październiku 1905 r. zajął miejsce Trepowa, a wśród powierzonych mu zadań było opracowanie planu reformy zarządzania w jednostkach terytorialnych. Nieprzyjęcie projektu spowodowało dymisję Urusowa. W 1906 roku był deputowanym do I Dumy. Skazany w procesie de facto politycznym na 3 miesiące. W 1913 r. Urusow został skazany za Zapiski gubernatora na 4 miesiące więzienia. W Rządzie Tymczasowym w 1917 r. był krótko współpracownikiem ministra spraw wewnętrznych. Po przewrocie bolszewickim prześladowany, więziony, pozbawiony praw obywatelskich. 224.

Vaugan Diana zob. Taxil Leo

Wahl Wiktor W. von (1840-1915), generał kawalerii, w l. 1892-1895 naczelnik Petersburga. 257, 275.

Wałęga Leon, biskup. 427.

Warski (Warszawski) Adolf (1868-1937), działacz robotniczy, socjalistyczny i komunistyczny, dziennikarz i publicysta. członek I Proletariatu, założyciel Związku Robotników Polskich i SDKPiL. Brał udział w rewolucji 1905 r.. Był redaktorem „Robotnika”, „Czerwonego Sztandaru” i „Sprawy Robotniczej”. W 1918 r. współzałożyciel KPP. Zamordowany w ZSRR. 275.

Weryho-Darowski, poseł na sejm w I Rzeczypospolitej. 293.

Wieczorkiewicz A., por., jeden z oskarżonych o spowodowanie wybuchu w Cytadeli warszawskiej w 1923 r. 513.

Wielopolski Aleksander hr. (1803-1877), polityk polski. 166, 344, 370, 470.

Wikszemski, prorektor uniwersytetu w Dorpacie. 469.

Wilde Oskar, 118. 
Winawer Maksym M. (1862 a. 1863-1926), absolwent Uniwersytetu Warszawskiego, prawnik, działacz polityczny. W 1905 r. był jednym z założycieli i przywódców Partii Konstytucyjno-Demokratycznej. Rok później wybrano go z Petersburga deputowanym do I Dumy Państwowej. Zajmował się też pracą naukową, publikował prace z zakresu prawa i jego historii. Działał w Związku na Rzecz Równouprawnienia Żydów w Rosji, miał udział w wydawaniu żydowskich prasy („Jewriejskaja Starina” i „Nowyj Woschod”). Pod jego kierownictwem Komisja Historyczno-Etnograficzna Towarzystwa Szerzenia 0światy między Żydami w Rosji wydała zbiór materiałów do dziejów Żydów rosyjskich. Po rewolucji bolszewickiej aresztowany, następnie zwolniony, ukrywał się w Moskwie, potem brał udział w działalności antybolszewickiej na Krymie. Wyjechał z resztkami Armii Ochotniczej do Francji, gdzie działał w rosyjskich organizacjach emigracyjnych, wykładał prawo cywilne na rosyjskim uniwersytecie przy Sorbonie, którego był jednym z założycieli. 177.

Wiśniowiecki Jeremi (1612-1651), wojewoda ruski. 161.

Witte Sergiej J. (1849-1918), rosyjski polityk, minister finansów (1893-1903), reformator gospodarki i finansów Rosji. W 1905 r. przedstawił Mikołajowi II projekt liberalnych reform. Po wpływem Wittego car podpisał Manifest 17 października oraz ukaz o reformie Rady Ministrów, mianując go premierem. Na tym stanowisku Witte prowadził dość niejednoznaczną politykę, okazując się raz liberałem, innym razem znowu zwolennikiem rządów twardej ręki. 174.

Wojeiechowski Stanisław (1869-1953), działacz ruchu spółdzielczego, ZMP „Zet”, współzałożyciel PPS i członek jej kierownictwa w l. 18951905. W latach 1919-1920 był wiceministrem spraw wewnętrznych. Od 1922 r. (po śmierci Narutowicza) prezydent RP. Ustąpił z tej funkcji w wyniku przewrotu majowego, później był profesorem WSH i SGGW, dyrektorem Spółdzielczego Instytutu Naukowego. 476, 513, 559, 560, 561.

Wojeieszak A., autor listu do „Myśli Wolnej”. 479.

Wolski Ludwik (1833-1887), adwokat, pisarz, poseł do Rady Państwa ze Lwowa. 208.

Wolski Franciszek, autor artykułu w „Warszawskim Słowie”. 520.

Wołodkowiczówna Maria, żona H. Sienkiewicza. 425.

Wyspiański Stanisław, 379. 
Zamenhof Ludwik (1859-1917), lekarz okulista, twórca sztucznego, międzynarodowego języka esperanto. W 1887 r. wydał pod pseud. dr Esperanto Język międzynarodowy. Przedmowa i podręcznik kompletny, w 1893 słownik Universala vortaro, który wraz z podręcznikiem nazwany został Fundamento de Esperanto. 266, 383.

Zamoyski Mauryey, hr. (1871-1939), polityk i działacz społeczny, od 1903 prezes Towarzystwa Rolniczego. Członek Ligi Narodowej, poseł do I Dumy rosyjskiej. W wolnej Polsce poseł we Francji, od 1924 r. minister spraw zagranicznych. 548, $\mathbf{5 5 9}$.

Zdziechowski Marian (1861-1938), historyk i krytyk literatury, od 1899 wykładał na Uniwersytecie Jagiellońskim, w l. 1919-1932 na Uniwersytecie Stefana Batorego w Wilnie (przez 8 lat rektor USB). Członek Akademii Umiejętności. 15, 83, 92, 93, 486, 542.

Zdzitowiecki Stanisław, biskup. 427.

Zola Emil, 23, 28, 70, 119, 269.

Żabotinski Władimir a. Żabotyński Włodzimierz (1880-1940), żydowski dziennikarz i działacz polityczny, związany z radykalnym ruchem syjonistycznym. 277, 288, 290.

Żeleński-Boy Tadeusz, 22.

Żeleźniak Maksym (?-po 1768), Kozak, jeden z przywódców koliszczyzny. 161.

Żeromski Stefan, 23, 28, 120, 121, 123, 128, 131, 133, 212, 484.

Żyliński Wacław (1803-1863), biskup wileński i ostatni arcybiskup mohylewski. 481. 
I SBN $978-83-7188-968-4$
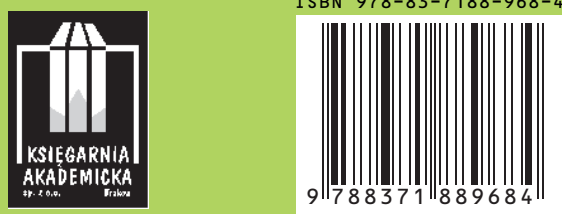